ANA PAULA CAMPOS LIMA

\title{
A HUMANIZAÇÃO DO CUIDADO PRÉ E PÓS-NATAL EM UMA ORGANIZAÇÃO NÃO-GOVERNAMENTAL
}




\section{A HUMANIZAÇÃO DO CUIDADO PRÉ E PÓS-NATAL EM UMA ORGANIZAÇÃO NÃO-GOVERNAMENTAL}

Dissertação apresentada ao Instituto de
Psicologia da Universidade de São Paulo,
como requisito parcial à obtenção do título de
Mestre em Psicologia.

Área de Concentração: Psicologia Clínica

Orientadora: Prof ${ }^{a}$ Associada Eliana Herzberg 
AUTORIZO A REPRODUÇÃO E DIVULGAÇÃO TOTAL OU PARCIAL DESTE TRABALHO, POR QUALQUER MEIO CONVENCIONAL OU ELETRÔNICO, PARA FINS DE ESTUDO E PESQUISA, DESDE QUE CITADA A FONTE.

Catalogação na publicação

Biblioteca Dante Moreira Leite

Instituto de Psicologia da Universidade de São Paulo

Lima, Ana Paula Campos.

A humanização do cuidado pré e pós-natal em uma organização não-governamental / Ana Paula Campos Lima; orientadora Eliana Herzberg. -- São Paulo, 2010.

$351 \mathrm{f}$.

Dissertação (Mestrado - Programa de Pós-Graduação em Psicologia. Área de Concentração: Psicologia Clínica) - Instituto de Psicologia da Universidade de São Paulo.

1. Gravidez 2. Cuidado pré-natal 3. Cuidado pós-natal 4. Acolhimento 5. Humanização da assistência 6. Assistência integral à saúde 7. Relações interpessoais I. Título. 
Nome: LIMA, Ana Paula Campos

Título: A humanização do cuidado pré e pós-natal em uma organização não-governamental

Dissertação apresentada ao Instituto de Psicologia da Universidade de São Paulo para obtenção do título de Mestre em Psicologia

Aprovado em:

Banca Examinadora

Prof. Dr.:

Instituição:

Assinatura:

Prof. Dr:

Instituição: Assinatura:

Prof. Dr::

Instituição: Assinatura: 


\section{AGRADECIMENTOS}

À Associação Comunitária Monte Azul, pela permissão à realização desta pesquisa, pela prontidão nas respostas ao que se fez necessário e pela gentil concessão de imagens, utilizadas neste trabalho. Mais especialmente, às profissionais participantes do estudo, que abriram espaço em sua rotina de trabalho e de vida para conceder esclarecimentos e compartilhar percepções, crenças, compreensões e experiências; e às mulheres-usuárias, por terem me permitido adentrar seus universos vivenciais.

À Coordenação de Aperfeiçoamento de Pessoal de Nível Superior (CAPES), pela concessão da bolsa de mestrado, que permitiu a realização desta pesquisa.

À professora. Eliana Herzberg, por sua abertura ao diálogo com diferentes olhares - o que favoreceu que eles revelassem as suas similaridades em meio às diferenças; por seu acompanhamento cuidadoso do percurso de elaboração deste trabalho; e por sua postura na relação, em que se equilibram discussões acadêmicas, partilha de experiências e afeto.

Às professoras Carmen Simone Grilo Diniz e Maria Cezira Fantini Nogueira-Martins, que participaram da banca de qualificação, pela rica e prazerosa discussão que proporcionaram na ocasião e por suas contribuições valiosas ao projeto.

À professora Janine Schirmer, pelo importante auxílio à obtenção de documentos e manuais relacionados ao Programa de Humanização no Pré-Natal e Nascimento (PHPN) e pela disponibilidade de conceder esclarecimentos sobre ele.

À Myrian Bove Fernandes, por sua presença consistente, sua crença na capacidade de realização dos indivíduos e estímulo constante. Nossos devaneios, reflexões e construções sobre Gestalt-Terapia, desenvolvimento humano e apego permearam esta pesquisa do início ao fim.

À Elizete Zanotti, por seu imprescindível auxílio à revisão do texto; auxílio muitas vezes convertido em precioso ensino de língua portuguesa. Seu apoio contínuo, ademais, ao longo 
dos últimos meses de trabalho, deixou mais leves as experiências dos momentos de finalização.

Às colegas de mestrado Débora Chammas e Fernanda Romano Soares, pela oportunidade de partilhar saberes e vivências; partilha que conferiu tons mais coloridos à experiência de pósgraduação e que, tantas vezes revestindo-se de cumplicidade, deu início à construção de um belo vínculo.

Aos queridos amigos Renata Carneiro, Andrea Gabriel, Carlos Habe, Victor Adena e Nilce Cattassini, por terem me acompanhado ao longo de todo este processo, apoiando-me e, muitas vezes, suportando minha ausência. O afeto de vocês me foi alimento essencial durante o percurso.

Ao "clã familiar", pelo estímulo, tolerância e compreensão, que me resguardaram um importante espaço para a produção deste trabalho.

Ao meu irmão, por sua disponibilidade para travar discussões e para me acompanhar no processo de elaboração de reflexões. Seus referenciais marxistas e sua visão política foram de grande contribuição à ampliação das compreensões aqui tecidas.

Aos meus pais, pelo estímulo ao caminho de produção de conhecimento e, mais especialmente, por sua atitude de confirmação de minhas potencialidades. Nossa história, ademais, e o afeto aí vivido, foram certamente fatores fundamentais na constituição de meu encantamento com o tema da gestação, da vinda de um novo ser ao mundo e do favorecimento de relações mais dialógicas entre os indivíduos.

Ao meu marido, grande amor e companheiro de todas as horas, por seu apoio, sua continência e estímulo; por sua crítica, que continuamente me provoca a rever argumentos, a descolar-me de introjeções e de preconceitos e a buscar fundamentos mais sólidos para o que penso, o que acredito e o que defendo; e por sua imprescindível ajuda com a formatação final do trabalho. 
Para que uma árvore carregue frutas, necessita de ar, de terra boa, de sol, de água.

Para que o ser humano se abra e se desenvolva, necessita de alimento e de proteção; de um coração aberto que lhe dê amor; de uma pessoa que lhe ajude a crescer. Ute Craemer 


\section{RESUMO}

LIMA, A. P. C. A humanização do cuidado pré e pós-natal em uma organização nãogovernamental. 2010. 351 f. Dissertação (Mestrado) - Instituto de Psicologia, Universidade de São Paulo, São Paulo, 2010.

A humanização do cuidado ao ciclo grávido-puerperal no Brasil é marcada por distintos sentidos e experiências. Diante de tal diversidade, um conceito de humanização foi elaborado no presente trabalho, a partir de uma análise de documentos do Programa de Humanização no Pré-Natal e Nascimento (PHPN), lançado pelo Ministério da Saúde em junho de 2000. Tal conceito norteou o estudo, que se constituiu em uma pesquisa qualitativa de referencial fenomenológico-existencial realizada, à luz do PHPN, no ambulatório de uma organização não-governamental que presta uma atenção pré e pós-natal autorreferida como humanizada. Teve como objetivos: observar, descrever e compreender como se dá a humanização de tal atenção, tendo em vista as inter-relações de alguns dos sujeitos envolvidos em sua produção (usuárias, colaboradores e coordenadores) e o cenário no qual tais inter-relações se dão; compreender de que forma os processos de acolhimento e de produção de vínculo estabelecem relações com a humanização do cuidado, caso tais aspectos se fizessem presentes no serviço estudado; e refletir sobre elementos que favoreçam a superação de algumas das contradições que permeiam o campo da humanização. A coleta de dados foi realizada a partir de observação participante, levantamento de dados de cartões de gestantes e entrevistas com profissionais de saúde ligados ao serviço em pauta e com mulheres lá atendidas. A análise dos dados evidenciou, como eixos centrais do cuidado produzido: o acolhimento, explicitado nas dimensões de postura do profissional (discutida como dialógica/de figura de apego seguro, segundo o referencial gestáltico) e de (re)organização do serviço; a produção de vínculos; e a integralidade (ali marcada pelo olhar da Antroposofia). Tais processos afiguraram-se também como aqueles que marcam a forma com que a humanização é compreendida e mobilizada no serviço. Mostraram-se, nesse sentido, especialmente importantes à restituição e/ou reafirmação da condição de sujeitos integrais de usuárias e de profissionais e à experiência de ampliação e efetivação de potências de tais atores. Por fim, revelaram-se aspectos fundamentais à efetivação das mudanças necessárias à sedimentação de um cuidado humanizado: o reconhecimento, a valorização e a legitimação institucional da condição de pessoa do profissional; a fundamentação da produção do cuidado em saúde em um referencial filosófico humanista e holístico; e a superação das contradições identificadas não apenas no universo dos discursos mas também na existencialidade de cada um dos sujeitos que de tais discursos se fizer portador e multiplicador.

Palavras-chave: Humanização da assistência, Cuidado pré-natal, Cuidado pós-natal, Acolhimento, Relações Interpessoais, Assistência Integral à Saúde 


\begin{abstract}
LIMA, A. P. C. The humanization of antenatal and postnatal care in a non-governmental organization. 2010. 351 f. Monograph (Master's Degree) - Instituto de Psicologia, Universidade de São Paulo, São Paulo, 2010.
\end{abstract}

In Brazil the humanization of maternity care is marked by different meanings and experiences. Facing such a diversity, a concept of humanization has been elaborated in this study, based on the analysis of documents from the Program for Humanization of Prenatal and Childbirth Care (PHPN), launched by the Ministry of Health in June 2000. The concept herein developed guided this work, which consisted of a qualitative research with an existentialphenomenological approach, held in the light of PHPN, in a non-governmental organization's ambulatory that provides a pre- and postnatal care which is self-defined as humanized. The aims of this study were (i) to observe, describe and understand the humanization of such a care, considering the interrelationships of some of the subjects involved in its production (users, collaborators and coordinators) and the environment in which the interrelationships take place, (ii) to understand how the processes of user embracement and promotion of bonding are related to the humanization of care, in the cases where the service studied included such aspects, (iii) and to reflect about elements that help to overcome some of the contradictions that are found in the humanization field. The data were collected through field participant observation, data collection from pregnants' attendance card and interviews with health professionals related to the service and women there attended. The data analysis demonstrated the axes of the production of care were (i) the user embracement, which appeared in the dimension of professional attitude (herein exposed as a dialogical attitude and/or as a secure attachment figure attitude, according to the gestaltic approach) and in the service reorganization dimension, (ii) the promotion of bonding; and (iii) the comprehensiveness (as understood in Anthroposophy, mainly). The humanization was associated with such processes, which showed themselves to be especially important to the restitution and/or reaffirmation of the integrality condition of users and professionals and to the experience of ampliation and realization of potentialities of these subjects. Finally, the following aspects proved to be essential points to implement the necessary changes which solidify the humanized care: (i) the recognition, the valorization and the institutional legitimation of the health professionals' personal condition, (ii) the grounding of the production of health care in a humanistic and holistic approach, (iii) and the overcoming of the contradictions identified not only at the level of discourses but also at the existential dimension of each subject that produces and propagates those discourses.

Keywords: Humanization of Assistance, Prenatal Care, Postnatal Care, User Embracement, Interpersonal Relations, Comprehensive Health Care 


\section{LISTA DE FIGURAS}

Figura 1: Organograma da Associação Comunitária Monte Azul...........................................98

Figura 2: Logotipo da Associação, reestilizado em 2008. ................................................100

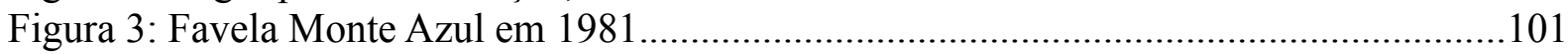

Figura 4: Mina de água que atraiu os primeiros moradores...............................................102

Figura 5: Obras de canalização do córrego......................................................................102

Figura 6: Vista superior atual do Núcleo Monte Azul - Praça Central da Favela..................102

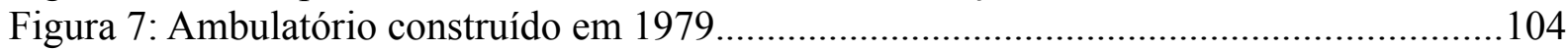

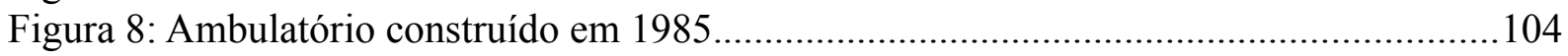




\section{LISTA DE GRÁFICOS}

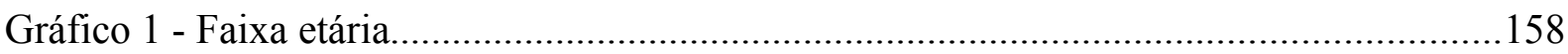

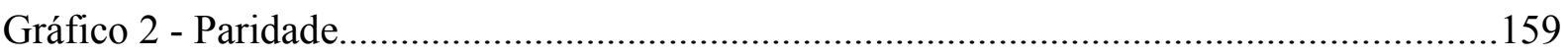

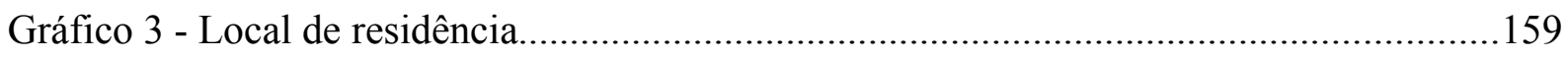

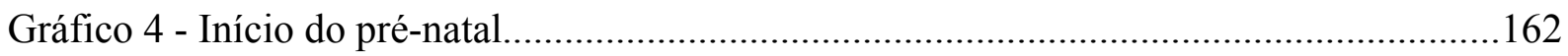

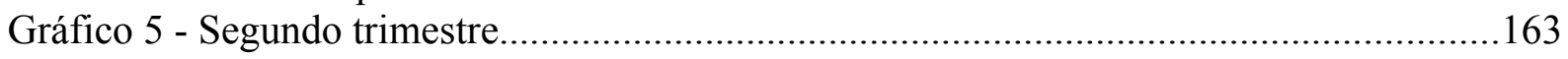

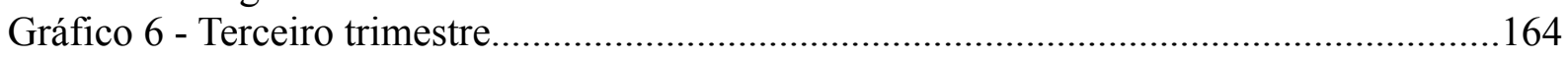

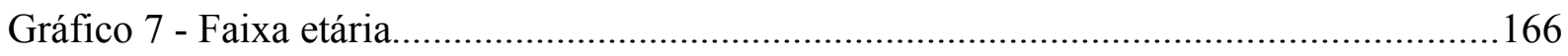

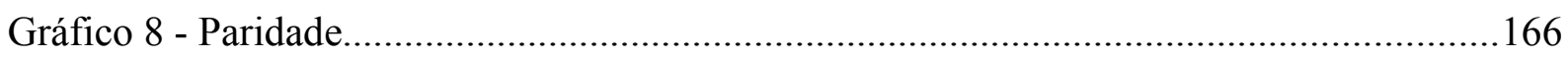

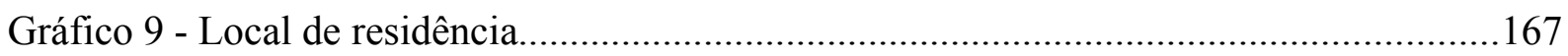

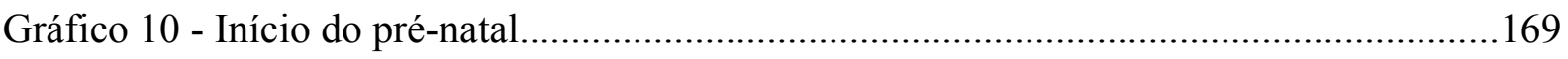

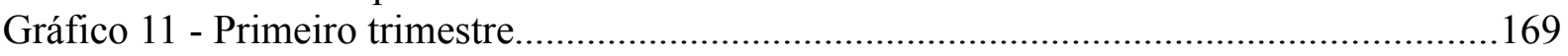

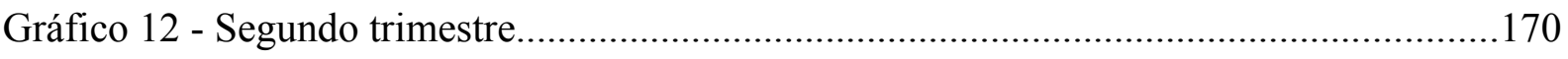

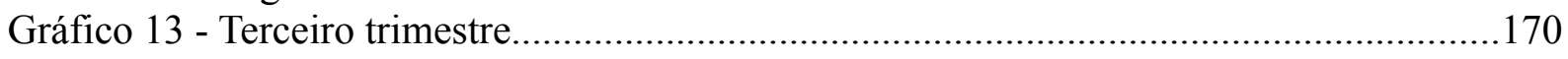




\section{LISTA DE MAPAS}

Mapa 1 - Localização do Núcleo Monte Azul e das residências das usuárias do ambulatório do

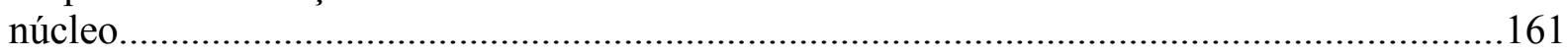
Mapa 2 - Localização do Núcleo Peinha e das residências das usuárias do ambulatório do núcleo. 


\section{LISTA DE TABELAS}

Tabela 1 - Caracterização das profissionais participantes....................................................121

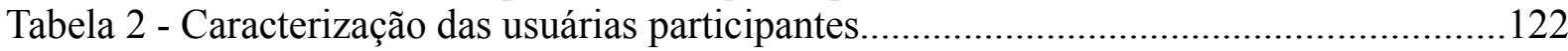

Tabela 3 - Caracterização das usuárias participantes.............................................................123

Tabela 4 - Momento de realização das entrevistas com as usuárias e intervalo entre elas.....132

Tabela 5 - Especialidades no ambulatório do núcleo monte azul........................................136

Tabela 6 - Programação do ciclo de palestras em 2008........................................................152

Tabela 7 - Caracterização da clientela e do serviço de atenção ao pré-natal do Núcleo Monte

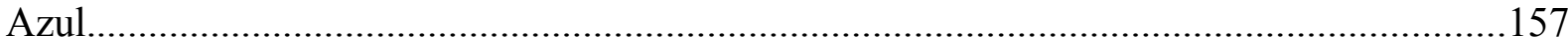

Tabela 8 - Caracterização da clientela e do serviço de atenção ao pré-natal do Núcleo Peinha.

Tabela 9 - Número de consultas pré-natais realizadas pelas participantes e distribuição ao

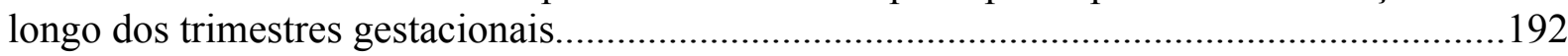

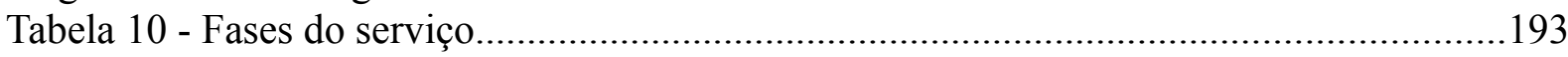

Tabela 11 - Fase de utilização do serviço pelas participantes................................................194

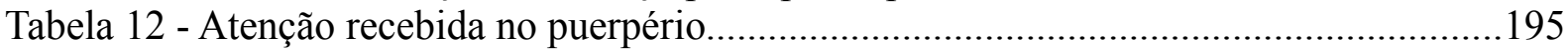

Tabela 13 - Participação em outras atividades no pré-natal e após o parto...............................196

Tabela 14 - Modo de chegada ao serviço................................................................................197 


\section{LISTA DE ABREVIATURAS E SIGLAS}

ACSs Agentes Comunitários de Saúde

MS Ministério da Saúde

OMS Organização Mundial de Saúde

PAISM Programa de Assistência Integral à Saúde da Mulher

PHPN Programa de Humanização no Pré-Natal e Nascimento

PNH Política Nacional de Humanização

PNHAH Programa Nacional de Humanização da Assistência Hospitalar

PSF Programa Saúde da Família

SUS Sistema Único de Saúde

UBS Unidade Básica de Saúde 


\section{SUMÁRIO}

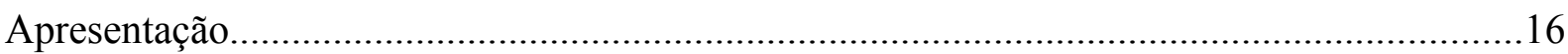

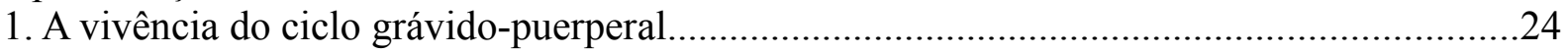

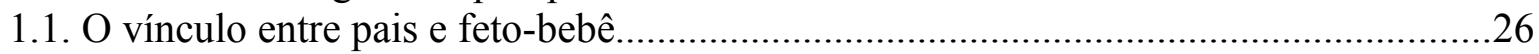

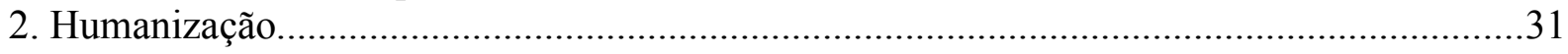

2.1. Humanização da assistência ao ciclo grávido-puerperal no Brasil..............................42

2.1.1. O Programa de Humanização no Pré-Natal e Nascimento.....................................44

2.1.2. Em busca de um conceito de humanização: análise de documentos ministeriais. 45

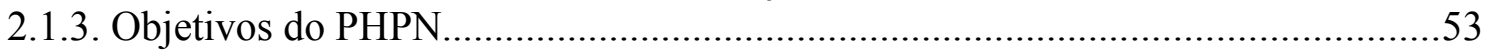

2.1.4. Algumas condutas definidas pelo PHPN..............................................................54

2.1.5. Implementação do PHPN no contexto brasileiro de atenção ao pré-natal e ao

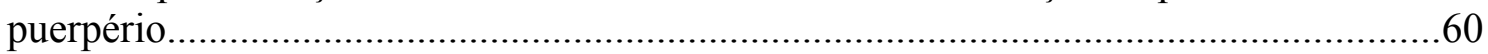

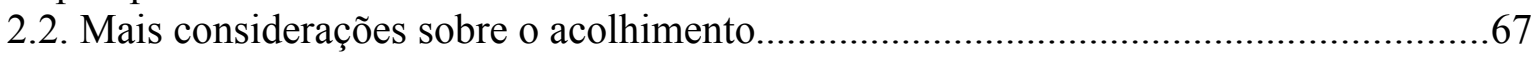

2.2.1. Discussões em torno do conceito de acolhimento...............................................68

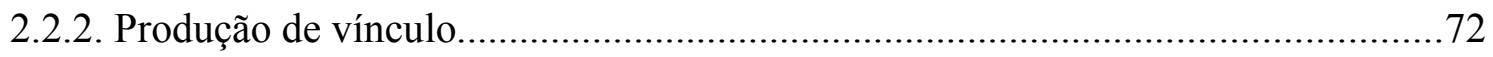

2.2.3. A investigação dos processos de acolhimento e produção de vínculo nos serviços

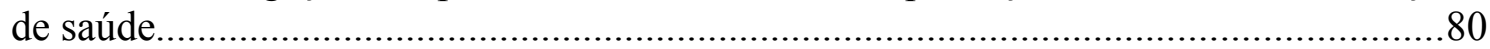

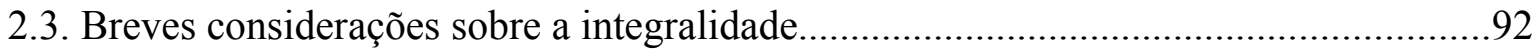

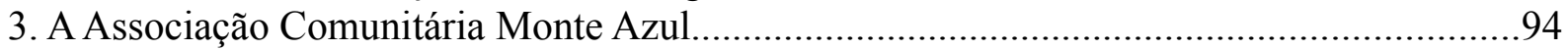

3.1. A área de saúde e o ambulatório do Núcleo Monte Azul...........................................103

3.1.1. Acompanhamento ao ciclo grávido-puerperal no Núcleo Monte Azul...............107

3.2. Antroposofia e sua aplicação no campo da Saúde....................................................110

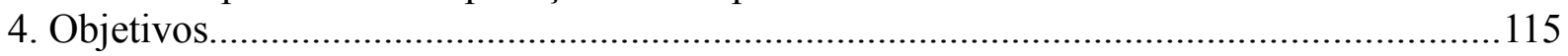

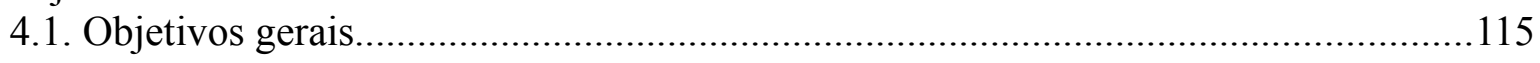

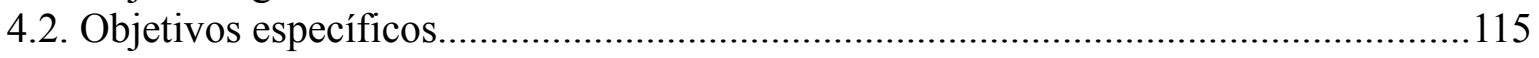

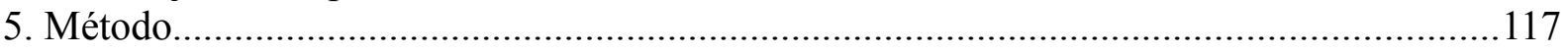

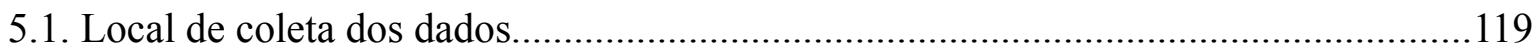

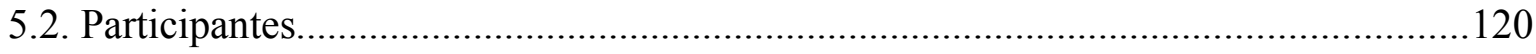

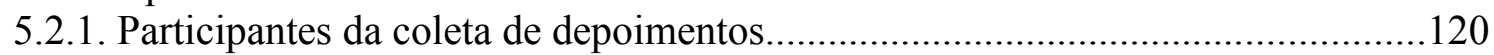

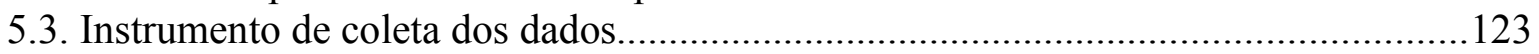

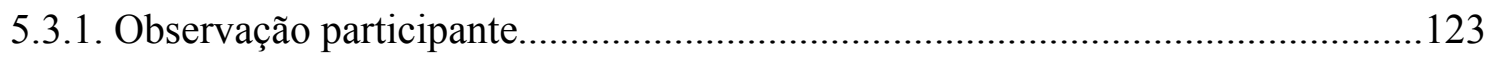

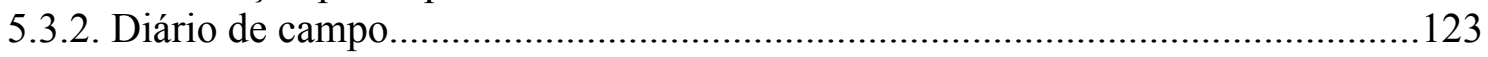

5.3.3. Entrevista semiestruturada segundo a ótica da reflexividade.............................. 124

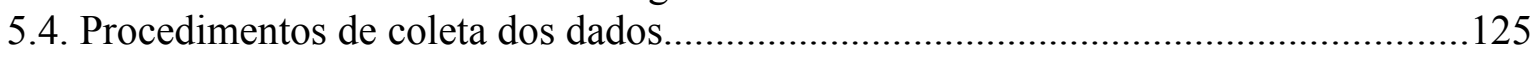

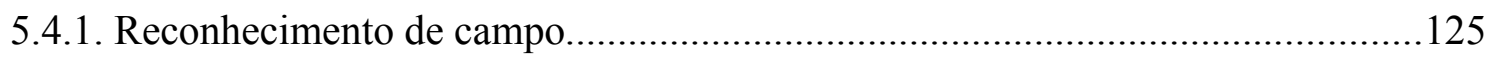

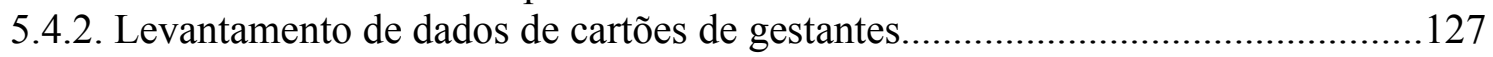

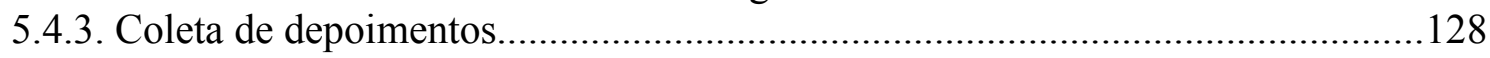

6. Descrevendo o campo: o serviço de atenção ao pré-natal e ao puerpério nos Núcleos Monte

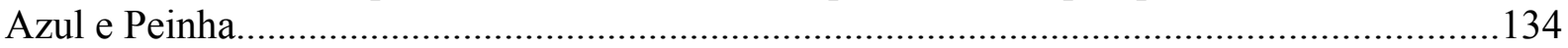

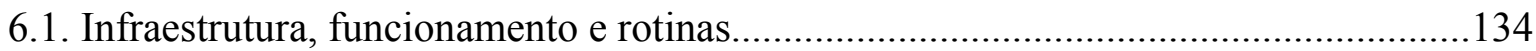

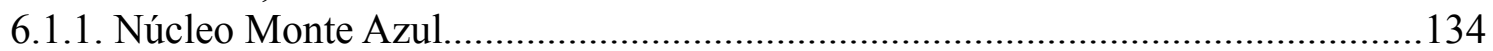

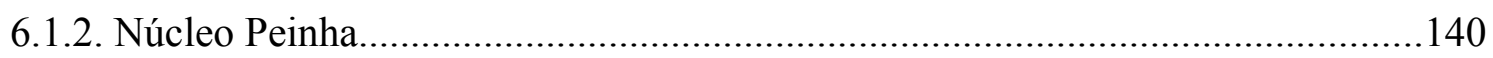

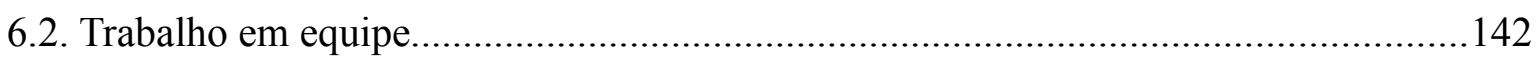

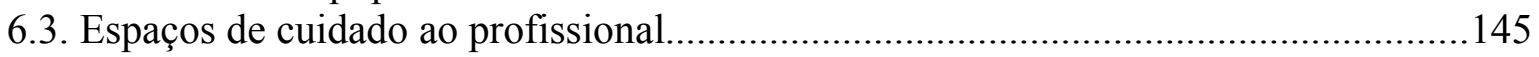

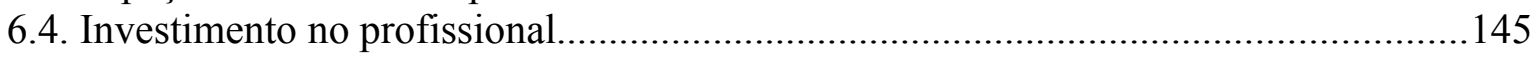

6.5. Atenção ao pré-natal e ao puerpério.................................................................. 146 


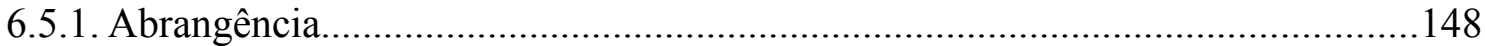

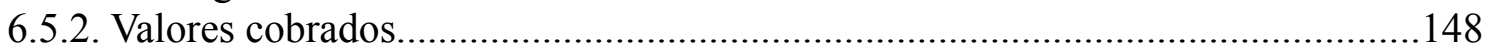

6.5.3. Parcerias entre o Núcleo Monte Azul e o SUS.....................................................149

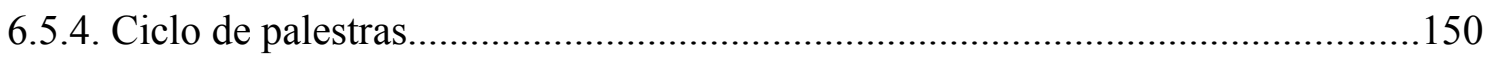

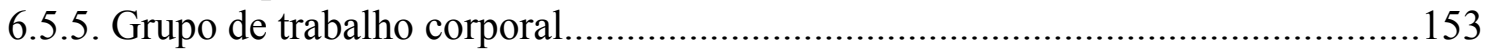

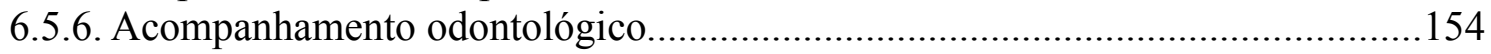

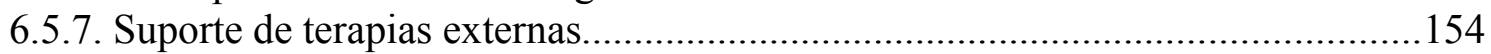

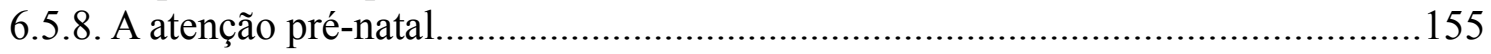

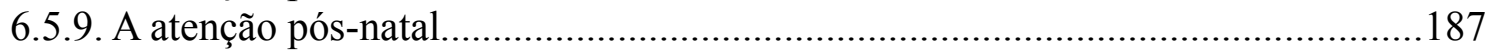

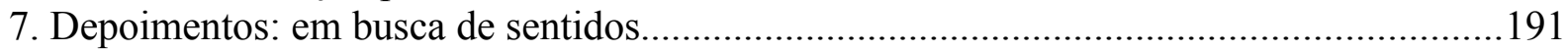

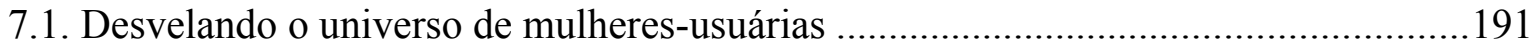

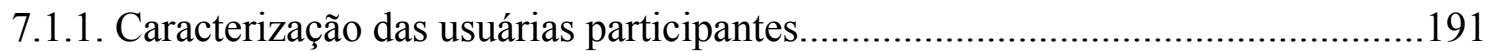

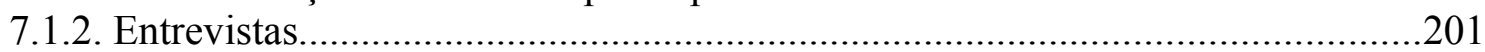

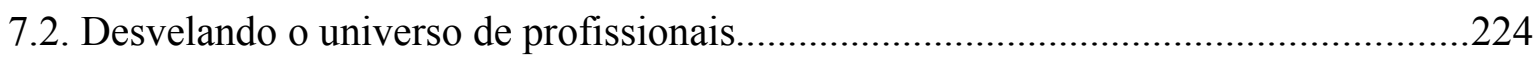

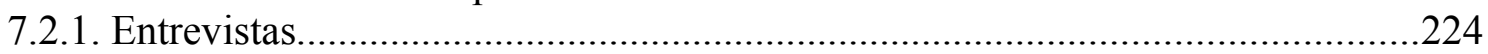

8. Humanização do cuidado pré e pós-natal no Núcleo Monte Azul: ampliações e articulações

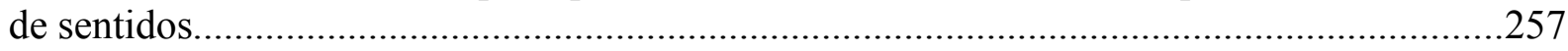

8.1. Percepções e avaliação do cuidado pré e pós-natal provido pelo Núcleo Monte Azul

.

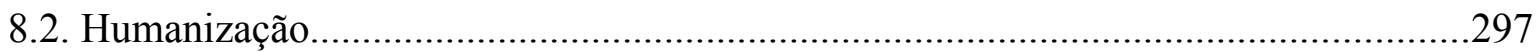

8.2.1. Breves considerações sobre alguns dos parâmetros definidos no PHPN............312

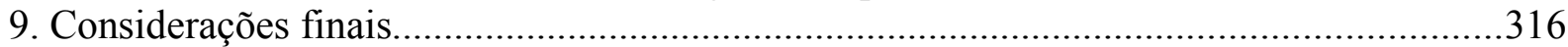

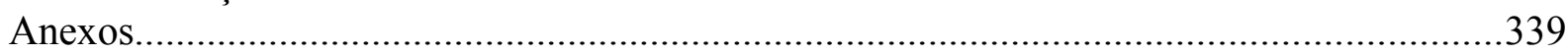

Anexo A - Indicadores de processo para monitoramento da atenção ao pré-natal e puerpério

Anexo B - Parâmetros estabelecidos para a atenção ao pré-natal e ao puerpério....................341

Anexo C - Autorização da Associação Comunitária Monte Azul à realização da pesquisa...343

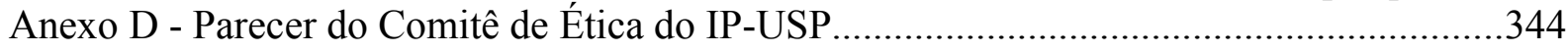

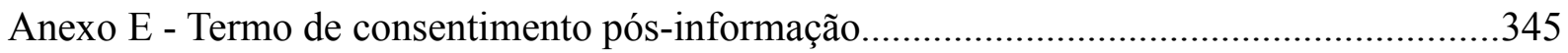

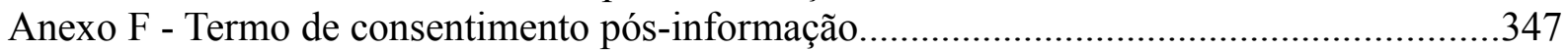

Anexo G - Termo de consentimento pós-informação................................................................. 


\section{APRESENTAÇÃO}

Foi já no início da graduação em Psicologia que me vi absolutamente encantada, e chamada, pelo tema da atenção à gravidez, ao parto e ao puerpério. Em meio aos escritos de Helen Bee e de Maria Thereza Maldonado, estudados na disciplina de Psicologia do Desenvolvimento I, comecei a tecer minhas primeiras reflexões acerca da possibilidade de o cuidado à família, no seu momento inicial, constituir-se importante recurso de promoção de saúde, especialmente por poder traduzir-se em apoio à construção de bases favoráveis ao desenvolvimento do bebê e da família.

As escolhas profissionais que fui fazendo desde então foram, em grande parte, mobilizadas por esse encantamento e por tal pressuposto, o qual, se no início era quase uma vaga ideia de uma estudante ainda em seus primeiros passos, foi ganhando mais nitidez e fundamentação a partir de pesquisas e referenciais teóricos com os quais fui tomando contato, e da própria prática que fui construindo nesse campo.

Foi nesse caminho que me deparei com o tema da humanização do cuidado ao ciclo grávido-puerperal - período que abrange a gravidez, o parto e o puerpério -, durante um curso do qual eu então participava, de formação de multiplicadores, promovido pela Aliança Pela Infância, uma rede de pessoas e organizações envolvidas com programas voltados para a infância. O que eu ali ouvi veio, justamente, ao encontro daquele meu pressuposto: a defesa da humanização como o cuidado comprometido com o trazer uma vida ao mundo com amor e respeito, de modo a promover uma cultura de paz. Produziu-se em mim, então, um segundo encantamento. Aquele meu pressuposto acabara de ganhar proporções ainda maiores ao se associar à possibilidade de contribuir para construção de uma nova sociedade.

Cabe aqui um aparte. Foi durante esse evento que conheci a Associação Comunitária Monte Azul - organização não-governamental vinculada à Aliança - e o serviço de pré e pósnatal por ela prestado. Alguns de seus colaboradores - dentre eles, a enfermeira-obstetra responsável por esse serviço na Associação - estavam ministrando minicursos e palestras, nos quais não apenas debatiam a tal humanização como apresentavam os projetos que estavam sendo desenvolvidos na instituição em torno deste fim.

A partir de então, paralelamente à investigação do tema da vivência do ciclo grávidopuerperal, pus-me a também estudar a questão da humanização, o que me levou a participar 
de um curso de formação em doula (acompanhante treinada de parto), promovido pelo Grupo de Apoio à Maternidade Ativa (GAMA). Tratou-se de uma experiência importante por ter me proporcionado ampliação de conhecimento acerca de outras frentes e sentidos associados à humanização. Ali, mais especialmente, eu contatei o lado da militância do movimento; militância de mulheres e de profissionais em favor da garantia à atenção ao ciclo grávidopuerperal baseada em evidências científicas e no direito da mulher a ser tratada com respeito e validada em seu protagonismo; incluindo-se aí o resgate da naturalidade do parto e do empoderamento da mulher, o que lhe permitiria a reconexão com a capacidade de seu corpo de gestar e parir e assumir, então, um lugar ativo na produção de cuidados ao pré-natal, ao parto e ao puerpério.

Foi também nessa ocasião que me familiarizei com os trabalhos de Michel Odent - um dos expoentes do movimento de humanização -, os quais apresentavam evidências sobre o substrato neuro-hormonal vivido pela mulher durante o parto e discutiam a associação entre um contexto favorável de gestação e de parto e a promoção da capacidade de amar. A interrelação dos meus temas de interesse tornava-se, assim, cada vez mais estreita; ao mesmo tempo, a minha prática com gestantes ia ganhando novos tons.

Paralelamente a esse caminho, eu estava também realizando uma formação em Gestalt-Terapia, o que imprimia, cada vez mais, determinadas especificidades ao meu olhar sobre o mundo, o homem e o viver. Resumidamente, o referencial gestáltico entende os fenômenos sempre situados em um dado campo, estabelecendo relações entre si e com esse campo. O homem, portanto, está sempre situado e em relação com o mundo e com os seres. E é pelo encontro genuíno com o outro - que em Gestalt denomina-se dialógico (JACOBS, 1997; YONTEF, 1998) - que ele realiza sua humanidade, que pode descobrir suas potencialidades e encontrar o caminho de se tornar quem é. Essa ênfase na relação, que nos faz acreditar que, no processo psicoterapêutico, a cura é por ela mobilizada, certamente influenciaria meu olhar sobre a humanização.

O homem, em Gestalt-Terapia, é também compreendido como totalidade, ou seja, corpo físico, emoções e cognições compõem uma unidade integrada (YONTEF, 1998). Em decorrência, o desenvolvimento humano deveria ser também pensado a partir dessa totalidade. Embora houvesse quase nada a respeito do ciclo grávido-puerperal sob a ótica da GestaltTerapia, o tema do desenvolvimento vinha sendo estudado por alguns autores. Principalmente com base nos trabalhos de Joana Wilheim acerca da vida fetal; de Thomas Berry Brazelton e 
de Marshal Klaus e John Kennell, sobre construção do apego no ciclo grávido-puerperal; e na teoria do apego de John Bowlby; vinha-se entendendo o pré-natal, o parto e as primeiras interações vividas após o nascimento como os primórdios do desenvolvimento e como matriz dos vínculos afetivos (NOGUEIRA et al., 1995; FERNANDES et al., 2000).

Todos esses referenciais, de humanização e de Gestalt-Terapia, acabaram por convergir em um trabalho de pesquisa que teve como foco principal a promoção e o fortalecimento do vínculo entre pais e bebê durante o pré-natal; e como objetivos específicos, a ampliação de consciência corporal na mulher e a elaboração dos papéis materno e paterno; a partir do acompanhamento de um casal do segundo mês gestacional ao terceiro mês pós-parto (LIMA, 2006). Tratou-se de um primeiro esforço no sentido de costurar tais referenciais, cujas inter-relações se mostravam, para mim, possíveis.

Durante o desenvolvimento de tal trabalho, começou a se destacar, como tema relevante de maior investigação, o impacto de um cuidado humanizado ao ciclo grávidopuerperal sobre a construção dos primeiros vínculos entre pais e bebê. Aprofundando a pesquisa na produção da área, notei que não havia muitos estudos produzidos pela Psicologia. Além disso, a ênfase residia principalmente na vivência do parto. Entendendo, porém, o ciclo grávido-puerperal como processo, evidenciava-se para mim uma lacuna. Por mais que o parto humanizado se mostrasse potencialmente favorecedor da construção dos primeiros vínculos o que passa também por outros fatores, como a experiência de satisfação da mulher com o próprio parto -, eu percebia a fragmentação de um processo que tinha início muito antes.

A partir de tais inquietações e motivações propus um projeto inicial de mestrado que visava compreender o impacto de uma prática humanizada, durante o ciclo grávido-puerperal, na construção dos primeiros vínculos entre pais e bebê. Como campo de realização do estudo, partindo da compreensão do processo vivido ao longo da gestação, do parto e do puerpério, pareceu-me importante procurar um serviço em que a humanização do cuidado se desse desde o pré-natal até o puerpério. Lembrando-me do que eu ouvira durante o curso da Aliança Pela Infância, o ambulatório da Associação Comunitária Monte Azul afigurou-se-me um local interessante para realizar o trabalho, na medida em que parecia atender a essa demanda. Era lá oferecido acompanhamento pré e pós-natal. Além disso, uma Casa de Parto estava, na época, em construção ${ }^{1}$. Caso fosse inaugurada a tempo da realização da coleta dos dados, haveria

1 À época do início da coleta dos dados, a construção da Casa estava para ser finalizada e a Associação aguardava efetivação de parceria com o SUS para inaugurá-la. Em função das indefinições em torno desse cenário, porém, o presente estudo focou apenas o cuidado pré e pós-natal. 
possibilidade de acompanhar o processo inteiro na organização; justamente como eu intencionava.

Assim, entrei em contato com a enfermeira-obstetra responsável pela prestação do serviço de pré e pós-natal na Associação, que eu conhecera no evento citado da Aliança Pela Infância, para saber se seria possível realizar o estudo naquela instituição. Ela, então, colocoume em contato com uma das diretoras da área de saúde que, após conhecer o projeto, autorizou-me a lá realizá-lo. Assim, em fevereiro de 2007 eu iniciava o trabalho de campo.

A despeito da autorreferência do serviço como humanizado, eu entendia que um dos primeiros passos do estudo deveria ser avaliá-lo de modo a verificar se tal humanização de fato se dava, e compreender, caso se desse, suas especificidades ali. Tendo em vista, porém, como apontado por Diniz (2005), a polissemia que marca o fenômeno, pareceu-me que eu deveria, primeiramente, definir um conceito norteador, que me permitisse situar em campo e melhor construir uma metodologia. O esforço empreendido nesse sentido levou-me ao Programa de Humanização no Pré-Natal e Nascimento (PHPN), instituído pelo Ministério da Saúde, em junho de 2000.

O PHPN acabou por se revelar referencial interessante de ser adotado no estudo, por alguns motivos. Inserido no campo de políticas públicas, embora aplicável mais diretamente ao SUS, permeia também os demais serviços de saúde do país, o que o põe em lugar de destaque no cenário de humanização da atenção ao ciclo grávido-puerperal. Ademais, por definir um conjunto de critérios para a constituição de um cuidado humanizado, ele me possibilitava melhor orientar em campo, especialmente no que se refere aos aspectos concernentes à estruturação do serviço e à operacionalização do cuidado, mais distantes de minha formação e prática como psicóloga.

Assim, pus-me a elaborar um conceito de humanização a partir de alguns referenciais presentes na literatura e, principalmente, da análise de documentos, manuais e cartilhas ligados ao PHPN e à PNH - Política Nacional de Humanização. Investiguei, também, outros materiais do Ministério da Saúde relacionados ao tema, assim como estudos voltados à avaliação da implementação do PHPN no país.

A partir de então, o projeto começou a se revestir de novos tons. Em meio a tais investigações identifiquei algumas contradições no PHPN, especialmente na proposta de monitoração do programa, que estabelecia indicadores de processo que não incluíam todas as dimensões ali definidas como aquelas que deveriam constituir um cuidado humanizado. Em 
decorrência, a maior parte dos estudos dedicados à avaliação da implementação do programa no país, pautados em tais indicadores, não abordava essas outras dimensões, a despeito do destaque dado a algumas delas - caso do acolhimento, referido no PHPN como "aspecto essencial da política de humanização" (BRASIL, 2006, p. 13). Diante disso, ao mesmo tempo em que se evidenciava para mim a relevância de empreender um estudo que abarcasse a humanização com ênfase no tema do acolhimento, à luz do PHPN, parecia-me importante refletir sobre tais contradições, suas possíveis repercussões à sedimentação da humanização do cuidado e as possibilidades de superá-las; o que incorporei, então, como pano de fundo do projeto.

Pensar nessas questões a partir de outro universo - como aquele traduzido por uma organização não-governamental - evidenciou-se, a princípio, um desafio, diante das especificidades próprias aí existentes. A experiência de campo e as reflexões que foram sendo tecidas mostravam-me, porém, ser viável estabelecer inter-relações desses universos. Ademais, a possibilidade de se colher dados que contribuíssem para uma percepção mais nítida de saídas às contradições identificadas, revelou-se-me promissora.

Paralelamente a tais ampliações, ocorriam drásticas alterações nos objetivos do trabalho e na metodologia. A complexidade do tema então definido como foco do estudo, especialmente dada pela variedade de fatores envolvidos, demonstrava-se não se encaixar na proposta de um trabalho de mestrado - principalmente tendo-se em vista questões de prazo. Assim, houve uma primeira reformulação no projeto inicial e o objetivo do estudo passou a ser investigar se gestantes e/ou casais em acompanhamento pré e pós-natal em uma instituição que presta cuidado humanizado consideram haver impacto de tal cuidado em sua vivência do ciclo grávido-puerperal; e de que forma percebem e compreendem esse impacto, caso considerem que exista. Uma série de vicissitudes de campo, porém, que relato no capítulo de método, também acabou por inviabilizar essa proposta.

Retomando o que eu já havia colhido em campo; a motivação para refletir sobre as contradições apreendidas no PHPN; e o conceito de humanização que eu elaborara, que a entendia como produzida em meio às inter-relações de vários sujeitos, e em íntima associação com os processos de acolhimento, produção de vínculo e integralidade, passei a considerar a possibilidade de ampliação do foco do estudo.

Assim, empreendi nova mudança no projeto, o qual passou, então, a visar: observar, descrever e compreender como se dá a humanização do cuidado pré e pós-natal oferecido pela 
Associação Comunitária Monte Azul, tendo em vista as inter-relações de alguns dos sujeitos envolvidos na produção desse cuidado - usuárias, colaboradores e coordenadores - e o cenário no qual tais inter-relações se dão; compreender de que forma os processos de acolhimento e de produção de vínculo estabelecem relações com a humanização do cuidado, caso tais aspectos se façam presentes no serviço estudado; e refletir sobre elementos que favoreçam a superação de algumas das contradições que permeiam o campo da humanização e que contribuam, assim, para sua sedimentação. A proposta de investigar se gestantes e/ou puérperas consideram que um cuidado humanizado promove impacto em sua vivência do ciclo grávido-puerperal permaneceu entre os objetivos específicos. Quanto ao tema do vínculo, embora não tenha sido diretamente investigado, estava de tal modo atrelado ao meu olhar, que permaneceu como pano de fundo de observações e reflexões tecidas.

A mudança de objetivos gerou, naturalmente, alterações no método. Algo significativo que se deu nesse sentido é que o foco se deslocou das mulheres para a relação entre elas e as profissionais, que foram, então, incluídas no procedimento de coleta de depoimentos. Vejo que a partir disso se produziu uma modificação importante também na evolução do estudo, que passou a enfatizar, ainda mais, as questões relativas àquilo que torna viável a sedimentação da humanização do cuidado; reflexão que transcendeu, em alguns momentos, o tema da atenção humanizada ao pré-natal e ao puerpério, alocando-se no campo mais amplo de produção de cuidados em saúde.

A despeito de se mostrar factível, a proposta foi se revelando, porém, não apenas ambiciosa como arriscada. Eu estava adentrando em universo mais abrangente, já que estava investigando a organização do serviço; experiências de mulheres e de profissionais; relações estabelecidas entre os sujeitos em meio a esse cenário; inter-relações de processos; além de adotar o PHPN como referencial de um estudo realizado em uma organização nãogovernamental. A chance de o trabalho se tornar uma enorme colcha de retalhos era grande. Ademais, parecia-me claro que, de um modo geral, além de melhor evidenciar alguns pontos que já estavam sendo discutidos na literatura, eu principalmente levantaria questões a serem mais investigadas em estudos futuros, já que a maior ênfase estava em compreender a interrelação de tais fenômenos, e não, em se olhar mais de perto para cada um deles. Algo como olhar de um ponto mais alto e mapear o terreno avistado, identificando becos sem saída, cruzamentos, caminhos tortuosos ou mais retos, rotas necessárias ou equivocadas; caberia a estudos futuros a exploração de cada um desses caminhos. 
Acreditando, porém, na relevância de, mais uma vez, contribuir com o olhar desse ponto mais alto e não apenas evidenciar as inter-relações em pauta mas principalmente identificar rotas equivocadas e tentar encontrar caminhos mais interessantes à efetivação da humanização do cuidado, resolvi assumir tal risco. Demonstrou-se, assim, ainda mais fundamental definir um referencial teórico consistente que se impusesse como norteador da construção de um método, de inserção em campo e de reflexões tecidas; referencial esse que eu entendia que seria definido não apenas a partir das premissas e questões que vinham sendo discutidas mas também do que se revelava em campo. O que então se segue é fruto de tais motivações, inquietações, preocupações, construções e desconstruções e de movimentos entre teoria e campo.

Discorro, no primeiro capítulo, sobre a temática da vivência do ciclo grávidopuerperal, considerando que ela se constitui aspecto importante do campo do cuidado humanizado ao pré-natal e ao puerpério e que se faria necessária à investigação do impacto da humanização sobre a vivência de mulheres - objetivo específico do presente estudo. A questão da construção do vínculo entre pais e bebê foi também abordada, por ter-se feito presente nos discursos de mulheres e de profissionais do Núcleo Monte Azul; por ter se evidenciado como aspecto da organização do serviço; e por ter possibilitado desdobramentos no que se refere às reflexões sobre as relações estabelecidas entre usuárias e cuidadores.

Gostaria, aliás, de fazer mais um aparte. O uso do termo "cuidador", que empreguei algumas vezes ao longo deste trabalho, pode sugerir que, a relação então construída entre profissional de saúde e mulher, seja uma relação entre alguém que assume o lugar de cuidar e alguém que assume o de ser cuidado, instaurando-se, então, uma verticalidade - o que seria absolutamente equivocado diante dos pressupostos que assumi. Ao contrário, parti da compreensão, especialmente fundamentada em Merhy (1998, 2000, 2002), Teixeira (2003, 2005) e outros autores; assim como em meu referencial gestáltico, de essa ser uma relação pautada na dialogicidade e produtora de autonomia, de empoderamento e de aumento e efetivação de potencialidades. O uso que faço, portanto, do termo "cuidador" se insere nessa compreensão. Justifico o emprego do termo principalmente por considerar que, embora o cuidado possa ser de fato produzido apenas quando ambos os atores se comprometem com essa produção, é responsabilidade do profissional de saúde criar as condições para que a relação possa se estabelecer e favorecer, então, a produção do cuidado; responsabilidade essa que deve ser entendida em um contexto mais amplo, de articulação de equipe e de serviços e 
de garantia de uma série de condições ao profissional que lhe permitam a realização do trabalho - como discuto ao longo deste estudo.

No capítulo segundo, desenvolvo o tema da humanização. Apresento os diferentes sentidos que vêm sendo associados ao termo. Discorro, brevemente, sobre o movimento de humanização do cuidado à gestação, ao parto e ao puerpério no Brasil. A seguir, realizo uma análise de documentos, manuais e cartilhas ligados ao PHPN, elaborando, então, um conceito de humanização norteador do presente estudo. Apresento alguns elementos importantes do programa e discorro sobre estudos voltados à avaliação de sua implementação no Brasil, discutindo, então, as contradições aí evidenciadas. Adiante, abordo a temática do acolhimento: situo o conceito; apresento alguns estudos que tiveram como foco esse fenômeno, tanto no campo mais amplo de produção de cuidados em saúde, quanto naquele de atenção ao pré-natal e ao puerpério; e analiso suas articulações com o processo de produção de vínculos, a partir de discussões presentes na literatura e de reflexões por mim tecidas a partir do referencial gestáltico de atitude dialógica e figura de apego seguro. Por fim, faço breves considerações sobre o tema da integralidade.

No terceiro capítulo, apresento a Associação Comunitária Monte Azul e discorro, brevemente, acerca da Antroposofia e de sua aplicação na área da saúde, uma vez que tal referencial filosófico fundamenta o trabalho realizado na organização.

No capítulo quarto, apresento os objetivos do presente estudo, e no quinto, o método. No sexto capítulo faço uma descrição do campo onde foram coletados os dados. No sétimo, analiso as entrevistas realizadas com as usuárias e com as profissionais. O capítulo oitavo é constituído pela discussão dos dados. E, por fim, no capítulo nono, faço considerações finais. 


\section{A VIVÊNCIA DO CICLO GRÁVIDO-PUERPERAL}

O ciclo grávido-puerperal - período que abrange gravidez, parto e puerpério - é um momento marcado por profundas transformações na identidade, na vida conjugal, se esse for o caso, e na dinâmica de vida dos futuros pais. Torna-se necessário um rearranjo de papéis e uma reorganização de todo o contexto de vida pessoal - especialmente da mulher - e conjugal. (LIMA, 2003).

A chegada de um bebê, para Brazelton (1988), é um evento desafiador. Pode ser recompensador e representar oportunidades, tais como formar, ou ampliar, uma família, crescer pessoalmente e amadurecer. Por outro lado, o sentimento de responsabilidade que surge pode vir acompanhado de ansiedade, preocupação excessiva e, se novos pais, sensação de inexperiência e inadequação. Esse movimento, segundo Maldonado (1999), se traduz em ambivalência, especialmente entre desejar e não desejar a maternidade/paternidade, que se manifesta desde o início da gestação.

A vivência do ciclo grávido-puerperal, para a autora, é um fenômeno em que interatua uma série de fatores que devem ser considerados. Um deles é o contexto existencial da gravidez, ou seja, o tipo de vínculo entre a gestante e o pai do bebê, a idade e o momento de vida da mulher, e se a gravidez veio após muitas tentativas ou abortos. Para Klaus e Kennell (1992), também importa saber: se a gravidez foi planejada; se está podendo ser aceita; se é o primeiro filho; se os pais vivem juntos e, nesse caso, como se relacionam; como a mulher vivencia as modificações psicofísicas ocasionadas pela gravidez; como o homem se relaciona com tais modificações; como ambos estão vivenciando o tornar-se pai/mãe.

Outros fatores apontados por Maldonado (1999, p. 32) são: características de evolução da gestação, especialmente se for de baixo ou alto risco; contexto socioeconômico, ou seja, quais as condições de que dispõem os futuros pais para cuidar do bebê; e contexto assistencial, isto é, "se a mulher recebe uma assistência adequada de profissionais nos quais confia ou se é atendida de modo precário e insatisfatório".

Para a autora, a compreensão das vivências do ciclo grávido-puerperal também deve considerar as peculiaridades de cada trimestre de gestação: no primeiro, são mais marcantes náuseas e vômitos, hipersonia, desejos ou aversões - especialmente em relação a alimentos -, oscilações de humor, aumento da sensibilidade e maior irritabilidade. Além disso, é 
importante atentar para a forma com que a mulher se percebe, ou não se percebe, grávida e como a ambivalência entre desejar ou não desejar ter um filho vai se manifestando. No segundo trimestre, são mais características alterações do desejo e desempenho sexual, modificações do esquema corporal e introversão, e passividade. $\mathrm{O}$ evento mais marcante desse período, entretanto, é a percepção dos movimentos fetais. A partir desse momento, segundo Klaus e Kennell (1992), o feto pode começar a ser percebido como um indivíduo independente e, assim, personificado por meio de características que passam a lhe ser atribuídas. Para os autores, tal acontecimento promove, de forma mais intensa, o vínculo entre pais e bebê. Por fim, no terceiro trimestre, conforme Maldonado (1999), a ansiedade tende a elevar-se novamente, em função da proximidade do parto e da mudança de vida que será imposta pela chegada do bebê. Surgem, também, os temores, que se manifestam tanto em fantasias como em sonhos, frequentemente relacionados a algo dar errado no parto ou ao feto apresentar alguma malformação. E torna-se mais nítida a preferência pelo sexo da criança.

Já no puerpério, definido por Gonçalves, Saldanha e Mendonça (1998, p. 227) como “o período que se segue após o nascimento do bebê até os quarenta dias pós-parto, ou até que os órgãos genitais e o estado geral da mulher voltem ao normal", a mulher, pontuam as autoras, frequentemente se sente bastante vulnerável e diante de emoções intensas, de modo que o apoio de uma rede social - companheiro, parentes e amigos - contribui de forma importante para a adaptação a essa nova fase.

Maldonado (1999) também destaca o puerpério como um período de intensas vivências emocionais. Além das alterações hormonais, ainda presentes, a nova mãe tem, então, que se haver com uma série de mudanças significativas, tanto no que se refere à rotina e às relações interpessoais, agora permeadas pelo protagonismo do bebê, quanto ao (re)conhecimento dele - em seus ritmos e demandas -, e de si mesma como cuidadora (LIMA, 2009). Ademais, Dennis e Ross (2005) e Gay, Lee e Lee (2004) apontam que tais vivências emocionais podem ser acentuadas - por vezes configurando-se em quadros de depressão - e acompanhadas de estados de fadiga devido à privação de sono frequentemente experienciada.

Alguns estudos também têm demonstrado que, findo o puerpério - cuja definição acima apresentada, vale notar, é essencialmente fundamentada em um estado orgânico -, as mulheres continuam a se deparar com questões de saúde física e mental, de estilo de vida e com aquelas concernentes à maternidade (WALKER; WILGING, 2000). A esse respeito, 
Brazelton (1988) destaca que os três primeiros meses após o parto são os mais difíceis e envolvem muitas adaptações; se os pais não sentirem que conseguiram superá-las, no quarto mês podem não conseguir se sentir satisfeitos com a própria paternidade e perceberem-se incompetentes nos papéis materno e paterno. Além disso, Diniz (2007) cita ter-se observado, na Inglaterra, que as dificuldades vividas se estendem ao longo de todo o primeiro ano de vida do bebê, o que se evidenciou a partir de alto índice de suicídio de mulheres nesse período. Por essa razão, estendeu-se, nesse país, o período de cuidados à família recém formada (informação verbal) ${ }^{2}$.

\subsection{O VÍNCULO ENTRE PAIS E FETO-BEBÊ}

Algo sobre o que ainda convém discorrer, a propósito da vivência do ciclo grávidopuerperal, refere-se à constituição do vínculo entre pais e bebê. Para Brazelton (1988), trata-se de um foco essencial desse período e que tem como elementos chave a elaboração, durante a gravidez, da tarefa de se tornar mãe e, após o parto, da aceitação do papel materno. O autor também aponta a importância da ansiedade vivida pelos pais durante a gestação, pois, à medida que, por conta dela, eles voltam a atenção e a preocupação para o feto, podem ir se ajustando e assim se preparando para dar conta das responsabilidades que envolvem um bebê.

Dentre outros aspectos relacionados à construção de vínculo, Klaus e Kennell (1992) destacam o contexto existencial da gestação e o suporte recebido pela mulher. A esse respeito, referem ter sido observada inibição da vinculação com o feto quando a mulher não recebe apoio durante a gravidez. Da mesma forma, de acordo com Bee (1994), as mulheres que mais obtêm suporte nesse período são aquelas que se mostram mais disponíveis para o bebê após o parto.

Outro elemento apontado por Klaus e Kennell (1992) reside na percepção dos movimentos fetais como algo importante à concretização da existência do feto e do vínculo com ele, como já mencionado. Por essa razão, a ecografia (BRASIL, 2006b) e a ultrassonografia (LIMA, 2006) valem ser ressaltadas como procedimentos que podem

2 Informação fornecida por Carmen Simone Grilo Diniz durante a disciplina "Saúde Materno-Infantil Baseada em Evidências" ministrada pela docente na FSP-USP em 2007. 
promover impactos significativos nesse sentido.

Lima (2006) descreve, ainda, como aspecto de tal construção, a ampliação de consciência corporal, considerada como veículo para percepção do próprio corpo em transformação pela gravidez e do feto em desenvolvimento no ventre materno.

Por sua vez, mais especificamente, a vinculação do pai com o feto-bebê, segundo Maldonado, Dickstein e Nahoum (1990), costuma ser mais lenta, consolidando-se, de fato, apenas após o parto; o que foi também observado por Lima (2003). Por essa razão, em trabalho posterior (LIMA, 2006), a autora salienta a importância de o pai ser incluído nas atividades de pré-natal e encorajado a interagir com o bebê via ventre materno.

No estudo em questão, Lima (2006) acompanhou um casal ao longo do ciclo grávidopuerperal visando ao fortalecimento do vínculo entre pais e feto-bebê. Ela descreve que nesse período a mulher, em especial, constantemente conversava com esse último, demonstrava afeto por ele, preocupação com seu bem-estar e, juntamente com o companheiro, já o consideravam como membro integrante da família, de modo que após o parto tal relação foi vivida como continuidade. Da mesma forma, refere-se em Klaus e Kennell (1992, p. 33):

\footnotetext{
O desenvolvimento do apego dos pais é evidenciado durante a gravidez à medida que ambos, afetuosamente, tocam e afagam o feto, através da delgada parede abdominal, e a quem percebem como alguém que lhes responde pelo movimento. Imediatamente após o nascimento, o comentário da mãe, quando o bebê volta-se em direção à voz do pai: "Veja, ela conhece sua voz; você falou tanto com ela", indica que os pais passaram momentos íntimos falando com o feto. Durante o terceiro trimestre, a mulher parece abraçar o feto no útero, quando, sentada, sorrindo, envolve com os braços, seu ventre.
}

Algo importante de se ter em vista é que à medida que se desenvolve, o feto vai se tornando capaz de interagir com o mundo, via ventre materno. Segundo Cyrulnik (2004), os órgãos sensoriais começam a se formar cedo e a partir da sétima semana de vida o feto já é capaz de experienciar sensações táteis. Olfato e paladar, operando ainda como um único sentido, surgem algumas semanas depois. Por volta da vigésima quarta semana, o bebê se torna capaz de perceber sons, especialmente por meio da vibração do corpo materno. Além disso, Wilheim (1997) destaca que o feto, além de já se movimentar, chora, suga o polegar, brinca com o cordão umbilical, dorme, sonha etc., o que representa aprendizagem e exercício de funções que lhe serão necessárias após o nascimento, ainda que em proporções diferentes. A autora ainda aponta que ele já apresenta, também, reações emocionais - como irritação 
diante de situações que o desagradam -, movimentos defensivos - como tentativa de afastar a agulha durante um exame de amniocentese -, e não apenas é capaz de apreender vivências emocionais de sua mãe e sua relação afetiva com ele como vive o impacto de tais experiências. De fato, segundo Odent (2002, 2003), diante de um ambiente intrauterino com altos índices de dopamina, serotonina e ocitocina, há a promoção da capacidade de amar; por outro lado, contextos de estresse podem aumentar o risco de prematuridade e de baixo peso ao nascimento e, mais tarde, de dificuldades de sociabilidade e de transtornos psiquiátricos.

Portanto, o feto-bebê já é um ser ativo em sua vida intrauterina. Uma primeira decorrência de tal compreensão, relacionada à construção do vínculo entre pais e bebê, é considerar que essa é também, em alguma medida, moldada pelo feto, como discutem Nogueira et al. (1995). Ademais, entendendo-se ser esse já um primeiro contexto de desenvolvimento, não apenas físico mas também psicológico - ainda que se considere que há muito a ser vivido posteriormente e, por isso, não se trate de algo determinístico (LIMA, 2009) - evidencia-se a importância de um adequado acompanhamento, durante o ciclo grávido-puerperal da mulher, de seu companheiro - se esse for o caso - e de demais figuras que integrem o campo familiar ${ }^{3}$.

Ainda no tema da constituição do vínculo entre pais e bebê, cabe um breve comentário acerca do apego, tal como proposto por Bowlby (1990), que se diferencia do emprego que Brazelton (1988) e Klaus e Kennell (1992) fazem do termo - também aplicado ao vínculo dos pais com o bebê. Bowlby (1990) o define como uma forte disposição da criança, principalmente quando cansada, assustada ou doente, a buscar a proximidade e o contato com uma figura específica - que vem a se constituir na figura de apego -, considerada mais capaz de lidar com o mundo e de exercer ações de cuidado. Por conta dessa especificidade, o vínculo estabelecido entre essa figura e o bebê é chamado pelo autor de "apego-cuidado". Dentre os tipos de apego descritos por Bowlby (1990), será de interesse para o presente trabalho o apego seguro, com foco, especialmente, em atitudes e comportamentos dos pais do bebê e demais cuidadores, promotores de tal tipo de apego.

O autor alega que uma relação permeada por apego seguro é marcada por afeto, intimidade e continuidade, e capaz de proporcionar prazer tanto à criança quanto à mãe - ou outro cuidador que esteja desempenhando o papel de figura de apego seguro. Ainsworth

3 Salienta-se que o conceito de família com o qual se trabalhará no presente estudo é aquele proposto por Szymanski (2001), que a define como um grupo de pessoas que estabelecem o compromisso de uma ligação duradora, e uma relação de cuidado entre os adultos e desses com crianças e idosos que façam parte de tal contexto. 
(1978), uma das principais colaboradoras de Bowlby, destaca que o cuidador que assume tal papel é sensível e atento às necessidades do bebê, percebendo e interpretando os sinais dele de maneira consistente e precisa, respondendo pronta $^{4}$ e adequadamente. Ajusta suas intervenções de acordo com os sinais do bebê, permitindo-lhe que se mobilize a responder em seu próprio ritmo. Não realiza os cuidados rotineiros de forma mecânica e, tampouco, com frieza; ao executá-los, interage cuidadosa e afetivamente com a criança. Inicia, continuamente, interações com ela, sempre permeadas por contato físico cuidadoso e amoroso, sem aversão ou ambivalência pronunciada. E, principalmente, mantém-se como base segura a partir da qual a criança pode se lançar ao mundo, tranquilizando-a quando ela se depara com alguma situação que a aflige. Logo, o cuidador é alguém em quem a criança aprende a confiar, alguém com quem ela sabe que poderá contar sempre que sinta necessidade. A figura de apego seguro, portanto, é alguém que compõe cuidado amoroso e consistente com promoção de autonomia.

Como sugere estudo realizado por Lima (2006), ainda que esses comportamentos se manifestem apenas após o parto, o período pré-natal constitui um momento importante, em que homem e mulher, envolvidos com o bebê em desenvolvimento no ambiente intrauterino, com a construção do vínculo com ele e com os cuidados com a gravidez, preparam-se para assumir a função de figura de apego seguro; o que deve ser facilitado pelos profissionais que os acompanham durante o ciclo grávido-puerperal.

Comentando sobre a importância do apego, Klaus e Kennell (1992, p. 29) afirmam que é a força dessa relação que permite aos pais fazer os sacrifícios necessários aos cuidados do bebê, como atravessar madrugadas e se porem continuamente disponíveis ao cuidado desse novo ser. Além disso, os autores apontam que "já que na espécie humana o bebê é totalmente dependente da sua mãe ou de um 'cuidador' para satisfazer todas as suas necessidades físicas e emocionais, a força e a durabilidade do apego podem perfeitamente determinar se ele irá ou não sobreviver e desenvolver-se favoravelmente".

De fato, no que se refere ao desenvolvimento psicológico, Bowlby (1990) afirma que a criança seguramente apegada é mais autoconfiante, utilizando a figura de apego seguro como base para lançar-se ao mundo; quando aflita, deixa-se confortar sem raiva ou ambivalência; é

4 Convém ressaltar que tanto Ainsworth (1978) quanto Bowlby (1990) defendem que a constituição de uma relação de apego seguro está relacionada com o fator "responsividade", o que envolve a rapidez com que a figura de apego atende a criança aflita. Brazelton (1988), por outro lado - posição com a qual se concorda no presente trabalho -, acredita que é importante que esse atendimento não seja imediato, de modo que a criança possa ter um tempo para se autoregular e, assim, ir descobrindo recursos para lidar com o mundo. 
mais tolerante à frustração e a experiências negativas; possuindo expectativas positivas em relação ao mundo, acredita no valor das pessoas e se coloca mais confiante nas relações; são mais curiosas, mais hábeis socialmente e mais sensíveis às aflições de outras crianças.

Apesar de ter desenvolvido o tema do apego com foco nas relações entre a criança e seus cuidadores, o próprio Bowlby (1990) adverte que, se os comportamentos de apego, por um lado, progressivamente perdem sua centralidade, por outro lado, eles se mantêm como algo fundamental ao longo de toda a vida, sendo acionados, especialmente, quando o indivíduo se vê diante de dificuldades. Além disso, conforme a criança cresce e seus universos relacionais se ampliam, novas figuras de apego começam a surgir, dentre membros da família ampliada, professores e outras pessoas com as quais se identifique e em quem confie; mais tarde, grupos, instituições e religião poderão também desempenhar esse papel. 


\section{HUMANIZAÇÃO}

O termo "humanização" deriva, segundo Minayo (2006, p. 26), do conceito de humanismo, o qual, no século XXI, poderia ser compreendido como a restituição do ser humano ao seu lugar de solidariedade com a natureza e a ênfase na harmonia entre razão e sentimento. $\mathrm{Na}$ área da Saúde, refere a autora, o tema do humanismo foi incorporado ao cenário de debates, políticas e propostas sob o termo "humanização", e pode ser entendido como "um movimento instituinte do cuidado e da valorização da intersubjetividade das relações".

De fato, a associação entre humanização e resgate da intersubjetividade nos processos de produção de saúde é discutida por diversos autores (BOSI; UCHIMURA, 2007; CASATE; CORRÊA, 2005; LEITE; STRONG, 2006; TRAVERSO-YÉPEZ; MORAES, 2004). Uma das argumentações surge da contraposição a condições entendidas como desumanizadoras, relacionadas a fatores como a tentativa de uma compreensão objetiva do homem, a soberania das questões de âmbito técnico e a excessiva especialização das áreas e do trabalho. Em decorrência de tais fatores, ocorre uma mecanização e uma fragmentação do indivíduo, excluindo-se os aspectos subjetivos de sua natureza; a concepção de saúde passa a ser focada principalmente na esfera orgânica, desconsiderando, assim, a complexidade dos aspectos envolvidos nos processos de saúde e doença; e as relações tornam-se coisificadas, marcadas por verticalidade - traduzida pela crença de que o profissional de saúde detém, exclusivamente, o saber acerca do que se passa com o usuário - e pela quase inexistência da dialogicidade.

Deslandes (2004), que analisou documentos ministeriais do Programa Nacional de Humanização da Assistência Hospitalar (PNHAH) - recentemente substituído por uma política nacional de assistência, a Humaniza SUS - do Ministério da Saúde (MS), acrescenta, ainda, a esse contexto, o tema da violência presente nos processos de produção de saúde, seja aquela de nível físico e psicológico, dos maus-tratos na assistência, seja aquela de nível simbólico, expressa pelo não reconhecimento das demandas emocionais e culturais dos usuários, discutido nos documentos do programa. Por essa razão, pontua que um dos eixos norteadores do PNHAH era o de humanização como oposição à violência.

Diante de tal cenário, diversos autores (BACKES; LUNARDI FILHO; LUNARDI, 
2005; BOSI; UCHIMURA, 2007; CASATE; CORRÊA, 2005; OLIVEIRA; COLLET; VIERA, 2006; ROLIM; CARDOSO, 2006) concordam que a proposta de humanização viria, então, como uma reafirmação da impossibilidade de se compreender o homem apartado de sua subjetividade e do campo intersubjetivo, e como promoção do (re)encontro entre os sujeitos. Por essa razão, apontam como fatores fundamentais à concretização do cuidado humanizado: adotar uma concepção de homem - entendido, no contexto em pauta, como usuários, acompanhantes, profissionais de saúde e gestores - em que esse seja entendido como ser único, integral - levando-se então em conta seus aspectos físicos, subjetivos e sociais -, de direitos e de relações dialógicas; dar voz ao vivido por usuários e por profissionais; e permear a relação estabelecida entre ambos por diálogo, respeito, solidariedade, maior horizontalidade, acolhimento e produção de vínculo.

Sobre o diálogo, mais especificamente, Deslandes (2004) assinala que o eixo central da proposta do PNHAH é a compreensão da humanização como ampliação do processo comunicacional, que implica reconhecer e validar, no ato do diálogo, a palavra do outro palavra que expressa representações, emoções, demandas; e em simetria e solidariedade na relação, condições essenciais ao diálogo. Como requisito à efetivação de tal ampliação está a instauração de uma nova cultura de atendimento, outro eixo da humanização proposta pelo programa, de acordo com a autora. Essa, por sua vez, pressupõe respeitar o outro como ser singular, digno e autônomo, e em conhecer quem é esse outro, em suas expectativas e práticas.

Diante disso, problematizando a possibilidade da concretização da humanização da assistência, Deslandes (2004, p. 8) defende que a ética, o diálogo e a negociação de estratégias e de sentidos da produção de cuidados em saúde devem ser tomados como eixos norteadores. Desse modo, a humanização se traduziria em um movimento instaurador de uma nova cultura assistencial, caracterizada por maior qualidade e por "uma nova ordem relacional, pautada no reconhecimento da alteridade e no diálogo".

Uma compreensão de humanização consonante com tais considerações, aqui destacada em função, especialmente, da ampliação que ela expressa, é aquela discutida por Teixeira (2005, p. 592). Baseado em uma concepção espinosana de homem - em que este é definido por sua potência - o autor propõe que humanização é aquela que é "comprometida com a busca dos melhores meios para o homem [efetivar e] aumentar sua potência" e vivenciar um processo de singularização existencial, promovido no encontro entre usuário e profissional de 
saúde. Não qualquer encontro porém, mas especialmente aquele que é permeado por acolhimento dialogado - aqui discutido mais adiante -, o qual gera afetos de confiança e de compaixão, assim como a vivência da alteridade. Teixeira (2005) alega, então, que a possibilidade de se viabilizar um cuidado humanizado relaciona-se com avaliar-se se a rede de encontros entre profissionais e usuários, que constitui os serviços de saúde, está se dando em favor de tais processos vivenciais.

A esse cenário de ênfase ao resgate da intersubjetividade nos processos de produção de saúde, Deslandes (2004) acrescenta que, no PNHAH, revela-se uma preocupação de que tal resgate se dê de modo articulado com uma tecnologia apropriada. E mais, que nos documentos do programa reconhece-se que se a alta tecnologia sem a delicadeza do cuidado desumaniza a assistência; da mesma forma, a carência de recursos tecnológicos necessários gera estresse e conflito nas interações entre profissionais de saúde e usuários. Problematizando essa questão, que para a autora revelou o eixo, no PNHAH, da humanização como qualidade no atendimento, dada pela articulação de avanços tecnológicos e bom relacionamento, Deslandes (2004) defende que para que essa articulação possa verdadeiramente se dar, condição que considera fundamental à concretização da humanização do cuidado, deve haver uma superação da díade tecnologia/fator humano, a partir da compreensão desse último também como uma tecnologia.

Parece importante fazer uma breve digressão sobre o tema, de modo a compreender tal posição de Deslandes (2004), baseada nos escritos de Merhy. Do conjunto da obra do autor, foram aqui selecionados três de seus trabalhos (MERHY, 1998, 2000, 2002), os quais evidenciam algumas das questões sobre as quais se vem aqui discutindo, a saber, a intersubjetividade inerente aos processos de produção de saúde e as articulações tecnológicas que se dão nesses processos. Ademais, embora em tais escritos o autor não faça menção à humanização, é bastante nítido que um dos modelos que ele descreve remete a uma atenção humanizada, enquanto que o outro revela condições desumanizantes. Portanto, trata-se de referência também importante à compreensão de tal fenômeno.

Merhy (2002) discute o trabalho em saúde como um trabalho vivo em ato ${ }^{5}$ que se dá a partir do encontro entre trabalhador e usuário, cada qual portador de suas próprias necessidades. Tal encontro define um espaço intercessor partilhado - marcado por trocas

5 Aquele em que o trabalhador, expressando sua liberdade e individualidade/subjetividade - história, habilidades, criatividade, inteligência -, lança mão de saberes tecnológicos de modo a organizar o processo de produção. No trabalho vivo em ato, então, o protagonismo do trabalhador se expressa, eminentemente, pela dimensão da liberdade (MERHY, 2002). 
intersubjetivas entre ambos os atores - dinamicamente configurado. Ou seja, o usuário, ao mesmo tempo em que se constitui em objeto da ação do trabalhador, é agente, manifestando e investindo seu universo - de intencionalidades, conhecimentos e representações, pelos quais sente e elabora suas necessidades em saúde - no momento de produção do trabalho. Da mesma forma, o trabalhador, ao mesmo tempo em que se torna portador de tais necessidades dos usuários, não se descola de sua subjetividade e de suas próprias demandas. É nesse encontro, portanto, que se torna possível elaborar e satisfazer as necessidades dos sujeitos. E é por essa razão que, como tecnologias relacionais, Merhy (2002) destaca as tecnologias leves como as mais adequadas para atender às demandas em saúde.

Configurado dessa forma, prossegue Merhy (1998), o processo de produção de saúde é usuário-centrado e regido por tecnologias leves (concernentes ao acolhimento, à produção de vínculo e de autonomia, e à gestão compartilhada), as quais articulam as tecnologias duras (máquinas, procedimentos, normas e estruturas organizacionais) e leve-duras (saberes profissionais estruturados utilizados no trabalho em saúde) em favor do atendimento das necessidades que emergem nesse espaço de encontro, e se comprometem permanentemente com as tarefas de acolhimento, resolutividade, responsabilização e autonomização. Além disso, o processo de trabalho é permeado por uma gestão compartilhada nas equipes de saúde, as quais são pautadas na interdisciplinaridade.

De acordo com o autor, apenas nesse tipo de configuração tecnológica é possível a produção de qualidade na atenção em saúde, traduzida pelo atendimento mais amplo das demandas dos usuários e pelo maior grau de promoção de autonomia, que se relaciona, conforme o que se vem aqui discorrendo, com um modelo de cuidado humanizado. Merhy (1998) salienta, entretanto, que, a despeito da centralidade das tecnologias leves, tal qualidade só é atingida se as demais tecnologias forem por elas articuladas; ou seja, embora fundamentais, não são suficientes. Como exemplos, ele destaca contextos em que não se provê os exames necessários à realização de dado diagnóstico - dimensão das tecnologias duras -, ou em que o profissional não disponibiliza toda a sua sabedoria clínica - âmbito das tecnologias leve-duras. Isso remete, portanto, à necessária articulação de bom relacionamento e avanços tecnológicos (DESLANDES, 2004).

Merhy (1998) também refere que em determinados modelos técnico-assistenciais produz-se uma inversão tecnológica, da qual decorre um contexto de atenção que denomina como procedimento-centrado. Neste, são especialmente as tecnologias duras que passam a 
reger os processos de saúde, que se tornam mais comprometidos com o uso de tais tecnologias e, portanto, com a produção de procedimentos, do que com o vivido pelos usuários. Mesmo as tecnologias leve-duras ficam mais empobrecidas, em função do olhar do profissional restringir-se progressivamente, até não ser mais capaz de apreender a complexidade das vivências humanas, carregadas de subjetividade. Em decorrência, ocorre um distanciamento dos interesses e demandas do usuário e a atuação se torna cada vez mais isolada dos demais membros da equipe de saúde; um contexto, como se pode notar, marcado por condições desumanizadoras.

A partir disso, parece ser possível dizer que um modelo de atenção humanizada é um modelo usuário-centrado, em que as tecnologias leves se destacam como regentes dos processos de produção de saúde, articulando as demais tecnologias em favor das demandas identificadas, elaboradas e negociadas no espaço de encontro entre profissionais de saúde e usuários.

De modo, porém, a propiciar ao profissional de saúde assumir uma nova postura ao se colocar em relação com o usuário - uma postura que leve em conta a intersubjetividade inerente aos processos de produção de saúde e que se dê no sentido de oferecer acolhimento e produção de vínculo -, alguns autores (BACKES; LUNARDI FILHO; LUNARDI, 2005; CASATE; CORRÊA, 2005; HOGA, 2004; OLIVEIRA; COLLET; VIERA, 2006) destacam a importância de o profissional ampliar o contato com a própria subjetividade, sensibilidade e disponibilidade para a escuta, o diálogo e o estabelecimento de vínculo. Nesse sentido, Hoga (2004) defende a ampliação de autoconhecimento como recurso fundamental, permitindo ao profissional, então, contatar e elaborar limitações, potencialidades e demandas. Assim, não apenas qualifica seu trabalho, como, entrando em contato com a própria humanidade, pode melhor compreender o vivido pelo usuário e atender às suas demandas.

Porém, uma vez que tal ampliação de contato também implica, segundo a autora, acessar conflitos, limitações e dúvidas, discute-se ser necessário legitimar espaços de cuidado ao cuidador (BACKES; LUNARDI FILHO; LUNARDI, 2005; CASATE; CORRÊA, 2005; OLIVEIRA; COLLET; VIERA, 2006). De fato, Rolim e Cardoso (2006), que investigaram opiniões de enfermeiras sobre a humanização do cuidado ao recém-nascido e aos seus familiares em uma Unidade de Terapia Intensiva Neonatal, apontam terem observado, entre as participantes, uma demanda por atividades de sensibilização à integralidade do usuário; de suporte e acolhimento às dificuldades vividas no contexto 
assistencial; e de reflexão acerca da própria atuação.

De acordo com alguns autores (CASATE; CORREAA, 2005; HOGA, 2004; LEITE; STRONG, 2006; OLIVEIRA; COLLET; VIERA, 2006), tal legitimação também inclui promoção de educação continuada (CASATE; CORRÊA, 2005; OLIVEIRA; COLLET; VIERA, 2006); e melhoria das condições de trabalho, entendendo-se que elevada carga horária, sobrecarga de atividades, baixos salários, perda de autonomia e riscos ocupacionais são condições desumanizantes e desfavoráveis à possibilidade de os profissionais adotarem práticas mais humanizadas. Deslandes (2004, p. 13) acrescenta a tal conjunto, apreendido como um dos eixos do PNHAH, incentivos, constituição de equipes de saúde funcionais e elementos de infraestrutura - tais como melhoria das instalações físicas e renovação dos equipamentos -, salientando tratar-se de aspecto essencial, uma vez que "humanizar a assistência é humanizar a produção dessa assistência".

Outro ponto evidenciado como fundamental à humanização refere-se à organização interdisciplinar do serviço (OLIVEIRA; COLLET; VIERA, 2006) que, especialmente tendo em vista a promoção de funcionalidade nas equipes de saúde assim constituídas, deve associar-se à sedimentação de um espaço de troca de experiências e de fortalecimento de vínculo entre os profissionais (BACKES; LUNARDI FILHO; LUNARDI, 2005). Merhy (1998, 2002) também aponta a importância de as anteriormente citadas articulações tecnológicas em favor da qualidade em saúde não se restringirem à dimensão da postura dos profissionais, abrangendo também o âmbito da organização dos serviços - tal como se discute mais adiante. Casate e Corrêa (2005) acrescentam, ainda, que para a humanização ser concretizada, além da reorganização dos serviços de saúde, deve haver reestruturação institucional e administrativa.

Para Traverso-Yépez e Moraes (2004), especialmente diante do quadro de passividade e resignação vivido pela maior parte dos usuários no atual contexto de atenção em saúde marcado pelas condições desumanizadoras anteriormente descritas -, a humanização deve implicar não apenas o resgate da intersubjetividade e da dialogicidade mas também a garantia dos direitos dos usuários previstos pelo Sistema Único de Saúde (SUS). Tal garantia envolve o fortalecimento da capacidade de indivíduos e comunidades para assumirem uma postura ativa perante os processos de produção de saúde; implica, portanto, desenvolvimento de cidadania e participação crítica (NOGUEIRA-MARTINS; BÓGUS, 2004; OLIVEIRA; COLLET; VIERA, 2006; TAKEMOTO; SILVA, 2007). 
Tal processo de fortalecimento de participação e cidadania, conforme salientam Nogueira-Martins e Bógus (2004, p. 46), remete ao importante conceito de empoderamento, o qual se traduz em propiciar ao indivíduo e/ou comunidade ganhar poder de tomada de decisões e de empreendimento de ações, em nível individual e coletivo. Relaciona-se, assim, com "autoestima, motivação, consciência e compromisso social". Ademais, assinalam que esse processo pode apenas se dar em meio a relações que transcendam o campo restritivo da técnica e sejam então capazes de produzir vínculos que gerem informações, orientações e suporte; o que evidencia, portanto, as inter-relações desses aspectos.

Algo que ainda convém discutir concerne a uma questão que pode ser denominada como paradigmática. Diversos autores (BOSI; UCHIMURA, 2007; CASATE; CORRÊA, 2005; LEITE; STRONG, 2006; TRAVERSO-YÉPEZ; MORAES, 2004) salientam, dentre os maiores desafios à concretização da possibilidade de se instaurar um cuidado humanizado, a adoção de uma concepção de homem integral nas práticas de saúde - algo que se relaciona ao tema da exclusão da intersubjetividade de tal campo. Embora nem todos os autores façam menção a essa questão, entende-se aqui que subjaz a esse cenário um dado paradigma que sustenta concepções e práticas, o qual foi nomeado por Davis-Floyd (2001) de tecnocrático. Cabe destacar que, a despeito de a autora ter discorrido sobre o tema com foco na assistência ao parto, suas afirmações mostram-se também válidas para o campo de atenção ao pré-natal e ao puerpério, e para o âmbito mais amplo de cuidado em saúde.

De acordo com Davis-Floyd (2001), o aspecto mais marcante do paradigma tecnocrático é o princípio da separação, o qual estabelece que os fenômenos podem ser melhor compreendidos se retirados de seu contexto original. Em decorrência, dá-se uma fragmentação do indivíduo, o que resulta, por sua vez, em duas situações principais: cisão entre mente e corpo e concepção do corpo como uma máquina. O indivíduo é reduzido, então, a um corpo-objeto e o profissional de saúde se desresponsabiliza por qualquer experiência que se dê em outros âmbitos que não aquele da esfera física. A subjetividade, portanto, é retirada dos processos de produção de saúde, e elementos como acolhimento e produção de vínculo se tornam dispensáveis. A visão do corpo-máquina, ademais, leva a uma concepção de que ele precisa ser reparado por alguém, o que exclui o respeito à autonomia do indivíduo e à sua coparticipação na produção dos cuidados, alocando o profissional de saúde no papel daquele que detém, exclusivamente, o poder de tomada de decisões. Outros fatores também ligados a esse paradigma, segundo Davis-Floyd (2001), são a pouca ênfase à atenção primária e a 
subordinação das demandas do indivíduo às práticas e rotinas institucionais.

Pode-se perceber, diante disso, que as questões decorrentes de tal paradigma estão, de fato, em contraposição ao que se pretende com a humanização do cuidado. Um dos aspectos mais fundamentais de tal compreensão, segundo se entende aqui, é o de que, tendo-se em vista uma verdadeira efetivação de mudanças em prol de uma humanização, não será suficiente apenas se instaurar novas práticas, reorganizar serviços ou elaborar políticas públicas. Se tais iniciativas não forem acompanhadas pela adoção de um novo paradigma, que possa sobrepor-se ao tecnocrático, perpetuar-se-á, no mínimo, um campo fértil para a produção de contradições em meio ao cenário de mudanças.

Nesse sentido, Leite e Strong (2006) defendem que a adoção de um referencial holístico - entendido como a consideração dos fenômenos em seus múltiplos aspectos favorece a implementação da humanização, na medida em que evidencia o reducionismo imposto pela sobreposição da técnica aos demais aspectos do cuidado, assim como a intersubjetividade inerente à produção deste, realocando, então, o acolhimento, a produção de vínculo e a vivência da alteridade como aspectos centrais de tal produção.

Diante das considerações até o momento realizadas, nota-se que embora, como destaca Deslandes (2004), o conceito de humanização demande definição clara, parece haver certa consonância nas assertivas dos autores, especialmente no que concerne: ao resgate da intersubjetividade e da dialogicidade na produção do cuidado; ao reconhecimento do usuário como ser singular, de direitos e de vivências subjetivas, culturais e sociais próprias; à melhoria das condições de trabalho, na qual se inclui o oferecimento de espaços de trabalho pessoal, supervisão, reflexão e suporte ao profissional; e à adoção de um conceito de homem e de saúde que leve em conta os múltiplos aspectos que os compõem - o que se inter-relaciona com a superação do paradigma tecnocrático. A esse conjunto, Deslandes (2004) acrescentou, ainda, o aspecto de que uma atenção humanizada é também aquela que não desconsidera a importância da qualidade do ponto de vista técnico. Parece revelar-se, assim, a complexidade que cerca o campo da humanização em saúde. De acordo com Diniz (2005), também se vê, a partir disso, a polissemia que marca o conceito.

$\mathrm{Na}$ área do cuidado ao ciclo grávido-puerperal, apesar de tais sentidos se fazerem também presentes, há algumas especificidades que demandam ser aqui salientadas. Porém, primeiro, cabe ressaltar que a maior parte dos estudos que trata do tema da humanização nesse campo específico aborda, especialmente, a atenção ao parto, excetuando-se os trabalhos que 
se inserem no âmbito de políticas e programas públicos, discutidos mais adiante. Em decorrência, embora alguns desses estudos sejam apresentados a seguir, dado que, como já referido, fatores relativos ao cuidado ao parto não se incluem aqui, serão analisados mais pormenorizadamente apenas os aspectos considerados possíveis de serem aplicados à esfera da atenção ao pré-natal e ao puerpério.

Um desses aspectos refere-se à percepção de que, se no âmbito mais amplo da atenção em saúde, integra a discussão da humanização a articulação do bom atendimento com recursos tecnológicos adequados, na esfera da assistência ao ciclo grávido-puerperal há grande ênfase à questão técnica, expressa em termos da constituição de uma atenção baseada em evidências científicas.

Segundo Diniz (2005, p. 633), tal tipo de assistência é aquele que se orienta pelo "conceito de tecnologia apropriada e pelo respeito à fisiologia", ou seja, é aquele que se baseia nas evidências produzidas por revisões sistemáticas de ensaios clínicos randomizados padrão ouro estabelecido na Medicina Baseada em Evidência $(\mathrm{MBE})^{6}$ - e não em opiniões e tradições, as quais vinham resultando em perpetuação de práticas implicadas com altos índices de morbi-mortalidade materno-infantil (TORNQUIST, 2003).

A MBE se destacou como instrumento importante no movimento pela humanização do cuidado ao ciclo grávido-puerperal. Diniz (2005) explica que a MBE redefiniu o corpo da mulher, que no lugar de ser considerado como algo defeituoso e demandante de constante manipulação pelo homem, em função de sua imprevisibilidade (DAVIS-FLOYD, 2001),

6 Segundo Nobre, Bernardo e Jatene (2003) a Medicina Baseada em Evidência (MBE) se fundamenta na busca pela evidência das práticas. A produção de evidência tem como "padrão ouro" revisões sistemáticas. Uma revisão sistemática é um levantamento de estudos de boa metodologia científica - preferencialmente ensaios clínicos randomizados (BERNARDO; NOBRE; JATENE, 2004) - já realizados no mundo sobre determinado assunto. A metodologia de uma revisão, quando consistente, permite que os resultados dela obtidos sejam largamente generalizáveis. Assim, quando ela produz evidência de que um dado procedimento é indicado, ou não, para uma dada população, tem-se uma validação de uma prática clínica - ou a imposição de sua mudança. Tais revisões ficam disponíveis em bases de dados denominadas secundárias. No que se refere à humanização da atenção ao ciclo grávido-puerperal, apesar de não conter apenas dados referentes à Obstetrícia, uma das bases mais utilizadas é a Biblioteca Cochrane (http://cochrane.bireme.br).

Uma característica importante de tais revisões é que elas sejam redigidas em linguagem simples, de modo que não apenas profissionais de saúde das mais variadas áreas possam ter acesso ao conhecimento produzido como também os usuários dos serviços de saúde. Tal característica se refere, de acordo com Nobre, Bernardo e Jatene (2003), a um aspecto central do paradigma por detrás da MBE: o paciente deve participar ativamente do processo de decisões que cercam seu tratamento. Esse paradigma também impõe mudanças importantes, portanto, à postura do profissional de saúde, já que esse deve, então, estabelecer uma relação mais horizontal com o paciente. Além disso, conforme os autores, o profissional deve também passar a considerar características para além do contexto biológico, ou seja, deve deixar de olhar para o paciente como um mero "hipertenso", por exemplo, e saber que ele tem um nome, um trabalho, uma família, amigos, gostos específicos. E, a partir disso, voltar seus esforços para questões de qualidade de vida e não meramente a "marcadores biológicos". 
passou a ser tomado como apto para gestar e dar à luz; da mesma forma, a gestação, o parto e o nascimento foram, a partir de então, compreendidos como processos físiológicos, sem necessidade de tantas intervenções, tidas como desnecessárias (DINIZ, 2005).

Uma decorrência importante de tal processo, que se tornou também recorrente nas discussões sobre a humanização, refere-se ao empoderamento da mulher. Diante de um cenário ainda de luta por mudanças, considera-se que contribuir para que as mulheres se apropriem de seus direitos, de conhecimentos providos pela MBE e da capacidade de seus corpos de gestarem e darem à luz uma vida traduz-se em promover seu empoderamento, ou seja, contribuir para que tenham condições de assumirem um papel ativo nos processos de produção de saúde e, mais especificamente, nas decisões incluídas em tais processos, assim como nas experiências vividas durante o ciclo grávido-puerperal (NOGUEIRA-MARTINS; BÓGUS, 2004; TORNQUIST, 2002).

As evidências então geradas também levaram à definição de uma série de práticas norteadoras da atenção ao ciclo grávido-puerperal. Por essa razão, materiais que se constituíram em fontes de evidências, como "As recomendações da OMS" (1996) e "o Livro do Enkin" (2005), como nomeia Diniz (2005), tornaram-se, segundo a autora, referências importantes ao movimento de humanização.

Diante de tal panorama, a despeito do viés tecnológico representado pelo aspecto da atenção baseada em evidência, Diniz (2005) destaca a importância de ter-se em vista que ele não deve ser reduzido ao âmbito técnico, uma vez que entre os ativistas do movimento pela humanização, a técnica é política, na medida em que visa a uma inversão de relações marcadas pela desigualdade. A esse respeito, convém também notar, o próprio paradigma por detrás da MBE implica o estabelecimento de relações mais horizontais e uma concepção de homem e de saúde mais abrangente (NOBRE; BERNARDO; JATENE, 2003).

De todo modo, o componente fortemente político que marca a compreensão da evidência, explicita outro viés que perpassa a forma com que a humanização do cuidado ao ciclo grávido-puerperal é compreendida: como assistência baseada em direitos, contrapondo-se, aí, especialmente à violência que marcava o cuidado (DINIZ, 2005). Cabe assinalar alguns dos direitos levantados por Diniz (2001) nesse cenário: à equidade e ao acesso ao leito obstétrico, à segurança, à integridade corporal, à autonomia e ao usufruto da sexualidade, de estar livre de sofrimento desnecessário e de humilhações e maus tratos. Dias (2006) acrescenta, ainda, o direito de a mulher ter suas demandas atendidas, no qual se inclui 
a presença de acompanhante.

Em inter-relação com tal aspecto, parece estar outro, apontado por Diniz (2005) dentre as significações em torno do termo "humanização" que apreendeu em um estudo de duas maternidades de São Paulo, autodefinidas como humanizadas: o de legitimidade da participação da mulher nas decisões acerca de sua saúde. Isso se refere a uma mudança nas relações entre profissional de saúde, instituição e mulher, abrindo-se espaço à participação de outros atores, como o pai, outros acompanhantes e doulas, e à negociação de procedimentos e rotinas. Ademais, remete ao tema do empoderamento, já referido.

Pode-se também aí incluir sentidos ao termo relatados por Dias (2006), que se propôs, dentre outros objetivos, a investigar as representações em torno do conceito de humanização da atenção à saúde, articuladas por profissionais ligados ao atendimento ao parto. Tais sentidos, que integram, é possível afirmar, uma dimensão relacional associada à promoção de autonomia, traduziram-se por: oferecimento de acolhimento e suporte; estabelecimento de uma boa relação com a usuária, permeada por respeito e pela percepção da mulher em sua totalidade; e provimento de informações sobre o cuidado oferecido.

Outras significações em torno do conceito de humanização apreendidas em estudo realizado por Diniz (2005) foram: resultado de uma tecnologia adequada à saúde da população, tanto no nível individual, como no coletivo, que remete à dimensão de políticas públicas; legitimidade profissional e corporativa, oficializando o papel da enfermeiraobstetra no cenário da atenção ao ciclo grávido-puerperal - ainda que em meio a disputas com a classe médica - e realocando espaços de assistência; e legitimidade financeira, que implica racionalidade no uso de recursos, alocando-os de forma mais eficiente e ampliando a efetividade das ações.

Dentre os sentidos acima apontados, Diniz (2005) enfatiza a compreensão da humanização como atenção baseada em evidência e como atenção baseada em direitos. Relata, também, que o termo aparece como estratégia mediadora no diálogo com os profissionais de saúde acerca da violência institucional. Ademais, assim compreendido, traduz-se, de acordo com a autora, em um movimento que se contrapõe ao modelo tecnocrático; o que também é pontuado por Tornquist (2003). Tais sentidos, somados àqueles anteriormente indicados - resgate da intersubjetividade e da dialogicidade na produção do cuidado, aliado à qualidade do ponto de vista técnico, o que se relaciona à discussão da centralidade das tecnologias leves nos processos de produção de saúde; melhoria das 
condições de trabalho; e adoção de um conceito de homem e de saúde que leve em conta os múltiplos aspectos que o compõem -, permeará a construção, mais adiante, de um conceito de humanização, o qual será adotado no presente trabalho como princípio norteador da compreensão da realidade estudada.

\subsection{HUMANIZAÇÃO DA ASSISTÊNCIA AO CICLO GRÁVIDO- PUERPERAL NO BRASIL}

O movimento de humanização ao ciclo grávido-puerperal no Brasil começou a ser impulsionado, segundo Diniz (2005), na década de 1970, quando alguns profissionais, como Galba de Araújo, começaram a desenvolver ações inspiradas por práticas tradicionais de parteiras e índios. Paralelamente, surgiam grupos de terapias alternativas, como o Instituto Aurora no Rio de Janeiro, que ajudavam a disseminar entre as usuárias dos serviços de saúde retorno ao parto natural. Algum tempo depois, na década de 1980, outros grupos começaram a oferecer assistência humanizada à gestação e ao parto, propondo mudanças nas práticas então estabelecidas, como o Coletivo Feminista de Sexualidade e Saúde e a Associação Comunitária Monte Azul, em São Paulo, e o Cais do Parto e o Curumim, em Pernambuco.

De acordo com Serruya, Lago e Cecatti (2004a, p. 518), em meio a esse contexto de luta por mudanças, o Ministério da Saúde lançou, em 1984, o Programa de Assistência Integral à Saúde da Mulher (PAISM). O programa "deveria prover ações relacionadas à gravidez, contracepção, esterilidade, prevenção de câncer ginecológico, diagnóstico e tratamento das doenças sexualmente transmissíveis, sexualidade, adolescência e climatério". Entretanto, segundo os autores, devido a entraves de ordens política, financeira e operacional, o programa não conseguiu atingir plenamente seus objetivos, especialmente no que se refere à atenção pré-natal.

Foi nesse contexto que surgiu, em 1993, a Rehuna - Rede pela Humanização do Parto e do Nascimento -, uma rede de pessoas, organizações e serviços de saúde, entre outros, voltada para a melhoria da qualidade da assistência obstétrica no país. No primeiro momento, a Rehuna tinha entre seus objetivos implementar as ações do PAISM, especialmente aquelas ligadas à assistência à gravidez, ao parto e ao puerpério (REHUNA, 2006). Hoje, ela visa: 
divulgar e promover a implementação das recomendações da Organização Mundial de Saúde (OMS) no que se refere às "tecnologias apropriadas ao Nascimento"; conscientizar e mobilizar a população, mostrando os riscos de práticas inadequadamente intervencionistas (como o uso rotineiro de enema ${ }^{7}$, tricotomia ${ }^{8}$ e episiotomia ${ }^{9}$, dentre outras), para que reivindique uma assistência mais humanizada. E mais:

\begin{abstract}
resgatar práticas humanizadas tradicionais de parto e nascimento, aliadas aos conhecimentos técnicos e científicos sistematizados e comprovados; construir coletivamente um referencial teórico e atuação prática capazes de intervir na assistência; e prover as autoridades que formulam e executam as políticas de saúde, de subsídios para adoção das práticas preconizadas pela OMS. (REHUNA, 2006)
\end{abstract}

Os participantes dessa rede, de acordo com Diniz (2005), acabaram por formar uma comunidade que se reunia várias vezes por ano. No início, "presencialmente" e, a partir do final dos anos 90, também virtualmente, através das inúmeras listas de discussão eletrônicas que foram surgindo, como "Parto Natural”, “Amigas do Parto", "Mães Empoderadas", entre outras. O movimento crescia, ganhava novos adeptos e, assim, aumentavam também as iniciativas, pessoais, institucionais ou de políticas públicas.

Em meio a esse panorama de luta por mudanças, o Ministério da Saúde lançou, em junho de 2000, o Programa de Humanização no Pré-Natal e Nascimento (PHPN). Quatro anos depois, vieram o Pacto Nacional pela Redução da Mortalidade Materna e Neonatal (BRASIL, 2007a) e a Política Nacional de Atenção Integral à Saúde da Mulher (BRASIL, 2004a), os quais, ainda que não tratem apenas de medidas de humanização do cuidado ao ciclo grávidopuerperal, as englobam.

Desde então, efetivou-se, no âmbito de políticas públicas, um conjunto de ações voltadas não apenas à humanização da assistência mas também à redução da morbimortalidade materna e neonatal - um dos objetivos, como se verá, do PHPN. Regulamentouse, em dezembro de 2005, a Lei no. 11.108, de abril de 2005, que garante a presença de acompanhante durante o parto. Incorporaram-se, na assistência, os dispositivos da Política Nacional de Humanização (PNH), com ênfase no acolhimento e na afirmação de direitos dos usuários dos serviços de saúde. Sedimentou-se apoio à implantação de hospitais preparados

7 Lavagem intestinal.

8 Raspagem dos pêlos púbicos.

9 Corte no perínio da parturiente no período expulsivo para evitar lacerações. Embora realizada rotineiramente, trata-se de uma prática indicada em apenas cerca de 10\% dos casos (DINIZ, 2001). 
para atendimento de interrupção de gravidez em casos de violência, conforme previsto em lei. Incluiu-se perspectiva etnorracial na assistência obstétrica e neonatal. Ampliou-se a Rede Nacional de Bancos de Leite Humano; dentre outras medidas (BRASIL, 2007a).

\subsubsection{O PROGRAMA DE HUMANIZAÇÃO NO PRÉ-NATAL E NASCIMENTO}

Abordar o Programa de Humanização no Pré-Natal e Nascimento (PHPN), em meio a um campo amplo e diverso como é o da humanização, é escolha que pressupõe o reconhecimento de sua importância no cenário da atenção humanizada ao ciclo grávidopuerperal no Brasil. Além disso, o programa define um conjunto claro de critérios acerca de como um cuidado humanizado deve se constituir, razão pela qual foi adotado como um dos princípios norteadores de análise do presente trabalho.

Os documentos, manuais e cartilhas ligados ao PHPN serviram de instrumento para investigação da forma como o cuidado humanizado é aí compreendido. Essa análise, acrescida das considerações anteriormente realizadas sobre tal fenômeno, conduziu à elaboração de um conceito de humanização que também norteou este estudo.

Algo importante de ser destacado é que antes do lançamento do PHPN, o tema da humanização já fazia parte da pauta do Ministério da Saúde. Em um manual acerca da Assistência Pré-Natal, publicado em 1998 (BRASIL, 1998), há um subcapítulo sobre o preparo para o parto e o nascimento humanizados; tema que consta, também, na ficha catalográfica da publicação.

Além disso, um programa anterior - o PAISM - já propunha uma atenção integrada à saúde das mulheres, a qual incluía uma série de elementos (como considerar a autonomia das mulheres, seus direitos e a necessidade de uma atenção integral) que, como será apresentado adiante, são aspectos centrais da humanização proposta pelo Ministério no PHPN - ainda que não se utilizasse, à época, tal terminologia. Entretanto, como já mencionado, o programa não foi capaz de operacionalizar a proposta (SERRUYA; LAGO; CECATTI, 2004a).

Assim, em meio ao contexto anteriormente descrito, em que o movimento de humanização tornava-se cada vez mais significativo, intensificando as discussões sobre o 
tema, e diante da necessidade de sistematizar um novo programa, em junho de 2000 o Ministério instituiu o Programa de Humanização no Pré-Natal e Nascimento (PHPN), com a edição da portaria GM/MS no. 569, publicada no Diário Oficial da União (BRASIL, 2000a). Com essa Portaria, foram também publicadas outras três, que estabeleceram os Componentes do programa: a GM/MS no. 570 (BRASIL, 2000b); a GM/MS no. 571 (BRASIL, 2000c); e a GM/MS no. 572 (BRASIL, 2000d).

Desde então, alguns manuais e cartilhas acerca do PHPN foram publicados. Destacamse, aqui, três dessas publicações: "Parto, Aborto e Puerpério: Assistência Humanizada à Mulher (BRASIL, 2001), o primeiro manual sobre o programa, lançado em 2001; "Humanização no Parto: Programa de Humanização no Pré-Natal e Nascimento" (BRASIL, 2002), publicação, de 2002, que sintetizou o conteúdo das portarias ministeriais relacionadas ao PHPN; e "Pré-Natal e Puerpério: Atenção Qualificada e Humanizada" (BRASIL, 2006b), cuja primeira edição foi lançada em 2005.

A integração do PHPN com outras instâncias é assinalada na última publicação do programa (BRASIL, 2006b), na qual se refere que ele está baseado nos princípios e diretrizes da Política Nacional de Humanização (PNH) - Humaniza SUS (BRASIL, 2004b), nas recomendações da OMS e nas evidências científicas atuais.

A seguir, conceitos de humanização extraídos de alguns dos documentos ministeriais, que tratam do tema em pauta, serão objeto de discussão, para, então, elaborar-se uma síntese do conceito que norteará a forma com que a humanização será compreendida nesse trabalho. $\mathrm{Na}$ sequência, apresentam-se os objetivos do PHPN e, por fim, algumas das condutas preconizadas para a atenção ao pré-natal e ao puerpério - tanto técnicas quanto de acolhimento. As condutas concernentes ao parto, definidas no programa, não serão aqui comentadas, por não fazerem parte do escopo do presente trabalho.

\subsubsection{EM BUSCA DE UM CONCEITO DE HUMANIZAÇÃO: ANÁLISE DE DOCUMENTOS MINISTERIAIS}

$\mathrm{Na}$ publicação de 1998, anterior ao lançamento do PHPN (BRASIL, 1998), humanização (do parto) foi definida como a relação de respeito que deve ser estabelecida 
entre os profissionais de saúde e a parturiente. Os elementos elencados para compor essa relação podem ser agrupados em pelo menos três categorias centrais: prática baseada em evidências científicas - consideração do parto como um processo natural e fisiológico, o que implica evitar condutas intervencionistas; acolhimento - respeito às emoções da mulher e oferecimento de suporte, de modo a se promover bem-estar físico e emocional durante todo o ciclo grávido-puerperal, bem como de informações e orientações; perspectiva de respeito aos direitos - garantia do direito da mulher escolher o local do parto e de ser acompanhada por quem o desejar (BRASIL, 1998). A despeito de tais aspectos, o foco da conceituação apresentada nessa publicação estava na relação entre profissional de saúde e parturiente.

Na instituição do PHPN, pelas portarias ministeriais (BRASIL, 2000a, 2000b, 2000c, 2000d), um conceito de humanização não foi claramente definido. A primeira vez que o entendimento de assistência humanizada foi apresentado, após a instituição do PHPN, ocorreu na publicação de 2001 (BRASIL, 2001, p. 9):

O conceito de atenção humanizada é amplo e envolve um conjunto de conhecimentos, práticas e atitudes que visam à promoção do parto e do nascimento saudáveis e a prevenção da morbi-mortalidade materna e perinatal. Inicia-se no prénatal e procura garantir que a equipe de saúde realize procedimentos comprovadamente benéficos para a mulher e o bebê, que evite intervenções desnecessárias e que preserve sua privacidade e autonomia.

Mais adiante, humanização também aparece ligada ao reconhecimento da individualidade da mulher, o que permite ao profissional perceber as necessidades e capacidades de cada gestante de lidar com a gravidez e o nascimento. É também o que possibilita que ele estabeleça uma relação mais horizontal e de confiança com ela. Embora não seja aqui utilizada essa nomenclatura, nota-se que esse ponto se refere ao acolhimento.

Para que seja possível assumir uma abordagem humanizada, ou seja, "para, de fato, mudar a relação profissional de saúde/mulher" (BRASIL, 2001, p. 10), defende-se ser necessária uma mudança de atitude e, para isso, é importante que o profissional esteja sintonizado com as novas propostas, pratique uma medicina baseada em evidências, não considere a gravidez como doença, reconheça a autonomia da mulher na vivência desse processo e, sobretudo, adote a ética como fundamento essencial de sua prática. É aqui que o aspecto da humanização como atenção baseada em evidência se destaca, assim como a influência da MBE sobre as transformações pretendidas nesse campo de cuidado ao ciclo 
grávido-puerperal.

Sobre a conceituação apresentada nesse manual (BRASIL, 2001), há alguns pontos importantes de serem ressaltados. O primeiro é o de que, apesar de se ter falado acerca de um conjunto amplo de "conhecimentos, práticas e atitudes" (BRASIL, 2001, p. 9) - que foram, aliás, definidos de forma difusa, não sendo possível discriminá-los com nitidez -, parece que a ênfase maior recai, novamente, sobre a relação entre profissional de saúde e usuário e que a concretização de um cuidado humanizado depende do comprometimento do profissional em sintonizar-se com as concepções apontadas, adquirir conhecimentos consonantes a essas e, então, mudar suas atitudes e práticas. Entretanto, em outros trechos do manual, encontram-se concepções que parecem transcender essa responsabilização do profissional de saúde, e a humanização pensada apenas no espaço de interação entre esse e o usuário. Aborda-se a importância de se adotar um conceito de saúde perpassado pelo contexto histórico, político e sóciocultural e, especialmente no caso do ciclo grávido-puerperal, por questões de gênero. E afirma-se que a humanização do cuidado depende de profissionais, usuários, e da sociedade em geral assimilarem esse novo conceito. Portanto, parece considerar-se que a humanização não implica apenas mudança de atitude do profissional, mas uma reconstrução de conceitos, e, por conseguinte, de posturas, por parte de todos os sujeitos envolvidos nos processos de produção de saúde.

O manual de 2002 (BRASIL, 2002) apresenta um novo conceito de humanização, ainda que possam ser observadas semelhanças em relação aos anteriores. Se antes a atenção humanizada havia sido definida como um "conjunto de conhecimentos, práticas e atitudes" (BRASIL, 2001, p. 9), apresentados de forma difusa, agora, tal conjunto parece ter sido, de certa forma, sintetizado em torno de "dois aspectos fundamentais" (BRASIL, 2002, p. 5) bem delimitados, como se nota a seguir:

\footnotetext{
A humanização compreende, entre outros, dois aspectos fundamentais. O primeiro diz respeito à convicção de que é dever das unidades de saúde receber com dignidade a mulher, seus familiares e o recém-nascido. Isto requer atitude ética e solidária por parte dos profissionais de saúde, organização da instituição de modo a criar um ambiente acolhedor e adotar condutas hospitalares que rompam com o tradicional isolamento imposto à mulher. $\mathrm{O}$ segundo refere-se à adoção de medidas $\mathrm{e}$ procedimentos sabidamente benéficos para o acompanhamento do parto e do nascimento, evitando práticas intervencionistas desnecessárias que, embora tradicionalmente realizadas, não beneficiam a mulher nem o recém-nascido e que, com frequência, acarretam maiores riscos para ambos.
} 
O primeiro aspecto fundamental - o do acolhimento com "dignidade" da mulher, de seus familiares e do bebê - parece englobar os elementos apresentados no manual anterior (BRASIL, 2001), ou seja, a adoção de uma atitude "ética e solidária" por parte do profissional de saúde; ainda que não se tenha, aqui, melhor explicitado do que se trata tal atitude. Além disso, parece ter-se integrado outros requisitos para que esse acolhimento possa se dar: reorganização institucional e a adoção de novas condutas hospitalares. Dessa forma, o acolhimento deixa de ser pensado apenas no espaço de intersubjetividade profissional de saúde/usuário, passando a ser inserido em um campo maior de interações. O segundo aspecto fundamental, por sua vez, parece dizer respeito a aspectos mais objetivos, da prática fundamentada em evidências científicas, o que, vale lembrar, implica questões como considerar a gravidez e o parto como processos fisiológicos.

Percebe-se que, embora essa definição tenha explicitado aspectos anteriormente apontados (BRASIL, 2001), ela focou apenas o momento do parto, fragmentando, assim, a vivência do ciclo grávido-puerperal. Além disso, não esclarece que as "medidas e procedimentos sabidamente benéficos" estavam pautados na Medicina Baseada em Evidências (que havia sido discutida no manual de 2001). Tampouco, apresenta elementos antes apontados como essenciais (BRASIL, 2001), como o conceito de saúde discutido. Outro ponto digno de nota é o de que, ainda que tenha sido importante a definição de cada um dos "aspectos fundamentais", a forma com que se os apresentou parece ter criado espaço para uma dicotomia no conceito: acolhimento de um lado e técnica de outro, entendidos quase que isoladamente. Tal dicotomia também parece favorecer maior ênfase em apenas um dos aspectos em determinados momentos, o que será apontado adiante.

Na publicação de 2006 (BRASIL, 2006b), mais uma vez, aparece uma nova definição acerca do conceito de humanização, agora, coincidente com aquele da Política Nacional de Humanização (Humaniza SUS) (BRASIL, 2004b). O cuidado humanizado é compreendido como:

a valorização dos diferentes sujeitos implicados no processo de produção de saúde usuários(as), trabalhadores(as) e gestores(as); fomento da autonomia e protagonismo desses sujeitos; a co-responsabilidade entre eles; o estabelecimento de vínculos solidários e de participação coletiva no processo de gestão; identificação das necessidades sociais de saúde; mudança nos modelos de atenção e gestão; compromisso com a ambiência, melhoria das condições de trabalho e de atendimento (BRASIL, 2006b, p. 9). 
Parece possível agrupar os requisitos à humanização e à qualificação da assistência apontados nesse manual (BRASIL, 2006b) em torno das seguintes categorias:

a) Adoção de um conceito de saúde integral: compreensão dos processos de saúde e doença a partir um novo olhar, que considere a pessoa em sua totalidade corpo-mente em interação com o meio sócio-econômico-cultural ${ }^{10}$ (BRASIL, 2006b).

b) Estabelecimento de relações entre profissionais de saúde, gestores e usuários pautadas no acolhimento: implica ética; valorização dos aspectos subjetivos envolvidos na assistência; e respeito pela privacidade e autonomia de mulheres e familiares, compartilhando-se as decisões acerca das condutas a serem adotadas (BRASIL, 2006b) - lembrando que, no que se refere a esse último item, ele também pode ser compreendido como direito (à autonomia e à privacidade), como aponta Diniz (2005); o que explicita a articulação entre essas categorias aqui propostas.

c) Constituição de uma cultura de respeito aos direitos humanos: inclui direitos sexuais e reprodutivos, bem como ao fácil acesso aos serviços de saúde (BRASIL, 2006b).

d) "Emprego de condutas acolhedoras e sem intervenções desnecessárias" (BRASIL, 2006b, p. 10): referem-se a procedimentos comprovadamente benéficos. Esse tipo de referência parece sugerir o que Deslandes (2004) defende acerca da superação da díade tecnologia/fator humano, compreendendo-se, conforme discute Merhy (2000), que equipamentos e procedimentos, conhecimentos dos profissionais, e acolhimento e produção de vínculo traduzem-se em diferentes formas de tecnologias, a saber, duras, leve-duras e leves, respectivamente. Além disso, parece também indicar que condutas que integram o acolhimento, como proposto pelo MS (BRASIL, 2006b), podem também ser entendidas a partir da ótica da evidência, especialmente tendo-se em vista o paradigma por detrás da MBE, já apontado, que implica posturas de acolhimento (NOBRE; BERNARDO; JATENE, 2003).

São ainda mencionados como requisitos para a humanização e para a qualificação da assistência (BRASIL, 2006b): a) provisão dos recursos necessários - o que pode ser

10 Pode-se dizer que esse conceito remete ao princípio de integralidade do SUS, o qual, por sua vez, implica demanda por uma equipe multiprofissional provendo o cuidado. Esse tema da equipe, entretanto, é apenas mencionado brevemente nessa publicação (BRASIL, 2006b), dentre as recomendações da OMS, quando são citados profissionais como cientistas sociais e parteiras. Mais adiante, porém, a equipe multiprofissional é definida como sendo constituída pelos seguintes profissionais: médico(a), enfermeira(o), auxiliar de enfermagem e agente comunitário de saúde. Em publicação posterior (BRASIL, 2001), houve, também, apenas menções breves a outros profissionais. 
compreendido como um dos fatores "estruturais" que Minayo (2006) destaca como necessários à viabilização de uma humanização do cuidado; aspecto também apontado por Deslandes (2004); e, b) ações de promoção, de prevenção e de assistência, integradas desde o atendimento ambulatorial básico até o hospitalar para alto risco - integração que se fundamenta em evidência, sendo recomendada por Enkin et al. (2005).

Houve, como se pode notar, uma mudança significativa no conceito de cuidado humanizado. De modo geral, parece que esse passou a ser pensado não apenas como operacionalização da assistência mas, principalmente, em termos de construção e viabilização de políticas e programas de humanização. Por essa razão, temas como gestão, participação social, identificação das necessidades sociais, ganharam destaque.

Por um lado, essa ampliação no conceito apresenta repercussões importantes. Uma delas é a do profissional de saúde ter deixado de ser responsabilizado, exclusivamente, pela concretização de uma atenção humanizada - o que já tinha acontecido no manual de 2002 (BRASIL, 2002), mas que aqui surgiu de forma muito mais clara. Ao mesmo tempo, deixouse de focar apenas o acolhimento e a valorização do usuário, estendendo-se tais dimensões também aos profissionais de saúde e gestores - algo destacado como necessário na literatura (BACKES; LUNARDI FILHO; LUNARDI, 2005; CASATE; CORRÊA, 2005; DESLANDES, 2004; HOGA, 2004; OLIVEIRA; COLLET; VIERA, 2006; ROLIM; CARDOSO, 2006). Ou seja, parece que se passou a considerar que a humanização só pode se dar no espaço de inter-relações corresponsáveis entre gestores, profisssionais de saúde, usuários e comunidade; e que ela depende da melhoria das condições de trabalho e do investimento nos profissionais. Ademais, deu-se mais ênfase à compreensão de que uma política e um programa de humanização não podem se concretizar sem o engajamento da população (o que já havia sido mencionado no manual de 2001), e que o conhecimento das necessidades desta é essencial à constituição de uma atenção que tenha sentido, porque tem sintonia e responde a tais necessidades.

Por outro lado, parece que, ao se pensar na atenção humanizada em termos de políticas e programas, alguns aspectos essenciais da humanização se perderam, aparecendo de forma diluída e pouco articulada entre os requisitos para humanização e para qualificação do cuidado. 


\subsubsection{ASPECTOS CENTRAIS NOS CONCEITOS DE HUMANIZAÇÃO APRESENTADOS NO PHPN}

A análise dos manuais do PHPN (BRASIL, 2001, 2002 e 2006b), de outros documentos que fazem referência ao programa - como a cartilha sobre a Política de Atenção Integral à Saúde da Mulher (BRASIL, 2004a) - ou daqueles anteriores ao PHPN, mas que mencionam o tema da humanização (BRASIL, 1998), permite notar aspectos centrais entre as diferentes conceituações apresentadas acerca do que seja um cuidado humanizado.

Um desses aspectos parece ser o de condutas acolhedoras e comprovadamente benéficas. Aqui se enquadram tanto as tecnologias duras - segundo conceituação de Merhy (2000) -, como o acolhimento, destacado como "aspecto essencial da política de humanização" (BRASIL, 2006b, p. 13), e apontado por Merhy (2000) como uma tecnologia leve. Essas tecnologias se articulam e se complementam em um cuidado ético que, como tal, não pode carecer nem de uma, nem de outra. Se a humanização for entendida, tal como proposto por Minayo (2006), como um resgate da harmonia entre razão e sentimento, entre objetivo e subjetivo, então, não há sentido em pensar em uma atenção humanizada que prioriza apenas um desses aspectos. E se a proposta, então, é de integração, também não há sentido em pensar apenas na dimensão de cuidados com o usuário; as interações, corresponsáveis, como sugere o MS (BRASIL, 2006b), entre os envolvidos nos processos de produção de saúde - usuário, profissional de saúde, gestor e comunidade - também precisam ser permeadas por essa harmonia entre objetivo e subjetivo.

Uma decorrência fundamental, aqui assinalada como um segundo aspecto da humanização, parece ser a compreensão, especialmente observada no manual mais recente relacionado ao PHPN (BRASIL, 2006b), de que não é possível desvincular a melhoria das condições de atendimento da melhoria das condições de trabalho; ou, como fora nomeado por Deslandes (2004), que humanização do cuidado implica humanização da produção desse cuidado; o que envolve não apenas a ética, a solidariedade (BRASIL, 2001, 2002) e o dialógico nas relações entre os sujeitos envolvidos nos processos de produção de saúde como também aquilo que Minayo (2006, p. 28) chamou de "pré-requisitos estruturais": recursos, ambiência, equipes de saúde funcionais, integração entre os serviços, dentre outros, como apontado pelo MS (BRASIL, 2004b, 2006b). 
Como terceiro aspecto, há o conceito de saúde integral, considerando-se que "a qualidade da atenção deve estar referida a um conjunto de aspectos que englobam as questões psicológicas, sociais, biológicas, sexuais, ambientais e culturais" (BRASIL, 2004a, p. 59). É a partir desse olhar que se torna possível conceber um outro referencial do humano, que possui demandas e precisa ser compreendido em todas essas dimensões. É esse olhar que articula tecnologias leves, leve-duras e duras. E é ele que justifica um cuidado integral, voltado para a mulher em relação com sua família e sua comunidade, e provido por uma equipe multidisciplinar. A adoção de um novo conceito de saúde e de homem, vale lembrar, é tema também recorrente na literatura sobre a humanização (BACKES; LUNARDI FILHO; LUNARDI, 2005; CASATE; CORRÊA, 2005; DIAS, 2006; LEITE; STRONG, 2006; ROLIM; CARDOSO, 2006; TORNQUIST, 2003; TRAVERSO-YÉPEZ; MORAES, 2004) e relaciona-se com um novo paradigma que possa se contrapor ao modelo tecnocrático.

Um último aspecto refere-se à “cultura de respeito aos direitos humanos", na qual se incluem os direitos sexuais e reprodutivos (BRASIL, 2006b). Vale registrar alguns desses direitos levantados nos manuais: direito da mulher escolher o local do parto e de ser acompanhada por quem o desejar (BRASIL, 1998); direito ao acesso a um atendimento digno e de qualidade; de saber e ter assegurado o acesso à maternidade em que se dará o parto; a uma assistência humanizada e segura (BRASIL, 2000a, 2002); “direito de ser mãe com humanidade e segurança" (BRASIL, 2001, p. 25); direito à privacidade e à autonomia (BRASIL, 2006b). Uma atenção baseada em direitos, como nomeia Diniz (2005), é também uma fundamentação importante à humanização, pois, da mesma forma que o faz o conceito de saúde integral, redefine o conceito de homem - dotado de direitos - e articula técnica e acolhimento.

A partir disso, parece ser possível dizer que a humanização do cuidado, tal como compreendida pelo MS no PHPN, operacionaliza-se a partir de condutas acolhedoras e comprovadamente benéficas, as quais demandam, por sua vez, "pré-requisitos estruturais", e fundamenta-se em uma cultura de respeito aos direitos humanos e em um conceito de saúde integral. Parece, porém, que falta, ainda, responder o que é a humanização em saúde.

Em busca de uma resposta, três referenciais foram tomados como norteadores: o conceito de humanização proposto por Minayo (2006), aquele apresentado por Teixeira (2005) e a discussão de Merhy (1998, 2000, 2002) acerca das articulações de tecnologias duras, leve-duras e leves nos processos de produção de saúde. Considerados tais referenciais, 
e tendo ainda em vista a análise realizada, entendeu-se humanização como aquela que restitui o humano - no contexto em pauta, entendido como gestores, trabalhadores, usuários e acompanhantes - como ser integral e de direitos nos processos de produção de saúde, e as tecnologias leves ao seu lugar de reger tais processos, resultando em efetivação e aumento de potência ${ }^{11}$.

Embora esse conceito tenha sido assumido como referencial norteador na construção da metodologia do presente trabalho, assim como na análise e discussão dos dados, de modo algum foi acatado como verdade absoluta, somando-se, pois, ao diálogo com as significações apreendidas em torno da humanização do cuidado ao pré-natal e ao puerpério no serviço estudado.

\subsubsection{OBJETIVOS DO PHPN}

A portaria GM/MS no. 569 (BRASIL, 2000a) apresenta como objetivos do PHPN: a prestação de atendimento digno e de qualidade durante a gravidez, o parto, o puerpério e o período neonatal; a redução das taxas de mortalidade materno-infantil; a ampliação do acesso, da cobertura e da qualidade da assistência ao ciclo grávido-puerperal e ao período neonatal o que inclui a ampliação da rede de assistência e a implantação de serviços voltados à gestação de alto risco; a regulação da assistência à gravidez, ao parto, ao puerpério e ao período neonatal; e a promoção do vínculo entre a assistência ambulatorial básica e especializada, e a assistência hospitalar.

Os fundamentos e as justificativas à instituição do programa são desenvolvidos a partir de uma perspectiva de direitos: direito a um atendimento digno e de qualidade; de saber e ter assegurado o acesso à maternidade em que se dará o parto; a uma assistência humanizada e segura, na qual também se inclui o recém-nascido. Direitos que devem ser assegurados pelas

11 É importante ressaltar que embora Teixeira (2005) tenha empregado esse termo fundamentado em uma concepção espinosana, ele será aqui compreendido e utilizado a partir do referencial da Gestalt-Terapia, que, apoiado na fenomenologia-existencial, entende o processo de ampliação e efetivação de potência em meio à experiência de vir-a-ser que define o homem (RIBEIRO, 1999). Este se renova à medida que descobre e efetiva novas potencialidades - que se referem a novas possibilidades de ser. Diante de algumas circunstâncias, porém, o indivíduo pode perder o contato com esse fluxo de transformação, cristalizando-se em modos de vida que já não são adequados para o contexto que vive; o que se torna, então, foco a ser trabalhado em relações de cuidado. 
autoridades sanitárias de âmbitos municipal, estadual e federal.

\subsubsection{ALGUMAS CONDUTAS DEFINIDAS PELO PHPN}

Apenas condutas concernentes ao pré-natal e ao puerpério serão aqui mencionadas, como já referido, uma vez que o parto não integra o escopo do presente trabalho. Além disso, partindo-se da expressão "condutas acolhedoras e sem intervenções desnecessárias" (BRASIL, 2006b, p. 10), optou-se por reunir ambos - acolhimento e procedimentos - nessa mesma seção. Assim, apresenta-se, primeiramente, a definição de acolhimento dada pelo MS e, posteriormente, alguns dos procedimentos preconizados para a atenção ao pré-natal e ao puerpério.

\subsubsection{ACOLHIMENTO}

O termo "acolhimento", embora tenha sido empregado apenas no manual mais recente (BRASIL, 2006b, p. 13), já vinha sendo discutido em manuais anteriores, especialmente quando se abordava o tema de elementos que devem pautar a postura dos profissionais de saúde e as relações que eles estabelecem com os usuários dos serviços. Ao conjunto de tais aspectos deu-se o nome "acolhimento", que é considerado "aspecto essencial da política de humanização".

Como definido no manual (BRASIL, 2006b), o acolhimento é uma postura ética e solidária, que envolve: apresentar-se e chamar as gestantes pelo nome; incentivar a presença de acompanhante; assegurar os direitos à privacidade e à autonomia; compartilhar as decisões acerca das condutas a serem efetuadas. Acolher envolve, também, uma escuta aberta, livre de julgamentos e preconceitos, que encoraje a mulher e seu parceiro a falarem a respeito de sua intimidade e a expressarem suas preocupações e angústias. Para tanto, é necessário que o profissional se aproxime da experiência vivida pela gestante, de sua forma de conceber e se 
relacionar com o mundo, de maneira a compreender um universo que, talvez, seja muito diferente do seu; e que valorize o que a gestante e seu companheiro compartilham. "O diálogo franco, a sensibilidade e a capacidade de percepção de quem acompanha o pré-natal são condições básicas para que o saber em saúde seja colocado à disposição da mulher e da sua família - atores principais da gestação e do parto" (BRASIL, 2006b, p. 13).

Acolher implica, ainda, tentar compreender os significados da gravidez para a mulher e sua família. Talvez, por esse motivo, esse manual tenha um capítulo dedicado aos aspectos emocionais da gravidez e do puerpério, no qual as definições acerca de acolhimento parecem ser complementadas. Aponta-se aí "ser necessário que o profissional de saúde aborde a mulher na sua inteireza, considerando a sua história de vida, os seus sentimentos e o ambiente em que vive, estabelecendo uma relação entre sujeito e sujeito e valorizando a unicidade e individualidade de cada caso e de cada pessoa" (BRASIL, 2006b, p. 35). Assim, pode-se afirmar que o acolhimento também inclui a valorização dos aspectos subjetivos envolvidos na assistência.

Algo notável é que nesse manual (BRASIL, 2006b) o acolhimento é apresentado apenas como conduta a ser incorporada pelo profissional de saúde em suas práticas; a despeito de, como já discutido, ser possível apreender neste e em outros documentos ligados ao PHPN que tal elemento deve permear as inter-relações de todos os sujeitos envolvidos nos processos de produção de saúde. Ademais, recente publicação da Política Nacional de Humanização PNH, com a qual o PHPN se articula - (BRASIL, 2008), exclusivamente dedicada ao acolhimento, acrescentou, ainda, outros aspectos à compreensão dele; razão por que merece ser aqui comentada.

Da mesma forma que o PHPN destaca o acolhimento como "aspecto essencial da política de humanização" (BRASIL, 2006b, p. 13), a PNH o discute como "uma das diretrizes de maior relevância ética/estética/política da Política Nacional de Humanização do SUS” (BRASIL, 2008, p. 6). Sua dimensão ética se traduz pelo comprometimento com o reconhecimento do outro em sua singularidade, podendo-se então acolhê-lo em seu modo próprio de estar no mundo. A dimensão estética refere-se às estratégias em favor da invenção de modos de vida mais dignos, e da construção da humanidade dos sujeitos envolvidos nos processos de produção de saúde. E a dimensão política diz respeito ao compromisso dos diversos sujeitos com encontros que potencializem seu protagonismo e seu viver.

Paralelamente, o acolhimento é assinalado como uma ferramenta tecnológica de 
qualificação de escuta, produção de vínculo, responsabilização e resolutividade; como uma “tecnologia do encontro" (BRASIL, 2008, p. 18) voltada à afirmação das redes relacionais que formam um serviço de saúde como redes comprometidas com os processos de efetivação e ampliação de potência de seus atores. Por essa razão, discute-se nesse manual (BRASIL, 2008) que, como ação técnico-assistencial, o acolhimento desloca o foco de análise dos processos de trabalho em saúde para as relações.

Do ponto de vista da postura do profissional, o acolhimento implica reconhecimento do usuário em sua condição de sujeito, dotado de subjetividade e de participação ativa na produção dos processos de saúde; valorização e abertura para o encontro; escuta qualificada e comprometida com a resolução das demandas apreendidas; compartilhamento de ideias, saberes, percepções, emoções e limites; e mudança de referenciais, tendo como foco não mais a doença, mas o sujeito, que vive não apenas questões físicas mas também psíquicas e sociais (BRASIL, 2008).

Essa postura também constitui, na visão do MS (BRASIL, 2008), a expressão do acolhimento como dispositivo operacional, ou seja, como estratégia de ação sobre os processos de trabalho. Implicando resolutividade e responsabilização, o acolhimento demanda que o profissional articule outros encontros, no próprio serviço ou em outros, de modo a garantir resposta às necessidades do usuário e continuidade no cuidado. Para que essa articulação possa ser mais amplamente possível, entende-se que o serviço deve ser estruturado com base em equipes multiprofissionais e pautado na interdisciplinaridade. Daí a importância do trabalho em favor do estabelecimento de equipes funcionais - que devem também prover espaços de acolhimento para o vivido de seus próprios membros - e de maior integração entre áreas. Ademais, integra ainda tal expressão do acolhimento como dispositivo operacional a gestão do serviço permeada por maior democracia, criando-se mais espaços de discussão e de decisão coletiva.

Como dispositivos de implantação do acolhimento, destaca-se (BRASIL, 2008) o investimento na qualificação das equipes no que se refere às tecnologias relacionais; a elaboração de protocolos que legitimem a participação dos diversos profissionais ligados à produção de saúde, o que contribui para a formação e o fortalecimento da equipe; a adequação da ambiência das unidades, garantindo não apenas mais conforto e segurança como também espaços de encontro e de troca entre profissionais, usuários e familiares; e a constituição de espaços de reflexão e debate, dos quais participem usuários, gestores, profissionais, 
representantes dos trabalhadores e instituições formadoras.

Como se vê, o acolhimento é claramente discutido em tal publicação como algo que transcende a postura do profissional de saúde perante o usuário. Além disso, compreende-se que, sendo fenômeno complexo, sua implementação demanda uma série de dispositivos. Mais adiante, apresenta-se discussão sobre o tema na literatura, em articulação com a compreensão expressa nas publicações ministeriais, de modo a melhor explicitar o conceito, assim como definir de que forma ele será entendido no presente trabalho.

\subsubsection{PROCEDIMENTOS NA ATENÇÃO HUMANIZADA AO PRÉ-NATAL}

O PHPN define um conjunto de procedimentos para a assistência ao ciclo grávidopuerperal. Para o pré-natal, há recomendação para captação precoce das gestantes - até o $120^{\circ}$ dia gestacional - e para realização de, no mínimo, seis consultas pré-natais, sendo, preferencialmente, uma no primeiro trimestre, duas no segundo e três no terceiro. Define-se, também, a realização de um conjunto de exames (1 ABO-Rh, 2 VDRL, 2 urina, 2 glicemia jejum, 1 Hemoglobina e 1 Hematócrito), da testagem anti-HIV (que deve ser acompanhada por aconselhamento pré e pós-teste) e da imunização antitetânica (BRASIL, 2006b). Esses procedimentos integram a definição do "acompanhamento pré-natal completo" (BRASIL, 2002, p. 8) e, acrescidos da consulta puerperal, constituem-se em base para o cálculo dos indicadores de processo (Anexo A), utilizados para monitoração da assistência ao pré-natal e ao puerpério (BRASIL, 2006b).

Além dessas condutas, outras são também recomendadas no PHPN entre os "parâmetros para a atenção ao pré-natal e ao puerpério" (BRASIL, 2006b, p. 8) (Anexo B); embora não estejam incluídas - fato digno de nota - no que se entende por "acompanhamento pré-natal completo" (BRASIL, 2002, p. 8), e, tampouco, constituam indicadores de monitoração do programa.

Esse é o caso de ações educativas. No manual mais recente acerca do PHPN (BRASIL, 2006b) essas ações são pensadas, especialmente, como atividades grupais, cujo formato deve incluir discussões, dramatizações e dinâmicas que facilitem a troca de experiências, evitando-se o estilo palestra. Recomenda-se, também, a integração de 
companheiros e familiares nas atividades, ainda que as gestantes permaneçam como protagonistas, objetivando-se, especialmente, o incentivo à participação dos homens durante todo o acompanhamento pré e pós-natal.

Quanto à relevância das atividades educativas, em manual anterior (BRASIL, 2001), destacou-se sua contribuição à promoção da adesão da mulher ao pré-natal, à redução de medos e ansiedades em relação à gravidez, ao parto e puerpério, ao auxílio na preparação para o parto e para a maternidade, bem como à ajuda à mulher para lidar com as vivências desse período e ao estímulo do autocuidado. Além disso, deu-se bastante ênfase a trabalhos corporais e técnicas de relaxamento, tendo em vista um adequado preparo ao parto natural.

No manual de 2006 (BRASIL, 2006b), os únicos aspectos apontados de maneira mais clara a esse respeito estão relacionados à promoção: de um preparo emocional e corporal que favoreça a vivência prazerosa da gravidez e plena do parto; e do envolvimento do pai durante o ciclo grávido-puerperal, de modo a propiciar a construção do vínculo com o bebê - o que é alegado como algo que contribui para o desenvolvimento da criança. De qualquer maneira, tais apontamentos são feitos dentre os temas sugeridos para as atividades educativas, e não dentre os objetivos e relevância das mesmas, tal como foi feito no manual anterior (BRASIL, 2001).

Um procedimento ressaltado nas portarias ministeriais que instituíram o PHPN e no manual de 2006 (BRASIL, 2006b) é a indicação, no cartão da gestante, do serviço a que ela deve recorrer para atendimento de intercorrências da gravidez e do hospital onde será realizado o parto. Ela é considerada uma informação fundamental à mulher e aos seus familiares, para reivindicação de atendimento nos serviços referenciados. Ao ser encaminhada para um serviço mais especializado, a gestante deve continuar, porém, sendo acompanhada, de forma conjunta, na Unidade Básica de Saúde (UBS) (BRASIL, 2006b).

A realização de pelo menos duas visitas durante a gravidez, preferencialmente por agentes comunitários, é também destacada no programa (BRASIL, 2006b). Estas visitas devem focar a gestante em seu contexto familiar e social e têm como objetivos: captar gestantes não inscritas no pré-natal; reconduzir aquelas que não estejam comparecendo às consultas, especialmente as de alto risco; acompanhar alguns aspectos da gestação quando a mulher não pode se deslocar até a UBS; e complementar ações educativas com a gestante e seus familiares. Além disso, quando se faz necessário, podem se configurar em consulta prénatal. 
São recomendadas, ainda, no PHPN (BRASIL, 2006b), as seguintes condutas: que a mulher seja referenciada para atendimento odontológico; que haja avaliação do risco obstétrico a cada consulta pré-natal; e que se realize orientação alimentar e acompanhamento nutricional $^{12}$. Há, também, condutas específicas para gestação múltipla, gravidez na adolescência, casos de violência contra a mulher durante a gestação e intercorrências gestacionais (BRASIL, 2006b).

\subsubsection{PROCEDIMENTOS NA ATENÇÃO HUMANIZADA AO PUERPÉRIO}

São definidos, na publicação de 2006 (BRASIL, 2006b) do PHPN, os seguintes objetivos da atenção no puerpério: avaliação do estado de saúde da mãe e do bebê, identificando-se e se conduzindo adequadamente situações de risco e intercorrências; orientação e o apoio à família para a amamentação; orientação quanto a cuidados básicos com o bebê e quanto a planejamento familiar; e avaliação da interação entre mãe bebê.

No que diz respeito a condutas, recomenda-se a realização de uma visita domiciliar na primeira semana após a alta do bebê; se o bebê tiver sido considerado "de risco", a visita deve acontecer até o terceiro dia após a alta. Além disso, o primeiro retorno da mulher, com o bebê, deve se dar ainda na primeira semana após o parto, uma vez que, afirma-se (BRASIL, 2006b), esse é um momento que acumula boa parte das ocorrências de morbi-mortalidade materna e neonatal. O retorno, que deve ser incentivado desde o pré-natal, assim como durante a visita domiciliar, deve abarcar ações tais como acolhimento; levantamento de dados acerca da gestação e do parto; verificação de condições sociais, psicológicas e clínico-ginecológicas da mulher; avaliação do aleitamento e do vínculo com o bebê; e investigação das condições de saúde do bebê.

Em manual anterior (BRASIL, 2001), sugeria-se que o companheiro da mulher também comparecesse, tanto no retorno como na consulta puerperal. Além disso, recomendava-se, no puerpério imediato, ainda durante a internação: o cuidado, por parte do profissional, de não se voltar exclusivamente para o bebê, especialmente por se tratar de um

12 Todas essas condutas constam entre os parâmetros estabelecidos para a atenção ao pré-natal e ao puerpério (BRASIL, 2006b). 
momento em que a relação entre mãe e bebê ainda está em construção; e a atenção para o diagnóstico precoce de psicose puerperal ou casos com profunda apatia - que no manual de 2006 apareceram diluídos em meio a conceitos como "alterações emocionais", "estado psíquico" e "condições psicoemocionais" (BRASIL, 2006b, p. 81-82).

A consulta puerperal deve acontecer até 42 dias após o parto. Se a mulher e o recémnascido ainda não tiverem se submetido às ações do retorno, esse é o momento de empreendêlas. Além disso, deve-se avaliar as condições de saúde da mulher e do recém-nascido, registrar as alterações, investigar amamentação, retorno da menstruação e da atividade sexual; realizar atividades educativas e fazer conduta adequada de possíveis intercorrências.

\subsubsection{IMPLEMENTAÇÃO DO PHPN NO CONTEXTO BRASILEIRO DE ATENÇÃO AO PRÉ-NATAL E AO PUERPÉRIO}

Desde o lançamento do PHPN, alguns estudos têm sido realizados para avaliar o impacto do programa na assistência ao ciclo grávido-puerperal. Boa parte deles se baseia nas condutas estabelecidas pelo Ministério da Saúde (BRASIL, 2006b). É o caso do trabalho realizado por Serruya, Lago e Cecatti (2004a), que empreendeu uma primeira avaliação do PHPN no Brasil, a partir dos dados contidos no SISPRENATAL (Sistema de Informação sobre o Programa de Humanização no Pré-Natal e Nascimento desenvolvido pelo DATASUS). Todos os indicadores de processo definidos no PHPN foram avaliados. Percebeu-se que a cobertura do programa em 2002 havia aumentado significativamente, tanto no que se refere à adesão dos municípios ao programa quanto ao número de mulheres cadastradas. Entretanto, notaram-se significativas diferenças regionais e, de maneira geral, alguns aspectos ainda com percentuais muito baixos, como a realização de seis ou mais consultas durante o pré-natal, de exames laboratoriais e da consulta puerperal. Não há menção ao acolhimento no estudo.

Trevisan et al. (2002) avaliaram a assistência pré-natal no município de Caxias do Sul, Rio Grande do Sul. Para tanto, nortearam-se pelos procedimentos preconizados pelo MS no PHPN, realizando entrevistas com puérperas e revisão de cartões de pré-natal e de prontuários médicos. Relatam cobertura de pré-natal de 95,4\%; número médio de consultas de 6,2; início 
tardio de pré-natal (a partir do segundo trimestre) em 65,3\% dos casos; realização de todos os exames complementares básicos em $44,3 \%$ dos casos. Esse é um dos poucos estudos que menciona atividades educativas, contidas entre as condutas estabelecidas pelo PHPN, tendo sido levantado que $74 \%$ das gestantes receberam orientações sobre aleitamento materno e $57 \%$ não receberam informações de caráter educativo durante a gravidez. O acolhimento em seu sentido mais amplo - entendendo-se que orientações e fornecimento de informações o integram -, entretanto, não é investigado.

Coutinho et al. (2003) avaliaram a atenção pré-natal em Juiz de Fora, Minas Gerais, a partir da auditoria de cartões de gestantes. Tendo por base os parâmetros do PHPN, foram analisados início e número de consultas, realização dos exames complementares básicos e de procedimentos clínico-obstétricos tidos como essenciais. Apurou-se alta cobertura - de 99,04\%; porém, apenas $29,7 \%$ das gestantes iniciaram o pré-natal no primeiro trimestre gestacional. A média de consultas foi de 6,4. Quanto ao conjunto de número de consultas, início do pré-natal e realização dos exames complementares básicos preconizados pelo PHPN, houve adequação em apenas $1,9 \%$ dos casos. Acrescentando-se a tal conjunto os procedimentos clínico-obstétricos considerados fundamentais à atenção pré-natal, houve adequação em apenas $1,1 \%$ dos casos. Os autores informam que a maior parte da literatura sobre o tema privilegia a análise de características e resultados da assistência, ficando a investigação do conteúdo das consultas relegada a segundo plano. Porém, no estudo, condutas acolhedoras não são mencionadas.

Costa, Guilhem e Walter (2005) avaliaram a atenção do SUS à gestação por meio de uma amostra de 627 municípios brasileiros. Foram entrevistados gestores, ou profissionais por eles indicados, investigando-se: questões administrativas do município; prioridade política atribuída à atenção ao pré-natal - incluindo-se o de alto risco -, ao parto e ao puerpério; aspectos relacionados aos critérios do PHPN; e cobertura das ações de pré-natal ofertadas, estimada pelo gestor. Dentre os dados descritos, discute-se o vínculo entre o profissional de saúde e a gestante a partir do índice de casos em que esta foi atendida por um mesmo profissional ao longo do pré-natal $-66,8 \%$ dos casos. Não se investiga, porém, o acolhimento em suas outras expressões.

Nagahama e Santiago (2006) avaliaram o serviço de atenção pré-natal do Programa de Assistência Pré-Natal a gestantes de baixo risco do Hospital Universitário de Maringá, no Paraná. Alguns parâmetros definidos pelo PHPN foram utilizados como critérios de 
mensuração. Relatam que $44,5 \%$ das gestantes iniciaram tardiamente o pré-natal (após o quarto mês de gestação), levantando-se como hipótese, porém, o índice, também observado, de que dentre tais mulheres, $68 \%$ se deslocaram de outro serviço, possivelmente em busca de melhor qualidade na atenção. O número médio de consultas de pré-natal, girou em torno de 9,8. Apesar de serem mencionados aspectos referentes à promoção de autonomia das mulheres, ao desenvolvimento de práticas educativas e ao relacionamento mais duradouro entre profissionais de saúde e gestantes, o estudo foca a avaliação do serviço no início do prénatal e no número de consultas, não investigando, portanto, o acolhimento.

Nascimento, Paiva e Rodrigues (2007) investigaram alguns dos indicadores de processo do Programa de Humanização do Pré-natal e Nascimento para a assistência prénatal, no município de Salvador. Foram levantados os percentuais de: UBSs que implantaram o PHPN; gestantes inscritas no programa; gestantes que iniciaram o pré-natal até o quarto mês de gravidez; imunização antitetânica; e de gestantes que voluntariamente aceitaram realizar o teste anti-HIV. Os dados, levantados a partir do SISPRENATAL, revelaram que, em 2002, $37,2 \%$ dos municípios estavam inscritos no PHPN; a cobertura de gestantes atendidas e que realizaram a primeira consulta até o quarto mês foi de $14,2 \% ; 33,5 \%$ das gestantes receberam imunização antitetânica e 17,6\% realizaram a testagem anti-HIV. Discute-se a necessidade de futuras investigações qualitativas, mas não há menção ao acolhimento.

Nascimento, Rodrigues e Almeida (2007) analisaram indicadores de qualidade da atenção pré-natal oferecida por serviços públicos de saúde em Salvador, Bahia, após a implantação do PHPN. O estudo também se baseou em alguns dos indicadores de processo definidos pelo PHPN (BRASIL, 2006b), incluindo-se aqueles que abrangem a realização de consulta puerperal. Apenas $9,76 \%$ das gestantes realizaram ao menos seis consultas prénatais; $7,81 \%$ realizaram as seis consultas pré-natais e os exames básicos; 5,66\% compareceram à consulta pré-natal; e 5,66\% concluíram a assistência pré-natal. Condutas acolhedoras são citadas no estudo, mas não foram investigadas.

Grangeiro, Diógenes e Moura (2008) avaliaram indicadores de processo, a partir do SISPRENATAL, em Quixadá, Ceará. O indicador de consulta puerperal foi incluído. No que diz respeito ao número mínimo de seis consultas, realização dos exames básicos preconizados, de testagem anti-HIV, de imunização antitetânica e de consulta puerperal, as autoras relatam índices crescentes no período de 2001 a 2004, a saber, zero, 2,6\%, 5,68\% e $21,11 \%$. Atividades educativas são citadas, mas não foram investigadas no estudo. Apesar do 
tema do acolhimento não ser explorado, aponta-se a importância do estabelecimento de uma relação de confiança entre profissionais de saúde e clientela.

Gonçalves et al. (2008) avaliaram a qualidade da assistência pré-natal prestada por uma unidade de saúde da família de um município da Grande São Paulo. Realizada análise dos prontuários das gestantes inscritas no programa de pré-natal da unidade, norteada pelos indicadores definidos no PHPN, verificou-se que $82 \%$ das gestantes iniciaram o pré-natal no primeiro trimestre gestacional e $88 \%$ das mulheres retornaram à unidade para consulta puerperal, - as demais (12\%) não o fizeram por terem se mudado da área de abrangência do serviço. As autoras apontam que tais dados evidenciam a importância de o cuidado pré e pósnatal ser prestado por um mesmo grupo de profissionais, o que estreita o vínculo entre estes e a gestante; assim como do trabalho dos agentes comunitários de saúde, que, realizando busca ativa das usuárias, reafirma a adesão delas ao acompanhamento pré e pós-natal. A despeito de tais considerações, porém, o acolhimento não foi investigado no estudo.

Parada (2008) avaliou a atenção pré e pós-natal prestada em municípios da regional de Botucatu - SP, inscritos no PHPN até 2003. Foram realizadas entrevistas com gestores municipais e análise de prontuários, orientadas pelas recomendações do Ministério da Saúde. A autora relata que $85,2 \%$ das gestantes iniciaram acompanhamento pré-natal até o $120^{\circ}$ dia gestacional; 75,9\% realizaram ao menos seis consultas pré-natais; 75,9\% submeteram-se a todos os exames básicos no início da gravidez, mas apenas 13,9\% o fizeram ao final da gestação. Em menos da metade dos municípios há atividades educativas regulares e em 30\% há educação permanente dos profissionais. No que se refere aos indicadores de processo, $58,7 \%$ das gestantes realizaram ao menos seis consultas pré-natais e a consulta puerperal; $13 \%$ realizaram ao menos seis consultas pré-natais e todos os exames básicos; e 10,1\% também realizaram consulta puerperal. Embora não se tenha investigado o acolhimento, dentre as medidas para melhorar os índices, Parada (2008) alega ser de fundamental importância investir-se: no acolhimento às mulheres, de maneira a reforçar o vínculo com o serviço; no fortalecimento da equipe multiprofissional; e na promoção de atividades educativas com as usuárias e de educação permanente dos profissionais.

Parada e Tonete (2008) objetivaram apreender as representações sociais de puérperas usuárias de serviços públicos de saúde sobre o cuidado à gravidez, ao parto e ao puerpério, com base no preconizado pelo PHPN. Foram entrevistadas apenas puérperas atendidas em municípios da região de Botucatu que haviam aderido ao programa até 2004, ano de 
realização do estudo. As autoras verificaram que o cuidado é significado pelas puérperas como satisfatório quando é permeado por simpatia, educação, cordialidade, escuta e atenção; devendo a qualidade técnica - traduzida pelo exame clínico, realização de exames laboratoriais, incluindo-se o ultrassom, e registro do pré-natal no cartão da gestante - também estar presente; assim como o reconhecimento da mulher como protagonista, o que implica participação ativa nas ações de cuidado. Atividades educativas referentes ao puerpério são mencionadas, tendo sido observado que, para as mulheres, trata-se de um aspecto valorizado e compreendido como algo que deve integrar o cuidado em saúde.

Tanaka et al. (2008) realizaram, em 2003, uma avaliação nacional do PHPN, por meio de projeto financiado pelo Ministério da Saúde e implementado pela Unesco. Integrou-se no estudo metodologias quantitativa e qualitativa. Esta última constituiu-se de entrevistas com os profissionais, e de grupos focais com usuárias, investigando-se organização do município, central de regulação e dispositivo de vinculação da gestante. Os autores relatam que, nos municípios de grande porte, encontravam-se melhores índices concernentes ao atendimento dos parâmetros preconizados no PHPN. Os dados qualitativos são consonantes com os quantitativos. Apontam, porém, a não concretização da integração funcional entre a atenção pré-natal e ao parto; e baixos índices de realização da segunda bateria de exames, durante o terceiro trimestre gestacional, e de consulta puerperal. Não há menção ao acolhimento.

Com base em dados coletados no estudo acima, Almeida e Tanaka (2009) desenvolveram trabalho com foco na análise da inclusão da perspectiva das mulheres-usuárias no PHPN. No que diz respeito à captação precoce das gestantes, descrevem dissonância entre o que é ofertado pelo serviço - teste de gravidez e primeiro atendimento - e a expectativa das mulheres por rápida resposta - o que muitas vezes as levam a buscar por um serviço que possa oferecer tal rapidez -, ou vivências perpassadas por fatores psicológicos, tais como não sentir urgência em confirmar a gravidez e iniciar o pré-natal, ou experimentar dificuldades de lidar com a possibilidade de uma gestação. Em relação à escolha do local para acompanhamento pré-natal, perceberam que, a despeito do PHPN definir como critério a proximidade geográfica da residência, experiências subjetivas, como empatia com os profissionais da unidade, ou relatos positivos de familiares anteriormente lá atendidos, destacam-se como elementos mais importantes. Quanto à realização de exames, identificou-se a dificuldade vivida pelas mulheres diante da frequente carência de oferta de tais procedimentos no serviço. Além disso, Almeida e Tanaka (2009) também apontam a demanda 
salientada pelas usuárias pela realização de ultrassonografia - a qual foi por elas mencionada como recurso essencial ao conhecimento da saúde do bebê; procedimento não incluído no PHPN. Quanto à consulta puerperal, observou-se que, na maior parte dos casos, o procedimento não foi considerado importante e/ou prioritário, ao mesmo tempo em que era obscurecido por melhor estruturação do cuidado à criança - o que fazia com que a mulher voltasse ao serviço em busca de pediatra, mas não de consulta de puerpério. A partir disso, Almeida e Tanaka (2009) salientam a importância da perspectiva da mulher-usuária ser incluída nos processos avaliativos do PHPN, de modo a permitir a reconfiguração dos parâmetros preconizados a partir das demandas e do vivido das mulheres. Nesse contexto, os autores chamam especial atenção para o acolhimento, a produção de vínculo e a participação ativa das usuárias nos processos de produção de saúde.

Ao mesmo tempo em que tais estudos descrevem o impacto da implementação do PHPN na atenção ao ciclo grávido-puerperal, revelando aspectos que tiveram significativa melhora - como é o caso da cobertura pré-natal -, e outros que enfrentam desafios - como a consulta puerperal, ainda pouco investigada, aliás, apesar de definida como indicador de processo no PHPN (BRASIL, 2006b) (Anexo A); também evidenciam o que pode ser denominado como contradições geradas pelo próprio programa.

Dentre os treze estudos levantados, quatro não fazem menção ao acolhimento (COUTINHO et al., 2003; NASCIMENTO; PAIVA; RODRIGUES, 2007; SERRUYA; LAGO; CECATTI, 2004a; TANAKA et al., 2008). Cinco, embora o mencionem, não o investigaram (GONÇALVES et al., 2008; GRANGEIRO; DIÓGENES; MOURA, 2008; NAGAHAMA; SANTIAGO, 2006; NASCIMENTO; RODRIGUES; ALMEIDA, 2007; PARADA, 2008). Dentre os quatro que avaliaram o acolhimento, dois (COSTA; GUILHEM; WALTER, 2005; TREVISAN et al., 2002) discutem apenas algum aspecto que o integra Trevisan et al. (2002) trataram de orientações acerca de aleitamento materno e provimento de informações de caráter educativo durante a gravidez; e Costa, Guilhem e Walter (2005) abordaram o vínculo entre a mulher e os profissionais de saúde, tendo em vista o índice de casos em que se manteve a mesma equipe provendo os cuidados pré-natais e puerperais. Portanto, dos treze estudos levantados que se propuseram a avaliar a atenção pré-natal e/ou pós-natal à luz do PHPN, apenas dois (ALMEIDA; TANAKA, 2009; PARADA; TONETE, 2008) incluíram, de modo mais aprofundado, o tema do acolhimento - sob a perspetiva das usuárias. 
Antes de prosseguir com as considerações a esse respeito, impõe-se uma ressalva. $\mathrm{O}$ fato de aqui se evidenciar que o acolhimento tenha recebido pouco, ou nenhum, espaço na maior parte de tais estudos, de forma alguma permite afirmar, ou inferir, que tal tema não venha sendo debatido na literatura. Como aponta Teixeira (2005), a questão do acolhimento vem sendo intensamente discutida. O que aqui se destaca é que no que se refere à monitoração do PHPN, tendo em vista o cuidado ao pré-natal e ao puerpério, tal aspecto, preconizado pelo programa, não vem sendo investigado.

Um dos principais fatores implicados em tal panorama parece estar em torno dos indicadores de processo e de resultado definidos pelo PHPN - os quais nortearam a maior parte dos estudos aqui levantados. Nas palavras de Parada e Tonete (2008, p. 45), "o PHPN, ao adotar indicadores para avaliação da qualidade da atenção que privilegiam o número de consultas pré-natais, a imunização e os exames básicos realizados, não está avançando na inclusão de aspectos que valorizem, de fato, outras dimensões do cuidado". Como decorrência, o acolhimento e outras condutas preconizadas pelo programa, mas não incluídas dentre tais indicadores, como é caso de atividades educativas, permanecem sem monitoramento, ainda que, a importância destas, seja ressaltada tanto no manual de 2001 (BRASIL, 2001) quanto no de 2006 (BRASIL, 2006b); e, como já mencionado, o acolhimento seja destacado como "aspecto essencial da política de humanização" (BRASIL, 2006b, p. 13); e/ou como "uma das diretrizes de maior relevância ética/estética/política da Política Nacional de Humanização do SUS” (BRASIL, 2008, p. 6).

Cabe considerar, porém, que a avaliação do acolhimento, mais especialmente, demandaria outros métodos de investigação, uma vez que ele não é um aspecto que pode ser facilmente monitorado pelo SISPRENATAL e similares. Sobre a avaliação do PHPN, Almeida e Tanaka (2009, p. 103) expõem ser de fundamental importância incluir as percepções expressas pelas usuárias acerca da atenção, assim como suas expectativas e demandas, ao dissertar que "valorizar a escuta de grupos focais pode ser um instrumento de gestão tão efetivo como a análise de indicadores epidemiológicos de resultado ou então de produção/produtividade do processo de atenção". Poder-se-ia acrescentar a essa consideração, tendo-se em vista a discussão do tema do acolhimento empreendida no PHPN (BRASIL, 2006b) e na PNH (BRASIL, 2008), a apreensão do vivido pelos profissionais no cotidiano de trabalho. Assim, cabe razão a Almeida e Tanaka (2009) quando manifestam a necessidade de se integrar metodologias de abordagem qualitativa. 
Outro ponto conveniente ao debate diz respeito ao referencial que se vem tentando adotar no PHPN: o de um cuidado pautado em uma concepção de saúde integral, ou seja, que englobe "questões psicológicas, sociais, biológicas, sexuais, ambientais e culturais" (BRASIL, 2004a, p. 59). Entretanto, ao definir indicadores que tratam apenas de procedimentos da área das tecnologias duras - segundo conceituação de Merhy (2000) - e não avaliar outras dimensões do cuidado, o programa se reveste de contradição essencial, e contribui, como se pode notar dentre os estudos levantados, para a reafirmação do "enfoque biologicista e medicalizador hegemônico" (BRASIL, 2004a, p. 59).

A partir de tais considerações, convém questionar que humanização, no campo do cuidado ao pré-natal e ao puerpério, vem sendo possível de ser implementada pelo PHPN. Além disso, parece evidenciar-se a relevância de se contribuir com estudos qualitativos, à luz do PHPN, acerca do fenômeno em pauta.

\subsection{MAIS CONSIDERAÇÕES SOBRE O ACOLHIMENTO}

Diante do panorama descrito, assim como da importância do acolhimento no campo da humanização - principalmente na PNH (BRASIL, 2008) e no PHPN (BRASIL, 2001, 2002, 2006b) -, uma ampliação da discussão sobre o tema mostrou-se relevante.

A seguir, é apresentado um referencial que integra de modo mais destacado o conjunto de norteadores de análise do presente trabalho: a proposta de acolhimento dialogado de Teixeira (2003), a qual, além de ser significativamente referenciada na literatura, aqui desencadeou articulações com outros referenciais. Posteriormente, é explorada a forma com que o acolhimento vem sendo compreendido na literatura e são relatados alguns estudos que se dedicaram a descrever/compreender as implicações de sua incorporação nos processos de produção de saúde. Mais adiante, é discutida a produção de vínculo entre profissional/equipe/serviço e usuário, como processo inter-relacionado ao acolhimento. $\mathrm{Na}$ sequência, são evidenciadas tais inter-relações a partir do referencial gestáltico de atitude dialógica - aqui tomada como possibilidade de ampliação da proposta de acolhimento dialogado de Teixeira (2003). E, por fim, são abordados, mais especificamente, tais processos no campo do cuidado ao pré-natal e ao puerpério. 


\subsubsection{DISCUSSÕES EM TORNO DO CONCEITO DE ACOLHIMENTO}

Entendendo, assim como Merhy (1998), o trabalho em saúde como trabalho vivo em ato, Teixeira (2003) postula que sua substância essencial é a conversa. De modo a ilustrar essa premissa, destaca que a observação de um serviço de saúde permite perceber que todo o seu funcionamento se fundamenta em conversas, sejam essas exclusivas ou motores de procedimentos em realização. Por essa razão, defende ser possível considerar a rede técnicoassistencial dos serviços de saúde como redes de conversação, nas quais o trabalhador se utiliza de determinadas "técnicas de conversa" (TEIXEIRA, 2003, p. 96), inscritas no terreno das tecnologias leves.

O autor então discorre acerca de uma técnica específica de conversa, que denomina de acolhimento dialogado, que se fundamenta na validação do outro em quem ele legitimamente é e no reconhecimento de que os sentidos de cada situação podem ser apenas desvelados no encontro intersubjetivo de trabalhador e usuário, dado que "todo mundo sabe alguma coisa e ninguém sabe tudo" (TEIXEIRA, 2003, p. 105); pauta-se também, portanto, em relação permeada por horizontalidade. A técnica se compõe de dois elementos: acolhimento e diálogo. O primeiro consiste em um movimento receptivo ao usuário, acolhendo-o no que ele traz como demanda. Porém, considerando-se que "nossas necessidades não nos são sempre imediatamente transparentes e nem jamais definitivamente definidas" (TEIXEIRA, 2003, p. 104), é função do diálogo propiciar melhor investigação, elaboração e negociação de tais demandas, assim como comprometer-se com a busca de formas de atendê-las. Nessa busca, ocasionalmente, o usuário é convidado a frequentar outros espaços/encontros. Por isso, segundo Teixeira (2003), o acolhimento tem o papel de manter tais espaços, que compõem a rede de saúde, conectados, propiciando ao usuário transitar mais amplamente por ela.

Para o autor, embora possa também se expressar pela atividade de recepção do usuário no serviço de saúde, o acolhimento dialogado não se restringe a ela, estendendo-se por todos os encontros que permeiam o trânsito daquele pela rede. Essa concepção é importante porque, assim como se dá com outros termos da área de saúde - caso da humanização, como já discutido - o acolhimento também vem sendo compreendido sob diferentes enfoques.

Um desses enfoques o associa à atividade de recepção do usuário ao serviço de saúde, realizada por uma equipe, usualmente denominada "de acolhimento" que, em alguns 
serviços, é constituída apenas por auxiliares de enfermagem, ainda que se defenda ser multiprofissional (ESPERANÇA; CAVALCANTE; MARCOLINO, 2006). Nessa dimensão, ele é discutido como dispositivo de garantia de acesso universal, de modo que todos os usuários possam ter suas demandas ouvidas e atendidas (FRANCO; BUENO; MERHY, 1999; ESPERANÇA; CAVALCANTE; MARCOLINO, 2006; SCHOLZE et al., 2006); como instrumento de qualificação da relação trabalhador-usuário, passando esta a ser permeada por solidariedade, humanidade e cidadania (FRANCO; BUENO; MERHY, 1999); como estratégia de aplicação dos princípios do SUS (SCHOLZE et al., 2006); e como espaço de desenvolvimento de ações preventivas (ESPERANÇA; CAVALCANTE; MARCOLINO, 2006). Ademais, orientado por um modelo centrado nos interesses dos usuários, destaca-se como alternativa de rompimento do modelo biomédico, médico-centrado, especialmente por mobilizar, com vistas à escuta e à resolução das demandas em saúde, a organização interdisciplinar do trabalho. Salienta-se também, nesse sentido, a importância de envolver os diversos profissionais nas tarefas de acolhimento (ESPERANÇA; CAVALCANTE; MARCOLINO, 2006; FRANCO; BUENO; MERHY, 1999; SCHOLZE et al., 2006).

Ainda nesse campo da compreensão do acolhimento, Takemoto e Silva (2007), entendem que ele não deve se restringir à recepção do usuário - o que é também acentuado por Brasil (2008), Inojosa (2005), Lima et al. (2007), Schimith e Lima (2004), Silveira et al. (2004), Solla (2005), Ramos e Lima (2003) e Teixeira (2003) - e discutem que, embora seja possível e interessante existir um espaço de acolhimento de porta de entrada, deve-se tomar o cuidado de que a constituição desse espaço não desresponsabilize o restante da equipe de saúde perante as tarefas de acolhimento, tal como observaram em algumas das Unidades Básicas de Saúde que integraram o estudo.

O acolhimento é também discutido como postura do profissional de saúde dimensão, cabe lembrar, que traduz a compreensão expressa no PHPN (BRASIL, 2006b). Em tal âmbito, Camelo et al. (2000) destacam atitudes como estabelecer uma relação próxima com o usuário, permeada por compreensão, corresponsabilidade e afeto; cumprimentá-lo, chamando-o pelo nome; valorizá-lo e individualizá-lo; e demonstrar interesse por ele e por suas questões. Marques e Lima (2004) apontam respeito e responsabilização pelas demandas dos usuários - a qual, por sua vez, é concernente aos processos de produção de vínculo e de autonomia, o que revela, para Marques e Lima (2004), a inter-relação do conceito com a noção de humanização. Ramos e Lima (2004) referem empatia, que permite apreender as 
necessidades dos usuários, e comprometimento para com o atendimento das mesmas. De modo semelhante, em Takemoto e Silva (2007), trata-se de uma postura, perante o usuário, de solidariedade, de permanente investigação e negociação das demandas em saúde e de busca de atendê-las. Silva Jr. e Mascarenhas (2005, p. 243) destacam uma atitude de recepção, de escuta, disponível para o diálogo, solidária com o vivido pelo usuário e comprometida com um cuidado humanizado, devendo ser tomada pelo profissional como importante instrumento de trabalho. Dela decorre "uma relação de mútuo interesse, confiança e apoio". Os autores ainda acentuam que tal atitude deve ser assumida não apenas nas relações entre equipe e usuário mas também naquelas estabelecidas na própria equipe e entre essa e gestores.

Para Silva Jr. e Mascarenhas (2005) o acolhimento é também dotado de uma dimensão técnica, que se refere à instrumentalização por ele gerada em termos de procedimentos e de ações organizadas, tais como constituição de equipes multiprofissionais, construção de saberes pautados na interdisciplinaridade e instauração de novas práticas. Assim compreendido, os autores o situam em zona de intersecção com outro âmbito do acolhimento: o de reorientador dos processos de trabalho e de diretriz do serviço, o qual, vale lembrar, é também apontado na cartilha da PNH acerca do tema (BRASIL, 2008).

Franco, Bueno e Merhy (1999) veem o acolhimento com uma função principal de reorganizar o serviço, de modo a garantir acesso universal, resolutividade e humanização do cuidado. Para eles, tal reorientação se dá, especialmente, pela mudança do modelo médicocentrado, deslocando-se, então, o eixo central da figura do médico para a equipe multiprofissional. Como descrito, tal reorientação foi também apontada por Esperança, Cavalcante e Marcolino (2006) e por Scholze et al. (2006). Marques e Lima (2004) salientam o acolhimento como fator de mudança nos processos de trabalho, potencializando e valorizando as ações dos profissionais e promovendo a interdisciplinaridade da organização do trabalho. Para Solla (2005), tal dimensão objetiva a qualificação da atenção e a ampliação da capacidade do serviço de identificar as demandas em saúde e atendê-las. Silva Jr. e Mascarenhas (2005) apontam, ainda, que o acolhimento como reorientador e diretriz do serviço integra critérios orientadores de composição das equipes de saúde, capacitação, organização de conteúdos de treinamentos, supervisão, avaliação dos trabalhadores e espaços de reflexão acerca dos processos de trabalho e das demandas em saúde. De modo semelhante, para Franco, Bueno e Merhy (1999), discussões contínuas sobre o processo de acolhimento, capacitação, utilização de protocolos e grupos programáticos são recursos essenciais ao 
acolhimento com vistas à resolutividade.

Discutindo, mais especificamente, a incorporação do acolhimento no Sistema Único de Saúde, Solla (2005) aponta, ainda, outro âmbito do acolhimento: o de diretriz para as políticas públicas de saúde, voltada à estruturação de um sistema constituído por tecnologias adequadas a responder às demandas dos usuários. Tal expressão do acolhimento como dispositivo político é também discutida na cartilha da PNH sobre o tema (BRASIL, 2008).

A partir de tais considerações, nota-se que ainda que alguns autores enfatizem mais determinada dimensão do acolhimento, parece importante considerá-lo como um fenômeno complexo, que deve ser entendido em meio a uma multiplicidade de aspectos constituintes, os quais, aliás, mostram-se em constante inter-relação. Embora, de fato, em alguns serviços de saúde haja apenas atividades de recepção e/ou triagem - como relatado por Esperança, Cavalcante e Marcolino (2006) e discutido pelo MS (BRASIL, 2008) -, percebese que tais atividades são usualmente descritas como reorientadoras e transformadoras dos processos de trabalho e das relações estabelecidas entre profissionais e usuários na porta de entrada. Em condições ideais, mobilizam, também, maior intercâmbio entre áreas, em razão das necessárias trocas entre equipe de acolhimento e demais equipes na UBS. Assim, mesmo quando compreendido como atividade de recepção, o acolhimento também se evidencia como reorganizador do serviço de saúde.

Na sua dimensão de postura, apesar de o acolhimento ser aí apontado pela maior parte dos autores como algo que se refere à relação com o usuário, parece importante ter-se em vista que se trata, na verdade, da construção de uma nova cultura de relações, considerando-se não apenas aquelas estabelecidas entre profissionais e usuários mas também entre profissionais e entre estes e gestores, como já mencionado em outras seções deste trabalho e como referido por Silva Jr. e Mascarenhas (2005). Além disso, a inter-relação de acolhimento como postura e como reorganização do serviço é especialmente evidenciada pelo fato de constituir essa postura contínuas identificação, elaboração e negociação de demandas, e um comprometimento para com o atendimento delas. Como aponta Teixeira (2003), isso muitas vezes implica o convite para que o usuário transite pela rede, frequentando outros espaços/encontros; trânsito que depende de equipes de saúde funcionais e conexões entre áreas - o que remete a outras questões já apresentadas, como as que integram o âmbito técnico apontado por Silva Jr. e Mascarenhas (2005).

A dimensão política, por sua vez, pode ser entendida como o que explicita a inter- 
relação de tais esferas. É ela que investiga modos de vida, que escuta a comunidade, os profissionais e os gestores, para que a compreensão do acolhimento e das maneiras possíveis de se implantá-lo nos serviços de saúde possa de fato atender às demandas vividas. É também o que garante os subsídios para a concretização de tais processos e formas de contínua avaliação do que é implementado. É importante ressaltar que, apesar de se manter tal compreensão como pano de fundo, essa esfera não será investigada no presente trabalho, que enfocará o acolhimento em suas dimensões de postura, de atividade receptiva e de reorientação do serviço e dos processos de trabalho.

\subsubsection{PRODUÇÃO DE VÍNCULO}

As inter-relações de processos de acolhimento e produção de vínculo entre usuários e profissional/equipe/serviço de saúde são discutidas e/ou referidas por alguns autores (FRANCO; BUENO; MERHY, 1999; INOJOSA, 2005; LIMA et al., 2007; MERHY, 1998; RAMOS; LIMA, 2004; SCHIMITH; LIMA, 2004). Faz-se especialmente importante discorrer sobre tal temática em função de se estar aqui tomando, como principais orientadores da compreensão da proposta de humanização e dos demais aspectos a ela relacionados - como é o caso do acolhimento -, os documentos do PHPN e da PNH. Como já apontado, a cartilha de acolhimento da PNH (BRASIL, 2008) acentua que tal elemento se traduz em ferramenta tecnológica de qualificação de escuta, produção de vínculo, responsabilização e resolutividade; e que, dentre os objetivos de se reinventar os processos de acolhimento nos serviços de saúde, deve estar a ampliação da responsabilização dos profissionais pela clientela e do vínculo entre ambos.

No contexto de produção de saúde, vínculo pode ser entendido como o estabelecimento de relações entre usuários e cuidadores pautadas no acolhimento, que propiciam a sensibilização destes para com o vivido pela clientela, sua responsabilização para com o atendimento das demandas identificadas, elaboradas e negociadas nesse espaço relacional e, mais especialmente, a adscrição dos usuários a uma equipe, multiprofissional, de saúde, a qual passa a ocupar um lugar de referência segura junto àqueles em favor da construção de autonomia (FRANCO; BUENO; MERHY, 1999; MERHY; FRANCO, 2005; 
MERHY, 1998).

Silva Jr. e Mascarenhas (2005) propõem que o vínculo seja pensado em três dimensões: afetividade, relação terapêutica e continuidade. A primeira associa-se ao interesse que o profissional deve nutrir por quem o usuário é e pelo que ele vive; o que é permeado, segundo os autores, pela relação que o cuidador estabelece com sua própria ocupação. A segunda dimensão se traduz pela compreensão do vínculo como um instrumento de trabalho que promove ampliação de autonomia, e que passa, portanto, por assumir o usuário em sua condição de sujeito e por estabelecer uma relação baseada em diálogo, corresponsabilidade, intersubjetividade, alteridade e aceitação - elementos que remetem, cabe notar, aos processos de acolhimento. E a terceira diz respeito à possibilidade de melhor compreender quem o usuário é e o que vive, para, a partir disso, desenvolver ações mais efetivas e garantir maior adesão aos projetos terapêuticos.

De modo semelhante, para Lima et al. (2007), o vínculo é elemento fundamental na produção do cuidado, uma vez que, por implicar relação permeada por proximidade e aceitação, propicia aos usuários satisfação e segurança; e aos profissionais, conhecimento mais amplo da clientela e de suas demandas, favorecendo, assim, os processos de responsabilização. Schimith e Lima (2004) afirmam ainda que o vínculo é fator essencial à adesão do usuário ao serviço, à sua participação ativa durante a prestação desse e à promoção de autonomia. Figueiredo e Rossoni (2008) complementam que tal elemento também promove maior eficácia nas ações em saúde.

Explicitando tais processos e, especialmente, evidenciado as inter-relações de acolhimento e vínculo, Merhy (1998) refere que a relação, pautada no acolhimento, vai sendo permeada por momentos de diálogo e de interpretações, em que as intenções de cada um são acolhidas. Esses momentos, segundo Ramos e Lima (2004), permitem ao profissional apreender o vivido pelo usuário e fazer, então, orientações mais eficientes, baseadas em tal vivido; e encorajam o usuário a fazer perguntas, às quais obtém respostas e esclarecimentos. Vão se gerando, então, momentos de cumplicidade, em que se produz a responsabilização em torno das questões com as quais se pretende lidar, e momentos de confiança (MERHY, 1998). Como resultado desse espaço sólido que se vai criando, que Merhy e Franco (2005) definem como a equipe se estabelecer como uma referência segura para o usuário, Ramos e Lima (2004) destacam que ele irá se sentindo cada vez mais confiante acerca de sua capacidade de lidar com eventuais dificuldades e dúvidas - conquistando, portanto, maior autonomia; o que, 
de fato, não terá sido ao acaso, uma vez que, como indicam Merhy e Franco (2005), a equipe que toma os processos de acolhimento e vínculo como diretrizes do serviço trabalha em favor do empoderamento dos usuários, que se dá, justamente, à medida que eles aprendem mecanismos de autocuidado e, progressivamente, se sentem mais capazes de se cuidar. Ademais, para Ramos e Lima (2004), tal contexto relacional também favorece o fortalecimento da confiança depositada na relação, sedimentando-se, assim, o vínculo. Evidencia-se, dessa maneira, o salientado por Lima et al. (2007) sobre o atendimento pautado no acolhimento, na resolutividade e no bom desempenho profissional promover o vínculo entre o usuário e o serviço de saúde.

Convém ainda destacar que essa construção do vínculo entre profissional e usuário tem o reconhecimento da condição de sujeito desse último - ou seja, que é alguém que tem algo a dizer, que nutre dadas expectativas e que avalia a si mesmo e ao processo de produção do cuidado - como elemento fundamental, sem o qual o vínculo não se constrói (FIGUEIREDO; ROSSONI, 2008). O acolhimento mais uma vez se evidencia, assim, como dispositivo de sedimentação do vínculo, especialmente se considerado um de seus elementos: “o reconhecimento do outro como um legítimo outro" (TEIXEIRA, 2003, p. 105).

Em termos de reorganização do serviço em favor dos processos de acolhimento e de produção de vínculo, Franco, Bueno e Merhy (1999) referem que, quando esses processos são tomados como diretrizes, o atendimento se torna fundamentado na adscrição da clientela a dada equipe, multiprofissional, da UBS, a qual se responsabiliza por essa clientela, mobilizando, assim, todos os recursos necessários ao provimento de respostas às demandas dela.

Aliás, como se depreende do já exposto, diversos autores destacam a associação entre produção de vínculo e processos de responsabilização (FRANCO; BUENO; MERHY, 1999; MERHY; FRANCO, 2005; LIMA et al., 2007; MERHY, 1998; SILVA JR.; MASCARENHAS, 2005). Silva Jr. e Mascarenhas (2005) entendem que o termo "responsabilização" pode ser compreendido como o profissional assumir a responsabilidade pelo que se passa com o usuário e se comprometer com a mobilização dos recursos necessários ao atendimento de suas demandas. Lima et al. (2007) ressaltam, porém, que não se deve entender tal processo em associação com a promoção e/ou manutenção de dependência do usuário, pois, ao contrário, o que se objetiva é favorecer o desenvolvimento de autocuidado e de autonomia. 
De modo a tornar viável a implementação de tais processos, Merhy (1998) declara ser essencial a compreensão de que qualquer profissional de saúde, independentemente da função que realize nos processos de produção de saúde, é um operador do cuidado e, como tal, deve ser capacitado no manejo de tecnologias leves e na gestão e na mediação das relações que se dão entre as diferentes equipes e saberes em favor da realização dos projetos terapêuticos. Esse segundo fator é especialmente importante à estruturação do serviço, que deve ser fundamentada em equipes multiprofissionais cujas relações entre seus integrantes sejam permeadas por solidariedade, diálogo e intercâmbio de saberes e práticas (MERHY; FRANCO, 2005). Além disso, apenas a partir de equipes integradas e funcionais é possível que todos os profissionais assumam os processos de acolhimento e de produção de vínculo como projetos de produção de saúde; algo considerado por Schimith e Lima (2004) e por Merhy e Franco (2005) como essencial à concretização de tais processos.

\subsubsection{ATITUDE DIALÓGICA E APEGO SEGURO: AMPLIANDO A COMPREENSÃO DAS INTER-RELAÇÕES DOS PROCESSOS DE ACOLHIMENTO E DE PRODUÇÃO DE VÍNCULO}

Partindo da compreensão do acolhimento como uma tecnologia e do serviço de saúde como uma rede de conversações, Teixeira (2003) centrou-se em uma técnica específica de conversa, à qual denominou acolhimento dialogado. Em meio a articulações de sua proposta com a leitura do acolhimento em sua dimensão de postura mais especificamente - conforme discutida por Camelo et al. (2000), Marques e Lima (2004), Ramos e Lima (2004), Silva Jr. e Mascarenhas (2005), Brasil (2006b, 2008) e Takemoto e Silva (2007) - e com a compreensão de vínculo aqui discutida, identificou-se similaridades com a atitude dialógica debatida na Gestalt-Terapia, especialmente no que se refere à sua interlocução com o conceito de figura de apego seguro, conforme discutido por Lima e Fernandes (2006).

Os processos de acolhimento e de produção de vínculo configuram-se em aspectos centrais na análise dos dados do presente estudo, especialmente pelo lugar que ocupam na compreensão de humanização aqui adotada. Além disso, Merhy (2002) defende que os melhores critérios norteadores de análise de um dado modelo técnico-assistencial consistem 
na avaliação de como as tecnologias leves operam, ou seja, se comandam ou se são comandadas pelas demais tecnologias. Por essas razões, julgou-se relevante discorrer sobre o dialógico no referencial gestáltico, em associação, como mencionado, com o tema do apego seguro, de modo a se ampliar os recursos de análise e, também, contribuir-se com mais uma possibilidade de se compreender e se evidenciar as inter-relações de tais processos de acolhimento e vínculo no cuidado em saúde.

Antes disso, porém, tendo em vista que Bowlby (1990) discute o tema do apego seguro especialmente nas relações entre cuidador e criança, convém explicitar porque aqui se compreende que em uma relação construída em meio a processos de produção de saúde, o vínculo estabelecido entre profissional e usuário é também permeado por apego e, quando bem sedimentado, o cuidador assume o papel de figura de apego seguro.

Como já mencionado, Bowlby (1990) refere que, ainda que vá perdendo sua centralidade ao longo da vida, o comportamento de apego se mantém como algo importante na fase adulta, especialmente quando o indivíduo se vê diante de dificuldades. Além disso, se antes apenas os cuidadores mais próximos da criança desempenhavam o papel de figura de apego, conforme ela cresce, outras pessoas, grupos e instituições podem passar a assumir tal lugar.

Partindo de tais considerações, a Equipe de Reflexão Clínica do Instituto Gestalt de São Paulo passou a permear suas discussões acerca de casos clínicos e de promoção de resiliência em contextos de saúde e de educação - foco de estudos da equipe no período de 2005 a 2006 - pela compreensão de que o cuidador assumir o lugar de figura de apego seguro perante aquele de quem cuida, era não apenas um elemento essencial à constituição do vínculo como também à promoção de desenvolvimento e de crescimento. Uma vez que tais discussões eram fundamentadas no referencial gestáltico, o aprofundamento do tema levou a se tecer a compreensão de que a figura de apego seguro tem uma atitude dialógica (LIMA; FERNANDES, 2006).

Posto isso, convém então discorrer sobre a temática. Em função de o objetivo aqui não ser o de discutir a relação dialógica, mas, mais especificamente, abordar a atitude dialógica em inter-relação com a figura de apego seguro nos processos de produção de saúde, a compreensão de dialógico em Gestalt-Terapia será contextualizada brevemente para, a seguir, apresentar-se alguns dos aspectos da atitude dialógica.

Para Hycner (1997), o homem só se torna completamente ele mesmo quando sua 
singularidade é reconhecida pelo outro. O dialógico, segundo o autor, refere-se, justamente, a esse espaço relacional em que um indivíduo, colocando-se como ser inteiro, valida o outro em sua unicidade e totalidade. De acordo com Jacobs (1997, p. 68), há uma atitude de "voltar-se para o outro plenamente, de corpo inteiro, uma entrega ao entre, com confiança nele". A relação assim constituída, portanto, é comandada pelo entre e permeada por amor. Yontef (1998) refere ainda que, em tal dimensão relacional, o outro é abordado como pessoa digna de respeito e não meramente como objeto que se pretende manipular de modo a se atingir determinados fins; e que é a partir de tal experiência que o homem pode se tornar inteiro. Ademais, Jacobs (1997) assinala que o contato dialógico permite o desenvolvimento existencial, realizando a pessoa no que ela é e no que ela pode vir a ser.

Quando se trata de relações de cuidado, é importante considerar que o foco está em o cuidador assumir uma atitude EU-TU, ou dialógica. Para tanto, Jacobs (1997) aponta elementos que se fazem necessários. Dentre alguns deles, são aqui destacados presença, inclusão e confirmação. Além disso, Lima e Fernandes (2006) mencionam a atitude amorosa como aspecto primordial da atitude dialógica. Convém, então, discorrer brevemente sobre cada um de tais elementos.

Hycner (1997) define presença como um voltar-se para o outro como pessoa inteira, reconhecendo-o em sua alteridade. Isso significa que todo o ser do cuidador se foca no que está se passando com o outro e na relação. Entende-se, porém, que para que possa estar plenamente presente, o contato consigo mesmo não pode ser perdido; esse se dá, entretanto, a serviço da relação e não como algo que promove ruptura. É esse contato que possibilita o que Yontef (1998) também carateriza como presença: no lugar de transmitir uma determinada imagem ou neutralidade, o cuidador se mostra como é, o que inclui compartilhar emoções, sensações, percepções, dúvidas e limites que identifique relevantes ao processo, e revela seu colocar-se como pessoa inteira e integrada na relação - ou seja, como ser pensante, emocional e de sensações. Trata-se, ademais, de deixar que o outro possa ser afetado por quem o cuidador é, como sustenta o autor.

Lima e Fernandes (2006) destacam que a figura de apego seguro pratica a presença. É especialmente por meio dela que transmite àquele de quem cuida que está inteiro, consistentemente presente e a serviço dele e da relação, pondo-se, então, como alguém em quem o outro percebe que pode confiar e com quem aprende a contar, especialmente em momentos de demanda de suporte, cuidado, orientação. 
A inclusão, para Hycner (1997), é um movimento de ir-e-vir, ou seja, uma tentativa de se colocar momentaneamente no universo do outro e olhar o mundo a partir de seus olhos, permanecendo, porém, centrado em si mesmo. Ao fazê-lo, segundo Yontef (1998, p. 252), o cuidador suspende seus referenciais, crenças e valores; "aprecia a mesma validade para uma realidade diferente" da sua; e se deixa ser afetado por quem o outro é. Tomando como base os escritos de Martin Buber, Hycner (1997) ainda pontua que a inclusão diferencia-se da empatia, pois enquanto esta concerne a um sentimento, aquela se refere a um movimento existencial que não ignora nenhum dos lados do diálogo.

A figura de apego seguro, afirmam Lima e Fernandes (2006), pratica a inclusão, que se revela como instrumento especialmente importante para que possa apreender demandas expressas por aquele de quem cuida; auxiliá-lo a também perceber suas potencialidades e a (re)tomar um caminho de desenvolvimento e realização de quem legitimamente é; assim como captar momentos em que intervenções se façam necessárias.

De acordo com Jacobs (1997), a confirmação depende do movimento de ir-e-vir da inclusão, uma vez que é esse movimento que permite a apreensão do outro. A partir do que é, então, apreendido, ela implica validar e aceitar o outro no que ele é, ou seja, em seus desejos, sentimentos, crenças, valores, conflitos e dificuldades; e no que pode vir a ser, o que Yontef (1998) registra como confirmar a pessoa em suas potencialidades mais completas, tanto aquelas concernentes a aspectos que a pessoa conhece de si como as referentes a elementos que desconhece ou nega.

Importante ressaltar que a aceitação implicada na confirmação refere-se à dimensão existencial, não significando que o cuidador, conforme Cardella (1994), não possa discordar de escolhas tomadas por aquele de quem cuida e intervir quando julgar adequado. Quando o faz, porém, é de forma focada e com respeito a quem o outro é, sem colocar em dúvida, portanto, seu valor como pessoa. Hycner (1997) assegura, ainda, que é a partir da confirmação que o homem concretiza sua existência; é ao se sentir olhado e validado que poderá de fato caminhar, sentindo a firmeza do terreno sobre o qual caminha - o seja, com autonomia - em direção a se tornar quem é.

Percebe-se, assim, que como sugerem Lima e Fernandes (2006), a figura de apego seguro pratica a confirmação. Ao acolher e validar o que expressa ou revela de si aquele de quem cuida, dá espaço para que esse se coloque como é, sentindo-se confortável para compartilhar o que vive. Ao mesmo tempo, ao permear suas intervenções por respeito e 
confirmação do valor existencial do outro, estabelece as bases para que a relação possa fluir dialogicamente, fortalecendo a abertura daquele de quem cuida à escuta e à consideração das intervenções realizadas; e sua capacidade de expressar discordâncias e se pôr em negociação. Ademais, confirmando a capacidade do outro de lidar com o que vive, encoraja-o a se colocar no mundo experimentando-se diante do novo. Assim, age no sentido de promoção de desenvolvimento, crescimento e fortalecimento de autonomia.

A atitude amorosa, por sua vez, possibilita, segundo Cardella (1994), a abertura para o diálogo e para a relação; é a própria expressão do Eu-Tu e o elemento que propicia o estabelecimento do vínculo com aquele de quem se cuida. Para Forghieri (1984, p. 20), tal atitude não apenas permite o encontro como também revela a humanidade dos sujeitos, pois "no amor os homens [...] deixam de ser uma coisa entre as coisas para se tornarem seres humanos semelhantes". De acordo com Lima e Fernandes (2006), é por meio da atitude amorosa que o cuidador se mobiliza a praticar a inclusão e a presença, adentrando no universo vivencial daquele de quem cuida e compartilhando do que ali encontra, mesmo que sejam vivências carregadas de dor; que pode se inspirar à compaixão, tanto por aqueles que despertam afeto e proximidade, quanto por aqueles que, a princípio, revelam-se de difícil contato; e que pode ampliar sua percepção acerca do outro, captando o sombrio e a potência, dificuldades e talentos, defeitos e virtudes. É por essa razão que as autoras defendem que a atitude amorosa está no cerne da postura dialógica - e, portanto, da atuação da figura de apego seguro - traduzindo-se em sua grande mola propulsora.

Como se vê, cada elemento da atitude dialógica contribui de um modo para o estabelecimento de um chão cada vez mais firme à construção da relação entre cuidador e aquele de quem se cuida - no contexto em pauta, profissional de saúde e usuário. Um chão que, revelando um profissional-pessoa que enxerga um usuário-sujeito, encoraja esse último a também se entregar à relação, mostrando-se como é, compartilhando o que vive e, progressivamente, ocupando um lugar mais ativo no processo de identificação, elaboração e negociação de demandas e se engajando com os projetos terapêuticos co-construídos. Um chão, portanto, que vai ampliando vivências de confiança, corresponsabilidade, autonomia, desenvolvimento e ampliação de potências e, assim, não apenas evidencia a inter-relação de acolhimento e vínculo como a razão de tais processos serem tão fundamentais à humanização do cuidado. 


\subsubsection{A INVESTIGAÇÃO DOS PROCESSOS DE ACOLHIMENTO E PRODUÇÃO DE VÍNCULO NOS SERVIÇOS DE SAÚDE}

A partir de tais considerações, serão mencionados alguns estudos que se propuseram a investigar os processos de acolhimento e vínculo nos serviços de saúde. Primeiro, são apresentados os trabalhos que tiveram como foco a atenção em saúde em uma esfera mais ampla, para, a seguir, discorrer sobre aqueles focados, especificamente, no campo do cuidado ao pré-natal e ao puerpério.

Franco, Bueno e Merhy (1999) descrevem experiência de implantação de uma equipe de acolhimento multiprofissional em uma UBS de Minas Gerais. A despeito de entenderem que o acolhimento permeia todos os encontros que se dão nos serviços de saúde, enfocaramno, especialmente, como dispositivo de reorientação do serviço de saúde. Dentre os resultados obtidos, relatam a ampliação da acessibilidade e do rendimento profissional e melhor resolutividade. Destacam, ainda, que os profissionais desenvolveram recursos de autoanálise, tornando-se mais implicados com o resultado de seu trabalho e mais conscientes acerca de sua capacidade de executá-lo. Como consequência, houve aumento nos processos de responsabilização - que os autores entendem, cabe destacar, como tradução do vínculo.

Dados semelhantes são mencionados por Scholze et al. (2006), que também se dedicaram a avaliar o processo de implantação do acolhimento - entendido como momento específico no serviço de saúde - em uma Unidade de Saúde na Família. Os autores relatam aumento nos processos de responsabilização, inversão no modelo médico-centrado, compartilhamento de informações acerca dos processos de trabalho entre profissionais e usuários e humanização da assistência.

Esperança, Cavalcante e Marcolino (2006) investigaram a demanda espontânea e os processos de acolhimento em uma UBS de uma cidade mineira. Descrevem o acolhimento como porta de entrada dos usuários no serviço. A função era eminentemente desenvolvida pelas auxiliares de enfermagem, que identificavam as demandas dos usuários e então os encaminhavam para os demais profissionais - geralmente, médicos. $\mathrm{O}$ acolhimento, portanto, como pontuado por Esperança, Cavalcante e Marcolino (2006), restringia-se a atividades de pré-consulta e triagem. Diante disso, destacam a importância de se investir em capacitações, de modo a ampliar os processos de acolhimento, especialmente integrando ações preventivas, 
e de se incluir os demais profissionais da UBS em tais processos.

Camelo et al. (2000) avaliaram, tendo como foco o acolhimento - entendido como postura do profissional -, as relações estabelecidas entre auxiliares de enfermagem e usuários, em duas unidades básicas de saúde. Identificam situações diversas, tais como: ausência de personalização no atendimento e de resposta às demandas do usuário; relação distanciada, restrita à execução de procedimentos; envolvimento e sensibilização para com o vivido pela clientela, acompanhada por dificuldades concernentes ao provimento de orientações; e escuta atenta, execução adequada de procedimentos e realização satisfatória de orientações. A diversidade encontrada sinaliza, de acordo com as autoras, a demanda por um projeto orientador do trabalho de acolhimento nas UBSs. Além disso, pontuam atividades contínuas de formação, supervisão e incentivos como fatores essenciais à concretização do acolhimento.

Schimith e Lima (2004) analisaram o trabalho realizado por uma equipe do Programa Saúde da Família (PSF) com foco nos processos de acolhimento - compreendido como atividade de recepção e como prática que permeia os diversos processos de produção de saúde - e de promoção de vínculo. Dentre as questões identificadas, indicam a dificuldade de acesso da clientela ao serviço, que se evidenciou centrado na figura do médico e precedido por longo tempo de espera; a falta de responsabilização da equipe para com as demandas dos usuários; e a carência de recursos - fator de insatisfação da clientela e dos profissionais. Por outro lado, também observaram alguns momentos de envolvimento da equipe para com o vivido pela clientela, nos quais se dava, então, processos de acolhimento diálogo - conforme conceitua Teixeira (2003). Relacionam tal alternância à individualidade e à subjetividade dos trabalhadores, fatores presentes nos momentos de produção de saúde. E defendem que, para se tornar uma proposta concretizável, os processos de acolhimento e vínculo devem ser de responsabilidade e tomados como projeto de toda a equipe de saúde.

Silveira et al. (2004) visaram identificar a concepção de acolhimento entre os profissionais de duas equipes do PSF em Campina Grande, Paraíba. Como significações apontam recepção respeitosa da clientela; tratamento ao usuário "como gente"; escuta de suas demandas e busca de novas formas de compreensão e de solidariedade com as mesmas; olhar atento ao que é expresso verbal e não-verbalmente; atenção dispensada na relação e, não necessariamente, resolução completa das demandas. Esclarecem, porém, que tais concepções foram articuladas em meio à compreensão do acolhimento como um momento específico do serviço, a saber, a prática em sala de espera. 
Baseadas em uma compreensão de acolhimento como postura profissional e como dispositivo de reorganização dos processos de trabalho, Takemoto e Silva (2007) investigaram transformações no trabalho de enfermagem a partir da incorporação de tal elemento do cuidado em cinco unidades básicas de saúde da região de Campinas, SP. Dentre os resultados, relatam que, em uma das unidades estudadas, o acolhimento era compreendido como consulta médica sem agendamento. Em três das unidades, traduzia-se em atividade, realizada por auxiliares de enfermagem, de avaliação de queixa do usuário e de decisão de realização de consulta médica no mesmo dia ou de agendamento em data posterior; portanto, como recurso de garantia de acesso universal e de escuta de demandas. Dentre as reverberações apreendidas nesse caso, fazem referência ao aumento da satisfação dos auxiliares com o trabalho realizado, por terem passado a ter melhor percepção acerca dos resultados deste e se sentirem mais reconhecidos e valorizados - embora alguns profissionais, por outro lado, alegassem sobrecarga de trabalho; e humanização das relações na porta de entrada. Na UBS restante, por sua vez, o acolhimento era compreendido como uma atitude dos profissionais, ao longo de todos os encontros no serviço, de escuta das demandas da clientela; de investigação de riscos e necessidades em saúde; de resposta às demandas apreendidas, especialmente aquelas concernentes a aspectos não-clínicos; e de produção de vínculo. Como recursos importantes à concretização do acolhimento, as autoras apontam educação permanente dos profissionais, supervisão e apoio institucional.

Relativamente à perspectiva dos usuários nos processos de produção de saúde, Ramos e Lima (2003) se propuseram a compreender as percepções daqueles sobre aspectos concernentes a acesso e acolhimento que consideram influenciar a qualidade da atenção, em uma UBS de Porto Alegre. As autoras descrevem que a escolha do serviço é especialmente marcada pela busca de profissionais que inspirem confiança e competência; por boa recepção e resolutividade no serviço; pelo respeito ao usuário; por relação humanizada; e por exame físico criterioso, que evidencia o cuidado do profissional para com o usuário. Ademais, prosseguem elas, as experiências negativas anteriores em serviço de mais fácil acesso geográfico mobilizam os usuários a irem em busca de atenção mais satisfatória, mesmo que implique maior deslocamento. Quanto ao vínculo entre clientela e serviço, pontuam que esse foi especialmente revelado pelo relato de usuários que já frequentavam o serviço há muitos anos; e pela manutenção da adesão mesmo em casos em que o usuário havia se mudado - o que implicava, então, ter de se deslocar por distâncias mais amplas. Concluem que, embora 
fatores econômicos e organizacionais tenham acentuada importância na definição da escolha de um serviço de saúde, o acolhimento se destaca como elemento preponderante.

Lima et al. (2007) avaliaram o acesso e a prestação de serviço em UBSs de Porto Alegre, a partir da opinião dos usuários sobre o acolhimento. Relatam que a despeito do longo tempo de espera observado, alguns usuários, sentindo-se atendidos em suas demandas, não destacavam tal fator como algo relevante. As autoras também observaram que o bom desempenho profissional, aliado à responsabilização para com o vivido pelo usuário, é medido pela clientela por meio da execução de exame físico criterioso, do oferecimento de espaço à realização de perguntas, do provimento de orientações e da resolutividade nas condutas. Outro aspecto de satisfação do usuário com o serviço foi associado à plasticidade deste, expressa pela realização de encaixes a partir da apreensão de demandas da clientela. Diante disso, as autoras observaram que, mesmo que existam serviços de saúde próximos à residência do usuário, é o acolhimento que define a escolha, ainda que seja necessário percorrer distâncias mais amplas.

Mais especificamente, na investigação do acolhimento no campo do cuidado ao pré-natal e ao puerpério, Tsunechiro, Bonadio e Oliveira (2002) avaliaram fatores que levam gestantes a frequentar um serviço de atendimento ao pré-natal geograficamente distante de suas residências. Tais fatores foram agrupados em relacionais - concernentes à esfera do acolhimento, que as autoras compreendem em termos de relacionamento interpessoal entre usuárias e profissionais e satisfação daquelas em relação ao serviço -, técnicos e administrativos. Elas descrevem que a dimensão relacional, seguida da técnica, foi destacada pelas usuárias como o que elas mais apreciam no serviço e como o que as faz buscar e manter adesão a ele. Na dimensão relacional, destacou-se a postura de aceitação/não julgamento, respeito e disponibilidade para o diálogo por parte dos profissionais, o que encorajava as usuárias a compartilhar suas vivências. No âmbito técnico, referiu-se o uso do aparelho sonarDoppler, pois permitia a ausculta fetal; e a possibilidade de realização de exames, ultrassonografia e parto no mesmo local. Apesar de a maioria das mulheres não ter denunciado fatores de insatisfação quanto ao serviço, aquelas que o fizeram restringiram-se apenas aos de âmbito administrativo: queixas quanto ao longo tempo de espera e à descontinuidade no atendimento ao parto. Tsunechiro, Bonadio e Oliveira (2002) salientam, ainda, o fato de a avaliação do serviço ter sido feita eminentemente com base em comparações com outros serviços. 
Felix e Silveira (2004), partindo da compreensão do acolhimento como postura do profissional, atendimento de demanda espontânea e dispositivo de reorientação dos processos de trabalho, analisaram as concepções de gestantes usuárias do PSF sobre o acolhimento e suas percepções sobre a prática dele no serviço. Relatam que esse elemento do cuidado é compreendido entre as mulheres especialmente como aquilo que confere qualidade ao serviço e satisfação em relação a ele, identificado pelos fatores de boa recepção e bom atendimento, permeados por respeito, os quais promovem uma relação de confiança com os profissionais. Aspectos de facilidade de acesso, espaço de escuta e de esclarecimento de dúvidas e comprometimento dos profissionais para com a resolutividade de suas demandas, foram também destacados pelas usuárias como relacionados à prática do acolhimento. Por outro lado, dificuldades para marcação de consultas e de exames especializados foram apontadas como falhas; isso, porém, não alterou de forma significativa a satisfação relatada em relação ao serviço.

Durães-Pereira, Novo e Armond (2007) percorreram as percepções de gestantes sobre a escuta e o diálogo oferecidos pela equipe de pré-natal de quatro UBSs - das quais duas eram de modelo tradicional (UBST), tal como nomearam os autores, e duas ligadas ao PSF (UBSF). A despeito de algumas diferenças observadas, relatam que em todas as unidades as gestantes sentiram encontrar espaços de escuta e diálogo, com tempo satisfatório de encontro entre profissional e usuário, abertura e disponibilidade daqueles para escuta e orientações realizadas a contento. Certa especificidade, no que se refere à melhor recepção à mulher no serviço, encontrada nas UBSFs, foi atribuída à atividade diária de acolhimento à demanda espontânea que há nessas unidades e ao contato frequente dos agentes comunitários de saúde com as gestantes. De todo modo, as mulheres relataram elevados índices de satisfação com os serviços.

Queiroz et al. (2007) se propuseram a descrever a satisfação de mulheres vivenciando o puerpério imediato em alojamento conjunto, em um hospital do SUS, referência em saúde materno-infantil no Estado do Ceará, quanto à qualidade do serviço, ao acesso e ao acolhimento. Mostraram que a maioria das puérperas estava satisfeita com o serviço, especialmente em função da postura dos profissionais, identificada como constituída de respeito, disponibilidade, esclarecimento de dúvidas, demonstração de interesse em relação ao bem-estar do bebê e competência - o que gerava, então, confiança. Pontualidade no atendimento, boa estrutura do hospital e disponibilidade de equipamentos foram também 
salientadas como aspectos satisfatórios quanto à qualidade do serviço. As insatisfações, apontadas pela minoria, residiram na demora do atendimento e na comunicação difícil com a equipe - especialmente em função do emprego de uma linguagem técnica, geralmente não compreendida pelas mulheres. Com tais dados, Queiroz et al. (2007) discutem sobre a importância das tecnologias leves nos processos de produção de saúde, especialmente tendo em vista a humanização do cuidado, e destacam a demanda de se investir em aprimoramento dos recursos humanos e materiais, melhoria das condições de trabalho, planos institucionais de capacitação permanente dos profissionais e políticas públicas que possam promover os subsídios necessários à efetivação de mudanças. Também explicitam ser fundamental a inclusão das perspectivas das usuárias na avaliação da qualidade da atenção em saúde.

De modo semelhante, Marques e Lima (2004), problematizando o atual contexto dos serviços de saúde, destacam ineficiência e consequente insatisfação da clientela, relacionadas a dificuldades de acesso, concretização da integralidade, baixa resolutividade e ações profissionais de pouca qualidade. A partir disso, propõem as tecnologias leves como orientadoras das práticas em saúde, defendendo que, apenas com a promoção de mudanças significativas nas relações entre gestores, profissionais e usuários, permeando-as por acolhimento, vínculo, responsabilização e humanização, e nas concepções de indivíduo, compreendendo-o em suas dimensões histórica e social, será possível de fato alcançar melhores níveis de qualidade nos serviços em saúde.

Figueiredo e Rossoni (2008) analisaram o acesso ao pré-natal, em uma UBS em Porto Alegre, a partir da ótica das gestantes. As autoras relatam dificuldades: de acesso, especialmente traduzidas por demora na marcação de consultas e por longa espera por atendimento; de estabelecimento de vínculo com os profissionais - principalmente os prénatalistas, que à época da coleta dos dados realizavam rodízio bimestralmente; de acesso a atendimento por equipe multiprofissional - tendo em vista a integralidade prevista pelo MS, dentre as diversas especialidades que as autoras entendem que deveria integrar a atenção à gestante, tais como nutrição, psicologia, serviço social e odontologia, apenas a assistência odontológica estava disponível; e de acesso a atividades educativas. As autoras discutem sobre a importância de inserir a ótica das usuárias na avaliação dos processos, de modo a melhor adequar o serviço às suas reais necessidades e a fortalecer o vínculo entre elas e os profissionais.

Em meio a esse panorama, convém lembrar que, segundo o MS (BRASIL, 2006b), o 
acolhimento, situado no campo de cuidado ao pré-natal e ao puerpério, implica também o incentivo à presença de acompanhante. Acerca de tal aspecto, Duarte (2007) e Oliveira et al. (2009) expressam dificuldades, em especial, na inserção do pai do bebê nas consultas de prénatal. A despeito de a maioria dos homens demonstrar interesse, quando questionados, de participar delas, destaca-se o pouco espaço ainda existente nos serviços para participação dos parceiros nas consultas e demais atividades pré-natais (DUARTE, 2007), e os horários de tais atividades, que frequentemente os impede de estar presentes (CAVALCANTE, 2003; OLIVEIRA et al., 2009), em função de não haver, ainda, uma legitimação de abono de faltas no trabalho para tais casos (OLIVEIRA et al., 2009). Isso denota a importância de se trabalhar no sentido de garantir a presença do acompanhante, o que, conforme lembra Cavalcante (2007), está previsto em lei, no estado de São Paulo, desde 1999. Dentre os benefícios dessa presença, aponta-se a melhor adesão da mulher ao pré-natal (DUARTE, 2007), a elaboração do papel paterno - quando o acompanhante é o pai do bebê (CAVALCANTE, 2007); e tempo de aleitamento mais longo (SILVEIRA; LAMOUNIER, 2006).

Acerca do cenário traçado por tais estudos, o primeiro ponto que convém perceber é que, a despeito das dificuldades apontadas, alguns autores expõem experiências bem sucedidas de implantação do acolhimento, assim como serviços em que os processos de acolhimento e de produção de vínculo se dão; ainda que nem sempre o seja do modo preconizado pelo MS (BRASIL, 2008) e aqui compreendido, ou seja, como fenômeno complexo que implica atividades de recepção, reorientação dos processos de trabalho e também postura que permeia todos os encontros que se dão ao longo do trânsito do usuário pelo serviço.

Além disso, de modo geral, questões relativas aos processos de acolhimento e de produção de vínculo, salientados na esfera mais ampla de atenção em saúde, são similares àquelas referidas na dimensão do cuidado ao pré-natal e ao puerpério, especialmente no que concerne às expectativas, percepções, concepções e eventuais dificuldades vividas pelos usuários/usuárias em torno de tais processos. Apesar disso, porém, parece importante brevemente explicitar-se, com base nas vivências que marcam a gestação e o puerpério já comentadas, a essencialidade de tais processos em tal campo de cuidado. 


\subsubsection{OS PROCESSOS DE ACOLHIMENTO E PRODUÇÃO DE VÍNCULO NO CAMPO DE CUIDADO AO PRÉ-NATAL E PUERPÉRIO}

O ciclo grávido-puerperal, como referido no início do presente trabalho, envolve vivências intensas e complexas e implica expressivas transformações de vida e identidade. Maldonado (1999) sugere tratar-se de uma fase do desenvolvimento humano e, como tal, de um período que pode ser experienciado como uma transição existencial - quando se consegue lidar com vivido e se realizar os ajustamentos necessários; ou de crise - quando se encontra dificuldades de se efetuar tais ajustamentos. Em decorrência, para auxiliar a mulher, e aqueles que com ela experienciam as mudanças então impostas, na identificação ou no desenvolvimento de recursos de enfrentamento, diversos autores assinalam a demanda de suporte e de um cuidado integral - que aborde tal gama de vivências.

Antes de apresentar tais considerações, cabe esclarecer que nem todos os autores a seguir mencionados utilizam a nomenclatura acolhimento e/ou produção de vínculo. Muitos discorrem sobre o tema fazendo menções a apoio social, psicológico e/ou emocional. Porém, aqui compreendendo tais tipos de suporte como: a constituição de espaços de escuta e diálogo voltados à ampliação de percepção do vivido, ao auxílio à elaboração dele e ao descobrimento de recursos de enfrentamento - em que se pode incluir o tão discutido processo de identificação, elaboração e negociação de demandas; e como a confirmação da presença do profissional como figura de referência para a mulher e seus acompanhantes - seja para tais processos de ampliação, elaboração e enfrentamento, seja para simplesmente acompanhá-los no que se mostra de mais difícil solução; entende-se que se configuram em traduções do acolhimento e da produção de vínculo.

Em Enkin et al. (2005, p. 11), cuja obra é referência sobre a assistência baseada em evidências científicas e, portanto, um dos pilares do movimento de humanização, em diversos países, pontua-se que, considerando-se as vivências significativas de ordem social, psicológica e física da mulher neste momento, "o apoio social e psicológico deve fazer parte de toda assistência a gestantes".

Tsunechiro, Bonadio e Oliveira (2002) destacam a importância para as gestantes do estabelecimento de um vínculo de confiança e de suporte, pois só a partir disso é possível auxiliá-las no enfrentamento do vivido durante a gravidez; promover melhores índices no que 
se refere à morbi-mortalidade materna e perinatal; e garantir um cuidado humanizado e integral. De modo semelhante, Durães-Pereira, Novo e Armond (2007) salientam que um cuidado permeado por escuta e diálogo é o que permite às mulheres descobrirem recursos para enfrentar eventuais dificuldades vividas.

Para Brazelton (1988), o suporte aos futuros pais é algo de fundamental importância. No que diz respeito, mais especificamente, a grupos de apoio para casais grávidos, o autor refere que, além das importantes informações fornecidas - como, por exemplo, acerca do desenvolvimento fetal e do parto -, a possibilidade de compartilhar experiências, dúvidas, ansiedades e angústias pode auxiliar os pais a vivenciarem a gravidez com satisfação e prepará-los para a fase seguinte.

Delfino et al. (2004), descrevendo experiência de oficinas para gestantes, relatam dentre os resultados: expressão e elaboração de vivências; ampliação de consciência acerca da importância de se desenvolver práticas de cuidado com a saúde; estreitamento do vínculo entre mãe e bebê; ressignificação das relações conjugais e familiares; e multiplicação da discussão sobre os direitos e dos conhecimentos produzidos no grupo.

Lima (2006) assinala, a partir de experiência de acompanhamento de um casal entre o segundo mês de gestação e o terceiro mês pós-parto, que o auxílio na ressignificação de relações familiares favorece o processo de construção do papel materno; que a promoção de suporte emocional pode ser especialmente importante para facilitar a abertura da mulher para recebê-lo também daqueles que estão ao seu redor, tanto durante a gestação quanto durante o parto e o puerpério; e que a harmonização de questões conjugais traduz-se em preparação do campo à elaboração dos papéis materno e paterno e ao recebimento do bebê. A partir desses processos, a autora observou ampliação de autoconfiança, tanto na vivência do parto quanto na assunção do papel de cuidador; estreitamento de vínculo com o bebê desde a gestação; e desenvolvimento de comportamentos propiciadores de apego seguro.

Também em um dos manuais do PHPN (BRASIL, 2006b, p. 13) se discute a complexidade do vivido durante a gravidez, salientando-se que o contexto em que essa se desenrola é determinante para a forma com que se desenvolve; para os processos de cuidado com o bebê; para a relação que será estabelecida entre a mulher, seus familiares e a criança; assim como para a amamentação. Defende-se que "um contexto favorável fortalece os vínculos familiares, condição básica para o desenvolvimento saudável do ser humano"; o que é apontado como uma das justificativas à importância do acolhimento. 
O processo de vinculação entre pais e bebê, como já mencionado, é também discutido por Klaus e Kennell (1992) e Bee (1994), que salientam a importância do suporte emocional à mulher para favorecê-lo, descrevendo inibição de sentimentos de vinculação quando há prejuízos em tais vivências de apoio. Nesse cenário, apontam que especialmente o suporte fornecido pelo pai do bebê desempenha função fundamental. A esse respeito foi constatado, conforme Klaus e Kennell (1992, p. 30), que "a capacidade do companheiro para este tipo de apoio e sustentação prognostica [...] a adaptação da mulher ao parto e ao nascimento, seu bem-estar psicológico e a qualidade de sua interação com seu bebê dois meses após o nascimento". Assim, evidencia-se também a demanda de se incluir o homem nas atividades pré-natais, de modo que ele possa encontrar um espaço de cuidado em que receba auxílio à elaboração de suas questões concernentes à paternidade e de possibilidades de assumir tal lugar de figura de suporte à mulher.

Ainda para Klaus e Kennell (1992, p. 68), constituir uma atenção ao ciclo grávidopuerperal com foco no cuidado à vinculação entre pais e bebê - que implica, como se viu, processos de acolhimento e produção de vínculo, dentre os demais aspectos mencionados que configuram uma atenção integral e humanizada - é algo de fundamental importância. Apontam, nesse sentido, que "o desejo de se evitar ou eliminar os distúrbios dos papéis parentais deve ser comparado com um objetivo similar para a erradicação da poliomielite", pois a prevenção inicial é sempre muito mais satisfatória, de menores custo financeiro e tempo, do que tentar dar conta de possíveis distúrbios que venham a se desenvolver posteriormente.

No que se refere ao puerpério, citando estudo sobre aspectos psicossociais do pósparto, Gonçalves, Saldanha e Mendonça (1998) assinalam ter-se observado que "a gratificação com a experiência do parto, a satisfação com a situação de vida e o suporte social recebido" revelaram-se como fatores contributivos à adaptação da mulher durante esse período.

Evidenciando a importância dos processos de produção de vínculo, Enkin et al. (2005) afirmam que as mulheres atendidas pelo mesmo provedor de saúde, ou por um pequeno grupo de provedores de saúde que possam conhecer bem, durante a gestação e o parto, sentem-se mais preparadas para cuidar do bebê. Tendo em vista, porém, o discutido por Penna, Carinhanha e Rodrigues (2006), que a realização de uma ou duas consultas puerperais com um profissional de saúde desconhecido não proporciona, geralmente, espaço seguro e 
confortável para as mulheres expressarem suas vivências subjetivas em níveis mais profundos; o que dificulta, por sua vez, um trabalho em favor de seu empoderamento; pode-se inferir a importância de também no pós-parto as mulheres encontrarem os mesmos profissionais que lhes acompanharam durante o pré-natal.

Hernandez, Kimelman e Montino (2000) salientam que se deve oferecer, no período pós-parto, um espaço de escuta à mulher, onde ela possa compartilhar eventuais dificuldades que esteja enfrentando; e de intervenções no sentido de ajudá-la a descobrir suas habilidades como cuidadora, de confirmá-la em seu papel de mãe e de promover vínculos seguros entre ela e o bebê - os quais se configuram em uma das bases para o bom desenvolvimento da criança. Para Penna, Carinhanha e Rodrigues (2006) deve-se também auxiliar a mulher a assumir-se como protagonista no enfrentamento do que vive e, mais especialmente, a legitimar um espaço para si mesma, de contato e expressão de questões e desejos não exclusivos ao bebê.

Além dessas considerações, que indicam a importância dos processos de acolhimento e de produção de vínculo às vivências do ciclo grávido-puerperal, há também outro aspecto relevante nesse cenário: o das expectativas das mulheres-usuárias. De acordo com Felix e Silveira (2004), as experiências vividas durante a gravidez intensificam, entre as mulheres, o desejo de se sentirem acolhidas pelos profissionais que as acompanham. Ademais, são tais processos que, aliados à qualidade técnica, determinam a escolha e a adesão ao serviço (ALMEIDA; TANAKA, 2009; PARADA; TONETE, 2008; TSUNECHIRO; BONADIO; OLIVEIRA, 2002).

A partir disso, ao menos dois pontos se tornam perceptíveis. Primeiro, não apenas para o Ministério da Saúde assim como para as mulheres, acolhimento e vínculo se constituem em "aspecto essencial da política de humanização" (BRASIL, 2006b, p. 13). Segundo, incluí-los nos processos de produção de saúde também revela o eixo de respeito aos direitos das mulheres, o qual se traduz em um dos fundamentos, vale lembrar, da humanização concebida no PHPN; ao direito não apenas de "acesso a atendimento digno e de qualidade" (BRASIL, 2002, p. 6) mas de que tal atendimento responda às suas expectativas e demandas. Será possível falar em humanização sem a incorporação de tais âmbitos?

Segundo Serruya, Lago e Ceccati (2004b, p. 278), a concepção do PHPN pressupôs que a "humanização da assistência pré-natal requer, antes de tudo, o cumprimento desse conjunto de procedimentos básicos a fim de prevenir agravos na gestação e garantir o direito 
fundamental de toda mulher à experiência da maternidade de maneira segura". Tendo-se aqui evidenciado, porém, o impacto dos processos de acolhimento e vínculo sobre as vivências do ciclo grávido-puerperal - que inclui aspectos como a promoção de vinculação favorável entre pais e bebê, assinalada como condição para o bom desenvolvimento da criança (BRASIL, 2006b; HERNANDEZ; KIMELMAN; MONTINO, 2000), e garantia de melhores índices de morbi-mortalidade materna e perinatal (TSUNECHIRO; BONADIO; OLIVEIRA, 2002), pergunta-se: é possível pensar em garantir uma maternidade segura apenas com o cumprimento de um conjunto de procedimentos básicos - como as seis consultas prénatais, os exames obrigatórios, a testagem anti-HIV, a imunização antitetânica, o parto e a consulta puerperal, que integram o "acompanhamento pré-natal completo", tal como definido no PHPN (BRASIL, 2002, p. 9)?

É claro que não se pretende encorajar, com tais perguntas, a desvalorização desses procedimentos. Como salienta Merhy (1998), da mesma forma que não se pode falar em qualidade em saúde quando não são as tecnologias leves a reger os processos de produção de saúde, também não se pode falar em qualidade quando os três tipos de tecnologias - duras, leve-duras e leves - não se articulam em favor dos processos de resolutividade e ampliação de autonomia. Se a humanização se evidencia como um meio de garantir maior e melhor qualidade na assistência, será que esse caminho, marcado de contradições, está levando à

\section{direção que se deseja?}

Foram esse cenário e esses questionamentos que motivaram a investigação mais atenta, à luz do PHPN, dos processos de humanização do cuidado ao pré-natal e ao puerpério em uma instituição que não apenas autorrefere a atenção ali produzida como humanizada, como, ao fazê-lo, enfatiza o acolhimento. Embora se saiba que, especialmente por se tratar de um serviço com particularidades diferentes daquelas encontradas na Rede SUS, não se vá conseguir respostas claras para as perguntas aqui levantadas, espera-se, por meio de tal investigação, revelar-se questões que apontem possibilidades de superação de tais contradições. 


\subsection{BREVES CONSIDERAÇÕES SOBRE A INTEGRALIDADE}

A despeito da significativa complexidade que reveste a integralidade - à qual não cabe aqui dar conta -, considerando a íntima inter-relação do tema com o da humanização, especialmente na forma com que esta vem sendo aqui compreendida - como reinserção dos sujeitos como seres integrais nos processos de produção de saúde -, breves considerações acerca da temática revelaram-se importantes de serem realizadas.

De acordo com Mattos (2001), o termo integralidade remete, primeiramente, à diretriz estabelecida pelo SUS na Constituição de 1988 - que, cabe ressaltar, não empregou tal vocábulo, referindo-se ao atendimento integral pautado em atividades prioritariamente preventivas. Em tal contexto, integralidade compõe, com a universalidade e a equidade, o quadro de princípios doutrinários do Sistema Único de Saúde e diz respeito à organização de políticas e serviços em favor da articulação de ações de promoção, de prevenção, de tratamento e de reabilitação (BRASIL, 2000e; SPINK; MATTA, 2007), no nível individual e no coletivo, em todas as esferas de complexidade do sistema (BRASIL, 2007b). Além disso, é também concernente à atuação de modo integral, isto é, fundamentada em uma concepção de homem que o considera como unidade psicofísica em interação com o meio socioeconômico e cultural; e focada nas necessidades específicas de indivíduos, família, grupos e comunidade (BRASIL, 2000e, 2006b, 2009).

Dessa forma, segundo Mattos (2001, p. 40), a integralidade se destaca como uma "bandeira de luta" em prol daquilo que se define como desejável no sistema de saúde, em suas instituições e em suas práticas; uma "imagem objetivo", que estabelece o que se pretende construir, demarcando a diferença entre o plano idealizado e a realidade vivida. Como imagem, porém, ela se reveste de pluralidade de sentidos, já que nasce da crítica dos diversos atores diante do vivido, e do projetado como possibilidade transformadora. Tomando, então, o cuidado de não propor uma definição única, pois, para o autor, isso implicaria silenciar algumas de tais possibilidades projetadas, Mattos (2001) sugere a compreensão da integralidade como princípio orientador: das práticas profissionais - foco que aloca o princípio da integralidade para além do SUS, uma vez que se trata, aí, de algo aplicável a todos os profissionais de saúde, tanto na esfera pública como na privada -; da organização dos serviços e dos processos de trabalho; e de respostas governamentais às demandas em saúde 
vividas pela população.

Mattos (2001, p.60) destaca que, independentemente de ser tomada como prática, como organização do serviço, ou como resposta governamental, a integralidade implica "uma recusa ao reducionismo, uma recusa à objetivação dos sujeitos e talvez uma afirmação da abertura para o diálogo". Pontua, também, que subjacente aos diversos sentidos está o princípio do direito de resposta às demandas em saúde, o qual evidencia, por sua vez, a integralidade como guia na busca dos melhores meios de atender a tais demandas, sempre em uma perspectiva amplificada.

A inter-relação que a integralidade estabelece com os processos de acolhimento e de produção de vínculo merece ser também mencionada. Tais processos, assim como aqueles que eles pressupõem, como a constituição de equipes multiprofissionais e a responsabilização de tais equipes para com as demandas da clientela, são apontados por Franco e Magalhães Jr. (2003) e por Silva Jr. e Mascarenhas (2005) como aspectos essenciais à viabilização da integralidade. Por essa razão, segundo Gomes e Pinheiro (2005), o acolhimento, a produção de vínculo e a responsabilização são práticas integrais. Essa inter-relação também se revela na compreensão, expressa por Mattos (2004), de que a defesa pela integralidade implica, antes de tudo, assumir que os processos de produção de saúde podem apenas se dar em meio à intersubjetividade; ou seja, implica relações estabelecidas entre profissionais e usuários em que ambos ocupam lugar de sujeito, marcadas por dialogicidade e em que as ações ofertadas são sempre resultantes do que é apreendido, elaborado e negociado em tal espaço de encontro.

Por fim, cabe salientar que o princípio da integralidade é apontado como aquele que representa maior desafio. Segundo Mattos (2004), mudanças que sugiram avanços nesse sentido têm acontecido apenas pontualmente e, por isso, de modo pouco expressivo em termos mais amplos. Isso é explicitado em relatos como o de Pinho, Siqueira e Pinho (2006), que, abordando o tema sob a dimensão das práticas profissionais, assinalam dificuldades encontradas por uma equipe de enfermagem em compreender tal princípio e aplicá-lo em sua prática cotidiana. Se consideradas as contradições e as dificuldades anteriormente destacadas no campo da humanização, tais apontamentos evidenciam-se carregados de sentido. 


\section{A ASSOCIAÇÃO COMUNITÁRIA MONTE AZUL}

Nascida em Weimar, na Alemanha, a pedagoga Ute Craemer chegou ao Brasil, na década de 1960, como voluntária de um serviço social alemão. Como tal, dedicou-se, entre 1965 e 1966, a ações de urbanização e de erradicação de favelas em Londrina-PR. Voltou, então, à Alemanha, para aprofundar seus estudos em Pedagogia Waldorf e, no início dos anos 70, retornou ao Brasil, como professora da Escola Rudolf Steiner em São Paulo (BALDI, 2003; CONNECTIVITY, 2009).

À época, Ute morava na região próxima à favela Monte Azul, localizada no Jardim São Luiz, na cidade de São Paulo, e formada principalmente por migrantes originários do Nordeste e dos estados de Minas Gerais e do Paraná. A comunidade nasceu ao redor de uma mina de água limpa, ainda existente, e padecia em razão das péssimas condições infraestruturais (CRAEMER; IGNACIO, 2008).

Sensibilizada pelas crianças que passavam frequentemente à porta de sua casa pedindo dinheiro ou comida, Ute passou a organizar, por volta de 1975, em sua residência, tardes recreativas para as crianças da favela, auxiliada por alguns voluntários adultos e por seus alunos da Escola Rudolf Steiner. Esse contato, para ela, representava a possibilidade de aproximação de universos sociais diferentes e, assim, de favorecimento à redução de preconceitos e à constituição de uma cultura de tolerância (CRAEMER; IGNACIO, 2008).

Três anos mais tarde, com 50 a 70 crianças participando de tais atividades, foi iniciado um movimento no sentido de se obter recursos para estruturar o trabalho e criar, então, uma associação. Como fruto desse esforço, fundou-se, em 25 de janeiro de 1979, a Associação Comunitária Monte Azul, que primeiramente contou com a construção de uma escolinha voltada ao atendimento de 110 crianças. No mesmo ano, organizaram-se, também, oficinas de trabalhos manuais e construiu-se, em mutirão, um ambulatório. No ano seguinte, veio a primeira creche; depois, um forno caipira, que representava o início de padaria constituída posteriormente; e a comunidade começou a se engajar em reivindicação por melhorias na favela (CRAEMER; IGNACIO, 2008).

Com o passar do tempo, as atividades cresceram - sempre com base nas demandas trazidas pelos moradores - propiciadas pelo aumento de doações, principalmente advindas da Alemanha, pelo convênio firmado com prefeitura, posteriormente, por parcerias com outras 
instituições e pelo número cada vez maior de colaboradores, tanto da própria comunidade, quanto de fora (BALDI, 2003). Assim, a partir de 1983, a Associação passou a atuar também em outras duas comunidades: Peinha, situada no Jardim Santo Antônio, e Horizonte Azul, bairro próximo à represa Guarapiranga (CRAEMER; IGNACIO, 2008).

Tais iniciativas foram decorrentes dos ideais de promover encontros entre pessoas de universos distintos e de favorecer a efetivação de potencialidades e o enfrentamento de dificuldades vividas, especialmente por indivíduos mais empobrecidos. Desses ideais resultou a elaboração da missão da Associação, sustentada por valores de respeito ao ser humano, de autenticidade, de legitimação da individualidade, de crença no potencial transformador de cada indivíduo, de liberdade com responsabilidade e de solidariedade para com o contexto social e ecológico:

\footnotetext{
Promover o amor pelo ser humano independente de nacionalidade, raça, religião, posição política e condição social e física, proporcionando oportunidades através da educação, cultura, saúde, principalmente para as pessoas não-privilegiadas, para que se desenvolvam material, social e espiritualmente, estimulando-as a agir conscientemente, com liberdade e amor (CRAEMER; IGNACIO, 2008, p. 148).
}

Além daqueles valores e dessa missão, há alguns outros princípios que cercam a concepção de como o trabalho na Associação deve ser constituído. Uma das questões apontadas por Craemer e Ignacio (2008) nesse sentido é a de que não é possível conceber tal trabalho sem haver um envolvimento genuíno dos colaboradores com as pessoas e com a comunidade. Isso porque é apenas por meio de tal envolvimento que se torna possível, verdadeiramente, compreender o outro e respeitá-lo por quem ele é - motor essencial de um trabalho que visa promover o desenvolvimento integral dos indivíduos. Uma decorrência dessa concepção, de acordo com as autoras, é o entendimento de que a almejada transformação na comunidade, e naqueles que nela vivem, passa pela transformação vivida pelos colaboradores; ou seja, à medida que trabalham em prol de tal transformação, os colaboradores, envolvidos com as pessoas e com as ações empreendidas, deixando-se verdadeiramente tocar pelo que experienciam nesse espaço de encontro, também se transformam - também crescem, desenvolvem-se, realizam-se; e é apenas porque se deixam tocar que podem assumir o papel de veículos de transformação.

Outro ponto destacado por Craemer e Ignacio (2008, p. 149) é o de que cada 
colaborador deve atuar "a partir do espírito", ou seja, movido por suas convicções e valores. Para que isso seja possível, porém, a instituição não deve apenas visar a metas de trabalho e ter em seus colaboradores meros instrumentos para alcançá-las; ela deve também olhá-los como seres humanos, entendendo que para se desenvolver como organização necessita, em primeiro lugar, do desenvolvimento de seus colaboradores. Esse processo deve se dar por meio de encontros, grupos de estudo e atividades artísticas. Além disso, é também necessário que as metas de trabalho sejam definidas por meio de planejamento participativo. E, por fim, salientam, mesmo que a princípio o indivíduo adentre na Associação especialmente para obter um emprego que lhe garanta o sustento, é importante que a partir do que comece a experienciar ali, supere essa condição e passe a se mobilizar, antes de tudo, pelo ideal. Essa é a condição, cabe ressaltar, que define a diferença entre um funcionário e um colaborador caracterizado por alguém que se envolve com a organização, com seus ideais e assume uma postura participativa no que ali acontece; por isso, na Associação os trabalhadores são nomeados colaboradores.

Paralelamente à promoção do desenvolvimento e do crescimento pessoal dos colaboradores, Craemer e Ignacio (2008) pontuam a demanda por uma filosofia clara embasando o trabalho realizado; condição fundamental à concretização de mudanças profundas em longo prazo. Justifica-se, assim, a ênfase ali dada à Antroposofia - comentada mais adiante -, a qual fornece sustentação a tudo o que ali se planeja, organiza e põe em ação.

Tendo em vista que, atualmente, de acordo com uma colaboradora da Associação (informação verbal) $^{13}$, a organização conta com 170 colaboradores - metade dos quais são moradores das comunidades em que atua (MONTE AZUL, 2007) - e 60 voluntários, dentre os quais 40 são brasileiros e 20 são estrangeiros, para que todos possam trabalhar em sintonia com tais filosofia, missão e valores, movidos "a partir do espírito" (CRAEMER; IGNACIO, 2008, p. 149) e envolvidos com o trabalho e com a comunidade; e para que a Associação possa continuamente promover o desenvolvimento e o crescimento pessoal deles; estruturouse um conjunto de atividades e reuniões constantes.

Mensalmente, ocorre uma reunião que agrega todos os colaboradores e voluntários, dos três Núcleos. Trata-se do dia de integração, o dia em que todos têm oportunidade de se conhecerem e aproximarem-se. Ademais, visa-se presentear a todos pelo trabalho desenvolvido e propiciar mais um momento de desenvolvimento de habilidades artísticas. Há

13 Informação fornecida por uma colaboradora da Associação durante visita monitorada da pesquisadora ao Núcleo Monte Azul em abril de 2007. 
atividades recreativas e de artes; e também espaços de discussão e reflexão sobre determinado tema, definido anualmente, como a paz, as religiões do mundo ou a história da cidade de São Paulo (CRAEMER; IGNACIO, 2008).

Semanalmente, além das reuniões de áreas - ambulatório, creches, oficinas etc. -, acontece, em cada um dos Núcleos, a "reunião geral de quinta-feira" (CRAEMER; IGNACIO, 2008, p. 49), tal como ficou tradicionalmente conhecida. Dela participam todos os colaboradores e voluntários do Núcleo, além de prestadores de serviço e moradores da comunidade que tiverem interesse. Trata-se de um momento de compartilhar vivências, trocar experiências - e, assim, aprender com o outro; organizar eventos e falar de problemas específicos do Núcleo; refletir sobre questões do mundo e discutir sobre temas como saúde, educação, arte, política, cidadania, religião, ecologia etc. O encontro serve, também, para exercitar a habilidade de estar-com o outro, aprendendo a ouvir e a abrir-se à possibilidade de aprender algo com ele; e a fomentar "o calor humano, a solidariedade, o carinho, a amizade" (CRAEMER; IGNACIO, 2008, p. 63) e a alimentação do espírito.

Há também reuniões do Grupos de Metas e reuniões do Grupo de Metas Ampliadas. O primeiro, composto por membros do segundo - um total de oito pessoas atualmente -, reúne-se semanalmente para discutir e tomar decisões sobre a Associação com um todo. Uma vez ao mês participam dessa reunião membros da diretoria da organização e do Conselho Consultivo (pessoas de áreas diversas que aconselham os colaboradores sobre temas de maior complexidade, que divulgam o trabalho da Associação e que oferecem suporte à captação de recursos). Do Grupo de Metas Ampliadas participam os coordenadores dos Núcleos que desejem refletir sobre o que se passa na instituição como um todo e tomar parte das decisões aí tomadas, especialmente daquelas concernentes a objetivos mais amplos, a prioridades nos Núcleos e a questões financeiras. Reúnem-se duas vezes ao mês e também participam de assembleias, embora sem poder de voto (CRAEMER; IGNACIO, 2008).

Além disso, para garantir espaços de formação e de desenvolvimento contínuos dos colaboradores, e considerando que "o desenvolvimento de uma organização depende principalmente do desenvolvimento das pessoas que nela trabalham" (CRAEMER; IGNACIO, 2008, p. 115), criou-se, em 1997, a Escola-Oficina Social - nome que remete à integração entre teoria (escola) e prática (oficina). Ela se fundamenta em uma perspectiva que se poderia chamar de dialógica, uma vez que, segundo Craemer e Ignacio (2008, p. 56) "todos têm alguma coisa para ensinar e todos têm habilidades a serem desenvolvidas". O objetivo 
primordial, para Craemer e Ignacio (2008), é garantir o desenvolvimento integral - ou seja, nos âmbitos do pensar, do sentir e do querer (relacionado à energia investida no agir e no realizar). Em termos mais específicos, visa ao aprimoramento das seguintes habilidades: trabalho em grupo; responsabilização e tomada de decisões; exercício da profissão específica sem se perder contato com o todo; localização no mundo, histórica e geograficamente; clareza nos pensamentos e em sua expressão; perseverança, autoconfiança e criatividade.

Cabe destacar que a importância da Escola-Oficina na Associação faz-se presente na imagem do organograma da instituição (Figura 1), cuja representação parece transmitir a ideia de que, ao lado da Mainumby - centro de formação de educadores comunitários, citado adiante -, a Escola-Oficina funciona como fluido condutor dessa grande engrenagem que representa a Associação. 


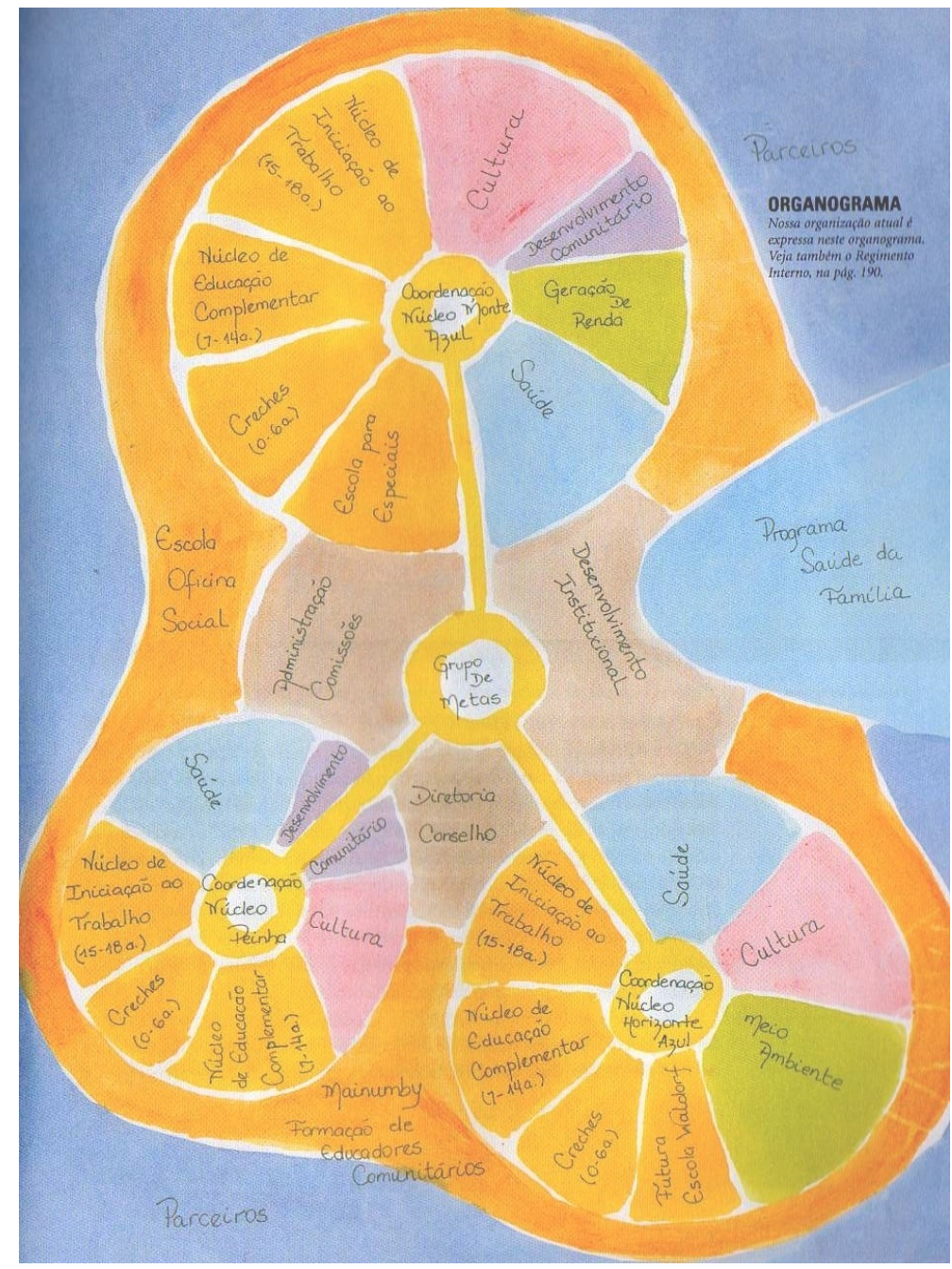

Figura 1: Organograma da Associação Comunitária Monte Azul. Fonte: Craemer e Ignacio (2008, p. 61)

Para atingir os objetivos anteriormente apontados, conforme Craemer e Ignacio (2008), o trabalho da Escola-Oficina Social se estabelece em quatro eixos: do desenvolvimento profissional, da compreensão do mundo e da ação humana, do tornar-se um agente social, e das atividades artísticas. O primeiro é voltado ao aprimoramento contínuo da qualidade do trabalho e à satisfação das expectativas da população atendida. Para tanto, são empreendidas ações de promoção: do desenvolvimento de habilidades específicas à função que o colaborador exerce, e da capacidade de reflexão sobre sua prática; e de constante aprofundamento em conteúdos relacionados à atuação de cada colaborador.

O segundo eixo leva à discussão e à aprendizagem de temas como história das religiões, biografia humana, história geral e brasileira, natureza e ecologia, por entender-se 
que o empreendimento de ações efetivas só é possível a partir da compreensão do homem situado geograficamente, na história e na natureza e em-relação com o meio e com os seres e de sua ação, sempre contextualizada e inter-relacionada às circunstâncias que o envolvem.

Destacado como o principal eixo da Escola-Oficina Social, o terceiro se estabelece pela experiência de participação em reuniões, pela convivência com colegas de trabalho oriundos de universos sociais e culturais distintos e pelos grupos de estudos sobre temas como trabalho social, autogestão e cidadania, processo de decisão em grupos, sistemas socioeconômicos, planejamento participativo, dentre outros.

E, por fim, o eixo das atividades artísticas, salientado como instrumento essencial de desenvolvimento e transformação, que promove, de modo especial, maior flexibilidade e tolerância, criatividade, sensibilidade e habilidades sociais; além de proporcionar prazer e elevação da alma por meio do belo. Dentre atividades como modelagem, pintura, música, dança, teatro, o colaborador-aluno deve escolher ao menos uma, a cada ano, para se dedicar. A arte é utilizada em todas as reuniões, por se entender que tal recurso favorece a melhor expressão de ideias.

Ao longo de todo esse processo, cada colaborador é acompanhado por um orientador que geralmente é o coordenador de área -, que deve conversar individualmente com o orientando pelo menos duas vezes ao ano, a fim de aconselhá-lo e de definir com ele um currículo - constituído pelos conteúdos a estudar e pelas atividades artísticas a fazer adequado às necessidades dele. Os coordenadores, assim como membros dos grupos de metas e ampliado de metas, são também orientados, podendo escolher livremente seus orientadores.

Cabe aqui um aparte sobre a centralidade da proposta de promoção do desenvolvimento integral dos indivíduos - sejam esses os integrantes da população beneficiada pelo trabalho da Associação, sejam os colaboradores da entidade -, evidenciada em tais considerações. Centralidade que se faz presente no próprio logotipo da organização (Figura 2). Como referem Craemer e Ignacio (2008) sobre a simbologia por detrás de tal logotipo, o coração ao redor da cabeça da imagem que representa o indivíduo expressa a tarefa diária de todos aqueles ligados à Associação de "pensar com o coração e sentir com objetividade" (CRAEMER; IGNACIO, p. 157). 


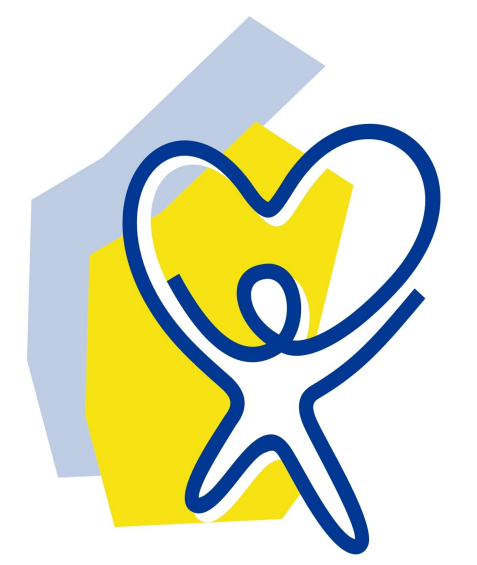

\section{Associação Comunitária MonteAzul}

Figura 2: Logotipo da Associação, reestilizado em 2008.

Fonte: Imagem gentilmente cedida pela Associação

No que concerne às ações empreendidas pela Associação, atualmente, nas três unidades - Núcleo Monte Azul, Núcleo Peinha e Núcleo Horizonte Azul - são realizadas atividades nas áreas de educação, cultura e saúde. Além disso, no núcleo Monte Azul há uma padaria e diversas atividades na área de urbanização - programas de saneamento básico, limpeza do córrego e construções de moradia, sempre por meio de mutirões. No núcleo Horizonte Azul há uma horta orgânica, que complementa a alimentação nas três unidades, e coleta seletiva de lixo (MONTE AZUL, 2007).

De fato, foram inúmeros os avanços e benefícios para comunidade desde que a Associação passou a atuar naquelas regiões. De acordo com Baldi (2003), houve diminuição expressiva da criminalidade e melhoria das condições de saneamento básico. Além disso, no que se refere, mais especificamente, ao Núcleo Monte Azul, conquistou-se a canalização do córrego e um amplo projeto de urbanização foi levado a efeito. 


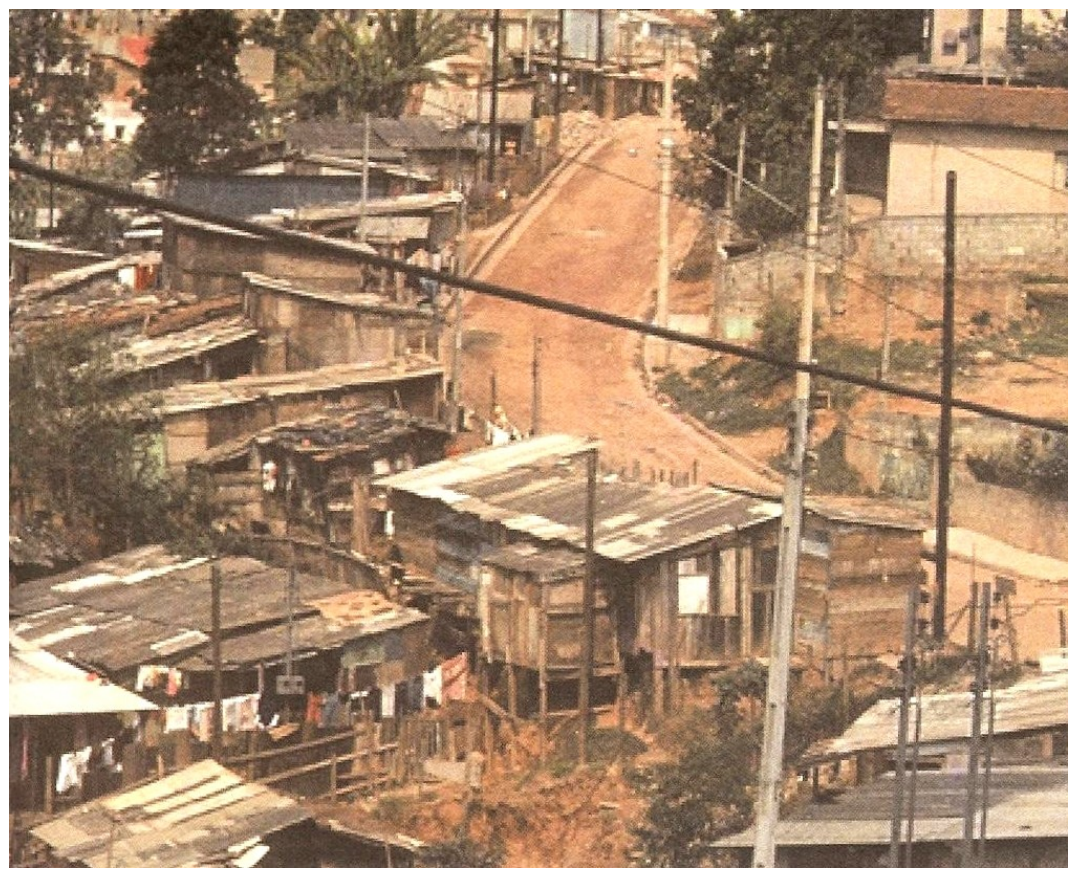

Figura 3: Favela Monte Azul em 1981.

Fonte: Craemer e Ignacio (2008, p. 29).

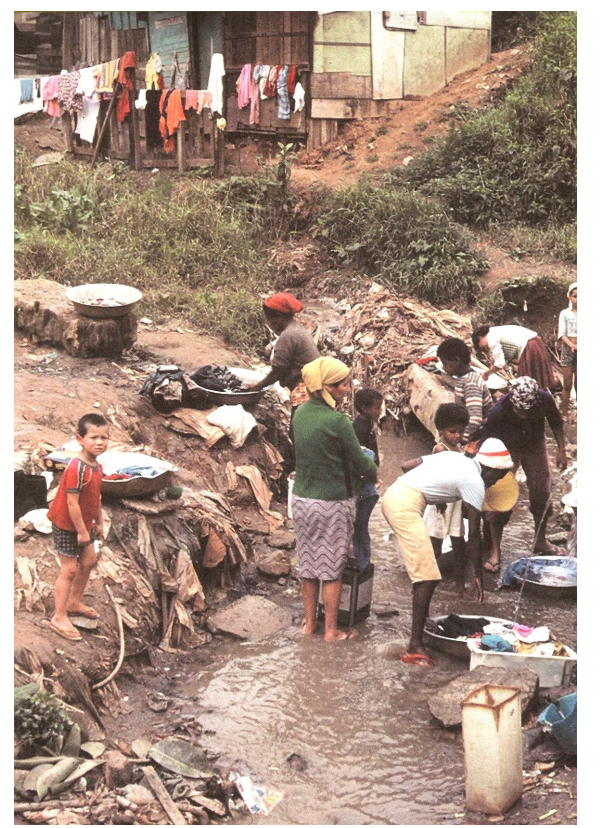

Figura 4: Mina de água que atraiu os primeiros moradores.

Fonte: Craemer e Ignacio (2008, p. 27).

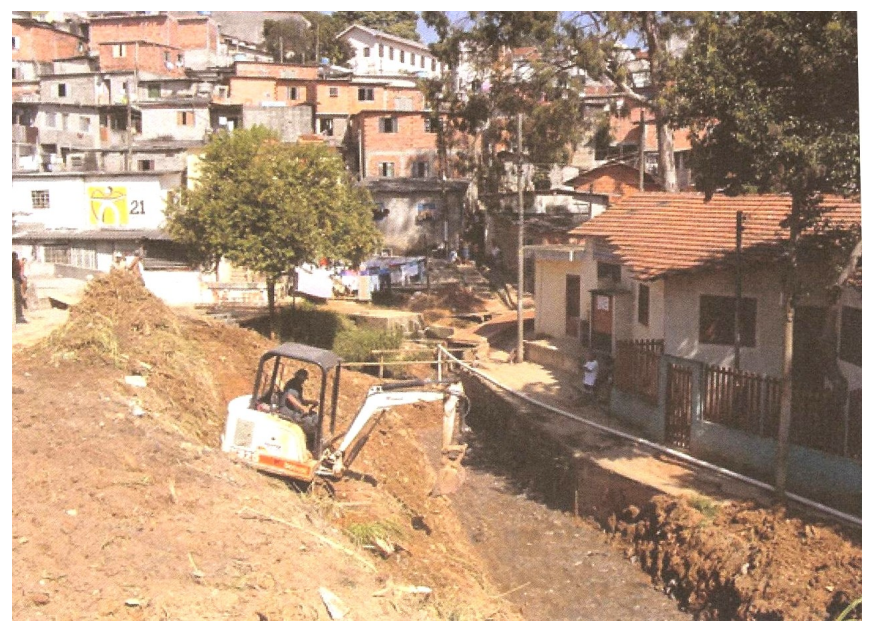

Figura 5: Obras de canalização do córrego.

Fonte: Craemer e Ignacio (2008, p. 109). 


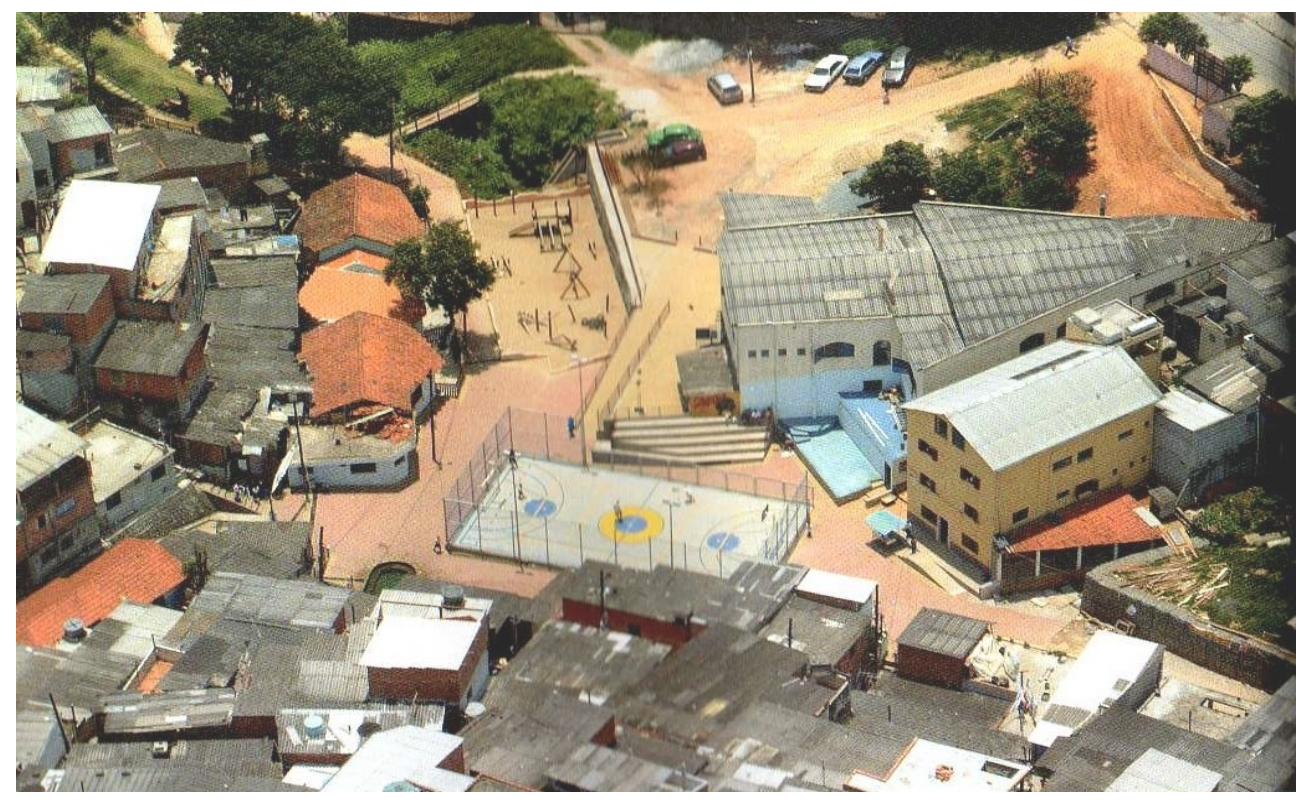

Figura 6: Vista superior atual do Núcleo Monte Azul - Praça Central da Favela.

Fonte: Craemer e Ignacio (2008, p. 12).

As ações específicas na área de educação, guiada pela Pedagogia Waldorf, abrangem berçário, creche, pré-escola, centro de juventude, escola para excepcionais, oficinas de iniciação de trabalho e um centro de formação de educadores comunitários - Mainumby voltado à formação contínua e à reciclagem (CRAEMER; IGNACIO, 2008; MONTE AZUL, 2007). Segundo uma colaboradora da organização, no berçário, na creche e na pré-escola, o período é integral. Após essa fase, as atividades são complementares ao período escolar. O número de crianças por sala é controlado - nas creches, por exemplo, varia em torno de 18 a 25, e nunca ultrapassa esse número. Há, também, a preocupação de não haver variações de faixa etária nas salas (informação verbal) ${ }^{14}$. Nas oficinas, as ações estão direcionadas para as áreas de marcenaria, padaria, corte e costura, reciclagem de papel, técnicas de venda, informática e atuação em escritório, atendendo, atualmente, cerca de 80 adolescentes (CRAEMER; IGNACIO, 2008). São atividades voltadas para jovens de 15 a 18 anos, e exigem como requisito frequência na escola oficial, cabendo à oficina manter-se como atividade complementar (informação verbal) ${ }^{15}$. Uma loja, instalada no Núcleo Monte Azul, um dos setores de geração de renda da Associação, comercializa os artigos produzidos nas

14 Informação fornecida por uma colaboradora da Associação durante visita monitorada da pesquisadora ao Núcleo Monte Azul em abril de 2007.

15 Informação fornecida por uma colaboradora da Associação durante a fase de reconhecimento de campo do presente estudo. 
oficinas (CRAEMER; IGNACIO, 2008).

$\mathrm{Na}$ área de cultura há oficinas de teatro, dança e música, coral, espetáculos, passeios e festas (MONTE AZUL, 2007), organizadas pelo Centro Cultural, construído em 1991, hoje sede da Associação. Além disso, frequentemente ocorrem workshops que abordam temas ligados à arte e anualmente acontecem mostras de teatro, dança e música (CRAEMER; IGNACIO, 2008). O serviço de saúde será descrito a seguir.

\subsection{A ÁREA DE SAÚDE E O AMBULATÓRIO DO NÚCLEO MONTE AZUL}

O ambulatório, como já referido, foi construído, em mutirão, no mesmo ano em que a Associação Comunitária Monte Azul foi fundada. No início, tratava-se apenas de um barraco de madeira e a equipe consistia, segundo Baldi (2003), em um médico e um atendente de enfermagem. Alguns anos depois, a demanda cresceu, especialmente porque pessoas de fora da comunidade também começaram a procurar pelo serviço. Explicam Craemer e Ignacio (2008) que o espaço já não era mais capaz de responder a essa demanda. Assim, em 1985 o pequeno barracão foi derrubado e, em seu lugar, construiu-se a atual casa que abriga o ambulatório do Núcleo.

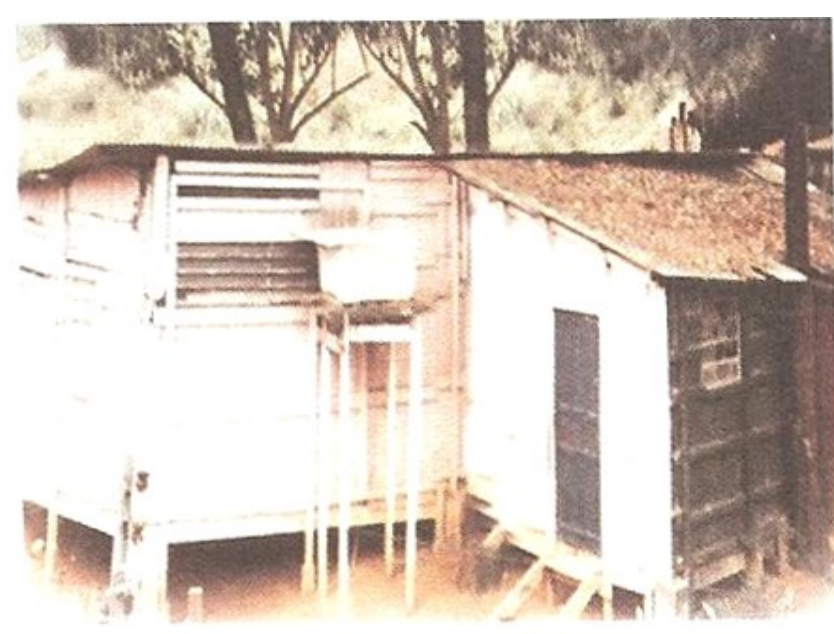

Figura 7: Ambulatório construído em 1979.

Fonte: Craemer e Ignacio (2008, p. 52)

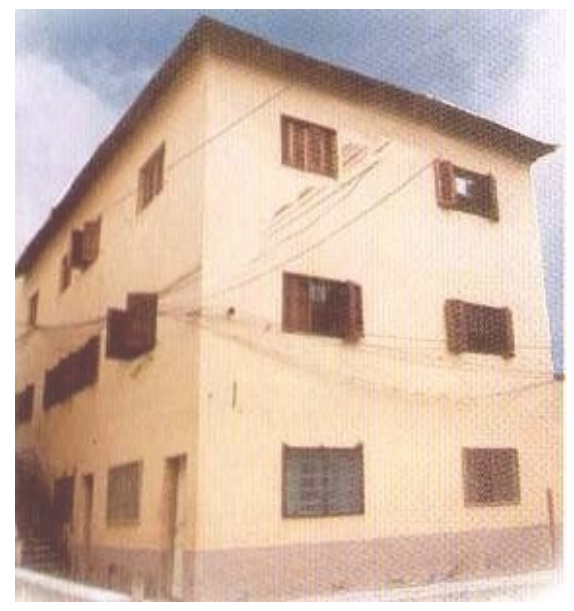

Figura 8: Ambulatório construído em 1985.

Fonte: Craemer e Ignacio (2008, p. 53) 
Também nesse período, de acordo com Craemer e Ignacio (2008), a Associação Beneficente Tobias, uma instituição de medicina antroposófica, passou a apoiar o serviço de saúde, disponibilizando leitos na Clínica Tobias para quando necessário. Além disso, mais médicos tornaram-se voluntários no ambulatório. Pouco depois, houve uma integração maior entre as áreas de saúde e de educação, que resultou no oferecimento de orientações sobre alimentação e higiene e em atendimentos terapêuticos para crianças com dificuldades especiais. Segundo Baldi (2003, p. 99), o serviço de saúde ali oferecido passou a se consolidar, então, como "prática comunitária" e outros profissionais - mais enfermeiros, psicólogos e massagistas - interessaram-se em atuar no ambulatório. Em decorrência, também de acordo com Craemer e Ignacio (2008), começaram a ser disponibilizados procedimentos como exames de fezes e ultrassom; atendimento ao pré-natal, ao parto e ao puerpério descrito adiante; e um pequeno ambulatório foi inaugurado na Peinha. Tempos depois, a Associação Beneficente Tobias passou também a arcar com os honorários de médicos e terapeutas que prestavam atendimento no ambulatório, os quais deixaram de ser, então, voluntários (CRAEMER; IGNACIO, 2008).

Diante de tais avanços, Hotimski (2001) expõe que era claro para a Associação a demanda por convênios e acordos com profissionais, serviços e instituições de saúde, em âmbito público e privado, para garantir o provimento de atividades e de procedimentos. De fato, Figueiredo (1999) aponta que os materiais para exames de sangue, urina, fezes e papanicolau eram coletados no ambulatório e enviados a um laboratório, o qual, na época, também fornecia anticoncepcionais hormonais orais, que eram, então, gratuitamente distribuídos às usuárias. Além disso, um estreito contato era mantido com o Hospital do Campo Limpo e com a UBS Vila das Belezas - próxima ao Núcleo Monte Azul -, garantindo apoio em tratamentos e fornecimento de materiais eventualmente necessários. Hotimski (2001) também descreve acordo com a UBS do Jardim Matsutami, que encaminhava os exames coletados no ambulatório do Núcleo Monte Azul à Escola Paulista de Medicina, onde eram gratuitamente processados, e depois retornava os resultados ao ambulatório do Núcleo. Um acordo com a Weleda - uma das farmácias em São Paulo que manipula e fornece remédios e demais produtos antroposóficos - garantia 50\% de desconto aos usuários do ambulatório (HOTIMSKI, 2001).

Em 2001, houve nova ampliação nas atividades da área de saúde. Craemer e Ignacio (2008) assinalam que, a convite da Secretaria de Saúde do Município de São Paulo, a 
Associação assumiu a função de parceira na implantação do Programa de Saúde na Família (PSF) no distrito do Jardim São Luiz, visando, especialmente, à possibilidade de oferta da medicina antroposófica a uma população mais ampla do que aquela que estava sendo atendida no ambulatório. Hoje, realiza gestão compartilhada do PSF na região com a Secretaria de Saúde. É interessante registrar que, segundo Craemer e Ignacio (2008, p.60), o projeto é mantido um pouco distante da Associação, uma vez que se considera não ser possível, dada a sua grande amplitude, "permeá-lo tão fortemente com o espírito da Monte Azul”.

Atualmente, a área de saúde, segundo Baldi (2003, p. 102), engloba "atividades preventivas", "atividades curativas" e "atividades terapêuticas". As primeiras se traduzem em campanhas de saúde, planejamento familiar e saneamento básico. Além disso, pode-se também aí incluir aquelas que Hotimski (2001) denomina estarem entre as ações de promoção de saúde: melhoria na qualidade de vida, de condições de habitação, de saneamento, de alimentação e de vestuário; e oferta de empregos; ações que revelam, cabe notar, o conceito de saúde ampliado adotado na Associação. De fato, tal como pontuam Craemer e Ignacio (2008, p. 21), “a questão da saúde não se restringe somente a questões físicas, mas leva em conta a qualidade de vida em todos os seus âmbitos". As atividades curativas, descreve Baldi (2003), acontecem no ambulatório, nas especialidades de clínica-geral, ginecologia, psiquiatria, odontologia e pediatria. E as atividades terapêuticas são desenvolvidas, segundo a autora, nas áreas de psicologia, terapia artística, enfermagem, farmácia, fisioterapia, quirofonética e massagem rítmica - essas duas últimas são apresentadas adiante, quando se discorre acerca da medicina antroposófica e suas práticas.

Como parte da área de saúde estão, ainda, a assistência pré e pós-natal, e a já mencionada cogestão do PSF (MONTE AZUL, 2007). Todas as práticas, como referido, fundamentam-se na medicina antroposófica. No que diz respeito, especificamente, ao ambulatório médico-odontológico do Núcleo Monte Azul, segundo uma colaboradora da organização (informação verbal) ${ }^{16}$, cerca de 3000 pessoas são lá atendidas mensalmente; dado consonante com aquele fornecido por Baldi (2003), que complementa que o número total de atendimentos nos três núcleos, à época da coleta de dados de seu trabalho, era de 3.951 por mês.

Conforme uma das coordenadoras da área de saúde da Associação (informação

16 Informação fornecida por uma colaboradora da Associação durante visita monitorada da pesquisadora ao Núcleo Monte Azul em abril de 2007. 
verbal $)^{17}$, o ambulatório do Núcleo Monte Azul estava se cadastrando como Estabelecimento de Saúde, de modo a se tornar um observatório de práticas antroposóficas na Rede SUS. Essa iniciativa se insere na Política Nacional de Práticas Integrativas e Complementares no SUS (BRASIL, 2006a), sedimentada com o objetivo mais amplo de garantir a integralidade na atenção à saúde; e, mais especificamente, de ampliar o conhecimento sobre tais práticas - a saber, a Medicina Chinesa, a Acupuntura, a Homeopatia, a Fitoterapia, a Medicina Antroposófica e o Termalismo-Crenoterapia -, e de apoiar e implementar experiências já em andamento na rede pública em alguns locais. $\mathrm{O}$ estabelecimento de observatórios responde à demanda de se melhor conhecer tais práticas, assim como seu impacto na saúde. Cabe destacar que inclusão do ambulatório do Núcleo Monte Azul em tal medida é referida em um dos manuais de tal política (BRASIL, 2006a), no qual também se destaca sua longa atuação no campo da medicina antroposófica.

Outro ponto que estava também em andamento na área de saúde da Associação é a inauguração de uma Casa de Parto - a Casa Angela - próxima ao Núcleo Monte Azul. O processo de parceria com a prefeitura, necessário à sua abertura e funcionamento, porém, estava encontrando algumas dificuldades e até o encerramento da coleta de dados do presente estudo, a Casa ainda não estava operando (informação verbal) ${ }^{18}$.

\subsubsection{ACOMPANHAMENTO AO CICLO GRÁVIDO-PUERPERAL NO NÚCLEO MONTE AZUL}

O acompanhamento ao ciclo grávido-puerperal teve início, no Núcleo Monte Azul, em 1983, quando a parteira alemã Angela Gehrke começou a atuar como voluntária na comunidade (HOTIMSKI, 2001). Estruturou-se, porém, em 1985 (BALDI, 2003; HOTIMSKI, 2001). Baldi (2003) relata que, passando pelas casas da região, Angela convidava as gestantes para a realização do pré-natal. Acompanhava-as, então, durante toda a gravidez. Em boa parte dos casos, realizava também os partos - que passaram a ser

17 Informação fornecida por uma das coordenadoras da área de saúde da Associação durante o período de coleta de depoimentos do presente estudo.

18 Informação fornecida por uma das coordenadoras da área de saúde da Associação durante o período de coleta de depoimentos do presente estudo. 
divulgados entre profissionais de saúde, na imprensa e nos meios acadêmicos, assim como pela própria Associação, como humanizados (HOTIMSKI, 2001) - seja na Casa de Parto por ela inaugurada (BALDI, 2003), seja nos domicílios das mulheres da comunidade (HOTIMSKI, 2001). E seguia com o acompanhamento no pós-parto (FIGUEIREDO, 1999; HOTIMSKI, 2001), quando realizava cerca de duas visitas domiciliares, de modo a checar o estado da mulher e a retirar pontos daquelas que haviam realizado cesariana (FIGUEIREDO, 1999). Quando necessário, era providenciado encaminhamento para hospital. No caso do Hospital do Campo Limpo havia uma especificidade, pois, Angela, em razão de acordo com a instituição, tinha livre acesso, o que lhe permitia acompanhar a mulher durante o parto e o período de internação (HOTIMSKI, 2001).

Hotimski (2001) refere que em meados da década de 1990 - época em que empreendeu estudo na instituição ${ }^{19}$ - a média de atendimentos ao pré-natal e ao puerpério realizados no ambulatório do Núcleo era de cerca de 300. Quanto à clientela que frequentava o serviço nesse período, Hotimski (2001) relata que 93,9\% das 564 mulheres que integraram a amostra do estudo eram domiciliadas no município de São Paulo. Deste contingente, a maioria residia no distrito do Jardim São Luís $(54,8 \%)$ ou em distritos circunvizinhos - Vila Andrade (14,9\%), Capão Redondo (10,5\%), Jardim Angela (5,8\%) e Campo Limpo (5,2\%). Porém, apenas $22,8 \%$ eram residentes na área de abrangência do ambulatório - seja na comunidade seja no bairro Jardim Monte Azul, onde o Núcleo se localiza; o que, para a autora, revelou que a proximidade geográfica não se destacava como critério de escolha do serviço. Ademais, 7,6\% das mulheres integravam o que na época se definia por "clientela particular”, que pagava, findo o acompanhamento, pelos serviços prestados. Essas mulheres pertenciam a classes mais favorecidas e se dirigiam ao serviço em busca do parto "humanizado, em conformidade com a linha antroposófica" (HOTIMSKI, 2001, p. 146) oferecido na Casa de Parto; mantinham-se, porém, em acompanhamento paralelo na rede privada ou conveniada.

Hotimski (2001) também descreve que, a partir de 1996, Angela começou a contar com a ajuda de outra parteira alemã - Érika Alfe -, em parte dos atendimentos. As consultas pré-natais costumavam durar, em média, 15 minutos, com exceção da primeira, na qual, devido à realização de anamnese e à preocupação de estabelecimento de um bom vínculo com

19 A autora realizou estudo no Núcleo Monte Azul que visou a compreender como mulheres de camadas populares e médias conheceram e passaram a frequentar o serviço de acompanhamento ao pré-natal, ao parto e ao puerpério, do ambulatório e da Casa de Parto, então em funcionamento, da Associação Comunitária Monte Azul. Os dados levantados referiram-se ao período de abril de 1995 a março de 1998. 
a gestante, dedicava-se um tempo maior. Em todas as consultas media-se peso, pressão e altura uterina. Os exames eram coletados no ambulatório e gratuitamente processados em outro serviço. $\mathrm{Na}$ época efetuava-se, ademais, testagem anti-HIV; e ultrassom, mediante pagamento de uma taxa.

A média de consultas pré-natais realizadas pelas usuárias do serviço, segundo Hotimski (2001), era de 4,7; e pela clientela particular, de 2,7; embora houvesse casos em que a gestante realizara apenas uma consulta pré-natal; ou então, em que não participara de consulta alguma, chegando apenas para o parto; e casos, por outro lado, em que a mulher realizava até 16 consultas pré-natais. Especialmente entre a clientela particular, a autora destaca o acompanhamento paralelo em dois serviços como fator de impacto sobre tal média. De acordo com Figueiredo $(1999)^{20}$, porém, essa era uma prática também presente entre as usuárias, que procuravam pela UBS nas ocasiões em que a parteira se ausentava, ou para ter acesso a exames e medicamentos que não eram oferecidos gratuitamente no Núcleo.

Tanto Figueiredo (1999) quanto Hotimski (2001) mencionam um clima de familiaridade observado no ambulatório, em função de, na maioria dos casos, usuárias e colaboradores já se conhecerem; algumas vezes, por serem vizinhos, ou na própria comunidade, ou no bairro Jardim Monte Azul, onde o Núcleo está localizado. Assim, Figueiredo (1999) relata que, muitas vezes, as usuárias eram imediatamente reconhecidas e chamadas pelo nome, e se estabeleciam conversas informais entre essas e os colaboradores o que foi também descrito por Hotimski (2001).

Além disso, conforme Hotimski (2001), um aspecto recorrente nos relatos das mulheres entrevistadas em seu estudo, era o de referências ao acolhimento caloroso e ao espaço de escuta oferecido por Angela e por outros colaboradores do ambulatório; o que, em muitos casos, favorecia o estabelecimento de uma relação descrita pelas usuárias como semelhante àquela existente entre mãe e filha, ou entre amigas. O vínculo então construído era vivido pelas mulheres como muito satisfatório, tendo por base um acompanhamento que consideravam competente, individualizado e atencioso. A escolha e a adesão ao serviço eram definidas prioritariamente por esses aspectos, segundo a autora.

Esses relatos de mulheres frequentemente se davam, de acordo com Hotimski (2001), em meio a comparações com as experiências vividas em outros serviços, as quais remetiam a vivências de insegurança e insatisfação diante de maus tratos; da falta de empatia,

20 A autora desenvolveu estudo no ambulatório do Núcleo Monte Azul também em meados da década de 90, acerca de saúde sexual e reprodutiva em mulheres de baixa renda. 
sensibilidade, paciência, atenção e disponibilidade do profissional; e de um relacionamento permeado por frieza e dificuldades de estabelecimento de diálogo e de esclarecimento de dúvidas. Tudo isso resultava, então, na não-sedimentação de confiança no profissional. Em suma, como salienta Hotimski (2001, p. 297), as mulheres não se sentiam reconhecidas, em tais serviços, em sua condição de sujeitos, "com valores, demandas e necessidades próprias relacionadas ao processo reprodutivo e à atenção requerida"; o que, por outro lado, encontravam no cuidado prestado no Núcleo. Em decorrência dessa qualidade encontrada no ambulatório, pontua Figueiredo (1999), as mulheres se tornavam mais exigentes sobre o que desejavam de um serviço. Defende, por essa razão, que o trabalho realizado no Núcleo contribuía, também, para a formação de uma população mais crítica acerca de seus direitos.

Hotimski (2001) refere que o serviço provido por Angela operou durante aproximadamente 15 anos, tendo sido largamente reconhecido por sua qualidade nesse período, nos meios acadêmicos, na impressa e por profissionais de saúde; o que lhe gerou convites para ministrar palestras em uma série de eventos. Em março de 1998, porém, a Casa de Parto foi fechada, após notificação do Conselho Regional de Enfermagem de São Paulo (COREN-SP) de que Angela infringia a lei e que deveria, para regularizar sua situação, obter diploma de enfermeira-obstetra, ou de obstetriz, no Brasil. Um ano depois, Angela recebia a notícia de que seu diploma fora revalidado pela Escola de Enfermagem Anna Nery da UFRJ; porém, com câncer de pulmão em estágio avançado, retornou à Alemanha, onde faleceu em meados de 2000. Por volta dessa época o serviço de atenção ao pré-natal e ao puerpério foi assumido por uma enfermeira-obstetra - até hoje na Associação - e por um gineco-obstetra homeopata. $\mathrm{O}$ atendimento ao parto, porém, ficou suspenso desde então.

\subsection{ANTROPOSOFIA E SUA APLICAÇÃO NO CAMPO DA SAÚDE}

A Antroposofia é um movimento teosófico, fundado pelo filósofo e pedagogo austríaco Rudolf Steiner, em 1901 (HOTIMSKI, 2001). Trata-se de um caminho de conhecimento da natureza do homem e do universo (BALDI, 2003) caracterizado por um sincretismo religioso e filosófico, que adota elementos do cristianismo e do misticismo alemão (HOTIMSKI, 2001). É aplicável nas mais variadas áreas da vida humana: pedagogia, 
medicina, arquitetura, agricultura, organização social, arte, entre outras (FEW, 2007).

A partir dos princípios antroposóficos, o homem é compreendido como uma unidade psico-físico-espiritual (FEW, 2007), a qual diz respeito, segundo Baldi (2003), à concepção trimembrada do humano, ou seja, há um corpo - concernente à esfera somática -, uma Alma relativa à esfera psíquica - e um Eu - referente à esfera espiritual. Essa esfera, cabe destacar, é compreendida como manifestação da individualidade e, de acordo com Craemer e Ignacio (2008), se expressa concretamente naquilo que todo indivíduo possui em termos de talentos e potências a serem desenvolvidos. Trata-se de uma força criadora que mobiliza o homem a crescer e se desenvolver. À medida que se transforma e adquire, ou realiza - no sentido de efetivação de potências - novas habilidades, pode então assumir cada vez mais responsabilidades em sua atuação no mundo, independentemente de nível socioeconômico e educacional. Além disso, de acordo com as autoras, trata-se, também, de uma força que permite ao indivíduo uma transposição para além das questões cotidianas para, então, enfrentar dificuldades vividas.

Essas três instâncias estão em constante movimento e interação e é por intermédio delas que o homem pode compreender sua própria natureza (BALDI, 2003). Ademais, entende-se, na Antroposofia, que o homem, como unidade físico-psíquica-espiritual, está em constante relação com o meio e com os outros seres, devendo sempre ser aí compreendido (CRAEMER; IGNACIO, 2008).

Além da trimembração acima referida, que segundo Baldi (2003), constitui o ser humano, uma quadrimembração define o corpo humano. Na concepção de Rudolf Steiner, segundo a autora, o homem possui um corpo físico, que se refere aos sentidos corpóreos; um corpo vital, que é aquele que lhe permite vida no corpo físico e está ligado ao crescimento, à regeneração e à reprodução; um corpo anímico, que lhe possibilita a percepção de sentimentos e desejos; e um quarto corpo, a Organização do Eu, também chamado corpo calórico, concernente à atuação e à manifestação do Espírito. Segundo Hotimski (2001) é através do Eu que o homem adquire a capacidade de efetuar escolhas e de se desenvolver moralmente. Ela também destaca que tal esfera se distingue dos demais corpos, já que não se reveste da provisoriedade dos outros.

A organização tríplice parece ser uma marca essencial no pensamento antroposófico. O corpo humano possui três partes fundamentais: cabeça, tronco e membros (BALDI, 2003). São também três as faculdades preponderantes da alma: o pensar, referente à dimensão mais 
objetiva; o sentir, que diz respeito à subjetividade; e o querer, concernente à força de vontade, à energia investida no agir (CRAEMER; IGNACIO, 2008). E três os aspectos do espírito: consciência, estado desperto; semiconsciência, que se dá ao sonhar; e inconsciência, quando se está em sono profundo (BALDI, 2003).

Da mesma forma, a Biografia Humana, segundo Baldi (2003), organiza-se em três grandes etapas: os primeiros 21 anos de vida são necessários ao amadurecimento do corpo; dos 21 aos 42 anos se dá o amadurecimento da psique; e dos 42 aos 63 anos se desenvolve a individualidade (após os 63 anos a vida continua em ritmo mais livre e de colheita). Cada um desses ciclos pode ser dividido, ainda, em três ciclos menores - os setênios.

O nascimento é considerado, de acordo com Hotimski (2001), parte do primeiro setênio de vida da criança. É tido como uma reencarnação e, por isso, como fruto de um processo de escolha do Eu. Configura-se em vivência de grande impacto e desafio, tanto na vida do novo ser que vem ao mundo, como na de seus pais e de demais sujeitos que acompanham o processo. No que se refere, especificamente, ao parto vaginal, considera-se que, sendo um desafio à mulher, ao bebê e ao profissional que os assiste, sua superação propicia uma vivência transformadora e, especificamente ao bebê, oferece segurança e confiança, garantindo, então, bases sólidas ao seu futuro desenvolvimento. Ademais, entendendo-se que a partir de então se inicia o desenvolvimento de seu corpo etérico, quaisquer intervenções desnecessárias durante esse momento podem prejudicar seu desenvolvimento espiritual.

Uma decorrência dessa compreensão acerca da natureza humana refere-se à concepção de que corpo, alma e espírito não podem ser considerados de modo isolado. Conforme o homem cresce, desenvolve-se, adoece, as transformações que vão se dando no nível biológico são sempre vinculadas ao que se passa nos âmbitos psicológico e espiritual (BALDI, 2003).

Além disso, nota-se que tais concepções convertem-se em formas específicas de atuação. Em termos mais amplos, a integralidade evidencia-se como base das ações voltadas à promoção de crescimento e desenvolvimento. Partindo-se de um conceito de trimembração humana, produz-se um cuidado que aborda o corpo, a alma e o espírito. E compreendendo-se o homem em complexas inter-relações com o mundo, considera-se que o fomento da educação, por exemplo, não pode estar desvinculado de ações no campo da saúde ou do social - uma vez que uma criança não terá condições de aprender, conforme salientam Craemer e Ignacio (2008), se estiver doente ou vivendo sob condições muito precárias. Ademais, parece 
ser também possível afirmar que se entende que o homem apenas poderá realizar sua natureza humana de modo pleno, se o seu desenvolvimento for promovido nas diversas áreas do viver.

A aplicação dos princípios antroposóficos à saúde, mais especificamente, de acordo com Figueiredo (1999), resulta na proposta de ampliação do conceito de cura, então associada à promoção de desenvolvimento do indivíduo como um todo - ou seja, física, psíquica e espiritualmente. Além disso, da forte ênfase na compreensão de que a maior parte das doenças físicas se relaciona intimamente com vivências psicológicas, decorrem intervenções que integram a investigação e a elaboração dessas vivências. Convém lembrar, porém, que a abordagem não se restringe apenas a esses campos. Como Craemer e Ignacio (2008) evidenciam, entende-se que o vivido em outras esferas - como a social - também impacta quadros de doenças e de demais dificuldades.

O diagnóstico, conforme Figueiredo (1999), costuma ser realizado por meio de exames convencionais e de uma investigação profunda do vivido pelo sujeito em suas diversas dimensões, incluindo-se um levantamento de sua biografia, para avaliar o experienciado em cada setênio. $\mathrm{O}$ tratamento, destaca a autora, se dá prioritariamente por meio da promoção de alimentação de melhor qualidade, do emprego de medicação homeopática, que é obtida a partir dos reinos animal, vegetal e mineral (BALDI, 2003), e de terapias complementares, como a euritmia curativa, a massagem rítmica ou a terapia artística. Em casos mais graves, porém, são receitados medicamentos alopáticos com encaminhamento, se necessário, a especialistas da medicina tradicional para acompanhamento paralelo. Quanto à relação terapêutica, Hotimski (2001) a aponta como um encontro cármico, que pode promover o desenvolvimento espiritual tanto do paciente quanto do terapeuta. Um encontro em que a escuta clínica e o estabelecimento de vínculo são tidos como recursos de fundamental importância.

Um aspecto também marcante no cuidado em saúde fundamentado na Antroposofia, segundo Baldi (2003), associado à concepção tríplice do humano e à visão do indivíduo como um todo, é a constituição de equipes multidisciplinares, que atuam de forma integrada. Como consta no manual da PNPIC (BRASIL, 2006a, p. 23), o modelo de atenção que aí se tem por base "está organizado de maneira transdisciplinar, buscando a integralidade do cuidado em saúde". Assim, ainda em Baldi (2003), para cuidar do corpo, tem-se a Medicina e a Enfermagem Antroposóficas, a Quirofonética, a Euritmia Curativa, a Fonoaudiologia, a Odontologia, a Massagem Rítmica e a Nutrição. Para cuidar da alma, há a Psicologia e a 
Terapia Artística. E para a área da individualidade, há o trabalho biográfico.

Os profissionais praticantes da Medicina Antroposófica possuem formação convencional, com o competente registro no Conselho Regional de Medicina do estado brasileiro em que atuam, acrescida de um curso básico e de um curso de formação específica para médicos e dentistas (BALDI, 2003).

A Enfermagem Antroposófica é voltada, segundo Baldi (2003), especialmente, à aplicação de terapias externas, como banhos medicinais, enfaixamentos, deslizamentos (espécie de massagem), compressas, massagem suave, e tantas outras, voltadas ao fortalecimento da pessoa e à minimização do sofrimento; atuam, portanto, como suporte nos processos de cura.

A Quirofonética é uma terapia corporal que integra recursos da fala e da massagem. Fundamenta-se na organização tríplice da natureza humana e no conceito de Metamorfose de Goethe, considerando, a partir disso, que o aparelho fonador relaciona-se ao homem como um todo. A laringe, por exemplo, é tida como o útero metamorfoseado: este traz um novo ser ao mundo, aquela o faz com os fonemas. Sua aplicação se dá por meio de deslizamentos que simulam o movimento do ar durante a emissão de fonemas, acompanhados da entonação de sons, por parte do terapeuta, correspondentes ao fonema escolhido (ABMA, 2009b).

A Euritmia Curativa se baseia no princípio de que a expressão máxima do movimento do homem está na fala, ou seja, nos sutis, diversos e complexos movimentos empregados na produção de fonemas. A partir disso, propõe movimentos corporais, especialmente com os braços, que simulam o fluxo de ar no organismo fonador conforme se fala, promovendo, assim, transformação e cura (ABMA, 2009a).

A Massagem Rítmica se pauta na massagem clássica, nos princípios antroposóficos e, especialmente, na importância do equilíbrio do sistema rítmico (sistemas circulatório e respiratório) para promover a saúde do organismo, a prevenção de quadros de estresse e o apoio em processos de cura. Assim, por meio de movimentos que simulam os ritmos da vida como mudança das estações do ano, a inspiração e a expiração, sístole e diástole etc. -, ela visa à harmonização do sistema rítmico e, em termos mais amplos, a criação de um novo cenário de desenvolvimento e crescimento interior (GILDE, 2009).

A Terapia Artística se fundamenta nos princípios antroposóficos e no conhecimento das artes plásticas. Busca, por meio do emprego de elementos artísticos (forma, volume, cor etc.), propiciar a vivência de reconexão com a essência sanadora que todo indivíduo possui. 
Trabalha com a ampliação e a integração do observar, do pensar, do sentir e do agir. E, especialmente pelo contato com a natureza, com o ritmo, com o belo e com a harmonia, propicia ao indivíduo a experiência de se sentir (novamente) inteiro (ABMA, 2009c).

Por fim, a Terapia Biográfica propõe o resgate do vivido pelo indivíduo como instrumento de compreensão da própria história e de como sua essência se manifesta. A partir disso, espera-se que ele amplie o entendimento do sentido e da missão de sua existência e, então, efetue as mudanças necessárias à vivência da vida em sintonia com as descobertas (GUERRA, 2009). 


\section{OBJETIVOS}

\subsection{OBJETIVOS GERAIS}

- Observar, descrever e compreender como se dá a humanização do cuidado pré e pósnatal em uma organização não-governamental, tendo em vista as inter-relações de alguns dos sujeitos envolvidos na produção desse cuidado - usuárias, colaboradores e coordenadores - e o cenário no qual tais inter-relações se dão.

- Compreender de que forma os processos de acolhimento e de produção de vínculo estabelecem relações com a humanização do cuidado, caso tais aspectos se façam presentes no serviço estudado.

- Refletir sobre elementos que favoreçam a superação de algumas contradições que permeiam o campo da humanização e que contribuam, assim, para sua sedimentação.

\subsection{OBJETIVOS ESPECÍFICOS}

- Avaliar o serviço de atenção pré e pós-natal oferecido pela $\mathrm{ONG}$, a partir dos seguintes tópicos:

- Observação de infraestrutura, rotinas e procedimentos.

- Caracterização parcial do serviço, com base em alguns dos parâmetros definidos no PHPN.

- Caracterização parcial da clientela.

- Estudo da incorporação dos processos de acolhimento e de produção de vínculo ao serviço, caso se façam aí presentes.

- Observação das relações estabelecidas entre coordenadores, colaboradores e clientela.

- Investigação de percepções de colaboradores e coordenadores sobre o serviço 
prestado.

- Compreender como a humanização é entendida na $\mathrm{ONG}$, a partir do fazer, do discurso e das concepções de colaboradores e coordenadores.

- Compreender como as usuárias do serviço de atenção pré e pós-natal avaliam o cuidado recebido, por meio da investigação dos seguintes tópicos:

- Se priorizam aspectos do atendimento ao qualificá-lo; em caso positivo, quais aspectos são priorizados.

- Se consideram que tais aspectos contribuem, de alguma forma, para a sua vivência do ciclo grávido-puerperal; em caso positivo, de que maneira.

- Se acolhimento e produção de vínculo são referidos; em caso positivo, de que forma. 


\section{MÉTODO}

O presente estudo constituiu-se de uma pesquisa qualitativa de referencial fenomenológico-existencial. Os métodos qualitativos de pesquisa, conforme argumenta Turato (2003), são indicados para apreender e compreender os sentidos e significados que os sujeitos atribuem a um dado fenômeno; e a fenomenologia é a principal base filosófica das pesquisas qualitativas em que o homem é o objeto de estudo.

Critelli (1996) chama a atenção para o fato de a fenomenologia não ser uma teoria, ou apenas um instrumento para viabilização de novos procedimentos de investigação. Ela instaura uma nova visão de mundo, de homem e de compreensão da existência. Até então, o referencial positivista, como apontado por Forghieri (1984), concebia o mundo separado e independente do sujeito e, por isso, passível de estudo objetivo, a partir da anulação da subjetividade daquele que se punha a conhecê-lo. Segundo a autora, a fenomenologia surgiu para contestar esse modelo, principalmente quando aplicado às ciências humanas, por não ser possível conceber homem e mundo separadamente.

A fenomenologia desenvolvida por Merleau-Ponty (1994) apresenta o homem como ser-no-mundo cuja consciência corporificada (ser-no-mundo) é dotada de intencionalidade, ou seja, existe como percepção intermediada pelo corpo e está sempre relacionada a algo, voltada para o mundo e dando significado a ele. O mundo, por sua vez, sempre existe para uma dada consciência e só tem sentido porque é significado pelo sujeito. Assim, consciência e objeto, sujeito e mundo, deixam de ser considerados como duas instâncias separadas.

Em um campo de pesquisa, isso implica dizer que pesquisador e sujeito pesquisado estão dialeticamente ligados, como referem Martins e Bicudo (1989). Dessa maneira, o processo de apreensão e compreensão do fenômeno se estabelece no campo relacional, entre ambos, e o conhecimento, então produzido, resulta de uma construção conjunta de significados, ou seja, é intersubjetivo. Como desdobramento, valoriza-se, nesse referencial, a imersão do pesquisador no contexto, de modo que este interaja com os participantes da pesquisa e tente apreender, dessa relação, os significados atribuídos aos fenômenos investigados. O pesquisador faz parte da realidade que estuda, interage com ela e, por isso, "a influência dos valores é inerente ao processo de investigação" (ALVES, 1991, p. 55). De acordo com Veríssimo (2005), Merleau-Ponty, baseando-se em Koffka e Köhler, aponta ser 
próprio do método fenomenológico o pesquisador fazer uso da própria experiência ao investigar os fenômenos; sua subjetividade é, assim, recurso importante na aproximação ao vivido que pretende compreender.

Integrar a subjetividade, entretanto, aos processos de construção de conhecimento, demanda cautela, que pode ser garantida pelo recurso de redução fenomenológica. Forghieri (2002) apresenta uma possibilidade de uso desse recurso em contexto de pesquisa. Ela propõe dois momentos no processo de redução fenomenológica: envolvimento existencial e distanciamento reflexivo. No primeiro, o pesquisador deve identificar os seus preconceitos relacionados ao fenômeno - ideias preconcebidas, hipóteses, conhecimentos já adquiridos - e suspendê-los, para poder se lançar ao mundo-vida e encontrar-se profunda e genuinamente com seu objeto de estudo. Desse encontro emerge uma "compreensão global, intuitiva e préreflexiva" (FORGHIERI, 2002, p. 60) do fenômeno. Esse processo, para Merleau-Ponty (1994), nunca é completo, mas, segundo Forghieri (2002), é importante que o pesquisador esteja consciente de seus preconceitos.

O outro momento da redução fenomenológica, proposto por Forghieri (2002), referese a um movimento, por parte do pesquisador, de se distanciar do fenômeno em estudo, para poder refletir sobre a compreensão obtida no envolvimento existencial e apreender seu sentido; sem, entretanto, distanciar-se a ponto de perder o vínculo com o fenômeno. Assinala Forghieri (1984, p. 17): “a reflexão não deve ser uma especulação abstrata, mas uma forma de vida, que engloba tanto os meus pensamentos quanto os meus sentimentos. O meu existir é anterior ao meu pensar e é dele que devo partir para encontrar a verdade".

Segundo Ciornai (2004, p. 38), é um movimento pendular entre envolver-se existencialmente, de modo que aflorem sensações e sentimentos que propiciem uma compreensão ainda intuitiva e pré-reflexiva, e distanciar-se, para permitir-se uma reflexão em que a experiência possa ser nomeada de uma forma o mais próxima possível do vivido. Assim, flui-se "do 'nada além que processo', do vivido na relação, para um momento de reflexão sobre esse vivido".

O homem é compreendido, no referencial fenomenológico-existencial, como ser-nomundo (MERLEAU-PONTY, 1994), ou, como aponta Ribeiro (1999, p. 28), segundo uma “visão unitária do ser como-um-todo-no-mundo e do mundo como-um-todo-no-ser". Além disso, o sujeito só pode ser compreendido como um ser-em-relação, que se torna humano ao se relacionar com outros homens e que se reconhece, constrói e significa a sua vida e ao 
mundo nessa relação. Por isso, refere Carmo (2002, p. 13), o homem deve ser "pensado em seu meio natural, cultural e histórico, ou seja, como ser-no-mundo" e como ser-em-situação. Além disso, o homem, segundo o autor, deve também ser compreendido como projeto existencial - em constante processo de vir-a-ser - situado no mundo.

Dessa maneira, explica Boemer (1989, p. 32), o pesquisador que trabalha segundo um enfoque fenomenológico-existencial, ao se preocupar com o sujeito situado, "encaminha-se para seu mundo-vida [...] [tentando analisá-lo] em termos de experiência vivida”. O sentido que uma dada situação tem para uma pessoa, segundo Forghieri (2002), ou a maneira como a experiência é percebida por aquele que a vive, como referem Martins e Bicudo (1989), é a experiência vivida, ou vivência. Por isso, o fenômeno - aquilo que se revela tal como é (CARMO, 2002) -, foco de estudos fenomenológicos, é, também, sempre situado, ou seja, vivenciado por um dado sujeito em uma determinada situação (MARTINS; BICUDO, 1989).

\subsection{LOCAL DE COLETA DOS DADOS}

A Associação Comunitária Monte Azul - que atua nos Núcleos Monte Azul, Peinha e Horizonte Azul - foi escolhida para local de realização do estudo em função da divulgação do serviço de atenção ao pré-natal e ao puerpério prestado, autorreferido como humanizado.

Os dados foram coletados principalmente no ambulatório do Núcleo Monte Azul. No Núcleo Peinha realizou-se apenas reconhecimento de campo e levantamento de dados de cartões de gestantes, uma vez que à época da realização de entrevistas com mulheres-usuárias e com profissionais, ali já não mais se oferecia atenção pré e pós-natal. Optou-se por manter os relatos dos dados coletados nesse Núcleo por se entender que contribuiriam para a compreensão do serviço oferecido pela Associação e de como se dá, ali, a humanização.

O Núcleo Horizonte Azul não foi inserido no trabalho porque, segundo uma das coordenadoras da área de saúde, nele inexistia serviço estruturado de acompanhamento pré e pós-natal; oferecia-se somente atividades complementares. Além disso, a localização inviabilizaria visitas mais frequentes. 


\subsection{PARTICIPANTES}

Participaram do presente estudo colaboradores e coordenadores da Associação Comunitária Monte Azul, especialmente aqueles ligados aos serviços de acompanhamento pré e pós-natal; e usuários dos serviços prestados pelos ambulatórios Monte Azul e Peinha, mais especialmente, gestantes, puérperas e familiares.

\subsubsection{PARTICIPANTES DA COLETA DE DEPOIMENTOS}

\subsubsection{COLABORADORES E COORDENADORES}

Dentre os colaboradores e coordenadores da Associação ligados ao serviço de atenção pré e pós-natal, foram entrevistadas:

- A coordenadora da área de saúde materno-infantil, médica que também participa da atenção ao pré-natal e ao puerpério oferecendo suporte emocional às mulheres e, em alguns casos, aplicando massagem rítmica e terapias externas.

- A coordenadora do ambulatório, enfermeira-obstetra, que realiza atendimento prénatal na ausência da enfermeira por ele responsável, e atendimento de puerpério.

- A enfermeira-obstetra que realiza o pré-natal e as consultas de puerpério.

- A auxiliar de enfermagem responsável pelo acompanhamento das gestantes e puérperas.

- A fisioterapeuta encarregada dos grupos de trabalho corporal semanais com as gestantes.

- A dentista responsável pelo acompanhamento odontológico de gestantes e pelos grupos de orientação sobre os cuidados com a dentição do bebê.

A escolha desses profissionais foi norteada pela ligação deles ao serviço de atenção pré e pós-natal como responsáveis por alguma área ou projeto; e/ou pelo desenvolvimento de 
atividades que os coloca em contato próximo e frequente com as gestantes/puérperas.

A seguir, uma tabela (Tabela 1) apresenta alguns dados relativos à caracterização das participantes, a saber, tempo de formação profissional; de trabalho na Associação Comunitária Monte Azul; e de ligação com o serviço de atenção pré e pós-natal oferecido pela organização. Os nomes fictícios atribuídos a elas não foram empregados neste momento e não serão associados com a ocupação que possuem no Núcleo como garantia de anonimato - em razão de não existirem muitos profissionais de uma mesma especialidade ligados ao serviço em pauta.

Tabela 1 - Caracterização das profissionais participantes

\begin{tabular}{lccc}
\hline \multicolumn{1}{c}{ Participante } & TFP (anos) & TMA (anos) & TLSAPP (anos) \\
\hline Coordenadora da área de saúde & 11 & 5 & 5 \\
materno-infantil & & & \\
Coordenadora do ambulatório & 23 & 2 & 2 \\
Enfermeira-obstetra & 31 & 8 & 7,5 \\
Auxiliar de Enfermagem & 9 & 9 & 1,5 \\
Fisioterapeuta & 3 & 7 & 0,5 \\
Dentista & 27 & 5 & 2 \\
\hline
\end{tabular}

TFP: tempo de formação profissional; TMA: tempo de Monte Azul; TLSAPP: tempo de ligação com o serviço de atenção pré e pós-natal

\subsubsection{MULHERES-USUÁRIAS}

Foram entrevistadas seis mulheres-usuárias do serviço de atenção ao pré-natal e ao puerpério do Núcleo Monte Azul, que atenderam aos seguintes critérios de inclusão:

- Idade entre 18 e 35 anos;

- Acompanhamento pré-natal no Núcleo Monte Azul;

- Assistência durante o puerpério, configurada ou não em consulta puerperal.

Além desses critérios, deu-se preferência às usuárias que haviam realizado ao menos seis consultas pré-natais; isto não foi, entretanto, tomado como critério de inclusão. Quanto à 
atenção ao puerpério, a consulta puerperal não foi considerada como exigência porque, enquanto procedimento, foi consolidado apenas em meados do primeiro semestre de 2008, trazendo dificuldades para encontrar participantes que atendessem a todos os critérios; dificuldades estas, potencializadas pelo reduzido número de gestantes e puérperas em acompanhamento no ambulatório na época em que os depoimentos estavam sendo coletados.

No que concerne à caracterização das participantes, em termos de faixa etária, houve uma variação de 26 a 33 anos, com exceção de uma participante, que tinha 18 anos. Excluída uma, com condição sócioeconômica mais favorecida ${ }^{21}$, as demais eram moradoras da área de abrangência do Núcleo Monte Azul - Jardim Monte Azul e Jardim Mirante. Quanto ao estado civil, todas eram casadas. Abaixo, uma tabela com tais dados (Tabela 2), construída com os nomes fictícios atribuídos às participantes.

Tabela 2 - Caracterização das usuárias participantes

\begin{tabular}{lccc}
\hline Participante & Idade & Residência & Estado Civil \\
\hline Gabriela & 29 & Área de abrangência do Núcleo & Casada \\
Leila & 18 & Área de abrangência do Núcleo & Casada \\
Carolina & 33 & Área de abrangência do Núcleo & Casada \\
Lourdes & 28 & Área de abrangência do Núcleo & Casada \\
Juliana & 26 & Área de abrangência do Núcleo & Casada \\
Sofia & 32 & Fora da área de abrangência do Núcleo & Casada \\
\hline
\end{tabular}

A paridade, em quatro mulheres, era de segunda gravidez, e, em duas, de primeira. Dentre as não primigestas, três haviam engravidado pela segunda vez após um período de alguns anos - entre 7 e 10 anos; e três caracterizaram a segunda gravidez como mais difícil do que a primeira. Três mulheres vivenciaram a gestação atual com alguma intercorrência. Em um desses casos não se identificou registro no cartão da gestante a esse respeito. Quanto ao parto, três participantes fizeram parto normal e três, cesariana; dentre estas, uma vivenciou complicações durante o parto.

21 Não se realizou levantamento de perfil sócioeconômico. Tal afirmação é feita com base, especialmente, no relato da própria participante, que mencionou, durante a entrevista, ter vivido um desconforto inicial no uso do serviço de pré-natal do Núcleo Monte Azul, porque sentia "medo de tirar uma vaga de alguém da comunidade" que precisasse. Ela, então, contribuía com um dado valor. 
Tabela 3 - Caracterização das usuárias participantes

\begin{tabular}{lccc}
\hline Participante & Paridade & Intercorrências na gestação atual & Parto \\
\hline Gabriela & $2^{\text {a }}$ gestação & Não & Cesariana \\
Leila & $2^{\text {a }}$ gestação & Não & Normal \\
Carolina & $2^{\text {a } \text { gestação }}$ & Hipertensão arterial ao final da & Cesariana com \\
& & gestação & complicações \\
Lourdes & Primigesta & Relato de aumento de pressão arterial & Cesariana \\
& & ao final da gestação & Normal \\
Juliana & $2^{\text {a gestação }}$ & Não & Normal \\
Sofia & Primigesta & Hiperêmese Gravídica &
\end{tabular}

\subsection{INSTRUMENTO DE COLETA DOS DADOS}

\subsubsection{OBSERVAÇÃO PARTICIPANTE}

Observação participante, segundo Minayo (2000), é aquela que pressupõe que o pesquisador coletor dos dados também é parte do contexto sob observação, modificando-o e sendo modificado por ele. Nessa perspectiva, o observador deve se colocar no mundo dos seus sujeitos, entrando na cena social dos entrevistados como pessoa comum que compartilha de seu cotidiano. Deve, também, manter uma perspectiva dinâmica, que, ao mesmo tempo, leve em conta as relevâncias dos atores sociais e tenha em mente o conjunto de relevâncias de sua abordagem teórica - o que lhe permite interagir ativamente com o campo.

\subsubsection{DIÁRIO DE CAMPO}

O diário de campo, aliado à observação participante, aponta Mayan (2001), constituise de relatos descritivos acerca do que se sucede no cenário em estudo. Cabe ao pesquisador 
registrar de maneira fidedigna o que observa, incluindo, também, sua percepção acerca do impacto de sua presença no cenário e suas reflexões, sentimentos, confusões e interpretações acerca do que apreende. É um instrumento que auxilia o pesquisador a ampliar a compreensão do objeto em estudo, e a definir e redefinir as próximas etapas no processo investigativo.

Quanto à sua consecução, Mayan (2001) sugere que o pesquisador faça seus registros tão logo seja possível. Quando estiver no cenário em estudo, as anotações dos relatos de pessoas devem, preferencialmente, ser literais. Caso não se lembre das palavras exatas, deve utilizar as que mais delas se aproximem. Também é importante apontar a data de cada registro realizado.

\subsubsection{ENTREVISTA SEMIESTRUTURADA SEGUNDO A ÓTICA DA REFLEXIVIDADE}

A entrevista semiestruturada, para Nogueira-Martins e Bógus (2004), caracteriza-se por partir-se de determinadas perguntas, as quais constituem o roteiro de entrevista, e fundamentam-se em aportes teóricos, em informações coletadas acerca do fenômeno a ser estudado e em hipóteses do pesquisador. À medida que o contato com a realidade estudada se estreita e novas hipóteses surgem, o conjunto inicial de questões vai sendo reformulado. Ademais, durante a entrevista, o roteiro se revela instrumento flexível, abrindo espaço para o entrevistado, a partir do foco proposto pelo entrevistador, expor livremente suas reflexões, assumindo, assim, um lugar de coconstrutor da entrevista e, em decorrência, da própria pesquisa.

No presente estudo, acrescentou-se a esse instrumento a proposta de reflexividade de Szymanski (2000), que integra um método específico de entrevista elaborado pela autora, denominado "entrevista reflexiva". Originalmente, esse método se caracteriza por se desenvolver a partir de uma questão desencadeadora. Além disso, envolve dois momentos: um encontro inicial, no qual se dá a primeira entrevista; e um segundo encontro, no qual o pesquisador dá uma devolutiva ao entrevistado, constituída de uma pré-análise do conteúdo que emergiu durante o primeiro encontro; a partir disso, desenvolve-se a segunda entrevista. Esses procedimentos não foram empregados no presente estudo. Apenas e tão somente foram 
incorporados aspectos que compõem o método em pauta - descritos a seguir. Por isso, considerou-se adequado nomear o instrumento aqui utilizado de "entrevista semiestruturada segundo a proposta da reflexividade".

Uma entrevista que se baseia em tal proposta, segundo Szymanski (2000), parte do pressuposto de que a entrevista é um encontro interpessoal, que inclui a subjetividade de seus protagonistas - pesquisador e participante(s). Como fruto desse encontro, dotado de horizontalidade e equilíbrio das relações de poder, um conhecimento será coconstruído.

Em termos de procedimento, refere Szymanski (2000, p.197), o entrevistador deve refletir a fala do entrevistado, de forma a expressar a compreensão dela obtida; incluindo, também, suas impressões sobre estados emocionais e índices não-verbais emitidos pelo participante. Desse procedimento seguem duas decorrências importantes. Ao submeter tal compreensão ao entrevistado, torna-se possível aprimorar a fidedignidade. Além disso, "ao deparar-se com sua fala, na fala do pesquisador, há a possibilidade de outro movimento reflexivo - o entrevistado pode voltar para a questão discutida e articulá-la de uma outra maneira, uma nova narrativa a partir da narrativa do pesquisador”. Portanto, torna-se possível ao entrevistado não só discordar do que foi dito como também reconstruir suas proposições durante a entrevista.

\subsection{PROCEDIMENTOS DE COLETA DOS DADOS}

\subsubsection{RECONHECIMENTO DE CAMPO}

A observação do serviço prestado, na perspectiva participante, focou-se nos seguintes aspectos, mais especialmente:

- Funcionamento institucional: organização, ambiente, infraestrutura, rotinas, normas.

- Interação entre alguns dos sujeitos envolvidos na produção da humanização do cuidado pré e pós-natal - coordenadores, colaboradores e usuárias:

- Interação entre coordenadores e colaboradores, incluindo-se funcionamento de 
equipe;

- Interação entre coordenadores, colaboradores e usuárias: postura dos profissionais ao prestar assistência - que abrange os aspectos "acolhimento" e produção de vínculo; e impacto de tal postura entre as usuárias;

- Interação entre usuárias.

- Condutas e procedimentos técnicos que integram o acompanhamento pré e pós-natal, tendo especialmente por base alguns dos critérios definidos pelo PHPN (BRASIL, 2002, 2006b): recepção, pré-atendimento, consultas pré-natais e atividades educativas. Procedimentos relacionados ao acompanhamento pós-natal não foram observados, em função de o serviço ter sido mais bem estruturado apenas na etapa final de coleta dos dados. Todos os dados apreendidos foram registrados em diário de campo, cujos relatos são apresentados no capítulo seguinte.

Convém destacar que apesar de o reconhecimento de campo ter sido uma etapa da pesquisa, foi, também, algo que permeou todo o processo de coleta dos dados. Consideração que se pauta no entendimento de que: a complexidade dos fenômenos implica algo novo continuamente se desvelando; a subjetividade de quem se põe a apreender tais fenômenos, subjetividade que perpassa o olhar e seleciona, define haver sempre algo novo a ser apreendido; e a dinamicidade do campo o afirma em constante reconfiguração, revelando, assim, novas nuances. Como etapa formal, porém, o reconhecimento de campo abrangeu o período de fevereiro a agosto de 2007.

No primeiro mês coube acompanhar, segundo a perspectiva da observação participante, as consultas pré e pós-natais, realizadas pela enfermeira-obstetra responsável por esses atendimentos nos Núcleos Monte Azul e Peinha, e algumas atividades educativas. Foram observadas 28 consultas - dentre as quais, conforme descrito na seção de resultados, 26 se constituíram de atendimentos pré-natais e 2 em suporte ao puerpério - e três palestras.

Entre meados de março e maio de 2007, em experiência de campo nos ambulatórios dos Núcleos Monte Azul e Peinha, conversou-se com colaboradores e coordenadores da área de saúde, com o objetivo de obter uma descrição de seu trabalho, sua percepção sobre a Associação e sua compreensão acerca da humanização ali presente; observou-se interações entre colaboradores e coordenadores, e entre esses e usuários; acompanhou-se outros procedimentos, como o pré-atendimento; e atentou-se para fatores de infraestrutura e de rotina. Ademais, realizou-se uma visita monitorada ao Núcleo Monte Azul, promovida pela 
Associação, para conhecimento das outras dependências ali existentes.

No período entre final de maio e meados de junho, empreendeu-se o levantamento de dados de cartões das gestantes - conforme descrito a seguir. E, por fim, entre julho e agosto, participou-se de uma palestra para gestantes e de um evento na Casa de Parto, organizado em comemoração à finalização de obras de sua construção.

A etapa de reconhecimento de campo foi iniciada após a obtenção de autorização informal da Associação Comunitária Monte Azul - oficializada posteriormente (Anexo C) -, a partir de contato prévio com a instituição, para a realização da pesquisa em seus ambulatórios. Porém, apenas após a aprovação do projeto pelo Comitê de Ética do IP-USP (Anexo D), deuse início à coleta dos depoimentos.

\subsubsection{LEVANTAMENTO DE DADOS DE CARTÕES DE GESTANTES}

Com a finalidade de se obter uma caracterização das usuárias atendidas no serviço de atenção pré e pós-natal dos Núcleos Monte Azul e Peinha, assim como da atenção ali prestada, empreendeu-se um levantamento de dados de cartões de gestantes, no período entre maio e junho de 2007. Importante ressaltar que tais cartões, na ocasião, não ficavam arquivados com os prontuários das usuárias. Cartões antigos eram guardados em uma gaveta, desorganizadamente. Em arquivo constavam apenas registros realizados pelas auxiliares de enfermagem. Por essas razões, no levantamento incluíram-se apenas os casos de gestantes em acompanhamento, ou que o haviam finalizado há poucos meses (durante o primeiro semestre de 2007), cujos cartões encontravam-se sobre a mesa da enfermeira-obstetra, ordenados alfabeticamente em uma caixa. O número de casos então reunidos foi pequeno: 17 usuárias no Núcleo Monte Azul e 15, no Núcleo Peinha.

A partir desses cartões, foram recolhidos dados que permitissem traçar um perfil da clientela e realizar a análise preliminar de alguns dos parâmetros estabelecidos pelo Ministério da Saúde, tais como: idade, número de gestações, número de consultas realizadas, momento da primeira consulta, distribuição das consultas ao longo dos trimestres gestacionais, histórico de parto (o que poderia sinalizar uma consulta pós-natal) e local de residência. Também integraram o levantamento, dados que informassem se a mulher havia 
iniciado pré-natal em outro local, se estava realizando acompanhamento paralelo em outro serviço - prática comum, como se verá, especialmente no Núcleo Monte Azul - e motivos acerca de eventual interrupção do acompanhamento na Associação.

Os dados então coletados foram organizados em duas tabelas, cada uma referente a um Núcleo, ambas com as mesmas categorias de informação. Tais tabelas e a descrição dos dados nelas contidos são apresentadas no capítulo 6.

\subsubsection{COLETA DE DEPOIMENTOS}

\subsubsection{MULHERES-USUÁRIAS}

Inicialmente, estava previsto, como parte do método do presente trabalho, a coleta de depoimentos de algumas gestantes durante a fase de reconhecimento de campo, de modo a investigar como o serviço era por elas percebido e avaliado. Tais mulheres eram abordadas na sala de espera do ambulatório no dia da realização do pré-natal e, então, eram convidadas a participar da pesquisa. Quando consentiam, eram entrevistadas em uma sala do ambulatório que estivesse livre, de sorte que a privacidade fosse preservada. As seguintes perguntas norteavam a entrevista (Roteiro I):

- Como você ficou sabendo do serviço de pré-natal na Associação Comunitária Monte Azul?

- Por que você procurou esse serviço?

- Nesta gravidez, você foi a outros postos de saúde antes de vir aqui?

- O que você acha do serviço aqui oferecido?

- Do que você mais gosta? Por quê?

- (Para hipótese de ser mencionado mais de um aspecto) Dentre essas coisas que você mencionou, o que você considera ser mais importante?

- Há algo nesse serviço que a incomoda ou que você gostaria de mudar? O quê? Por quê? 
- Você recomendaria esse serviço?

- Se você fosse muito poderosa e/ou tivesse muito dinheiro e fosse contratada para fazer o que fosse necessário aqui no ambulatório, o que faria?

Essa etapa foi cumprida entre fevereiro e março de 2008. Não foi possível iniciá-la antes em função de algumas dificuldades. Primeiramente, o parecer favorável ao presente trabalho foi concedido pelo Comitê de Ética do IP-USP apenas em novembro de 2007 - em virtude de questões internas do comitê somadas a um longo período de greve existente na USP naquele ano. Obtida a aprovação, contatou-se a Associação, para dar início à coleta dos depoimentos. Porém, duas coordenadoras informaram que o atendimento pré-natal, na ocasião, estava prejudicado em função de comprometimento na disponibilidade da enfermeira-obstetra, responsável pela realização das consultas. Assim, o número de gestantes, que já era pequeno, ficou ainda mais reduzido ao final do ano. No início de janeiro de 2008, em novo contato com uma das coordenadoras, verificou-se que a enfermeira-obstetra estaria em férias até o dia 20. Durante esse período, o atendimento de gestantes que comparecessem para consulta ficaria a cargo da coordenadora do ambulatório; porém, segundo relato desta coordenadora,havia ainda pouca procura pelo serviço. Assim, apenas em fevereiro houve aumento no fluxo de gestantes.

Finda essa etapa, o passo seguinte era acompanhar um casal ao longo do pré-natal e do puerpério, o que foi iniciado em março de 2008. Entre março e abril, foram observadas duas consultas pré-natais da gestante participante desta etapa; e com ela foi realizada uma entrevista. Em maio seria coletado mais um depoimento - desta vez, incluindo-se o pai do bebê. Porém, a gestante não retornou mais ao serviço, por ter-se mudado, conforme apurado em contato telefônico posterior.

Tais dificuldades ensejaram novos ajustes no desenho metodológico, sendo então definido o procedimento de entrevistar mulheres em final do puerpério, ou que já o tivessem vivido. Para tanto, no dia de realização da consulta pediátrica ${ }^{22}$, abordava-se, na sala de espera do ambulatório do Núcleo Monte Azul, as usuárias que haviam feito pré-natal no serviço em pauta e que atendiam aos critérios de inclusão já referidos - o que era checado por meio de prontuários e de informações providas pela auxiliar de enfermagem -, cujos bebês estivessem

22 O serviço de pediatria voltou a ser consolidado no Núcleo Monte Azul em agosto de 2008, tendo o ambulatório passado por um período sem essa especialidade. A partir da data referida, a auxiliar de enfermagem responsável pelo acompanhamento de gestação e puerpério passou a ligar para as mulheres que realizaram pré-natal no Núcleo convidando-as a levarem seus bebês para consulta pediátrica, pois havia sido definido que a prioridade desse atendimento seria para elas. Posteriormente, o serviço foi também disponibilizado para outras crianças. 
aguardando consulta. Foi assim estabelecida uma segunda fase de coleta de depoimentos, iniciada em agosto de 2008.

Para também investigar se as participantes percebiam algum impacto da assistência prestada em sua vivência do ciclo grávido-puerperal e como o compreendiam, quando consideravam havê-lo, foram acrescentadas ao roteiro anterior de entrevista as seguintes perguntas (Roteiro II):

- Como foi sua gravidez? Me conte cenas e/ou momentos que ficaram mais marcados em sua memória.

- Como foi o pré-natal aqui? Me conte um pouco o que você fazia aqui.

- (Se puérpera) Como foi o parto? E o pós-parto? Como foram os primeiros momentos com o bebê? E os primeiros dias em casa com ele? Me conte cenas e/ou momentos que ficaram mais marcados em sua memória.

- O que, para você, significa ser mãe? Do que você acha que uma mulher, durante a gravidez e o pós-parto, necessita? E de que maneira você acredita que um serviço pode dar conta de tal(is) necessidade(s)?

- Você diria que o acompanhamento que você recebeu aqui teve algum efeito sobre sua gravidez, parto e pós-parto? O que foi dito e feito que ficou mais marcante para você?

- Se houve, que efeito?

Tanto na primeira quanto na segunda fase de coleta de depoimentos, o contato inicial com a usuária ocorria na sala de espera, sempre com uma apresentação nominal, breve explanação da pesquisa ${ }^{23}$ e convite para prestar depoimento. Diante da concordância em fazêlo, a usuária era entrevistada em uma sala do ambulatório, disponível no momento, de modo a preservar a privacidade. Tais salas eram indicadas pelas auxiliares de enfermagem, à exceção de um dos depoimentos coletados, em que a mulher, indicada pela enfermeira-obstetra, foi entrevistada em seu local de trabalho, durante o intervalo, mas também em sala que lhe garantiu privacidade. Antes do início da entrevista, realizada segundo o método da reflexividade, como exposto anteriormente, era assinado o termo de consentimento pósinformação (Anexos $\mathrm{E}$ e F), pelo qual se assegurava às participantes o direito à privacidade,

23 Neste contato inicial, era dito à usuária que se estava acompanhando as atividades do serviço de pré-natal do Núcleo a fim de se conhecer o trabalho ali realizado. E que um dos pontos considerado importante para tanto, era ouvir o que as mulheres tinham a dizer sobre esse serviço. A ela era explicado que, caso concordasse em participar da pesquisa, ser-lhe-iam feitas algumas perguntas, em conversa que levaria cerca de 10 minutos, na primeira fase de levantamento de depoimentos; ou de 30 minutos, na segunda fase. Esclarecimentos mais pormenorizados sobre o trabalho eram fornecidos antes do início da entrevista, durante a leitura do termo de consentimento pós-informação, quando a usuária consentia participar. 
ao sigilo e ao eventual encerramento da participação na pesquisa no momento em que assim o desejassem. Todos os depoimentos foram gravados em fita cassete, também com consentimento delas.

Da primeira fase de entrevistas, foram incluídos no presente estudo apenas os depoimentos das usuárias que também participaram da segunda etapa. Dentre as seis mulheres que constituíram o grupo de participantes-usuárias deste trabalho, cinco concederam duas entrevistas - a primeira norteada pelos temas do Roteiro I e a segunda, após breve retomada do que fora conversado durante o primeiro encontro, abordando os temas do Roteiro II. Nesses casos, o intervalo entre a primeira e a segunda etapa de coleta variou entre quatro e nove meses.

Com a sexta participante houve apenas uma entrevista, guiada pelos temas dos Roteiros I e II. A despeito de possíveis variações decorrentes de tal diferença de procedimento, importou incluí-la na pesquisa, em função de ela ter passado a frequentar o serviço no momento em que outras atividades - tais como o ciclo de palestras e o grupo de trabalho corporal - estavam mais estruturadas. Assim, pôde contribuir com dados a esse respeito. Ademais, tendo estabelecido um bom vínculo com a pesquisadora, concedeu um dos depoimentos mais longos e detalhados dentre as participantes. A seguir, uma tabela (Tabela 4) com os dados referentes ao momento de realização da primeira e da segunda entrevista e ao intervalo entre ambas. 
Tabela 4 - Momento de realização das entrevistas com as usuárias e intervalo entre elas

\begin{tabular}{lccc}
\hline \multicolumn{1}{c}{ Participante } & Primeira Entrevista & Segunda Entrevista & Intervalo \\
\hline Gabriela & $34^{\mathrm{a}}$ semana gestacional & $5^{\circ}$ mês pós-parto & 7 meses \\
Leila & $30^{\mathrm{a}}$ semana gestacional & $5^{\circ}$ mês pós-parto & 7 meses \\
Carolina & $34^{\mathrm{a}}$ semana gestacional & $3^{\circ}$ mês pós-parto & 4 meses \\
Lourdes & $3^{\circ}$ mês pós-parto & $8^{\circ}$ mês pós-parto & 5 meses \\
Juliana & 1 mês e meio pós-parto & - & - \\
Sofia & $25^{\text {a }}$ semana gestacional & $5^{\circ}$ mês pós-parto & 9 meses \\
\hline
\end{tabular}

\subsubsection{COLABORADORES E COORDENADORES}

Como é próprio de processos investigativos, o desenho metodológico do presente trabalho sofreu algumas alterações ao longo de seu curso, seja em função das dificuldades apontadas, seja por conta do contato com a realidade estudada e do aprofundamento realizado na compreensão do fenômeno pesquisado. Especialmente esses dois últimos fatores determinaram a inclusão da realização de entrevistas com as profissionais ligadas ao serviço de atenção pré e pós-natal do Núcleo Monte Azul dentre os procedimentos de coleta dos dados. À medida que também o foco do trabalho se transformava, passando então a visar à compreensão da humanização do cuidado à gestação e ao puerpério produzida no ambulatório do Núcleo, tornava-se fundamental também ouvir, com mais profundidade do que aquela que marcou as conversas informais durante a fase de reconhecimento de campo, tais atores, figuras igualmente essenciais à concretização da humanização.

O percurso para agendar as entrevistas iniciou-se em agosto de 2008. Em alguns casos, porém, o agendamento levou alguns meses para poder ser efetuado, devido a indisponibilidades de horários geradas por atividades de trabalho que estavam, à época, sendo desenvolvidas pelas profissionais. Todas se mostraram, porém, muito colaborativas. Ademais, com exceção da fisioterapeuta, que havia passado a integrar o serviço de atenção ao pré-natal e ao puerpério em meados de março de 2008, estavam bastante familiarizadas com a pesquisa e já haviam cedido ao menos breves depoimentos durante a fase de reconhecimento de campo.

Quatro das seis profissionais participantes foram entrevistadas no ambulatório do 
Núcleo Monte Azul, em sala que garantiu a privacidade. A enfermeira-obstetra foi entrevistada em seu consultório particular e a coordenadora da área de saúde materno-infantil, no local de um evento do qual participava à época do agendamento da entrevista; em ambos os casos, também foram garantidas as condições de privacidade. Os depoimentos foram coletados entre setembro e novembro de 2008.

Tal qual se deu com as usuárias, antes do início da entrevista era assinado o termo de consentimento pós-informação (Anexo G), pelo qual se assegurava às participantes o direito à privacidade, ao sigilo e ao eventual encerramento da participação na pesquisa no momento em que assim o desejassem. Todos os depoimentos foram gravados em fita cassete, também com consentimento delas.

O roteiro de entrevista foi composto pelas seguintes questões:

- Como você vê a Associação Comunitária Monte Azul?

- Como você vê o serviço de atenção pré e pós-natal que é aqui oferecido?

- Se você tivesse muito dinheiro e/ou fosse muito poderosa, você faria ou transformaria algo no serviço? O quê?

- Você trabalhou em algum outro lugar antes, em que também houvesse acompanhamento pré e pós-natal? Era parecido? De que forma? Diferente? De que forma?

- Me conte um pouco sobre sua participação no serviço de atenção pré e pós-natal aqui oferecido. Como você vê seu trabalho?

- O que, para você, significa ser mãe? Do que você acha que uma mulher durante a gravidez e o pós-parto necessita? E de que maneira você acredita que um serviço pode dar conta de tal(is) necessidade(s)?

- Você já ouviu falar em humanização? O que isso significa para você?

- Você acha que isso se aplica ao serviço de atenção pré e pós-natal aqui oferecido? De que forma? Há algo que acontece aqui no serviço que complementa esse conceito? Há algo que você acha que ainda precisaria ser mais desenvolvido, tendo em vista esse conceito de humanização que você relatou? 


\section{DESCREVENDO O CAMPO: O SERVIÇO DE ATENÇÃO AO PRÉ- NATAL E AO PUERPÉRIO NOS NÚCLEOS MONTE AZUL E PEINHA}

O conteúdo desta seção advém, prioritariamente, do material colhido durante a fase de reconhecimento de campo. Incluem-se nele também alguns trechos das entrevistas realizadas com as profissionais, concernentes ao funcionamento do serviço em pauta. Nestes casos, de modo a identificar a procedência da transcrição, empregou-se a notação "Depoimento, profissional que o concedeu, data em que foi realizado".

\subsection{INFRAESTRUTURA, FUNCIONAMENTO E ROTINAS}

\subsubsection{NÚCLEO MONTE AZUL}

Um dos acessos ao Núcleo Monte Azul localiza-se em uma travessa da Avenida João Dias, próximo ao terminal urbano e à estação de metrô Giovanni Gronchi. O local tem tráfego e movimento de pessoas bastante intensos. Ao entrar na travessa, porém, a sensação é de que a agitação ficou para trás. Na rua tranquila, são poucos os carros a passar; aqueles que o fazem transitam com dificuldade entre os buracos no asfalto. As calçadas estreitas fazem com que, no geral, os pedestres caminhem próximo à sarjeta.

Não há muitas casas antes de chegar ao Núcleo. De um lado da rua, há uma distribuidora de bebidas; do outro, um motel saindo da avenida e, logo adiante, uma fábrica. É somente quando se entra no Núcleo que se torna mais evidente o que há ao redor: dezenas de casebres contam que já se está na favela.

Logo na entrada há um estacionamento, a loja de artigos produzidos nas oficinas da Associação e uma biblioteca onde anteriormente ficava a padaria. Descendo, um corredor leva ao ambulatório: uma casa com dois andares, que parece reformada há pouco. No térreo há a sala de espera, uma sala de pré-consulta, um banheiro, uma sala administrativa, três salas de 
atendimento e o Posto de Coleta de Leite Materno - inaugurado em maio de 2007. No piso superior, mais um banheiro, uma cozinha para uso dos colaboradores e voluntários, um almoxarifado, seis salas de atendimento e o acesso ao sótão - o local de reuniões.

$\mathrm{Na}$ sala de espera as pessoas aguardam sentadas em cadeiras plásticas. Algumas preferem ficar do lado de fora, nos bancos de madeira. Um balcão serve à recepcionista; sobre ele, um computador com aspecto de inutilizado, um telefone e alguns folhetos sobre cuidados com a saúde. Embaixo da escada que leva ao segundo andar, um vão guarda os brinquedos para as crianças que esperam por atendimento ou acompanham os pais. Nas paredes, estão distribuídos cartazes, com informações diversas: venda de medicação da Weleda, por valores mais acessíveis - os descontos variam entre $15 \%$ e $45 \%$, dependendo do custo da matériaprima do medicamento; preços de alimentos integrais, à venda na padaria da Associação; eventos na comunidade; e cuidados em relação à saúde - como, por exemplo, benefícios do consumo de frutas. Há, também, quadros que contam um pouco da trajetória histórica do ambulatório: um deles traz uma foto de como era o lugar quando inaugurado - um casebre em meio a um matagal; outro mostra o ambulatório antes da última reforma que parece ter ampliado o local.

O ambiente mostra-se permeado por arte. Enormes grafites na fachada da biblioteca eram vistos tão logo se adentrava no Núcleo. Em março de 2008 eles se foram e, e nas paredes do caminho que conduz ao ambulatório surgiram pinturas complementando os mosaicos já existentes - encontrados em tantos outros locais da comunidade. Em frente à entrada do ambulatório, mais pinturas. Em seu interior, pequenos adereços, como uma planta com enfeites pendurados; sobre uma mesa de canto, uma família de pintinhos feitos de lã; na parede, um enorme quadro de tela bordada, com a oração de São Francisco - prece cara à Associação, e que integra a maior parte das reuniões de colaboradores.

O movimento de pessoas na sala de espera chama a atenção pela heterogeneidade, uma característica, segundo relato de colaboradores, definida pela própria região, uma vez que a área de abrangência do ambulatório inclui a comunidade Monte Azul, e o bairro Jardim Monte Azul - onde também moram pessoas em condições sócioeconômicas mais favorecidas. Entretanto, trata-se apenas de impressão, pois não há pesquisa dos colaboradores do Núcleo nesse sentido, e também não se buscou estudos sobre esse tema.

A sala onde acontece o pré-natal fica no segundo andar. Uma sala pequena, mas agradável, que parece ter sido reformada recentemente. As paredes, pintadas de salmão, 
sustentam alguns quadros relacionados com a maternidade - pinturas estilizadas e fotos de bebê no seio ou no colo da mãe. Há uma mesa, três cadeiras, uma maca e uma pequena pia.

\subsubsection{ESPECIALIDADES DO AMBULATÓRIO DO NÚCLEO MONTE AZUL}

Tabela 5 - Especialidades no ambulatório do núcleo monte azul

\begin{tabular}{|c|c|c|c|c|}
\hline Segunda & Terça & Quarta & Quinta & Sexta \\
\hline Psicologia & Fisioterapia & Fonoaudiologia & Deslizamento & Deslizamento \\
\hline Pediatria & Pediatria & Quirofonética & Pré-Natal & Hebiatria \\
\hline Neurologia & Clínica Geral & Psiquiatria & $\begin{array}{l}\text { Massagem } \\
\text { Rítmica }\end{array}$ & Fonoaudiologia \\
\hline Deslizamento & Deslizamento & $\begin{array}{c}\text { Pedagogia } \\
\text { Curativa }\end{array}$ & Ginecologia & Odontologia \\
\hline Fonoaudiologia & $\begin{array}{l}\text { Massagem } \\
\text { Rítmica }\end{array}$ & Odontologia & Euritmia & \\
\hline Quirofonética & $\begin{array}{c}\text { Acompanhament } \\
\text { o } \\
\text { de puerpério }\end{array}$ & & Odontologia & \\
\hline $\begin{array}{c}\text { Clínica Geral / } \\
\text { Ginecologia }\end{array}$ & Psiquiatria & & & \\
\hline Psiquiatria & $\begin{array}{c}\text { Pedagogia } \\
\text { Curativa }\end{array}$ & & & \\
\hline \multirow[t]{2}{*}{ Odontologia } & Euritmia & & & \\
\hline & Odontologia & & & \\
\hline
\end{tabular}

Sobre tais especialidades, convém esclarecer que o deslizamento é uma espécie de massagem, enquadrada na categoria de terapias externas. Uma colaboradora, discorrendo acerca de algumas de suas possíveis aplicações, refere que ele pode ser utilizado para 
promover o reequilíbrio da circulação sanguínea no caso, por exemplo, de uma pessoa que possua extremidades frias (Diário de campo, Núcleo Monte Azul, 03/04/08). Além dele, são também realizados, em horários diversos, escalda-pés, enfaixamento, compressas e banhos nutritivos.

Quanto à pedagogia curativa, não descrita anteriormente, trata-se, de acordo com uma coordenadora, de uma prática fundamentada na Antroposofia que integra os campos da psicologia e da pedagogia. É especialmente voltada àqueles que vivenciam necessidades especiais e visa ao fomento da capacidade do indivíduo de vivenciar aquilo que é mais autêntico em si mesmo, favorecendo a descoberta de alternativas à vivência das limitações impostas pelo corpo físico.

\subsubsection{MARCAÇÃO DE CONSULTAS}

A marcação de consultas com alguns dos profissionais que atendem no ambulatório, como clínico-geral e ginecologistas, é presencial e acontece em dias pré-definidos. O retorno, inclusive para outras especialidades como o pré-natal e o atendimento odontológico, pode ser agendado pelo por telefone. O primeiro atendimento dessas duas últimas, porém, tem a particularidade de bastar a pessoa comparecer ao ambulatório no dia em que as consultas acontecem. Tanto em um como em outro caso, a ordem dos atendimentos, ainda que estejam agendados, é definida por senhas. Outra situação é a de especialidades como terapia, fonoaudiologia, terapias externas e terapia artística, que acontecem semanal ou quinzenalmente, mediante agendamento de horários.

\subsubsection{RECEPÇÃO, PRÉ-ATENDIMENTO E CUIDADOS DE ENFERMAGEM}

Às quintas-feiras pela manhã, há três auxiliares de enfermagem que se alternam semanalmente entre as tarefas de suporte na recepção, pré e pós-consulta e atendimentos de 
enfermaria. Uma quarta auxiliar realiza alguns procedimentos, mas, à época da coleta dos dados para o presente estudo, ela se dividia, especialmente, entre as atividades de recepcionista e as administrativas. Além dela, na ausência de auxiliar na recepção, uma assistente odontológica também executa essa função, se estiver livre; e também a pessoa responsável por serviços de limpeza e organização do local fornece suporte nesse sentido, se dispondo a chamar por alguém para realizar o atendimento. Todas costumam ser atenciosas. E por, geralmente, já conhecerem as pessoas que estão por ali, não raro conversam sobre outros assuntos, conferindo um tom familiar ao ambulatório.

Pergunto pela [coordenadora] para a recepcionista, que atenciosamente me diz que ela não chegou ainda. Preocupada com o horário - uma vez que [a coordenadora] costuma chegar mais tarde - liga para ela, para saber se ela estava se lembrando da reunião. Vem, então, me avisar que [a coordenadora] chegaria em 15 minutos. (Diário de campo, Núcleo Monte Azul, 24/01/07).

Uma auxiliar, bastante atenciosa, oferece água para os usuários em espera, falando do calor e disponibilizando copos para quem quisesse pegar água no bebedouro. Pouco depois, chega uma atendente e cumprimenta as pessoas na sala de espera. Vê uma gestante conhecida e conversa com ela, perguntando do bebê. (Diário de campo, Núcleo Monte Azul, 08/03/2007).

Um usuário chega perguntando por um medicamento [homeopático] que o médico receitara. A recepcionista fala, atenciosamente, que, se comprasse ali, ele teria desconto no medicamento e explica, então, os procedimentos. (Diário de campo, Núcleo Monte Azul, 22/03/2007).

Em algumas ocasiões, entretanto, algumas colaboradoras se mostravam menos disponíveis. Observou-se cerca de quatro episódios em que o atendimento foi permeado por impaciência, pouca atenção, nos quais elas se limitaram a responder, em poucas palavras, o que lhes havia sido perguntado ou pedido. Seguem, abaixo, trechos que relatam dois desses episódios:

Chega um senhor, que parecia estar passando muito mal, pedindo para ser atendido. Uma colaboradora, impaciente, responde que ali era um ambulatório e que ele teria que ir a um hospital. O senhor pede que a enfermeira o atenda - "pelo menos medir a pressão!" A colaboradora volta a dizer que ele deveria ir ao hospital. O senhor insiste. A contragosto a colaboradora vai chamar uma auxiliar de enfermagem. (Diário de campo, Núcleo Monte Azul, 22/02/07).

Uma mulher pergunta para uma colaboradora se poderia marcar consulta com o clínico geral. A colaboradora responde, secamente, que havia dia específico para marcar essa consulta e que ela deveria comparecer nessa data, apontando para o 
quadro de marcação de consultas. (Diário de campo, 01/03/07, Núcleo Monte Azul).

\subsubsection{SATISFAÇÃO/INSATISFAÇÃO DOS USUÁRIOS}

O ambulatório do Núcleo Monte Azul, de acordo com a enfermeira-obstetra, tornou-se um centro de referência, por conta dos bons serviços prestados e também em função da fundamentação antroposófica dos atendimentos. De fato, foi possível observar algumas pessoas falando a esse respeito:

Enquanto aguardo, na sala de espera, pela chegada de [uma das coordenadoras da área de saúde], começo a conversar com as pessoas que estavam ali aguardando atendimento - não havia muita gente. Algumas mulheres se diziam satisfeitas - "no posto de saúde é impossível! Perde-se um dia todo para ser atendido e, geralmente, a consulta é rápida e ruim. Aqui, pelo menos, não é assim". (Diário de campo, Núcleo Monte Azul, 15/02/07).

Mas também foi possível observar algumas pessoas insatisfeitas, quando ocorriam atrasos nos atendimentos:

Quando chego, sento-me em umas das cadeiras vazias, na sala de espera, perto de duas meninas já inquietas - elas me contam que estavam esperando há cerca de duas horas por sua vez de passar pelo dentista. (Diário de campo, Núcleo Monte Azul, 22/02/07).

Fico na sala de espera. As pessoas começam a reclamar do atraso. 11h a enfermeiraobstetra ainda estava envolvida com outras atividades. Quando subo - às $11 \mathrm{~h} 15$ para acompanhar o primeiro atendimento, a gestante comenta com a enfermeira que as pessoas estavam reclamando por conta da demora. A enfermeira justifica-se, dizendo que em outros serviços a espera é muito maior; e que até na rede privada existe atraso. A gestante diz que por ela tudo bem, já que costuma esperar cerca de duas horas no hospital X... (Diário de campo, Núcleo Monte Azul, 08/03/07). 


\subsubsection{NÚCLEO PEINHA}

O Núcleo Peinha fica do outro lado da Avenida João Dias, mais próximo da Marginal Pinheiros e um pouco mais distante do terminal urbano. De frente para uma grande avenida, a sensação de agitação não se esvai como no caminho para o Núcleo Monte Azul. Além disso, é fácil perceber que a favela já está ali - o morro se ergue a partir de uma rua, separada da avenida por uma ilha gramada, que serve de estacionamento para alguns carros. A entrada do Núcleo fica no pé do morro.

É por uma ruela que se entra na unidade Peinha. A primeira casa, à direita, abriga a creche e a escola; ao lado, uma biblioteca. Mais adiante, em frente, está o ambulatório, bem menor do que o da Monte Azul. Ao entrar, há uma sala de espera pequena com dois bancos compridos de madeira. Em uma pia, copos para beber água dividem a cena com um aviso convidando os usuários a lavá-los após o uso. À esquerda, há um banheiro, onde também ficam guardados alguns materiais. As paredes são azulejadas, e as peças descoladas foram recentemente consertadas. O piso está envelhecido. O que há de arte, parece improvisado. À esquerda da entrada do ambulatório fica a recepção, equipada com uma mesa e duas cadeiras; e duas salas de atendimento; na parte externa, mais duas salas de atendimento e uma cozinha.

Diferentemente do Núcleo Monte Azul, aqui, o movimento de pessoas sugere mais homogeneidade e integração entre elas. Além disso, em grande parte, elas são usuárias de outros serviços oferecidos pela Associação. Gestantes, com alguma frequência, falavam sobre outros filhos no berçário, ou na creche (Diário de campo, Núcleo Peinha, 15/03/07 e 14/06/07), ou mesmo mães que apareciam por conta de outros serviços - algum atendimento com a auxiliar de enfermagem, ou para marcar consulta em outra especialidade que não o prénatal - contavam ter passado por pré-natal ali e que agora tinham inscrito o filho no berçário da Associação (Diário de campo, Núcleo Peinha, 01/03/07 e 26/04/07). No Núcleo Monte Azul, embora a enfermeira tenha relatado alguns casos como esses, nenhum foi presenciado.

\footnotetext{
O movimento na sala de espera é grande. Enquanto esperam por sua vez de passar por atendimento, as mulheres conversam entre si. Percebo que algumas moram próximas, ou são vizinhas; perguntam umas para as outras como está o filho menor, que havia se machucado, ou a mãe, que estava doente. Algumas comentam sobre o filho que está no berçário, ou na creche da Associação. Interessadas, duas primíparas perguntam como proceder para conseguir uma vaga para o bebê que está vindo. (Diário de campo, Núcleo Peinha, 10/05/07).
} 
A sala, onde acontecem os atendimentos de pré-natal, é grande. A porta permanece aberta e a privacidade é garantida por um biombo. As janelas têm que ficar com as cortinas fechadas, pois as crianças, que brincam do lado de fora, divertem-se "espionando" os atendimentos.

\subsubsection{ESPECIALIDADES DO AMBULATÓRIO PEINHA}

Às quintas-feiras à tarde, aconteciam, apenas, atendimento pré-natal e fonoaudiológico no ambulatório do Núcleo Peinha. Ao final de 2007, o pré-natal deixou de ser ali oferecido, de acordo com uma coordenadora, por conta de duas razões: redução do número de gestantes à procura do serviço e custos de manutenção. Explicou a coordenadora que, em algumas ocasiões, a enfermeira-obstetra atendeu a uma ou a duas gestantes apenas. Citou relato de uma auxiliar, sobre uma redução no número de gestantes na comunidade, enfatizando, porém, que não estava claro ser essa a razão da baixa procura por atendimento. Somando-se a tal cenário os custos implicados na manutenção do serviço de pré-natal, decidiu-se não mais oferecê-lo, passando-se, então, a se encaminhar eventuais gestantes para o Núcleo Monte Azul; o que já acontecia em outras especialidades, como será descrito adiante.

Além dessas especialidades, há também, em outros horários, no Núcleo Peinha, atendimento odontológico, clínico-geral, pediátrico, psiquiátrico e psicológico. Os demais tipos de atendimento acontecem apenas no Núcleo Monte Azul.

\subsubsection{MARCAÇÃO DE CONSULTAS}

Segue os mesmos critérios do Núcleo Monte Azul. 


\subsubsection{RECEPÇÃO, PRÉ-ATENDIMENTO E CUIDADOS DE ENFERMAGEM}

Há, no Núcleo Peinha, apenas uma auxiliar de enfermagem que, quando não pode estar ali, conta com a ajuda de uma auxiliar do berçário. Ela é responsável por receber as pessoas, marcar consultas e organizar o ambulatório. Além das tarefas como auxiliar de enfermagem - realizar pré-consulta e demais procedimentos, tais como administrar inalação ou distribuir medicamento - ela tem ainda função de acompanhar os familiares dos pacientes.

Segundo relatos de uma colaboradora, essa auxiliar possui grande engajamento na comunidade Peinha. Com frequência, ela acompanha, mais intimamente, famílias em dificuldades. No ambulatório, em quase todas as visitas realizadas, observou-se o relacionamento próximo que ela estabelece com as gestantes. Telefona para convidá-las para uma palestra ou avisá-las de que a enfermeira, eventualmente, não poderá comparecer. Conhece detalhes da vida pessoal da maior parte das usuárias e, geralmente, conversa com elas sobre esses assuntos durante o pré-atendimento. Dificilmente não sabe o nome de alguma mulher em acompanhamento. É muito cuidadosa, atenciosa e amável.

\footnotetext{
Quando chego para assistir a palestra, vejo a auxiliar preparando, com esmero, o lanche a ser servido ao final. Ela diz: "é simples, mas foi feito com carinho". Ela arruma a sala, preocupada em acomodar bem as cadeiras. Ao falar com as gestantes, é afetiva e carinhosa. E apenas se tranquiliza quando vê todas as participantes para o grupo bem acomodadas. (Diário de campo, Núcleo Peinha, 01/03/07).

Chega uma mãe com uma criança para fazer inalação. Era para ela ter vindo na palestra [que aconteceu no período da manhã], mas não veio. A auxiliar diz: "tudo bem, eu sei que é difícil. Estava frio e ela [a bebê] é tão pequenininha...". A mãe responde: "eu falei que vinha... são minhas noites mal dormidas...". A auxiliar, carinhosa, diz: “eu sei”. (Diário de campo, Núcleo Peinha, 10/05/07).
}

\subsection{TRABALHO EM EQUIPE}

Segundo uma das coordenadoras da Associação, existe uma preocupação de capacitar todos os colaboradores e voluntários para as atividades lá realizadas. As reuniões que 
acontecem semanal e mensalmente são também voltadas a esse fim. Nessas ocasiões são, por exemplo, empreendidas discussões sobre aleitamento materno, o que permite, segundo a coordenadora, a uma colaboradora, varrendo a sala de espera, "deixar de lado a vassoura", sentar-se ao lado de uma mãe dando mamadeira a um bebê, e conversar com ela (Diário de campo, Núcleo Monte Azul, 22/03/07). De modo semelhante, uma colaboradora explica que, ao ser contratada, a pessoa é inserida na filosofia da Associação, para compreender a preocupação com o ser humano ali atendido e o tipo de cuidado que cerca o "serviço diferenciado" prestado, podendo, então, "receber as pessoas com esse cuidado" (Diário de campo, Núcleo Monte Azul, 19/04/07).

De fato, durante a experiência de reconhecimento de campo, embora não se tenha participado de tais reuniões, dados coletados atestam seu acontecimento. Às quintas-feiras pela manhã, compunha a rotina do ambulatório a reunião de metas; e ocasionalmente, reuniões da equipe de profissionais ligados ao serviço de pré-natal. Às quartas-feiras pela manhã, ocorriam reuniões entre a coordenadora do ambulatório e as auxiliares de enfermagem, e em datas diversas, reuniões de projetos específicos - como o da Casa de Parto, descrito adiante. Uma sexta-feira por mês, o ambulatório não funcionava, por conta do dia da integração. E se soube de grupos de estudos que envolviam, por exemplo, aqueles interessados em estudar Antroposofia. Ademais, observou-se espaços constituídos, durante a rotina de trabalho, voltados a trocas entre as profissionais acerca de assuntos concernentes à produção do cuidado pré e pós-natal, de casos atendidos, e de dificuldades vividas, fossem profissionais ou pessoais. Entretanto, pelo que indica o relato de uma colaboradora, nem sempre tais espaços garantiram um trabalho de equipe integrado:

\footnotetext{
“Agora está melhor. Além da boa integração com a fonoaudióloga, estou também em um bom relacionamento com as coordenadoras pedagógicas, o que torna o trabalho mais bem costurado. E isso é super importante. Eu acho, inclusive, que os três núcleos da Monte Azul precisam estar muito bem integrados, e as pessoas, falando a mesma linguagem". (Diário de campo, Núcleo Monte Azul, 22/03/07).
}

De todo modo, os trabalhos desenvolvidos na Associação, de acordo com uma coordenadora, são multidisciplinares; "ainda que não em um plano ideal, de transdisciplinaridade, existem". Para ela, parte da importância de tal característica reside na constituição, então possível, "de relações sólidas em torno do paciente, que o fazem ter 
confiança no serviço”. (Diário de campo, Núcleo Monte Azul, 22/03/07). De fato, como descrito adiante, a atenção ao pré-natal e ao puerpério é multidisciplinar e está inserida em um projeto - "Tecendo laços: Redes para o futuro" - que envolve uma série de profissionais e áreas.

Talvez, seja decorrência de conexões entre as diversas disciplinas e dos espaços de encontro, de troca e de reflexões então constituídos, a sintonia observada entre coordenadores e colaboradores; algo verbalizado por alguns deles como aspecto positivo no trabalho na Associação.

\footnotetext{
"O serviço prestado pela Associação é algo diferente. Aqui você percebe que todo mundo dá o melhor que pode e há sintonia entre as pessoas. Por isso, ainda que por vezes falte recurso, dá satisfação trabalhar aqui”. (Diário de campo, Núcleo Peinha, relato de uma coordenadora, 28/03/07).

"Às vezes eu estou aflita, cheia de problemas. Mas quando eu chego aqui, esqueço de tudo. Porque aqui tem harmonia entre as pessoas, tem olhos nos olhos, tem cuidado". (Diário de campo, Núcleo Peinha, relato de uma colaboradora, 26/04/07).

"Ah, aqui é diferente. Quando eu trabalhava no SUS era difícil, porque você nunca consegue fazer nada pelas pessoas. Aqui não é assim. Embora também existam regras e limites, você nota um esforço de todo mundo aqui para poder fazer o possível por quem nos procura. Para mim foi um alívio começar a trabalhar aqui”. (Diário de campo, Núcleo Monte Azul, relato de uma colaboradora, 03/05/07).
}

No geral, há consonância nos discursos de colaboradores e coordenadores. Por exemplo, uma coordenadora destacou que o trabalho realizado no pré-natal, muitas vezes é de conscientização e conforto, orientando a mulher para possibilitá-la a se responsabilizar pelo bebê que está sendo gerado (Diário de campo, Núcleo Monte Azul, 22/03/07). E esse é um dos focos no pré-natal dado pela enfermeira-obstetra, como visto mais adiante. Outra colaboradora classificou como algo fundamental o suporte, pois acredita no fato de que a gestante se sente bem quando é bem cuidada (Diário de campo, Núcleo Monte Azul, 22/03/07). Da mesma forma, uma coordenadora apontou que o acompanhamento pré-natal e as atividades educativas oferecem suporte para a mulher viver esse período (Diário de campo, Núcleo Peinha, 28/03/07). 


\subsection{ESPAÇOS DE CUIDADO AO PROFISSIONAL}

$\mathrm{Na}$ Associação, parece que também o profissional encontra espaços de escuta, de validação e de cuidado para as dificuldades que vive. Embora a investigação desse aspecto não tenha sido aprofundada, foi possível detectá-lo a partir de alguns dados de observação e de alguns relatos, como o de uma colaboradora sobre algumas profissionais estarem em psicoterapia no próprio ambulatório (Diário de campo, Núcleo Monte Azul, 01/03/07); ou nas menções a colaboradores em acompanhamento antroposófico no Núcleo por conta de vivências como ansiedade ou depressão (Diário de campo, Núcleo Monte Azul, 13/03/08; 03/04/08). Verificou-se momentos de trocas entre colaboradores acerca de dificuldades vividas, fossem essas pessoais ou profissionais (Diário de campo, Núcleo Monte Azul, 22/03/07; 13/03/08). E constatou-se a existência de espaço para solicitação de alguns dias de folga quando diante de uma sobrecarga de trabalho ou de vivências pessoais difíceis, conforme revelam os trechos abaixo:

\footnotetext{
“Está bem difícil. Estou bem cansada. É muita coisa, né? Mas a [diretora da área de saúde] já me disse para pegar uns dias de folga. Agora está um pouco complicado parar, porque tem umas coisas que eu preciso resolver [processos de trabalho] e é importante que isso possa ser resolvido logo. Mas assim que der uma aliviada nisso, vou sair uns dias sim! Estou precisando! (Diário de campo, Núcleo Monte Azul, relato de uma colaboradora, 13/08/08).

"Não, a [colaboradora] não está aqui. Ela saiu uns dias. Está com uns problemas pessoais, não estava muito bem...”. (Diário de campo, Núcleo Monte Azul, relato de uma colaboradora, 06/03/08).
}

\subsection{INVESTIMENTO NO PROFISSIONAL}

Além dos espaços de reuniões, grupo de estudos e de cuidado ao profissional, teve-se também notícias de participação de colaboradores do ambulatório em eventos externos, nas áreas de saúde e de educação (Diário de campo, Núcleo Monte Azul, 31/01/08 e 19/11/08).

Ademais, também se apreendeu experiências de aprimoramento e/ou aprendizagem de 
novos procedimentos. Na fase de observação de campo, houve contato com uma estudante alemã de medicina que viera ao Brasil para atuar na Associação durante o período de um ano. Sua função, no ambulatório do Núcleo Monte Azul, relacionava-se especialmente à aplicação de deslizamento. Em meio à sua rotina, ela passou a também ensinar tal técnica às auxiliares de enfermagem (Diário de campo, Núcleo Monte Azul, 13/03/08 e 03/04/08). Adicionalmente, uma colaboradora referiu, em depoimento, que algumas profissionais do ambulatório do Núcleo estavam se especializando em deslizamento para gestantes (Depoimento, Auxiliar de Enfermagem, 26/09/08).

\subsection{ATENÇÃO AO PRÉ-NATAL E AO PUERPÉRIO}

A atenção ao pré-natal e ao puerpério faz parte de um projeto amplo existente na Associação. Tal projeto, denominado "Tecendo Laços: Redes para o futuro", é voltado à formação de uma rede de proteção psicossocial ao redor da criança, envolvendo, para isso, diferentes frentes e profissionais. Ele integra, além do cuidado pré e pós-natal, um grupo de adolescentes - cujo foco é abordar a sexualidade, a afetividade e a preparação à futura paternidade - e cursos de capacitação para profissionais das áreas de educação e saúde (Depoimento, Coordenadora da área de saúde materno-infantil, 21/09/08).

No que concerne à atenção à gravidez e ao puerpério, de acordo com o depoimento de uma coordenadora, desde que a parteira Angela Gehrke deixara "de atender as mulheres de uma forma integral no pré-natal, no parto e no pós-parto", apenas o pré-natal era ofertado na Associação (Depoimento, Coordenadora da área de saúde materno-infantil, 21/09/08). A partir do projeto "Tecendo Laços", o serviço se ampliou, rumo, novamente, ao cuidado integral. À época do encerramento da coleta dos dados, integravam o serviço:

- Teste de gravidez;

- Consultas pré-natais;

- Suporte de terapias externas;

- Acompanhamento odontológico às gestantes;

- Grupo de trabalho corporal para gestantes e puérperas; 
- Ciclo de palestras: ciclo de encontros temáticos voltados a gestantes, puérperas, mulheres, companheiros e demais acompanhantes;

- Visitas domiciliares durante a gravidez e, especialmente, após o parto;

- Atenção ao puerpério;

- Posto de coleta de leite materno.

Além dessas atividades, ainda estavam sendo empreendidos esforços no sentido de melhor organizar ou concretizar: o programa odonto-bebê; a atenção ao parto; e a Bolsa-Bebê. O primeiro será descrito na seção acerca do acompanhamento odontológico, uma vez que, embora não estivesse ainda plenamente estruturado, algumas de suas atividades vinham sendo integradas ao serviço de odontologia já existente.

A oferta de atenção ao parto seria concretizada com a inauguração da Casa de Parto, cujas obras foram finalizadas em meados de 2007. O funcionamento da Casa, porém, dependia de parcerias, especialmente com a prefeitura - considerada de fundamental importância -, as quais, embora estivessem sendo negociadas já há algum tempo, até o encerramento da coleta dos dados - em novembro de 2008 -, ainda não haviam sido formalizadas. De todo modo, segundo uma coordenadora, a Casa de Parto abrangeria um cuidado mais amplo à mulher e à família. Toda a atenção ao pré-natal, ao parto e ao puerpério seria ali centralizada; e, especialmente esta última, seria estendida, acompanhando-se a família, por meio de atividades grupais e de consultas individuais, durante, ao menos, os seis primeiros meses após o parto - preferencialmente, porém, ao longo de todo o primeiro ano de vida do bebê (Depoimento, Coordenadora da área de saúde materno-infantil, 21/09/08).

A Bolsa-Bebê, por sua vez, de acordo com essa coordenadora, consiste em auxílio financeiro a mães que queiram se dedicar exclusivamente aos cuidados com o bebê por cerca de seis meses a um ano após o parto. Trata-se de um projeto já implementado na Associação, que havia rendido bons resultados, mas que, por ausência de recursos, teve de ser interrompido. Por meio do projeto "Tecendo Laços" pretendia-se retomá-lo a partir de novas parcerias e patrocínios (Depoimento, Coordenadora da área de saúde materno-infantil, 21/09/08).

As atividades do serviço de atenção ao pré-natal e ao puerpério da Associação que estavam em funcionamento à época da coleta de dados, serão descritas mais detalhadamente adiante. 


\subsubsection{ABRANGÊNCIA}

O cuidado pré e pós-natal oferecido pela Associação abrange gestação de baixo risco. Segundo uma colaboradora, quando detectada alguma complicação, a mulher é encaminhada para outro serviço, mantendo-se o atendimento paralelo na instituição, se aquela o desejar.

A área de abrangência da Associação Comunitária Monte Azul, inclui o bairro Jardim Monte Azul e a comunidade Monte Azul. O serviço recebe, porém, segundo relato de colaboradores, mulheres de diversas regiões, do município de São Paulo e também de outros, tais como Embu. Além disso, ele passou a ser referência para as mulheres do Núcleo Peinha, quando deixou de ser lá ofertado; e, desde fevereiro de 2008, também para as mulheres do Núcleo Horizonte Azul: consultas pré e pós-natais, voltadas a essas usuárias, passaram a ser realizadas às terças-feiras no Núcleo Monte Azul, pela mesma enfermeira responsável pelo serviço complementar antes prestado naquele Núcleo.

\subsubsection{VALORES COBRADOS}

As atividades que integram o serviço de atenção ao pré-natal e ao puerpério dos Núcleos são gratuitas. Entretanto, para quem tem possibilidade, especialmente no que concerne às consultas, é solicitada colaboração, na forma de taxa simbólica, de R \$ 5,00 ou R\$ 10,00, ou de doação de materiais de uso comum no ambulatório, como papel higiênico e copos descartáveis. De pessoas com condições sócioeconômicas mais favorecidas, segundo relato de colaboradores, espera-se uma contribuição um pouco maior. Em qualquer dos casos a colaboração é sempre voluntária e definida pelo usuário.

Os materiais para exames são coletados no ambulatório e processados em um laboratório parceiro da Associação; à exceção de ultrassonografias, realizadas em outro local, também conveniado. Essas parcerias, porém, não garantem gratuidade nos procedimentos apenas abatimento. Como no pré-natal os exames necessários são em grande número, na época da pesquisa, somavam em torno de R\$250,00. Por isso, na maior parte dos casos, as gestantes-usuárias recorrem à Rede SUS. 
Até meados de 2008, porém, com exceção da UBS da região de abrangência do Núcleo Peinha, as demais não estavam aceitando pedidos de exames emitidos na Associação. Em decorrência, as mulheres tinham de se submeter a um segundo pré-natal, na UBS, para, assim, ter direito à realização de exames na Rede SUS; salvo em alguns casos, quando encontravam alternativas tais como um encaixe com o ginecologista do posto de saúde que, então, emitia novo pedido.

Segundo a auxiliar de enfermagem, essas circunstâncias evidenciavam a importância de parceria com a UBS, o que a levou a integrar em suas atividades visitas aos postos de saúde da região, para apresentar o trabalho realizado na Associação (Depoimento, Auxiliar de Enfermagem, 26/09/08). Em meio a tal iniciativa, houve mudança de gestão na UBS de referência da área de abrangência do Núcleo Monte Azul, o que criou um campo mais amistoso de relações entre os dois serviços. A partir de então, essa UBS passou a aceitar pedidos de exames emitidos pelas enfermeiras-obstetras do Núcleo e, assim, deixou de ser necessário às mulheres que a frequentavam se submeterem a dois acompanhamentos prénatais (Diário de campo, Núcleo Monte Azul, 13/08/08).

\subsubsection{PARCERIAS ENTRE O NÚCLEO MONTE AZUL E O SUS}

A realização de exames passou a ser mais garantida no Núcleo Monte Azul a partir da formalização de parceria com a UBS de referência da região. De modo semelhante, ao final de 2008, estava-se sedimentando parceria com o PSF, para cobrir deficiências na divulgação do serviço entre as moradoras da área de abrangência do Núcleo Monte Azul. Esperava-se, especialmente a partir de informações providas pelos agentes comunitários de saúde (ACSs), obter mais conhecimento sobre aquela população e, particularmente, sobre a presença de gestantes ali (Depoimento, Coordenadora do Ambulatório, 19/11/08). Os ACSs, por sua vez, estavam começando a solicitar à auxiliar de enfermagem que eles empreendessem algumas visitas domiciliares em conjunto, pois o trabalho dela ganhava cada vez mais repercussão entre as mulheres, que manifestavam preferência de serem por ela acompanhadas (Depoimento, Auxiliar de Enfermagem, 26/09/08).

Outro exemplo de parceria, mas em direção inversa, é o acompanhamento 
odontológico de gestantes oferecido pelo Núcleo que começava, por volta de setembro de 2008, a se estabelecer como referência na região, de modo que as UBSs principiavam, então, a encaminharem-lhe gestantes. (Depoimento, Dentista, 15/09/08). Além disso, os postos de saúde também divulgavam o ciclo de palestras, e o Núcleo recebia, então, mulheres atendidas naqueles serviços interessadas em participar de tais atividades.

\subsubsection{CICLO DE PALESTRAS}

Em $1^{\text {o }}$ de março de 2007, nos ambulatórios dos Núcleos Monte Azul e Peinha, teve início um ciclo de palestras para gestantes, que integrava um projeto patrocinado pela Pepsico $^{24}$. Os seguintes temas foram abarcados:

- Aspectos físicos, emocionais e psicológicos da gravidez

- Evolução da gravidez: pré-natal e pré-parto

- Aleitamento materno e dieta alimentar

- Amamentação na Odontologia e na Fonoaudiologia

- Pós-parto e cuidados com o bebê

- Métodos contraceptivos, planejamento familiar e doenças sexualmente transmissíveis

Cada ciclo era composto das seis palestras, reiniciando-se ao final. Foram três ciclos de palestras ao longo de 2007. O projeto já existia no Núcleo Horizonte Azul, com bons resultados, segundo uma coordenadora. Implantado nos Núcleos Monte Azul e Peinha, as palestras tinham datas e horários específicos para cada um dos Núcleos. No início houve dificuldade de implantação do projeto, pois em dadas ocasiões, não havia participantes para as palestras, inviabilizando a realização de algumas delas.

\footnotetext{
Chego cedo para assistir a palestra no Núcleo Monte Azul, mas ninguém havia comparecido para a mesma. A enfermeira refere que possivelmente havia algo em torno da questão do horário - "a maior parte das gestantes não gosta de acordar cedo. Acrescente-se a isso o fato de muitas morarem longe, terem que pegar condução...”. (Diário de campo, Núcleo Monte Azul, 15/03/07).
}

24 Empresa de produtos de consumo nas áreas de alimentos e bebidas que, no Brasil, comercializa marcas como Elma Chips, Pepsi, Quaker e Coqueiro. 
Vou, em uma quarta-feira, à Peinha para poder assistir à palestra de Aleitamento materno e dieta alimentar. Mas ninguém apareceu (Diário de campo, Núcleo Peinha, 28/03/07).

No Núcleo Peinha, observou-se, durante o primeiro ciclo, que, quando as palestras aconteciam no período da tarde, antes do pré-natal, contavam com maior número de gestantes participantes. De todo modo, segundo relatos de colaboradores, após algum tempo as usuárias começaram a participar mais, em ambos os Núcleos.

Acompanhou-se três dessas palestras: uma sobre os aspectos físicos, emocionais e psicológicos da gravidez; uma sobre evolução da gravidez: pré-natal e pós-parto; e outra sobre aleitamento materno, cuidados odontológicos e fonoaudiologia. O tom era informativo e as palestras se desenvolviam por meio de bate-papo com as gestantes. Nas duas primeiras, ministradas pela enfermeira-obstetra que realiza o pré-natal, também foram praticados exercícios físicos. Em duas das palestras observou-se a participação de acompanhantes (Diário de campo, Núcleo Peinha, 01/03/07; Núcleo Monte Azul, 13/07/07); e em outra, mulheres da comunidade também compareceram (Diário de campo, Núcleo Peinha, 01/03/07). Ao final, sempre era oferecido um lanche.

Segundo uma coordenadora, essas atividades são de fundamental importância, uma vez que propiciam informação e, portanto, educação (Diário de campo, Núcleo Peinha, 28/03/07). Outra disse observar que, após o parto, muitas mulheres se assustam com o bebê e se esquecem de metade das informações recebidas durante o pré-natal. Entretanto, ainda que o trabalho possa parecer, por isso, improfícuo, no retorno da mulher, por ocasião de uma segunda gravidez, percebe-se, segundo a coordenadora, que ficou algum registro. De qualquer forma, para ela, o mais importante é o suporte que o pré-natal e tais atividades oferecem; o que ajuda a mulher a enfrentar as dificuldades encontradas pelo caminho (Diário de campo, Núcleo Monte Azul, 22/03/07).

Em fevereiro de 2008, um novo ciclo de palestras, reformulado, foi iniciado. Adotouse novo formato, mais próximo daquele do Núcleo Horizonte Azul - palestra, lanche, oficina. E foram integrados novos temas. A seguir, a programação de 2008. 
Tabela 6 - Programação do ciclo de palestras em 2008

\begin{tabular}{lll}
\hline Data & \multicolumn{1}{c}{ Tema } & \multicolumn{1}{c}{ Oficina } \\
\hline $08 / 02$ & Corpo da mulher & Dança circular \\
$05 / 03$ & Gravidez: Tempo de novas vivências & Bem-estar \\
$02 / 04$ & Meu filho: A relação entre mãe, pai e bebê & Bonecas \\
$07 / 05$ & Parto e nascimento & Bonecas \\
$04 / 06$ & Pós-Parto: Cuidados com a mãe e com o bebê & Canções \\
$02 / 07$ & Aleitamento materno: Nutrindo o corpo e a alma & Canto e massagem \\
$06 / 08$ & Planejando a família: Responsabilidade do casal & Artesanato \\
$03 / 09$ & Cuidando do desenvolvimento da criança de 0 a 3 & Brincadeiras \\
& anos & Fabricação de \\
$01 / 10$ & Brincar: A atividade mais séria da criança & brinquedos \\
$05 / 11$ & Alimentação para crianças a partir do sexto mês & Receitas \\
\hline
\end{tabular}

Com exceção do primeiro encontro, havido em uma sexta-feira, todos os demais aconteceram na primeira quarta-feira do mês, entre $9 \mathrm{~h}$ e $11 \mathrm{~h}$, na Casa de Parto, próxima ao Núcleo Monte Azul - que, embora ainda não estivesse em funcionamento, estava sendo utilizada para encontros grupais, tais como as palestras e o trabalho corporal. Eram voltados às usuárias e aos seus acompanhantes, dos Núcleos Monte Azul e Peinha - uma vez que o Núcleo Horizonte Azul contava com programação própria - e às demais mulheres da comunidade que quisessem participar. Antes de cada encontro, a auxiliar de enfermagem ligava para as usuárias convidando-as. No final de 2008, segundo depoimento de uma coordenadora, o grupo contava com aproximadamente 25 mulheres.

Cabe salientar que, a despeito de existir um cronograma de palestras, o objetivo é que a mulher continue a participar dos encontros mesmo após o fechamento de um ciclo. Da mesma forma, embora se espere que ela o inicie durante a gravidez, visa-se a que, mesmo findo o puerpério, ela ainda o frequente. O espaço então constituído volta-se não apenas ao provimento de informações e de orientações mas, especialmente, à troca de experiências, entre mulheres, acompanhantes e profissionais, e ao convívio. Assim, torna-se também um 
espaço privilegiado de construção e/ou fortalecimento de vínculos entre esses sujeitos. Ademais, ao enfocar mulheres, e não apenas gestantes, garante um espaço de cuidado às usuárias findo o acompanhamento puerperal.

Talvez pela amplitude de tal proposta, tenha-se apreendido, entre as profissionais, diferentes nomes atribuídos a esses encontros, a saber, "grupo de gestantes", "grupo de mulheres", e "grupo de pais" - sendo este apenas raramente empregado. Tais nomes parecem sugerir que, embora se entenda e encoraje que os parceiros também participem dos grupos, a ênfase recai sobre a mulher, então considerada a protagonista.

\subsubsection{GRUPO DE TRABALHO CORPORAL}

O grupo de trabalho corporal, conduzido por uma fisioterapeuta, tem suas atividades conciliadas com os encontros do ciclo de palestras: acontece às quarta-feiras, às $11 \mathrm{~h}$, na Casa Angela, com exceção de uma quarta-feira por mês, quando se dá, então, o encontro do ciclo. A despeito de ser principalmente voltado às gestantes, como se nota pelo relato da fisioterapeuta, é também aberto às puérperas. Com sessões de cerca de uma hora, o trabalho, segundo a fisioterapeuta, objetiva ampliar a consciência corporal a partir de exercícios respiratórios e posturais; trabalhar o sistema circulatório, principalmente para prevenção de inchaços, queixa recorrente do período da gravidez; e oferecer orientações que propiciem aplicar o vivido no grupo ao cotidiano. Dentre os benefícios secundários do trabalho, a profissional destaca o fortalecimento das pernas para "carregar durante 9 meses essa barriga que está cada vez maior"; e dos braços, que terão de, após o parto, "sustentar o bebê". Ademais, salienta a fisioterapeuta, embora o grupo não tenha como foco o compartilhamento de experiências, as mulheres constantemente expressam suas vivências, "às vezes, até mais íntimas. Por isso, abre-se às vezes um pouco dessa discussão de aconselhamento"(Depoimento, Fisioterapeuta, 10/09/08). 


\subsubsection{ACOMPANHAMENTO ODONTOLÓGICO}

O acompanhamento odontológico exclusivo para gestantes se dá mensalmente, às segundas-feiras, no Núcleo Monte Azul. Segundo depoimento da dentista, essa atividade inicia-se com uma avaliação e, se necessário, passa-se ao tratamento. Além disso, empreendese ações preventivas, tais como higienização e orientações; e proporciona-se espaço de escuta àquilo que a mulher queira compartilhar. Em setembro de 2008, de acordo com a profissional, foram atendidas entre 6 e 8 gestantes. Ademais, como já destacado, o serviço estava se tornando referência na região, em atendimento odontológico de gestantes, e estava começando a receber mulheres que não as do pré-natal do Núcleo (Depoimento, Dentista, 15/09/08). Vale lembrar que tal atendimento consta dos parâmetros definidos pelo MS à atenção ao pré-natal (BRASIL, 2006b).

O programa odonto-bebê, de acordo com informações da dentista, seria desenvolvido especialmente a partir de grupos de mães, nos quais se abordaria temas como a importância da amamentação para o bom desenvolvimento dos maxilares e dentes, boa mastigação e adequado funcionamento do aparelho respiratório; cuidados com a boca do bebê desde o nascimento; e desencorajamento do uso de chupeta (Depoimento, Dentista, 15/09/08).

Uma vez que os grupos ainda não haviam sido constituídos, a dentista relata em depoimento, que vinha se valendo, mais especialmente, de duas oportunidades para oferecer as orientações: eventualmente, o dia de pré-natal, quando reunia um grupo de mulheres após as consultas, e, mais frequentemente, o ciclo de palestras. (Depoimento, Dentista, 15/09/08).

\subsubsection{SUPORTE DE TERAPIAS EXTERNAS}

As terapias externas, embora não voltadas apenas à atenção ao pré-natal e ao puerpério, integram-se a esse serviço, como modo de ampliar a integralidade do cuidado. A esse respeito, especial destaque foi dado ao deslizamento - uma espécie de massagem - e ao escalda-pés. Segundo uma colaboradora, as auxiliares de enfermagem estavam se especializando em deslizamento para gestantes, técnica que além de atuar como suporte no 
tratamento de complicações experienciadas durante a gravidez e o puerpério, mostra-se útil à promoção da elaboração de vivências emocionais, e da vinculação da gestante com a equipe algo especialmente proporcionado pelo "toque" (Depoimento, Auxiliar de Enfermagem, 26/09/08). O escalda-pés, por sua vez, foi mencionado por uma usuária, que relatou benefícios às intercorrências vividas na gravidez a partir de aplicações dessa terapia (Depoimento, Sofia, 14/02/08 e 14/11/08). Ademais, referências ao recebimento de massagens foram feitas por algumas mulheres (Depoimento, Carolina, 31/01/08; Sofia, 14/02/08).

\subsubsection{A ATENÇÃO PRÉ-NATAL}

\subsubsection{REALIZAÇÃO DE TESTE DE GRAVIDEZ}

Segundo uma auxiliar de enfermagem, o teste de gravidez é o primeiro passo no serviço de pré-natal. Uma vez constatado resultado positivo, a gestante é orientada sobre a importância de fazer o acompanhamento pré-natal e, nesse ato, apresenta-se a ela a atenção provida pelo Núcleo Monte Azul. Caso a mulher manifeste interesse, uma primeira consulta já é marcada (Depoimento, Auxiliar de Enfermagem, 26/09/08).

Relata também aquela profissional a demanda de se escutar e acolher a mulher nesse momento de descoberta de uma gravidez, o qual é permeado por reações diversas. Ademais, trata-se de conduta que também contribui para o início de um estabelecimento de vínculo e, em decorrência, de adesão ao pré-natal:

“Constatando o teste de gravidez, é falado sobre o pré-natal que existe aqui no ambulatório. [...] tem aquela que quer muito [o bebê] e já sai com a consulta de prénatal marcada. E tem aquela [...] [que se abala com a notícia]. E você tem que respeitar. [...] Mas muitas vezes não adianta. Você tem que conversar e às vezes as coisas depois vão acontecendo. Mas depois ela volta. Por quê? Porque o primeiro atendimento foi legal". (Depoimento, Auxiliar de Enfermagem, 26/09/08). 


\subsubsection{VISITAS DOMICILIARES}

Durante o pré-natal, eventualmente, a auxiliar de enfermagem, que acompanha as gestantes e puérperas, pode fazer visita domiciliar àquela que esteja experimentando dificuldades de se dirigir ao ambulatório e/ou que solicite a visita. Tal visita não substitui, porém, a consulta pré-natal, pois se trata apenas de suporte para avaliar a condição da mulher, fornecer orientações necessárias, oferecer acolhimento e reforçar o vínculo e a adesão ao prénatal. Ademais, não se trata de procedimento padrão - como se dá no puerpério, tal qual se descreve mais adiante (Depoimento, Auxiliar de Enfermagem, 26/09/08).

\subsubsection{CARACTERIZAÇÃO DAS GESTANTES ATENDIDAS NOS NÚCLEOS MONTE AZUL E PEINHA E DO SERVIÇO PRESTADO}

Antes de prosseguir com a descrição dos demais aspectos concernentes à atenção prénatal, considerou-se oportuno apresentar os dados obtidos pelos cartões das gestantes, que fornecem uma caracterização da clientela atendida e do serviço prestado - especialmente no que diz respeito às consultas pré-natais.

Duas tabelas, a partir desses dados, foram montadas - uma para cada Núcleo. Para efetuar a descrição e a análise dos dados nelas contidos, optou-se por trabalhar com valores percentuais relativos aproximados - considerados propícios para melhor identificação do cenário que evidenciam, por serem grandezas comparáveis - e com gráficos que permitam fácil visualização. Toda a população que estava sendo atendida, ou que havia finalizado prénatal no serviço em pauta, à época da coleta dos dados, foi incluída no levantamento, razão pela qual, acredita-se, tais dados revelem como o serviço estava constituído naquele período. 
Tabela 7 - Caracterização da clientela e do serviço de atenção ao pré-natal do Núcleo Monte Azul.

\begin{tabular}{|c|c|c|c|c|c|c|c|c|c|c|c|}
\hline & Idade & Gestação & MGPC (semanas) & NTC & C 1T & C 2T & C 3T & MGUC (semanas) & Histórico de Parto & Observações & Residência \\
\hline 1 & 28 & $7 a$. & 20 & 12 & 0 & 6 & 6 & 35 & PN, SE & & Jd. Monte Azul \\
\hline 2 & 25 & $3 a$. & 13 & 9 & 1 & 3 & 5 & 38 & Não consta & & Embu \\
\hline 3 & 28 & 1a. & 6 & 9 & 2 & 5 & 2 & 36 & Não consta & APC & Jd. Monte Azul \\
\hline 4 & 26 & $3 a$. & 16 & 4 & 0 & 2 & 2 & 35 & Não consta & & Jd. Vista Alegre \\
\hline 5 & 25 & $2 a$. & 7 & $7 *$ & 3 & 4 & - & 25 & Não consta & Mudou-se & Jd. Monte Azul \\
\hline 6 & 16 & $1 \mathrm{a}$. & 13 & 6 & 1 & 3 & 2 & 31 & Não consta & AP UBS. EUBS & Jd. Monte Azul \\
\hline 7 & 18 & 1a. & 21 & $7 *$ & 0 & 4 & 3 & & Em acompanhamento & & Paraisópolis \\
\hline 8 & 38 & $4 a$. & 25 & 1 & 0 & 1 & - & 25 & & EUBS & Jd. Itaóca \\
\hline 9 & 14 & $1 \mathrm{a}$. & 6 & $8^{*}$ & 2 & 6 & & & Em acompanhamento & & Jd. Casablanca \\
\hline 10 & 35 & $4 a$. & 16 & 1 & 0 & 1 & - & 16 & & & Jd. Capelinha \\
\hline 11 & 23 & $3 a$. & 13 & 1 & 0 & 1 & - & 13 & & & Jd. Monte Azul \\
\hline 12 & 19 & $4 a$. & 19 & 1 & 0 & 1 & - & 19 & & EUBS & Jd. Monte Azul \\
\hline 13 & 33 & $5 a$. & 7 & $1^{*}$ & 1 & & & & Em acompanhamento & & Jd. Casablanca \\
\hline 14 & 24 & $1 \mathrm{a}$. & 7 & $1 *$ & 1 & & & & Em acompanhamento & & Jd. Sto Antonio \\
\hline 15 & 18 & $1 \mathrm{a}$. & 16 & 6 & 0 & 2 & 4 & 39 & Não consta & & Jd. Monte Azul \\
\hline 16 & 21 & $2 a$. & 23 & $9 *$ & 0 & 3 & 6 & & Em acompanhamento & AUBS & Jd. Monte Azul \\
\hline 17 & 27 & 1a. & 10 & $3 *$ & 2 & 1 & & & Em acompanhamento & & Jd. Mirante \\
\hline
\end{tabular}

\section{Legendas}

- MGPC: Momento gestacional de realização da primeira consulta pré-natal

- NTC: Número total de consultas pré-natais

- *: Número de consultas no momento em que se deu o levantamento

- C 1T: Total de consultas pré-natais realizadas durante o primeiro trimestre de gravidez

- C 2T: Total de consultas pré-natais realizadas durante o segundo trimestre de gravidez

- C 3T: Total de consultas pré-natais realizadas durante o terceiro trimestre de gravidez

- MGUC: Momento gestacional de realização da última consulta pré-natal

- PN: Parto normal

- SE: sem episiotomia

- APC: Acompanhamento paralelo em Rede Conveniada

- AP UBS: Acompanhamento paralelo em UBS

- EUBS: Gestante encaminhada para realização de pré-natal na UBS

- AUBS: Estava realizando pré-natal na UBS antes de procurar pelo ambulatório do Núcleo 


\subsection{Núcleo Monte Azul}

Um dos primeiros dados que se pode extrair da tabela, refere-se à faixa etária da população atendida no serviço de pré-natal do Núcleo Monte Azul. Nota-se que 29,41\% das mulheres eram adolescentes, 58,82\% tinham entre 20 e 34 anos e $11,77 \%$ estavam na faixa acima dos 35 anos (Gráfico 1). Quanto à paridade, 41,19\% estavam na primeira gravidez; $11,76 \%$ na segunda; $17,64 \%$ na terceira; $17,64 \%$ na quarta; $5,88 \%$ na quinta; e $5,88 \%$ na sétima (Gráfico 2).

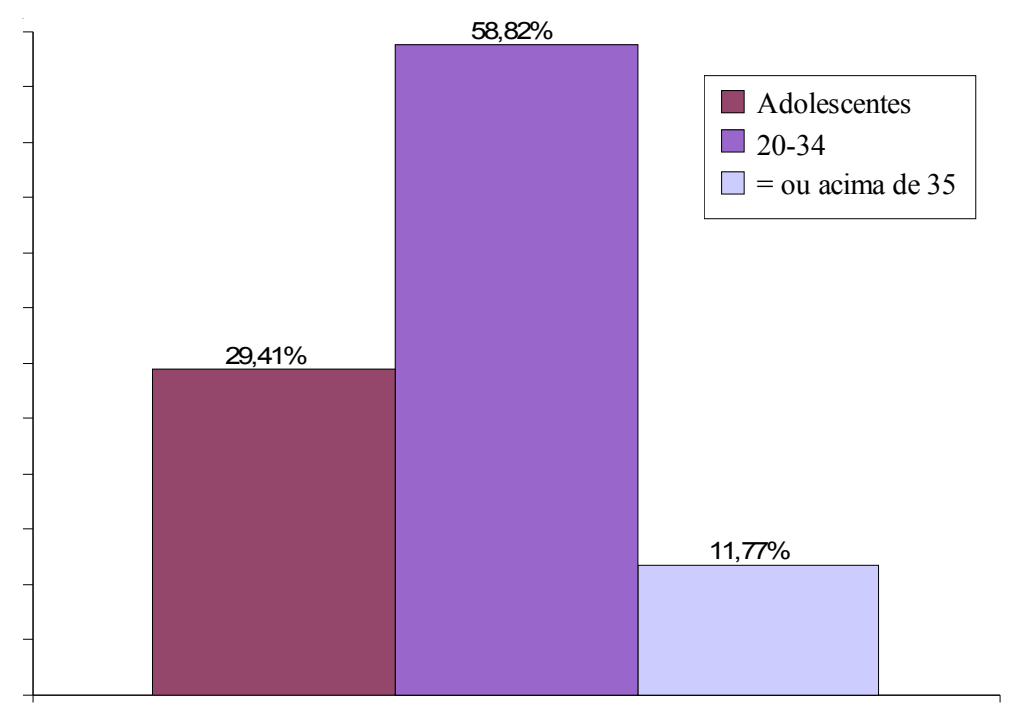

Gráfico 1 - Faixa etária 


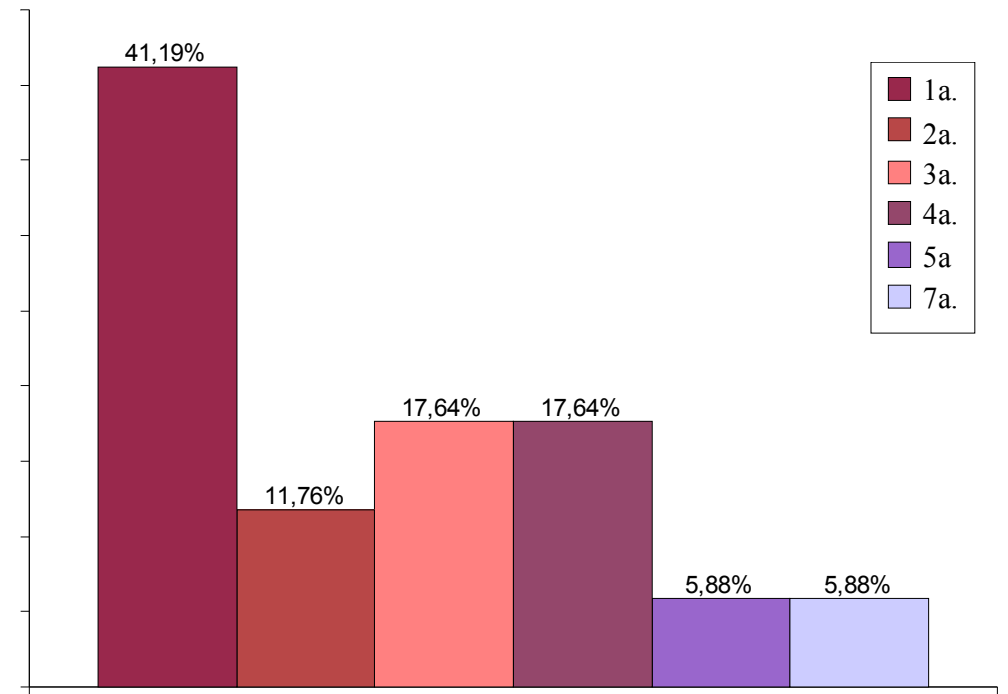

Gráfico 2 - Paridade

No que se diz respeito ao local de residência, observa-se que o grupo de mulheres residentes no Jardim Monte Azul, área de abrangência do ambulatório Monte Azul, é expressivamente maior do que os demais. $11,77 \%$ das usuárias residiam no Jardim Casablanca. As restantes dividiram-se de maneira homogênea entre os outros bairros identificados no levantamento (Gráfico 3).

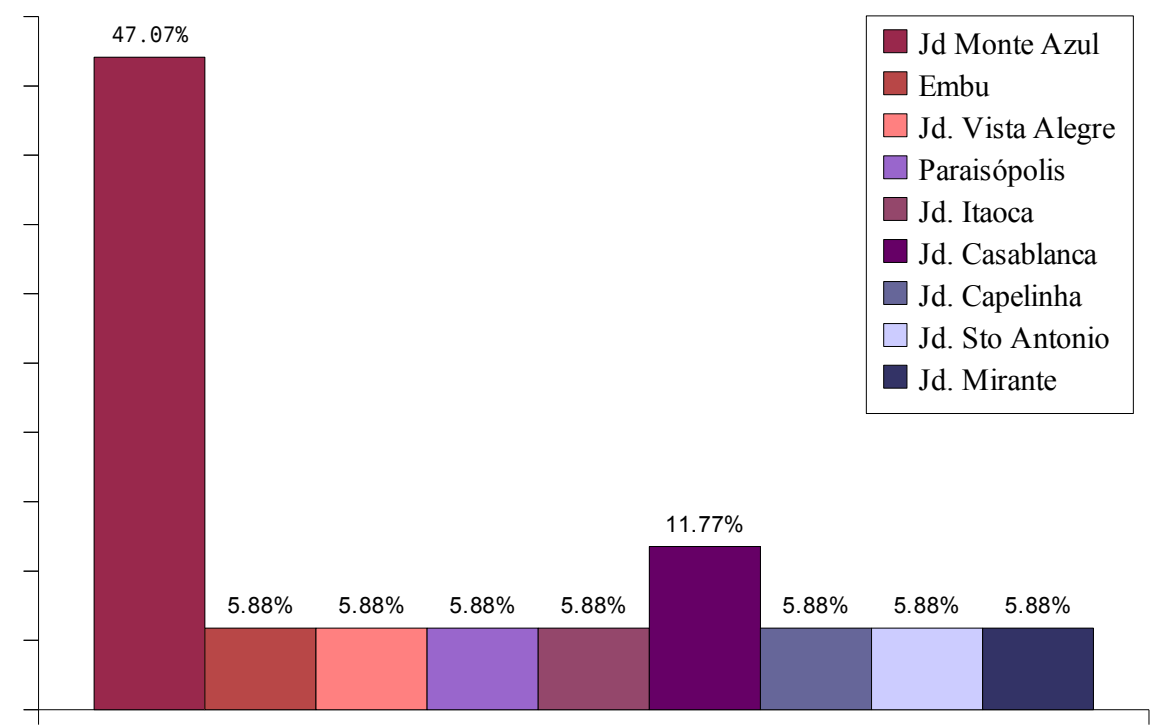

Gráfico 3 - Local de residência 
É importante, para melhor explicitar a distância entre o Núcleo Monte Azul e os bairros que constam no Gráfico 3, situá-los por aproximação. O Jardim Monte Azul e o Jardim Mirante abrangem a mesma região; isto significa que, na verdade, $52,95 \%$ das mulheres residiam na área de abrangência do serviço. No Jardim Santo Antônio está a comunidade Peinha, área de abrangência de outro Núcleo da Associação - o Núcleo Peinha. O Jardim Casablanca localiza-se razoavelmente próximo ao Jardim Monte Azul. Jardim Itaóca, Jardim Capelinha e Paraisópolis estão um pouco mais distantes do Núcleo Monte Azul. O município de Embu e o bairro Jardim Vista Alegre - este situado na zona norte da cidade de São Paulo - podem ser enquadrados na categoria de muito distantes. A seguir, alguns mapas, em escalas diferenciadas, que melhor ilustram essa configuração geográfica. 


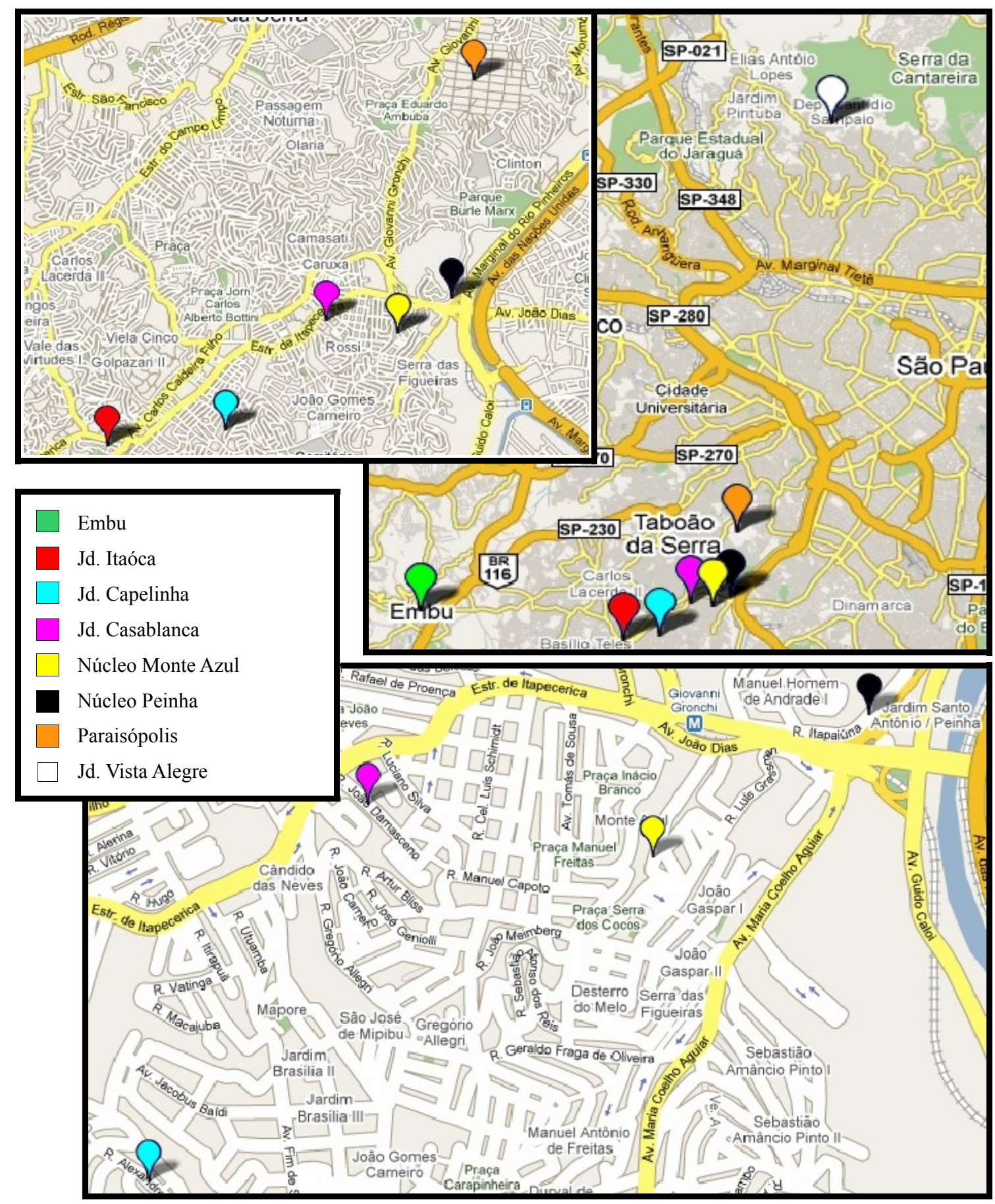

Mapa 1 - Localização do Núcleo Monte Azul e das residências das usuárias do ambulatório do núcleo

Ainda com relação à residência, é importante notar que mais de 50\% das mulheresusuárias do serviço de pré-natal do Núcleo Monte Azul não eram de sua área de abrangência, o que parece atestar que o serviço se constitui, de fato, referência de qualidade - tal como 
pontuado por colaboradores -, especialmente se vistos os casos de deslocamento geográfico mais amplo.

De modo a avaliar o serviço a partir de alguns dos parâmetros à atenção à gestação definidos pelo MS (BRASIL, 2006b), um primeiro dado a ser destacado refere-se ao momento de realização da primeira consulta pré-natal: $52,94 \%$ das mulheres o fizeram durante o primeiro trimestre gestacional e 47,06\% no segundo (Gráfico 4). Não houve, nesse Núcleo, nenhum caso em que o pré-natal foi iniciado apenas no terceiro trimestre. Das mulheres que realizaram a primeira consulta no segundo trimestre, $12,5 \%$ iniciaram o prénatal, anteriormente, na UBS. Há indícios, entretanto, de que nem sempre esse dado foi registrado no cartão da gestante: durante o período de acompanhamento das consultas observou-se um caso, cujo cartão não continha registro a esse respeito, em que a mulher, ao chegar para a primeira consulta no Núcleo, relatou que estava, até então, em pré-natal na UBS (Diário de campo, Núcleo Monte Azul, 15/02/07).

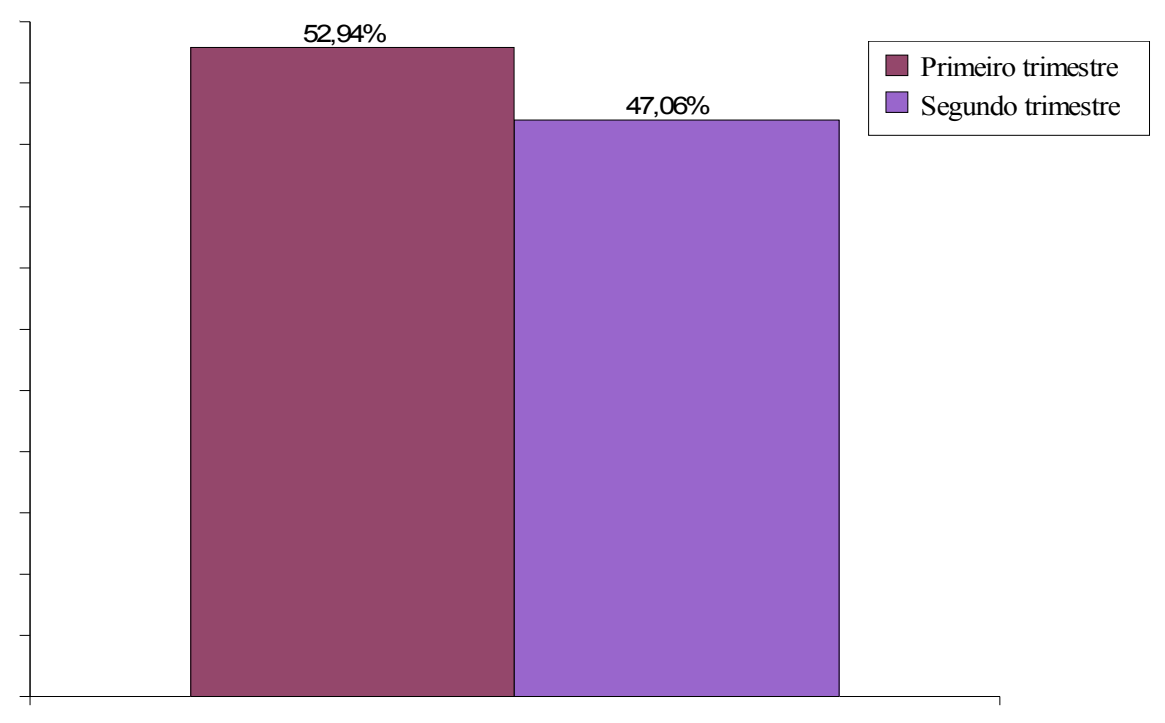

Gráfico 4 - Início do pré-natal

Segundo os parâmetros definidos pelo MS, as gestantes devem se submeter, pelo menos, a seis consultas durante o período gestacional. A distribuição dessas consultas ao longo dos trimestres gestacionais, preferencialmente, deve atender o seguinte critério: uma no primeiro trimestre, duas no segundo e três no terceiro (BRASIL, 2006b). No Núcleo Monte Azul, considerada essa orientação, 52,94\% das mulheres se enquadravam nos parâmetros 
para o primeiro trimestre. Dentre as demais (47,06\%), sabe-se que $12,5 \%$ estavam, anteriormente, em acompanhamento na UBS (Gráfico 4).

Quanto ao segundo trimestre, observa-se, a partir dos dados da tabela, que sobre 3 dentre as 17 mulheres que compuseram a amostra nada se pode afirmar, uma vez que, apesar de, até então, não terem cumprido a meta de realização de ao menos duas consultas no período, tinham, ainda, possibilidade de atingi-la. Dentre as demais 14, nota-se pelo Gráfico 5, que $71,44 \%$ cumpriram a meta; $14,28 \%$ não o fizeram; e 14,28\% haviam sido encaminhadas para a UBS.

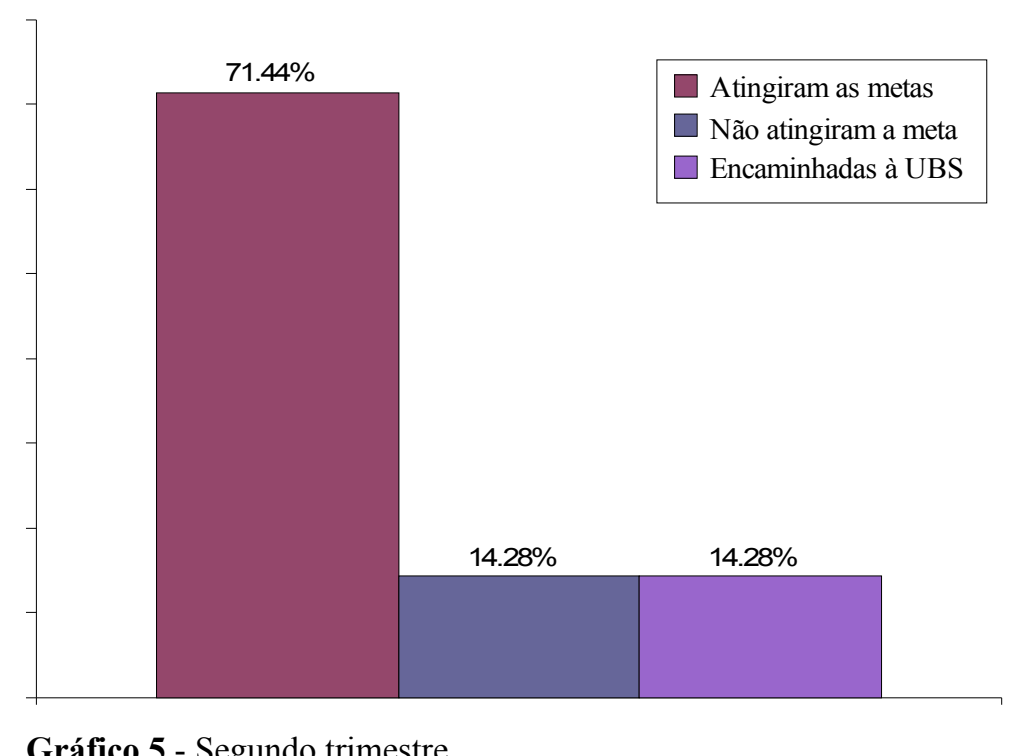

Gráfico 5 - Segundo trimestre

Para análise do terceiro trimestre, foi desconsiderado o caso da usuária que se mudou. Dentre as demais 16 mulheres, observa-se que sobre 8 nada se pode afirmar, uma vez que, embora ainda não houvessem realizado o mínimo de três consultas pré-natais no período em questão, havia-lhes, ainda, a possibilidade de completá-las. Em 2 de tais casos, porém, a probabilidade de não o terem feito não é desprezível, pois, à época da coleta dos dados, as usuárias estavam já com cerca de 40 semanas gestacionais, não havendo, portanto, muito tempo hábil à realização de novas consultas. Assim, dentre as demais 8 mulheres, nota-se, pelo Gráfico 6, que 62,5\% cumpriram o parâmetro definido pelo MS para o terceiro trimestre, e $37,5 \%$ haviam sido encaminhadas para a UBS. Não houve, portanto, a partir dos dados então disponíveis, casos de não cumprimento da meta para o período. 


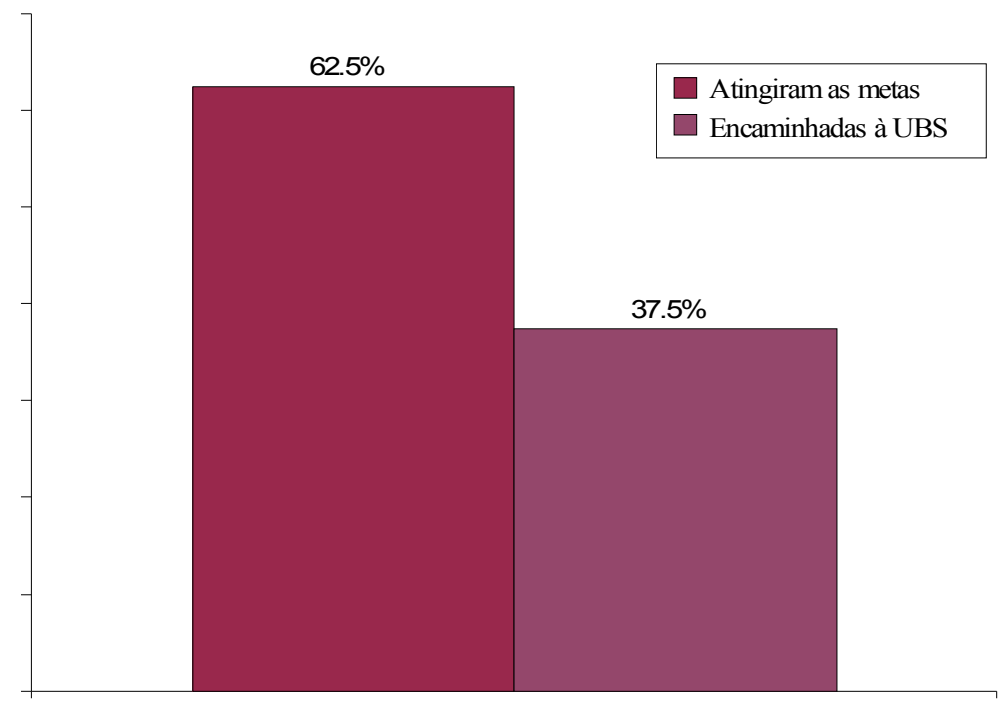

Gráfico 6 - Terceiro trimestre

No que concerne aos parâmetros definidos pelo MS para os três trimestres gestacionais, verifica-se que apenas sobre 5 mulheres, dentre as 17 que compuseram a amostra, pode-se afirmar algo. Daquelas, somente $20 \%$ (o equivalente a 1 caso) cumpriram os parâmetros em questão. Quanto à média de consultas realizadas por essas usuárias, tem-se um valor igual ou maior do que 8,6 - dado que uma das gestantes não havia ainda finalizado o acompanhamento pré-natal e, por essa razão, poderia realizar mais consultas.

Um dado também possível de ser extraído da tabela é o de que 2 usuárias estavam com acompanhamento paralelo em outra instituição - seja em UBS ou na rede conveniada. Dessas, 1 foi encaminhada para UBS, de modo a lá fixar o pré-natal. Acredita-se, porém, que tal dado não seja fidedigno, pois, na época da coleta dos dados, era ainda corriqueira a submissão das mulheres a um segundo pré-natal na UBS para acesso à realização de exames. Possivelmente, portanto, houve falhas no registro de tais informações em cartão de gestante.

Por fim, ressalta-se que apenas no cartão de uma mulher, dentre as que finalizaram acompanhamento pré-natal no Núcleo Monte Azul, encontrou-se registros acerca de histórico de parto. Embora, como já mencionado, prováveis falhas de registros nos cartões das gestantes tenham sido observadas, a hipótese de que, de fato, havia um baixo índice de realização de consulta puerperal no Núcleo, é bastante razoável. 
Tabela 8 - Caracterização da clientela e do serviço de atenção ao pré-natal do Núcleo Peinha.

\begin{tabular}{|c|c|c|c|c|c|c|c|c|c|c|c|}
\hline & Idade & Gestação & MGPC (semanas) & NTC & C 1T & C 2T & C 3T & MGUC & Histórico de Parto & Observações & Residência \\
\hline 1 & 38 & $2 a$. & 8 & $4^{*}$ & 2 & 2 & & & Em acompanhamento & & Peinha \\
\hline 2 & 22 & 3a. & 9 & $2 *$ & 2 & & & & Em acompanhamento & & Jd. Recanto do Morumbi \\
\hline 3 & 37 & 3a. & 10 & 8 & 1 & 3 & 4 & 43 & Não consta & & Jd. Sto Antônio \\
\hline 4 & 20 & 2a. & 22 & 4 & 0 & 1 & 3 & 37 & Não consta & & Jd. Novo Morumbi \\
\hline 5 & 16 & 1a. & 23 & 3 & 0 & 1 & 2 & 32 & $\mathrm{PN}, \mathrm{CE}, \mathrm{CA}$ & AUBS & Jd. Sto Antônio \\
\hline 6 & 25 & 2a. & 14 & 9 & 0 & 3 & 6 & 38 & Não consta & & Jd. Sto Antônio \\
\hline 7 & 20 & 1a. & 15 & $1 *$ & 0 & 1 & & & Em acompanhamento & & Jd. Sto Antônio \\
\hline 8 & 20 & 1a. & 13 & $9 *$ & 1 & 4 & 4 & & Em acompanhamento & & Jd. Novo Morumbi \\
\hline 9 & 31 & $7 \mathrm{a}$. & 15 & 3 & 0 & 3 & - & & & EUBS & Jd. Novo Morumbi \\
\hline 10 & 20 & $3 a$. & 15 & 9 & 0 & 3 & 6 & 36 & Não consta & & Jd. Novo Morumbi \\
\hline 11 & 21 & $3 a$. & 29 & 2 & 0 & 0 & 2 & 33 & Não consta & AUBS & Jd. Novo Morumbi \\
\hline 12 & 31 & $2 a$. & 20 & 1 & 0 & 1 & - & & & AUBS & Paraisópolis \\
\hline 13 & 16 & 1a. & 35 & 1 & 0 & 0 & 1 & & & & Jd. São Luiz \\
\hline 14 & 20 & $2 a$. & 19 & 10 & 0 & 2 & 7 & 43 & $\mathrm{PN}, \mathrm{CE}, \mathrm{CA}$ & & Jd. Novo Morumbi \\
\hline 15 & 25 & 1a. & 13 & 7 & 1 & 2 & 4 & 39 & Não consta & & Jd. Sto Antônio \\
\hline
\end{tabular}

$\underline{\text { Legendas }}$

- MGPC: Momento gestacional de realização da primeira consulta pré-natal

- NTC: Número total de consultas pré-natais

- *: Número de consultas no momento em que se deu o levantamento

- C 1T: Total de consultas pré-natais realizadas durante o primeiro trimestre de gravidez

- C 2T: Total de consultas pré-natais realizadas durante o segundo trimestre de gravidez

- C 3T: Total de consultas pré-natais realizadas durante o terceiro trimestre de gravidez

- MGUC: Momento gestacional de realização da última consulta pré-natal

- PN: Parto normal

- CE: Com episiotomia

- CA: Com anestesia

- EUBS: Gestante encaminhada para realização de pré-natal apenas na UBS

- AUBS: Estava realizando pré-natal na UBS antes de procurar pelo ambulatório do Núcleo 


\subsection{Núcleo Peinha}

A partir dos dados contidos na tabela, no que se refere à faixa etária, nota-se que $13,33 \%$ das mulheres atendidas no serviço de pré-natal do Núcleo Peinha eram adolescentes, $73,34 \%$ tinham entre 20 e 34 anos e 13,33\% estavam na faixa acima dos 35 anos (Gráfico 7). Quanto à paridade, 33,33\% estavam na primeira gravidez; 33,33\% na segunda; $26,67 \%$ na terceira; e 6,66\% na sétima (Gráfico 8).

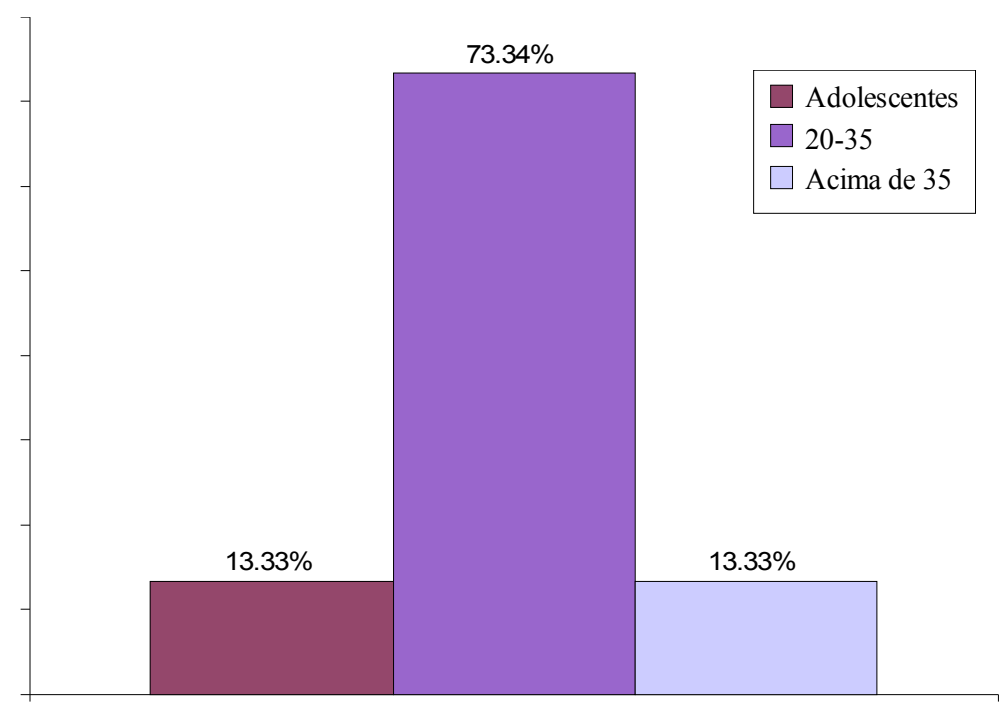

Gráfico 7 - Faixa etária

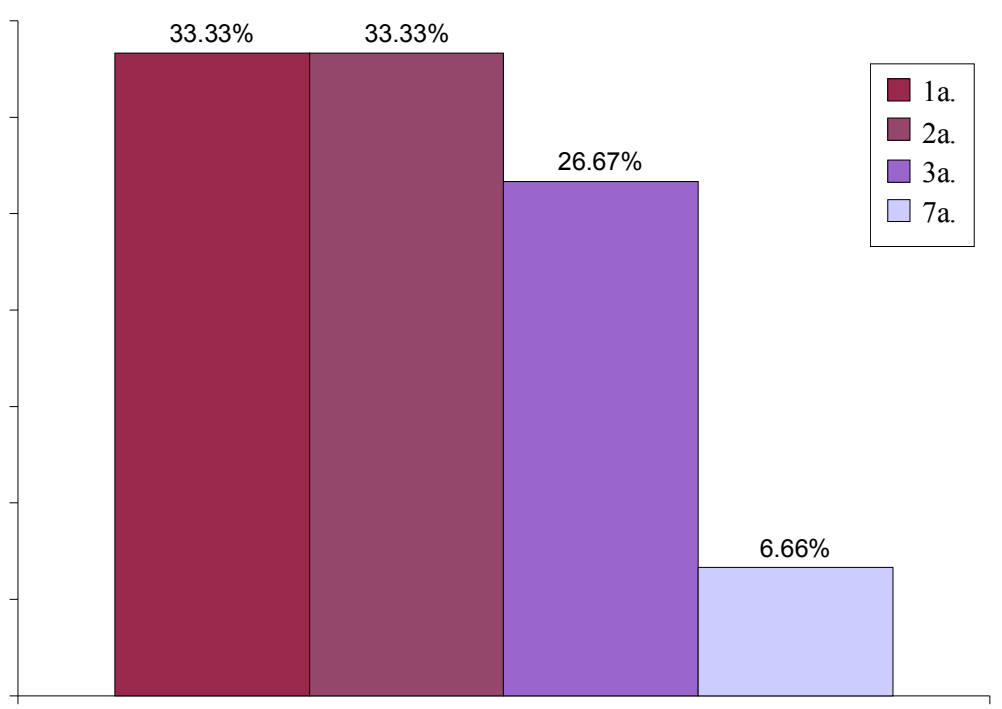

Gráfico 8 - Paridade 
No que concerne ao local de residência, $40 \%$ das mulheres-usuárias do serviço de pré-natal do Núcleo Peinha residiam no Jardim Santo Antônio e 40\%, no Jardim Novo Morumbi - bairros adjacentes e que integram a área de abrangência do Núcleo. As demais, como se nota no Gráfico 9, dividiram-se de maneira homogênea entre os outros bairros que constaram do levantamento. Dentre esses, é importante esclarecer que o Jardim São Luís é, na verdade, um distrito administrativo que abriga diversos bairros, onde se inclui o Jardim Monte Azul, por exemplo; nesse caso, portanto, não houve como definir se o local de residência era muito ou pouco distante do Núcleo Peinha, à vista da extensão do distrito. Quanto a Paraisópolis e Jardim Recanto do Morumbi, tratam-se de regiões mais distantes, tal como se pode observar no mapa adiante.

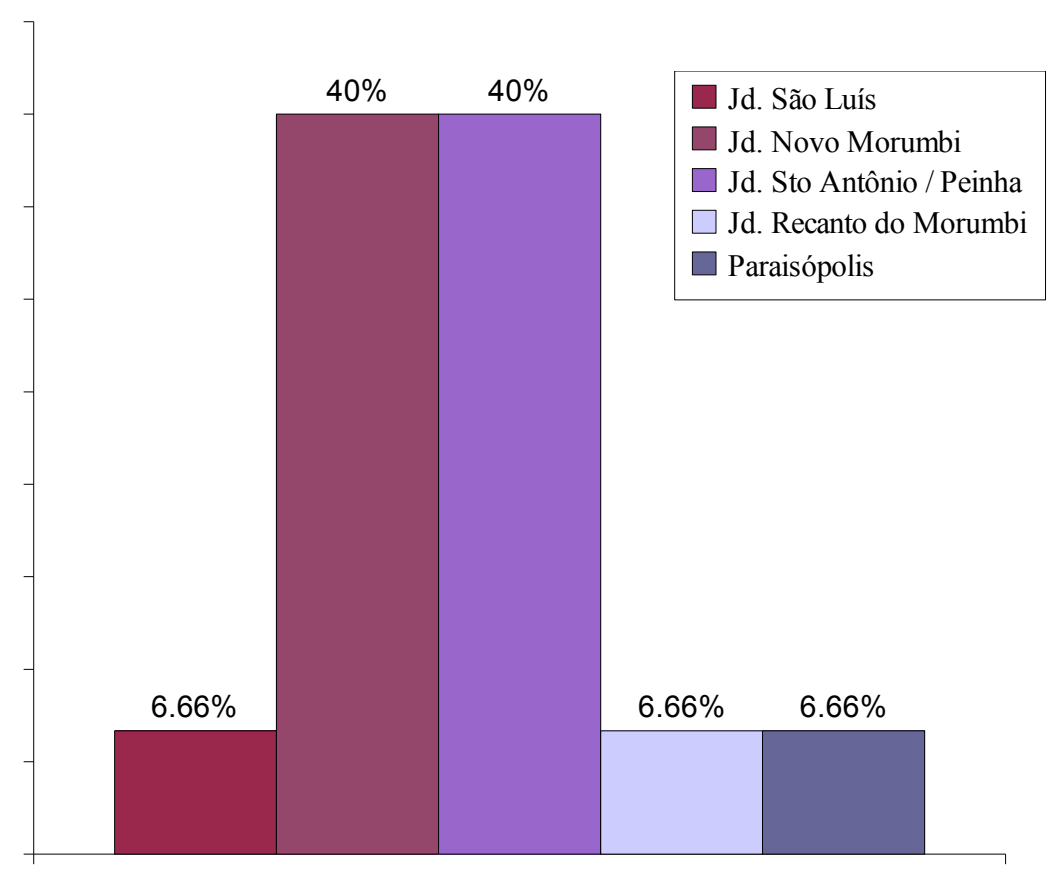

Gráfico 9 - Local de residência 

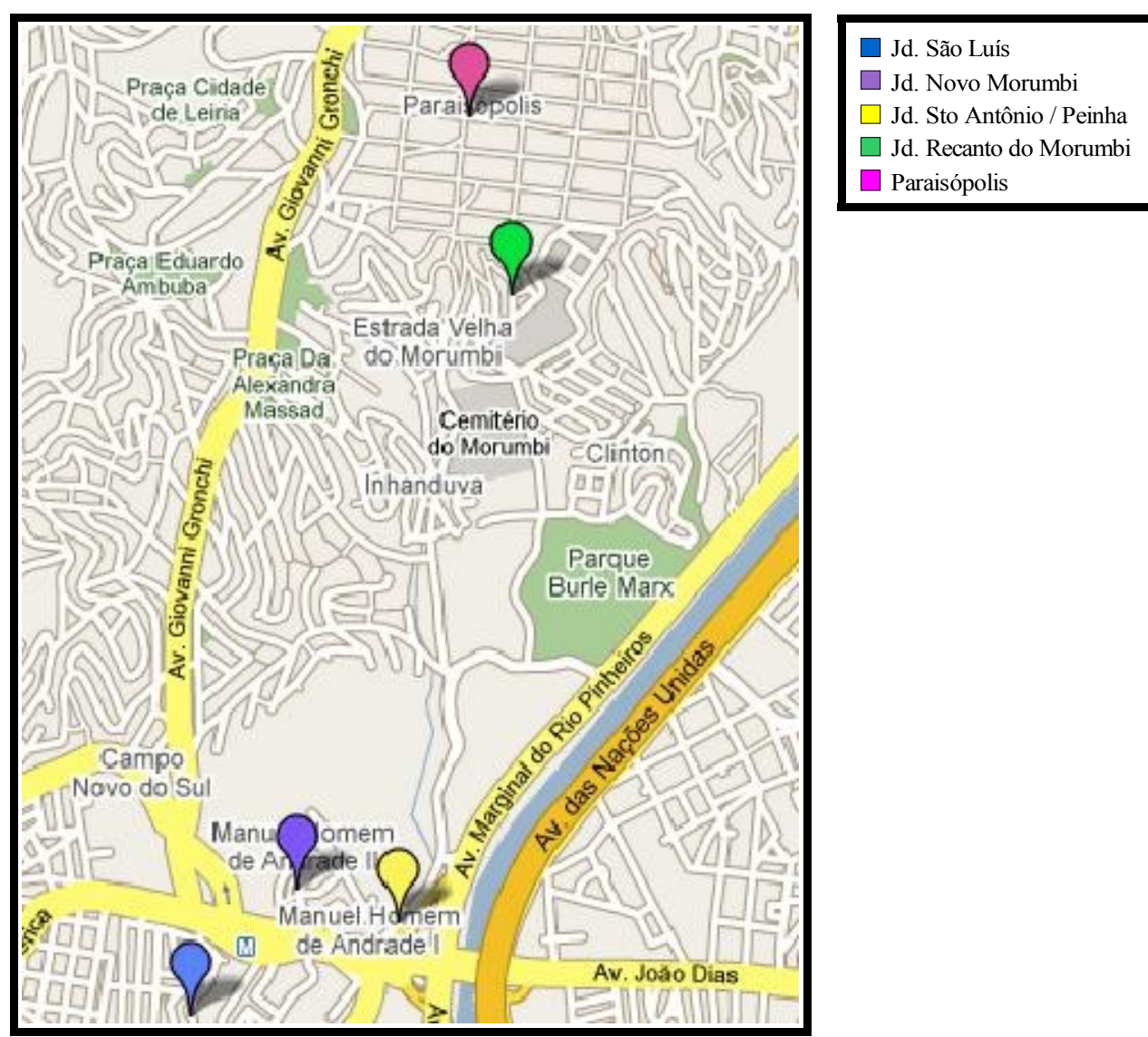

Mapa 2 - Localização do Núcleo Peinha e das residências das usuárias do ambulatório do núcleo

Tais dados também permitem notar que, diferentemente do Núcleo Monte Azul, no Núcleo Peinha a maioria significativa da clientela residia na área de abrangência do serviço; o que atesta a impressão, anteriormente descrita, de que se tratava de público mais homogêneo e caracterizado por relações mais próximas entre si.

De modo a avaliar o serviço a partir de alguns dos parâmetros à atenção à gestação definidos pelo MS (BRASIL, 2006b), um primeiro ponto a ser destacado refere-se ao momento de realização da primeira consulta pré-natal: cerca de $40 \%$ das mulheres fizeram-na durante o primeiro trimestre; $46,66 \%$, no segundo; e 13,33\%, no terceiro (Gráfico 10). Portanto, no que concerne às metas do MS relativas ao número de consultas realizadas no primeiro trimestre gestacional - ao menos uma -, observa-se que $40 \%$ das mulheres cumpriram tais metas e 60\%, não (Gráfico 11). Dentre essas, sabe-se que 33,33\% estavam, anteriormente, em acompanhamento na UBS. 


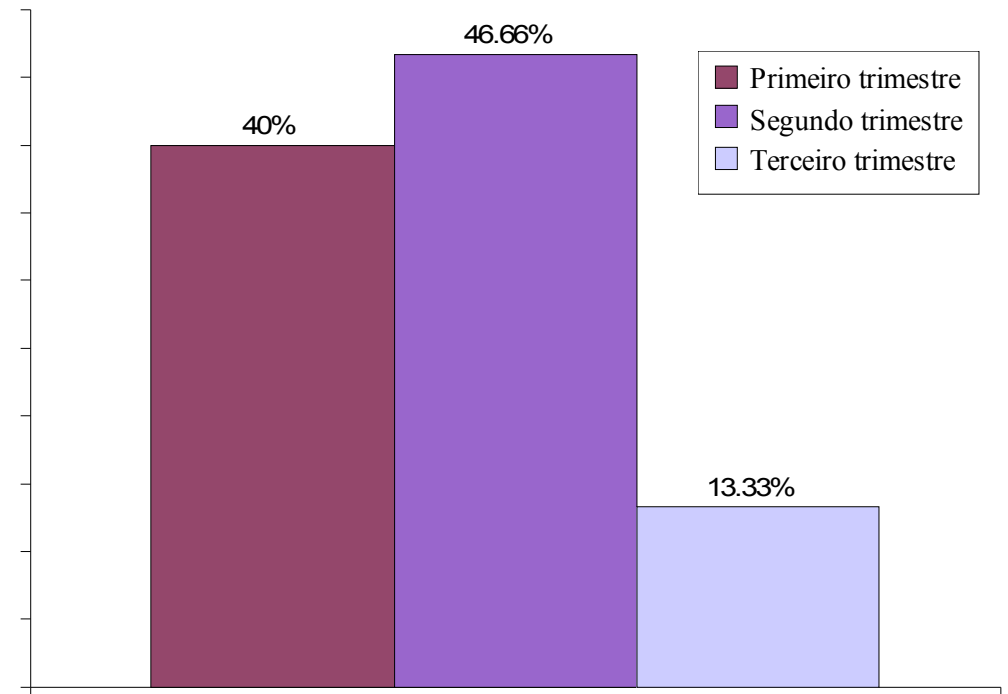

Gráfico 10 - Início do pré-natal

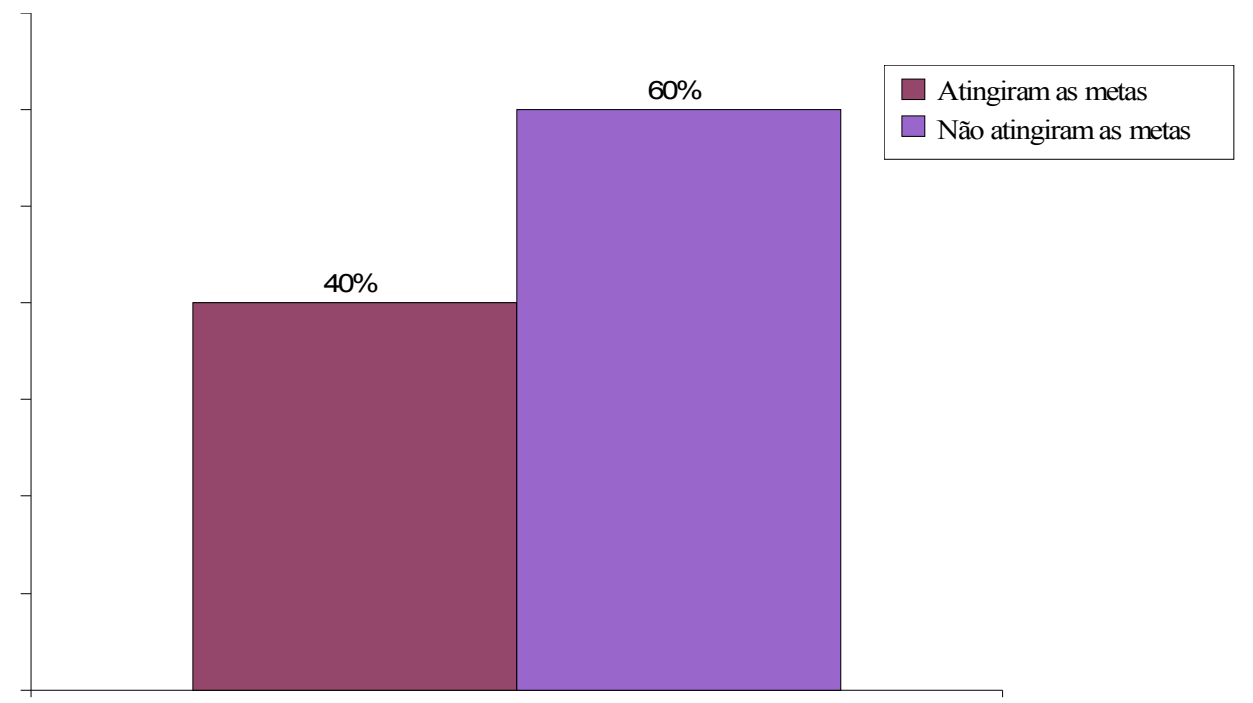

Gráfico 11 - Primeiro trimestre

Quanto ao segundo trimestre, sempre a partir dos dados da tabela, sobre 2, dentre as 15 mulheres que compuseram a amostra, nada se pode afirmar, uma vez que, apesar de ainda não terem cumprido a meta de realização de ao menos duas consultas no período em questão, tinham, ainda, possibilidade de atingi-la. Dentre as demais 13, observa-se, pelo Gráfico 12, que $61,54 \%$ cumpriram os parâmetros do MS; e 38,46\% não o fizeram. Dessas, sabe-se que $60 \%$ estavam, anteriormente, em acompanhamento na UBS. 


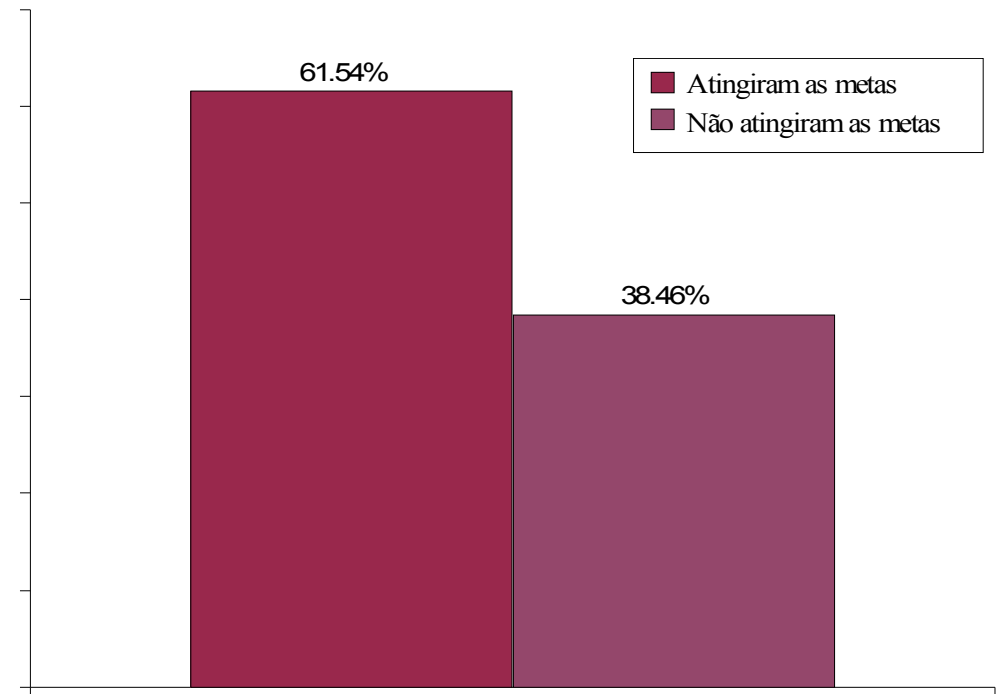

Gráfico 12 - Segundo trimestre

No que se refere ao terceiro trimestre, observa-se que sobre 4, dentre as 15 mulheres que compuseram a amostra, nada se pode afirmar, uma vez que, apesar de ainda não terem cumprido o parâmetro definido pelo MS de realização de ao menos três consultas no período em questão, tinham, ainda, possibilidade de atingi-lo. Dentre as demais 11, nota-se, pelo Gráfico 13 , que $63,63 \%$ atingiram a meta para o período; $27,27 \%$ não o fizeram; e $9,1 \%$ haviam sido encaminhadas para a UBS, para lá fixar o acompanhamento pré-natal.

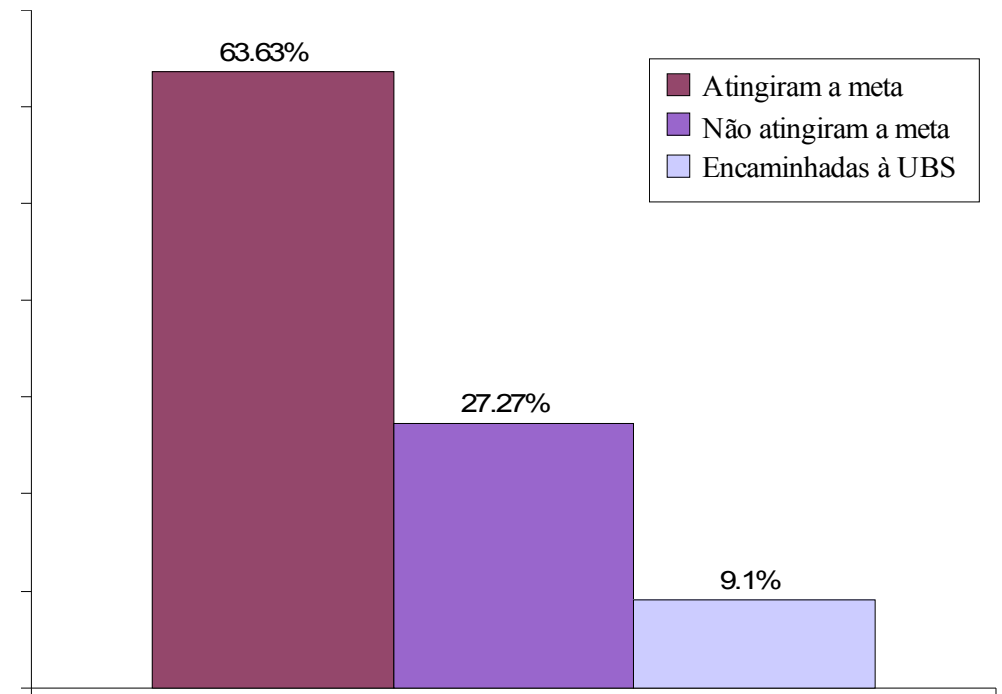

Gráfico 13 - Terceiro trimestre 
Para fechar a análise à luz do PHPN, seguem os casos que cumpriram os parâmetros para os três trimestres gestacionais, e o número médio de consultas pré-natais. Apenas sobre 7 mulheres, dentre as 15 que compuseram a amostra, pode-se afirmar algo. Dentre aquelas usuárias, $\mathbf{5 7 , 1 4 \%}$ cumpriram os parâmetros em questão. Quanto à média de consultas realizadas tem-se um valor de $\mathbf{8}$.

Não foram identificados, conforme se verifica na tabela, casos de mulheres realizando pré-natal em outros lugares paralelamente ao acompanhamento no Núcleo Peinha. Embora seja possível pensar também aqui na existência de falhas nos registros, há um indício de que o contexto desse Núcleo era distinto daquele do Núcleo Monte Azul: segundo relato da enfermeira, a UBS de referência da região do Jardim Santo Antônio - donde se inclui a comunidade Peinha - e do Jardim Novo Morumbi aceitava seus pedidos de exame, de maneira que não era então necessário que a mulher se submetesse a um segundo pré-natal (Diário de campo, Núcleo Peinha, 01/03/07).

Por fim, convém destacar que, assim como no Núcleo Monte Azul, no Núcleo Peinha poucos registros acerca de histórico de parto foram identificados. Cartões de apenas duas mulheres, dentre as 7 que finalizaram acompanhamento pré-natal no Núcleo Peinha, apresentavam tais dados. Em um desses casos, sabe-se que não houve consulta puerperal, pois durante o reconhecimento de campo assistiu-se à vinda da puérpera ao Núcleo para mostrar o bebê para a enfermeira, sem que, entretanto, realizasse a consulta. Tal qual observado no Núcleo Monte Azul, portanto, a despeito de prováveis falhas na notação dos cartões, é possível levantar a hipótese de que também havia baixo índice de realização de consulta puerperal no Núcleo Peinha.

\subsubsection{HORÁRIO DAS CONSULTAS PRÉ-NATAIS}

No Núcleo Monte Azul, até meados de 2007, a enfermeira-obstetra responsável pelo pré-natal colhia material para o exame papanicolau até as $10 \mathrm{~h} 30 \mathrm{e}$, a partir de então, começava a atender às gestantes. Antes do término do primeiro semestre daquele ano, ela deixou de realizar aquela coleta e o pré-natal foi adiantado para as $10 \mathrm{~h}$. No início de 2008 , respondendo ao aumento da demanda pelo serviço, decorrente do encaminhamento das 
gestantes do Núcleo Peinha para o Núcleo Monte Azul, os atendimentos de pré-natal passaram-se a iniciar mais cedo, às $9 \mathrm{~h}$. O horário oficial de encerramento deveria ser ao meiodia, mas, geralmente, os atendimentos se estendiam até $12 \mathrm{~h} 30$ ou $13 \mathrm{~h}$; eventualmente chegava às $13 \mathrm{~h} 30$ ou $14 \mathrm{~h}$.

A partir de maio de 2008, o atendimento, que anteriormente era às quintas-feiras, foi mudado para as terças-feiras, mantido, entretanto, o horário. Segundo a enfermeira-obstetra, a mudança se deu em função de alguns motivos. Primeiro, suas faltas estavam sendo mais frequentes, porque os processos relativos à inauguração da Casa de Parto requeriam sua presença em reuniões diversas. Na ausência dela, uma das coordenadoras da área de saúde, também enfermeira-obstetra, deveria atender às gestantes. Porém, isso nem sempre era possível, uma vez que, às quintas-feiras, a rotina do ambulatório e as reuniões de equipe e do Núcleo que acontecem pela manhã, por vezes, comprometiam a disponibilidade dessa coordenadora para realização dos atendimentos; o que não se daria às terças-feiras, segundo comentário da enfermeira. Outra razão por esta alegada, foi a de que, conhecendo a ginecologista que atende às terças há mais tempo, os encaminhamentos entre as especialidades se tornariam mais fáceis. Convém, aliás, destacar a esse respeito que, segundo depoimento de uma profissional, o dia da semana e o período em que o pré-natal é realizado são definidos não apenas pela disponibilidade das enfermeiras mas também pela possibilidade da presença de um ginecologista, o que garante auxílio médico diante de eventuais intercorrências.

Até janeiro de 2008, a despeito de se ter como norma o agendamento das consultas posteriores à primeira (que, cabe lembrar, não precisa ser agendada, bastando a mulher comparecer no dia de realização do pré-natal), pouquíssimas usuárias o faziam. A partir, mais especialmente, de março de 2008, começou-se a empreender esforços para que as mulheres incorporassem esse hábito. Segundo relatos de uma auxiliar de enfermagem, houve, porém, grande dificuldade: havia gestantes que marcavam consulta e no dia não compareciam; e muitas, ainda, que não marcavam, apesar das recomendações para tanto (Diário de campo, Núcleo Monte Azul, 27/03/08). Importante destacar que o agendamento não se contrapõe à possibilidade de livre acesso, ou seja, de que a gestante compareça ao serviço quando sentir necessidade.

As senhas, distribuídas às mulheres presentes no ambulatório, definem a ordem dos atendimentos, independentemente de agendamento. $\mathrm{O}$ horário máximo de chegada 
recomendado é às $11 \mathrm{~h}$. Se a gestante chegar mais tarde, há risco, segundo uma auxiliar de enfermagem, de não obter atendimento naquele dia, se houver muito movimento; não foram, porém, observados casos em que isso se deu.

No Núcleo Peinha, tal qual no Núcleo Monte Azul, os atendimentos de pré-natal eram submetidos a senhas. O pré-natal, realizado pela mesma enfermeira, tinha início às $13 \mathrm{~h} 30$ e se estendia até cerca de $16 \mathrm{~h}, 16 \mathrm{~h} 30$.

\subsubsection{PRÉ-ATENDIMENTO NO PRÉ-NATAL DO NÚCLEO MONTE AZUL}

De posse de uma senha, a gestante aguarda pelo pré-atendimento, ou pré-consulta, o qual é realizado por uma auxiliar de enfermagem. No primeiro atendimento, a auxiliar abre um cartão para a gestante, no qual ela registra os dados de cadastro da mulher - como nome completo, endereço, estado civil e ocupação. Peso e pressão também são medidos e anotados, a cada consulta de pré-natal.

Convém destacar, sobre tais cartões, que até meados de 2007, sua armazenagem não era adequada, como já mencionado. No segundo semestre daquele ano, uma auxiliar de enfermagem abriu prontuários para mulheres que nunca haviam passado por outros procedimentos no ambulatório do Núcleo Monte Azul e desarquivou aqueles de gestantes que já o haviam feito. Desde esse fato, o cartão da gestante passou a ser guardado dentro de seu prontuário, colocado em ordem alfabética em uma pasta específica de pré-natal.

A partir do primeiro trimestre de 2008, o pré-atendimento se tornou, ainda, um dos momentos oportunos para convidar a mulher para assistir às palestras do novo ciclo então iniciado, para o trabalho corporal semanal, realizado com a fisioterapeuta, e para o atendimento odontológico voltado para gestantes - atividades que passaram a integrar a atenção ao pré-natal. O convite é feito, mais especialmente, por uma das auxiliares de enfermagem, seguido das informações sobre o funcionamento dessas atividades e importância da participação da gestante. Adicionalmente, são dadas notícias sobre o que foi abordado e como transcorreu o último encontro do ciclo de palestras; e um panfleto com a programação do ciclo é anexado ao cartão da gestante (Diário de campo, Núcleo Monte Azul, 13/03/08).

A despeito do rodízio de atividades entre as auxiliares de enfermagem anteriormente 
descrito, a responsável pela captação de doadoras de leite também foi designada para acompanhar as gestantes no pré-atendimento, de modo a fortalecer o vínculo com elas desde a gravidez e facilitar, então, tal processo de captação de doadoras, principalmente. Apenas na sua ausência, a pré-consulta das gestantes é realizada por outra auxiliar.

Algumas especificidades observadas no atendimento prestado por essa auxiliar não podem deixar de ser comentadas. De modo geral, as auxiliares de enfermagem costumam ser amáveis e atenciosas: "É gestante? [amável] Pode vir aqui. Vou medir sua pressão e seu peso, tá bom?" (Diário de campo, Núcleo Monte Azul, 22/03/07). Porém, a menos que conheçam a gestante, não costumam chamá-la pelo nome e, tampouco, perguntar como ela está se sentindo. Segue abaixo um dos exemplos dentre os observados.

Acompanho consultas de pré-atendimento: a auxiliar mede a pressão, pesa e anota os dados no cartão de pré-natal. É educada, conversa e ri; mas raramente chama alguém pelo nome. (Diário de campo, Núcleo Monte Azul, 03/05/07).

A auxiliar de enfermagem designada para o pré-natal, por outro lado, se ainda não conhece a gestante, preocupa-se, primeiramente, em perguntar o nome dela e dizer o seu. A partir de então, dirigi-se à gestante sempre pelo nome. Além disso, enquanto confere o cartão de pré-natal e faz os procedimentos devidos (medir o peso e a pressão), pergunta como a gestante está, dando espaço para que ela expresse suas questões, se o desejar. Se conhece a gestante, pergunta como está a família, a casa, ou sobre situações que tenham sido anteriormente compartilhadas (Diário de campo, Núcleo Monte Azul, 14/02/08, 13/03/08). Ademais, não raro, divide, com as usuárias, vivências pessoais suas, especialmente quando identifica similaridades entre as suas e aquelas vividas pelas mulheres. Algumas vezes, ouviuse usuárias fazendo referências a essa auxiliar como alguém que as compreendia, na medida em que haviam tido experiências de vida semelhantes (Diário de campo, Núcleo Monte Azul, 03/04/08, 06/08/08).

\footnotetext{
"Eu entendo exatamente o que você está vivendo. Eu também vivi isso quando estava grávida [diz nome da gestante]. Foi difícil [descreve a situação]. Mas eu busquei ajuda, enfrentei e fiquei bem depois. Você vai ver como também irá conseguir! E nós estamos aqui também para isso: para te ajudar". (Diário de campo, Núcleo Monte Azul, 13/03/08).
} 
Findo o pré-atendimento, a gestante retorna à sala de espera, e aguarda a sua vez de subir para a consulta de pré-natal. Em algumas ocasiões, porém, parece que o pré-atendimento não se deu, ou não foi feito adequadamente, tendo sido então observado a enfermeira-obstetra medindo pressão e peso da gestante.

\begin{abstract}
Enquanto espero tenho a impressão de que as coisas estavam um pouco confusas. A enfermeira já tinha começado os atendimentos de pré-natal. Entretanto, após uma gestante descer, ela chamou uma mulher que estava esperando para colher papanicolau. Ela me contou, depois, que havia tido um problema entre as auxiliares, acabou não ficando nenhuma na recepção e "virou uma bagunça" - tal como ela referiu. Por conta disso, algumas gestantes não haviam sido pesadas, e ela mesma teve que descer para fazê-lo, o que estava atrasando os atendimentos. (Diário de campo, Núcleo Monte Azul, 01/03/07).
\end{abstract}

Após a primeira gestante sair da sala [havia reclamado acerca dos atrasos no atendimento], a enfermeira reclama, nervosa: "não há colaboração: as meninas lá embaixo [auxiliares] não estão medindo a pressão e nem pesando as gestantes. Eu precisava de material para coletar papa, tive que pegar tudo sozinha; não tinha nada preparado aqui. E tudo isso atrasa os atendimentos!" (Diário de campo, Núcleo Monte Azul, 08/03/07).

Algumas colaboradoras do ambulatório, dentre as quais se incluem as auxiliares de enfermagem, segundo depoimento de uma profissional, estavam sobrecarregadas de atividades, o que, por vezes, prejudicava a funcionalidade de atuações e tarefas. De fato, observou-se que, às quintas-feiras pela manhã, uma das auxiliares ficava, geralmente, até cerca de $9 \mathrm{~h}$ ou $9 \mathrm{~h} 30$ realizando atividades no ambulatório, pois em seguida, participava da reunião de metas, que se estendia até as $11 \mathrm{~h}$, aproximadamente. Era também comum ausentarse do ambulatório para ir às creches. (Diário de Campo, Núcleo Monte Azul, 14/02/08, 27/03/08). A auxiliar responsável pelo pré-natal, especialmente em função do andamento do processo para funcionamento da Casa de Parto, por vezes precisava receber órgãos fiscalizadores, representantes de instituições, ou demais pessoas relacionadas, entre outras providências que tinha de tomar, o que a fazia, em tais ocasiões, também ausentar-se do ambulatório. Outra auxiliar dividia-se em atividades administrativas, aplicação de terapias externas e recepção à clientela no ambulatório. Dado que uma quarta auxiliar estava, por vezes, voltada à função de cuidados de enfermagem, não raro, não havia ninguém na recepção e, tampouco, alguém que pudesse logo se prontificar a fazê-lo; e, no pré-atendimento, da mesma forma, ocorriam atrasos ou ele era prejudicado de alguma maneira (Diário de campo, Núcleo Monte Azul, 03/05/07; 31/01/08). 


\subsubsection{PROCEDIMENTO EM RELAÇÃO ÀS FALTAS DA ENFERMEIRA- OBSTETRA}

Quando a enfermeira notifica que não poderá comparecer para realizar os atendimentos, o procedimento padrão é avisar as gestantes por telefone e marcar retorno. Entretanto, como não há agendamento para a primeira consulta, como nem sempre o retorno é marcado na agenda, como há liberdade de acesso e como, por vezes, a enfermeira não avisa previamente o não comparecimento, não raro, a gestante descobre a ausência da enfermeira apenas quando chega ao ambulatório. Para contornar essa situação, uma das coordenadoras, também enfermeira-obstetra, disponibiliza-se para atendimento. A coordenadora ainda assume essa função no caso de férias da enfermeira-obstetra responsável pelo pré-natal, para evitar intervalos prolongados entre os atendimentos. Observou-se, porém, algumas ocasiões em que a substituição não se deu: em uma delas a coordenadora também não estava presente (Diário de campo, Núcleo Monte Azul, 31/01/08) e em outra não foi chamada pelas auxiliares para realizar o atendimento (Diário de Campo, Núcleo Monte Azul, 07/01/08). No Núcleo Peinha, o procedimento de substituição não era adotado.

\subsubsection{ATRASOS}

Já foram aqui anteriormente transcritas algumas falas sobre atrasos no início do atendimento pré-natal, no Núcleo Monte Azul. Dois episódios dessa espécie foram observados nesse Núcleo: um de meia hora (Diário de campo, 15/02/07) e um de quarenta e cinco minutos (Diário de campo, 08/03/07). Mais dois ocorreram no Núcleo Peinha: um de uma hora (Diário de campo, 26/04/07) e um de uma hora e meia (Diário de campo, 10/05/07). Nos dois primeiros casos, os atrasos foram decorrentes do tempo dispendido na coleta de material para exame de papanicolau, e as gestantes estavam cientes do que estava acontecendo. No Núcleo Peinha, por outro lado, a auxiliar de enfermagem tentou contatar a enfermeira, para colocar-se a par da situação, mas não conseguiu, e as gestantes permaneceram sem informação. Nas duas ocasiões, após a chegada, ela esclareceu que estava em reunião relativa 
à Casa de Parto, na época, em fase final de construção.

\subsubsection{DURAÇÃO DAS CONSULTAS PRÉ-NATAIS}

A duração dos atendimentos é definida de acordo com a demanda expressa pela gestante e/ou identificada pela enfermeira, podendo variar, conforme foi observado, de cinco minutos a uma hora e meia. O primeiro caso ocorria, usualmente, quando a gestante retornava na semana seguinte para, por exemplo, levar o resultado de um exame que esquecera na semana anterior, ou para checar alguma condição que estava demandando acompanhamento mais frequente (Diário de campo, Núcleo Monte Azul, 15/02/07; Núcleo Peinha, 01/03/07).

O segundo caso, por sua vez, foi observado em dois episódios, ambos relativos a atendimento de puérperas e configurados em cuidados de mastites e provimento de orientações, em ato, sobre amamentação (Diário de campo, Núcleo Peinha, 01/03/08; Núcleo Monte Azul, 15/03/07). Quando a enfermeira era notificada pelas auxiliares de enfermagem de que havia esse tipo de atendimento para ser feito, pedia para que fosse deixado por último, a fim de atendê-lo com mais tranquilidade.

\subsubsection{CONDUTAS DURANTE AS CONSULTAS PRÉ-NATAIS}

\subsection{Anamnese}

Na primeira consulta, é feita a anamnese, em que são levantados dados como: idade, estado civil, ocupação, data da última menstruação, uso de algum método contraceptivo, peso antes da gravidez, gestações e partos anteriores, amamentação da gravidez anterior - se a gestante não for primípara - e histórico de doenças da gestante e de sua família de origem. Há, ainda, registro de sintomas e queixas. 


\subsection{Exame clínico}

Durante o exame clínico a enfermeira realiza palpação obstétrica, mede a altura uterina e ausculta o coração do bebê. Se a gravidez está mais avançada, ela pergunta à gestante se sente o bebê mexer. E, também nesse momento, frequentemente, passa exercícios de respiração à mulher, que incluem o manejo de relaxamento da região abdominal. Segundo a enfermeira, trata-se de uma atividade corporal importante, uma vez que, se a musculatura estiver contraída, em estágio mais avançado, o espaço para o bebê se mexer estará reduzido; além de dificultar o exame clínico. Além disso, essa prática, acompanhada dos exercícios respiratórios, permite ampliação de consciência corporal e se traduz em recurso para a vivência do parto.

\subsection{Evolução da gravidez}

Como parte do acompanhamento pré-natal, há o controle da evolução da gravidez por meio do exame clínico, variações no peso e na pressão e exames laboratoriais, os quais, apesar de geralmente não serem realizados no Núcleo, são pedidos e avaliados pela enfermeira; tanto os de rotina quanto os julgados necessários conforme a evolução do caso. No cartão da gestante constam campos para os seguintes exames: VDRL, hemograma, urina, fezes, curvaglicêmica, papanicolau, toxoplasmose, HIV, rubéola, "outros" - dentre os quais costumam aparecer anotações acerca de hepatite $\mathrm{B}$ e $\mathrm{C}$ e, em alguns casos, de CMV (citomegalovírus) - e ultrassom.

Conforme depoimento de uma profissional, o Núcleo segue o protocolo do Ministério da Saúde, reconhecendo a importância de o pré-natal ser também acompanhado a partir de tais exames, e considerando que o cumprimento dos critérios definidos pelo MS associa-se à garantia à mulher de bom atendimento no parto na Rede SUS: 
mulheres vão na UBS fazer os exames. E a gente segue o protocolo do MS. Porque elas vão ter parto no serviço público. E se ela chegar no serviço público sem os exames protocolados, elas podem viver maus tratos e maus cuidados, porque não fez pré-natal direito". (Depoimento, Enfermeira-Obstetra, 29/09/08).

O retorno da gestante independe de ela já ter em mãos os resultados dos exames. Quanto ao ultrassom, cabe destacar que a enfermeira desencoraja as gestantes a fazerem esse exame apenas para saber o sexo do bebê, embora respeite esse desejo se ela o percebe subsistente.

A enfermeira tranquiliza a gestante, que estava preocupada pelo posto não ter concordado em fazer ultrassom morfológico: explica que tudo está bem e, por isso, não haveria motivo para tanto; mas que se ela fosse ficar mais tranquila, poderia fazer o ultrassom normal mesmo - e dá um pedido. (Diário de campo, Núcleo Monte Azul, 08/03/07).

A gestante conta que fizera um primeiro ultrassom, com pedido do posto de saúde, mas depois quis fazer outro, para saber o sexo da criança. A enfermeira pergunta: "e qual a diferença de saber o sexo?". E a gestante responde: “Ah, muita”. (Diário de campo, Núcleo Peinha, 15/03/07).

\subsection{Inclusão do acompanhante}

$\mathrm{Na}$ consulta, é permitida a entrada de acompanhantes na sala de atendimento, se a gestante assim o desejar. Nessa oportunidade, a enfermeira se empenha em inclúi-los na consulta e nas vivências da gravidez, especialmente os companheiros e familiares. Há espaço para exposição de suas dúvidas ou curiosidades e todos são convidados a escutar os batimentos cardíacos do bebê. As crianças, por sua vez, são, algumas vezes, chamadas para o papel de "assistentes" da enfermeira, como forma de integração.

Eu a tinha visto com o companheiro na sala de espera, mas como a enfermeira não sabia, a gestante entra só. A enfermeira diz-me, depois, que quando vê pede para entrar, pois eles [os companheiros] geralmente estão tão acostumados a não serem convidados para tanto, que não tomam essa iniciativa. (Diário de Campo, Núcleo Monte Azul, 15/02/07).

Enquanto ausculta o coração do bebê, a enfermeira pergunta se o companheiro queria ouvir - a gestante diz que sim. Diz que após os atendimentos eles poderiam 
subir novamente [o companheiro havia ido à lanchonete bem no momento em que ela foi chamada para atendimento]. (Diário de campo, Núcleo Monte Azul, 01/03/07).

A gestante diz que o marido estava lá embaixo - a enfermeira o convida a subir. E ele sobe com o filho. Mais adiante, compartilha com a enfermeira suas preocupações pela esposa não estar se alimentando corretamente. (Diário de campo, Núcleo Monte Azul, 01/03/07).

A gestante chama o filho para escutar os batimentos cardíacos do bebê - o menino parece vibrar. A enfermeira o integra, deixando que ele apalpe o ventre da mãe depois dela fazê-lo. (Diário de campo, Núcleo Peinha, 15/03/07).

Cabem algumas considerações sobre os acompanhantes. Apesar de ter sido observada a presença de alguns companheiros na sala de espera, com mais frequência, especialmente no Núcleo Peinha, talvez por conta do horário vespertino em que o pré-natal era realizado, as mulheres estavam sozinhas ou acompanhadas de seus filhos, de amigas e/ou vizinhas e, principalmente as mais jovens, de suas mães ou sogras. Dentre as 28 consultas observadas, apenas em duas houve participação do companheiro da gestante (Diário de campo, Núcleo Monte Azul, 01/03/07, 08/03/07). Por outro lado, em cinco consultas as mães das gestantes estavam presentes (Diário de campo, Monte Azul, 15/02/07, 08/03/07 e 15/03/07; Núcleo Peinha, 15/03/07); em três, filhos participaram (Diário de campo, Monte Azul, 15/02/07 e 22/02/07; Núcleo Peinha, 15/03/07); em duas, amigas acompanharam (Diário de campo, Núcleo Peinha, 01/03/07; Núcleo Monte Azul, 15/03/07); e, em uma, a sogra (Diário de campo, Núcleo Peinha, 01/03/07).

\subsection{Orientações quanto à alimentação}

A alimentação também é centro de interesse da enfermeira-obstetra, que pergunta para a gestante o que come e quando come, orientando-a quando necessário. Se ela está tendo muita dor de cabeça ou tontura, se está engordando demais, ou de menos, ou simplesmente como algo que deve ser cuidado, a alimentação é sempre discutida. A enfermeira tem por hábito orientar a mulher a consumir muita fruta e verdura - especialmente as de folhas verdes; a eliminar o refrigerante, sucos artificiais, salgadinhos e doces em excesso; a controlar a 
quantidade de açúcar e de sal; a fazer refeições a cada três horas; e a ingerir no mínimo dois litros de água diariamente. As possibilidades financeiras, as preferências e os gostos, assim como a rotina da gestante, são sempre considerados, o que permite a avaliação dos melhores meios de inserção dessas recomendações em seu cotidiano (Diário de Campo, Núcleo Monte Azul, 15/02/07, 22/02/07, 01/03/07, 08/03/07, 15/03/07; Núcleo Peinha, 01/03/07, 15/03/07).

Segundo a enfermeira, o cuidado com a alimentação é um ponto especialmente importante porque ela não deve indicar complementos ou receitar vitamínicos, sabendo que não poderá consegui-los para as gestantes (Diário de Campo, Núcleo Monte Azul, 01/03/07). Entretanto, há também aqui a concepção antroposófica de saúde, que se manifesta, inclusive, em outros momentos, tal como a indicação de chá de sálvia e manjericão para alguma vaginite.

\subsection{Orientações quanto a exercícios físicos}

O estímulo a atividades físicas também é constante; entre elas se incluem atividades sexuais, caminhadas, rebolado, dança. Além disso, seja durante as consultas, seja durante palestras que profira às gestantes na Associação (Diário de Campo, Núcleo Peinha, 01/03/07 e 15/03/07), a enfermeira ensina alguns exercícios específicos para serem praticados em casa.

\subsection{Outras orientações}

A enfermeira oferece, ainda, outras orientações. Algumas são voltadas a assuntos mais específicos, como tomar sol, para melhor absorção de vitaminas; ou, especialmente no caso de algumas multíparas, usar roupas que ofereçam melhor sustentação ao abdome. Outras, são relativas à vida conjugal, familiar e em comunidade, como sugerir que o companheiro de uma gestante a ajude mais em casa (Diário de campo, 08/03/07, Núcleo Monte Azul); que um filho não revide após uma briga em que saiu perdendo (Diário de campo, Núcleo Monte Azul, 
22/02/07); ou, ainda, que não seja travado confronto físico entre um casal (Diário de campo, Núcleo Monte Azul, 15/03/07).

\title{
6.5.8.9.8. Espaço de diálogo
}

Nesse cenário, as orientações são providas de modo dialógico, ou seja, emergem a partir do contexto da consulta, dos saberes da enfermeira e do expresso pela gestante; e sua discussão é permeada pelo que a mulher vivencia e compreende. Além disso, é garantido o espaço para a expressão de dúvidas, conflitos e vivências da usuária e de seus acompanhantes.

\begin{abstract}
A gestante parecia aflita. Compartilha com a enfermeira que estava com receio de que a criança nascesse com algum problema. A enfermeira a tranquiliza, salientando que seus exames estavam ok e que tudo no pré-natal apontava que tudo estava bem (Diário de campo, Núcleo Peinha, 01/03/07).

O último atendimento foi com uma mulher que estava vivenciado dificuldades concernentes a aleitamento. Ela estava muito aflita, imaginando que, por não estar conseguindo amamentar bem seu bebê, ele estava passando fome. A enfermeira a tranquiliza, dizendo que o bebê não estava passando fome, pois quando o está "não faz xixi nem cocô". Após a enfermeira ajudar a puérpera com a amamentação e realizar orientações, finaliza, "está mais confiante?". "Ah, agora eu estou! nossa, nunca vi mamar assim...”. (Diário de campo, Núcleo Peinha, 01/03/07).
\end{abstract}

A enfermeira pergunta à gestante se ela estava sentindo algo. A mulher expressa algumas questões e a enfermeira vai, então, explicando o porquê de ela estar sentindo o que estava sentindo (Diário de campo, Núcleo Monte Azul, 08/03/07).

A gestante pede para fazer ultrassom. A enfermeira explica que não há necessidade, mas a gestante insiste, pois quer se certificar de que tudo está bem com o bebê. A enfermeira percebe que há algo errado e pergunta o que há. A gestante diz que tem medo de que algo aconteça com o bebê, pois "são tantas histórias...". Conta uma dessas e a enfermeira explica que o caso era diferente. A enfermeira pergunta se a gestante se sentia triste e ela diz que não. A enfermeira então explica que essas preocupações são normais ao final da gravidez. "Riscos sempre existem - podemos tropeçar na rua. Mas eu vejo que está tudo bem com você e com o bebê. Não fique se comparando com outras mulheres. Cada uma é uma". (Diário de campo, Núcleo Monte Azul, 15/03/07).

Esse espaço dialógico por vezes também envolvia a enfermeira "dar broncas" - tal como nomeado por algumas usuárias - mas sempre, conforme o que se pôde observar, com 
respeito e como expressão de preocupação com o bem-estar da gestante. O tema mais frequente era a alimentação.

A enfermeira, avaliando os resultados de exames trazidos pela gestante, salienta que a glicemia estava muito elevada; além disso, nota que ela estava engordando muito. Chama-lhe a atenção, dizendo que ela continuava sem cuidar da alimentação e sem se exercitar, e pontua o risco de uma diabetes gestacional (Diário de campo, Núcleo Monte Azul, 15/02/07).

A enfermeira pesou a gestante e constatou que, em uma semana, ela engordara quase um $1 \mathrm{k}$. Ela chamou, então, a atenção da gestante para o risco de uma hipertensão ao final da gravidez, além do aumento de peso, falando então da necessidade de um maior cuidado com a alimentação (Diário de campo, Núcleo Monte Azul, 22/02/07).

"A [enfermeira] é muito atenciosa. Eu gosto muito dela. Ela conversa muito com a gente. E também dá broncas de vez em quando! [...] Porque não pode engordar muito na gravidez. Ela conversa. Fala o que pode comer, o que não pode. Fala que não pode comer muita besteira... Ela é muito atenciosa!" (Diário de campo, Núcleo Monte Azul, 14/02/08, relato de uma usuária).

\subsection{Estímulo à autonomia e à responsabilidade}

Outro foco muito presente nos atendimentos é o estímulo à autonomia e à responsabilidade para com a gravidez e o bebê. A enfermeira ressalta que "se a gravidez foi planejada, é momento da mulher curtir e cuidar. Se não foi, é necessário cuidar da mesma forma, pois se trata de uma vida vindo ao mundo". Com adolescentes o tema é reforçado, especialmente quando a enfermeira percebe que o cuidado está sendo deixado a cargo da mãe.

Era a mãe da adolescente quem fazia as perguntas e os comentários. A enfermeira se interpõe - não com a mãe, mas com a menina. Diz que a gravidez era dela e, portanto, a responsabilidade também. (Diário de campo, Núcleo Monte Azul, 15/02/07).

"Mulher que tem saúde engravida. E tem que manter a saúde durante a gravidez. A responsabilidade pelo cuidado é da gestante". (Diário de campo, Núcleo Peinha, fala da enfermeira durante palestra por ela proferida acerca de "Evolução da gravidez: pré-natal e pré-parto", 15/03/07). 


\subsection{0. $\quad$ Ênfase na força feminina da mulher grávida}

Quando atende a uma gestante que compartilha alguma dificuldade, a enfermeira procura abordar o assunto, de modo geral, por dois caminhos: sugere à mulher concentrar-se nas coisas boas da vida para seguir adiante, ressaltando o poder da vontade para conquista do desejado; e/ou relembra-a da força feminina de gestar e de pôr um filho no mundo; força que, segundo ela, surge na mulher grávida, intensifica-se a partir do segundo trimestre gestacional e torna a mulher mais confiante em si mesma e apta para enfrentar o que for preciso (o que inclui o parto, sob que condições forem).

Em meio à palestra sobre os aspectos físicos, psicológicos e emocionais da gravidez, a enfermeira refere: "a mulher tem uma força de gestar e pôr um filho no mundo. Mulher e homem são diferentes. É a mulher que acolhe, que recebe, e que tem essa força; que vem mais forte a partir do quarto mês ou quinto mês de gravidez". Nesse momento, uma gestante se coloca dizendo que só suportou a gravidez por conta do suporte da enfermeira. Essa reforça a ideia de que foi a força da própria gestante (Diário de campo, Núcleo Peinha, 01/03/07).

Entra uma gestante para o atendimento muito mobilizada por conta de uma briga com o companheiro. Em dado momento a enfermeira lhe diz: "não pode brigar desse jeito; pode discutir, mas não assim. Antes de fazer isso, respira dez vezes. A gravidez deixa a mulher mais forte! Tem uma vida aí dentro, você não pode fazer isso. Ânimo, você já passou por coisa pior". (Diário de campo, Núcleo Monte Azul, 15/03/07).

\subsection{Liberdade de acesso}

Ao perceber alguma demanda por acompanhamento mais frequente, a enfermeira indica à gestante retorno semanal ou quinzenal. Essa indicação é também muito comum quando há início tardio no pré-natal - no segundo ou no terceiro trimestre. Porém, mesmo que não haja demanda explícita nesse sentido, a enfermeira deixa a cargo da gestante o retorno: caso esta sinta necessidade de fazê-lo semanalmente, sabe que há possibilidade para tanto. Em casos mais graves, a enfermeira também disponibiliza seu telefone. 
O terceiro atendimento que acompanho é de uma mulher que passa semanalmente com enfermeira por conta de ter sido submetida a um procedimento que demandava acompanhamento mais constante (Diário de campo, Núcleo Monte Azul, 15/02/07).

A enfermeira pede para a gestante retornar assim que tivesse os resultados dos exames, ou após 30 dias. E logo em seguida ela complementa: "ou antes, se você quiser”. (Diário de campo, Núcleo Monte Azul, 01/03/07).

A enfermeira pede que a puérpera retorne na semana seguinte e diz para ela ligar, caso houvesse necessidade (Diário de campo, Núcleo Peinha, 01/03/07).

\subsection{Dificuldades em relação à continuidade do pré-natal}

Os dados obtidos dos cartões das gestantes revelaram dificuldades na continuidade do pré-natal: tanto no Núcleo Monte Azul como no Peinha, foram identificados alguns casos em que a mulher, até então em acompanhamento pré-natal em UBS, procurou o Núcleo, realizou uma única consulta e, até a época da coleta dos dados, não retornara ainda. Além disso, também apontaram, assim como o fizeram algumas observações do campo, situações de gestantes encaminhadas à UBS, segundo relato da enfermeira, experimentando dificuldades para manutenção de acompanhamento em duas instituições - o que se dava, como mencionado, especialmente nos casos em que, para ter acesso à realização de exames, a mulher tinha que se submeter a um segundo pré-natal na UBS. (Diário de campo, Núcleo Monte Azul, 24/05/07; Núcleo Peinha, 14/06/07).

\subsection{Preferência pelo serviço da associação}

Por outro lado, há casos em que as mulheres expressavam preferência pelo serviço da Associação, tendo se mobilizado a procurá-lo, estimuladas pelos comentários positivos a respeito da atenção ali prestada ou em razão de insatisfações vividas em outros serviços; e mantendo aderência ao serviço, mesmo quando precisavam se submeter a um segundo prénatal na UBS. 
A gestante estava já no quinto mês de gestação. Iniciara o pré-natal próximo de sua casa, mas sua sogra lhe falou da Monte Azul e ela preferiu se deslocar até a Associação.(Diário de campo, Núcleo Monte Azul, 15/02/07).

A usuária relata que começara o pré-natal no posto de saúde, mas as médicas saíram de férias e ela ficou dois meses sem atendimento. Por isso, resolveu procurar pelo serviço do Núcleo. (Diário de campo, Núcleo Monte Azul, 01/03/07).

Estava fazendo pré-natal perto de sua casa, mas referiu que o médico era muito ruim. (Diário de campo, Núcleo Monte Azul, 15/03/07).

\subsection{Vínculo entre as gestantes e a enfermeira-obstetra}

Presenciou-se, mais de uma vez, comentários de usuárias sobre o quão importante para elas era, ou tinha sido em uma gestação anterior, o vínculo com a enfermeira; ou situações de mulheres cuidadas no serviço de pré-natal do ambulatório, que anos mais tarde retornavam com a filha grávida. Cabe destacar que em alguns desses casos, dado o tempo transcorrido, o vínculo se transferira para serviço, e deixara, portanto, de ser com a enfermeira.

Enquanto aguardo o início da palestra, ouço as mulheres conversando. Uma delas, não gestante, diz que tinha feito questão de vir à palestra porque estava com saudades da enfermeira. Conta que essa acompanhou as duas últimas de suas três gestações e brinca que estava pensando em engravidar novamente só para poder ser cuidada por ela de novo (Diário de campo, Núcleo Peinha, 01/03/07).

A gestante, em meio a um grupo, relata que apenas conseguiu dar conta da nova gravidez, não planejada e que lhe causava muitos receios, por conta da enfermeira (Diário de campo, 01/03/07, Núcleo Peinha). Essa mesma mulher, durante uma consulta, diz para a enfermeira: “Ah, o que seria de mim sem você!" (Diário de campo, Núcleo Peinha, 15/03/07).

O último atendimento é de uma adolescente que entra acompanhada pela mãe e a irmã mais nova. Finda a consulta, a enfermeira me conta que a mãe da adolescente fizera pré-natal ali, com ela, quando grávida da menininha, e que agora retornava com a filha mais velha, com suspeita de gravidez, para que essa fosse também ali acompanhada (Diário de campo, Núcleo Monte Azul, 15/02/07).

Enquanto aguardo pelo início do pré-natal, sento-me do lado de fora do ambulatório. Logo em seguida uma mulher se senta ao meu lado e se põe a conversar comigo. Conta-me que seu primeiro filho nascera ali, com Angela. E agora, grávida novamente, retornava ao ambulatório, para realizar o pré-natal (Diário de campo, Núcleo Monte Azul, 08/03/07). 
Esse vínculo também parece transparecer no comprometimento de algumas mulheres com o pré-natal, comparecendo semanal ou quinzenalmente às consultas, quando há indicação. Dois episódios chamaram mais atenção, dentre os que puderam ser observados. Um primeiro, de uma adolescente que iniciara o pré-natal do Núcleo Monte Azul há pouco tempo; a enfermeira solicitou seu retorno na semana seguinte, com os resultados dos exames que, segundo a gestante, já estavam prontos, mas não os havia retirado. Na semana seguinte a gestante retorna, mesmo sem os exames, contando que ainda não tinha conseguido pegá-los. (Diário de campo, Núcleo Monte Azul, 22/02/07). O segundo caso é o de uma gestante, já mencionada aqui, que comparecia semanalmente à consulta por conta de um procedimento que demandava acompanhamento mais frequente. Além de ela dificilmente faltar, atraiu a atenção o fato de que ela tinha muitos filhos, ninguém para ajudá-la e, durante algum tempo, esteve com dificuldades de locomoção, por conta de um ferimento. Mesmo assim, vinha para a consulta e se dispunha a subir a escada para ser atendida na sala de pré-natal, a despeito de a enfermeira se dispor a atendê-la no andar de baixo (Diário de campo, Núcleo Monte Azul, 22/02/07).

\subsubsection{A ATENÇÃO PÓS-NATAL}

Os dados levantados pelos cartões das gestantes, como apontado anteriormente, revelaram ausência de registros sugestivos de realização de consulta puerperal. De modo semelhante, dentre as 28 consultas observadas no período entre 15 de fevereiro e 15 de março de 2007, apenas duas foram relativas ao atendimento pós-parto - uma no Núcleo Monte Azul e uma no Núcleo Peinha. Porém, ambos os atendimentos abarcaram, apenas, orientações e cuidados concernentes à amamentação, não se configurando, portanto, em consulta puerperal.

Segundo a enfermeira-obstetra, a distância entre o ambulatório e a residência da mulher pode ser um fator que torna mais difícil o retorno dela após o parto; o que seria potencializado, ainda conforme essa profissional, em casos em que a usuária, tendo tido sua autoconfiança fortalecida ao longo do pré-natal, não via necessidade de retornar. Porém, sabese, pela caracterização da clientela, que grande parte das gestantes é da área de abrangência dos ambulatórios (Monte Azul e Peinha), logo, parece que o local de residência da mulher não 
pode ser considerado como fator significativo na compreensão do baixo índice, ou inexistência, de realização de consulta puerperal.

Tal achado foi validado por uma das coordenadoras, que relatou que, na época, a atenção ao puerpério não estava estruturada. O que era ofertado, desde meados de 2007 , era o acompanhamento de doadoras de leite, configurado especialmente a partir de visitas domiciliares voltadas à captação de doadoras, à coleta de leite materno e ao provimento de orientações relativas à amamentação. Adicionalmente, nessas oportunidades, estabelecia-se espaço para acolhimento de outras questões vividas pela mulher, com os encaminhamentos necessários (Diário de campo, Núcleo Monte Azul, 24/01/08).

Apenas no início de 2008 o serviço de atenção ao puerpério começou a ser melhor organizado. A partir de então, o foco das visitas dirigiu-se à avaliação do estado da mulher no pós-parto e elas se tornaram atreladas à realização de consulta puerperal no Núcleo, conforme se descreve a seguir.

\subsubsection{VISITAS DOMICILIARES}

A mesma auxiliar de enfermagem que acompanha as gestantes e realiza seu préatendimento é responsável pelas visitas domiciliares. Segundo seu relato, ela contata todas as mulheres que finalizaram o acompanhamento pré-natal no Núcleo para agendar uma visita domiciliar, preferencialmente, por volta do terceiro dia após o parto. Quando não pode se deslocar até a residência da puérpera, a auxiliar pede-lhe que se dirija ao ambulatório.

O objetivo é checar o estado da mulher no pós-parto, oferecer suporte, dar orientações e, quando possível, convidá-la para ser doadora de leite (Diário de campo, Núcleo Monte Azul, 31/01/08). A enfermeira acompanha a auxiliar em visitas de casos que demandem condutas interventivas, tais como cuidado de mastites ou de complicações em pontos de cesariana ou de episiotomia.

Ao longo do puerpério, as visitas costumam ser semanais. Sua maior ou menor periodicidade, porém, assim como a duração de cada visita e o período de acompanhamento, são definidos pelas demandas vividas por cada mulher, e também pela disponibilidade da auxiliar de enfermagem. Os casos de doadoras de leite configuram-se em exceção quanto ao 
período de acompanhamento, que se prolonga enquanto se mantém a doação (Depoimento, Auxiliar de Enfermagem, 26/09/08).

Além disso, em alguns casos, oferece-se também suporte via canal telefônico, especialmente quando esse tipo de contato é requerido. A esse respeito, pontua a auxiliar de enfermagem:

\footnotetext{
"Só que assim, tem mães que além de eu fazer a visita, eu tenho que ligar, porque ela sente a necessidade. E se eu não ligo, eu sou cobrada: nossa, você nem me ligou... Então, é uma coisa de se apegar, de confiar". (Depoimento, Auxiliar de Enfermagem, 26/09/08).
}

\subsubsection{CONSULTA PUERPERAL}

Em março de 2008 a coordenadora do ambulatório, também enfermeira-obstetra, passou a atender puérperas às terças-feiras pela manhã. Posteriormente, a enfermeira responsável pelo pré-natal incorporou em suas tarefas esse atendimento. A consulta, agendada durante a visita domiciliar, é marcada, geralmente, entre a segunda e a terceira semana após o parto, e abarca os seguintes procedimentos: avaliação da puérpera e do bebê; provimento de orientações; e encaminhamento da usuária ao ginecologista, para o prosseguimento do cuidado puerperal e, mais especificamente, para orientação sobre contracepção - alvo de preocupação das mulheres nessa fase, segundo relato de uma colaboradora (Diário de campo, Núcleo Monte Azul, 03/04/08). Sobre esse encaminhamento ao ginecologista, uma profissional o refere como fundamental, porque "quem medica é médico" (Depoimento, Auxiliar de Enfermagem, 26/09/08). Por fim, dá-se encaminhamento do bebê ao pediatra.

Embora o protocolo no Núcleo estabeleça apenas uma consulta puerperal com a enfermeira, dependendo da demanda expressa/identificada, outras podem ser agendadas (Diário de Campo, Núcleo Monte Azul, 27/03/08). Ademais, especial atenção parece ser dada ao vínculo formado entre a enfermeira e a mulher: quando a auxiliar de enfermagem identifica um ponto mais delicado sobre o qual a puérpera talvez não se sinta à vontade para abordar com o/a ginecologista, ela agenda uma nova consulta com a enfermeira, pois "foi a pessoa que fez o pré-natal e é onde [se] consegue amarrar" (Depoimento, Auxiliar de Enfermagem, 
26/09/08).

\title{
6.5.9.3. O POSTO DE COLETA DE LEITE MATERNO
}

O posto de coleta de leite materno, inaugurado em maio de 2007, é fruto de um projeto originalmente proposto pela coordenadora do ambulatório. Diz ela:

\begin{abstract}
"Quando eu cheguei aqui, não tinha esse trabalho. Daí eu conheci um outro e senti muito desejo da gente implantar aqui. Porque realmente é fantástico, né? Esse poder do leite para uma criança prematura, para uma criança hospitalizada... Então eu achei, e pensei junto com algumas pessoas aqui, que a gente podia fazer esse trabalho, já que a gente incentiva o aleitamento... Tem muita mãe que tem leite excedente, né? Então, por que não doar? Por que jogar fora? Já que aqui na Monte Azul a gente tem muito essa questão do reaproveitamento... da reciclagem. Então, leite também. Vou jogar fora por que, se ele é vida? Se ele pode salvar vidas!" (Depoimento, Coordenadora do Ambulatório, 19/11/08).
\end{abstract}

Uma sala do ambulatório do Núcleo Monte Azul foi equipada para funcionamento do posto de coleta com: uma poltrona, para acomodar as mulheres que desejassem doar leite quando estivessem no ambulatório - lembrando que o leite é geralmente coletado durante as visitas domiciliares realizadas pela auxiliar de enfermagem; uma pia; e uma geladeira, onde é feita a estocagem do material até sua retirada pelo Hospital Regional Sul.

Durante o pré-natal a auxiliar de enfermagem divulga o trabalho entre as gestantes convidando-as, após o parto, para integrar o projeto. Se aceito o convite, são realizadas visitas semanais, para coleta de doações e acompanhamento do aleitamento. Dado que o trabalho é também divulgado na comunidade, há, entre as doadoras, mulheres que não fizeram seu prénatal no Núcleo Monte Azul (Diário de campo, Núcleo Monte Azul, 24/01/08).

No período de janeiro a outubro de 2008, de acordo com a coordenadora do ambulatório, foram doados 29 litros de leite, com participação média de duas a seis doadoras a cada mês (Depoimento, Coordenadora do Ambulatório, 19/11/08). 


\section{DEPOIMENTOS: EM BUSCA DE SENTIDOS}

Esta seção é dedicada à análise das entrevistas realizadas com as usuárias do serviço de atenção ao pré-natal e ao puerpério do Núcleo Monte Azul e com as profissionais por eles responsáveis. O trabalho aqui empreendido é eminentemente descritivo dos temas que se destacaram dos depoimentos, entendendo-se a descrição como um primeiro passo à apreensão dos fenômenos. Buscando, então, um desvelamento de percepções, experiências e sentidos nos discursos de cada grupo de participantes, entrevistas com usuárias são analisadas separadamente daquelas realizadas com profissionais. Será na etapa da discussão dos dados que se tentará tecer interpretações que revelem encontros e desencontros entre esses universos e entre estes e o contexto de produção do cuidado no Núcleo.

\subsection{DESVELANDO O UNIVERSO DE MULHERES-USUÁRIAS}

Considerou-se importante ampliar a caracterização das usuárias participantes apresentada na seção de método (p. 123), acrescentando-se-lhe alguns dados concernentes ao acompanhamento pré e pós-natal por elas realizado no Núcleo Monte Azul e alguns aspectos de suas vivências durante o ciclo grávido-puerperal. Os temas que se sobressaíram em seus depoimentos são descritos na sequência.

\subsubsection{CARACTERIZAÇÃO DAS USUÁRIAS PARTICIPANTES}

As seis mulheres participantes da pesquisa cumpriram o critério de inclusão, aqui adotado, de realização do acompanhamento pré-natal no ambulatório do Núcleo Monte Azul da Associação Comunitária Monte Azul. Além disso, com exceção de Leila, acerca da qual não se obteve dados completos, em função da não localização de seu prontuário, todas as 
demais se submeteram, pelo menos, a seis consultas pré-natais. Na tabela a seguir (Tabela 9), visualiza-se o número de consultas de cada mulher, o momento em que se deu a primeira consulta e a distribuição delas ao longo dos trimestres gestacionais.

Tabela 9 - Número de consultas pré-natais realizadas pelas participantes e distribuição ao longo dos trimestres gestacionais

\begin{tabular}{lccc}
\hline Participante & $\mathbf{N}^{\mathbf{0}}$ Total de Consultas & Primeira Consulta & Distribuição das consultas \\
\hline Gabriela & 11 & 13 semanas & $1^{\circ} \mathrm{T}: 1 / 2^{\circ} \mathrm{T}: 3 / 3^{\circ} \mathrm{T}: 7$ \\
Leila & - & - & - \\
Carolina & 13 & 7 semanas & $1^{\circ} \mathrm{T}: 3 / 2^{\circ} \mathrm{T}: 6 / 3^{\circ} \mathrm{T}: 4$ \\
Lourdes & 16 & 10 semanas & $1^{\circ} \mathrm{T}: 2 / 2^{\circ} \mathrm{T}: 4 / 3^{\circ} \mathrm{T}: 10$ \\
Juliana & 7 & 23 semanas & $1^{\circ} \mathrm{T}: 0 / 2^{\circ} \mathrm{T}: 1 / 3^{\circ} \mathrm{T}: 6$ \\
Sofia & 6 & 21 semanas & $1^{\circ} \mathrm{T}: 0 / 2^{\circ} \mathrm{T}: 4 / 3^{\circ} \mathrm{T}: 2$ \\
\hline
\end{tabular}

$1^{\circ} \mathrm{T}$ : primeiro trimestre; $2^{\circ} \mathrm{T}$ : segundo trimestre; $3^{\circ} \mathrm{T}$ : terceiro trimestre

No que concerne ao total de consultas realizadas por Carolina, é importante considerar a possibilidade de falhas no registro em seu cartão, uma vez que ela relata ter comparecido semanalmente ao pré-natal a partir do sexto mês de gravidez, em virtude do quadro hipertensivo então instalado. No caso de Sofia, o fato de, ao final da gravidez, ela ter passado a ir ao consultório particular de uma das enfermeiras (o que revela a relação diferenciada que essa mulher estabeleceu com o serviço), possivelmente foi fator de impacto sobre o total de consultas. Cabe ainda a observação de que ambas - Carolina e Sofia - fizeram acompanhamento pré-natal no Núcleo e, paralelamente, na rede conveniada; e que Juliana e Sofia estavam, antes de iniciarem o pré-natal no Núcleo, em acompanhamento em outros serviços - Juliana, na rede pública e Sofia, na rede conveniada.

Quanto à atenção ao puerpério e à participação das mulheres em outras atividades incluídas na atenção pré e pós-natal provida pelo Núcleo, identificaram-se ao menos três fases no serviço em pauta, ao longo da coleta dos dados: a primeira, em 2007, quando havia consultas pré-natais e o ciclo de palestras, este ainda em sedimentação; a segunda fase, a partir do início de 2008, em que estavam começando a ser estruturadas novas atividades, tais como as consultas puerperais, as visitas domiciliares, um novo ciclo de palestras, o grupo de trabalho corporal e o acompanhamento odontológico; e a terceira fase, com tais atividades, 
então, já mais estruturadas.

Tabela 10 - Fases do serviço

\begin{tabular}{|c|c|}
\hline Fase & Configuração do Serviço \\
\hline 1 & $\begin{array}{l}\text { - Consultas pré-natais } \\
\text { - Ciclo de palestras em constituição }\end{array}$ \\
\hline 2 & $\begin{array}{l}\text { - Consultas pré-natais } \\
\text { - Em constituição: } \\
\text { - Consultas puerperais } \\
\text { - Visitas domiciliares } \\
\text { - Ciclo de palestras em novo formato } \\
\text { - Grupo de trabalho corporal } \\
\text { - Acompanhamento odontológico }\end{array}$ \\
\hline 3 & $\begin{array}{l}\text { - } \text { Consultas pré-natais } \\
\text { - Consultas puerperais } \\
\text { - Visitas domiciliares } \\
\text { - Ciclo de palestras em novo formato } \\
\text { - Grupo de trabalho corporal } \\
\text { - } \text { Acompanhamento odontológico }\end{array}$ \\
\hline
\end{tabular}

Dentre as participantes, considerado o período em que utilizaram o serviço de atenção ao pré-natal e ao puerpério do Núcleo, conforme ilustrado pela Tabela 11, uma pertencia à primeira fase; quatro, à segunda fase - ou seja, estavam finalizando o acompanhamento prénatal em meio à estruturação das novas atividades e, por isso, nem todas tiveram acesso a elas; e uma, à terceira fase. 
Tabela 11 - Fase de utilização do serviço pelas participantes

\begin{tabular}{|c|c|}
\hline Participante & Momento do Serviço \\
\hline Gabriela & Fase 2 \\
\hline Leila & Fase 2 \\
\hline Carolina & Fase 2 \\
\hline Lourdes & Fase 1 \\
\hline Juliana & Fase 3 \\
\hline Sofia & Fase 2 \\
\hline
\end{tabular}

No que se refere à atenção pós-natal, quatro, das seis participantes, realizaram consulta puerperal no Núcleo, com uma enfermeira-obstetra. Dentre as demais, Sofia foi acompanhada, durante esse período, por uma das enfermeiras em seu consultório particular. E Lourdes relata ter comparecido ao ambulatório do Núcleo, no pós-parto, para a retirada dos pontos da cesariana e em momentos em que sentiu necessidade; não houve, porém, registro em seu prontuário que configurasse alguma dessas ocasiões em consulta puerperal, a qual não estava, ainda, estruturada. Esse último caso, portanto, será classificado como "alguma assistência durante o pós-parto"; prerrequisito atendido, então, por todas as mulheres participantes da pesquisa. Ademais, duas das entrevistadas consultaram-se posteriormente com ginecologista; e três receberam visitas domiciliares - dentre as que não receberam, uma (Sofia) não pertencia à área de abrangência do Núcleo Monte Azul, e a outra (Leila) relatou ter recebido visita da UBS. 
Tabela 12 - Atenção recebida no puerpério

\begin{tabular}{|c|c|}
\hline Participante & Acompanhamento pós-natal \\
\hline Gabriela & $\begin{array}{l}\text { - } 3 \text { visitas domiciliares } \\
\text { - } 1 \text { consulta puerperal com enfermeira } \\
\text { - } 1 \text { consulta com ginecologista }\end{array}$ \\
\hline Leila & $\begin{array}{l}\text { - } \quad \text { Não recebeu visitas domiciliares } \\
\text { - } 1 \text { consulta puerperal com enfermeira }\end{array}$ \\
\hline Carolina & $\begin{array}{l}\text { - } \quad \text { Ao menos } 1 \text { visita domiciliar } \\
\text { - } 1 \text { consulta puerperal com enfermeira } \\
\text { - } 1 \text { consulta com ginecologista }\end{array}$ \\
\hline Lourdes & $\begin{array}{l}\text { - Não recebeu visitas domiciliares } \\
\text { - Não realizou consulta puerperal } \\
\text { - Retirada de pontos da cesariana e busca de suporte no } \\
\text { ambulatório }\end{array}$ \\
\hline Juliana & $\begin{array}{l}\text { - Relata ter recebido visitas domiciliares } \\
\text { - Realização de } 2 \text { consultas puerperais com enfermeira }\end{array}$ \\
\hline Sofia & $\begin{array}{l}\text { - Não recebeu visitas domiciliares } \\
\text { - Realizou consultas puerperais no consultório particular da } \\
\text { enfermeira }\end{array}$ \\
\hline
\end{tabular}

A tabela a seguir (Tabela 13) demonstra a participação das mulheres em outras atividades durante o pré-natal e após o parto. Cabe ressaltar que essa participação não diz respeito, em todos os casos, apenas à fase do serviço, ou seja, ao oferecimento, ou não, de tais atividades, ainda que Juliana, representante do que aqui se nomeou como Fase 3, tenha relatado participação assídua em todas as atividades, durante o pré-natal, e estivesse apenas esperando melhor se recuperar do parto para então retornar, no pós-parto, ao grupo de trabalho corporal. Os casos de Gabriela e Sofia acusam, principalmente, dificuldades de participação em palestras em função do horário de trabalho. Porém, se Sofia, em licençamaternidade, compareceu semanalmente ao Núcleo para participar das palestras e do grupo de trabalho corporal, o mesmo não se deu com Gabriela. Leila, por outro lado, diz não tê-lo feito, “não por falta de aviso. Por preguiça mesmo". 
Tabela 13 - Participação em outras atividades no pré-natal e após o parto

\begin{tabular}{|c|c|c|}
\hline Participante & Pré-Natal & Após o parto \\
\hline Gabriela & - Participação em uma palestra & $\begin{array}{l}\text { - Não participação em outras } \\
\text { atividades }\end{array}$ \\
\hline Leila & $\begin{array}{l}\text { - Não participação em outras } \\
\text { atividades }\end{array}$ & $\begin{array}{l}\text { - Não participação em outras } \\
\text { atividades }\end{array}$ \\
\hline Carolina & $\begin{array}{l}\text { - Participação em todas as } \\
\text { palestras }\end{array}$ & $\begin{array}{l}\text { - Participação em todas as } \\
\text { palestras }\end{array}$ \\
\hline Lourdes & $\begin{array}{l}\text { - Não participação em outras } \\
\text { atividades }\end{array}$ & $\begin{array}{l}\text { - Grupo de orientação com a } \\
\text { dentista, no terceiro mês pós- } \\
\text { parto }\end{array}$ \\
\hline Juliana & $\begin{array}{l}\text { - Todas as palestras } \\
\text { - Grupo de trabalho corporal } \\
\text { - Acompanhamento } \\
\text { odontológico }\end{array}$ & - Palestras \\
\hline Sofia & - Algumas palestras & $\begin{array}{l}\text { - Algumas palestras } \\
\text { - Grupo de trabalho corporal }\end{array}$ \\
\hline
\end{tabular}

No item chegada ao serviço de pré-natal do Núcleo Monte Azul, tem-se que, das seis participantes, três (Carolina, Gabriela e Leila) já eram usuárias de outros serviços do ambulatório e sabiam da existência do acompanhamento pré-natal. Dentre essas, uma já havia sido ali acompanhada, na época por outros profissionais, na primeira gravidez. Outras três desconheciam-no. Lourdes soube, por meio de uma amiga, que o ambulatório realizava teste de gravidez, e para isso o procurou. Após o resultado positivo, relata, foi convidada pela auxiliar de enfermagem a ser ali acompanhada durante a gravidez. Sofia conta que fazia tratamento antroposófico em outro local, onde não existia acompanhamento pré-natal. Desejava muito que um profissional da Antroposofia a assistisse durante esse período, porém não tinha condições de arcar com os custos de um acompanhamento na rede privada. Em dada ocasião, em local ligado à Antroposofia, conheceu uma das coordenadoras da área de saúde da Associação, que a convidou para fazê-lo no Núcleo. Antes de iniciar as consultas pré-natais, porém, ela se submeteu, ali, a sessões de massagem rítmica e de acupuntura. Juliana, insatisfeita com acompanhamento no posto de saúde, narrou ter tomado conhecimento do trabalho do Núcleo Monte Azul por uma auxiliar de enfermagem que fazia visitas domiciliares à sua vizinha. Convidada para acompanhar o pré-natal no ambulatório, ela foi, 
inicialmente, para uma palestra, quando compartilhou as suas dificuldades e, no mesmo dia, uma das enfermeiras ofereceu-lhe um primeiro atendimento.

Tabela 14 - Modo de chegada ao serviço

\begin{tabular}{lc}
\hline \multicolumn{1}{c}{ Participante } & Modo de chegada ao serviço \\
\hline $\begin{array}{l}\text { Gabriela } \\
\text { Leila } \\
\text { Carolina }\end{array}$ & $\begin{array}{c}\text { Usuária de outros serviços do ambulatório } \\
\text { Usuária de outros serviços do ambulatório }\end{array}$ \\
$\begin{array}{l}\text { Lourdes } \\
\text { Juliana }\end{array}$ & $\begin{array}{c}\text { Usuária de outros serviços do ambulatório e, em gestação anterior, do } \\
\text { pré-natal }\end{array}$ \\
Cofia & Convidada ao pré-natal após realização do teste de gravidez \\
& Convidada ao pré-natal por uma coordenadora do Núcleo \\
\hline
\end{tabular}

É importante também caracterizar, ainda que em apertado resumo, as vivências durante o ciclo grávido-puerperal de cada uma dessas mulheres, uma vez que tais aspectos fazem parte do fundo sobre o qual percepções, discursos e encontros se construíram.

Gabriela relata uma gravidez tranquila, sem intercorrências. Ao final, porém, vivenciou um elevado nível de estresse, por conta de sobrecarga de deveres: cuidar do filho mais velho, reforma da casa, tarefas domésticas e o trabalho que "exige muito" dela. Diz ter descontado no marido muito do estresse vivido o que, por vezes, deixava-o irritado. Por outro lado, recebeu atenção e carinho dos que estavam ao seu lado: "Mas era bom... Foi até uma fase boa, que a gente é bem paparicada, né?’. O parto, uma cesariana, não foi como desejava - normal, por não gostar de "cicatriz em seu corpo". O pós-parto foi ainda mais difícil. Durante a segunda entrevista, no quinto mês após o parto, ela contou estar vivendo uma crise conjugal em meio a um conjunto ainda maior de dificuldades, então acrescido pelos cuidados com o bebê, pelo sofrimento de ter que deixá-lo na creche para poder ir ao serviço e pela exigência de maior carga de trabalho, em razão de dívidas geradas pela reforma da casa. Além disso, sentia-se sem o suporte do marido e da mãe, que estava viajando há alguns meses. Convém ressaltar que Gabriela não estava mantendo vínculo com o serviço do Núcleo nesse período: 
Eu estou achando que se não melhorar, eu não vou conseguir... combinar tudo... dar atenção para tudo. Porque na verdade, eu não sei se eu estou sendo um pouco egoísta, mas depois da gravidez, eu me sobrecarrego com quase tudo. Porque eu tenho meu filho [...] para dar atenção, eu tenho a minha bebê, eu tenho a casa, eu tenho o meu serviço, eu tenho as dívidas que eu tenho que ajudar também [...] Ele [marido] acha que não é, que eu estou botando coisa na minha cabeça, que não é só eu que estou fazendo as coisas. E realmente não é só eu. Mas a que tem que estar à frente de tudo sou eu. [...] Estava pensando que se ela [mãe] estivesse por aqui, não estaria tão difícil assim. Porque eu não estaria tendo que deixar a bebê na creche... Porque isso é muito difícil sabe?

A segunda gravidez de Leila foi, conforme referiu, "cansativa e dolorida", um pouco mais difícil do que a primeira. Sentiu intensas dores nas costas, também por conta do tamanho do bebê, que estava muito grande, segundo ela; dores que foram destacadas como o evento mais marcante da gravidez. Além disso, teve enjoos e "vontades", "frescuras" que não sentiu na primeira gestação. Sentia-se ansiosa e com medo de que surgisse alguma complicação, especialmente no início da gravidez. E, muitas vezes, ficava com raiva e chorosa, devido a desentendimentos com a mãe. O parto, por outro lado, foi muito rápido e tranquilo. O pósparto também transcorreu bem, sem maiores dificuldades. O que mais transparece nesse período é o vínculo com o bebê, como será apresentado adiante.

Carolina descreve sua gravidez como especialmente difícil a partir do sexto mês, quando começou o quadro de hipertensão. A partir de então passou a ter dificuldades para dormir. No último mês, em função do inchaço, relata, "tinha que fazer força para levantar os pés" e, por essa razão, tudo era cansativo. Duas semanas antes do parto, destaca, teve um pesadelo em que via muito sangue. O parto, no hospital de seu plano de saúde, foi uma cesariana difícil, por conta de uma enorme hemorragia, decorrente de um aumento de pressão, que quase a levou para uma histerectomia. Tal vivência parece ter conferido tons mais fortes ao pós-parto. Carolina conta que durante os primeiros dias em casa, "sentia dor nos pontos e pensava que ia morrer". Parecia, também, estar com receio de que seus sonhos fossem o prenúncio de mais experiências difíceis: "Porque aquele sangue do sonho parece que foi o que aconteceu. Então, eu fiquei um bom tempo assim... tudo o que eu sonhava, eu falava, vai acontecer, porque aconteceu da outra vez". Além disso, no início acreditava que não saberia cuidar direito da filha, que havia esquecido como se cuida de um bebê, pois já fazia muito tempo que engravidara pela primeira vez. Segundo narra, porém, ao final, tudo acabou transcorrendo bem. 
Eu acho que com o primeiro foi mais fácil [...] Com ela, como já tinham se passado [...] anos, para mim ficou tudo esquecido, porque é diferente. Até pelo fato de ser menina, para você dar um banho, para você trocar... Eu falo até hoje que eu não lembrava mais como era. Porque depois dele eu não tive contato com nenhum outro bebê. Então, ficava difícil... Eu pensava, ah, não vou saber... [...] Mas aí, foi tudo bem, foi sossegado.

Para Lourdes a gravidez foi "boa", apesar de alguns momentos difíceis. Ao final da gestação sua pressão aumentou e, sabendo do risco que havia para o bebê, "sentia medo, muito medo do que pudesse acontecer com ela [a filha]". Fez um parto cesário, em que, segundo relata, o bebê "nasceu com falta de ar e ficou ainda uma hora no oxigênio". O pósparto foi um pouco sofrido ao longo da primeira semana, em função de dificuldades para amamentar: "no início ela não pegava meu peito. Foram oito dias para poder pegar o peito... Eu ficava nervosa, chorava muito. Mas depois de oito dias ela começou a mamar e aí foi tudo bem". A mãe a ajudou nesse período. De fato, parece que depois a situação se tranquilizou um pouco, pois Lourdes refere que acreditava, durante a gravidez, que sofreria de depressão pósparto, por conta de já ter tido depressão anteriormente, mas ficou bem. Na segunda entrevista, porém, ela parecia um pouco cansada, sentindo-se sem suporte para auxiliá-la nos cuidados com o bebê e com a casa e sem tempo para cuidar de si: "Às vezes é difícil. Não tem tempo pra sair, não tem tempo para nada. [...] É só eu e o pai dela. O pai dela trabalha o dia inteiro... Aí... é só eu. [...] É... muito pesado. Cuidar de casa, dela... Nossa!".

Juliana disse ter sentido a segunda gravidez mais difícil do que a primeira. No início da gestação, passou por algumas dificuldades em função de receios em torno do resultado de um exame que indicava "contato com rubéola". Como será descrito adiante, apenas se tranquilizou quando recebeu esclarecimentos no Núcleo Monte Azul de que tal "contato" não implicava risco algum. Além disso, relata que "sentia muito medo" quando não sentia o bebê mexendo, o que a levava a fazer ultrassonagrafias de modo a checar se tudo estava bem. A partir do sétimo mês sentiu muitas dores, devido ao tamanho e ao posicionamento do bebê, que lhe "machucava o osso" e incomodava as pernas; e de contrações constantes. O parto normal a termo, em um hospital da rede pública, foi, segundo conta,"um pouquinho complicado", em razão de o bebê ser grande e, por um momento, ter se sentido sem forças para continuar; o que resultou em uma lesão, reversível, na clavícula do bebê, segundo ela. Paralelamente, porém, acrescentou, sentiu-se preparada para vivenciar o parto. No início do pós-parto, teve um pouco de dificuldade para amamentar, pois com leite em abundância, 
precisava retirá-lo com uma bombinha; além disso, o bebê não estava com a pega correta, o que gerou feridas nos seios. Após orientações dos profissionais do Núcleo, a situação se resolveu. Também narra ter se sentido melancólica durante algum tempo: "Eu queria chorar por tudo! Por tudo! [...] Parecia que tudo estava me fazendo falta. Aí me batia aquela vontade de chorar. E eu pensava, gente, mas não está me faltando nada!”. Entretanto, recebeu muito suporte do marido e da filha mais velha, durante todo o ciclo grávido-puerperal, além de algum suporte de sua mãe, o que a ajudou a enfrentar tais dificuldades. Passada essa fase, sentiu-se mais madura e mais apropriada de sua capacidade de cuidar do bebê, diferentemente do que viveu em sua primeira gravidez.

\begin{abstract}
[Durante a gravidez] tudo o que eu quis o meu marido me deu... Qualquer hora... [...] No finalzinho da minha gravidez, que eu fui ganhar ela, ele foi me levar, ficou lá comigo. Depois ele pegou férias, foi ele quem cuidou de mim... Eu não fiz nada, ele fazia tudo - fazia comida, limpava a casa... Ficou um mês em casa! Um mês e cinco dias! Para cuidar de mim e dela. [...] A minha mãe veio e ficou uma semana comigo. Mas como o meu marido tirou férias, não precisava ela ficar mais. [...] Então eu não deixei me abalar. Porque eu tinha o amor da minha filha, do meu marido, e agora, essa coisa gostosa da minha vida... que é tudo na minha vida. [...] O carinho do marido, da mãe e da filha, ajuda bastante! Você se recupera mais rápido. Fica tudo bem para você. Para mim foi uma maravilha o meu marido ter pegado férias para ficar em casa.
\end{abstract}

Sofia teve um início de gravidez muito difícil. O quadro de hiperêmese gravídica vivido a levou à internação algumas vezes, sem melhora, o que a deixava cada vez mais abatida: "De não ter vontade de nada mais na vida, porque passava muito mal, só vomitava. Eu cheguei a vomitar 10 vezes num dia. Então, bem difícil, estava bem desanimada”. Além disso, sentia-se com medo à medida que a gravidez ia tomando maior concretude: "Deu uma paranoia. De repente eu tenho um ser aqui dentro. Foi uma coisa meio chocante, que eu nunca tinha parado para pensar... Então, acho que isso que também ajudou a passar muito mal". Não se sentia preparada para viver a gestação, especialmente por não ter tido experiências anteriores de proximidade com mulheres grávidas. Desejava que o marido assumisse um papel presente e participativo como pai; e que o parto fosse natural, o que, para ela, demandava preparação adequada. O parto foi como esperava: normal a termo, em um hospital da rede conveniada, com anestesia apenas ao final. O pós-parto imediato, porém, apresentou algumas complicações: uma anemia intensa e um quadro de infecção hospitalar a levaram a uma semana de internação no hospital e a procedimentos no centro cirúrgico, o que ela 
descreve como "meio pesado". Em relação à maternidade, entretanto, prossegue Sofia, não houve problemas; o marido, ocupando o papel que ela esperava, ficou ao seu lado e a ajudou nos cuidados com o bebê. Quando foi para casa, sentia-se tranquila e segura, mesmo porque, segundo conta, essa era uma parte conhecida, por sempre ter estado rodeada de crianças:

Ah, depois quando eu fui para casa foi a recuperação... Sentia bastante sono, mas com o bebê eu tirei de letra. Não tive problema nenhum. Antes de eu trabalhar fora, eu ficava em casa com a minha mãe, e a minha mãe sempre teve criança em casa. [...] Então eu sempre estive no meio de criança, então eu não tive dificuldade. [...] A minha mãe e a minha sogra até queriam que eu tivesse solicitado mais elas, mas não precisou. Até preferi ficar um pouco mais sozinha, depois quando o meu marido foi trabalhar. [...] Que eu tinha mais liberdade para dormir, para descansar...

\subsubsection{ENTREVISTAS}

A maior parte dos temas descritos a seguir, destacados no conjunto de entrevistas realizadas com as mulheres-participantes, já havia sido anteriormente definida como norteadora de análise, quando da elaboração dos roteiros de observação e de entrevista. Outros, porém, sobressaíram a partir da leitura dos depoimentos. Tais temas foram assim nomeados:

- Necessidades da mulher durante o ciclo grávido-puerperal;

- Avaliação do serviço em seus aspectos positivos e negativos;

- Acompanhamento em dois serviços: benefícios e malefícios daí advindos; comparações entre os serviços;

- Vínculo com o bebê e experiência de ser mãe;

- Percepção do impacto do serviço na vivência do ciclo grávido-puerperal. 


\subsubsection{NECESSIDADES DA MULHER DURANTE O CICLO GRÁVIDO- PUERPERAL}

Nos discursos das participantes sobre as necessidades da mulher durante o ciclo grávido-puerperal, dois aspectos se destacam: apoio e diálogo. A gravidez, o parto e o pósparto foram descritos como momentos em que a mulher vivencia um estado de maior instabilidade emocional, muitas vezes sentindo-se deprimida e carente, o que impõe maior demanda por afeto e atenção. Por essa razão, o apoio foi assinalado como fator fundamental, devendo ser oferecido especialmente pelo companheiro; e também pelos familiares, amigos e profissionais. Estes têm papel ainda mais importante quando a mulher não pode contar com o suporte do pai do bebê e daqueles que estão ao seu redor; tendo sido também destacados por sua função de prover orientações, especialmente no pós-parto.

\footnotetext{
Apoio é fundamental. Tanto dos profissionais, quanto da família. (Leila)

Acho que precisa de apoio da família... marido. Apoio, força... Às vezes a gente fica meio deprimida. [...] Como as meninas aqui ajudam. Quando eu preciso eu sempre venho. Elas ajudam, conversam... A [auxiliar de enfermagem]... nossa... ajuda muito. (Lourdes)
}

Eu acho que na gravidez você precisa ter um companheiro legal, que te acompanhe sempre que ele puder. Acompanhar ao médico. Após ganhar, é bom ter o companheiro, ter outras pessoas que te auxiliem - no caso eu tive as meninas do ambulatório. (Carolina)

A mulher, quando está grávida, fica bastante carente, né? Mesmo que ela tenha todo mundo ao seu redor, ela fica bastante carente. [...] A mulher precisa muito de carinho, de compreensão, de bajulação... A gente fica muito carente! E a pessoa fica sem saber por que está desse jeito. Tudo quer chorar... (Juliana)

É importante compreender o conceito que as mulheres têm de apoio/suporte. A partir dos fragmentos acima, deduz-se que apoio se relaciona a afeto, à presença consistente das figuras eleitas para desempenharem tal papel, à compreensão e à ajuda para encontrar os recursos, em si mesmas, que lhes permitam lidar com o vivido.

O tema do diálogo, apontado pelas mulheres, aparece muito associado ao do apoio. Constitui-se de um espaço de escuta em que conflitos e necessidades são ouvidos. E também em um espaço em que dúvidas são esclarecidas, orientações são realizadas, conhecimentos 
são transmitidos. Tal espaço parece favorecer o fortalecimento da autoconfiança da mulher em sua capacidade de gestar, parir e cuidar de um bebê. Tendo mais recursos para lidar com as dificuldades, e sentindo que há um lugar de suporte para os momentos julgados necessários, diminui-se a probabilidade, como pontua uma participante, de que quadros de estresse e de depressão se instalem.

E trocar. Eu acho que isso ajuda muito. Eu até brincava com a [umas das enfermeiras], acho que ela nem gostava muito, eu falava que ela era minha psicóloga. Porque de ouvir mesmo os meus conflitos, para me ajudar. [...] E eu acho que ter informação, ter conhecimento, acho que isso dá muita segurança. [...] um conhecimento também do próprio corpo. [...] [Para que] flua acho que como natural, como deve ser. (Sofia)

Tem que explicar bastante, tem que conversar... Diálogo! É a melhor coisa. [...] Às vezes a mulher tem muitas dúvidas. [...] tem que passar bastante coisa para a mulher. Tanto antes da gravidez, quanto pós também. (Leila)

Eu acho que até a criança ter um ano, você ainda é muito dependente de alguém que saiba mais do que você - de uma enfermeira, de uma médica. [...] Eu acho que muitas mulheres acabam deprimindo porque não sabem como devem fazer. E aí ficam nervosas. E muitas mulheres não têm o parceiro do lado, né? Conforme tem o pessoal do ambulatório, você esquece esse lado tão carente, né? (Carolina)

Outro ponto, mencionado como necessidade da mulher que vivencia esse período, refere-se ao auxílio na construção e no fortalecimento da nova família, oferecido pelo profissional que a acompanha, de maneira que também o pai do bebê possa ser integrado tanto nas ações de cuidado ao ciclo grávido-puerperal como em tal processo de construção.

De trazer uma família, uma coisa acolhedora, e não um... [...] [No convênio] ele [o companheiro] entrava, mas não tinha espaço... Consulta rápida. A médica dá uma olhada e pronto, tchau. (Sofia)

\subsubsection{AVALIAÇÃO DO SERVIÇO}

O espaço de diálogo, especialmente de escuta, encontrado no ambulatório do Núcleo, foi um dos pontos positivos mais mencionados pelas mulheres na avaliação do serviço. Ele foi associado a: esclarecimento de dúvidas e orientação; educação dos 
profissionais, que sabem como conversar com as mulheres, escutando-as e explicando-lhes bem o que necessitam saber; escuta e cuidado das diferentes dimensões vivenciais que cercam a gravidez, como alimentação, saúde do bebê, como melhor proceder para viver bem a gravidez e o parto, e vivências emocionais; espaço de confiança, em que se consegue compartilhar vivências; escuta das necessidades de cada mulher; e espaço de suporte.

\begin{abstract}
Os médicos são perfeitos. Eles são educados, sabe? Conversam. [...] é bom porque tira todas as dúvidas... [...] A [umas das enfermeiras-obstetras] já tem uma doçura, já sabe conversar... E ela não me dava bronca. Ela sabia explicar... [...] eu conversava bastante com as meninas. Com a [auxiliar de enfermagem] principalmente. [...] Ela dava bastante conselho. Sempre dialogou perfeitamente. (Leila)
\end{abstract}

Tudo ela [uma das enfermeiras] me explica. Da minha alimentação, do que eu sinto, do bebê mexer, tudo. [...] Coisa que eu não tenho com outro médico. O médico só fala o básico. O que ele está entendendo para ele está bom. E ela não. Ela deixa a gente à par de tudo. $\mathrm{O}$ que a gente tem que fazer. $\mathrm{O}$ que é melhor para a gente. Se vai fazer mal durante o parto. [...] Ela conversa bastante. E tira minhas dúvidas. Coisas que eu não consigo chegar em outro médico e falar, com ela eu consigo. (Gabriela)

$\mathrm{O}$ atendimento. $\mathrm{O}$ mais importante. Porque o atendimento é tudo, né? De conversar. De ver qual a sua necessidade. O que falta, o que precisa... (Sofia)

Tratam a gente super bem. Adorei o atendimento. A [umas das enfermeirasobstetras] não tenho nem palavras. Muito boa. Conversa com a gente... Dá força. Porque a gente grávida, às vezes fica meio... depressiva, né? Mas ela dá muita força para a gente. É muito boa. (Lourdes)

Em alguns casos, a atenção, o afeto, dados pelos profissionais, e a reciprocidade, encontrada nesse espaço de diálogo, acrescentaram outro tom ao relacionamento com eles: o de amizade. O relato das mulheres indica, entretanto, que esse tom era mais frequentemente sentido na relação com auxiliares de enfermagem, ou profissionais residentes da região.

\begin{abstract}
A [uma das auxiliares de enfermagem] foi uma das que me escutavam bastante. Eu escutava ela. Ela me escutava. Nossa, foi muito bom. Uma amiga que eu ganhei aqui dentro. Eu já conhecia as outras, mas com ela eu nunca tinha conversado. Aí ela foi fazer a minha ficha, a gente começou a conversar e fez amizade. Até hoje, é uma das meninas que eu mais gosto aqui dentro. Gosto bastante dela. (Leila)
\end{abstract}

Até porque, não são só profissionais que estão tratando com a gente. Tem toda uma amizade. Bem ou mal, somos vizinhas. (Gabriela)

Outro aspecto positivo foi o da liberdade de acesso, expresso de diferentes formas: 
poder ser atendida, por encaixe, mesmo sem ter marcado consulta; compartilhar uma dificuldade em uma palestra e, ao final, ser atendida por uma das profissionais; sentir as "portas sempre abertas", para além dos espaços de consulta e de palestra, para esclarecer uma dúvida ou dividir um conflito, seja por telefone seja pessoalmente.

Mas aí a [auxiliar de enfermagem] falou que tinha aqui e aqui eles faziam o prénatal, acabei indo na reunião; na reunião acabei conhecendo [uma das enfermeiras]. E aí ela falou, "você quer descer comigo?". Acabou a reunião, eu desci com ela, ela viu os exames e pediu outro exame de sangue. (Juliana)

[Nos primeiros dias após o parto] sempre que eu tinha alguma dúvida ou algo assim, eu ligava. Tinha dia que o meu marido descia aqui... Mas normalmente eu ligava. Conversava. Elas me olhavam... (Carolina)

Quando eu tenho qualquer dúvida, como eu acho chato ficar ligando para cá, porque elas estão sempre ocupadas com um monte de coisas, [...] eu desço e sempre venho aqui. Eu passo aqui pelo menos uma vez por semana. Aí, se eu tenho alguma dúvida, eu pergunto. Quando a [auxiliar de enfermagem] não sabe, eu pergunto para a [coordenadora do ambulatório]. [...] Na semana passada, a gente teve uma palestra na Casa de Parto. [...] Nas palestras eu não sou de perguntar, as minhas dúvidas eu tiro depois. Mas eu, qualquer coisa eu pergunto. [...] Qualquer problema eu corro lá. [...] Se todo posto de saúde fosse assim, seria muito bom... (Carolina)

Como as meninas aqui ajudam. Quando eu preciso, eu sempre venho. (Lourdes)

Em alguns casos, a liberdade de acesso ampliava-se, como quando a enfermeiraobstetra passava seu número de celular para uma mulher que julgasse precisar desse tipo de suporte - conforme critérios apresentados na seção de descrição do campo. No caso de Sofia, entretanto, a situação parece ter sido permeada por maior especificidade, pois a relação profissional-usuária estabelecida transcendeu o âmbito institucional: Sofia, como descrito, passou a frequentar o consultório particular da enfermeira no final da gravidez, e continuou no puerpério. Além disso, durante o parto, como tal profissional não pôde acompanhá-la, a coordenadora da área de saúde materno-infantil, que também estava acompanhando Sofia no pré-natal, aplicando acupuntura e massagem rítmica, assumiu o papel.

Ela me deu o celular dela para eu ligar se acontecesse alguma coisa... Muito atenciosa, muito mesmo. Amei. (Gabriela)

Mas aí a [enfermeira-obstetra] não pôde me acompanhar no parto: eu fui com a [coordenadora da área de saúde materno-infantil] e o médico mesmo, que já estava sabendo... (Sofia) 
Parece que algumas mulheres, é importante salientar, também desejariam ter esse tipo de possibilidade de suporte.

Ela é enfermeira. Que faz até parto em casa. Se eu pudesse eu faria em casa. Mas como no dia em que eu comecei a sentir dor, foi de noite, e eu não tinha o telefone dela também, então, acabei indo para o hospital. (Juliana)

O desejo de que a enfermeira que realizou o pré-natal fosse a profissional a acompanhar o parto foi também expresso pela expectativa de que a Casa de Parto ficasse pronta a tempo.

E eu também estava aguardando, ver se eu conseguia ganhar neném na Casa. Que ela falou que tomara que já esteja funcionando, porque ela quer pegar minha neném. Então, eu estou aguardando. (Gabriela)

Como parte da avaliação do serviço, outro tema que se destacou no discurso das mulheres foi o de uma atenção sentida como diferenciada, por conta de o cuidado abranger diversas dimensões - consultas de pré-natal, trabalho corporal com fisioterapeuta, acompanhamento odontológico, palestras e oficinas. Também foi mencionada a rapidez com que chegam os resultados dos exames - quando lá realizados, mediante o pagamento da taxa já referida; o menor tempo de espera para atendimento; o exame clínico mais cuidadoso; e as orientações e o cuidado recebidos em casa, durante as visitas domiciliares.

Na gravidez até tive dentista... a dentista cuidou dos meus dentes. [...] Dentista, prénatal, palestras, que eu vou todo mês... tem a aula de ginástica que eu vou... [...] Mas a palestra, eu nunca faltei, que é todo mês também... É muito bom! Explica sobre o parto, sobre como amamentar, sobre tudo! [...] Tem a oficina. Eles dão lanche para as pessoas. É super bom lá. [...] E ainda vou marcar dentista, que ainda vou passar com ela. E depois eu vou dar continuidade a ela [o bebê] também, né? Que ela fala que depois que começar a nascer dente e essas coisas, que é para eu trazer para ela ver. (Juliana)

O exame aqui chega super rápido - de uma semana para outra você já fica sabendo. Não tem muito tempo de espera... aqui rapidinho você marca e você já passa, não demora muito. [...] Aqui eles olham, mediam a barriga, escutava o coraçãozinho... A [enfermeira-obstetra] escuta bastante. [...] [Depois do parto] a [auxiliar de enfermagem] foi lá para ensinar como dava o peito da maneira certa. [...] ela me orientou direitinho. (Juliana) 
Nos primeiros dias que eu cheguei em casa, eu sentia dor nos pontos e pensava que ia morrer. Aí eu ligava para cá, a [auxiliar de enfermagem] conversava comigo [...]. Ela e a [coordenadora do ambulatório] foram na minha casa. [...] No segundo dia o meu peito inflamou. Aí a [coordenadora do ambulatório] foi lá, me ensinou a fazer uma massagem, e aí não inflamou mais. Meu peito sarou. (Carolina)

Os trechos acima parecem evidenciar, ainda, a percepção das usuárias acerca da competência técnica das profissionais, especialmente pelas menções a intervenções cuidadosas e eficazes. Outro aspecto positivo verificado foi o do cuidado guiado pela Medicina Antroposófica. Ainda que as mulheres, com exceção de Sofia, não tenham feito referências diretas à Antroposofia, para algumas, as práticas de terapias externas e a indicação de medicamentos naturais foram fatores que as fizeram preferir o cuidado prestado pelo Núcleo.

\footnotetext{
Evita passar remédio - você toma remédio em último caso. Pode fazer até uma massagem, outra coisa, mas evita tomar remédio. [...] Os remédios aqui são também bem diferentes. [...] eu acho que prejudica menos, porque eles são mais naturais. (Carolina)

Ela falava para a gente fazer tudo naturalmente... nada de artificial e essas coisas. [...] O remédio daqui é natural, não é nada de farmácia e essas coisas. [...] Eu acho [melhor]! (Juliana)
}

Os aspectos negativos, é importante ressaltar, foram, de modo geral, pouco manifestados pelas usuárias, considerando-se também as mulheres ouvidas durante a fase de reconhecimento de campo. O mais frequentemente relatado era: tudo no serviço era bom; não havia nada ali de que não gostassem ou que poderia ser melhorado. Uma participante, ademais, quando questionada a esse respeito, expressou apenas sua gratidão por aquilo que lá recebera, referindo que, se tivesse poder aquisitivo para fazê-lo, ajudaria a Associação naquilo que fosse necessário; ainda que não identificasse algum foco específico.

Eu acho que se eu tivesse muito dinheiro, eu usaria meu dinheiro para fazer tudo aqui. Eu ajudaria aqui em algumas coisas que eu ache que precise. Tipo... doar para a creche... Aqui eu doava para fazer algo que fosse necessário. (Lourdes)

No conjunto dos depoimentos, porém, foram identificadas reações diferentes diante das duas questões do roteiro de entrevista que abordaram o tema, o que revelou significativo 
campo de contradições. Algumas mulheres, quando questionadas acerca do que não gostavam muito no serviço, ou do que consideravam que poderia ser melhor, diziam nada haver para melhorar, apesar de terem mencionado alguma insatisfação ao falarem sobre o que ali transformariam.

Não. Não vi nada aqui que me incomodasse. [...] Aqui eu acho que não tem nada para mudar. Acho que está legal aqui. Todo mundo competente... As médicas ótimas. A [...] uma enfermeira excelente. [...] A [coordenadora da área de saúde maternoinfantil] também. [...] Eu já passei com ela, com a [coordenadora do ambulatório]... Todas uns amores... (Juliana)

Ah, não. Eu acho que está bom. Não. Eu acho que o que importa mesmo é o atendimento e não a estrutura... (Sofia)

Outras, a despeito de terem apontado algum inconveniente ao discorrerem sobre o que não gostavam muito no ambulatório e/ou no serviço, quando questionadas acerca do que transformariam ali, referiram que nada havia para mudar.

Ah... não pensei nisso não! Acho que nada! Não mudaria nada! Todo mundo trata bem aqui e eu acho isso fundamental. Acho que nada eu mudaria. As meninas que estão aqui são maravilhosas. (Leila)

É importante notar, nos relatos acima, que quando as mulheres salientam não haver necessidade de mudanças enfatizam o atendimento, o qual é considerado muito bom, deixando então subjacentes ou esquecidos outros aspectos do serviço, tais como infraestrutura, exames, espera - a despeito de menções negativas a esse respeito em outros momentos do depoimento.

Quanto às insatisfações presentes no discurso das mulheres, o ponto mais frequente não reside no serviço existente até então, mas sim na não abertura, até o momento em que as participantes foram entrevistadas, da Casa de Parto:

A Casa Angela não funcionar ainda eu acho uma pena. (Sofia)

A casa de parto. Que eu tava torcendo para ficar pronta logo, para eu ganhar lá... mas acabou que não deu certo... Mas fora isso, não tenho o que reclamar daqui, que é muito bom. (Juliana) 
Eu queria ter ganhado na Casa Angela, mas... (Leila)

Outros aspectos reportam-se aos exames, ao tempo de espera e ao horário das palestras. Em um dos relatos observa-se que não é feita uma crítica clara e direta aos exames. A princípio a questão é apontada como um inconveniente para terceiros. Quando, adiante, a usuária a enfatiza como uma carência do ambulatório, imediatamente a reveste de tom amenizador, tratando-a como o único ponto negativo no serviço, que ainda assim, apresenta melhor qualidade do que outros.

Tem muita gente que não gosta do ambulatório. Porque não tem isso e não tem aquilo. Mas aqui é bem melhor do que um hospital. Não se compara. [...] Pode faltar assim, em matéria de aparelhagem, mas outra coisa não. (Carolina)

Em relato de outra participante, é mais claramente manifestada a insatisfação de se recorrer à UBS quando não é possível arcar com a taxa cobrada no Núcleo, apontando esse aspecto como algo que gostaria de transformar no serviço.

\begin{abstract}
Porque a própria [enfermeira-obstetra] dá uma opção. Ela fala que tem os exames aqui, mas você vai ter que pagar. Então ela fala, "vai no postinho, ele vai te pedir os exames, você faz lá, que vão ser de graça, e aí você traz para mim". Fica a seu critério. Aí claro, chega uma hora em que você está em um momento difícil e não dá para fazer aqui, né? Então, você tem que ir para lá. Então é essa parte de exames que se eu pudesse eu faria para melhorar. (Gabriela)
\end{abstract}

O tempo de espera, em um relato, foi mencionado em termos mais abrangentes: espera por atendimento no ambulatório. Em outro depoimento, referiu-se, mais especificamente, à demora na pré-consulta; cabe notar, nesse caso, que mais uma vez a menção à insatisfação é seguida de um tom de menor importância.

Ah, demora. Demora um pouco. Muito cansativo ficar esperando. Eu não nasci para isso. Não tenho paciência para esperar. (Leila)

A agilidade das meninas ali na frente. A doutora [enfermeira-obstetra] sabe que eu tenho horário para chegar no trabalho e em relação a isso ela tenta me ajudar. Ela fala, "mas por que você chega aqui cedo e eu só te atendo às $10 \mathrm{~h}$ ? Não, começa a vir antes que eu te atendo antes - a partir das $9 \mathrm{~h}$ eu já estou aqui”. Mas só que as meninas têm todo um preparo antes de eu passar com ela, né? Tem que pesar, tem 
que tirar a pressão. Isso tudo é feito entre as $9 \mathrm{~h}$ e as $10 \mathrm{~h}$. Mas elas ficam ali e não fazem nada. Já dava para elas irem adiantando o trabalho. A própria doutora pediu, acho que não tem por que elas não fazerem. Porque às vezes atrasa o meu lado. [...] A única coisa eu acho. E não é nem nada tão grave... Então, tudo bem. (Gabriela) (grifo nosso)

O horário das palestras não foi apontado pelas participantes como uma crítica ao serviço. Foi aqui destacado, porém, como aspecto negativo, por ter se configurado inviabilizante para aquelas que demonstraram algum interesse em participar dos eventos.

Fui em um ou outro grupo - das palestras de quarta-feira -, porque eu estava trabalhando. (Sofia)

Participei de uma palestra lá na Casa Angela. Porque ficava muito corrido para mim, né? Então, não dava. [...] Eu fico até um pouco chateada de não poder passar pelas palestras quando ela [a auxiliar de enfermagem] me liga perguntando se eu vou. Só não estou vindo com mais frequência por causa do que eu estou te falando - estou totalmente sem tempo. Mas eu quero sim estar vindo aqui sempre, frequentando. (Gabriela)

Outro tema que não foi apontado como crítica, mas que aqui está sendo entendido como integrado aos aspectos negativos do serviço, refere-se à pouca divulgação. Algumas participantes contam que já conheciam o ambulatório, porém, não sabiam que ali se oferecia atenção ao pré-natal. Houve também um caso em que se destacou acreditar-se que o ambulatório era voltado apenas aos usuários das creches e oficinas da Associação.

Eu vim fazer o teste de gravidez aqui. [...] Porque uma colega minha que já tinha feito aqui, falou. [...] Aí na hora que eu fiz o teste, que deu positivo, a moça me explicou que tinha a doutora [enfermeira-obstetra] que fazia o pré-natal. Aí eu decidi fazer aqui. (Lourdes)

Eu já sabia que tinha o ambulatório - passava aqui desde pequena. Uma vez eu fiquei doente, aí meu professor falou que tinha ginecologista aqui, aí eu vim. E aí conversando com o ginecologista, eu soube que tinha o pré-natal. (Leila)

Eu conheço a Monte Azul, a lojinha, sei que tem o atendimento. [...] Mas o pré-natal eu não sabia como era. (Sofia)

Não, para mim isso aqui era só para a escolinha que tem aqui. Mas não, eles atendem as pessoas de fora também. Aí eu tava no posto e acabei vindo para cá. (Juliana) 
Uma das participantes indicou a divulgação do serviço como algo que gostaria de fazer pelo Núcleo; algo que gostaria de transformar, caso pudesse fazê-lo. Pontua, porém, que acredita no fato de que mais acesso ao serviço não depende apenas de divulgação, mas de busca pessoal por algo diferente, como o que a Associação oferece.

Eu gostaria que mais pessoas chegassem até eles. Mas não sei se mesmo sendo uma pessoa poderosa isso seria possível. Porque não são todas as pessoas que estão buscando alguma coisa diferente. (Sofia)

Um aspecto, também mencionado por duas participantes, diz respeito ao espaço físico, que poderia ser mais amplo; para uma delas, mais especialmente, para tornar possível o atendimento de mais pessoas.

\footnotetext{
O espaço não é muito grande, mas... é bom também. [...] O espaço eu acho que poderia ser maior. (Lourdes)

Aqui eu ampliaria. Para poder ter mais salas e poder dar ainda mais assistência, poder pegar todo o público. Não só do bairro, mas de outros bairros também. Porque é maravilhoso aqui, então eu acho que todo mundo mereceria ter um pouco disso aqui. (Gabriela)
}

Outros dois fatores apontados referem-se, na verdade, a atividades que na época em que a participante foi atendida ainda não estavam estruturadas. De qualquer forma, valem ser mencionados, uma vez que destacam a importância de sua existência. Um deles concerne à atenção ao puerpério; o outro, à inexistência de pediatra. Quando Lourdes vivenciou essa fase do ciclo grávido-puerperal, o serviço ainda estava começando a ser mais estruturado. Como já mencionado, ela não passou por consulta puerperal, nem recebeu visitas domiciliares, e passou por momentos difíceis em seu pós-parto. Assim ela relata:

Não [me ligaram no pós-parto]... Fez [falta]. É... quando é mãe de primeira viagem então... Se não fosse a minha mãe ficar comigo... Nossa! [...] Eu acho que tinha [sido melhor se alguém tivesse ido lá ajudar]. (Lourdes).

Quanto ao outro fator, Lourdes se deu por satisfeita quando a especialidade foi incluída no ambulatório, conforme retrata: 
O que eu achava que estava faltando era o pediatra. Mas agora já tem... Eu sempre vinha e perguntava se já tinha. Aí a [auxiliar de enfermagem] me avisou, ligou para mim e falou que já tinha. Aí eu trouxe ela [a bebê]. (Lourdes)

\subsubsection{ACOMPANHAMENTO EM DOIS SERVIÇOS}

Quatro dentre as seis mulheres participantes mantiveram vínculo, durante o pré-natal, com dois serviços: duas, com o Núcleo Monte Azul e com a rede conveniada; e duas, com o Núcleo e com a UBS. As que relataram terem se dirigido à UBS apontaram como razão a realização de exames. Gabriela, assim como outros casos observados durante a fase de reconhecimento de campo, passou por consulta com o médico pré-natalista do posto de saúde apenas pontualmente, para poder realizar os exames. Leila, porém, encontrou um meio de não ter de fazê-lo: conseguia encaixes com a ginecologista da UBS, que então lhe passava novos pedidos de exame.

\footnotetext{
Eu comecei aqui primeiro. Só que ela me encaminhou para lá porque tinha exames para ser feito (sic). Coisa que aqui paga uma taxa. [...] Aí eu optei por iniciar lá, para que eu ganhasse os exames. É o mínimo também, né? Já que o atendimento já não é tão... Aí eu fiz os exames lá e vim para cá. E desde então eu parei de ir lá. (Gabriela)

Ela pede aqui. Como no posto que eu vou não aceita o pedido da Monte Azul, apesar de ser associado, eu faço encaixe lá, falo só com a ginecologista, mostro os exames que a médica aqui pediu, ela faz outro [pedido] e aí eu faço lá. (Leila)
}

No que concerne à manutenção do acompanhamento pré-natal paralelo na rede conveniada, foram destacadas: a garantia de um local para a realização do parto, a conveniência da realização de exames e a possibilidade de atendimento em horários em que o ambulatório está fechado, como aos finais de semana - ainda que, nesse caso, a comparação seja entre serviços de atenção primária e serviços de atenção terciária, e apenas estes últimos possam dar conta de demandas em horários como os que a participante referiu.

Facilita para ganhar, né? Não precisa ir para um hospital público, ficar esperando... Então, você já tem o lugar certo. [...] Não dá para parar o convênio, porque a gente nunca sabe. Final de semana... (Carolina) 
Observou-se, porém, alguns inconvenientes no acompanhamento em dois serviços. Em um dos casos, a mulher, sentindo-se bem cuidada no Núcleo, não compreendia por que continuar a ir à UBS. Em outro, acabou por haver falha no acompanhamento - alguns exames não foram pedidos ao final da gestação - que, segundo a participante, ocorreu em função das muitas mudanças de médico que fez na rede conveniada.

\begin{abstract}
Aí eu fiz os exames lá e vim para cá. E desde então eu parei de ir lá. Porque eu não vi necessidade de eu ir. Sendo bem tratada aqui. Tendo todo o apoio que eu preciso aqui... Bem mais do que lá... Eu falei, ah, não tem necessidade de ir em dois lugares. (Gabriela)

O que complicou um pouco depois foi que quando eu fui sair do hospital eu passei mal, tive uma anemia fortíssima. Mas eu acho que já veio antes, da gravidez, porque eu dei uma bobeada, o médico não pediu exame... Porque como eu queria muito parto normal, [...] eu fui trocando de médico. Porque os médicos de convênio queriam marcar cesária já. [...] Então, eu acho que por isso, de eu ficar trocando muito de médico, e eu peguei esse quadro no final da gravidez, ele [o médico que fez o parto] acabou não pedindo exame para ver anemia e eu fiquei com uma anemia bem forte depois do parto. [...] Porque eu também não lembrei, e o médico também acabou não pedindo. Ele pediu outros e esse ele não pediu. Então, acabou atrapalhando um pouco. (Sofia)
\end{abstract}

Uma questão que se observa nesse tema de acompanhamento em dois serviços diz respeito às comparações que as participantes efetuaram entre ambos - ainda que um tom comparativo, em relação à temática da avaliação do serviço, tenha marcado todos os depoimentos. De todo modo, faz-se interessante explorar essas comparações porque, ao mesmo tempo em que evidenciam a motivação das usuárias para se manter em acompanhamento no Núcleo - em vez de optar por ficar apenas no outro serviço - fornecem mais dados acerca de como o avaliam. Também aqui o tema do espaço de diálogo se destacou:

No convênio, você chega lá, a médica olha, ela fala o que ela acha, pergunta se você está bem... mas não tem aquele aconchego, é diferente, né? [...] Você passa cinco ou dez minutos na sala. E às vezes, o que você fala não é levado em consideração. [...] As duas coisas são importantes [escuta e aparelhagem]. Mas eu acho que a pessoa olhar para você, conversar com você, tocar você para saber o que você tem, é bem mais importante. Porque às vezes, tem pessoa que fala, estou com isso ou estou com aquilo, e aí, uma conversa... [...] Se todos os postos de saúde fossem como aqui, muitas pessoas não entrariam em depressão como a gente vê por aí, né? (Carolina)

O acompanhamento aqui é bem melhor que o do posto. [...] A médica te dá uma assistência melhor. Te informa. Ela te explica. Coisa que os médicos do postinho não 
fazem. Não fazem. Tanto que eu parei de ir. (Gabriela)

Eu passava lá em cima na [UBS]. Eu não fiquei muito confortável de passar com o médico de lá porque ele não passava direito as informações. Eu não gostava... E por causa de um exame que eu acabei fazendo, deu um resultado e ele não me explicou direito, eu resolvi procurar outro lugar. (Juliana)

Mais um ponto, também relacionado com tal espaço dialógico, já descrito como a ele associado, refere-se à escuta das necessidades de cada mulher, que aqui parece ficar mais evidenciado como ver cada mulher em sua unicidade. Nesse caso, parece que a usuária não se sente apenas mais uma. Ela pode expressar sua singularidade e ser ouvida, o que a faz se sentir verdadeiramente olhada e cuidada.

Aqui é diferente, né? É especial... Tem coisa que no convênio médico... A médica chega lá, para toda grávida é o mesmo procedimento. Então, você chega lá, ela não quer saber do jeito que você está ou não; "ah, você toma isso e isso e pronto". É diferente. E aqui eles vêem cada uma. Qual a necessidade... (Sofia)

Não é uma consulta que você chega e o médico está lá anotando. Não. São 40 minutos de consulta. Ela pára. Ela olha para você. Ela pergunta. E você tem a possibilidade de expor o que você acha. Não é a médica que diz, "você está com isso". Não, "eu estou sentindo assim e assim”, você explica. (Carolina)

O cuidado guiado pela Antroposofia também foi novamente mencionado. Aqui, entretanto, uma das participantes deu mais ênfase à insatisfação que sentia com a abordagem alopática do acompanhamento na rede conveniada, a qual acreditava não estar contribuindo para melhora do quadro de hiperêmese que vinha apresentando.

Eu ia na médica no convênio, que era a que estava me acompanhando no pré-natal e ela, “ah, não tem o que fazer, é assim mesmo". E aí ela falou, vai para o hospital se você estiver muito ruim. Então, eu ia sempre para o hospital e eles davam dramin, plasil... Mas não adiantava nada. Então, eu acabava tomando remédio mais forte ainda. [...] Mas aí, acabei indo na Monte Azul. Passei com a [coordenadora da área de saúde materno-infantil], com a [enfermeira-obstetra] e aí que foi melhorando. E com coisas simples: fazendo escalda-pés... ajudava a dar uma centrada melhor... (Sofia)

Esse tipo de escuta e de cuidado foi também associado por essa participante à preparação da mulher para o vivido ao longo do ciclo grávido-puerperal, para que ela tenha condições de escolher como quer vivenciar cada fase; mais especificamente, que saiba que o 
corpo feminino foi preparado para dar à luz naturalmente, e assim possa então preparar-se para poder fazer essa escolha.

Porque é bem voltado mesmo para o... não sei se é para o natural. Os médicos de convênio, acho um absurdo, não dão opção para a pessoa, eles impõem o que eles querem. E a Monte Azul, é o contrário, é totalmente o contrário. De escolha, de preparar a pessoa. [...] Até não sei se você já ouviu um comentário da [enfermeiraobstetra]: se fosse para as mulheres terem bebê por cesária, Deus teria feito um zíper na barriga, abria, tirava o neném, fechava o zíper. É isso mais ou menos o que eu acho. Elas dão condições lá para que a gente conheça tudo isso. No convênio não. (Sofia)

Outros aspectos comparados foram os de espera, que, segundo a participante, embora também aconteça no Núcleo, não se compara àquela que ocorre na UBS,

Ah, aqui é bem melhor. Eu reclamo da demora aqui, mas é bem melhor. No posto de saúde demora mais. E... às vezes não tira tanta dúvida que nem aqui. De posto de saúde eu não gosto muito não. Prefiro aqui. (Leila)

Atenção diferenciada, que, segundo a usuária, no que se refere a exame clínico, na UBS não acontece de forma tão cuidadosa,

E eles não são muito de olhar direito. Aqui não. Aqui eles olham, mediam a barriga, escutava o coraçãozinho... A [enfermeira-obstetra] escuta bastante. (Juliana)

Liberdade de acesso, que, de acordo com a participante, também não acontece na UBS,

Porque no posto, às vezes você vai, você não marca a consulta e você vai, você nem passa. Aqui eu não marcava, às vezes eu vinha por encaixe, e eles atendiam muito bem. Nunca vim aqui para não passar. (Juliana)

E exames. No que se refere a esse aspecto, a participante parece pesar os benefícios e malefícios de cada um dos serviços. Aponta como vantagem a gratuidade dos exames na rede pública. Por outro lado, a demora dos resultados é mencionada como um fator difícil para uma 
mulher grávida, que anseia por saber se tudo está bem consigo e com o bebê; demora que não acontece no Núcleo.

Os exames... eu fiz lá, porque eu comecei lá, só que lá demorava... apesar que lá era público, né? Aqui eu já fiz pago... Mas demorava mais ou menos dois meses para chegar o exame... Pra gente que está grávida, a gente quer saber logo, né? Porque além da vida da gente, ainda tem outra vida que está dentro da gente. (Juliana)

\subsubsection{VÍNCULO COM O BEBÊ E EXPERIÊNCIA DE SER MÃE}

Apesar de o vínculo com o bebê não ter sido um tema diretamente investigado nas entrevistas, observou-se que a maior parte das participantes mostrou-se preocupada com o bem-estar de seu bebê e sobre ele expressou proximidade e carinho.

Foi gostoso. Sorrisinho, chorinho... [...] Em relação a ela foi tudo bom. Agora que está querendo falar está melhor ainda. (Leila)

Todo dia eu vou sair, eu olho para ela, eu penso, "ai que vontade de ficar com você. De dar atenção...”. E ela tão de um jeito... Dá mais vontade de ficar com ela e nenhuma vontade de desapegar. Ela acorda... assim que ela põe a carinha no berço, ela já abre aquele sorrisão... É um amor. (Gabriela)

E ele também um anjinho, porque com um mês ele já dormia a noite inteira. Não é um bebê de ficar chorando, não teve cólica... (Sofia)

Não pode passar despercebido o fato de, em dois casos, o bebê, desde a gravidez, ter sido considerado um ser em relação com o mundo. Em um dos casos, já expressava reações emocionais quando em interação - via ventre materno - com os demais; e no outro, a mãe demonstrava preocupação sobre as dificuldades vividas ao longo da gestação interferirem no desenvolvimento do bebê.

Ela gostava muito quando ele [o marido] passava a mão na minha barriga. (Juliana)

Olha, eu tentei ao máximo me controlar. Mesmo porque eu pensava muito na neném. [...] Eu fico olhando o jeito da bebê. Ela é muito tranquila. Eu pensei, "ah meu deus, eu estresso tanto! Será que vai afetar meu bebê?” E não. Ela é a calmaria em pessoa. 
(Gabriela)

No pós-parto, destacam-se as situações em que, apesar de dores e dificuldades, a mulher mantinha-se disponível para os cuidados com o bebê.

Mas o bebê ficou junto, me acompanhando. [...]. Mesmo assim eu consegui amamentar, apesar das dores, que eu passava bem mal. (Sofia)

[...] às vezes machucava. Meus bicos feriram bastante. [...] Meus peitos ficaram enormes. Então, ela não conseguia pegar direito e quando ela pegava... machucava, feria, saía sangue... Mas mesmo assim eu dei! Mesmo ferido. (Juliana)

Finda a licença-maternidade, foram expressas preocupações em torno de se ter que entregar o bebê aos cuidados de terceiros.

Eu observo muito meu bebê, sabe? As reações. Porque o bebê é assim: se estão fazendo bem para ele, ele adora. Então, eu vou deixar ela na creche, eu fíco observando - ela gosta muito da tia. Ela vê, já abre aquele sorriso... Disso eu tiro que deve estar indo tudo bem. (Gabriela)

Acerca da experiência de ser mãe, alguns aspectos apontados pelas mulheres também remetem à disponibilidade materna para os cuidados com o bebê. Disponibilidade essa permeada pela consciência de que aquele ser depende de cuidados, o que por vezes implica prioridade em horários e em escolhas. Em algumas situações, isso parece ser encarado com naturalidade, como algo que simplesmente faz parte da maternidade - caso da participante que coloca como pano de fundo de menor importância as transformações no corpo advindas dessa experiência e eventuais dores provocadas pela amamentação, pois em primeiro lugar estaria a nutrição e o cuidado do bebê.

Eu falo, ah, a partir do momento que você engravida, seus peitos automaticamente caem. Eles enchem de leite, depois esvaziam... Então, já que vão cair, já deixa cair logo que pelo menos você alimentou seu filho. [...] Porque tem mãe que fala, "ah, começa a ferir, eu não aguento dar", porque dói muito. Mas se não for assim, você não vai alimentar seu filho. Então, mesmo com dor eu dei. Em vista da dor do parto, isso aqui não é nada, né? (Juliana) 
Em outras situações, essa experiência parece ser, ainda, fator que promove amadurecimento, na medida em que a adoção do papel de cuidador demanda maior responsabilidade.

\begin{abstract}
Por mais que quando você está grávida, ah, eu não quero meu filho, eu não quero, quando você vê... De você saber que está carregando um ser ali, que começa a crescer, mexer... Aos poucos você amolece e é capaz de defender seu filho de tudo e de todos. [...] Como mãe, você fala, "ah, eu tenho uma pessoa agora que depende de mim, né?" Então, ser mãe é ficar muito mais responsável, saber que tem uma pessoa que depende totalmente de você. (Carolina)
\end{abstract}

Há vezes, porém, em que a ambivalência se evidencia, e o lado sofrido de tanto desvelamento fica mais nítido.

Acho que é tudo de bom! Nossa, é uma experiência inesquecível! [...] Muda tudo! É outra vida. Antes você acordava tarde... agora você tem que acordar na hora que ela chorar. Tem dia que nem dorme. Toda hora fica olhando... é uma preocupação. [...] Vivo para ela. Não faz mais nada, não se cuida... Tudo é ela... [...] Às vezes é difícil. Não tem tempo pra sair, não tem tempo para nada. (Lourdes)

A experiência de ser mãe foi ainda associada à construção de uma família, com o engajamento do homem e da mulher; construção que parece requerer, por vezes, o auxílio de profissionais de saúde para apoiá-la e facilitá-la.

Vem uma família. A [enfermeira-obstetra] lidou muito com isso - comigo e meu marido na gravidez. De realmente agora ter uma família. E vem uma família bem legal. Com mudanças, até do meu marido... sempre pensando no bebê também. Ai, ainda está difícil falar. Ah, sei lá, eu estou transbordando de felicidade. (Sofia)

Por fim, foi destacado o afeto recíproco e genuíno como algo que caracteriza a maternidade:

Ter alguém que ama você de verdade... [...]. E amar também... dar todo o carinho que tem guardado dentro da gente... (Leila) 


\subsubsection{PERCEPÇÃO DO IMPACTO DO SERVIÇO NA VIVÊNCIA DO CICLO GRÁVIDO-PUERPERAL}

Antes de adentrar na descrição desse tema, é importante mencionar que alguns pontos já foram anteriormente destacados a esse respeito. Quando as participantes estavam discorrendo sobre as necessidades de uma mulher que vivencia o ciclo grávido-puerperal, estavam também se referindo às suas próprias necessidades, algumas das quais foram atendidas, segundo relataram, no Núcleo Monte Azul. Da mesma forma, quando estavam avaliando o serviço, ou comparando-o com aquele fornecido por outras instituições, remetiam-se a alguns benefícios percebidos em suas vivências a partir do acompanhamento no Núcleo. Portanto, faz-se, agora, a retomada de alguns desses aspectos já apontados e o acréscimo de outros, concernentes à temática, que foram apreendidos do discurso das participantes.

O tema suporte foi um dos mais mencionados pelas mulheres. Suporte que se traduziu em espaço de escuta e aconselhamento. Em garantia de um lugar de referência para o qual a mulher podia se dirigir quando sentia necessidade. Em convite para atividades que propiciavam sensações de cuidado e atenção; além, talvez, de facilitarem a elaboração do vivido. E em presença, especialmente nos momentos em que não havia outra figura de apoio com que a mulher pudesse contar; algo que, em alguns casos, era acrescido do sentimento de amizade vivido na relação com o profissional de saúde.

Eu brigava muito com a minha mãe. E sempre chegava aqui chorando. Tanto é que eu conversava bastante com as meninas. Com a [auxiliar de enfermagem] principalmente. [...] Ela dava bastante conselho. [...] A [coordenadora do ambulatório] conversava bastante comigo. Para eu ter calma, paciência, que não adiantava eu passar raiva, que não ia fazer bem. (Leila)

Eu lia muito. E até a [enfermeira-obstetra] falou para mim: "não, pára tudo, não lê mais nada, isso é uma coisa que você vai ter que sentir, e não ficar com mais coisa na cabeça". Se não dá um nó mesmo. E aí que foi acalmando. E fui melhorando. E foi bem legal. O final da gravidez, nossa, foi ótimo para mim. (Sofia)

Eu acho que tanto as meninas aqui que são enfermeiras, quanto o pessoal da equipe médica me ajudou bastante. Tinha dia que eu vinha e falava assim, "não vou aguentar". Quando tinha palestra, as meninas [...] me ligavam de manhã, eu chegava lá, me perguntavam se eu estava bem, tinha uns exercícios para a gente fazer. Então, eu acho que eu ficava mais animada. (Carolina) 
Eles que fizeram parte disso, mais do que todo mundo, sabe? Mais até do que a minha mãe. Porque minha mãe viajou e agora eu fiquei só esse tempo. E chega a ser importante, porque às vezes a minha mãe não está e tem outra pessoa, um amigo... que está ali para dar uma assistência. É muito bom ter um diálogo, uma conversa. [...] Eu estou numa fase que precisa bastante de atenção, então, as meninas aqui estão me dando isso, me proporcionando isso, sabe? [...] Fora que eu estou tendo assistência. (Gabriela)

Esse suporte também parece poder ser traduzido em termos do olhar dirigido para cada mulher e da demostração de interesse acerca de como ela está e de como está seu bebê, com disponibilidade para o que ela precise.

Teve, teve [efeito] sim. Sabe o que eu percebi? [...] É tão bom a gente ter as pessoas que estão sempre à nossa volta... querendo a sua atenção, perguntando se você está precisando de alguma coisa, querendo saber como está o seu bebê... [...] Para mim é muito gratificante, porque é atenção que estão me dando, e isso para mim é muito bom. (Gabriela)

Se te perguntam se você está bem, te dão atenção... acho que isso ajuda bastante, né? (Carolina)

Outro aspecto apreendido do discurso das participantes, muito associado ao suporte, foi o de receber orientações, que aparece diretamente ligado a um contexto de liberdade de acesso. As usuárias sentiam-se livres para comparecerem ao ambulatório sempre que surgisse uma dúvida. Além disso, nas consultas, sabiam haver disponibilidade da enfermeira para ouvilas e prover orientações. Como resultado, sentiam-se mais tranquila, sabendo que encontrariam respostas, confiáveis, quando sentissem necessidade.

Quando eu tenho qualquer dúvida, [...] eu desço e sempre venho aqui. [...] Você fica mais sossegada, porque tem pessoas perto de você que sabem bem mais. (Carolina)

Porque se eu não tivesse vindo passar aqui, eu não estaria me sentindo bem. [...] A [coordenadora da área de saúde materno-infantil] me ajudou - é uma pessoa suuuper legal. A [enfermeira-obstetra] me ajudou bastante - "ah, faz isso, faz aquilo", toda vez que eu vinha, passava o maior tempão na sala comigo, $[\ldots]$ me explicava quando eu tinha dúvida, me orientava. [...] Para mim foi ótimo. (Juliana)

O cuidado mais abrangente, que integra outras dimensões, é também extraído dos depoimentos. Uma das participantes destacou os benefícios vividos a partir dos exercícios que a fisioterapeuta, no pré-natal, durante os grupos de trabalho corporal, ensinou-lhe para aliviar 
as dores sentidas em função do posicionamento do bebê.

Ajuda bastante. Minhas pernas, que eu tinha muita... Porque ela ficava nessa perna, então adormecia muito. E ela [a fisioterapeuta, durante os grupos de trabalho corporal] me ensinava o que fazer... (Juliana)

Sofia, como já mencionado, narrou a melhora vivida no quadro de hiperêmese gravídica, assim como a experiência por ela denominada de "centramento", proporcionadas pelo tratamento antroposófico oferecido no Núcleo.

De não ter vontade de nada mais na vida, porque passava muito mal, só vomitava. Eu cheguei a vomitar 10 vezes num dia. Então, bem difícil, estava bem desanimada. [...] Até que a [coordenadora da área de saúde materno-infantil] veio aqui na loja e falou, não, vai lá na Monte Azul. E aí eu comecei a ir lá [...]. E aí foi a bênção. [...] Passei com a [coordenadora da área de saúde materno-infantil], com a [enfermeiraobstetra], e aí que foi melhorando. E com coisas simples: fazendo escalda pé... ajudava a dar uma centrada melhor... (Sofia)

Outro tema apontado por essa participante diz respeito ao trabalho de fortalecimento da família, durante o acompanhamento no Núcleo, realizado com ela e propiciado pela inclusão do marido nas atividades do pré-natal, especialmente nas consultas.

\begin{abstract}
A [enfermeira-obstetra] lidou muito com isso - comigo e meu marido na gravidez. De realmente agora ter uma família. E vem uma família bem legal. Com mudanças, até do meu marido... sempre pensando no bebê também. [...] E isso foi o que ajudou lá. Engraçado que eu acho que a primeira consulta que eu fui lá foi com a [coordenadora da área de saúde materno-infantil]. E ela atendeu a gente junto. E ele também falava e perguntava, preocupado comigo. Então, o atendimento... ali já começou uma família. (Sofia)
\end{abstract}

$\mathrm{Na}$ maior parte das situações acima referidas, as mulheres relatam suas percepções acerca do impacto do serviço em sua vivência do ciclo grávido-puerperal nomeando, mais nitidamente, o que foi feito no Núcleo - como o suporte, as orientações etc. -, do que o efeito percebido em função de tal atividade ou atitude - na maioria das vezes genericamente descritas como "ajuda". De qualquer maneira, é possível notar que o discurso delas, em geral, retrata terem se sentido, neste serviço, amparadas, acolhidas, reconhecidas em sua unicidade, atendidas em suas necessidades, e cuidadas; o que tanto pode ser observado a 
partir dos trechos anteriores, como também já havia sido mencionado em outros pontos dessa seção. Mas, também parece ser possível apreender, dos depoimentos, outro efeito, associado e potencializado pelos demais: o fortalecimento da autoconfiança da mulher. Revelam-se, em seus depoimentos, mulheres mais fortalecidas e mais confiantes acerca da capacidade de lidar com as dificuldades vividas e da possibilidade de se assumirem como cuidadoras do bebê.

Que ela conversava muito com a gente, a [enfermeira-obstetra]. Dava força. [...] Eu ficava bem, saía feliz, ficava em paz. [...] Isso foi muito importante. [...] Eu sou muito nervosa. Já tive depressão. Eu achava que depois que eu ganhasse eu ia ter depressão pós-parto. Só que não. Foi tranquilo, não tive nada. Acho que o pré-natal aqui ajudou muito nisso. (Lourdes)

Ah, porque sempre a gente fica [ansiosa], né? Será que vai dar tudo certo? No começo que eu estava bem com medo. Mas depois, a [coordenadora do ambulatório] foi conversando comigo... Meu parto só foi bom por causa dela. Ela que me ajudou... Explicava tudo direitinho para mim. Ela que me ajudou a ter um pouco mais de experiência. (Leila)

E a Monte Azul, é o contrário, é totalmente o contrário. De escolha, de preparar a pessoa. A [enfermeira-obstetra], a primeira consulta com ela, o exercício de respiração que ela fez, que é respirar pela barriga, eu usei a gravidez inteira, eu usei no parto e eu uso até hoje. [...] Eu tive um momento de poder acertar algumas coisas. Família, vida... (Sofia)

Agora eu me sinto até mais experiente. [...] Porque quando eu estava com a minha mãe, eu dependia muito da minha mãe. Então, se ela [a primeira filha] chorasse, a minha mãe olhava. Agora, essa aqui não. [...] Agora eu tenho que botar isso na cabeça: quem tem que fazer as coisas sou eu; eu que tenho que acordar à noite, eu que tenho que botar ela para arrotar; quando não sou eu, é meu esposo... Então, eu é que tenho que fazer tudo sozinha, não tenho que depender da minha mãe. [...] Então, aqui eles me ajudaram bastante, principalmente a [enfermeira-obstetra]. Ela me orientou em tudo, em tudo. Me ensinou bastante coisa. (Juliana)

Esse fortalecimento foi também expresso em um tema mais específico: sentir-se preparada para o parto. As participantes que fizeram parto normal sentiram-se com mais recursos para viver esse momento a partir do trabalho realizado no Núcleo. Saber como se desenrola o trabalho de parto e como melhor proceder em cada momento; conhecer dinâmicas hospitalares e como melhor lidar com elas - por exemplo, adiando a ida ao hospital; manejar exercícios de alívio da dor e facilitadores do bom desenrolar do trabalho de parto; sentir-se segura, confiando em sua capacidade, e na capacidade de seu corpo, de parir; foram alguns dos aspectos mencionados nesse sentido. 
A [coordenadora do ambulatório] sabia explicar... Tanto é que ela falava: as contrações de um em um minuto, você sempre vai ter um minuto para descansar. E foi nesse minuto que eu conseguia descansar, fazer força para ela nascer... [...] Por isso que eu acho que eu sofri menos no parto. (Leila)

A [enfermeira-obstetra] me ensinou bastante a fazer exercício - agachar na janela e ficar tipo rebolando a cintura, que é onde ajudava o bebê a encaixar mais para você não sentir muita dor. Ela me incentivou também a quando estivesse com dor, não correr imediatamente para o hospital, porque você vai para o hospital e só sofre. Sem contar que eles colocam aquele soro que é um absurdo. Então, eu comecei a sentir dor meia-noite e fiquei até às 6 horas aguentando. Aí eu fui andando até o terminal aqui, vim descendo até o terminal. Eu acho que aí me ajudou mais ainda, porque eu cheguei com seis centímetros de dilatação. Então eu acho que me ajudou bastante. Pelo menos as coisas que eles me falaram aqui eu segui direitinho e me ajudou bastante. (Juliana)

E no fim eu estava super preparada. [...] Eu estava bem segura, muito segura. Eu conseguia me controlar... [...] O médico ficou meio de cabelo em pé lá, porque ele queria colocar ocitocina para agilizar, aí eu não quis. Ele queria estourar a bolsa, eu falei não. No fim a gente passou a madrugada inteira no hospital e nasceu às 6 da manhã. [...] Por eles que eu consegui tanta coisa, que eu consegui realmente o que eu queria. [...] A Monte Azul que proporcionou isso, os profissionais de lá. (Sofia)

Por fim, comporta comentar as percepções relatadas por uma participante sobre a segurança sentida ao final da gravidez, no parto e no pós-parto, ter repercutido em sua vida pessoal, levando-a a querer realizar mudanças que antes não se considerava capaz. Embora essa vivência deva ser compreendida em meio a um contexto mais amplo de fatores, parece ser possível considerar que o acompanhamento pré e pós-natal oferecido pelo Núcleo contribuiu de maneira significativa para esse processo, já que, segundo a própria participante, como mencionado anteriormente, foram os profissionais da Monte Azul que lhe proporcionaram a revisão de uma série de aspectos de sua vida durante esse período e o fortalecimento de sua autoconfiança.

E acho que toda essa minha busca assim que me deu uma confiança legal. [...] Agora eu voltei a trabalhar e falei, "ah não, não dá". Aí eu pedi para eles se eles podem me mandar embora, para ficar um tempo em casa com o bebê e aí depois, daqui a um tempinho, eu vou estudar e vou buscar alguma coisa diferente, porque eu sei que posso. [...] Eu sempre me senti muito insegura de sair. De sair e buscar um emprego. Medo de passar dificuldade... Então, sei lá. Algumas coisas refletem na vida, né? (Sofia) 


\subsection{DESVELANDO O UNIVERSO DE PROFISSIONAIS}

Os dados considerados relevantes à caracterização das profissionais participantes do presente estudo foram apresentados na seção de método (p. 122). Cabe apenas acrescentar que todas as profissionais foram entrevistadas no período aqui identificado como Fase 3, ou seja, quando a atenção ao puerpério já estava mais estruturada, assim como as demais atividades integradas ao serviço de atenção pré e pós-natal, tais como acompanhamento odontológico, grupo de trabalho corporal e novo ciclo de palestras.

\subsubsection{ENTREVISTAS}

Também aqui a maior parte dos temas, destacados no conjunto de entrevistas realizadas com as profissionais, já havia sido anteriormente definida como norteadora de análise, quando foram elaborados os roteiros de observação e de entrevista. Outros, porém, sobressaíram a partir da leitura dos depoimentos. Tais temas são nomeados abaixo e, a seguir, descritos:

- Como as profissionais percebem a Associação;

- Como avaliam o serviço de atenção pré e pós-natal;

- Comparações entre o serviço oferecido pelo Núcleo e outros serviços;

- Significações em torno da experiência de ser mãe;

- Percepção sobre as necessidades da mulher durante o ciclo grávido-puerperal;

- Percepção sobre como um serviço de acompanhamento pré e pós-natal pode dar conta de tais necessidades;

- Percepções sobre o impacto do serviço na vivência do ciclo grávido-puerperal e na maternidade;

- Conceito de humanização e sua aplicação no serviço de atenção pré e pós-natal do Núcleo Monte Azul. 


\subsubsection{COMO PERCEBEM A ASSOCIAÇÃO}

\section{O comprometimento com a promoção do desenvolvimento do indivíduo e da}

comunidade foi um dos pontos mais mencionados pelas profissionais, no que diz respeito ao modo como percebem a Associação Comunitária Monte Azul. O fundamento principal dessa proposta parece estar na crença no valor da pessoa humana, considerada capaz de se desenvolver sob quaisquer condições de vida. Diante dessa premissa, algumas profissionais referiram que integra o trabalho realizado pela Associação, a promoção de ampliação de consciência, de modo que esse valor que cada indivíduo possui no mundo possa ser resgatado - trabalho, como sublinha uma participante, que não se dirige apenas aos moradores da comunidade mas a qualquer pessoa que procure pelos serviços oferecidos pela Associação. Também nele se inclui o oferecimento de oportunidades de aprendizagem de ofícios.

Eu acho que a Associação tem um compromisso com a comunidade. [...] Ela ajuda as pessoas da comunidade a pensarem, a entenderem onde elas podem contribuir; onde elas podem produzir. [...] Ela realmente ajuda as pessoas da comunidade a formarem essa consciência. De que elas são importantes, de que elas podem ser úteis. [...] A Monte Azul tenta colocar as pessoas no mundo de uma forma diferente. [...] Porque [...] tem um perfil de trazer e resgatar as pessoas que a sociedade não mais acreditava. (Isabela)

E também um grande projeto de acreditar em cada ser humano que possa se desenvolver apesar das condições, muitas vezes adversas que estão em volta. Isso tanto no caso das crianças, como também dos adultos. (Cláudia)

Mas que tem um fortalecimento humano muito forte em termos da população que vive lá. (Sônia)

Eu sinto que é uma porta de oportunidades. [...] porque no meio de tantos funcionários, a maioria são moradores. Pessoas que... não tinham nenhuma esperança de vida, não tinham uma oportunidade, não tinham escolaridade... Com a entrada da Monte Azul dentro da comunidade - eu falo os 3 núcleos - trouxe um estímulo para as pessoas. Que foi: incentivar o trabalho, o estudo... Hoje [...] chega na padaria, um menino que entrou com 17 anos como aprendiz, hoje com 24 é padeiro - o padeiro oficial da padaria. O pessoal [que há alguns anos] eram aprendizes de marcenaria, hoje são donos de uma marcenaria. (Mariana)

A Monte Azul está muito de portas abertas [...] para poder atender a quem quer que seja. Não só a população... ela tem tentado transformar essa comunidade mais do que todo mundo, mas ela está aberta para poder acolher quem tiver essa necessidade e esse interesse de estar se cuidando. Então, vem um pouco também essa coisa de abrir um pouco a consciência: como você está, como você não está... [...] Eu acho que esse é o nosso trabalho. É dar estrutura física e emocional para essa pessoa poder crescer na vida. (Érica) 
A integralidade é outro aspecto destacado, dentre os elementos que fundamentam a proposta de promover o desenvolvimento do indivíduo e da comunidade. Integralidade que define que tal promoção seja realizada nos diversos campos de experiência: educacional, social, cultural, e de saúde - esta, da mesma forma, compreendida para além do corpo físico. Segundo uma profissional, uma das decorrências de ter como base a integralidade é a transcendência do mero assistencialismo, na medida em que ela colabora para o trabalho de ampliação de consciência.

Para mim é um grande projeto em favor do desenvolvimento integral do ser humano. E principalmente, partindo mesmo da infância. [...] de ter uma visão tão integral. Juntar a área da cultura, junto com a área da saúde, junto com a área pedagógica... (Cláudia)

Um lugar para se crescer de maneira integral. [...] Integral, é que não é só com a questão da saúde física. Mas a questão desse desenvolvimento da alma mesmo, né? Da parte cultural, que a Monte Azul trabalha muito. Tentar integrar as pessoas em uma rotina de trabalho... Isso é o integral. Ela não se preocupa só, por exemplo, em oferecer uma cesta básica. Não. Ela ajuda as pessoas da comunidade a pensarem, a entenderem onde elas podem contribuir; onde elas podem produzir. Isso eu acho que é o todo. Ela realmente ajuda as pessoas da comunidade a formarem essa consciência. (Isabela)

O fortalecimento da família foi apontado por uma participante como o foco central, ainda que não explícito, da proposta da Associação e das atividades realizadas no ambulatório. Para ela, isso se revela na história da organização, que desde seu início constituiu ações voltadas, direta ou indiretamente, às mulheres e à família. E se associa à visão antroposófica ali adotada, já que se entende, a partir de tal visão, que o cuidado ao pré-natal relaciona-se com a garantia do bom recebimento do bebê no mundo; e que essa boa recepção promove o estabelecimento de relações familiares mais favorecedoras do bom desenvolvimento da criança.

Eu sinto que o foco maior [no ambulatório] é a saúde da mulher, sem falar. [...] Porque também, eu acho, a história da Monte Azul começa assim, né? A Ute cuidava das crianças e depois conseguiu chegar nas mulheres. [...] As mulheres puxando os maridos, conseguiram construir em mutirão o ambulatório e uma sala de aula. Então, tem uma história de cuidado com as mulheres. Que também teve a história da Angela, que ficou cuidando das mulheres... mulheres e família. Então, é a preservação da família, ou o resgate de uma história familiar, do que é família. [...] eu acho que tem muito disso, do fortalecimento da família. [...] É guiado pela antroposofia, que tem uns fundamentos bem simples também: você cuida de uma grávida, aí você vai receber melhor o seu filho. E aí, se você recebe bem o seu filho, 
você vai cuidá-lo melhor na infância, e daí para frente. Isso eu acho é o que a Monte Azul acredita. (Sônia)

Outro ponto mencionado por algumas participantes, relativo às suas percepções sobre a Associação, concerne ao crescimento pessoal e profissional que lá vivenciam, a partir: do trabalho realizado, que, comparado com experiências anteriores, foi percebido como permeado por novas nuances; do contato com a população, que em sua especificidade de experiências enriquece aquelas do profissional e amplifica sua compreensão acerca do humano; da filosofia da Associação, que transmite outro modo de olhar para os homens; e da proposta de trabalho da organização, a qual, por envolver integrações contínuas entre os profissionais das diferentes áreas, amplia o conhecimento sobre elas.

\begin{abstract}
A Associação Comunitária Monte Azul... para a minha vida foi super importante falando da individualidade - porque foi lá que tudo começou nessa transformação que eu vivi, em termos [caminho profissional]... E foi lá que tudo se abriu. E foi lá que muito eu aprendi com a população. Então, mais do que dar coisas, ensinar coisas, eu aprendi a viver com a individualidade do ser, a enxergar mesmo o ser - o ser vivo humano. (Sônia)
\end{abstract}

E é um trabalho gratificante. É muito diferente você trabalhar com uma população mais rica, que sabe de tudo. É muito contrastante você trabalhar com dois pólos e isso é muito enriquecedor. (Érica)

Um lugar que nos ensina a olhar o ser humano com amor e respeito. [...] eu nunca tinha trabalhado numa ONG. É muito diferente! Toda a questão do processo de trabalho... E a gente cresce, porque uma vez por mês tem integração... São discutidos vários temas... A gente, nas reuniões, acaba conhecendo todas as áreas... Então, para a gente que trabalha também é um crescimento, né? (Isabela)

Também foi referido que a Associação proporciona liberdade de atuação ao profissional, de modo que ele se sente com espaço para desenvolver os projetos em que acredita e para transcender normas e protocolos.

Para fazer um trabalho preventivo você tem que ter essa abertura que a Monte Azul dá para a gente aqui. [...] Hoje aqui na Monte Azul eu faço um trabalho preventivo, eu tenho projetos que eu posso estar desenvolvendo. Esse projeto futuramente pode virar um programa. Tem muito ainda a ser percorrido, mas existe um caminho, existe uma estratégia, você vai chegar em um determinado ponto. (Noeli)

Mas assim, a gente consegue atuar também como indivíduo, sem ter que seguir tantas normas e normas. Em função de como as pessoas vivem e pela proposta da 
Associação. (Sônia)

Por fim, dificuldades vividas pela Associação, especialmente, no campo financeiro foram relatadas. Tais dificuldades se expressam, ocasionalmente, em salários mais baixos para os funcionários; e acabam por gerar uma atmosfera de incertezas acerca da extensão do trabalho, uma vez que não se sabe até quando se poderá contar com recursos para mantê-lo.

Tem fases mais difíceis, tem fases que... mesmo os profissionais que são pagos pela Associação, a gente às vezes tem queda de salário... (Érica)

O financeiro. Como é uma Associação, a gente não sabe até que ponto podemos ir; e cresce o tempo inteiro. (Mariana)

\subsubsection{COMO AVALIAM OS SERVIÇOS DE ATENÇÃO PRÉ E PÓS-NATAL}

Um dos aspectos que mais se destacou no discurso das participantes, acerca da avaliação do serviço, foi o acolhimento oferecido à clientela, o qual foi traduzido de diferentes maneiras: vínculo com as usuárias, trabalho guiado pelas necessidades delas, liberdade de acesso, escuta e fortalecimento da família. No que se refere ao vínculo, percebese que as profissionais atuam no sentido de se manterem como figuras de referência para as mulheres, de modo que estas sintam que têm com quem contar quando sentem necessidade. Para tanto, há uma conduta ativa de: contatar-se e conversar com as usuárias na sala de espera ou em outros lugares onde um encontro aconteça - como se dá durante as palestras na Casa Angela; ligar para as usuárias; visitá-las; e acompanhá-las de maneira próxima.

Então, nesse período de pré-natal a gente se encontra nos grupos, encontra para tirar dúvidas, deu uma infecção, "Mariana", "to aqui". (Mariana)

Nós não temos muitas gestantes. Mas as que a gente tem, a gente costuma acompanhar, visitar, telefonar. Tem um elo realmente muito forte; essa questão do vínculo com essa pessoa é muito forte. (Isabela)

Todo contato, uma vez por semana eu que faço com essas mulheres - quando elas vêm no pré-natal, porque eu também estou aqui... às vezes eu estou na pré-consulta, sempre convidando, sempre interagindo... [...] é um vínculo que eu tenho com essas 
mulheres também. [...] eu sempre procuro estar junto, estar conhecendo essas mulheres que chegam, estar acompanhando as que já ganharam bebê, que passam no pediatra... Para manter esse vínculo. (Isabela)

Então, são dúvidas que elas podem trazer para grupos como as reuniões da Casa de Parto, ou individual com o pré-natal. Então, acho que acolhimento no sentido de estar ao lado dela e dizer, "estamos aí". Se ela precisar, você vai estar lá. (Érica)

E eu participo das palestras, das oficinas, me integro, acabo fazendo alguma oficina também com elas. [...] E esse vínculo está sendo muito bom porque é [uma] referência [para] elas. [...] E elas me procuram quando têm dúvida. (Noeli)

Esse vínculo mantido com a gestante também se estende para além do ciclo grávidopuerperal, como algumas profissionais destacaram:

\begin{abstract}
Não é porque teve o bebê que não vamos convidar mais. Pelo contrário. [...] Lá não é um grupo de gestantes, né? É um grupo de mulheres. Então, a gente sempre está em contato. Sempre, sempre. (Isabela)

Então, não é teve o neném e vai embora. Não, teve o neném, fica com a gente. (Mariana)
\end{abstract}

Em outras situações, embora, findo o acompanhamento pré e pós-natal, o contato com a mulher não continue a se dar, o vínculo então construído a mobiliza a procurar novamente pelo serviço, em uma gravidez subsequente.

Esse vínculo, não sei se pelo acolhimento, ou de confiança, ou a própria segurança mesmo. [...] Elas procuram. Tem mulher que eu nunca mais vi e depois de 3, 4 anos de repente aparece grávida. Vão lá porque querem ser atendidas. (Sônia)

Um último ponto a ser observado a respeito do vínculo estabelecido com as usuárias é que, para uma participante, ele parece transcender o âmbito profissional, adquirindo nuances de uma relação de amizade.

Eu sou amiga delas. Então, na verdade, cria um laço de amizade mesmo, de confiança. (Mariana)

A liberdade de acesso, que se destacou no discurso de algumas profissionais, aparece 
de forma intimamente ligada ao vínculo - tendo em vista a maneira como este é compreendido e vivenciado. As participantes assinalaram a possibilidade de a mulher comparecer ao ambulatório sempre que sentir necessidade, independentemente dos horários das consultas; de receber um retorno telefônico ou uma visita domiciliar, caso não obtenha suporte quando se dirige ao serviço; de telefonar para o ambulatório para esclarecimento de dúvidas; e de agendar uma visita domiciliar quando se encontra impossibilitada de se deslocar até o Núcleo.

\begin{abstract}
A questão do vínculo que a gestante cria com os profissionais, eu vejo como nunca, como é importante isso. Que fora da consulta marcada, a gestante pode vir a qualquer momento no ambulatório e pedir um help. A [auxiliar de enfermagem], mesmo se não tem tempo, no dia seguinte vai lá na casa... (Cláudia)

E tem umas que solicitam, até, visita domiciliar. Tem umas que precisam. Que está grávida e está deprimida, não está bem, e aí [é feito]. Normalmente, as visitas são feitas pós-parto, mas existem as exceções. (Mariana)

Às vezes o lugar que elas têm para vir, para bater um papo... é aqui. (Isabela)

O pós-natal, dificilmente elas voltam, mas elas sabem que podem voltar. Então, muitas vezes telefonam, para tirar alguma dúvida... (Sônia)
\end{abstract}

Um ponto também relacionado ao tema do acolhimento, destacado pelas participantes, diz respeito à tentativa de se estabelecer uma forma de trabalho guiado pelas necessidades da mulher. Isto se traduz pelos ajustes que as profissionais vão realizando em seu trabalho e/ou no serviço, a partir das demandas das usuárias, como por exemplo, visitar uma puérpera três vezes em uma mesma semana, ainda que o mais frequente seja uma visita semanal; ou definir a duração de uma consulta pré-natal de acordo com o que a mulher sinaliza necessitar em cada ocasião.

A visita domiciliar [...] normalmente é uma vez por semana; tem mães que [precisam] três vezes por semana, você tem que ver a necessidade. [...] Tem mães que antes de dois meses [não dá para] deixar. Tem mãe que com um mês você sente que já está firme, tirou os pontos... [...] Então, eu não falo para você, olha, é por um mês. Não existe isso. É a necessidade delas. [...] E, à vezes, uma visita que era para durar meia hora, [dura quase três] horas. (Mariana)

A consulta é bem individualizada. Individualizada assim: respeitando a individualidade do ser, [...] da mulher grávida. Então, tem dia que ela vem e em cinco minutos ela já está querendo ir embora. Só quer ouvir o bebê e medir a barriga, não precisa conversar. Mas vem um outro dia que aí ela quer conversar e 
fica meia hora, quarenta minutos com coisas que estão dentro dela. (Sônia)

Para que esse ajustamento seja possível, porém, parece ser necessário que o profissional esteja atento às necessidades expressas pela clientela, de maneira a poder escutála. Esse aspecto da escuta se destacou de forma significativa no discurso das profissionais. Escuta do que é verbal e não verbalmente expresso; e daquilo que compõe o vivido da mulher - vivido este que inclui as questões "médicas" e os demais elementos que compõem a complexidade do ciclo grávido-puerperal, assim como aspectos de outros contextos vivenciais, tais como o sócioeconômico e o cultural. Escuta que permite o acompanhamento próximo e o auxílio da mulher na elaboração das vivências do ciclo grávido-puerperal. Que, muitas vezes, não supõe resolução de problemas, mas suporte amoroso. E que favorece a percepção do outro, em sua individualidade.

É no pré-natal que você conhece a gestante. A boca dela não fala, mas o olhar dela pode ajudar você. (Mariana)

Além de tudo o que é importante no acompanhamento médico da gestante, em toda essa questão do pré-natal, no sentido médico, técnico, eu vejo que o profissional que trabalha com gestantes tem que ter uma, de uma maneira bem especial, tem que desenvolver uma empatia para aquilo que não é expresso em palavras. Isso eu sinto muito que muitas vezes tem muitas coisas para se abordar para uma gestante poder se tornar parturiente e poder se tornar mãe. E tudo isso eu acho que o profissional tem que ter ouvidos para ouvir isso e tem que saber também como lidar com isso, como abordar, como encaminhar. (Cláudia)

Não é só a questão da gestação. Porque elas vêm, muitas vezes elas estão com algum problema, têm alguma situação... Elas querem conversar. Então, é aí nisso que eu falo da questão do apoio. Por exemplo, no pós-natal, [...] a gente pede licença para entrar na casa dessa pessoa. E a gente acaba entrando na intimidade dela. Nas dificuldades dela... E a gente vê muitas vezes alguns problemas que essa mulher tem, que ela apresenta, que não é só a questão do período gestacional ou pós que ela está vivendo, mas a questão social, de onde ela está inserida. Então, a gente tenta apoiar nesse sentido, de escutar. Às vezes, a gente não tem uma resolução para o problema, mas a gente escuta, partilha. (Isabela)

[...] [nem sempre a mulher] precisa de muita informação; precisa de um ouvido, de um abraço, de um apoio - só isso. A pessoa não precisa de mais nada. Mesmo com toda pobreza, mesmo com toda dificuldade, a pessoa não precisa de mais nada, ela precisa só ser ouvida; ser olhada. (Mariana)

O profissional que acompanha uma gestante tem que enxergar aquela mulher, como uma mulher grávida, com uma individualidade, um nome... Eu acho que tem que chamar pelo nome e cuidar da mulher porque ela é uma mulher grávida, em um momento de vida no máximo do poder da mulher. (Sônia) 
Ainda em relação ao tema do acolhimento, algumas profissionais destacaram o trabalho de fortalecimento da família que permeia o serviço, que se traduz especialmente pela inclusão, no acompanhamento pré e pós-natal, daqueles que desempenham o papel de figuras de referência para a mulher - não necessariamente seus familiares apenas, mas também amigos, vizinhos etc. Para uma participante, esse é aspecto importante à preservação de questões trabalhadas no Núcleo, como o incentivo ao aleitamento materno exclusivo durante os seis primeiros meses após o parto e o desencorajamento do uso de chupetas e mamadeiras. Outra manifestou a compreensão de que essas pessoas integram o vivido da mulher durante o ciclo grávido-puerperal, compartilhando questões que demandam escuta e elaboração; e que também constituem o campo que receberá a criança, necessitando, por isso, serem igualmente fortalecidas - nesse caso, especialmente tendo em vista a família em formação.

\footnotetext{
Nos grupos nós costumamos trabalhar com os companheiros. Se não é o namorado ou o marido, é quem está perto de você. É sua mãe? É sua vizinha? É sua tia? Quem está mais perto de você? Porque essa pessoa tem que estar preparada para quando chegar esse bebê. Porque eu vou estar cheia de dor, vou querer dormir e o bebê não vai querer pegar o peito. E aí eu sou uma pessoa de referência sua, que estou cuidando de você. E aí, ah, dá um chazinho que não mata não, fulano não morreu! Ou então, dá um leitinho... (Mariana)

O pré-natal é isso. É mais de fortalecimento da mulher, do casal, da mulher. Elas sempre contam bastante. Eu peço para trazer o marido, companheiro, ou mãe, ou quem está no foco do problema do momento. [...] [No pós-parto] Dessa família [...] que se forma, eu acho super importante cuidar mesmo. (Sônia)
}

Por fim, no que diz respeito ao acolhimento, foi também destacada a preocupação de que esse trabalho, no Núcleo, seja realizado em todas as etapas do acompanhamento da mulher; mais especialmente, que possa ser feito desde a porta de entrada. A profissional que pontua esse aspecto destaca o pré-atendimento como uma fonte de apoio sólida, capaz de compensar eventuais dificuldades vividas nas consultas de pré-natal, ou de potencializar o cuidado fornecido. Por isso, relata o esforço empreendido para que todos os profissionais que recepcionam a mulher no serviço possam oferecer-lhe esse acolhimento, ainda que nem sempre se sintam preparados para fazê-lo, em razão das especificidades da clientela que vive o ciclo grávido-puerperal.

A [auxiliar de enfermagem é] a porta de entrada delas. [...] se a pessoa chega na porta e é bem atendida, capaz que a consulta não foi legal, que ela não queria ouvir 
aquilo, que não deu... Mas está bom. E se você consegue casar isso com a enfermeira-obstetra que está fazendo o pré-natal, melhor ainda. Então, é isso que eu tenho procurado: sempre trabalhar... desde o balcão. (Mariana)

Outro tema destacado na avaliação do serviço de atenção pré e pós-natal do Núcleo Monte Azul foi a integralidade, que se apresenta pela estrutura de tal serviço. Essa estrutura, por abranger diferentes áreas, como consulta pré-natal, acompanhamento odontológico, trabalho corporal e grupo de gestantes, permite à usuária ser "cuidada como um todo". Para que se mantenha em funcionamento, concordam as profissionais, o trabalho em equipe é imprescindível.

\begin{abstract}
A gente está pegando a gestante desde lá o pré-natal e está cuidando dela como um todo. Elas têm oportunidade de fazer desde um pré-natal com a [enfermeiraobstetra], um tratamento odontológico, uma terapia com as meninas de... ginástica... Esse grupo mesmo de gestantes passa um conhecimento para elas do dia-a-dia, desde cuidar do corpo até o bebê. Então eu acho que é um pré-natal que se não está completo, está chegando lá. Deixa de ser só um pré-natal. A gestante é cuidada como um todo. [...] Porque pré-natal não é só vir aqui e medir barriga. Elas questionam muito isso: fui em tal lugar, só mediu a barriga e eu fui embora. Acho que não é bem por aí". (Noeli)
\end{abstract}

Os profissionais que atendem são super bons, super preocupados, tentam trazer o melhor dentro de todo o contexto... Desde a alimentação até a parte física mesmo. (Érica)

E a gente trabalha assim, em conjunto, [...] eu não estou sozinha. Tem a [enfermeiraobstetra] no pré-natal, tem a [coordenadora da área de saúde materno-infantil] cuidando da Casa de Parto, tem a equipe do ambulatório que abraça, tem a dentista, tem a fono que dá um conteúdo já preparando... Tem que ser todo mundo junto, uma equipe mesmo, para poder chegar onde nós estamos chegando. (Mariana)

Também concernente à integralidade, no âmbito da atuação do profisssional, uma participante destacou a importância de o pré-natal não se restringir a procedimentos clínicos, como medir altura uterina e verificar peso e pressão. De modo a alcançar a complexidade do vivido pela mulher durante esse período, perpassado por questões emocionais, corporais e de alimentação, o profissional deve incluir, referiu, tais dimensões no cuidado.

E atender o pré-natal, batimento cardíaco, pesar, ver pressão, medir altura uterina, é importante, porque a gente tem que ver desenvolvimento da gravidez. Mas, o resto, o que a gente faz... muitas vezes o problema corporal, vem com uma dor aqui, ali... Faço uma massagem. [...] Orientar sobre alimentação - uma reorganização alimentar, para que ela tenha um ritmo de alimentação e para poder vivenciar o 
ritmo do bebê também. [...] Eu acho que o serviço é para isso. [...] só medir, pesar, ouvir o bebê e mandar fazer exames de laboratório e ultrassom: o pré-natal não é só isso. O pré-natal é PRÉ-NATAL. [...] tem toda uma mudança emocional [...]. E eu acho que tudo isso, o profissional tem que tê-las à mão, do que consegue, para suprir essa necessidade da mulher de uma conversa, de uma orientação... E ela se fortalecer. Porque se for só para medir, pesar e dar bronca porque engordou, não vale a pena. (Sônia)

A Antroposofia, mais um ponto relativo à avaliação do serviço, depreendido dos depoimentos das profissionais, foi apresentada como fator que o imbui de diferenciais. Segundo uma participante, uma das expressões desse referencial filosófico - a Pedagogia Waldorf - confere outro tipo de olhar e de abordagem ao trabalho, ao permitir a compreensão do ciclo grávido-puerperal em meio a um período mais extenso - a primeira infância. Por sua vez, as terapias externas - como o deslizamento - cumprem o papel de recurso facilitador no acompanhamento de algumas usuárias, por promoverem a ampliação do contato da mulher com o próprio corpo e, portanto, com a gravidez; e, também, porque, quando integram o toque, constituem-se mais um meio de suporte para a clientela, especialmente no pós-parto.

Eu acho que para mim o mais forte é a linha da pedagogia Waldorf. [...] Que tem esse olhar tão especial para o período gestacional e da primeira infância. Então isso é um diferencial. [...] A gente começa com o corpo da mulher, gestação... E vai introduzindo a questão do desenvolvimento infantil de 0 a 3, alimentação... até completar o primeiro setênio. Esse é o nosso ciclo dos grupos. Então eu penso que é um diferencial. A gente não fica só na gestação e parto. (Isabela)

Agora, nós estamos tentando nos especializar em deslizamento para gestante. Porque no primeiro contato que você tem com a gestante, você encontra ela, muitas vezes, fechada. [...] Até o quarto mês é super difícil você levar essa gravidez com essa mãe. Porque ela fica muito fechada, ela te passa muito pouca informação, está sempre tudo bem, porque ela está olhando o coração dela, ela não está olhando barriga. [...] [No pós-parto] estou feia, estou gorda, ele não me olha mais, ela só chora, eu não durmo... E é onde você precisa do toque também. (Mariana)

Um último aspecto, apontado pelas profissionais, associado à avaliação do serviço foi concernente às dificuldades vividas na Associação. Uma participante destacou, a esse respeito, o impacto da carência de recursos sobre a qualidade do serviço: a sobrecarga de funções vivida pelos profissionais prejudica o bom desempenho de tarefas e, consequentemente, do cuidado produzido. 
trabalha é boa. Mas eu sinto que a gente poderia, com mais recursos, [...] se estruturar ainda melhor. [...] Como a gente não tem muitos recursos, todo mundo acaba assumindo múltiplas funções e acho que com isso o trabalho que chega lá na base, ele às vezes sofre com isso. [...] Acho que a gente daria um salto. Tanto em atender mais pessoas, quanto... mantendo a mesma qualidade ou com uma qualidade melhor. (Cláudia)

A dificuldade de adesão e/ou assiduidade das mulheres em algumas atividades, como o grupo de trabalho corporal e o de bebês com o foco da odontologia, foi também mencionada. $\mathrm{Na}$ visão de uma das profissionais, essa questão se relaciona com a pouca consciência, ainda, das mulheres, sobre a importância da continuidade do acompanhamento no pós-parto. Para outra, trata-se da falta de divulgação do cuidado oferecido pelo Núcleo.

\footnotetext{
Ainda não [foi possível] formar esse grupo [de odonto-bebê], mas o pré está bem redondinho. [...] Porque eu acho que ainda não passou pela cabeça delas que elas precisam continuar isso aí. Tipo assim: ganhou o bebê, está ótimo, daqui para frente não preciso voltar mais. Então eu acho que o grupo de mães no pós-natal precisa continuar muito forte e elas se conscientizarem dessa importância; as mulheres. [...] Mas é questão de hábito, eu acho que é uma coisa cultural. Precisamos continuar... Porque eu acho que não é falha, mas acho que faltou para elas esse trabalho. (Noeli)

Então, foi bem interessante. Hoje, [tinham] três novas [no grupo de trabalho corporal]; não estavam sabendo da divulgação - a gente carece de melhorar um pouco a divulgação. (Érica)
}

Cabe salientar que algumas das dificuldades relatadas pelas profissionais foram expressas em termos do que pode ser feito para superá-las. Foram apontados como recursos: a clareza acerca da proposta da Associação, especialmente no que se refere à ampliação de consciência da população - clareza que contribui para a persistência dos profissionais; o investimento na divulgação do serviço; o ajustamento diante do que se mostra ser mais viável, como se dá com o grupo de bebês, ainda não estruturado; a contínua avaliação do serviço, de modo que os profissionais identifiquem aspectos que demandam novas estratégias; e os encontros do ciclo de palestras, espaço promotor de ampliação de consciência sobre a importância do trabalho.

Mudar a população, [...] é um pouco mais difícil. Mas eu acho que essa é a luta da Monte Azul: trazer a consciência para aquilo que... dar uma estrutura que você possa acolher e a pessoa possa achar que aquilo é para ela. [...] E é triste, porque a gente oferece um trabalho que é totalmente gratuito, tem lá o profissional esperando e eu já cheguei lá e tinha dias que não tinha ninguém para atender! Mas... a gente tem 
muita persistência. E sempre uma nova divulgação vem mais um grupo. (Érica)

O grupo de bebês [acontece] ali mesmo [durante as palestras]. Porque se você for marcar um outro grupo, para deslocar mais uma vez com o bebê... [...] Tem que continuar com os grupos. $\mathrm{E}$ as mulheres que tiverem os bebês continuarem vindo. [...] Eu acho que é aí que a gente consegue amarrar tudo [...] Então, eu acho que falta alguma coisa? Muita ainda. Mas a gente vai cada vez crescendo mais e acertando o erros, e vendo onde a gente está falhando. (Noeli)

No que se refere ao que gostariam que fosse diferente no serviço - tema também relacionado às dificuldades vividas -, as profissionais apontaram, novamente, a divulgação como recurso de sensibilização da clientela e também de outros serviços, quanto à qualidade da atenção oferecida no Núcleo. Nos dois fragmentos transcritos sobre esse ponto, observa-se a crença de que o diferencial que marca a proposta da Associação demanda ser mais bem compreendido, tanto para que haja aumento na adesão ao serviço do Núcleo, como para que possa ser incorporada em outras instituições essa forma de trabalho. Nesse ponto, então, notase a concepção de que seria interessante se houvesse tal incorporação.

\footnotetext{
Uma ampliação, para que mais pessoas pudessem ser atendidas. Uma boa divulgação... assim, um super marketing. E aí precisaria ter mais profissionais. Mas tentar mostrar mesmo para a população a qualidade desse serviço. Mostrar o nosso diferencial. (Noeli)

Eu queria espalhar...o trabalho. Que eu queria ter esse poder de ajudar as pessoas a entenderem a importância de tudo isso e de espalhar. Por todas as prefeituras...nós não temos materiais de primeira qualidade, produtos de primeira qualidade... Mas o que tem é transformado. [...] Essa consciência de que você não precisa de muito.[...] [O básico é] o material humano, né? É a troca. É o que elas [as mulheres] trazem! O que a gente também leva. Que a gente troca. Isso é o mais importante. (Isabela)
}

Foram também mencionados, dentre os elementos relativos à promoção de transformações no serviço: informatização do ambulatório; facilitação de cursos e treinamentos aos profissionais, oferecidos por pessoas não pertencentes à Associação; oportunidades de contato com outras entidades; e oferta de mais opções de lazer em conjunto para os profissionais, tais como viagens. Trata-se, conforme se depreende da reprodução textual das palavras de uma colaboradora, de ações de investimento e cuidado com o funcionário, o que promove melhoria na qualidade do serviço prestado. 
atendimento para eles, o atendimento fica melhor. [...] Se eu tivesse poder de dinheiro mesmo, eu melhoraria muitas coisas no ambulatório: informatizava, tudo o que fosse para facilitar; pessoas para fazer treinamento; daria uma viagem de trabalho de equipe... [...] Cursos fora, para abrir a cabeça. [...] Eu acho que eu melhoraria a estrutura do ambulatório, e aquelas pessoas que quisessem eu daria oportunidades. Conhecer outros lugares, conhecer outras entidades, principalmente como o a Monte Azul; que não é a Monte Azul que é só a Monte Azul... A Monte Azul é conhecida, mas tem outras coisas no mundo lá fora para você buscar. (Mariana) [grifo nosso]

Propostas mais específicas também foram levantadas, como a estruturação de um espaço onde as mulheres possam ter uma convivência mais intensa entre si e se envolvam com atividades que as auxiliem na preparação para a maternidade, especialmente no período pós-parto.

No pré-natal, fazer as mulheres passarem o dia lá para fazer atividades, conversar, fazer grupos... depois do parto, elas virem com os bebês, para aprenderem a cuidar dos bebês. Alimentação, como fazer papinha, comida... Viver mais... viver com elas. [...] Muitas vezes elas ficam o dia todo em casa assistindo televisão. Dar mamar, troca fralda. E não tem muita atividade. Fica na televisão... e de repente fazer uma dinâmica, de elas terem onde ir. De conversar, trocar... [...] Então, para ajudá-las a viver esse cada momento com seus filhos. Mesmo aquelas que já tiveram filhos e os filhos já estão adultos, se elas quiserem participar, têm muito a ajudar. Passando experiências, contando histórias... É um espaço de mulheres mesmo. Ou de família, né? (Sônia)

\subsubsection{COMPARAÇÃO ENTRE OS SERVIÇOS}

O acolhimento foi o aspecto mais destacado no discurso das participantes como fator que diferencia o serviço prestado pelo Núcleo dos demais. A par disso, discorreram também sobre a escuta e o cuidado que transcendem o corpo físico, e sobre o comprometimento com o usuário e com a comunidade, externado, uma vez definidos os limites, em providências que, entendem, não são de responsabilidade do Núcleo - tal como oferecer transporte a uma pessoa que necessite se deslocar até um hospital.

O lado da Monte Azul eu olho que é o lado mais humano. Porque o que nós olhamos não é só a matéria, a carne - a ferida, a pressão, a cabeça, a barriga... Não, a gente olha o todo, que é o espírito. Às vezes a pessoa não está bem mesmo, então a gente 
cuida mais do lado emocional mesmo. Uma outra coisa: precisou, nós nos desdobramos para levar aquela pessoa para um hospital. Às vezes, não tem nada a ver com a gente, mas a gente leva. Então, eu sinto que tem um trabalho diferenciado no sentido de abraçar mesmo a comunidade, abraçar os pacientes... Lógico, trazendo a consciência do que é obrigação deles e o que é obrigação nossa. (Mariana)

Foram também apontadas questões que evidenciam a dificuldade de se prover tal acolhimento em outros serviços, com relevância para o fato de inexistir, aí, uma "cultura" de atendimento, como há na Associação - uma cultura que tenha o acolhimento como um de seus pilares. Assim, a prática do acolhimento, em tais serviços, depende de alguns profissionais que a tenham integrada em suas posturas.

Eu acho que a grande questão é realmente o acompanhamento individualizado, diferenciado, que a gente trabalha muito pouco com padrões de procedimentos. A questão do calor humano, que eu acho que é uma das nossas fortalezas. Eu acho que é por isso que as mulheres nos procuram, porque na verdade hoje em dia tem tantos postos de saúde, né? [...] Lá também você vai encontrar um médico, uma enfermeira, um auxiliar, que trata com muita empatia e tudo, mas aí depende de cada um deles. Pode acontecer que você encontre alguém. Na Monte Azul é uma cultura. É uma atitude... Faz parte dos nossos valores. [...] Não é que não tenha em outros serviços também, pessoas, profissionais que tenha esse lado. Mas na Monte Azul eu vejo que é uma prioridade, é algo que caracteriza. (Cláudia)

Em outros locais, a instituição se sobrepõe ao sujeito, prosseguem as participantes, o que inviabiliza a percepção das necessidades deste e o respeito por sua individualidade. Além disso, sentem que a rigidez dos protocolos que devem ser seguidos distancia o profissional de sua humanidade, impondo um tipo de atuação mecanizada.

$\mathrm{Na}$ Monte Azul a gente tem esse respeito pelo indivíduo. Faz-se o possível para não se atrasar consultas, para não fazer com que eles esperem. Mas a cultura de instituição é de atrasos em consultas, consultas de 2 minutos, mal olha para a mulher, em qualquer segmento, né? Nem sabe o nome das pessoas que estão atendendo, então é mais fácil chamar de mãezinha, gordinha, gravidinha. Porque não se preocupa em olhar a ficha e olhar primeiro o nome. Então é difícil valorizar o ser que está ali e qualquer pessoa que vai em uma instituição, elas vão temerosas, sem saber como é que serão tratadas. [...] $\mathrm{E}$ isso independe de ser serviço público ou particular. Quem manda é a instituição, sem perceber a necessidade daquela pessoa. (Sônia)

Na Monte Azul a gente tem um trabalho de promover uma qualidade, promover um contato físico. [...] [Em outros lugares] a mobilização do trabalho é feita em cima de quanto [...] eu vou proporcionar no final do mês para a instituição. [...] Você tem um protocolo para atender, você não pode ficar pulando protocolo... [...] Então, querendo ou não, a qualidade cai um pouco. Você não atende um paciente... ouve 
todas as queixas dele... [...] Eu tento lá, mas aqui eu consigo mais, eu tenho esse espaço de tempo para poder conversar com o paciente e saber como ele está emocionalmente. Lá não: é um entra e sai meio maquininha, fabriquinha, uma coisa muito mecanizada. [...] Você dá umas fugidas [do protocolo], volta, a gente tenta mobilizar. Porque a gente tem consciência de que a gente está tentando trabalhar como ser humano, né? Não como uma maquininha, né? (Érica)

A demanda intensa que costuma estar presente em outros locais, e que muitas vezes define a imposição de um padrão de quantidade, foi contraposta à realidade do ambulatório do Núcleo, onde, não havendo que "dar conta de números", é possível priorizar o tempo para a escuta. Além disso, a não consideração, em outros serviços, de outras dimensões, como a social, foi levantada como fator que dificulta a compreensão das vivências da mulher durante o ciclo grávido-puerperal.

Porque a maioria dos serviços de saúde, não é talvez porque eles não querem, porque os profissionais não querem, mas porque não têm tempo, né? E aqui a gente procura dar essa prioridade, dessa questão do tempo para escutar, para não ter pressa no atendimento. E ainda a gente consegue fazer isso. Eu penso que sim. Que a gente ainda consegue ter esse tempo disponível. Porque a gente não trabalha aqui com produção. Nós não temos que prestar contas dos números. A gente preza mais esse lado da qualidade, né? (Isabela)

E a gestante vai apresentando algumas coisas que você não entende [em outros serviços]. Mas aqui não. Aqui a gente consegue compreender, porque aqui a gente consegue entrar um pouco nessa questão do social dessa mulher, então isso é um diferencial muito grande. (Isabela)

Uma das profissionais discorreu sobre a possibilidade de repercussões mais graves, em alguns serviços, em função não apenas da falta de acolhimento mas do próprio acompanhamento clínico se dar de forma, segundo relato, menos cuidadosa.

[...] [Tinha] uma lá que... alcóolatra, [...] [fazia abuso de drogas], diabética... a gravidez foi um caos. Gravidez de risco... E ela estava fazendo o pré-natal na UBS, mas vinha [aqui também], porque a gente dá uma cuidada. Tinha chamado a atenção o resultado de um exame, que estava feio, estava ruim [...] [uma profissional do Núcleo foi] falar lá com a médica do posto... sondar se ela percebeu esse exame muito ruim. Parece que não. [...] [Falou-se para a usuária:], "você não pode ficar indo lá. Você tem que fazer o pré-natal de alto risco, em um lugar que faz alto risco". Aí ela falou, "mas a médica do posto falou que fazendo lá está bom". [...] Aí ela foi para o [serviço de atenção à gravidez de alto risco] e ficou internada uma semana. Eles ficaram assustadérrimos (sic) com a situação dessa mulher. (Sônia) 
Reforçou, ainda, que faz parte indissociável do acolhimento dispender com as usuárias, na consulta de pré-natal, o tempo que lhes for necessário e chamá-las pelo nome.

O duro desses consultórios, não importa onde, é que as mulheres entram de costas, para a saída ser mais rápida. $\mathrm{O}$ médico, na verdade, ou o profissional, mal olha na cara das pessoas, mal sabe o nome das pessoas. E eu acho um caos. [...] É muito importante ser chamado pelo nome. Porque se a gente tem um nome é porque a gente existe. (Sônia)

Outra questão abordada diz respeito à proposta preventiva da Associação, que se contrapõe a serviços cujo foco é apenas "curativo", nos quais não se consegue resultados em longo prazo, pois as ações empreendidas não geram transformações.

No outro lugar, o trabalho que eu fazia era curativo. [...] de pronto-socorro. [...] Então, eu falei, vou abandonar. Porque a gente não via uma continuidade no trabalho, você não colhia frutos. Você colhia números. Então era uma coisa assim, ai que lindo, você atendeu 30 crianças... e aí? Que vão voltar daqui 6 meses e vão virar 60. (Noeli)

Por fim, ainda comparando serviços, foram levantados aspectos ofertados na rede SUS, mais especificamente, e não disponíveis no Núcleo, como a informatização dos serviços e o fornecimento gratuito de exames e de medicamentos. Por conta disso, foi apontada a existência de uma complementariedade mútua, de forma que as UBSs proveem tais recursos às usuárias, enquanto a Associação oferece o acolhimento e o cuidado integral.

Porque a UBS tem o que a gente não tem! Os exames de sangue são gratuitos lá. [...] A UBS tem anticoncepcionais... [...] O lado da Monte Azul eu olho que é o lado mais humano. [...] Qual a diferença com as UBSs? As UBSs têm uma qualidade agora que eu estou até admirada, mais prática, de facilidade: tudo informatizado. [...] Só que tem aquele lado muito frio ainda. [...] Então, quando eu falo que o trabalho é diferenciado, não é que o ambulatório é melhor. Cada um tem a sua qualidade. [...] Eles têm o que nós precisamos, que é a prática - a informatização, remédios... E nós temos o acolhimento. (Mariana) 


\subsubsection{EXPERIÊNCIA DE SER MÃE}

A compreensão da maior parte das profissionais sobre o significado de ser mãe se fundamenta na ideia de que a maternidade não diz respeito apenas a gerar ou a dar à luz a uma vida, mas, mais especialmente, a acompanhar esse novo ser em seu desenvolvimento; o que demanda que a mulher disponibilize-se para acolher essa vida em seu corpo e em sua alma; e seja capaz de reconhecer o bebê e suas necessidades.

Acho que ser mãe não é só gerar. É criar. Gerar, todo mundo pode. Mas criar... educar, criar, para mim é o lado de ser mãe. (Noeli)

Mãe não é só ter. Ser mãe é acompanhar, é cuidar, é viver e tentar não deixar se perder. (Mariana)

É saber acolher o próximo, porque na verdade você está acolhendo um serzinho que vai ser um ser humano. É uma mudança muito grande, física e psicológica. Eu acho que ser mãe é você abrir para acolher um novo ser. Você tem que estar aberta para isso: você está doando o seu corpo, você está doando a sua alma, a sua essência, para poder acolher aquele ser e gerar, e criar. (Érica)

Acho que cada mulher tem o seu jeito de ser mãe. [...] Para mim, acho que o mínimo que cada mulher tem que ter, tanto para se sentir mãe, como para o bebê sentir que ele tem uma mãe, é que ela se ponha à disposição a algo que não é ela, e que ela consiga fazer isso... eu não diria com prazer, mas com uma satisfação. [...] acolher um outro ser - nesse caso o bebê - e reconhecer ele com as necessidades dele. (Cláudia)

Tal concepção parece guiar o trabalho realizado no Núcleo, especialmente no que concerne ao fortalecimento de vínculos e da família, tal qual exposto no trecho a seguir:

Para mim, ser mãe é gerar no coração, e é isso que a gente trabalha. [...] Então, sendo assim, eu tento buscar muito isso no meu trabalho - buscar, levar. De ajudar essas mulheres a construírem o vínculo. A gerar no coração. Porque gerar só no ventre, você expulsa essa criança. Chegou nove meses, um pouco antes, ela vai parir. E só. Mas não tem a questão da gestação, de gerar essa criança no coração. Então, para mim ser mãe é isso. (Isabela)

A maternidade também foi associada a uma experiência de profunda transformação e que oferece à mulher uma vivência de completude e de máxima realização. 
Eu acho que é realmente ser uma mulher completa. (Mariana)

É o máximo que uma mulher pode chegar. [...] Depois de uma gravidez, você nunca é a mesma. [...] É completar. [...] É bem uma morte do que era e um renascimento... (Sônia)

A experiência de ser mãe, por fim, foi retratada como uma possibilidade de ampliação de consciência e de responsabilidade; o que garantiria à mulher a retomada de caminhos considerados como de menor prejuízo ao seu desenvolvimento.

Como a [mulher acompanhada no Núcleo], que eu acabei de contar. Tirou ela de um abismo. Ela estava entrando no mundo das drogas, de baladas... Nessa gravidez, porque ela foi abandonada pelo companheiro. E a gravidez trouxe para ela uma luz. (Mariana)

\subsubsection{NECESSIDADES DA MULHER DURANTE O CICLO GRÁVIDO- PUERPERAL}

O acolhimento foi assinalado pelas participantes como a principal necessidade vivida pela mulher ao longo do ciclo grávido-puerperal, destacando-se, portanto, mais uma vez, como tema prioritário. Concernentes a esse tema, foram mencionadas como demandas da mulher: obter apoio das figuras próximas - especialmente entendido como cuidado e como suporte psicossocial; ser ouvida e respeitada em sua individualidade; e ser estimulada a contatar vivências emocionais e a compartilhá-las com alguém que verdadeiramente se coloque ao lado dela - alguém que possa adotar tal postura e fortalecê-la de maneira a auxiliála a "se tornar autora de seu próprio livro". Foi destacada, ainda, a importância de não ser desconsiderada a necessidade de cuidado aos "aspectos médicos", a despeito da essencialidade do acolhimento.

A primeira coisa: apoio, apoio de um modo geral. Ou do companheiro, ou do namorado, ou da família. [...] Um cuidar apoiando. Em todos os sentidos. (Noeli)

É a necessidade de ter uma estrutura física - ter o seu lar, ter o seu canto, para poder acolher bem essa criança. Poder ter uma estrutura emocional de família, de acolhimento, de ter alguém que olhe por ela também. Socialmente, que ela possa ser 
cuidada, observada, ter alguém a quem possa recorrer nas horas que tem dúvidas e tem seus problemas. (Érica)

Necessidade de ser respeitada como ela é, sentir-se à vontade para ela expressar qualquer coisa que ela viva durante a gravidez, tanto as vivências positivas, quanto as negativas. [...] $\mathrm{O}$ que também é uma necessidade é um apoio emocional verdadeiro, realmente de sentir com ela, e rir com ela, de reforçar tudo o que é emocional. [...] E tudo o que tem a ver com... fortalecer a auto-estima. Nunca, nunca, qualquer ela coisa que ela faça, criticar num sentido de deixar ela mais fraca. $\mathrm{Eu}$ acho que tudo que fortalece, que empodera, que deixa ela se sentir como sujeito da própria história, autora do próprio livro, eu acho o mais importante. Lógico que também tem toda a questão da saúde, de cuidar, de tentar influenciar estilo de vida, e essas coisas mais de médico, do pré-natal. Mas no sentido de acolhimento é um pouco isso. (Cláudia)

Salientou-se o trabalho de fortalecimento da família, e do vínculo com a criança, como algo essencial, especialmente ao considerar sua repercussão nas interações da nova família após o nascimento do bebê.

Que se ela não tem o vínculo, se ela só ficou grávida... Vai ser muito complicado depois a relação com essa criança, o aleitamento materno, e tudo mais. [...] Então, não é só ela. Ela precisa do apoio - do companheiro, do namorado, da família, para conseguir fortalecer esse vínculo com a família. (Isabela)

Algumas profissionais referiram-se ao pós-parto como um momento em que algumas vivências e dificuldades acentuam-se, de modo que o acolhimento - considerado em seus diversos elementos, tal como destacados - torna-se ainda mais importante nessa fase.

E a hora que nasce o bebê, eu acho que esse apoio tem que ser redobrado. Porque é um serzinho que não vem com bula, uma coisinha pequeninha que deixa a casa de ponta cabeça. Tudo o que você tinha no lugar, de repente está tudo fora do lugar. (Noeli)

Que o pós é quando você entra mais na casa, entra mais na vida. Porque aí [...] é onde vem a situação da dificuldade. Nasceu. E aí? Aí era uma, agora somos dois. O que a gente vai fazer com isso? Eu estou cheia de dor. Foi uma cesariana, ou foi um parto normal que me cortaram, eu não estou conseguindo ir ao banheiro, meu leite não desce, meu leite é fraco, ele não pega, ele só chora. Dou mamadeira, já dei chazinho, dou chupeta. Então vem o momento da confusão mental. Você pode ter tido 5 filhos, mas é sempre um diferente do outro. [...] A mulher precisa ser cuidada, respeitada, precisa ter o espaço dela. (Mariana)

No pós-parto, eu diria que ainda mais a mulher deve ser fortalecida de todas as maneiras, mesmo. Principalmente nas primeiras 6 semanas, o que muitas vezes acontece é que a mulher é muito criticada, influenciada, por pessoas que acham que 
sabem melhor. (Cláudia)

O ciclo grávido-puerperal foi descrito por algumas participantes como um momento em que algumas experiências são resgatadas. Como decorrência, apontaram a importância de a mulher contatar, expressar e elaborar tais vivências, para poder assumir a maternidade sentindo-se sujeito de sua história e pronta para também viver o papel de mãe cuidadora - e não mais apenas aquele de filha.

Cada mulher na gravidez vive momentos de crise, onde surgem coisas dela, que têm a ver com a biografia dela, que têm a ver com medos, angústias profundas que ela tem... teve antes da gravidez, e agora se apresentam de outra forma... Acho que de ela poder expressar isso e se sentir sujeito disso. Acho que isso é muito importante da mulher poder se sentir a autora do próprio livro. [...] Eu sinto que a gravidez tem um grande potencial de se elaborar sentimentos que talvez já faz muito tempo, não apareceram mais. (Cláudia)

Mulheres que têm problema com mãe, têm que resolver na gravidez. Se ela não resolveu antes, a história aparece, aflora na gravidez. E ela tem que resolver essa história com a mãe. Se não ela não consegue, para ela, virar mãe é muito difícil. Então, fica na história de filha sempre. (Sônia)

Por fim, foi assinalada como necessidade da mulher durante o ciclo grávido-puerperal, a vivência de um processo de ampliação de consciência corporal, o qual contribui para prepará-la para a experiência das modificações que se dão nessa dimensão; e, também, para a redução de ansiedade, à medida que, mais consciente do próprio corpo, e de si mesma, a mulher se sente com mais recursos para enfrentar e elaborar o vivido.

O nosso corpo... é a nossa casa. [...] Eu acho que a importância está aí, principalmente falando das grávidas. [...] Então, é o que muitas falam: essa ansiedade que vem vindo com o parto se aproximando é um pouquinho também, não só é claro, falta de consciência e trazer um pouco de tranquilidade para esse corpo através da consciência. Se você se estrutura bem, faz alguma atividade física que te traz... não só a consciência é claro, mas movimenta esse corpo, você está mais firme de você mesmo, mais consciente, mais tranquilo. (Érica) 


\title{
7.2.1.6. ACOMPANHAMENTO PRÉ E PÓS-NATAL E AS NECESSIDADES DA MULHER
}

A temática das percepções das profissionais sobre como um serviço de acompanhamento pré e pós-natal pode atender às necessidades da mulher durante o ciclo grávido-puerperal, já foi visto em alguns dos trechos citados anteriormente. São aqui destacados, porém, aqueles que mais diretamente expressam a questão. Mais uma vez, o acolhimento foi um dos temas da pauta, tendo sido apontada a disponibilidade do profissional para fornecer apoio à mulher no momento em que ela o considere necessário.

\begin{abstract}
Eu acho que é essa ajuda, da hora que ela precisar, ela ter esse apoio. Eu falo que é um plantão 24 horas. Na hora do desespero ela vai ligar. E ter alguém para responder naquele momento. [...] criar um grupo de pessoas para dar esse apoio no momento que ela precisa. Se você falar que vai daqui a meia hora, já não precisa mais. Que a minha lágrima está caindo agora. (Noeli)
\end{abstract}

Foi também levantada a importância de o profissional estar ao lado da mulher de forma próxima, assumindo uma postura não daquele que sabe o que deve ser feito e então estabelece os caminhos, mas daquele que compartilha, que acompanha, que atua em favor do fortalecimento da autonomia; apoiando e orientando a mulher no que seja necessário, acolhendo suas vivências e a auxiliando na elaboração delas.

Ajudá-las a viver esse momento - como esposas, como namoradas, como mulheres sozinhas. Para ter esse filho. (Sônia)

A gente procura escutar aquilo que ela traz. E não só colocar: não, você tem que... Nada disso. É um trabalho. É algo que a gente tem como valor, de poder ajudá-la nesse momento. E o mais importante até... de ela resolver os conflitos, né? (Isabela)

Acho que nessa fase, a necessidade no fundo, agora olhando o profissional, é dele ajudar sem assumir algo que na verdade é o papel da mulher, de estar muito presente, ajudar nos primeiros cuidados da mulher com o bebê, ajudar na amamentação, e nessas primeiras interações também. Mas fazer isso de uma maneira muito... tipo como uma participação... não mandando fazer nada, mas olhando qual é o jeito dessa mulher. Ajudar a mulher a descobrir o próprio jeito. Acho que isso é muito importante. (Cláudia)

Ainda no que se refere ao acolhimento, o tema do fortalecimento da família, e do 
vínculo com o bebê, foi retomado como um trabalho que também deve ser integrado no acompanhamento pré e pós-natal, tendo em vista as necessidades da mulher durante esse período. O profissional, segundo as participantes, deve atuar como facilitador, especialmente no que diz respeito à comunicação no relacionamento conjugal; e auxiliar a mulher a encontrar-se e assumir-se como mãe e cuidadora. Além disso, os membros dessa nova família devem ser incluídos no trabalho, de modo a estreitar e a fortalecer seus vínculos.

\footnotetext{
E também eu sinto que isso pode ser uma coisa que o profissional pode assumir, de fazer um pouco essa ponte, de tentar trazer o pai para perto e ajudar ela a se expressar perante o marido. Isso muitas vezes tem efeitos muito benéficos. (Cláudia)

É um trabalho que eu sinto que é para que ela consiga enxergar algumas coisas. E procurar o lugar dela na Terra; o lugar dela de grávida e cuidar desse ser que está vindo. Uma coisa que eu foco muito é esse filho que está ali dentro. E que ela vai ser mãe. (Sônia)
}

E essa questão de gerar no coração, a gente faz um trabalho muito integrado com a família. (Isabela)

Foram também mencionadas situações mais específicas de realização desse trabalho, como a de mulheres que enfrentam dificuldades no processo de aceitação da gravidez e aventam a possibilidade de interrompê-la. Em tais situações, a atuação segue no sentido de auxiliar a mulher a elaborar suas questões, de modo que possa assumir a gravidez e levá-la adiante.

\begin{abstract}
A gente trabalha muito essa questão. Em todos os grupos a gente trabalha. Mesmo quando chega uma pessoa que está grávida e não está feliz com a gestação, a gente tenta... ou arrumar uma terapia com psicólogo... Estar realmente acompanhando. Para que ela possa se fortalecer com esse processo. Lógico que tem umas que realmente não querem e que partem para um outro caminho. Mas a gente faz o que a gente pode para ajudar a fazer esse ninho no coração, preparar o ninho na casa. (Isabela)
\end{abstract}

Outro aspecto relativo às percepções das profissionais sobre como um serviço de acompanhamento pré e pós-natal pode atender às necessidades da mulher durante o ciclo grávido-puerperal, refere-se à integralidade. Foram pontuadas, a esse respeito, demandas de: a usuária ser percebida, no serviço, em suas várias dimensões de experiência - que abrangem, como destacado anteriormente, questões físicas, psíquicas e sociais; e de o profissional 
assumir uma postura em que, por meio de tal olhar, transcenda "questões técnicas" e não se aprisione em protocolos, tendo, assim, condições de oferecer um tipo de acompanhamento em que a mulher é considerada em sua individualidade.

Importante também que o serviço a veja como um ser integral e não só como grávida. (Isabela)

Isso é uma das partes que a gente está tentando proporcionar como Associação: tentar trazer um pouquinho de acolhimento social para elas. Tanto médico, psicológico e físico. (Érica)

Tem que ter a vontade de se dedicar além das questões técnicas e realmente levar a sério cada mulher na situação específica dela. Cada mulher é um caso. Acho que um profissional que acompanha, não importa, gestação, ou parto, ou puerpério, tem que ter uma visão muito individualizada. Ele nunca deve se deixar guiar por padrões, rotinas. Tem que saber o que tem que fazer, mas tem que ir além disso. Tem que ter toda uma... eu diria que é empatia, principalmente. E a capacidade de lidar com aquilo que ele está encontrando em cada caso. (Cláudia)

Por fim, foi levantada a importância de se incluir no serviço um trabalho em favor da ampliação de consciência das mulheres acerca de seus direitos, que, segundo algumas profissionais, são desconhecidos por grande parte da população atendida no Núcleo.

Tem outras que têm emprego e não sabem seus direitos, os direitos da mulher, do indivíduo... Então, isso eu sempre explico. A maioria não sabe dos direitos que tem. [...] Então, esse fortalecimento do que é o direito cívico da mulher, do indivíduo, isso eu puxo também. (Sônia)

Eu acho que muitas vezes elas não sabem lutar pelos direitos delas. E se ela não sabe lutar pelos direitos dela em uma gestação, ela não vai saber lutar pelos direitos de uma criança. E isso é ser mãe: é olhar para ela e olhar para uma gestação também. (Mariana)

\subsubsection{PERCEPÇÕES SOBRE O IMPACTO DO SERVIÇO NA VIVÊNCIA DO CICLO GRÁVIDO-PUERPERAL}

Quase todas as profissionais fizeram referência a percepções sobre o impacto na vivência do ciclo grávido-puerperal gerado pelas intervenções realizadas ao longo do 
acompanhamento pré e pós-natal. Dois focos, inter-relacionados, destacaram-se na explanação desse tema: o fortalecimento da mulher e fortalecimento do vínculo com o bebê. A respeito do primeiro, foi destacado que se a mulher é acolhida, recebendo suporte e orientação, e fortalecida em sua capacidade de viver esse momento, ela consegue vivenciá-lo bem e dar conta de eventuais dificuldades.

Uma das coisas que eu foco muito é que a mulher, tomando conta do que é dela, ela vive bem o momento, não importa onde. (Sônia)

Se você tem uma orientação legal no seu pré-natal, se você tem pessoas que estão com um olhar legal para você, você consegue passar tudo isso. A cesária vai ser o de menos. Vai ser dolorida? Vai. Mas você vai conseguir mudar isso, porque você teve informação. Se tem uma pessoa que abraçou a sua ideia, abraçou a sua causa, que cada uma tem uma história... e tentou da forma que pôde te ajudar. (Mariana)

O fortalecimento do vínculo com o bebê, por sua vez, foi retratado como decorrente do fortalecimento da mulher em sua autonomia e autoconfiança. Nesse sentido, a orientação e o suporte integral foram novamente apontados como intervenções que favorecem a preparação da mulher para receber bem a criança e assumir-se no papel de cuidadora dela este entendido como algo que envolve sua capacidade de perceber o bebê e de promover seu desenvolvimento como indivíduo seguro.

E se ela vive bem a gravidez - a gente orientando, cuidando, conversando - aí, quando virar mãe, ela vai conseguir perceber melhor esse filho que chegou. (Sônia)

Quando a gente tem um apoio - em todos os sentidos, apoio emocional, físico, moral - essa pessoa consegue ser uma mãe. (Mariana)

Tentar trazer um pouquinho de acolhimento social para elas. Tanto médico, psicológico e físico. Acho que são chaves para que você possa dar uma estrutura para que essa nova criança e essa mãe que está precisando de um acolhimento poder se estruturar, poder ter esses alicerces para criar essa criança. (Érica)

[...] [fortalecê-la] $\mathrm{Na}$ autonomia e na autoconfiança. Na medida em que ela confia nela, ela consegue transmitir confiança e segurança para o filho. (Cláudia)

Uma participante salientou a inter-relação do vivido da mulher durante o ciclo grávido-puerperal com a forma com que ela experiencia a maternidade e estabelece o vínculo com o bebê, chamando também a atenção para o impacto desse vivido sobre o 
desenvolvimento da criança, no que diz respeito à segurança e autoconfiança. Para ela, $o$ estabelecimento de um vínculo, não apenas profissional mas também afetivo, com a mulher é um recurso importante para poder acompanhá-la, fortalecê-la e auxiliá-la no estabelecimento de um vínculo afetivo com a criança; ou seja, esse vínculo profissional-mulher atua, segundo ela, como uma referência, de tal maneira que, se a mulher o vivencia, ele atua como facilitador na construção do vínculo com seu filho.

\begin{abstract}
O vínculo influencia de uma forma muito importante a forma como a mulher vivencia a gravidez. [...] a gente às vezes esquece que tudo o que a mulher vivencia nessa fase vai influenciar de forma muito marcante sua disposição de se tornar mãe, o prazer que ela sente de se tornar mãe e também a capacidade de enfrentar as dificuldades, os desafios, as frustrações... E tudo isso acho que dá para fortalecer a mulher, empoderá-la. E isso através do vínculo. Isso para mim é muito claro. Se você consegue criar um vínculo afetivo, também profissional, mas um vínculo afetivo com uma mulher, uma gestante, ela vai poder desenvolver melhor os vínculos afetivos com o próprio bebê. Além de toda a questão do casal e tudo isso. Para mim isso é fundamental. E pensando que a forma com que a mulher vive a gravidez, não só depois do parto vai influenciar a forma com que ela lida com o bebê, mas já durante a gravidez vai influenciar já a capacidade do bebê de criar também confiança, segurança, e tudo isso que já se sabe. [...] Tudo o que tem a ver com continência, acho que se constrói através de relações humanas, que são vínculos. (Cláudia)
\end{abstract}

Por fim, foram referidas repercussões mais amplas desse trabalho de fortalecimento da mulher e dos vínculos, destacando-se que cuidar da usuária, e de sua família, durante o ciclo grávido-puerperal, é cuidar das bases para que a criança possa ser bem recebida no mundo, em um contexto em que suas necessidades básicas são conhecidas - vínculos afetivos, alimentação, brincar - e em que se faz o possível para atendê-las; um contexto, portanto, que favorece o desenvolvimento dessa criança como indivíduo seguro, capaz de dar conta das dificuldades que encontra pelo caminho, mais "tranquilo", e que se coloca de forma mais pacífica no mundo. Por essa razão, segundo uma profissional, esse trabalho contribui para o estabelecimento de uma cultura de paz.

A proposta é também acompanhar o desenvolvimento da criança - até 6 meses até 3 anos. Fazer um movimento de cuidar mesmo, de fortalecer essa família. Então, como diz na Aliança Pela Infância, que cuidar da infância cresce um indivíduo melhor. A infância começa no parto, ou antes do parto. (Sônia)

Se você for falar da questão da comunidade, faz toda a diferença. Porque a questão social é crítica e se essa mãe, esse pai, essa família, consegue ter esse olhar das coisas que essa criança precisa, que são as coisas essenciais - o vínculo, o brincar, a 
alimentação dentro daquilo que eles têm -, já faz uma diferença enorme. Principalmente a questão do vínculo. Que numa situação de periferia, quanto mais a gente consegue falar dessa questão do vínculo, dessa criança com essa família e dessa família com ela, vai fazer toda a diferença na vida adulta dessa criança. [...] Promove a paz! Promove a segurança do ser humano. Vai fazer com que essa criança seja um adulto mais seguro, mesmo diante das dificuldades sociais. Um ser humano mais tranquilo... [...] Vínculo para uma cultura de paz. (Isabela)

\subsubsection{HUMANIZAÇÃO}

Muito do que já foi aqui descrito revela aspectos intimamente relacionados com a maneira como a humanização é compreendida e concretizada na Associação. O que é a seguir apresentado refere-se ao que foi mais diretamente apontado pelas profissionais, ou apreendido de seu discurso, acerca do tema.

Um dos pontos por elas salientados associa humanização ao cuidado revestido de humanidade, definido como aquele em que o profissional percebe aquele de quem cuida como um ser humano e se coloca nessa interação também como humano. E elas entendem que faz parte de ser humano olhar o outro nos olhos e relacionar-se com ele afetivamente; compreender que o usuário tem dúvidas, conflitos e necessidades que demandam ser acolhidas; escutá-lo e dialogar com ele, permeando a interação por respeito; e tocá-lo; aspectos relacionados ao acolhimento, tal como anteriormente descrito. Esse tipo de interação, pontuam, favorece ao profissional a reconexão com a humanidade daquele de quem cuida, e com a sua própria - o que, por sua vez, permite-lhe lembrar-se de que não é apenas uma máquina que produz resultados. Nesse sentido, humanização seria mais bem compreendida, segundo uma das participantes, como um reumanizar-se.

É olho no olho. É cuidar mesmo. E cuidar é amparo, é aconchego, abraço. É a presença. Presença de verdade. (Noeli)

Significa acolher, apoiar, ouvir e tratar o cliente como único. Considerar e respeitar o ser humano que cada um é. (Isabela)

Eu acho que esse acolhimento é humanização. Trazer esse aconchego. Esse aquecimento no sentido familiar e social, acho que isso é humanização. É tratar o próximo como ser humano. Com seus problemas e suas dúvidas, e suas necessidades, e tentar acolher isso. Tentar trazer um aconchego. (Érica) 
Humanização envolve sempre o paciente e o profissional. O profissional também. É um ser humano escutar o outro, dialogar com o outro. Isso é humano. Interação, comunicação, respeito, dignidade... Tudo isso é... É... hoje em dia realmente tem que se fazer essa pergunta: o que é o ser humano? (Cláudia)

Eu acho que humanização é esse enxergar o ser humano. De ser humano para ser humano. [...] Ou reumanizar. Eu acho que desumanizou demais. Tem gente que nem olha para a pessoa e pede um ultrassom. Já vi consultório particular que o médico não botou a mão na mulher durante a gravidez inteirinha. [...] Hoje é muito comum não ter esse toque - a não ser o toque do aparelho. É um desumanizar, né? E aí o profissional fica igual ao aparelho: não fala, não ouve... mas tem um resultado. Então, eu sinto que em termos de humanização é um reumanizar, é virar humano. (Sônia)

Se você tem uma pessoa que realmente é humana, ela vai fazer um trabalho humano. [...] Humanização é você ter um olhar para o outro como se você estivesse olhando para você mesma. É difícil. Mas você conseguir olhar para a pessoa, com um olhar mesmo de ajuda, de necessidade, de cuidado, eu acho que já é uma humanização. (Mariana)

Algumas participantes compreendem que, em alguns casos, pode ser difícil para o profissional adotar tal postura. Uma delas aponta que para enxergar o outro é preciso que o cuidador enxergue a si mesmo, o que muitas vezes não ocorre. Assim, torna-se-lhe necessário ser submetido a situações em que é cuidado para, então, poder se reconectar com tal dimensão. Outra destaca circunstâncias em que, devido aos ajustamentos então necessários, o profissional acaba por se distanciar de sua humanidade; o que impõe sofrimento tanto para o paciente quanto para o cuidador.

Acho que na verdade as pessoas nem se enxergam, né? E quando a gente não se enxerga, não enxerga o outro. A gente ouve muitos profissionais - profissionais de saúde - falando que só perceberam o que é estar doente, ou o que é precisar de um cuidado profissional quando ficou. E não precisa, né? Ser internado, ficar doente, sofrer um acidente para aprender o que é ser humano. (Sônia)

Porque eu tenho certeza que cada ser humano tem isso dentro dele. Sente, sabe. Mas foi, por conta de circunstâncias absurdas, acabou se adaptando a algo que é estranho a ele mesmo. [...] Acho que faz mal não só para o paciente, mas para o profissional. (Cláudia)

Sendo compreendida de tal maneira associada à humanidade, a humanização do cuidado demanda, segundo algumas participantes, que a questão do que é ser humano seja continuamente recolocada e que se reflita sobre como estabelecer um cuidado que vise à expressão, o desenvolvimento e a realização do indivíduo; um cuidado, ademais, que se dá 
com o reconhecimento de alteridade e, assim estabelecido, no lugar de reforçar a dependência daquele de quem se cuida, fortalece sua autonomia.

Quer dizer que algo é desumano, e que a gente tem que voltar para trás. Então tem a ver com o fato da gente se tocar para aquilo, na verdade, para a pergunta: o que é o ser humano, o que é uma criança, qual é o cerne disso, e como a gente pode agir da forma melhor para que esse humano possa se expressar, possa se desenvolver, possa desabrochar. (Cláudia)

É você estar ali cuidando daquela pessoa, falando, orientando... Não é cuidar de carregar no colo. É lidar com gente. É de igual para igual. (Sônia)

Nesse sentido, foi questionada a posição de alguns profissionais que consideram a humanização atrelada à demanda de determinados equipamentos para que possa se dar falando-se mais especificamente da humanização do parto. Para a participante, tais equipamentos não têm impacto algum se se perde de vista esse aspecto de humanidade no cuidado.

Para ter parto normal, dizem, precisa de uma bola, de cavalinho, de... eu falo, não precisa nada. Precisa de gente. Se não tiver gente, não adianta ter todos esses equipamentos. Não precisa de nada desse equipamento se tiver uma mão, ou uma palavra de carinho, uma presença mesmo. (Sônia)

Humanização também foi associada à integralidade, na medida em que remete a um cuidado considerado em suas várias dimensões - definidas pela participante como física, emocional e espiritual; e a um resgate da humanidade, em que se toma o homem como um ser dotado de movimento, sentimento, intelectualidade e individualidade - lembrando que na Antroposofia a individualidade do ser remete à dimensão da espiritualidade.

Eu posso não solucionar a sua situação, mas eu posso te ouvir. Por que essa ferida não sara? Porque a pessoa não está comendo adequadamente; não tem condições de manter; não pode vir aqui 3 vezes por semana fazer o curativo. [...] A doença tá ligada no todo - no físico, no emocional e no espírito mesmo. De olhar para o todo ser humano. (Mariana)

Eu acho que se a gente conseguir se enxergar, aí a gente retoma o ser humano. Ser de virar humano mesmo. Que é ser gente. Estar vivo. Saber que a gente tem movimento, que a gente tem sentimento, que a gente tem entendimento intelectual... Acho que ter uma individualidade... Ser humano é isso. (Sônia) 


\title{
7.2.1.9. HUMANIZAÇÃO DO CUIDADO NA ASSOCIAÇÃO
}

Todas as profissionais declararam que o cuidado oferecido pelo ambulatório do Núcleo Monte Azul é humanizado - considerada a compreensão de humanização como anteriormente descrita, ou seja, permeada por humanidade, acolhimento e integralidade.

\begin{abstract}
A observação, a orientação, a missão, o foco é esse. (Sônia)
Acredito que as mulheres sentem algo diferente neste serviço. Aqui elas não são número e nem só grávidas. São pessoas, representam famílias. Nas visitas domiciliares tentamos dizer a esta mulher que ela não está sozinha. Nos grupos de gestante partilhamos vida e tentamos oferecer algo nas oficinas que elas possam produzir, algo de belo que são capazes de realizar. (Isabela)

É a presença. É apoio. É abraço. É estou aqui do seu lado. Eu acho que é o que acontece muito nesse pré-natal aqui. A pessoa tem alguém presente. Talvez não seja $100 \%$ presente, mas existe a presença. [...] E mesmo aqui comigo. Às vezes ela fala, ah, era tudo isso que eu estava precisando. Às vezes um bate-papo aqui bobo. Eu passo mais tempo conversando com ela do que preenchendo a ficha. E para elas passa a ser gratificante: alguém está me... escutando, me olhando... [...] Alguém está me ouvindo é super importante. (Noeli)
\end{abstract}

Os encontros do ciclo de palestras foram citados por algumas participantes como um dos lugares privilegiados onde a humanização é concretizada, especialmente por conta do foco no fortalecimento da família; no resgate da capacidade da mulher e de seus familiares de produzirem algo belo para esse ninho familiar - material e afetivamente; e na promoção de cultura de paz.

De ela perceber que ela pode fazer, que ela pode preparar o ninho da criança. [...] Vão resgatando essa beleza interior! De produzir, que hoje em dia isso está muito perdido, né? [...] Porque lá no grupo ela sempre produz alguma coisa para ela ou para o bebê - para a família, né? [...] Fortalecimento da família. [...] Para que essa criança quando chegar possa ter uma família fortalecida, ajudar a fortalecer a família... [...] cultura de paz. (Isabela)

Saíram levando aquilo, nossa, olha que coisa linda que eu fiz para o meu filho! Teve uma que falou, nossa, mas eu não sei nem pôr a mão na agulha. Mas ninguém sabe, vamos começar? E elas saíram assim, nossa eu não sabia que eu era tão capaz. (Noeli) 
Também foi referido o aspecto de mutualidade no cuidado humanizado ali oferecido, pois, a partir do momento em que o profissional se deixa envolver e tocar por aquele de quem cuida, compartilha do vivido; o que lhe possibilita desenvolver uma relação afetiva com a clientela; relação que transcende os protocolos de consulta e/ou demais procedimentos e pode passar a integrar um "cafezinho".

Eu acho que a humanização acaba sendo não só para elas - para a gente também. É uma troca muito grande. [...] Eu acho que elas passam muita coisa para a gente também. Não é você só dar - você recebe muito delas. [...] Você entra no ambulatório não é você entrando por uma porta e já atendendo o paciente. Aqui a gente tem essa troca - um bom dia, uma boa tarde... [...] O afeto! Chamar para o cafezinho. (Noeli)

Para dar conta da integralidade que permeia a atenção humanizada oferecida pelo Núcleo, uma das profissionais mencionou a importância do trabalho em equipe.

\begin{abstract}
A gente não trabalha sozinho, a gente trabalha em equipe. [...] Com toda a dificuldade que nós temos aqui, todo mundo tem um objetivo, e isso é legal. [...] Eu preciso de um médico que dê um remédio para equilibrar a pressão. Preciso de uma auxiliar que cuide dessa ferida. Eu preciso de uma psicóloga para ouvir. Preciso de um terapeuta para fazer um deslizamento. Então, nós trabalhamos em equipe. (Mariana)
\end{abstract}

Outra participante salientou que a humanização não é um "selo" que um serviço adquire indefinidamente, mas, sim, um processo sempre em movimento, acerca do qual se deve continuamente refletir. Na Associação, afirmou, isso é feito a partir da sensibilização dos profissionais - promovida nas reuniões realizadas e, especialmente, pelo uso da Arte -, para questões importantes que permeiam o serviço e para suas atitudes e posturas.

Eu diria que o atendimento na Monte Azul é humanizado. Eu diria que comparado com muitos outros serviços, tem um atendimento humanizado. Isso não quer dizer que a gente não tenha perguntas. A gente tem que se perguntar. Sempre tem coisas para melhorar. Eu diria que isso não é um selo que a Monte Azul tem e pronto. Mas é algo que é um processo que está sempre caminhando. Humanização tem muito a ver com refletir sobre posturas e atitudes. Tem a ver com autorreflexão. E eu acho que na Monte Azul a gente tem uma forma de manter isso vivo e de desenvolver isso nas pessoas. Por meio das reuniões... a gente trabalha muito com a arte como meio de sensibilizar as pessoas para aquilo que elas fazem muitas vezes sem pensar, de costume. [...] Acho que isso ajuda a manter essa busca daquilo que é humano, vivo dentro da Monte Azul. Nesse sentido, a Monte Azul tem um trabalho humano, 
humanizado. Mas isso não quer dizer que dentro disso não aparecem coisas desumanas também. Mas pelo menos tem essa proposta, de vamos trabalhar isso. (Cláudia)

Foi também destacada a importância da avaliação do serviço a partir dos referenciais e percepções da clientela.

Eu acho que está sendo um caminho bem organizado, bem estruturado. Talvez mais para frente a gente sinta falta de alguma coisa ou de outra. E talvez olhando mais de fora, mais através delas [usuárias] para ver quais são as necessidades não atingidas. (Érica)

Quanto às dificuldades relativas à concretização do cuidado humanizado na Associação, seria ainda necessário, segundo as participantes, melhorar alguns aspectos, como mais horários disponíveis para atendimento e menos espera; o que demandaria contratação de mais profissionais e reformulação do fluxo de trabalho. Eu vejo coisas que eu gostaria de mudar, de melhorar. Por exemplo, um exemplo
que parece muito banal: eu acho que as gestantes têm que esperar muito tempo. Eu
não acho isso muito legal. Muitas vezes elas chegam lá às 7 horas e esperam,
esperam, esperam... Também por uma opção delas, muitas vezes, mas... Por
exemplo, a forma como a gente organiza o fluxo pode ser melhor nesse sentido
humanizado. (Cláudia)

Às vezes faltam horários. Está sempre de agenda lotada. Isso poderia mudar se tivesse mais profissionais, se tivesse mais estrutura. (Érica)

Que a gente vai precisar aumentar a questão dos profissionais, o pré-natal, a questão da divulgação, isso tudo é importante. (Isabela)

Por fim, uma participante salientou que nem sempre os profissionais do Núcleo assumem uma postura de promoção desse cuidado humanizado - postura que integra os aspectos destacados anteriormente. Para ela, há ali, de certa forma, um exagero no respeito pela individualidade dos colaboradores, o que abre precedente para falhas. Apesar disso, considera o serviço prestado pela Associação humanizado.

Por isso que eu brigo tanto quando eu vejo que não fazem isso. [...] Acontece. É gente, né? [...] pela individualidade. Respeita-se muito essa individualidade. E 
sempre se acha que a pessoa tem que ter a chance de afinar, melhorar. Então, acaba tendo mesmo algumas falhas de vez em quando. Mas no geral eu sinto que tem um foco legal. E até comparado com outros lugares, dá para a gente falar que tem esse trabalho. (Sônia) 


\section{HUMANIZAÇÃO DO CUIDADO PRÉ E PÓS-NATAL NO NÚCLEO MONTE AZUL: AMPLIAÇÕES E ARTICULAÇÕES DE SENTIDOS}

A análise dos dados procurou compreender as particularidades dos discursos das mulheres-usuárias do serviço de atenção pré e pós-natal, oferecido pelo Núcleo Monte Azul, e das profissionais prestadoras desse serviço. O próximo passo busca uma síntese reveladora de sentidos que se encontram ou se desencontram nesses dois universos e que constroem possibilidades de humanização do cuidado lá produzido. Para gerar uma ampliação da compreensão do fenômeno proposto à investigação, tal síntese deve se fazer acompanhar por uma integração dos dados obtidos durante a fase de reconhecimento de campo, e das discussões já empreendidas por outros autores acerca do tema em pauta. Além disso, será de grande importância que essa construção seja também permeada pela reflexão sobre aspectos que se mostrem favorecedores à superação de desafios e contradições da humanização das práticas em outros contextos.

Para nortear essa elaboração será tomado por base o conceito de humanização discutido no início do presente trabalho a partir da análise de documentos do PHPN (BRASIL, 2001, 2002, 2006b), assim como alguns dos critérios definidos em tal programa, principalmente, aqueles relativos ao acolhimento. E para melhor organizá-la, ela será dividida em dois blocos: o primeiro, composto de percepções, avaliações e impacto do serviço de atenção pré e pós-natal provido pelo Núcleo Monte Azul; o segundo, pelo tema da humanização ali concretizada.

\subsection{PERCEPÇÕES E AVALIAÇÃO DO CUIDADO PRÉ E PÓS-NATAL PROVIDO PELO NÚCLEO MONTE AZUL}

A leitura das análises dos depoimentos das mulheres-usuárias e das profissionais do Núcleo Monte Azul revela a sintonia de sentidos entre esses dois universos. De modo geral, as necessidades apontadas pelas usuárias são as mesmas ressaltadas pelas profissionais; e os aspectos do serviço priorizados por aquelas são, da mesma forma, salientados por estas. Seja 
no tema das demandas vividas pela mulher, seja no da avaliação do serviço, evidenciam-se dois eixos centrais: acolhimento e integralidade.

Embora as usuárias não tenham empregado exatamente essa terminologia, dos seus discursos, acerca do vivido no acompanhamento pré e pós-natal do Núcleo, depreende-se que o acolhimento é entendido por elas como aquilo que lhes proporciona, no contexto de cuidado, a sensação de serem compreendidas, reconhecidas e atendidas em suas necessidades; o que pode também ser considerado como percepção e validação das expressões de sua individualidade, uma demanda, salientada pelas mulheres, vivida nas relações de cuidado durante o ciclo grávido-puerperal.

Tais sentidos vão ao encontro de eixos centrais na definição de acolhimento apresentada pelo Ministério da Saúde (BRASIL, 2006b, 2008): atuação centrada no sujeito e em suas necessidades; postura atenta à unicidade de cada caso, empática e sensível, propícia à compreensão do vivido pela mulher; e escuta qualificada e comprometida com a resolução das demandas apreendidas; tal como também ressaltado por Ramos e Lima (2004), Silva Jr. e Mascarenhas (2005) e Takemoto e Silva (2007).

A maneira como as usuárias se sentiram compreendidas, reconhecidas e atendidas em suas demandas, e de que forma isso foi propiciado pelo serviço, merece, porém, mais considerações. A temática será, então, abordada em conjunto com a discussão sobre os sentidos em torno do acolhimento, apreendidos a partir dos depoimentos das profissionais.

Dentre estas, o acolhimento foi exposto como recurso fundamental à construção do vínculo com as mulheres, e se traduz, essencialmente, pela constituição de um espaço dialógico, pela percepção da mulher em sua unicidade e pelo oferecimento de apoio. Fortalecimento da mulher e dos vínculos familiares, assim como inclusão de acompanhante(s) no cuidado pré e pós-natal, devem ser também compreendidos como expressões do acolhimento no Núcleo. Plasticidade na atuação e liberdade de acesso, por sua vez, destacam-se como recursos indissociáveis ao acolhimento, por permitirem sua concretização no serviço em dimensões mais amplas.

O diálogo parece se evidenciar como elemento fundamental ao acolhimento. Um dos pontos assinalados pelas profissionais foi a importância da escuta do que é expresso verbal e não verbalmente pela clientela - aspecto também mencionado em estudo de Silveira et al. (2004) -, com atenção às questões biológicas assim como às experiências subjetivas e vivências do contexto mais amplo - familiar, social, ocupacional, dentre outros -, entendidas 
como componentes do vivido ao longo do ciclo grávido-puerperal.

De fato, como destacam Klaus e Kennell (1992) e Maldonado (1999), a consideração dessa complexidade de fatores é imprescindível à compreensão das vivências do ciclo e ao seu adequado acompanhamento. Da mesma forma, referem Enkin et al. (2005) que, durante esse período, as mulheres vivenciam importantes questões de ordem física, psicológica e social, as quais devem ser incluídas na atenção provida. Além disso, o reconhecimento da mulher em sua inteireza, levando em conta sua história, seus sentimentos e o ambiente em que vive, é apontado em um dos manuais do PHPN (BRASIL, 2006b) como um dos aspectos do acolhimento.

Foram descritas inúmeras situações em que, no Núcleo, abriu-se espaço para as mulheres expressarem suas vivências nos diferentes campos de experiência; temática, aliás, recorrente nos depoimentos das usuárias. Também ilustrativas dessa consideração das diversas esferas implicadas na vivência do ciclo grávido-puerperal, são as orientações realizadas pela enfermeira durante as consultas pré-natais, que abordavam temas como: tomar sol, para melhor absorção de vitaminas; usar roupas que melhor sustentem o abdome, no caso de multíparas cuja musculatura não estivesse dando conta do peso; recomendar ao companheiro da gestante que a ajude mais em casa, ou ao filho de outra que não revide após uma briga; ou, ainda, orientar uma usuária a não enfrentar fisicamente o companheiro.

Ainda sobre a escuta, nota-se que a ênfase dada a esse elemento, a forma como ele é compreendido e sua aplicação no cotidiano do serviço, revelam uma postura de disponibilidade para a mulher-usuária, para aquilo que ela expressa e, portanto, para o reconhecimento e para a validação de sua individualidade - o que esteve presente nos depoimentos das profissionais, tendo sido diretamente mencionado por Sônia. Uma postura que se diferencia daquela que implica interação dirigida apenas pelo profissional, em que este define os temas a serem tratados e atém-se apenas a eles, tão bem expressa nos relatos de Carolina sobre o vivido na rede conveniada: "No convênio, você chega lá, a médica olha, ela fala o que ela acha. [...] Você passa cinco ou dez minutos na sala. E às vezes, o que você fala não é levado em consideração"; e nos de Sofia: "no convênio médico, a médica chega lá, para toda grávida é o mesmo procedimento. Então, você chega lá, ela não quer saber do jeito que você está ou não; 'ah, você toma isso e isso e pronto"'; ambos proferidos em contraposição ao que essas mulheres salientaram terem encontrado no Núcleo.

A título de ilustrar tal postura de disponibilidade das profissionais, dois dentre os 
muitos exemplos observados nesse sentido no serviço em pauta podem ser retomados. Durante a pré-consulta, enquanto conferia o cartão de pré-natal e fazia os procedimentos devidos - de medir o peso e a pressão -, a auxiliar de enfermagem indagava sobre o estado da mulher e lhe dava espaço para compartilhar o que desejasse; se a conhecia, procurava também saber da família, da casa, ou de situações anteriormente compartilhadas. De forma semelhante, nas consultas de pré-natal, a enfermeira-obstetra sempre criava espaço para a mulher expressar suas questões. A partir disso, ela guiava, então, a consulta, permeando-a, também, por aspectos que ela considerava importante explorar. O tema da alimentação é marcante nesse sentido: as recomendações realizadas pela enfermeira geralmente partiam de alguma queixa expressa pela usuária e perpassavam-se pelo que ela tomava como relevante em termos de horários de refeições e consumo de dados alimentos - e pelo que a gestante expressava ser possível - tendo em vista sua condição sócioeconômica, rotina e gostos.

Também é possível afirmar, considerando especialmente o segundo exemplo, que essa atitude de disponibilidade se fundamenta no princípio de que, na relação profissional-usuária, cada um dos atores é dono de dados saberes. Como expressou Carolina sobre o vivido nas consultas pré-natais no Núcleo: "você tem a possibilidade de expôr o que você acha. Não é a médica que diz, 'você está com isso'. Não, 'eu estou sentindo assim e assim', você explica". Estabelece-se, portanto, uma relação horizontal, em que se valida mulher naquilo que ela mostra de si e se compreende que os sentidos de cada situação podem ser apenas desvelados em conjunto. Em decorrência, as demandas vividas vão sendo identificadas, elaboradas e negociadas no espaço intersubjetivo de profissional e usuária, tal como discute Teixeira (2003) em sua proposta de acolhimento dialogado.

Aqui se está evidenciando, portanto, uma dada dimensão do acolhimento: aquela de postura. Tendo entrado no aspecto da dialogicidade que integra tal dimensão - conforme o discutido por Silva Jr. e Mascarenhas (2005), Teixeira (2003) e também pontuado na PNH (BRASIL, 2008) e no PHPN (BRASIL, 2006b) - e observando sua importância nos discursos de profissionais e de usuárias sobre o tema do acolhimento, assim como sua inserção na prática cotidiana do serviço, faz-se interessante aprofundar a discussão a respeito de tal aspecto. Isso será feito a partir do referencial gestáltico de atitude dialógica, proposto como possibilidade de ampliação da compreensão dos processos de acolhimento e de produção de vínculo no início do presente trabalho. Dentre os quatro elementos de tal postura então abordados, discute-se, nesse momento, três - presença, inclusão e confirmação; a atitude 
amorosa é abordada mais adiante.

A presença, como então referido, relaciona-se intimamente com o tema da alteridade. Ela pressupõe o reconhecimento do outro e, ao mesmo tempo, o colocar-se inteiro na relação, deixando que aquele de quem se cuida possa ser afetado por quem se é (HYCNER, 1997; YONTEF, 1998). As similaridades entre tais considerações e um trecho de um dos manuais do MS, que versa sobre o acolhimento, merecem destaque: "a vida não é o que se passa apenas em cada um dos sujeitos, mas principalmente o que se passa entre os sujeitos, nos vínculos que constroem e que os constroem como potência de afetar e ser afetado" (BRASIL, 2008, p. 8, grifo nosso).

No Núcleo Monte Azul, esse elemento pôde ser observado especialmente na postura das profissionais de se colocarem como, o que se poderia denominar, profissionais-pessoas; ou seja, de se colocarem nas relações com as usuárias não apenas com seus saberes mas, sobretudo, como sujeitos - com uma história, uma subjetividade, uma dada forma de ver o mundo. As interações então estabelecidas, tal como destacado pelas mulheres e profissionais, eram permeadas por "olho no olho", toque, trocas afetivas. Ademais, frequentemente as profissionais compartilhavam com as usuárias preocupações sobre o seu bem-estar, o que era por estas significado como receber atenção e suporte; ser reconhecida e acolhida; e sentir que havia alguém ali consistentemente presente e disponível para elas. Um ato, portanto, que ia ao encontro de demandas por elas vividas e que, ao serem atendidas, proporcionavam sensações de impacto positivo na vivência do ciclo grávido-puerperal e de satisfação com o serviço esta também descrita em estudo de Queiroz et al. (2007) como algo associado à expressão de preocupação por parte do profisssional em relação à mulher e ao bebê.

Ainda acerca do exercício da presença no Núcleo, ocasionalmente, algumas profissionais também dividiam dúvidas e limites - ponto integrante desse elemento da postura dialógica, conforme destacado por Yontef (1998), e uma das traduções do acolhimento, segundo o Ministério da Saúde (BRASIL, 2008). Esse aspecto aparece especialmente no depoimento de Carolina, que relatou por vezes expressar dúvida que a auxiliar de enfermagem não sabia responder, o que, então, as levava a buscar pela coordenadora do ambulatório.

Um exemplo que traduz uma forma mais particular da prática da presença é o da postura da auxiliar de enfermagem. A partir da vivência que a mulher expressava, essa profissional frequentemente compartilhava algo que também havia vivido, tentando ilustrar de que forma havia enfrentado uma dada situação, ou então, simplesmente, para demonstrar que 
compreendia o que a usuária estava vivendo, uma vez que também passara por algo semelhante. As mulheres, por sua vez, depois relatavam que essa auxiliar era alguém que dividia suas vivências com elas; ou que, assim como elas, passara por dificuldades na vida, ou na gravidez. Isso se destacava como forte elemento de vinculação com essa profissional, como será discutido mais adiante.

A inclusão, retomada em breves linhas, é o movimento de, sem se perder de si próprio, inserir-se no universo daquele de quem se cuida e, por meio de uma suspensão dos próprios referenciais, tentar apreender o que ali se passa (HYCNER, 1997; YONTEF, 1998), como quem se põe a olhar o mundo a partir dos olhos do outro - algo que se aproxima, cabe notar, de alguns aspectos do acolhimento destacados em um dos manuais do PHPN (BRASIL, 2006b).

Embora seja um elemento de mais difícil observação, parece possível dizer que os depoimentos das mulheres, ao explicitarem sensações de compreensão e reconhecimento, atestam a prática da inclusão. Nas entrevistas com as profissionais, dois trechos a revelam mais claramente: o relato de Isabela acerca da importância de, ao interagir com o usuário, o profissional de saúde colocar os próprios preconceitos de lado, para melhor compreender o que o outro expressa e vivencia; e o de Cláudia, concernente à essencialidade de o profissional de saúde ser capaz de, por meio de empatia, apreender o que a mulher vive, mesmo que se trate de algo "não expresso em palavras". Quanto aos dados colhidos em campo, um exemplo que evidencia de modo especial a prática da inclusão refere-se ao episódio em que a auxiliar de enfermagem do ambulatório do Núcleo Peinha, atendendo a uma mulher que levava o bebê para fazer inalação, expressou compreensão diante das explicações da usuária acerca do por que não havia comparecido à palestra que acontecera pela manhã; expressão que, acompanhada por um tom verdadeiro, revelou que a profissional fez um movimento de se colocar no lugar daquela mulher, sentir seu cansaço decorrente dos cuidados com o bebê e apreender a dificuldade por ela vivida de acordar cedo e se dirigir ao ambulatório (ainda que o não comparecimento à palestra possa também ter sido mobilizado por outros fatores).

Como possibilidade, então, de se deixar tocar pelo outro, por aquilo que ele vive e por quem é, a inclusão, juntamente com a presença, impulsiona o movimento, na relação, de “afetar e ser afetado" (BRASIL, 2008, p. 8), de falar e escutar, de perceber e ser percebido. Além disso, se, como aponta Teixeira (2003, p. 104), as "nossas necessidades não nos são 
sempre imediatamente transparentes e nem jamais definitivamente definidas", a prática da inclusão, como elemento da postura dialógica, torna-se instrumento que favorece o processo de investigação de demandas, ao permitir que se apreenda o outro tanto no mais claramente manifesto quanto no mais obscuro, ou no que ainda vive em forma de potência.

No depoimento de Sofia, essa questão aparece mais nitidamente. Ela destacou sentir no Núcleo um movimento, por parte das profissionais, de explorar a necessidade de cada mulher e de, a partir disso, prover o necessário para que, como pontuou Cláudia, cada uma possa se tornar uma parturiente e uma mãe; o que, de fato, pôde ser observado nas experiências de reconhecimento de campo, e nos relatos das demais participantes.

A confirmação, por sua vez, se traduz pela validação do outro em quem ele é, ou seja, em seus desejos, necessidades, sentimentos, crenças, valores, conflitos e dificuldades; e em quem pode vir a ser (JACOBS, 1997; YONTEF, 1998). Implica também, portanto, respeito diante do que se apreende do outro - a partir da inclusão -, criando-se, então, um espaço em que o usuário se sinta encorajado a se colocar como é. A partir disso, parece possível afirmar que inclusão e confirmação se constituem em expressões da dimensão ética do acolhimento como diretriz da Política Nacional de Humanização, uma vez que essa "se refere ao compromisso com o reconhecimento do outro, na atitude de acolhê-lo em suas diferenças, suas dores, suas alegrias, seus modos de viver, sentir e estar na vida" (BRASIL, 2008, p. 6).

Não foram raros os relatos de mulheres-usuárias do ambulatório do Núcleo Monte Azul acerca de como ali se sentiam à vontade para expressar quaisquer vivências e dúvidas; ou então, no caso daquelas que frequentavam, ou haviam frequentado, outros serviços, da dificuldade lá vivida para manifestarem suas questões, seja porque não havia espaço para tanto, seja porque o profissional "não levava em consideração", como assinalou Carolina, o que expressavam.

A confirmação permeada por limite - considerando que, como pontua Cardella (1994), a confirmação se dá em nível existencial, não significando, portanto, que o cuidador não pode discordar de escolhas tomadas por aquele de quem cuida e intervir quando julga adequado tem exemplo ilustrativo nos depoimentos de usuárias acerca das advertências - por elas nomeadas de "broncas" - da enfermeira-obstetra, pela alimentação inadequada e/ou pelo ganho de peso, feitas, conforme presenciado na fase de observação, respeitosamente. De maneira geral, as mulheres pareciam entender que tais "broncas" faziam sentido e eram necessárias; podendo ser compreendidas, assim, como algo que integrava os cuidados para 
com elas. Ou seja, tratava-se de um ato de confirmação porque o limite era dialogado, de modo que o outro pudesse apreender o seu sentido, e era colocado como algo pontual, sem ser associado ao valor daquela mulher como pessoa no mundo.

Porém, houve episódios observados no Núcleo, convém também salientar, em que tal confirmação não se deu, como nos casos relacionados a atrasos no atendimento. Em tais ocasiões, ainda que o discurso da profissional fosse, algumas vezes, de preocupação, no contato com as mulheres isso geralmente não era transmitido. Não era demonstrada empatia em relação à espera, nem validação dessa difícil experiência. Em uma das situações observadas, a justificativa baseou-se na comparação com outros serviços, para mostrar que estes seriam ainda piores.

Acerca dos demais aspectos que se constituíram em traduções do acolhimento no Núcleo Monte Azul, a percepção da mulher em sua unicidade foi já desvelada em meio às reflexões sobre a dialogicidade. Porém, há ainda mais um fator relacionado a esse aspecto: a importância dada pelas profissionais ao ato de se nomear as usuárias. Embora tenham sido descritos episódios, em situações de pré-atendimento, em que tal ato não se integrava à prática cotidiana, de modo geral, observou-se que no Núcleo Monte Azul as usuárias eram tratadas pelo nome. Um ponto que, acredita-se, muito contribui para essa prática, situa-se no caráter de familiaridade apreendido no serviço, onde frequentemente usuários e profissionais já se conheciam. Porém, especialmente no que concerne aos profissionais ligados à atenção ao prénatal e ao puerpério, esse ato se explicitou como norma. Como descrito, a auxiliar de enfermagem, ao recepcionar uma mulher no serviço pela primeira vez, se ainda não a conhecia, preocupava-se, primeiramente, com as apresentações nominais. A partir de então, dirigia-se à usuária sempre pelo nome. De modo semelhante, Sônia referiu-se, durante entrevista, à sua preocupação de sempre chamar a mulher pelo nome, especialmente por considerar esse ato uma validação da existência do outro como pessoa.

O PHPN (BRASIL, 2006b) também aponta como componente do acolhimento o profissional se apresentar e chamar o usuário pelo nome. Em termos de dialogicidade, isso revela, de certa forma, um movimento entre presença - pois, ao se apresentar, o profissional se personaliza - e confirmação - ao se traduzir em validação do outro em sua condição de sujeito, contraposta ao tratamento de "gravidinha", por exemplo, que a mulher muitas vezes recebe no serviço de saúde, tal como destacou Sônia. De modo semelhante, Camelo et al. (2000) referem que chamar o usuário pelo nome, contribui para lhe transmitir uma sensação 
de importância; assegurar-lhe a singularidade; e personalizar a relação com ele estabelecida.

Outro elemento que se revelou como expressão do acolhimento no Núcleo, e que caminha na direção de uma demanda especialmente destacada por usuárias e por profissionais, refere-se ao apoio. Aquelas mencionaram, nesse sentido, a importância de a mulher que vive o ciclo grávido-puerperal ser olhada como alguém que possivelmente estará se sentindo mais fragilizado e carente; e, por essa razão, necessitando do suporte de outrem; o que foi também apontado pelas profissionais e é discutido na literatura (BEE, 1994; BRAZELTON, 1988; KLAUS; KENNELL, 1992; MALDONADO, 1999). Em nível mais particular, todas as mulheres-participantes relataram situações de demanda por suporte, seja por conta de vivências diretamente ligadas ao ciclo grávido-puerperal - como preocupações em relação ao bom desenvolvimento do bebê ou complicações vividas durante a gravidez, o parto, ou o puerpério -, seja em função de circunstâncias difíceis no contexto mais amplo, que ganhavam tons mais fortes devido ao momento vivido - como desentendimentos familiares e/ou conjugais, ou experiência de estresse em razão de sobrecarga de tarefas.

Ademais, embora a principal ênfase, quando questionadas acerca das necessidades da mulher durante o ciclo grávido-puerperal, tenha sido ao suporte oferecido pelo companheiro e por demais familiares - o que explicita a importância do trabalho de fortalecimento de tais vínculos, discutido adiante - todas as participantes relataram vivências importantes nesse sentido com a equipe de profissionais. Os significados apreendidos desse tema revelam uma gama de experiências associadas ao impacto que essas mulheres observaram em seu vivido ao longo da gravidez, do parto e do puerpério: receberem afeto; sentirem-se compreendidas; sentirem a presença consistente das figuras eleitas para desempenharem tal papel de suporte o que se associa à questão do vínculo, sobre a qual se reflete mais à frente; receberem informações e orientações; perceberem-se auxiliadas a encontrar recursos para lidar com o vivido. Em meio a essas vivências destaca-se a experiência de se sentir mais fortalecida para viver o ciclo e a maternidade.

Diante disso, nota-se que o oferecimento de apoio e o trabalho de fortalecimento da mulher estabelecem íntima inter-relação, a qual evidencia também este como expressão do acolhimento no Núcleo Monte Azul. A associação entre acolhimento e fortalecimento da mulher, cabe destacar, consta de um dos manuais do PHPN, que refere que o primeiro promove o segundo e ajuda a mulher na "construção de um conhecimento sobre si mesma" (BRASIL, 2006b, p. 16). 
Um primeiro ponto importante a ser comentado sobre esse trabalho diz respeito à sua inter-relação com o tema do empoderamento. $\mathrm{Na}$ dimensão de apropriação dos direitos que esse processo envolve (NOGUEIRA-MARTINS; BÓGUS, 2004; TORNQUIST, 2002), especialmente Sônia e Mariana salientaram intervenções no sentido de se promover, entre as usuárias, ampliação de conhecimentos sobre seus direitos, assim como auxiliá-las e estimulálas a lutar por eles. A esfera de apropriação da capacidade do próprio corpo de gestar e dar à luz a uma vida, e de se assumir como mãe, também associada ao empoderamento (TORNQUIST, 2002), manifestou-se em depoimentos como o de Cláudia, que destacou a importância de auxiliar a mulher a se tornar "autora de seu próprio livro"; ou seja, ajudá-la a se apropriar de recursos para lidar com o vivido de modo que, mais autoconfiante, possa se colocar de forma mais ativa e autônoma no mundo.

Dentre os meios utilizados para esse fim, as profissionais salientaram, fundamentalmente, aspectos ligados ao acolhimento: escuta disponível, especialmente para as experiências subjetivas; oferecimento de suporte e de orientações; fortalecimento de autoestima. Também destacaram a adoção de uma postura - entendida aqui como dialógica de se colocar ao lado da mulher e ajudá-la a "descobrir seu próprio jeito" de ser gestante, parturiente e mãe - como referiu Cláudia -, e de resolver seus conflitos - como mencionou Isabela; ou ainda, conforme salientou Sônia, de auxiliá-la a "procurar o lugar dela na Terra", de grávida e de mãe-cuidadora.

$\mathrm{Na}$ fase de reconhecimento de campo, observou-se, nesse sentido, alguns episódios em que a enfermeira-obstetra lembrava as usuárias, diante de um momento difícil, de outras circunstâncias que haviam vivido e conseguido enfrentar. Além disso, frequentemente exautava a força que tinham, especialmente intensificada pela gravidez; força que lhes permitia viver os processos de gestação, parto e puerpério e lidar com eventuais dificuldades, deste contexto e daqueles mais amplos. Ao mesmo tempo, presenciou-se relatos de usuárias sobre experiências de conseguir levar a gravidez adiante, ou enfrentar determinada situação, por conta do suporte oferecido pela enfermeira. Do encontro desses dois universos evidenciase a importância da relação de base dialógica estabelecida entre profissionais e mulheres ao processo de fortalecimento vivenciado pelas usuárias.

Nos depoimentos das usuárias, por sua vez, revela-se mais nitidamente o impacto por elas percebido em suas vivências do ciclo grávido-puerperal a partir desse trabalho de fortalecimento da mulher. Embora seja preciso compreender esse impacto em um contexto 
mais amplo de fatores, como momento de vida, história pessoal, atividades desenvolvidas e rede social, de um modo geral, as mulheres se sentiram mais fortalecidas e autoconfiantes quanto à sua capacidade de vivenciar as experiências do ciclo grávido-puerperal, de lidar com as dificuldades vividas e de se assumirem como cuidadoras do bebê.

Em relação à parição, todas as participantes que fizeram parto normal falaram sobre se perceberem com mais recursos para vivê-lo. Recursos relativos a saber como se desenrola o trabalho de parto e como melhor proceder em cada momento; a conhecer dinâmicas hospitalares e como melhor lidar com elas - por exemplo, adiando a ida ao hospital; a manejar exercícios de alívio da dor e facilitadores do bom desenrolar do trabalho de parto. Recursos que as fizeram se sentir seguras, confiantes em sua capacidade e na capacidade de seu corpo, de parir - algo que também remete ao trabalho de ampliação de consciência corporal descrito pela fisioterapeuta, mas também observado na atuação da enfermeira-obstetra. Recursos que, para as mulheres não primigestas, favoreceram experiências de menos dor durante o trabalho de parto e parto; e que, para a usuária primigesta, propiciaram a vivência do parto conforme o desejado, acompanhada, portanto, de grande satisfação e sensação de realização. É importante lembrar que todos esses aspectos associam-se à promoção da humanização da atenção ao parto (BRASIL, 2001), assim como com o elemento de provimento de orientações e de informações que integra o acolhimento (BRASIL, 2006b, 2008; CAMELO et al., 2000; LIMA et al., 2007).

Algumas mulheres também relataram efeitos de prevenção de vivências de depressão e estresse. Lourdes, por exemplo, concluiu que o acompanhamento pré-natal a ajudou a não desenvolver um quadro de depressão pós-parto. Apesar de, como se sabe, esse ser um quadro perpassado por uma série de questões, o que o relato dessa usuária expressa é que, sentindo-se mais fortalecida, julgou-se menos suscetível à depressão, vivência familiar em seu histórico. De forma semelhante, Carolina salientou que se a mulher descobre e/ou constrói mais recursos para lidar com as dificuldades encontradas e sente que tem um lugar de suporte para os momentos julgados necessários, é menos provável que experiencie quadros de estresse e de depressão. De fato, como se afirma em um dos manuais do PHPN (BRASIL, 2006b), apoio psicológico e ações educativas constituem-se fatores que garantem a prevenção de complicações.

Outro impacto reside na elaboração do papel materno. Juliana assinalou que, em sua segunda gravidez, sentiu-se mais apta a assumir a responsabilidade pelos cuidados do bebê, 
não carecendo delegá-los à mãe, como ocorreu na primeira gestação. Sofia afirmou que o espaço oferecido no pré-natal do Núcleo, para que questões fossem ouvidas e elaboradas, possibilitou-a a sentir-se mais preparada para lidar com o vivido e experienciar a gravidez e a maternidade com satisfação. Cabe notar que esses casos demonstram, mais especificamente, a inter-relação do trabalho de fortalecimento da mulher com o de fortalecimento dos vínculos familiares - outro grande foco do cuidado pré e pós-natal do Núcleo Monte Azul e que aqui foi também compreendido como expressão do acolhimento.

De fato, as profissionais entendem o fortalecimento da mulher como meio de preparála para receber bem o bebê, destacando que se ela é cuidada ao longo do ciclo grávidopuerperal, se recebe apoio e encontra espaço para contatar e elaborar suas questões, torna-se mais fortalecida, autoconfiante e disponível para assumir o papel de cuidadora do bebê e, portanto, para garantir seu bom desenvolvimento; considerações que encontram suporte em Brazelton (1988), Delfino et al. (2004) e Lima (2006).

Elas também referiram a importância de se promover, desde a gestação, o desenvolvimento da capacidade da mulher de perceber o bebê e as necessidades dele, o que é feito especialmente durante o ciclo de palestras, e também durante as consultas de pré-natal. Como defende Lima (2009), a percepção do bebê se desenvolvendo intraútero como um ser ativo já em interação com o mundo - via ventre materno -, propiciada a partir de ampliação de consciência corporal, favorece a sedimentação do vínculo entre mãe e bebê. Assim, o trabalho corporal realizado pela fisioterapeuta, bem como o estímulo à percepção do próprio corpo promovido pela enfermeira, podem também ser agregados às iniciativas, no Núcleo, em favor do fortalecimento de vínculos; ainda que seja importante notar que se entra, então, em um campo em que esse trabalho transcende a dimensão do acolhimento.

Apesar de o tema da vinculação entre mãe e bebê não ter sido investigado no presente estudo, alguns dados sugestivos acerca de possíveis resultados desse trabalho de fortalecimento de vínculos podem ser aqui abordados. A despeito de as mulheres-participantes terem relatado dificuldades vividas no pós-parto e período subsequente, não foram observados prejuízos aparentes em sua relação com o bebê. Pelo contrário, consta que elas se mantiveram disponíveis para os cuidados com ele, algumas vezes preocupadas em resguardar o espaço de interações das dificuldades e dos conflitos vividos no contexto mais amplo - como Gabriela, que em meio a questões conjugais e financeiras, angustiava-se com a possibilidade de o estresse aí vivido interferir em sua relação com a filha. Outro ponto que merece destaque é 
relativo à forma como as mulheres se referiam aos bebês: com afetividade, e expressando preocupação com o bem-estar dele. Além disso, algumas usuárias, já durante a gravidez, consideravam-no como um ser em relação com o mundo, reagindo emocionalmente quando em interação, via ventre materno, com os demais e sofrendo impacto de situações de estresse vividas pela mãe. Por fim, o conceito de maternidade expresso pelas mulheres também revelou disponibilidade para a construção desse vínculo com o bebê. Acredita-se que tais questões mereceriam investigação mais ampla em estudos futuros.

Algo a ser ainda comentado sobre o trabalho de fortalecimento de vínculos familiares refere-se ao fato de ele ir ao encontro de uma demanda, destacada por algumas usuárias, da mulher que vive o ciclo grávido-puerperal: de que pessoas de seu círculo mais íntimo de relações, e de modo especial o companheiro, assumam o lugar de figuras de apoio. Cabe lembrar que associações entre provimento de suporte à mulher durante a gestação e experiência satisfatória de parto, vinculação com feto/bebê e estabelecimento de boas interações com ele, são assinaladas por Bee (1994) e Klaus e Kennell (1992). Revela-se, dessa forma, a importância do espaço, oferecido durante o pré-natal, à elaboração de conflitos e à ampliação da possibilidade de entendimento e afeto nas relações conjugais/familiares, tendo em vista não apenas a promoção de um bom contexto de desenvolvimento para o bebê como também a possibilidade dessas pessoas assumirem o lugar de figuras de suporte à mulher.

Essa questão esteve presente no depoimento das profissionais principalmente sob o tema da inclusão de acompanhante(s) nas atividades que integram o cuidado pré e pós-natal do Núcleo Monte Azul, a qual é salientada no PHPN (BRASIL, 2006b) como aspecto do acolhimento e foi também aqui tomada como sua expressão. Merecem destaque os relatos de Cláudia sobre a importância de o profissional "trazer o pai para perto" e favorecer a expressão e a elaboração de vivências entre ambos; e de Sônia, acerca da inserção, nas atividades, do pai, e também das demais pessoas envolvidas no vivido pela mulher.

Entre as usuárias, o depoimento de Sofia ilustra de modo especial a demanda pela inclusão de acompanhantes no cuidado pré e pós-natal - que se está aqui entendendo em interrelação com o trabalho de fortalecimento de vínculos familiares -, assim como as repercussões dessa inclusão em seu vivido. Ela salientou a importância do espaço que teve durante o pré-natal, onde ela e o companheiro puderam melhor trabalhar determinadas questões. A partir disso, descreveu, o marido pôde se aproximar mais dela, melhor compreender o que se passava com ela, elaborar suas próprias questões, e, então, além de ficar 
mais disponível para apoiá-la, melhor assumir o papel de pai. Em decorrência, segundo seu relato, sentiu que havia construído com o companheiro uma família.

Outro ponto concernente à inclusão de acompanhantes no cuidado do Núcleo referese, como os dados de reconhecimento de campo revelam, ao tipo de uso de tal espaço/possibilidade. Dentre as 28 consultas observadas, 13 tiveram presença de acompanhantes. Com exceção daquelas em que o acompanhante era o pai do bebê, quando então se fazia necessário o convite da enfermeira, nos demais casos verificou-se que espontaneamente as mulheres entravam em consulta com seus filhos, mães, sogras, amigas, ou quem as estivesse acompanhando, havendo participação ativa de todos durante os atendimentos. Depreende-se, a partir disso, que essas mulheres estavam apropriadas de um direito, direito de escolha para comparecer ao pré-natal sozinhas, ou acompanhadas por quem desejassem; e que responde, no caso dessa segunda opção, a uma necessidade de terem a presença daqueles que participam de suas vidas em outros espaços, também ali. Além disso, também para os acompanhantes esse espaço revelou-se importante, já que podiam então ter validada a sua participação na gestação e na vinda ao mundo do novo ser, e, assim, viver-com a mulher esse momento - como no episódio do menino que exultou ao ser integrado no exame clínico da mãe e ouvir os batimentos cardíacos do irmão no ventre materno, ou das mães, sogras e maridos que puderam externar suas perguntas, comentários e vivências. Mais uma vez, portanto, evidencia-se o tema do fortalecimento de vínculos.

O fato, porém, do uso de tal espaço ter sido mais difícil, ou raro, quando se tratava do pai do bebê - presença pouco expressiva de companheiros em sala de espera, e participação destes em apenas 2 das 13 consultas que incluíram acompanhantes - merece alguns comentários à parte. Uma primeira hipótese que pode ser aventada é relativa à possibilidade de, para algumas usuárias, o ciclo grávido-puerperal ser um evento eminentemente feminino e, por essa razão, o acompanhante escolhido não ser o pai do bebê, como descrito por Cavalcante (2007).

Outra questão refere-se à demanda constante de convite desses atores à entrada em consulta, o que, para a enfermeira do Núcleo, revela dificuldade dos homens de se apropriarem do direito de uso desse espaço. De fato, Duarte (2007) aponta a não legitimação de tal participação em outros serviços, relatando que, em estudo realizado em Ribeirão Preto junto aos usuários da Rede SUS, 94\% dos homens referiram desejo de participarem das consultas pré-natais de suas parceiras, mas se frustravam diante do impedimento então 
frequentemente vivido.

Oliveira et al. (2009) indicam, ainda, outro aspecto concernente a esse tema: no estudo que realizaram, o trabalho foi um dos motivos de impedimento à participação em consultas pré-natais mais apontados pelos homens. Embora desde 1999, conforme aponta Cavalcante (2007), o direito da mulher à acompanhante em consultas pré-natais esteja, no Estado de São Paulo, garantido em lei, não há, ainda, segundo Oliveira et al. (2009), legitimação, por exemplo, do abono de faltas de trabalho aos homens que acompanham a parceira em consultas pré-natais. Não pode ser desconsiderado, nesse sentido, o dado de observação de, no Núcleo Peinha, onde o pré-natal realizava-se no período vespertino, não ter sido verificada presença de companheiros.

De todo modo, é interessante salientar que nas duas consultas que contaram com participação do companheiro, criou-se oportunidade para a produção de um cuidado mais amplo e eficiente. Em uma delas a enfermeira trabalhou algumas questões conjugais, no sentido de o parceiro oferecer mais suporte à mulher. Em outra, o marido forneceu dados importantes, como a gestante não estar se alimentando adequadamente, o que permitiu à enfermeira a adoção de condutas a esse respeito. Convém considerar que, conforme Duarte (2007), o envolvimento do parceiro na atenção pré-natal é agente promotor de maior adesão da mulher às consultas, assim como às orientações e aos cuidados providos.

Em nível mais amplo - ou seja, tendo como foco não apenas o parceiro mas também os demais membros da rede social da mulher -, a inclusão de acompanhantes foi ainda apontada por algumas profissionais como meio de sedimentar melhor determinadas práticas, como aquelas relacionadas ao parto e aos cuidados com a amamentação. O depoimento de Mariana é ilustrativo, quando a profissional destaca que a inserção das pessoas próximas à usuária nas atividades do ciclo de palestras permite-lhes que também sejam preparadas para a chegada do bebê, e favorece que ajudem a mulher a aplicar, no pós-parto, as orientações recebidas, como não oferecer chás ou leite não materno ao bebê. De fato, a inclusão do acompanhante é salientada na literatura como fator fundamental à preparação para o parto, de modo que ele possa encontrar um espaço de expressão e elaboração de suas próprias questões - principalmente quando se trata do pai do bebê - (LIMA, 2003; MALDONADO, 1999) e melhor assumir o lugar de promotor de suporte à mulher durante o parto (BRASIL, 2001; CARVALHO, 2003; ENKIN et al., 2005). Além disso, Silveira e Lamounier (2006) associam a importância de o pai ser inserido no acompanhamento ao ciclo grávido-puerperal à sua 
influência no aleitamento materno.

A plasticidade na atuação é outro elemento que se revelou favorecedor à concretização da prática do acolhimento no Núcleo. Ela pode ser vista, em grande medida, associada ao dialógico e à percepção da mulher em sua singularidade. Ao acolher as demandas das usuárias, para melhor atendê-las, as profissionais efetuam os ajustamentos em sua atuação e/ou no serviço que se mostrem necessários em cada caso, como visitar uma puérpera três vezes em uma mesma semana, ainda que o mais frequente seja uma visita semanal; ou definir a duração de uma consulta pré-natal de acordo com o que a mulher sinaliza necessitar em cada ocasião.

Faz-se importante, porém, compreender essa plasticidade na atuação em um contexto institucional mais amplo, uma vez que, para ser possível, é necessário haver flexibilidade no serviço e permissão aos profissionais para que ajam de forma autônoma. A autonomia do trabalhador associada à prática do acolhimento foi relatada em estudo realizado por Takemoto e Silva (2007). Da mesma forma, em uma das cartilhas da PNH (BRASIL, 2008) a ampliação da autonomia dos sujeitos envolvidos nos processos de produção de saúde é apontada como meio e como fim de um cuidado acolhedor e humanizado.

A liberdade de acesso, da mesma forma que a plasticidade na atuação, funciona no Núcleo como instrumento que traduz, promove e amplia a concretização do acolhimento. Verificou-se, entre as profissionais, disponibilidade para acolher as mulheres-usuárias em contextos para além daqueles de consulta marcada ou de procedimentos, sempre que estas expressavam uma demanda nesse sentido, presencialmente ou, em alguns casos, por meio de contatos telefônicos. Para as mulheres, esse aspecto se destacou no cuidado, pois, ao gerar a reafirmação do lugar de figura de referência ocupado pela maior parte das profissionais e o oferecimento de respostas mais imediatas às questões vividas, proporcionou maior sensação de acolhimento e de suporte.

É importante notar que os aspectos do acolhimento no Núcleo Monte Azul até o momento discutidos, especialmente os de inclusão de acompanhante, plasticidade de atuação e liberdade de acesso, situam-se em um espaço de intersecção, uma vez que ao mesmo tempo em que refletem a postura e a atuação das profissionais, traduzem a forma com que o serviço do ambulatório do Núcleo se estrutura e se organiza. Essa é uma questão importante, uma vez que se refere a outra dimensão do acolhimento: a de (re)organizador do serviço, tal como apontado por alguns autores (ESPERANÇA; CAVALCANTE; MARCOLINO, 2006; 
FRANCO; BUENO; MERHY, 1999; MARQUES; LIMA, 2004; SCHOLZE et al., 2006; SILVA JR.; MASCARENHAS, 2005; SOLLA, 2005) e também discutido pelo MS (BRASIL, 2008).

Uma das facetas dessa dimensão do acolhimento, conforme Esperança, Cavalcante e Marcolino (2006), Franco, Bueno e Merhy (1999) e Scholze et al. (2006), é a atividade de recepção ao usuário. No Núcleo, o investimento de esforços voltados ao oferecimento de um bom atendimento à mulher desde a porta de entrada teve destaque especialmente no depoimento de Mariana, que expressou a compreensão de que uma boa recepção favorece a adesão da usuária às demais atividades integrantes do acompanhamento pré e pós-natal, e constitui-se um primeiro espaço de construção de vínculo. Além disso, principalmente se considerado o tema do acolhimento à demanda espontânea durante a atividade de recepção (ESPERANÇA; CAVALCANTE; MARCOLINO, 2006; FRANCO; BUENO; MERHY, 1999; SCHOLZE et al., 2006), a liberdade de acesso praticada no Núcleo também se evidencia como expressão dessa atividade.

Porém, como defendem Brasil (2008), Inojosa (2005), Lima et al. (2007), Ramos e Lima (2003), Schimith e Lima (2004), Silveira et al. (2004), Solla (2005), Takemoto e Silva (2007) e Teixeira (2003), ainda que possa ser interessante e importante um espaço de acolhimento de porta de entrada, ele não deve se reduzir a esse espaço. De fato, como até aqui discutido, o acolhimento no Núcleo, embora praticado na recepção à usuária, estende-se pelos demais encontros que permeiam o acompanhamento pré e pós-natal. O relato de Juliana exemplifica de modo especial essa questão, evidenciando uma das articulações possíveis entre os espaços do serviço promovida pelo acolhimento, dialogado (TEIXEIRA, 2003), com vistas à resolutividade. Segundo ela, após o término de um encontro do ciclo de palestras - sua porta de entrada no Núcleo -, no qual compartilhara as dificuldades vividas na UBS onde realizava o pré-natal, foi acolhida por uma das enfermeiras, que então lhe esclareceu dúvidas e providenciou novos pedidos de exames, para melhor investigar a situação experienciada. Após retornar com os resultados, Juliana obteve mais esclarecimentos, o que lhe permitiu alívio das angústias então vividas.

A PNH (BRASIL, 2008, p. 21) propõe que, com vistas a se "prestar um atendimento com resolutividade e responsabilização", essa articulação entre espaços, prevista pela sedimentação do acolhimento, ocorra também entre serviços. Um exemplo disso, no Núcleo Monte Azul, é o de um caso relatado por Sônia acerca de uma mulher que estava em 
acompanhamento paralelo na UBS. Após se identificar, na Associação, que esta usuária estava vivenciando uma gestação de alto risco e conferir-se na UBS se isso fora diagnosticado, foram tomadas providências em caráter de urgência para garantir o atendimento imediato da usuária em serviço de referência de alto risco, tais como, contato com um desses serviços, obtenção de encaixe para atendimento e oferecimento de recursos financeiros para a usuária conseguir se deslocar até lá, uma vez que se tratava de uma família sem condições econômicas para arcar com os custos do transporte.

Convém, porém, observar que a especificidade na concepção de resolutividade associada ao conceito de acolhimento entre as profissionais do Núcleo Monte Azul, nem sempre se expressa da forma acima descrita. Os depoimentos apontam, especialmente, a importância de que as mulheres sejam acolhidas em suas vivências subjetivas. $\mathrm{O}$ relato de Isabela é bastante significativo quando ela afirma que, muitas vezes, as profissionais identificam dificuldades vividas pelas mulheres para as quais não enxergam resolução. Entretanto, escutam e apoiam a usuária no que ela compartilha, atendendo, portanto, às necessidades da ordem da subjetividade. Da mesma forma, Mariana destacou a compreensão existente entre os profissionais do Núcleo de que, em muitos casos, a demanda do usuário não é, apenas, de acompanhamento clínico mas de compartilhamento e de obtenção de suporte diante das dificuldades vividas; ou ainda, que mesmo em situações precárias de vida, muitas vezes a principal demanda da mulher é ser ouvida e olhada, receber um abraço e um apoio. Tais situações remetem, novamente, à questão do dialógico já discutida; e evidenciam o caráter de o profissional se solidarizar com as necessidades da clientela, tal como referido em uma das cartilhas da PNH acerca do acolhimento (BRASIL, 2008).

Vale ressaltar que esses dados estão em consonância com aqueles encontrados por Takemoto e Silva (2007, p. 338) em um dos Centros de Saúde incluídos em seu estudo, onde um dos sentidos do acolhimento apreendidos entre os profissionais foi o de resposta, especialmente, às necessidades não clínicas dos usuários, ou seja, aquelas que abrangem as demandas de "conversar, desabafar, falar dos problemas"; mesmo em casos em que havia também questões de ordem clínica. Da mesma forma, referem Silveira et al. (2004, p. 73) que entre os profissionais de equipes do Programa de Saúde da Família que integraram o estudo, o acolhimento foi associado não apenas à resolução completa das demandas apresentadas pela clientela mas também à "atenção dispensada, através da escuta, à valorização das queixas e à identificação das necessidades". 
A partir de tais considerações, destaca-se a importância de um serviço de saúde ampliar a compreensão acerca do conceito de resolutividade. Especialmente tendo em vista uma perspectiva de promoção de autonomia, tal como aquela que permeia as propostas de acolhimento e humanização (BRASIL, 2008), é fundamental considerar que, diante de algumas dificuldades vividas por uma usuária, o trabalho é de, a partir da postura dialógica, assegurar-lhe que há ali alguém para viver aquilo com ela e para ajudá-la a perceber os recursos que possui e/ou que pode desenvolver para lidar com o vivido - considerando-se, inclusive, que, por vezes, o caminho não está em ações dirigidas "ao que está no mundo", mas em uma mudança na forma com que o sujeito se relaciona e se posiciona diante do que vive. Amplia-se, assim, a própria concepção de resolutividade, podendo-se então validar ações de suporte, escuta e diálogo como atos legítimos de promoção de saúde; o que se mostra de fundamental importância se o desejo é avançar na concretização de uma humanização do cuidado.

Ainda sobre a intersecção do acolhimento como postura e como (re)organizador de um serviço, convém considerar que nem todos os colaboradores do ambulatório do Núcleo parecem facilmente assumir uma postura acolhedora em todos os seus elementos. Foram descritos alguns episódios em que na recepção, ou na pós-consulta, os atendimentos foram permeados por impaciência e/ou pouca atenção. Além disso, acompanhou-se pré-consultas em que, embora as auxiliares de enfermagem fossem atenciosas e respeitosas, limitavam-se a realizar os procedimentos, não chamando as usuárias pelo nome e, tampouco, dando espaço para que elas expressassem suas questões e demandas. Depoimentos de algumas profissionais também fizeram referência a dificuldades de colaboradores a esse respeito.

A Associação, porém, entendendo que "o desenvolvimento de uma organização depende principalmente do desenvolvimento das pessoas que nela trabalham" (CRAEMER; IGNACIO, 2008, p. 115), e adotando uma "cultura", como pontuado por Cláudia, que tem o acolhimento como um de seus pilares fundamentais, parece ter criado uma estrutura - como sugerem os indícios colhidos a esse respeito - voltada ao trabalho de falhas como as acima descritas, as quais, ainda que dignas de nota, não foram expressivas se considerado o conjunto dos dados coletados. Uma estrutura constituída de espaços tais como grupos de estudo; reuniões de convivência, de equipe, de metas; encontros e conversas durante o expediente de trabalho. Espaços de reflexão sobre a filosofia da instituição; modos de concepção do trabalho e de estruturação do serviço; questões em torno do ciclo grávido-puerperal; funcionamento de 
equipe; conquistas e dificuldades vivenciadas no serviço. Espaços de compartilhamento de questões, profissionais ou pessoais, com colegas de equipe ou com coordenadores. Espaços de trabalho e desenvolvimento pessoal, promovidos principalmente pelo uso da arte. E espaços de cuidado ao profissional, traduzidos pelo oferecimento de psicoterapia ou acompanhamento antroposófico e pela possibilidade de solicitação de dias de folga e de negociação de férias. Uma estrutura, portanto, provedora de condições à concretização do acolhimento, e da humanização, na produção do cuidado; e reveladora da compreensão de que essa concretização demanda que a rede de acolhimento se estenda também aos trabalhadores, tal como defendido no início deste estudo.

A importância da constituição de espaços, como os acima descritos, à sedimentação do acolhimento vem sendo, de fato, discutida na literatura. As dificuldades vividas na prática do acolhimento, tais como não saber como proceder em uma dada situação (TAKEMOTO; SILVA, 2007), deparar-se com as próprias vulnerabilidades e limitações (INOJOSA, 2005), ou travar contato mais próximo com o sofrimento vivido pela clientela (TAKEMOTO; SILVA, 2007), vêm sendo tomadas como evidência da demanda por espaços de: supervisão (CAMELO et al., 2000; TAKEMOTO; SILVA, 2007), os quais devem integrar reflexões a respeito do próprio processo de trabalho e das necessidades de saúde (SILVA JR.; MASCARENHAS, 2005); educação continuada (INOJOSA, 2005); qualificação dos profissionais, especialmente no que se refere a "atributos e habilidades relacionais de escuta qualificada" (BRASIL, 2008, p. 30); e de compartilhamento de dores, conflitos e dificuldades vivenciados no cotidiano de trabalho (TAKEMOTO; SILVA, 2007). Espaços, como se viu, incorporados à rotina da Associação.

Outro aspecto do acolhimento importante de ser discutido reside em sua dimensão de dispositivo de produção e reforço do vínculo entre o usuário e o profissional/equipe/serviço de saúde (BRASIL, 2008; FRANCO; BUENO; MERHY, 1999; INOJOSA, 2005; LIMA et al., 2007; MERHY, 1998; RAMOS; LIMA, 2004; SCHIMITH; LIMA, 2004). No Núcleo Monte Azul, um dos objetivos associados à adoção do acolhimento como um dos pilares da atenção provida revelou ser a sedimentação de um vínculo sólido com a clientela, de modo que os cuidadores se constituam em figuras de referência para as mulheres e seus familiares, principalmente durante o ciclo grávido-puerperal, mas também no período que se segue. Consideração que vai ao encontro do assinalado por Franco, Bueno e Merhy (1999), Merhy e Franco (2005) e Merhy (1998), sobre vínculo poder ser compreendido como adscrição dos 
usuários a uma equipe de saúde, a qual passa a ocupar um lugar de referência segura junto àqueles. Vale também salientar a esse respeito o apontamento de Ramos e Lima (2003) acerca da sedimentação do vínculo entre clientela e profissionais de saúde se dar a partir de relações de confiança. Segundo as autoras, à medida que o usuário é encorajado a fazer perguntas e obtém respostas consistentes, recebe orientações e esclarecimentos sobre suas questões, e se sente reconhecido em sua singularidade - o que está sendo aqui compreendido como acolhimento permeado por postura dialógica -, vai se sentindo mais seguro para enfrentar eventuais dificuldades e a relação de confiança, já existente, fortalece-se.

De fato, os depoimentos das mulheres evidenciam, como já mencionado, a confiança que sentiam em algumas profissionais, que as encorajava a compartilhar questões e dúvidas; diferentemente do que se dava em outros serviços. Além disso, foram também frequentes referências às orientações e aos esclarecimentos recebidos. Cabe aqui o depoimento de Carolina acerca de como o ambulatório do Núcleo representava para ela um local de referência buscado sempre que tinha alguma dúvida ou se via diante de dificuldades; assim como da vinculação por ela expressa especialmente pela auxiliar de enfermagem, pela coordenadora do ambulatório e pela coordenadora da área de saúde materno-infantil.

Tal vinculação das mulheres com as profissionais, aliás, destacou-se ao longo dos depoimentos, expressando-se, em alguns casos, também de outras formas. Foram apresentados, na seção de descrição do campo, relatos de mulheres, que haviam sido cuidadas na Associação em gestações anteriores, sobre o desejo de engravidar novamente para viver mais uma vez a experiência de cuidado com a enfermeira; ou ainda, de usuárias que assinalaram apenas ter conseguido enfrentar dificuldades por conta do suporte da profissional. Da mesma forma, foram descritos episódios de mulheres cujo retorno ao Núcleo após o parto objetivava apenas mostrar o bebê para a enfermeira.

O comparecimento semanal às consultas pré-natais, praticado por algumas usuárias que experienciavam demanda a esse respeito, pode também ser tomado como evidência de vínculo. Um exemplo notável, apreendido em fase de reconhecimento de campo, é o da usuária que semanalmente comparecia para atendimento, a despeito de, durante um período, ter apresentado dificuldades de locomoção, devido a um ferimento, e de viver precárias condições de vida, com muitos filhos, e ninguém para ajudá-la. Casos como esse atestam a inter-relação de adesão ao acompanhamento e vínculo com o serviço/equipe/profissional de saúde, apontada por Ramos e Lima (2003) e Schimith e Lima (2004). Inter-relação também 
ilustrada pelo relato de Juliana sobre a interrupção do pré-natal na UBS por conta da insatisfação que lá viveu com o atendimento; e sobre sua adesão a todas as atividades integrantes do acompanhamento pré e pós-natal do Núcleo Monte Azul em função da resposta que obteve às suas demandas e da satisfação com o serviço.

O fato de algumas mulheres retornarem ao Núcleo na segunda gravidez é outro dado que revela vinculação - mesmo que entre as gestações a usuária não tivesse mantido contato com o serviço. Além disso, descreveu-se episódios em que a mulher havia sido cuidada em suas gestações e, posteriormente, retornava com a filha, grávida, para que fosse também ali acompanhada. Em alguns desses casos, pelo período transcorrido, a equipe já não era mais formada pelos mesmos cuidadores, e o vínculo, portanto, era com o serviço, tal como expresso no depoimento de Carolina, cuja primeira gravidez havia sido acompanhada no Núcleo, mas por outra equipe.

Observa-se que o lugar de referência ocupado pelas profissionais diante das mulheres e o vínculo então constituído entre elas podem ser compreendidos em termos de apego seguro. A esse respeito, cabe lembrar que o presente estudo pautou-se nas considerações de Bowlby (1990) sobre a presença de relações de apego na vida adulta; na possibilidade de o cuidador assumir o papel de figura de apego seguro (LIMA; FERNANDES, 2006); e na compreensão de tal figura como alguém que assume uma postura dialógica (LIMA; FERNANDES, 2006). Em função desse último ponto, as reflexões já tecidas sobre a dialogicidade podem também ser tomadas como ilustrativas de relações de apego seguro entre profissionais e usuárias no Núcleo Monte Azul. Porém, visa-se nesse momento aprofundar a discussão com foco no tema da produção de vínculo.

Para tanto, convém, primeiramente, retomar as características da figura de apego seguro em breves linhas. Essencialmente, trata-se de alguém que é sensível às necessidades daquele de quem cuida e, a partir de presença e cuidado consistentes, transmite ao outro confiança, de modo que esse pode então saber que ali está uma base segura à qual pode recorrer quando precisar (AINSWORTH, 1978; BOWLBY, 1990). Esses aspectos se destacaram nos depoimentos das profissionais, que demonstraram preocupação, como mencionado, de se constituírem em figuras de referência para as mulheres, de modo que elas percebam que têm com quem contar quando sentirem necessidade; o que também remete, aliás, à relevância da liberdade de acesso. Como se viu, as usuárias, por sua vez, de fato viam as profissionais, e o serviço, como referência segura. 
Além de se constituir como base de segurança, a figura de apego seguro também se mantém atenta às necessidades daquele de quem cuida, de modo a exercer ações de cuidado quando identifica demandas nesse sentido (BOWLBY, 1990). Essa consideração se fez nítida no depoimento de Isabela, que relatou a preocupação de constituir um elo forte com as mulheres, acompanhando-as de forma próxima, visitando-as, telefonando para elas e sempre tentando criar espaços de conversa, seja na sala de espera, na pré-consulta ou nos grupos; questões que também despontaram em outros depoimentos, e que, de fato, foram observadas no fazer das profissionais. Por outro lado, é importante assinalar que no puerpério essas ações se deram mais amplamente apenas a partir do primeiro semestre de 2008, o que sinaliza que, até então, embora a equipe e o serviço se colocassem como "porto seguro", tal papel de figura de apego seguro não estava sendo plenamente cumprido.

A partir do discorrido Ainsworth (1978) e por Bowlby (1990), pode-se depreender que a figura de apego seguro atua, ainda, no sentido de ajudar o outro a perceber os recursos que possui para lidar com as dificuldades vividas; e como descobrir e desenvolver novos recursos que se façam necessários. É, portanto, alguém que favorece a promoção de autonomia. Associações entre sedimentação de vínculo e autonomia nos processos de produção de saúde, convém salientar, são apontadas por diversos autores (BRASIL, 2008; FRANCO; BUENO; MERHY, 1999; MERHY; FRANCO, 2005; LIMA et al., 2007; MERHY, 1998; RAMOS; LIMA, 2004; SCHIMITH; LIMA, 2004; SILVA JR.; MASCARENHAS, 2005), entendendose que o sujeito se torna mais autônomo à medida que se empodera ${ }^{25}$ e se sente mais confiante acerca de sua capacidade de lidar com eventuais dificuldades e dúvidas (RAMOS; LIMA, 2004).

Evidencia-se, a partir de tais considerações, a relação, no Núcleo Monte Azul, entre produção de vínculo, na perspectiva de apego seguro, e o trabalho de fortalecimento da mulher, cujo impacto nas vivências das usuárias, em alguns casos, traduziram-se em empoderamento e ampliação de autonomia, como descrito. Também reveladora a esse respeito é a importância destacada pelas profissionais de o cuidador estar ao lado da mulher de forma próxima, assumindo uma postura que não seja a daquele que sabe o que deve ser feito e que então estabelece os caminhos, mas, sim, daquele que compartilha, acompanha, apoia e orienta a usuária no que for necessário, acolhendo suas vivências e auxiliando-a na elaboração delas.

25 Para Merhy e Franco (2005) refere-se à apropriação de recursos de autocuidado, mas o conceito pode ser aqui também compreendido nos termos já mencionados (TORNQUIST, 2002; NOGUEIRA-MARTINS; BÓGUS, 2004) 
A relação que se estabelece, portanto, proporciona espaço para a mulher progressivamente descobrir-se como alguém capaz de lidar com o que vive e participar de decisões nos processos de produção de saúde - como a escolha do tipo de cuidado que deseja receber, o tipo de parto que quer viver etc.

A figura de apego seguro, assumindo uma postura dialógica, é também alguém que permeia sua atuação por uma atitude amorosa (LIMA; FERNANDES, 2006). No início deste trabalho, foi assinalado que no referencial gestáltico essa atitude é compreendida como cerne e mola propulsora da postura dialógica (LIMA; FERNANDES, 2006). O tema do amor e de suas inter-relações com processos de acolhimento e de produção de vínculo não é, porém exclusivo à Gestalt-Terapia, sendo também discutido por outros autores. Camelo et al. (2000), aplicando trabalho desenvolvido sobre relações de ajuda na compreensão do acolhimento em unidades básicas de saúde, mencionam que o profissional deve assumir a postura de um auxiliador e, como tal, não apenas ter disponibilidade interna para ajudar, como amar aquele de quem cuida. Teixeira $(2005$, p.596) defende que o acolhimento se traduz em uma "paixão que nos predispõe a aceitar o outro como um legítimo outro", e se expressa, especialmente, por afetos de compaixão - que permitem que se viva-com o outro naquilo que ele expressa -, e afetos de confiança - que se revelam pelo suporte ao outro diante das dificuldades compartilhadas, confiando-se em sua capacidade de enfrentar o vivido e promovendo a entrega na relação. Segundo o autor, é a partir disso que o vínculo se constrói. Da mesma forma, em Gestalt-Terapia o amor, e o compartilhar de humanidade então possibilitado, é entendido como a verdadeira base para o estabelecimento do vínculo entre o cuidador e aquele de quem cuida (Cardella, 1994). Associações entre afetividade e vínculo são ainda referidas por Silva Jr. e Mascarenhas $(2005)^{26}$.

No Núcleo Monte Azul, a questão afetiva se evidenciou no cuidado produzido, assim como nos depoimentos de profissionais e de mulheres. No que se refere às primeiras, merece destaque o relato de Cláudia sobre a importância do estabelecimento de vínculos afetivos com

26 É importante considerar que contextos marcados por condições desumanizantes aos profissionais, como baixos salários, sobrecarga de trabalho, perda de autonomia, dentre outros (CASATE; CORRÊA, 2005; HOGA, 2004; LEITE; STRONG, 2006; OLIVEIRA; COLLET; VIERA, 2006), podem dificultar o exercício da dialogicidade, que inclui a atitude amorosa. Por isso, é preciso novamente chamar a atenção para a importância de espaços de supervisão e cuidado ao trabalhador, de modo que de fato se ofereça recursos para que este possa assumir tal atitude amorosa no cotidiano da atenção em saúde. Também não se pode desconsiderar questões como o que motiva o profissional a exercer seu trabalho, qual a sua disponibilidade para desenvolver uma atitude amorosa e quais os seus limites e possibilidades de se engajar em uma relação de tal forma permeada por afeto com aquele de quem cuida. Voltar-se-á a algumas dessas questões mais adiante. 
as mulheres; algo para ela também associado à promoção de um bom vínculo entre mãe e bebê. Como aponta a profissional, "tudo o que tem a ver com continência, acho que se constrói através de relações humanas, que são vínculos". Quanto ao cuidado permeado por afetividade, são representativos os episódios, apreendidos durante a fase de reconhecimento de campo, de profissionais se dirigindo carinhosamente às usuárias.

Os depoimentos das mulheres, por sua vez, insistem na atenção recebida das profissionais, que se preocupavam com o bem-estar delas e com o do bebê. Percebe-se que elas se sentiam queridas naquele espaço; em outras palavras, circundadas de vínculos afetivos. Em algumas situações, principalmente com a auxiliar de enfermagem, que fora também moradora da comunidade Monte Azul, esses vínculos pareciam transcender as fronteiras do campo profissional, para serem, então, reconhecidos como relação de amizade, o que se mostrou importante para algumas mulheres. Como contou Gabriela, "não são só profissionais que estão tratando com a gente. Tem toda uma amizade. Bem ou mal, somos vizinhas”.

Em estudo realizado por Silveira et al. (2004), os agentes comunitários de saúde foram considerados como figuras geradoras de vínculo diferenciado com a clientela, uma vez que compartilham de uma mesma microcultura, mobilizando-se, em alguns casos, a estabelecer uma relação de amizade com os usuários. Da mesma forma, em Camelo et al. (2000), uma das auxiliares de enfermagem que integraram o estudo estabelecia um vínculo mais próximo com a clientela, pois, sendo moradora de bairro próximo à UBS, conhecia boa parte dos usuários. Por outro lado, no trabalho realizado por Hotimsky (2001) no Núcleo Monte Azul, essa relação de amizade foi também observada com a profissional que na época realizava o prénatal, o parto e o acompanhamento puerperal; uma parteira alemã cujo universo vivencial de origem era, a princípio, significativamente diferente daquele da clientela, mas que, a partir de uma postura acolhedora e calorosa, e de uma inserção na vida da comunidade, também proporcionava tal tipo de relação com algumas mulheres. Esse dado permite supor que a relação diferenciada, estabelecida entre a auxiliar de enfermagem e as mulheres, não se dava apenas em função de também ela ter sido uma moradora da comunidade. Como descrito, essa profissional estabelecia um tipo de interação com as usuárias em que, muitas vezes, compartilhava questões pessoais. Esse parece ter sido o fator preponderante nesse sentido; como disse Leila "eu escutava ela. Ela me escutava. Nossa, foi muito bom. Uma amiga que eu ganhei aqui dentro".

A mesma trajetória que se deu para o acolhimento em suas dimensões de postura do 
profissional e de organização do serviço, parece ser interessante empregar ao vínculo. No que se refere, então, à dimensão de (re)organização do serviço, nota-se que a sedimentação do vínculo com a clientela no Núcleo Monte Azul reflete-se, também, em procedimentos como designar uma auxiliar de enfermagem especialmente para acompanhar as mulheres - a mesma pessoa que está no pré-atendimento é a que liga para as usuárias para agendar consultas e convidá-las para atividades ligadas à gestação, ao parto e ao puerpério; que acompanha as oficinas; que realiza visitas domiciliares; e que faz captação de doadoras de leite, assim como a coleta dessas doações. Além disso, caso a mulher telefone ou se dirija ao ambulatório em outros horários que não aqueles ligados ao serviço de atenção pré e pós-natal, encontrará mais facilmente essa auxiliar.

De qualquer forma, além dessa profissional, há o empenho em garantir a continuidade no cuidado, uma vez que é o mesmo grupo de profissionais que acompanha as mulheres ao longo do pré-natal e do puerpério. Essa é uma prática encorajada por Enkin et al. (2005), que recomendam, também, que o grupo de provedores se mantenha ao longo do parto. De fato, foram frequentes os relatos de mulheres expressando o desejo de que a Casa de Parto fosse inaugurada a tempo, especialmente para que a pessoa que vinha delas cuidando ao longo do pré-natal pudesse também realizar seu parto. Nesse sentido, percebe-se que será de grande importância a inauguração desse serviço.

Outro aspecto da atenção favorecedor da sedimentação do vínculo é o que diz respeito à experiência de grupo promovida pelo ciclo de palestras. Esse é um espaço, especialmente tratado por algumas profissionais, que possibilita oferecimento de informações e orientações, troca de experiências, expressão de vivências, e estreitamento de relações entre usuárias, familiares e profissionais. Contribui, também, para a elaboração do vivido, por meio do diálogo e da arte - experimentada nas oficinas. Além disso, por não ser restrito ao ciclo grávido-puerperal, propicia seguimento do acompanhamento das mulheres - o que vai ao encontro da necessidade, pontuada em alguns estudos, de se estender o cuidado à mulher para além do puerpério (WALKER; WILGING, 2000). Esse é um espaço, portanto, que funciona como um local privilegiado da prática do acolhimento e da produção/manutenção de vínculo lembrando que, embora o acolhimento, segundo o Ministério da Saúde (BRASIL, 2008), deva permear todos os encontros e espaços de um serviço, recomenda-se o uso de alguns dispositivos, como a constituição de grupos com usuários.

A despeito de tais contribuições, é importante notar que, como dispositivo de produção 
de vínculo e de cuidado, o grupo não cobre todos os casos. Primeiramente porque o seu horário inviabiliza a participação das mulheres que trabalham, como evidenciado pelos casos de Gabriela e Sofia - esta, especialmente interessada em tais atividades, buscou um grupo não institucionalizado em horário noturno. Além disso, algumas usuárias parecem não ser receptivas à participação em vivências grupais - caso de mulheres que dificilmente compareciam aos grupos, mas que apresentavam adesão às consultas individuais. Essa situação é bem representada pelo relato de Leila sobre a "preguiça" de comparecer aos grupos, apesar dos convites contínuos para tanto.

Essa é também uma lacuna da possibilidade de liberdade de acesso, uma vez que, como já discutido, nem sempre o usuário tem clareza de que necessita, ou de que pode se beneficiar, de cuidados em saúde. Na esfera psicológica, constatou-se dois casos em que as mulheres, que não frequentavam os grupos, e que se dirigiam ao ambulatório apenas esporadicamente, alguns meses após o término do puerpério estavam vivendo algum tipo de dificuldade relacionada à maternidade e/ou à vida familiar e demandavam suporte; queixas diagnosticadas apenas durante a entrevista para o presente trabalho.

Cabe um aparte para destacar que esses exemplos evidenciam, novamente, a necessidade de se estender o cuidado à mulher para além do puerpério (WALKER; WILGING, 2000). Além disso, revelam a demanda pelo desenvolvimento de condutas ativas também nessa fase, tais como prolongar o período de visitas domiciliares - ainda que com menos frequência após os primeiros meses pós-parto - e agendar consultas individuais para as mulheres que não comparecem aos grupos e/ou apresentam dificuldades de neles se expressarem - como referido por algumas usuárias.

As visitas domiciliares, aliás, revelam-se como importante dispositivo de fortalecimento do vínculo entre a usuária e a equipe/serviço; o que é apontado em um dos manuais do PHPN (BRASIL, 2006b) como um dos objetivos desse procedimento. Observa-se que, ao possibilitarem a entrada no universo concreto vivido pela mulher, as visitas se constituíram em espaço também privilegiado de prática do acolhimento, favorecendo o processo de identificação de demandas, assim como de atendimento de algumas delas, tal como expresso no depoimento de Mariana e nos relatos da auxiliar de enfermagem durante a fase de reconhecimento de campo. Somando-se a isso as demais condutas aí empreendidas de avaliação do estado da mulher, nota-se que, durante o puerpério, as visitas cobrem as lacunas deixadas pelo ciclo de palestras e pela liberdade de acesso, favorecem a adesão à consulta 
puerperal e contribuem para a produção de um cuidado mais consistente. Tais fatores apontam a importância de esse procedimento ser também incorporado à atenção pré-natal, não apenas como algo ocasional, tal qual vinha se dando; o que talvez tenha sido solucionado por meio da parceria estabelecida entre o Núcleo e o PSF da região.

Ainda sobre os processos de acolhimento e de produção de vínculo, considerando a forma como são compreendidos e empreendidos na Associação, vê-se que eles aparecem de modo intimamente relacionado a outro aspecto do serviço que também se destacou no discurso de mulheres-usuárias e de profissionais: o da integralidade.

A inter-relação de tais processos vem sendo discutida na literatura. Para Gomes e Pinheiro (2005), as estratégias de acolhimento e vínculo são práticas de cuidado integral. Da mesma forma, Franco e Magalhães Jr. (2003) defendem que o primeiro passo à integralidade está na organização de um serviço que opere segundo as diretrizes de acolhimento e vínculo; o que é evidenciado por Mattos (2004), ao apontar que a integralidade implica, em primeiro lugar, considerar que as práticas de saúde são sempre intersubjetivas, nas quais os usuários integram as relações com os profissionais de saúde na condição de sujeitos, e não de objetos; e os projetos terapêuticos são construídos por meio de encontros dialógicos entre ambos.

Tendo então em vista essa inter-relação, observa-se que uma das expressões da integralidade - considerada em sua dimensão de atuação integral (BRASIL, 2000e, 2006b, 2009) - no Núcleo evidencia-se nos depoimentos de mulheres-usuárias sobre como se sentiram acolhidas e cuidadas nas diversas dimensões existenciais ao longo do acompanhamento pré e pós-natal; o que não pode ser compreendido de modo apartado do tema da postura das profissionais e da organização do serviço.

$\mathrm{Na}$ dimensão da postura, viu-se que, de um modo geral, as profissionais abriam espaço para a escuta, a compreensão e o atendimento das diferentes necessidades expressas e negociadas. Em seus depoimentos, ademais, enfatizaram a importância de o pré-natal não se restringir a procedimentos clínicos, como medir altura uterina e verificar peso e pressão, compreendendo que a complexidade do vivido pela mulher durante esse período requer acolhimento e cuidado às várias dimensões componentes dessa complexidade.

Aqui é importante incluir o que Mattos (2001) defende significar integralidade: dentre outras coisas, ela implica recusa a reducionismos; recusa, por exemplo, a considerar que um paciente se reduza a uma lesão; ou no caso que está aqui em pauta, em tomar uma gestante como um mero ventre grávido. Trata-se de algo, portanto, que mais uma vez revela o olhar 
integral que se tem no Núcleo para as usuárias e seu vivido ao longo do ciclo grávidopuerperal; algo que, segundo Pinho, Siqueira e Pinho (2006), tem se mostrado difícil nos serviços de saúde, mas que ali parece ser nutrido como um dos pilares do cuidado; algo, portanto, que vai ao encontro daquilo que consta em alguns manuais do Ministério da Saúde (Brasil, 2001, 2004a, 2006b) acerca de um novo conceito de saúde, integral.

$\mathrm{Na}$ dimensão da organização de um serviço de atenção pré e pós-natal que garanta à mulher ser "cuidada como um todo", as profissionais assinalaram a importância do oferecimento de diversas especialidades e atividades - como consultas pré e pós-natais, terapias externas, visitas domiciliares, acompanhamento odontológico, trabalho corporal e experiências grupais no ciclo de palestras. Esse tema, porém, apareceu no relato de apenas uma usuária - Juliana -, a única participante do presente estudo que entrou no serviço em um momento em que tais atividades estavam mais estruturadas.

Para manter em funcionamento tal estrutura, as profissionais valorizaram o trabalho em equipe; tema também salientado durante a fase de reconhecimento de campo e que é consonante com os apontamentos de alguns autores. Franco e Magalhães Jr. (2003) defendem que a concretização da integralidade depende de uma atenção provida em caráter multiprofissional. Da mesma forma, Pinho, Siqueira e Pinho (2006, p. 47) referem que essa concretização "deve ser fruto do esforço e confluência dos vários saberes de uma equipe multiprofissional". Um dos manuais do PHPN (BRASIL, 2006b), com base em recomendações da OMS, também assinala essa inter-relação, ao salientar que o cuidado ao ciclo grávido-puerperal deve ser integral e, portanto, provido por equipe multidisciplinar. Porém, quando apresenta sua versão de tal multidisciplinaridade, aponta uma equipe constituída por médico, enfermeira, auxiliar de enfermagem e agente comunitário de saúde. Contradições como essa, discutidas no início deste trabalho, revelam como pode ser difícil transpor o que está no campo das ideias para o campo das ações.

Nesse sentido, a concretização da integralidade apreendida no Núcleo Monte Azul mostra-se relevante a esse campo de discussões, ao indicar uma possibilidade de viabilização da proposta de um cuidado integral e, portanto, de superação de algumas contradições. A esse respeito, além dos pontos já comentados, de postura profissional, de organização do serviço e de constituição de equipe multiprofissional, outro que cabe ainda destacar é o da preocupação cultivada no Núcleo de que a equipe possa funcionar de modo realmente integrado. Algo que ali se constrói a partir dos encontros, reuniões e grupos de estudos apontados; e se revela nos 
projetos propostos - como é o caso do "Tecendo Laços", que envolve uma série de especialidades e profissionais -, na consonância observada nos discursos das profissionais e na satisfação relatada acerca de tal trabalho em equipe.

É importante, entretanto, também apontar limitações e lacunas presentes nessa concretização da integralidade no Núcleo, a saber, a não garantia da realização de exames gratuitamente, especialmente considerando o momento anterior à articulação do Núcleo Monte Azul com a UBS da região; a não sedimentação do acompanhamento pós-natal até o início de 2008; e a não articulação entre a atenção ao pré-natal e ao parto, já que era ainda aguardada, na época do encerramento da coleta dos dados, a inauguração da Casa de Parto.

Igualmente importante é ampliar a compreensão de tais lacunas e limitações. Mattos (2001, p. 63) propõe que a integralidade seja entendida como bandeira de luta; luta, entre outras coisas, pelo "direito universal ao atendimento das necessidades de saúde"; e, assim, luta em prol de respostas cada vez mais abrangentes às necessidades identificadas. Diante disso, pode-se dizer que as transformações acompanhadas no serviço do Núcleo ao longo deste estudo evidenciam esse movimento. Existe, ali, um esforço contínuo de estruturar um serviço que busque ao máximo responder às demandas da clientela - tanto no que diz respeito ao que esta expressa, quanto àquilo que se percebe a partir do olhar acolhedor e integral ali cultivado; esforço que tem permitido avanços como a articulação mais eficiente com a UBS de referência da região, que passou a então aceitar a realização de exames com o pedido emitido pelo Núcleo.

Acerca dessa articulação com outros serviços, em estudos anteriores (FIGUEIREDO, 1999; HOTIMSKY, 2001) ali realizados ela foi também mencionada. Como aponta Hotimsky (2001), desde a inauguração do ambulatório do Núcleo Monte Azul havia uma preocupação por parte da Associação de estabelecer vínculos estreitos com profissionais e instituições, públicas e privadas. Atualmente, além da recente parceria firmada com uma UBS da região, há o acordo com a Weleda, que envia medicamentos com desconto; convênios com dois laboratórios, um para processamento de exames a preços módicos, cujos materiais são coletados no próprio Núcleo, e outro para realização de exames de ultrassom por valores reduzidos; e a parceria com o Hospital Regional Sul, que retira, do Posto de Coleta de Leite, o leite materno doado pelas usuárias do serviço do Núcleo e/ou moradoras da comunidade. Tais articulações, conforme registrado por Figueiredo (1999) e por Hotimski (2001), fazem parte da história do Núcleo e, convertidas em busca dos melhores meios de se atender às demandas 
vividas pelas usuárias, promovem o avanço em direção a um cuidado cada vez mais integral.

Por outro lado, essa constante renovação de parcerias entre o Núcleo e demais serviços/instituições por vezes implicam retrocessos, no lugar de novas conquistas. O cenário descrito por Figueiredo (1999) revela, por exemplo, a garantia do fornecimento gratuito de anticoncepcionais, o que não estava se dando à época da coleta dos dados do presente estudo.

Além disso, nem sempre tais parcerias respondem às demandas da clientela de modo satisfatório. A forma com que se vinha garantindo a realização de exames até então obrigava a maior parte das mulheres a submeter-se a um segundo pré-natal na UBS, uma vez que os descontos garantidos pelo Núcleo em tais procedimentos não se faziam suficientes. A solução posteriormente adotada para garantia de aceitação, na UBS da região, dos pedidos de exame emitidos no Núcleo, parece também não ter sido plenamente satisfatória, já que alguns relatos e depoimentos de usuárias evidenciaram que, embora a imposição de um segundo acompanhamento pré-natal no SUS fosse o fator de maior desagrado, o desejo era de que todos os procedimentos pudessem ser realizados no próprio Núcleo. De fato, Tsunechiro, Bonadio e Oliveira (2002) advertem que a possibilidade de realização de exames e do parto no mesmo serviço são fatores favorecedores da escolha e da adesão a ele; algo que pode ser associado, a partir da discussão aqui empreendida, ao desejo das mulheres de serem cuidadas, em todas as etapas, pela equipe de profissionais/serviço com os quais o vínculo foi estabelecido; desejo que pode ser mais intenso quando a mulher tem que se dirigir a um serviço onde são vividas insatisfações. Isso foi também evidenciado nos relatos de lamento pela Casa de Parto não ter sido inaugurada, até o momento do encerramento da coleta dos dados.

Uma questão ainda importante a ser discutida refere-se ao fato de que, tendo em vista que a Associação adota como referencial a Antroposofia e que esta define o homem como um ser integral (BALDI, 2003; CRAEMER; IGNACIO, 2008), a integralidade ali pode ser não apenas considerada uma decorrência como sua concretização em tal serviço deve ser compreendida a partir do viés antroposófico.

A concepção do indivíduo como um ser de sentidos, emoções, cognições e individualidade - relativa à esfera espiritual -, em constante relação com o mundo (BALDI, 2003; CRAEMER; IGNACIO, 2008), parece permear compreensões expressas pelas profissionais, como a de que a mulher grávida precisa trabalhar o corpo - e não apenas ser cuidada nos aspectos clínicos que ele apresenta; e precisa ter, também, um espaço de escuta e 
elaboração de suas emoções, ideias e potências. Ou ainda, a de que para um usuário que chega com queixa de pressão alta, é necessário ter ouvidos para outras dimensões, de modo a apreender se, mais do que medicação, ele não demanda acolhimento, como pontuado por Mariana. Nesse sentido, cabe a referência de Craemer e Ignacio (2008, p. 21) sobre como a saúde é entendida pela Antroposofia: "não se restringe somente a questões físicas, mas leva em conta a qualidade de vida em todos os seus âmbitos".

Além disso, a partir da Antroposofia desenvolvem-se determinados instrumentos, técnicas e formas de cuidado para dar conta de tal integralidade. Como exemplos no Núcleo, tem-se a estruturação da equipe multidisciplinar, que Baldi (2003) aponta ser o meio de se poder ocupar do ser humano como um todo. Tem-se a preferência dada ao uso de substâncias naturais, tais como chás, no tratamento de determinados quadros, como visto na seção de descrição do campo. Ademais, o tipo de medicação comumente utilizada baseia-se, da mesma forma, na concepção do homem como um ser integral - segundo uma das profissionais do Núcleo, ela é manipulada tendo sempre em vista o reequilíbrio das quatro dimensões do corpo - física, vital, anímica e calórica (Baldi, 2003). E tem-se, ainda, a disponibilização de terapias externas, que se baseiam nesse mesmo princípio.

As repercussões de tal tipo de abordagem de cuidado entre as usuárias apareceram especialmente no caso de Sofia que, com quadro de hiperêmese gravídica, não respondia ao tratamento alopático e apenas apresentou melhora a partir do cuidado integral e antroposófico encontrado no Núcleo. A propósito, não apenas essa mulher como também outras, falaram da Antroposofia - frequentemente nomeada como "cuidado mais natural" - como algo que lhes proporcionou uma sensação de cuidado mais amplo. Ademais, algumas mulheres expressaram uma preferência por esse tipo de atenção à saúde, como foi o caso de Carolina e Juliana. Depreende-se, portanto, que o oferecimento de tal serviço no Núcleo Monte Azul valida, como apontam Pinheiro e Luz (2003), o exercício de cidadania do usuário, que pode então se valer do direito de escolha acerca de que tipo de cuidado deseja receber.

Mais um elemento da Antroposofia é a importância dada à inserção da arte no trabalho realizado - o que ocorre principalmente nas oficinas do ciclo de palestras. Acredita-se, como pontuado por algumas profissionais, que o contato com o belo proporciona uma experiência que auxilia o engajamento da mulher e de seus familiares na construção do ninho familiar na medida em que esses percebem que são capazes de produzir e preencher esse ninho de coisas belas. Promove, sobretudo, a (re)descoberta da beleza interior e do valor como pessoa 
no mundo, a partir da qual o indivíduo pode mais facilmente reconhecer, também, o valor e a beleza da criança, ajudando-a a percebê-los em si mesma - um dos aspectos importantes na constituição de um apego seguro (LIMA; FERNANDES, 2006). Além disso, como assinalam Craemer e Ignacio (2008, p. 121) a arte se constitui em um "grande instrumento de transformação e autodesenvolvimento", ao promover expressão, contato e elaboração do vivido - o que é especialmente importante àquilo que se encontra mais enrijecido -, proporcionar prazer e "elevar a alma” (CRAEMER; IGNACIO, p. 122).

Dessa forma, vai-se percebendo que a integralidade concretizada no Núcleo, perpassada pela Antroposofia, visa abordar também o ser social, a partir do trabalho de seus vínculos e interações com os outros e com o mundo. Isso se torna ainda mais nítido ao se considerar as ações empreendidas no contexto mais amplo da Associação. Foi já relatada, na seção de análise dos dados, a preocupação de que o desenvolvimento individual e comunitário que se pretende promover na região ocorra nos vários níveis de experiência humana: social, cultural, educacional e de saúde. Além disso, conforme Craemer e Ignacio (2008), integra a missão de a Associação proporcionar, por meio de atividades ligadas à educação, à cultura e à saúde, o desenvolvimento material, social e espiritual dos indivíduos. Considerações que remetem ao pontuado pelo Ministério da Saúde sobre a atuação integral se fundamentar em uma concepção de homem que o considera como unidade psicofísica em interação com o meio socioeconômico e cultural (BRASIL, 2000e, 2006b, 2009); embora a inclusão do âmbito espiritual que há no Núcleo transcenda tal compreensão.

Tendo em conta, então, que os processos de acolhimento, de produção de vínculo e de integralidade revelam-se como eixos centrais da produção do cuidado no ambulatório do Núcleo Monte Azul, faz-se importante notar que esses processos foram salientados pelas usuárias como os principais fatores que justificaram a escolha pela atenção ali oferecida, e/ou a manutenção em dois serviços. Figueiredo (1999) e Hotimski (2001), em estudos realizados na Associação, apontam dados semelhantes. Para Figueiredo (1999), a qualidade da atenção dispensada à clientela é fator de preferência pelo serviço do Núcleo. Hotimski (2001) faz menção à sensibilidade e à empatia das profissionais, à escuta clínica e ao tipo de relação estabelecida com a clientela como aspectos por esta salientados no que concerne à escolha e à avaliação do serviço.

Tais apontamentos são consonantes com os dados encontrados na literatura. O acolhimento é destacado como o que confere qualidade ao serviço e satisfação (FELIX; 
SILVEIRA, 2004; QUEIROZ et al., 2007), especialmente se aliado à qualidade técnica e à valorização do protagonismo da mulher (PARADA; TONETE, 2008). Além disso, é também salientado como fator preponderante na escolha e no vínculo com um serviço (RAMOS; LIMA, 2003), ainda que sejam necessários significativos deslocamentos geográficos (LIMA et al., 2007; TSUNECHIRO; BONADIO; OLIVEIRA, 2002).

A respeito de tais deslocamentos, aliás, embora o levantamento realizado a partir dos cartões das gestantes tenha revelado que a maioria da clientela residia na área de abrangência do Núcleo Monte Azul, é importante observar que, em busca de um atendimento que consideraram melhor responder às suas demandas, 47,05\% das usuárias deixaram de usar o serviço próximo à sua residência e se submeteram a deslocamentos geográficos, fossem estes mais significativos - mulheres que vinham de outras regiões da cidade ou até de outros municípios - ou menos - mulheres que residiam próximo ao Núcleo Peinha ou em bairro próximo ao Núcleo Monte Azul.

Quanto ao tema da qualidade técnica segundo a percepção das mulheres, o exame clínico foi descrito como mais cuidadoso do que aquele realizado na UBS. Convém ter em vista que, segundo Ramos e Lima (2003), um exame físico detalhado e criterioso revela o interesse do profissional pelo usuário, e transmite confiança de diagnóstico e de tratamento mais precisos. A rapidez na entrega dos resultados de exames também foi referida como algo importante, especialmente ao se considerar a ansiedade vivida pela gestante de saber se tudo corre bem com seu bebê, conforme levantou Juliana; embora apresentassem a desvantagem de serem pagos, o que inviabilizava para a maior parte das mulheres realizá-los pelo Núcleo. Algumas usuárias fizeram, ainda, menção a intervenções sentidas como eficazes, como bem relata Carolina: "No segundo dia o meu peito inflamou. Aí a [coordenadora do ambulatório] foi lá, me ensinou a fazer uma massagem, e aí não inflamou mais. Meu peito sarou”.

É importante notar o caráter de complementariedade que marca o tema da manutenção em dois serviços. O tom comparativo presente na maior parte dos relatos caracterizou a Associação como o local onde se podia obter um cuidado acolhedor e permeado por um olhar mais integral. Aos demais serviços, cabia apenas dar conta do que não era atendido no Núcleo. Entre as profissionais, essa dicotomia se expressou de maneira mais nítida no depoimento de Mariana que, se de um lado, ponderou positivamente o atendimento gratuito das UBSs quanto aos exames e medicamentos, por outro, classificou-o como, no geral, ainda "muito frio", havendo, segundo Cláudia, apenas um ou outro profissional que 
integra em sua atuação uma postura acolhedora.

Entre as usuárias que se mantiveram em dois serviços, as considerações favoráveis à rede SUS e à rede conveniada contemplavam: a garantia de realização de exames; o atendimento 24 horas; e, na rede conveniada, o atendimento ao parto. Porém, era no Núcleo que as mulheres pareciam se sentir ouvidas, reconhecidas e atendidas em suas demais demandas, especialmente aquelas de ordem subjetiva; e era com os profissionais do Núcleo que demonstravam estar mais vinculadas.

Convém observar que nem sempre esse caráter complementar implicava satisfação com o acompanhamento em dois serviços. Notou-se que, de modo geral, no caso das mulheres em acompanhamento paralelo na rede conveniada, tratava-se de uma escolha, em função dos benefícios que consideravam ser por ela oferecidos. Já entre as mulheres que tinham de se manter em um segundo pré-natal na UBS, explicitava-se uma submissão, que se contrapunha, conforme aqui se entende, à dimensão de respeito pelos direitos das mulheres em um cuidado humanizado. Algo retratado no depoimento de Gabriela, que assinalou não conseguir compreender por que deveria continuar a ir à UBS, se já estava sendo cuidada no Núcleo. Assim, mais uma vez se evidencia a importância de ter havido melhor articulação entre o Núcleo e a UBS.

A complementariedade entre serviços, convém mencionar, foi também descrita em trabalhos anteriores realizados na Associação. Figueiredo (1999) relata que, apesar da preferência observada na clientela pelo serviço do Núcleo, não raro as usuárias também faziam uso da rede conveniada - quando possuíam plano de saúde - e da rede pública - de modo a ter acesso, por exemplo, a medicamentos e a exames gratuitamente. Esse uso concomitante de serviços foi também observado por Hotimsky (2001). Além disso, ambas as autoras fizeram menção a insatisfações das mulheres com os demais serviços semelhantes às encontradas no presente estudo. Figueiredo (1999) destaca como fatores desse descontentamento na rede pública o tempo de espera para atendimento, a não assiduidade dos médicos, consultas demasiadamente curtas e a pouca atenção dispensada à usuária. Hotimsky (2001) pontua, especialmente, a falta de acolhimento vivida pelas mulheres, na qual se incluem frieza no atendimento, maus-tratos, dificuldade de esclarecer dúvidas e de se engajar em diálogo com os profissionais de saúde, o que as mobilizava, então, a procurar o Núcleo e a melhor aderir ao serviço dele, onde encontravam um cuidado mais humano e afetivo, como aponta Figueiredo (1999). 
Diante de tais considerações, é importante ter em vista que, embora os dados coletados para o presente estudo revelem dificuldades vividas pelas mulheres em outros serviços e sejam consonantes com aqueles apontados por Camelo et al. (2000), Figueiredo e Rossoni (2008) e Schimith e Lima (2004), esses serviços não foram aqui avaliados. Assim, deve haver cautela quanto à compreensão de tais dados, especialmente no que se refere à sua generalização a toda a Rede SUS, já que estudos como os de Camelo et al. (2000), DurãesPereira, Novo e Armond (2007), Lima et al. (2007) e Ribeiro et al. (2004) evidenciam acolhimento no serviço da rede pública e experiências de satisfação com ele.

Ainda sobre a realização de pré-natal em dois serviços, foi detectada a possibilidade de falhas no acompanhamento em função de este estar a cargo de diferentes profissionais, sem comunicação entre si. Essa questão foi especialmente explicitada no relato de Sofia sobre um exame não ter sido pedido ao final da gravidez, o que pode ter contribuído para as complicações por ela vividas no pós-parto. Considerando-se, nesse caso, tratar-se, como mencionado, de escolha das mulheres, em função de garantias oferecidas pelo outro serviço, destaca-se com relevância os profissionais do Núcleo melhor administrarem tais situações.

As queixas em relação ao serviço do Núcleo, apontadas pelas mulheres, é dado importante de ser aqui retomado e discutido. Esse mostrou-se um tema difícil para as usuárias. Mais frequentemente, elas relatavam que não havia nada no serviço de que não gostassem. As poucas críticas foram, em grande parte, expressas em tom ameno e seguidas por algum tipo de desvalorização ou compensação: "isso nem é tão importante", "não é nada grave" ou, "mas, também, é a única coisa, porque todo o resto é maravilhoso". Além disso, transparecem algumas contradições nos discursos das usuárias acerca do que não gostavam muito no serviço e do que gostariam de transformar ali.

Três questões podem se constituir em aspectos importantes à compreensão de tal panorama. A primeira, já discutida, relaciona-se à priorização das mulheres por um cuidado acolhedor e integral. Sentindo-se atendidas em tais âmbitos, eventuais queixas relacionadas a aspectos operacionais e estruturais se mostravam, então, de menor importância; algo também observado em estudo de Tsunechiro, Bonadio e Oliveira (2002).

A segunda questão repousa na observação de alguns casos em que as mulheres demonstravam-se não só satisfeitas mas sobretudo gratas pelo que o serviço lhes oferecia. Logo, a crítica poderia ser sentida como ingratidão, o que inibiria a reflexão sobre o tema e a sua expressão. Nesses casos, é importante considerar a possibilidade de a percepção do 
serviço não se dar a partir da perspectiva de direito, e sim da caridade, especialmente influenciada pelo fato de se tratar de um serviço gratuito, mas não público.

Por fim, o terceiro ponto é relativo às percepções de algumas profissionais do Núcleo sobre boa parte das mulheres viverem em certa passividade e com pouca consciência acerca dos próprios direitos. A esse respeito, o estudo de Schimith e Lima (2004), ao trazer à discussão a reação da população diante da falta de medicação e de exames laboratoriais em uma unidade de saúde da família, aponta revolta ou resignação perante a impotência vivida nesse contexto. Uma posição de conformismo, resignação e impotência diante de serviços insatisfatórios foi também descrita por Traverso-Yépez e Morais (2004). Por outro lado, apontam Kloetzel et al. (1998) que, quando se questiona os usuários acerca de críticas e sugestões visando a melhoria de um serviço, raramente eles deixam de fazê-lo.

De todo modo, no presente estudo observou-se algumas ocasiões em que as usuárias não articulavam uma resposta, pressupondo inexistência de reflexão anterior sobre o assunto, especialmente no que se refere às sugestões de transformação no serviço. Esse ponto merece atenção, pois, como discutido, privilegia-se, no Núcleo, a expressão e o atendimento das demandas da clientela, e desenvolve-se uma postura que atua no sentido de promoção de autonomia. Além disso, integra a missão da Associação o engajamento da comunidade nas obras que visam seu desenvolvimento (CRAEMER; IGNACIO, 2008). Entretanto, parece que, na formulação do serviço de atenção pré e pós-natal, não há, ainda, expressiva participação da clientela, o que representa um prejuízo no eixo que vem sendo defendido pelo MS (BRASIL, 2006b, 2008) de fomento de direitos, cidadania e coprodução de ações de saúde, e, portanto, de empoderamento (NOGUEIRA-MARTINS; BÓGUS, 2004).

Algumas queixas, porém, foram ouvidas e observadas. A dificuldade vivida em torno da realização de exames - que era mais pronunciada antes da sedimentação da articulação com a UBS próxima ao Núcleo - foi, como discutido, um dos pontos destacados pelas mulheres. Outra questão, apreendida durante a fase de reconhecimento de campo, concerne à impaciência e à insatisfação das usuárias diante de episódios de até uma hora e meia de atraso no início do pré-natal. Esse tema da espera por atendimento foi também levantado nos depoimentos de Gabriela e Leila. Para Cláudia, cabe destacar, esse é um aspecto a ainda se avançar no serviço do Núcleo; o que sinaliza uma percepção acerca das insatisfações da clientela e, ao mesmo tempo, uma preocupação no sentido de se aprimorar a qualidade do serviço. 
Tanto as usuárias como as profissionais, veem a divulgação do serviço como algo a ser melhorado. Os depoimentos de algumas mulheres revelaram que, apesar de morarem na comunidade, ou nas imediações, há algum tempo, desconheciam o serviço ou acreditavam ser restrito ao público das creches e oficinas da Associação.

Algumas profissionais, reconhecendo essa deficiência, destacaram-na não apenas como algo a ser, de fato, melhor trabalhado como desfilaram algumas tentativas de superá-la. A mais importante parece estar na articulação com os agentes comunitários de saúde da região, que estava sendo pactuada, para permitir ao Núcleo um conhecimento mais amplo sobre o número de gestantes em sua área de abrangência. A partir disso, uma auxiliar do ambulatório entraria em contato com elas, para explicar-lhes o trabalho e convidá-las para o pré-natal. Essa iniciativa se revela fundamental porque, além de fornecer dados importantes ao Núcleo e maior envolvimento com a comunidade, também permite à comunidade tomar conhecimento de mais um serviço disponível e, então, exercitar seu direito de escolha acerca daquele que mais lhe convém.

Além disso, entendendo que essa divulgação é também recurso importante à maior e melhor articulação entre os serviços do Núcleo e de UBSs, uma auxiliar deu início a um trabalho de apresentação da proposta da Associação nessas instituições. Esse trabalho, como já explicado, estava rendendo resultados importantes, como o caso da UBS que passou a aceitar os pedidos de exame do Núcleo; ou de agentes comunitários de saúde que por vezes requisitavam visitas domiciliares da auxiliar de enfermagem responsável por elas. Segundo Hotimsky (2001), a Associação sempre demonstrou compreender a importância da divulgação da entidade e de seus serviços, de modo a promover estreitamento de vínculos e parcerias com profissionais e instituições. Porém, esse fazer-se conhecer deve de fato se dar de modo contínuo, pois as mudanças de acordos e parcerias ao longo dos anos, como se nota a partir dos dados do trabalho da autora, daquele relatado por Figueiredo (1999) e do presente estudo, são constantes. Ademais, muitas vezes parcerias com instituições privadas estão sujeitas a reconsiderações, e as estabelecidas com órgãos e instituições públicas frequentemente se perdem conforme mudança de governo ou gestão, tal como apreendido em Craemer e Ignacio (2008).

Um ponto interessante nesse tema da divulgação diz respeito à crença das profissionais e de algumas mulheres na qualidade do serviço. A divulgação foi mencionada, nesse caso, como meio de mais pessoas conhecerem e terem acesso a algo considerado muito bom. Entre 
as mulheres, esse apontamento mostrou-se associado à percepção dos benefícios em suas vivências, e também se evidenciou, em alguns casos, pelo desejo de ampliação do ambulatório, contratação de mais profissionais, aquisição de equipamentos, dentre outros; não apenas para dar conta de falhas no serviço mas especialmente para estender o acesso a um número maior de pessoas. As profissionais expressaram ainda o desejo de que, por meio de mais divulgação e sensibilização, a proposta do Núcleo possa ser mais bem compreendida e assim, incorporada em outros serviços - ou seja, acreditam que o modelo da Associação poderia promover contribuições em outros espaços e contextos.

A sensibilização da clientela para maior adesão às atividades oferecidas, especialmente no que se refere àquelas que estavam à época da coleta de dados ainda pouco sedimentadas no cuidado pré e pós-natal do Núcleo - como os grupos de trabalho corporal e o grupo de odontologia para bebês -, foi destaque entre as lacunas no serviço. Quanto ao ciclo de palestras, embora algumas usuárias tenham narrado participação em tais atividades, percebe-se que uma parcela significativa não se mobilizou a tanto, principalmente no início, e/ou apresentou dificuldades de incluí-las em seu cotidiano, em particular, por conta de horários de trabalho. Dado se tratar de uma prática recomendada por Enkin et al. (2005) e que integra o conjunto de procedimentos que devem fazer parte da atenção humanizada ao ciclo grávido-puerperal (BRASIL, 2006b); e tendo em vista estudos que apontam benefícios produzidos a partir da realização dessas atividades (DELFINO et al., 2004; LIMA, 2006; PARADA; TONETE, 2008), parece que se trata de um foco de negociação com as mulheres, tanto no que concerne a uma possível melhor adequação de horários, como à sensibilização para sua importância.

Falhas no serviço de atenção ao puerpério merecem especial consideração. Como relatado, ele não estava bem estruturado quando o presente estudo teve início. As mulheres eram apenas convidadas a retornarem após o parto e, quando o faziam, raramente se constituía uma consulta puerperal. Vale comentar, nesse sentido, o caso de Lourdes, que viveu a gestação e o puerpério nessa fase em que tal atenção ainda não estava estruturada e expressou ter sentido falta de mais suporte no pós-parto; o que foi também evidenciado em seu relato acerca das dificuldades vividas nesse período.

Observa-se que, embora o trabalho realizado ao longo do pré-natal seja de fundamental importância ao fortalecimento da mulher, ele não é suficiente. A vivência do parto, por vezes difícil, pode conferir tons mais fortes ao puerpério - tal como foi observado 
no caso de Carolina. Além disso, o pós-parto traz novos desafios (BRAZELTON, 1988; GONÇALVES; SALDANHA; MENDONÇA, 1998), como retratado no vivido de Lourdes, que apesar de ter sentido que o pré-natal contribuiu para que não desenvolvesse um quadro de depressão pós-parto, experimentou dificuldades no puerpério. Portanto, a mulher, de fato, precisa continuar a ser integralmente acompanhada, como sugerem as evidências (ENKIN et al., 2005) e preconiza o PHPN (BRASIL, 2006b); o que evidencia a importância desse serviço ter sido mais bem estruturado no Núcleo.

Aliás, os depoimentos de algumas profissionais revelaram o reconhecimento de tal demanda por cuidado vivido pela mulher após o parto. Elas descreveram o puerpério como um momento muitas vezes difícil, em que a chegada do bebê impõe novos ajustes, tanto em nível individual - mulher-mãe e homem-pai - como em nível conjugal - quando é esse o caso - e familiar. Também discorreram sobre eventuais complicações no pós-parto, tais como dores ou questões ligadas à amamentação, e o cansaço e as dificuldades de sono vividos. Em relação a estas últimas, vale ressaltar que a privação de sono vem sendo reconhecida como algo importante de ser considerado no vivido pela mulher ao longo desse período (GAY; LEE; LEE, 2004; DENNIS; ROSS, 2005). As profissionais mencionaram, ainda, que a demanda por suporte é especialmente importante quando a família assume uma postura de não validar a capacidade da mulher de se ajustar e dar conta do vivido; daí a importância de se incluir familiares e/ou figuras de referência para a usuária na atenção ao ciclo grávido-puerperal.

Apesar desse reconhecimento, apenas em meados de 2008 a atenção ao puerpério passou a ser mais bem estruturada no Núcleo Monte Azul, quando, além das visitas domiciliares, sedimentou-se a prática das consultas puerperais. Tendo em vista tal percepção das profissionais acerca das vivências pós-natais, evidencia-se aí uma contradição, ainda que não possam ser desconsideradas dificuldades financeiras e de organização do serviço.

Porém, o que aqui se defende, e isso é de fundamental importância, é que, findo o puerpério, seja mantido um espaço de cuidado para as mulheres, traduzido em visitas domiciliares, ainda que menos frequentes, em espaços grupais e em consultas individuais especialmente considerando o fator já apontado de que nem todas se beneficiam dos grupos. Tal importância foi notada, principalmente, nos casos de Gabriela e de Lourdes; embora possa também ser observada no depoimento de Carolina, que no quinto mês após o parto ainda se dirigia constantemente ao ambulatório, de modo a obter suporte e orientações. Além disso, a demanda por esse prolongamento do cuidado pós-parto também se revela nos estudos de 
Walker e Wilging (2000); no trabalho de Brazelton (1988), que enfatiza que o casal receba apoio de modo especial ao longo dos três primeiros meses após o parto, tendo em vista as muitas dificuldades então vividas e os ajustamentos que se fazem necessários; e no apontado por Diniz (2007) acerca dos altos índices de suicídio observados na Inglaterra entre mulheres durante primeiro ano de vida do bebê, que sugeriram a importância de suporte e cuidado ao longo de todo esse período (informação verbal) ${ }^{27}$. Cabe destacar que, em depoimento, Cláudia externou essa preocupação, ao afirmar que na Casa de Parto as mulheres serão acompanhadas ao longo de todo o primeiro ano após o parto.

\subsection{HUMANIZAÇÃ̃O}

O tema da humanização vem, de certa forma, sendo abordado desde o início desta seção. A estruturação e o acontecer do serviço, algumas das concepções que cercam o cuidado, a forma pela qual as mulheres e suas demandas são percebidas, as inter-relações de profissionais com clientela, permitiram já entrever um humanizar. O trabalho agora é, portanto, de melhor evidenciar de que maneira tais questões revelam essa humanização e refletir sobre as limitações existentes e as relações com outros contextos.

Um primeiro ponto sobre o qual convém discutir refere-se ao modo como as profissionais do Núcleo Monte Azul compreendem a humanização. Destacou-se em seus depoimentos que o que define um cuidado humanizado é o seu caráter de humanidade, ou seja, um cuidado em que o profissional percebe aquele de quem cuida como um ser humano e se coloca nessa interação também como tal; segundo a concepção de homem como uma unidade psico-física-espiritual em constante relação com o mundo (BALDI, 2003; CRAEMER; IGNACIO, 2008), proposta pela Antroposofia.

Nesta concepção de homem, faz parte do humano, como destacou Cláudia, "interação, comunicação, respeito, dignidade". Portanto, um contexto de atenção humanizada é, ainda, aquele em que se compreende que o usuário vive questões, conflitos e necessidades para além do corpo físico, que demandam acolhimento e cuidado; em que escuta e diálogo, permeados

27 Informação fornecida por Carmen Simone Grilo Diniz durante a disciplina "Saúde Materno-Infantil Baseada em Evidências" ministrada pela docente na FSP-USP em 2007. 
por respeito e afeto, são tônicas importantes; em que se olha o outro nos olhos, toca-se-o e deixa-se tocar; e em que, a partir disso, constroem-se vínculos. É, portanto, um contexto de atenção permeado por acolhimento dialógico, produção de vínculo e integralidade; os quais não apenas ali permeiam a compreensão acerca do que seja a humanização como, conforme o discutido até o momento, marcam sua concretização no Núcleo. Essas ponderações vão ao encontro de parte do conceito de humanização adotado como norteador no presente estudo; a parte que se refere à restituição, nos processos de produção de saúde, das tecnologias leves (MERHY, 1998, 2000, 2002) ao seu lugar de reger e articular as demais tecnologias a serviço das necessidades identificadas, elaboradas e negociadas no espaço de encontro entre usuários e profissionais de saúde.

Em trabalho realizado por Dias (2006), alguns dos sentidos apontados por profissionais de saúde ao termo "humanização (do parto)" foram semelhantes aos destacados, a saber: acolhimento, acompanhado de elementos que no presente estudo foram compreendidos como integrantes dele, como apoio, respeito, provimento de informações e estabelecimento de uma boa relação; e um olhar para a mulher como um todo - expressão também empregada pelas profissionais do Núcleo e que foi aqui discutida como aspecto da integralidade. Resultados semelhantes são apontados por Rolim e Cardoso (2006), que acrescentam, ainda, que o tema do resgate da subjetividade na atenção em saúde - aqui compreendido como também associado ao acolhimento e à integralidade - e da amorosidade permeando a relação - aspecto integrante, segundo aqui discutido, da postura dialógica foram assinalados pelas enfermeiras que participaram do estudo.

A associação entre os processos de acolhimento, produção de vínculo, integralidade e humanização é mencionada por diversos autores (BACKES; LUNARDI FILHO; LUNARDI, 2005; BOSI; UCHIMURA, 2007; FRANCO; BUENO; MERHY, 1999; MARQUES; LIMA, 2004; QUEIROZ et al. 2007; ROLIM; CARDOSO, 2006; SCHOLZE et al., 2006; SILVA JR.; MASCARENHAS, 2005; TAKEMOTO; SILVA, 2007 TEIXEIRA, 2005; TSUNECHIRO; BONADIO; OLIVEIRA, 2002). Ademais, a análise dos documentos ministeriais, realizada com o objetivo de definir um conceito de humanização, explicitou o acolhimento, "aspecto essencial da política de humanização" (BRASIL, 2006b, p. 13), como um dos meios de operacionalização da humanização da assistência - atrelado à produção de vínculo, segundo a compreensão apresentada na PNH (BRASIL, 2008); e a integralidade, especialmente se entendida a partir da dimensão de atuação pautada em uma concepção de homem integral 
(BRASIL, 2000e, 2006b, 2009), como um dos fundamentos da humanização. As reflexões que vêm sendo aqui tecidas, mostram, ainda, mais uma faceta das articulações desses processos: acolhimento, produção de vínculo e integralidade afiguram-se favorecedores da reinserção dos sujeitos nas práticas de saúde como sujeitos integrais.

No caso das mulheres-usuárias do serviço de atenção pré e pós-natal do Núcleo Monte Azul, viu-se o quanto, a partir de tais processos, elas se sentiram reconhecidas e atendidas não apenas em suas demandas concernentes à vivência do ciclo grávido-puerperal mas também naquelas que se poderia denominar existenciais: demanda de serem vistas em sua condição de sujeito - integral - e, como tal, vivendo experiências nos mais diversos campos; e demanda de, como pessoa, engajarem-se na produção de um cuidado mobilizado a partir do vínculo com alguém em quem confiam e que lhes dá espaço para se mostrarem como são.

O tema da dialogicidade merece destaque nesse cenário. Como Jacobs (1997) e Yontef (1998) discutem, a relação dialógica é aquela em que o cuidador se coloca em uma atitude EU-TU, ou seja, olha para o outro como pessoa e não como "um objeto a ser manipulado" (YONTEF, 1998, p. 242). No caso, não trata a mulher, por exemplo, como um mero ventre grávido, que não tem um nome, uma história e uma inserção no mundo. Além disso, por meio da confirmação, convida aquele de quem cuida a se mostrar como é; e, a partir da inclusão, pode melhor compreender o que o outro vive, em meio à complexidade própria do humano o que potencializa, então, o processo de identificação, elaboração e negociação de demandas nos diversos campos de experiência. Por fim, pela presença, revela-se como pessoa inteira que, acrescida da atitude amorosa, contribui para a sedimentação e o fortalecimento do vínculo, como discutido. Portanto, a dialogicidade não apenas evidencia um usuário-sujeito, cujas necessidades se manifestam em dimensões diversas, como, resgatando um profissionalpessoa, reinstaura a intersubjetividade inerente à produção do cuidado.

Tem-se já aí, então, o primeiro elemento revelador da reinserção também das profissionais do Núcleo como sujeitos integrais nas práticas de saúde. De fato, percebe-se que a atitude dialógica pode apenas ser exercitada se fundamentada na integralidade. Além disso, vê-se que ela provoca o profissional a contatar não só os seus saberes mas também a sua subjetividade. Para que possa apreender e confirmar o vivido pelo usuário, ele precisa estar em contato com suas próprias experiências, de modo a poder discernir o que é seu do que é do outro; o que deve ser colocado na relação, por estar a serviço dela ou do usuário, e o que deve ser mantido em suspensão, por então representar imposição de valores ou desrespeito para 
com aquele de quem cuida. Ela implica, ainda, um viver-com o outro, em que o cuidador se permite afetar aquele de quem cuida e ser por este afetado; em que afetos são compartilhados e experienciados como motores da relação; em que há uma disponibilidade para adentrar o universo vivencial do outro de modo a apreender o que ali há. E que, portanto, demanda contato com a própria possibilidade de estar-em-relação e assumir o lugar do TU, ou da figura de apego seguro (LIMA; FERNANDES, 2006).

Convém questionar, porém, o que favorece o profissional assumir tal postura acolhedora-dialógica permeada por uma concepção de homem integral. Na Associação, um primeiro ponto que se destaca nesse sentido é o olhar que parece haver para o profissional também ele é ali reconhecido em sua condição de sujeito integral. O salientado por Craemer e Ignacio (2008) acerca do foco principal da Escola-Oficina Social ser o desenvolvimento integral dos colaboradores, ou seja, nos âmbitos do pensar, do sentir e do agir, é notável a esse respeito. Ademais, pelos dados aqui coletados - embora, como já mencionado, trate-se apenas de indícios, uma vez que não houve investigação sobre esse aspecto -, os profissionais do ambulatório do Núcleo parecem encontrar ali espaços de acolhimento, traduzidos por reuniões, grupos de estudo, espaços informais de trocas de vivências, pessoais e profisssionais, e cuidado. É interessante aqui incluir o relato de Craemer e Ignacio (2008) sobre alguns desses espaços, descritos como permeados não só por estudo e reflexão mas também por promoção de contato com a própria subjetividade e por experiência de intersubjetividade com ênfase à troca de ideias e de vivências, e ao ouvir e ao aprender com o outro, o que aqui se entende tratar-se de um importante treino à dimensão dialógica.

Nesse cenário, o profissional se sente reconhecido em sua condição de sujeito integral, o que o convida a também assim se perceber, e se permitir ser, nos processos de produção de cuidado. Além disso, o estímulo à prática do acolhimento dialógico ${ }^{28}$ faz-se acompanhado de respaldo institucional para as eventuais dificuldades encontradas. $\mathrm{E}$ se legitima institucionalmente que ali o homem não pode ser compreendido apartado de sua subjetividade e do campo intersubjetivo - tal como defendido por diversos autores que discutem a proposta de humanização (BACKES; LUNARDI FILHO; LUNARDI, 2005; BOSI; UCHIMURA, 2007; CASATE; CORRÊA, 2005; HOGA, 2004; OLIVEIRA; COLLET; VIERA, 2006; ROLIM; CARDOSO, 2006). Revela-se, assim, uma compreensão de que apenas por meio do oferecimento de recursos e de cuidado ao profissional, torna-se

28 Tal como se está aqui chamando o acolhimento permeado pela atitude dialógica. 
possível viabilizar a humanização da atenção - já que esta é por aquele coproduzida.

A esse respeito, em estudo realizado por Rolim e Cardoso (2006), os espaços de supervisão e cuidado aos profissionais de saúde foram apontados como indispensáveis à concretização do cuidado humanizado. Backes, Lunardi Filho e Lunardi (2005) destacam a potencialidade deles para a promoção da humanização. Mais especificamente sobre o trabalho com a subjetividade, Hoga (2004) defende que o preparo adequado para o campo das relações humanas - fator fundamental à humanização - requer ampliação de autoconhecimento, de modo que o profissional contate suas fragilidades e limitações, e também suas potencialidades. Backes, Lunardi Filho e Lunardi (2005) acrescentam, ainda, que quanto mais o profissional contata seu mundo subjetivo, mais descobre recursos para desenvolver uma prática transformadora.

De fato, é importante considerar que o resgate de vivências subjetivas e o contato com elas, especialmente aquelas que dizem respeito à disponibilidade do profissional de se colocar em relação assumindo uma postura dialógica/de figura de apego seguro, é fundamental. $\mathrm{O}$ profissional necessita ampliar a consciência acerca de suas concepções em torno de como devem ser estabelecidas relações de cuidado; de como, em meio a tais concepções e à sua própria história, coloca-se em relação, acessando habilidades, limites, padrões e bloqueios; e do que há, então, para ser trabalhado/elaborado, de modo a aprimorar seu estar-com aquele de quem cuida. Assim, torna-se evidente que, embora reflexões teóricas sobre o cuidado sejam essenciais, é imprescindível também haver espaço para um trabalho verdadeiramente profundo dessas outras dimensões - o que, vale considerar, pode demandar acompanhamento psicológico em alguns casos. Como já se discutiu, a Associação, ao incluir como peça chave a promoção do desenvolvimento integral dos colaboradores, lançando mão, para isso, de artifícios como oficinas de arte e espaços de discussão, de compartilhamento de experiências subjetivas e de cuidado, parece também abordar esse nível mais profundo de trabalho pessoal de seus colaboradores; isso demandaria, porém, maior investigação em estudos futuros.

Um ponto importante de ser salientado em face dessa restituição de humanidade e integralidade aos profissionais é, nas palavras de Casate e Corrêa (2005, p. 110-111), que “como humanos podemos constituir ações 'humanizantes' que consideram o outro em seus direitos, em sua singularidade e integralidade; enfim, em sua dignidade e, ao mesmo tempo, somos capazes também de constituir ações 'desumanizantes' que 'coisificam' o outro ou nós mesmos". Portanto, pode-se afirmar que promover tal restituição também implica, como foi 
observado no Núcleo Monte Azul, por vezes ser impaciente; ficar menos disponível ao outro; ou sobrepôr questões institucionais ao vivido pelas usuárias. Registra-se, dessa forma, mais um fator que aponta para a importância de se constituir espaços que permitam aos profissionais contínuas reflexão e autorreflexão acerca do fazer em saúde; algo, vale lembrar, pontuado nos depoimentos de Sônia e de Cláudia.

É fundamental também considerar, porém, os limites verdadeiramente genuínos vividos pelos profissionais. Ainda pensando na disponibilidade de assumir uma atitude acolhedora dialógica nas relações de cuidado, é possível haver algumas situações nas quais o profissional realmente se veja diante de algo que o impeça de estar-com aquele de quem cuida; situações que talvez firam valores profundamente arraigados - lembrando que, como destaca Merleau-Ponty (1994), o processo de suspensão de pré-conceitos nunca se dá por completo -, ou que toquem questões de mais difícil elaboração. Parece razoável supôr que tais limitações são inerentes à condição de humanidade, justamente aquela que se pretende validar também no profissional na produção de um cuidado humanizado. Assim, pode-se pensar que, talvez, em algumas situações, tal atitude acolhedora dialógica de fato não se faça possível, o que, em contextos de humanização, implicaria, por exemplo, o encaminhamento do usuário a outro profissional.

Outro elemento que se considera também promotor da humanidade e da integralidade entre os cuidadores é a plasticidade de atuação. As profissionais do Núcleo Monte Azul relataram que sentem haver, ali, espaço para proposição de ideias e desenvolvimento de projetos em que acreditam, ainda que muitas vezes haja limitação de recursos financeiros; e para transcendência de normas e protocolos quando necessário - o que foi destacado por Cláudia como fator essencial à humanização do cuidado.

É interessante notar que algumas profissionais fizeram tais considerações em contraposição às experiências vividas em outros serviços, as quais foram associadas a contextos desumanizadores. Mencionaram que, nesses contextos, a instituição frequentemente se sobrepõe ao sujeito - tanto o sujeito-usuário quanto o sujeito-cuidador. No que se refere a este último, sua atuação acaba por ser então permeada por rigidez de protocolos e priorização de interesses institucionais. Isso impede, ou dificulta, que se perceba necessidades do usuário e que se respeite sua individualidade; e mecaniza a atuação, o que distancia o profissional de sua humanidade. Assinalaram ainda que tais condições são potencializadas quando o padrão de quantidade se sobrepõe àquele de qualidade, ou seja, em que a preocupação primeira reside 
em torno de índices de cobertura significativos, independentemente de como está se dando o cuidado.

Tais questões apontadas pelas profissionais permitem inferir que, em tais contextos, tanto o reconhecimento do usuário quanto a organização do trabalho e a atuação vão se tornando progressivamente mais fragmentados. Em decorrência, o profissional passa, então, a atuar meramente como homem-máquina, seguindo protocolos engessados, aplicando técnicas e procedimentos desconectados de contextos mais amplos e relacionando-se com usuárioscorpo, ou usuários-enfermidade. Merhy (1998) descreve tal contexto de atenção como aquele que é procedimento-centrado, o que é acompanhado por um distanciamento do profissional de interesses e necessidades do usuário e por atuação cada vez mais isolada dos demais membros da equipe de saúde - e, por isso, alienante e desumanizante.

No Núcleo Monte Azul, por outro lado, observa-se que a voz dada às profissionais, aliada à legitimação de suas ideias e de sua capacidade de tomar decisões a partir de suas percepções e saberes - mesmo no que concerne a decisões compartilhadas em equipe, nota-se que tais percepções e saberes encontram aí eco e validação -, garante atuação não mecanizada e não alienante; garante o exercício de sua autonomia e, portanto, o contato com sua condição humana. Como referem Franco, Bueno e Merhy (1999, p. 349), a autonomia do profissional diz respeito à possibilidade de tomada de decisão aliada ao "exercício pleno do saber-fazer", o que lhe permite apropriar-se do resultado de seu trabalho. Além disso, considerando-se especialmente que esse exercício de seu "saber-fazer" dá-se em processos humanizados e humanizadores de produção de saúde, de modo articulado aos fazeres dos demais atores, "a experimentação advinda da complexidade dos encontros possibilita que o profissional se reinvente, inventando-se com o outro" (BRASIL, 2008, p. 17).

Acerca dessa articulação de atuações e projetos terapêuticos, aliás, cabe observar que o trabalho em equipe também pode ser compreendido como fator (re)humanizador, tanto das condições de trabalho, como do próprio profissional de saúde, como apontam Oliveira, Collet e Viera (2006) e Backes, Lunardi Filho e Lunardi (2005). Atuando em conjunto e de forma integrada os profissionais têm mais condições, como já discutido, de garantir a resolutividade do serviço. Nesse sentido, cabe retomar o relato de uma colaboradora, obtido durante a fase de reconhecimento de campo. Ela narra que, diferentemente de seu trabalho anterior, onde frequentemente experimentava situações de impotência, na Associação percebia-se parte de uma equipe implicada com as questões da clientela, de modo que, apesar de eventuais 
limitações, sentia haver um movimento de esforço voltado ao atendimento das necessidades expressas - o que lhe proporcionava uma sensação de satisfação. De fato, Schimith e Lima (2004) descrevem sensações de indignação e insatisfação dos profissionais diante de situações que promoviam sofrimento aos usuários e que não sabiam como resolver. Takemoto e Silva (2007), por sua vez, assinalam que, atuando em equipe de forma integrada, o profissional desaliena-se, passando a ver de maneira mais nítida o produto de seu trabalho; que, ademais, ganha em potencialidade e sentido, conferindo, então, mais satisfação ao profissional. Assim, percebe-se tratar-se de algo que humaniza porque permite ao profissional abandonar o lugar, frequentemente ocupado, de mera máquina executante de procedimentos geralmente ineficazes - já que não alcançam a complexidade dos fenômenos - e se reconectar com sua condição de ator/sujeito inserido no campo da intersubjetividade.

No que concerne à dimensão de humanização das condições de trabalho, também possível de ser apreendida dessas considerações, nota-se que alguns dos fatores acima levantados compõem os "pré-requisitos estruturais" (MINAYO, 2006, p. 28) pontuados pelo MS (BRASIL, 2004b, 2006b) como necessários ao cuidado humanizado, a saber, ambiência especialmente tendo-se em vista a satisfação narrada pelas profissionais em virtude das relações estabelecidas entre si e dos valores e aspectos priorizados na promoção do cuidado e na estruturação do serviço - e equipe de saúde funcional. Quanto ao incentivo, levantado por Deslandes (2004) sobre essa temática, infere-se, a partir dos indícios colhidos, que a Associação investe continuamente nos profissionais, ao oferecer espaços de cuidado e de estudo; o contato com profissionais estrangeiros, que trazem novas formas de atuação; além de eventos ligados à produção de saúde e à educação. Pode-se também considerar como incentivo o espaço dado aos colaboradores e coordenadores para proporem ideias e projetos. Apontamentos que vão ao encontro do relatado por Craemer e Ignacio (2008) acerca das constantes atividades voltadas ao desenvolvimento de seus colaboradores.

Porém, foram destacadas, no Núcleo, dificuldades relativas à carga de trabalho e à remuneração, aspectos também associados à humanização das condições de trabalho segundo Deslandes (2004). Algumas profissionais mencionaram que a carência de recursos dificulta a contratação de maior número de profissionais, o que gera uma sobrecarga de funções e, em decorrência, um prejuízo no desempenho das tarefas que seriam de fato de responsabilidade de cada profissional - ponto, cabe ressaltar, assinalado por Cláudia como algo em que se deve ainda avançar, no Núcleo, com vistas à humanização. Instabilidade de salários foi também 
relatada.

É importante perceber, entretanto, que essas questões, de modo geral, foram colocadas como algo de reduzida importância pelas profissionais. Observa-se que a sintonia com as concepções da Associação, a crença na contribuição de suas propostas para a comunidade, assim como no trabalho que realizam, parecem tornar esse tema mais facilmente enfrentado. Além disso, quando sentem que atingiram o seu limite, no que se refere à carga de trabalho, parecem encontrar validação, suporte e cuidado, por meio de uma consulta com o clínico, de um espaço terapêutico, ou de alguns dias de folga. Fundamental destacar que não se pretende com tal discussão defender uma postura conivente com baixos salários, nem na Associação, nem em outras instituições. Muito menos apoiar sistemas que se baseiam em sobrecarregar funcionários e garantir a manutenção de tal contexto a partir de mecanismos compensatórios. O que se pretende aqui salientar é que, no Núcleo, reconhece-se limitações, tenta-se superar dificuldades e, valorizando-se o profissional, oferece-se espaços de cuidado. Paralelamente, vê-se que o fato de as profissionais perceberem sentido no que fazem, coloca-as de forma diferenciada no enfrentamento de dificuldades. Como afirmou Frankl (1984), aquele que compreende o sentido de sua inserção e atuação no mundo consegue suportar e lidar com quase qualquer dificuldade com a qual venha a se deparar.

Diante dessas considerações, nota-se que condições ocupacionais afinadas com a humanização e, mais especialmente, de envolvimento dos profissionais com seu trabalho, podem também contribuir para a adoção de uma postura acolhedora dialógica. É bem possível que alguém que não apreenda o sentido do que faz, que não se sinta mobilizado pelo cuidado em saúde e que não conheça seus talentos para engajar-se em relações de cuidado, vivencie condições de sofrimento no trabalho; condições que podem levá-lo a desenvolver uma atuação mais mecanizada e distante e, assim, dificultarem a adoção da postura dialógica. Por outro lado, aquele que assume seu trabalho como uma escolha plena de sentido e que se envolve com o que faz, especialmente por acreditar nos resultados do que realiza, mais provavelmente se colocará inteiro ali, o que favorece a dialogicidade. Cabe, a esse respeito, o apontamento de Craemer e Ignacio (2008, p. 149) sobre a concepção cultivada na Associação de que o bom desenvolvimento do trabalho realizado pressupõe que os colaboradores se orientem, "em primeiro lugar, pelo ideal e só em segundo lugar pela necessidade de ganhar dinheiro", ainda que muitos visem, no início, primordialmente, à garantia de um emprego. Algo, vale aqui destacar, que não pode ser pensado de forma apartada de condições que 
promovam a conexão com tais ideais.

Se as profissionais, então, assim como as mulheres-usuárias, parecem encontrar no Núcleo condições que favorecem a restituição, ou afirmação, de sua condição de humanidade, de sujeito integral; e se, tendo-se em vista as considerações de Teixeira (2005), uma das expressões dessa condição é a experiência do processo de ampliação e efetivação de potências; convém notar que, de fato, esse processo também ali se dá, entre usuárias e entre profissionais; o que contempla o terceiro e último aspecto do conceito de humanização aqui adotado - aquele que versa, justamente, sobre tal processo.

Foram já mencionados e discutidos exemplos de vivências de mulheres-usuárias do serviço do Núcleo que revelaram esse tipo de processo - mulheres que, encontrando espaço de expressão de suas experiências e de sua individualidade, e sendo aí validadas, descobriram "seu próprio jeito" - como destacou Cláudia sobre um dos objetivos do trabalho de fortalecimento da mulher - de enfrentar dificuldades, de viver o parto mais apropriadas de seu corpo, de se assumir como mães-cuidadoras de seus bebês.

O depoimento de Sofia evidencia de modo ainda mais amplo esse tema. A despeito de esses processos deverem ser entendidos em um contexto mais extenso de fatores, nota-se que, a partir do trabalho de fortalecimento vivido no Núcleo, Sofia sentiu-se mais preparada para viver a gestação com tranquilidade e o parto natural desejado. Como decorrência, experimentou mais autoconfiança, o que lhe permitiu, então, rever escolhas de vida e ir em busca de novos caminhos. Como ela referiu, "algumas coisas refletem na vida, né?".

É importante observar que o trabalho de fortalecimento da mulher, aliado ao acolhimento dialógico, explicita de modo especial a dimensão de ampliação e efetivação de potências da humanização do cuidado. O tema do empoderamento, que se revelou decorrente desse trabalho, é notável a esse respeito. A atitude dialógica, por sua vez, especialmente ao incluir a apreensão e a validação do outro, tanto na esfera do que se manifesta quanto naquela do que existe em forma de potência, favorece a realização de potencialidades e da própria condição de pessoa (JACOBS, 1997).

Observa-se que, entre as profissionais, a vivência desses processos aumentativos de potência evidenciam-se especialmente em seus relatos sobre percepções de crescimento profissional e/ou pessoal a partir da experiência de trabalho na Associação. Segundo Sônia, por exemplo, foi ali que ela descobriu e realizou - no sentido de efetivação de uma potencialidade - uma nova possibilidade em sua profissão e que, a partir do contato com a 
clientela, ampliou sua compreensão acerca do homem. Para Isabela, a Associação é um local que "ensina a olhar o ser humano com amor e respeito"; além disso, ela acredita que a forma de organização do trabalho e do serviço, que estabelece prioridades diferentes daquelas de outros estabelecimentos e que inclui reuniões de integração, de áreas e de estudo, geram importantes experiências de aprendizagem e crescimento. Érica também destacou vivências enriquecedoras em função do contato com a diversidade humana.

Nota-se que essas experiências são, ao mesmo tempo, favorecidas pela disponibilidade das profissionais de se envolverem e se deixarem tocar pelo trabalho que realizam e pelos encontros que o permeiam, e incentivadas pela própria Associação. Segundo Craemer e Ignacio (2008, p. 115), desde o início houve uma preocupação de se promover ali o crescimento pessoal dos colaboradores, por também se considerar que "o desenvolvimento de uma organização depende principalmente do desenvolvimento das pessoas que nela trabalham". Além disso, as autoras destacam que, por serem ali visados o desenvolvimento integral e a transformação comunitária, e por o respeito e a compreensão do outro serem tomados como elementos imprescindíveis, o envolvimento dos trabalhadores com as pessoas e com a comunidade é considerado ponto chave; do que decorre a percepção assinalada pelas autoras de que com o passar do tempo, "a transformação da comunidade passa por uma transformação interna" (CRAEMER; IGNACIO, 2008, p. 79) dos colaboradores.

Vê-se, portanto, que a compreensão da humanização do cuidado sob o viés da ampliação e da efetivação de potências encontra eco em concepções tomadas como norteadoras de atuações e da estruturação de projetos na Associação. O que foi também expresso no depoimento de Cláudia ao assinalar que a humanização na Associação implica construção de um cuidado que vise à expressão, ao desenvolvimento e à realização do indivíduo.

No que se refere à sintonia das profissionais com as concepções e propostas da Associação - a qual também se evidenciou a partir da coerência e da consonância de seus discursos - nota-se que, de fato, parece existir uma estrutura para que, desde a entrada do trabalhador na organização, haja um fortalecimento de tal sintonia. Como assinalou uma colaboradora durante a fase de reconhecimento de campo, há, ali, uma preocupação com o ser humano e com o cuidado dele e, quando alguém é contratado, a pessoa é "inserida na filosofia da Associação", de modo a poder receber os usuários com esse cuidado. Tal apontamento é corroborado por Craemer e Ignacio (2008), ao relatarem que, quando a Associação ganhou 
maiores proporções, começou-se a investir de modo mais especial na conscientização dos colaboradores acerca dos ideais e das propostas da entidade; o que vai ao encontro do pontuado por Schimith e Lima (2004), que discutindo acerca da concretização do SUS, alertam ser preciso que os profissionais de saúde se sintonizem com suas propostas e princípios e se sintam atores na busca desse projeto.

Diante dessas considerações, um ponto de fundamental importância se destaca: de acordo com Craemer e Ignacio (2008) qualquer proposta de mudança profunda em longo prazo demanda ser fundamentada em uma filosofia. A partir do que foi aqui possível apreender e compreender, a adoção de um sistema filosófico claro, que sustenta os ideais e propostas acima referidos, e que orienta as práticas desenvolvidas na Associação, aliado à preocupação com a sintonia de colaboradores e coordenadores com tal sistema, evidenciou-se

\section{como aspecto essencial à humanização do cuidado ali produzido.}

Como se discutiu na seção teórica do presente estudo, a adoção de um novo paradigma, que possa se sobrepôr ao tecnocrático (DAVIS-FLOYD, 2001), que ainda se mostra hegemônico, mostra-se de fundamental importância à humanização, especialmente para evitar que tentativas de instauração de novas práticas se façam permeadas por contradições. O PHPN se revelou ilustrativo a esse respeito, ao definir indicadores de processo que não incluem aspectos relacionados a outras dimensões do cuidado; o que também é apontado, vale lembrar, por Parada e Tonete (2008). Em decorrência, a maior parte dos estudos que objetivaram avaliar a implantação do PHPN no país não menciona o acolhimento (COUTINHO et al., 2003; SERRUYA; LAGO; CECATTI, 2004a; NASCIMENTO; PAIVA; RODRIGUES; 2007; TANAKA et al., 2008); ou, quando o faz, não o investiga (NAGAHAMA; SANTIAGO, 2006; NASCIMENTO; RODRIGUES; ALMEIDA, 2007; GRANGEIRO; DIÓGENES; MOURA, 2008). Desse modo, como referem Parada e Tonete (2008), o PHPN não avança na inclusão e na valorização de outras dimensões do cuidado. Além disso, nota-se que se continua a se reproduzir, então, "o enfoque biologicista e medicalizador hegemônico" (BRASIL, 2004a, p. 59).

No Núcleo Monte Azul, por outro lado, sendo a prática de cuidados fundamentada em um sistema filosófico que entende o homem como unidade psicofísica-espiritual em relação com o mundo (BALDI, 2003; CRAEMER; IGNACIO, 2008), constrói-se um cuidado que não privilegia dadas dimensões ou recursos tecnológicos - embora seja regido pelas tecnologias leves, essas ali articulam as demais tecnologias, como já discutido, em favor das 
demandas identificadas, elaboradas e negociadas; o que deixa, então, menos espaço para dicotomias e contradições.

Nota-se que tal questão vai ao encontro da importância destacada no PHPN (BRASIL, 2001, 2006b) de o cuidado humanizado ser pautado em um conceito de saúde integral, que propicie um novo olhar também sobre os indivíduos - ainda que no programa isso se revista das mencionadas contradições. Como então assinalado, a adoção de um novo conceito de saúde e de homem é tema também recorrente na literatura acerca da humanização (TRAVERSO-YÉPEZ; MORAES, 2004; BACKES; LUNARDI FILHO; LUNARDI, 2005; CASATE; CORRÊA, 2005; LEITE; STRONG, 2006; ROLIM; CARDOSO, 2006). Porém, a partir do que foi apreendido ao longo deste estudo, observa-se que, quando esses novos conceitos são assumidos segundo um sistema filosófico - associado a um paradigma humanista e/ou holístico - que lhes oferece maior sustentação, as atuações e os discursos vão sendo tecidos de modo mais consonante pelos diversos atores em torno das concepções adotadas. Torna-se, assim, mais viável construir a humanização do cuidado que se deseja.

Diante disso, convém também comentar sobre concepções que se mostram associadas ao sistema filosófico adotado no Núcleo e que contribuem para as formas pelas quais a humanização do cuidado pré e pós-natal ali se concretiza. Uma dessas concepções, que se destacou nos depoimentos das profissionais, é a crença no valor da pessoa humana, traduzida pela percepção de que qualquer indivíduo é capaz de se desenvolver, independentemente de suas condições de vida e de sua história; o que demanda, por vezes, que ele seja despertado para o seu valor no mundo.

Observa-se que essa crença predispõe as profissionais a olharem para a usuária e ali enxergarem o que há em termos de dificuldades e o que há em termos de força que impulsiona à realização e ao enfrentamento; a perceberem na mulher tanto a porção perdida, em conflito, que não sabe o que fazer com a gestação e com a maternidade, quanto a porção que se conecta com a capacidade de gestar, parir e cuidar do bebê - processo evidente no vivido de Sofia e também no de Carolina. Trata-se de uma crença, portanto, que se mostra em íntima associação com o processo de ampliação e efetivação de potências.

Além disso, essa crença também se revela favorecedora do acolhimento dialógico, não apenas no que diz respeito à pratica de inclusão e confirmação quanto à própria disponibilidade para se estar com o outro em relação. Isso se torna especialmente nítido ao se considerar que a atitude amorosa, mobilizadora da dialogicidade (LIMA; FERNANDES, 
2006), ao mesmo tempo em que se traduz em abertura ao outro, é favorecida pela percepção daquele de quem se cuida, independentemente de sua raça, condição sócioeconômica ou modo de se apresentar no mundo, como, antes de tudo, um ser humano, cujo valor é dado, em primeiro lugar, por sua condição de humanidade.

Outra concepção refere-se à compreensão - segundo algumas profissionais, também atrelada à Antroposofia - de que a preparação da mulher, durante o pré-natal, deve passar pelo resgate de, ou pelo tornar ainda mais evidente, sua capacidade de gestar, parir, nutrir e criar um novo ser. Permeando tal concepção parecem estar compreensões sobre o que seja a maternidade, como aquelas destacadas pelas profissionais: uma fase importante do desenvolvimento da mulher, que precisa então elaborar algumas questões de modo a assumir o novo papel; não se resume a gerar ou a dar à luz a uma nova vida, envolvendo também o acompanhamento desse novo ser em desenvolvimento; traduz-se em realização de potencialidades do feminino - de modo que a mulher pode então experimentar sensações de completude e de potência -, e em possibilidade de ampliação de consciência, de responsabilidade e de amadurecimento. Disso parece decorrer a ênfase dada ao trabalho de fortalecimento da mulher durante o acompanhamento pré e pós-natal realizado no Núcleo; como discutido, expressão do acolhimento e, portanto, da humanização do cuidado ali produzido.

Também é possível depreender, a partir dos depoimentos das profissionais, que ali se entende que o cuidado à mulher não basta, uma vez que ela está inserida em uma família, da qual necessitará suporte, e essa família constitui o campo que receberá o bebê. Também se compreende que com a atenção ao ciclo grávido-puerperal garante-se uma das bases para a criança ser bem recebida do mundo; e que uma família que recebe bem uma criança, terá melhores condições de cuidar dela ao longo da infância, garantindo-lhe, então, bom desenvolvimento. Evidenciam-se, assim, os pilares que parecem sustentar o trabalho de fortalecimento dos vínculos familiares incluído na atenção pré e pós-natal do Núcleo; também associado ao acolhimento ali concretizado e, em decorrência, à humanização do cuidado.

Uma das profissionais destacou, ainda, que a partir da Antroposofia entende-se a vivência do ciclo grávido-puerperal em um contexto mais amplo: o do primeiro setênio de vida da criança; o que é também apontado, vale lembrar, por Hotimski (2001). Em decorrência, parece haver, no Núcleo, uma preocupação de se articular o cuidado à gravidez e ao puerpério com as fases que se seguem; o que pôde ser especialmente observado na 
construção do programa do ciclo de palestras, cujos últimos encontros, conforme descrito na seção de descrição do campo, tratavam de temas relacionados com tal período subsequente.

Em meio a tais concepções, nota-se um tema que parece conferir especificidade à produção da humanização do cuidado pré e pós-natal no Núcleo Monte Azul: a preocupação com a promoção de uma cultura de paz; a qual se mostra intimamente relacionada com trabalho de fortalecimento da mulher e dos vínculos familiares. Conforme pontuou Isabela, o apoio à mulher e à família durante o ciclo grávido-puerperal; o fornecimento de informações acerca das necessidades da criança, aliado à investigação de possibilidades de essa família, em meio aos recursos disponíveis, responder a tais necessidades; e, especialmente, o fortalecimento do vínculo entre seus membros, "promove a paz. Promove a segurança do ser humano. Vai fazer com que essa criança seja um adulto mais seguro, mesmo diante das dificuldades sociais. Um ser humano mais tranquilo".

De fato, os estudos relatados por Wilheim (1997) e por Cyrulnik (2004), revelam que o feto, no ambiente intra-uterino, já vivencia o primeiro capítulo de seu desenvolvimento na vida, experimentando-se em alguns dos recursos que lhe serão importantes após o nascimento. Além disso, via corpo materno, já trava contato com o mundo, sentindo o impacto - positivo ou negativo - do que aí se passa. Tal como sugere Odent (2002; 2003), é já com essas experiências que se inicia a promoção da capacidade de amar. Ademais, refere que contextos de estresse durante a gravidez podem elevar o risco de prematuridade e de baixo peso ao nascimento e, mais tarde, de dificuldades de sociabilidade e de transtornos psiquiátricos. Evidencia-se, portanto, uma continuidade entre o vivido durante a vida intra-uterina e o que depois se segue.

A vinculação dos pais ao feto-bebê, por sua vez, é apontada como experiência importante durante o ciclo grávido-puerperal por Brazelton (1988) e Klaus e Kennell (1992). Ademais, para Lima (2006, 2009), o pré-natal se traduz em momento de já se auxiliar os pais a assumirem o papel de figuras de apego seguro.

Quanto a tal tipo de apego, aliás, conforme já mencionado no presente estudo, segundo Bowlby (1990) a criança seguramente apegada é mais autoconfiante, tolerante a frustração e a experiências negativas, hábil socialmente e sensível às aflições de outras crianças. Além disso, possuindo expectativas positivas em relação ao mundo, acredita no valor das pessoas e coloca-se mais confiante nas relações. Lima e Fernandes (2006) ainda acrescentam que são crianças com mais capacidade de encontrar caminhos saudáveis de desenvolvimento em meio 
às adversidades. Nota-se, assim, que não apenas tais considerações são consonantes àquelas apontadas por Isabela como se mostra possível propôr que promover apego seguro é também promover uma cultura de paz - o que demandaria maiores investigações em estudos futuros.

Diante disso, fica evidente a importância de promover um cuidado ao longo do ciclo grávido-puerperal afinado com a compreensão das vivências pré-natais em um contexto mais amplo de experiências, articuladas com o que depois se segue - ainda que não em tom determinístico. Além disso, se a humanização da atenção é também compreendida como validação da condição de humanidade - permeada por integralidade; e como "a busca dos melhores meios para o homem [efetivar e] aumentar sua potência" (TEIXEIRA, 2005, p. 592); parece razoável supor que, especialmente quando se trata de um contexto de cuidado à gestação, ao parto e ao puerpério, tais processos aumentativos de potência sejam também pensados em torno da mulher se (re)conectar com sua capacidade de gestar, parir e nutrir o bebê; de ela, o homem e outros membros familiares assumirem-se como cuidadores - na perspectiva de apego seguro - da criança; e de este novo ser poder ser inserido no mundo de relações em meio a encontros dialógicos - amorosos e que se traduzam em base segura -, que lhe proporcionem descobrir, de uma boa forma, o mundo dos homens, e a si mesmo como homem - o que, em níveis mais amplos, contribui para gerar uma nova qualidade de relações entre os indivíduos. Parece não apenas razoável, portanto, como também importante entender a humanização do cuidado pré e pós-natal, como aquela que é comprometida com o fortalecimento da mulher e dos vínculos e com a promoção de uma cultura de paz.

\subsubsection{BREVES CONSIDERAÇÕES SOBRE ALGUNS DOS PARÂMETROS DEFINIDOS NO PHPN}

Embora, no que concerne à operacionalização do cuidado humanizado, o foco do presente estudo tenha residido no acolhimento; e ainda que, por essa razão, não se tenha aprofundado a investigação dos demais parâmetros definidos no PHPN à atenção ao pré-natal e ao puerpério (BRASIL, 2006b) (Anexo B); faz-se interessante tecer algumas breves considerações acerca do que pôde ser observado a esse respeito.

É importante, porém, mais uma vez destacar o contexto em que tais dados devem ser 
compreendidos. Primeiramente, é preciso ter em vista que parte deles provém do levantamento realizado a partir dos cartões das gestantes, os quais, como discutido, não representaram fonte segura de informações, considerando-se os problemas de registro encontrados. Além disso, tal levantamento foi realizado durante um período, definido no presente estudo como Fase 1, em que o acompanhamento puerperal não estava ainda sedimentado, assim como uma série de atividades e articulações que foram inseridas no serviço posteriormente. Apesar disso, alguma discussão faz-se possível, a qual será pautada especialmente nos parâmetros do PHPN (BRASIL, 2006b) que aqui constam no Anexo B.

Quanto à captação precoce das gestantes, no Núcleo Monte Azul apenas 52,94\% das usuárias realizaram a primeira consulta ainda no primeiro trimestre. A partir dos relatos das mulheres, sabe-se que o fato de haver aquelas que, descontentes com o atendimento da UBS, dirigiam-se ao Núcleo, pode ser um fator de impacto sobre tal índice - algo também aventado em estudo de Nagahama e Santiago (2006). Porém, a inexistência ainda, naquela época, da articulação com os agentes comunitários de saúde - que garantiria mais conhecimento sobre as gestantes da região e, então, a captação ativa delas - parece ser o ponto mais fundamental na compreensão desse quadro.

O número médio de consultas pré-natais realizadas por cada mulher é alto - em torno de 8,6 -, dificilmente sendo inferior a seis - quando se trata de casos em que a mulher se manteve em acompanhamento na Associação. Entretanto, no que se refere à sua distribuição ao longo dos trimestres, apenas $20 \%$ das usuárias cumpriram os parâmetros de, ao menos, uma consulta no primeiro trimestre, duas no segundo e três no terceiro; o que indica ser esse, portanto, um aspecto a ser ainda melhor trabalhado no Núcleo. Visitas domiciliares durante o pré-natal e melhor articulação com os agentes comunitários de saúde da região parecem ser recursos importantes nesse sentido. Embora se tenha que também considerar que quase 50\% das mulheres-usuárias do serviço de atenção pré e pós-natal eram residentes de regiões mais ou menos distantes do Núcleo. Nesse caso, outros recursos teriam de ser, então, desenvolvidos.

Como amplamente discutido, o acolhimento é ali realizado. Da mesma forma o são as atividades educativas, que no presente estudo foram compreendidas como parte do exercício do acolhimento - durante as consultas; durante os encontros entre as profissionais e as usuárias em sala de espera ou em ocasiões em que essas se dirigiam ao ambulatório, fora do horário de consultas ou atividades; ou ainda, no ciclo de palestras, maior expressão de tais 
ações. Foi também descrito o estímulo ao parto normal, assim como a ênfase à naturalidade dele, o que também se revelou em alguns depoimentos de usuárias. Quanto a tal aspecto, cabe ressaltar que, conforme pontua Hotimski (2001), tais estímulo e ênfase relacionam-se com a concepção antroposófica que fundamenta o trabalho da Associação.

Considera-se não haver parâmetros suficientes para julgar se a anamnese e o exame clínico-obstétrico acontecem de acordo com os critérios definidos. Porém, convém salientar que as percepções das usuárias, apreendidas a partir de seus depoimentos e/ou relatos na fase de reconhecimento de campo, significaram tais procedimentos como sinais de que estavam, ali, sendo devidamente cuidadas. Além disso, em alguns casos, eles foram apontados como mais acurados do que aqueles realizados na UBS.

Não foram levantados dados relativos à realização de exames. Sabe-se, a partir dos relatos de usuárias e de profissionais, que eles são requisitados e controlados. Porém, não há como afirmar se as mulheres atendidas no Núcleo realizam, rotineiramente, todos os exames que constam no PHPN, especialmente considerando-se primeira e segunda baterias.

Também não se tem dados relevantes sobre a avaliação de estado nutricional e prevenção e tratamento de distúrbios nutricionais e sobre a classificação de risco gestacional. Cabe destacar, porém, que se observou que os hábitos alimentares são uma tônica marcantemente presente nas consultas pré-natais; e que há um cuidado da enfermeira-obstetra de identificar mulheres vivendo gestação de alto risco e encaminhá-las para os serviços de referência, mantendo-as, ainda, em acompanhamento no Núcleo.

Por fim, quanto aos cuidados com o puerpério, embora os dados coletados durante a fase de reconhecimento de campo tenham evidenciado o não cumprimento dos parâmetros estabelecidos, a posterior estruturação do serviço sugere melhoria em tal quadro. Vale mencionar, nesse sentido, que dentre as seis mulheres entrevistadas no presente estudo, quatro realizaram consultas de puerpério no Núcleo. Dentre as que não o fizeram, tem-se Lourdes, que viveu esse momento na fase em que o serviço ainda não estava estruturado; e Sofia, que durante o puerpério foi acompanhada no consultório particular da enfermeira-obstetra. Da mesma forma, excetuando-se Lourdes e Sofia - que não residia na área de abrangência do Núcleo - apenas Leila não recebeu visitas domiciliares.

Diante disso, nota-se que o tema da captação precoce das gestantes e da distribuição das consultas ao longo dos trimestres constitui os maiores desafios. A estratégia aventada por uma das coordenadoras do Núcleo de sedimentar melhor articulação com os agentes 
comunitários de saúde parece de fato ser importante; da mesma forma que o são as visitas domiciliares, não apenas no puerpério, mas também no pré-natal, como destacado no próprio PHPN (BRASIL, 2006b). De todo modo, dado ser esse um serviço que atrai uma população significativa de fora de sua área de abrangência, também se destacam fundamentais outras estratégias, tais como os encaminhamentos para outros serviços realizados pela enfermeiraobstetra em alguns casos - em um contexto de escuta e de negociação; o contato telefônico com as gestantes faltosas, empreendido pela auxiliar de enfermagem; e, possivelmente, maior investimento na sensibilização da clientela acerca da importância de se comparecer ao prénatal.

Quanto aos demais parâmetros, pode-se inferir que, em sua maioria, eles parecem ser contemplados no Núcleo. É interessante perceber, aliás, que as mudanças acompanhadas no serviço ao longo do período de coleta dos dados revelaram a identificação de algumas das lacunas então existentes e o desenvolvimento de estratégias voltadas à sua superação. De todo modo, é de fundamental importância considerar os limites do presente estudo à avaliação de tais parâmetros, assim como a demanda de melhor investigação deles em trabalhos futuros. 


\section{CONSIDERAÇÕES FINAIS}

As construções e desconstruções que permearam o presente estudo levaram a um extenso e abrangente percurso. Ao enfocar o tema da humanização do cuidado pré e pós-natal produzido em uma organização não-governamental, não houve como não transitar por campos diversos - universos de mulheres e de profissionais; estruturação de serviço; interlocuções com políticas públicas; inter-relações estabelecidas com outros processos, como acolhimento, produção de vínculo e integralidade.

A despeito do risco inerente à proposta de se abordar tal gama de questões, optou-se por assumi-lo com o objetivo de tornar mais evidente a importância desses campos e fenômenos à sedimentação de um cuidado humanizado. Para adentrar tão complexo e tortuoso caminho, porém, fazia-se essencial a definição de norteadores; tarefa que resultou não apenas na busca de delimitar um referencial teórico consistente como na construção de um conceito de humanização, orientador de observações e de compreensões tecidas.

Foi já aí, então, que o tema mostrou sua complexidade. Diante da tentativa de compreender o fenômeno, viu-se que a polissemia que o particularizava abria um campo marcadamente confuso. Especialmente nos documentos ministeriais relativos ao PHPN e à $\mathrm{PNH}$, e também em algumas referências na literatura, abordavam-se os fundamentos da humanização do cuidado e, especialmente, os elementos necessários à sua concretização. Pouco era dito, porém, acerca do que é a humanização. Assim, para construir um conceito considerou-se importante transitar por estes três âmbitos: o que é, como se operacionaliza e em que se fundamenta.

A partir de uma análise de documentos relacionados ao PHPN e à PNH, identificou-se que a humanização, conforme o MS, operacionaliza-se a partir de condutas acolhedoras e comprovadamente benéficas, as quais demandam, por sua vez, "pré-requisitos estruturais", e fundamenta-se em uma cultura de respeito aos direitos humanos e em um conceito de saúde integral. Acrescendo-se tal análise do conceito de humanização proposto por Minayo (2006), daquele apresentado por Teixeira (2005) e da discussão de Merhy (1998, 2000, 2002) sobre as articulações de tecnologias duras, leve-duras e leves nos processos de produção de saúde, definiu-se humanização como aquela que restitui o humano - no contexto em pauta, entendido como gestores, trabalhadores, usuários e acompanhantes - como ser integral e de 
direitos nos processos de produção de saúde, e as tecnologias leves ao seu lugar de reger tais processos, resultando em efetivação e aumento de potência.

Em face da amplitude que também revestiu esse conceito, de antemão ficou definido que o presente trabalho não daria conta do aspecto mais técnico que integra a operacionalização do cuidado humanizado; o foco, a esse respeito, residiria no acolhimento. Porém, findo o estudo, nota-se que também outro elemento não foi discutido mais profundamente, tendo permanecido apenas como fundo das reflexões tecidas: a reafirmação do respeito aos direitos humanos e reprodutivos, identificada como fundamento da humanização, e inserida em sua conceituação.

Além desse conceito, decidiu-se também tomar o próprio PHPN como norteador do estudo, assumindo-se então mais um risco: o de se adotar um referencial que, apesar de imposto aos diversos serviços de saúde, aplicava-se - e aplica-se - especialmente à realidade do SUS; uma realidade que, embora adentre o universo da Associação Comunitária Monte Azul, a partir das articulações entre serviços e do cadastramento do ambulatório do Núcleo como Estabelecimento de Saúde vinculado à Rede SUS, guarda especificidades próprias quando comparadas àquelas de uma organização não-governamental. Sem perder de vista tais especificidades, considerou-se, porém, possível estabelecer as inter-relações desses universos. Ademais, a partir das contradições observadas no PHPN, mostrou-se relevante desenvolver um estudo à luz de tal referencial, refletindo-se sobre fatores que se mostrassem mobilizadores da humanização e sobre eventuais contribuições evidenciadas no Núcleo que desvelassem possibilidades de superação das contradições.

Um dos primeiros pontos que se destacou concerne à mobilização da humanização do cuidado a partir dos processos de acolhimento, produção de vínculo e integralidade. No Núcleo Monte Azul, tais processos marcaram a convergência de discursos de usuárias e de profissionais acerca de demandas vividas durante o ciclo grávido-puerperal e de aspectos considerados importantes em um serviço de atenção ao pré-natal e ao puerpério. Além disso, esses processos também se mostraram ali como eixos norteadores da produção do cuidado, descortinando-se nas dimensões de postura das profissionais e de estruturação de serviços - o que potencializou, então, as ações de tais processos.

Nesse cenário, o tema da dialogicidade, discutido sob a ótica gestáltica da atitude dialógica/de figura de apego seguro, afigurou-se relevante, explicitando, ademais, as interrelações de acolhimento, produção de vínculo, integralidade e humanização. $\mathrm{O}$ acolhimento 
dialógico, concebido como possibilidade apenas se pautado em visão e atuação integrais, afirmou-se como dispositivo produtor de vínculo e, assim, como peça chave na restituição de intersubjetividade na produção do cuidado - especialmente ao resgatar, ou validar, um usuário-sujeito e um profissional-pessoa - e na ampliação e efetivação de potências nas vivências de mulheres e de profissionais.

A importância do acolhimento, da produção de vínculos e da integralidade no cuidado humanizado à gravidez e ao puerpério também pôde ser observada nas vozes das usuárias participantes deste trabalho, que mais uma vez apontaram - assim como estudos anteriores o fizeram - que são esses os aspectos priorizados na atenção e que definem a escolha, a adesão e a satisfação com um serviço; sustentando, ademais, deslocamentos geográficos mais ou menos amplos mobilizados pela busca de respostas às demandas vividas nesses campos.

Considerando-se o impacto de tais processos nas vivências do ciclo grávido-puerperal, os trabalhos de fortalecimento da mulher e dos vínculos familiares - que envolve a inclusão de acompanhantes -, entendidos aqui como expressões do acolhimento, também se destacaram de modo especial. Como indicado no início deste trabalho, partiu-se do pressuposto de que um dos grandes focos da vivência do ciclo grávido-puerperal é que a mulher, o homem e os demais membros familiares possam, por meio da elaboração de suas experiências, assumirem-se como cuidadores do bebê na perspectiva de apego seguro. Foco que deveria ser incluído na atenção ao ciclo, principalmente por favorecer a promoção das bases do bom desenvolvimento - não apenas psicológico mas também em suas outras dimensões - desse novo ser. Paralelamente, ressaltou-se a demanda de auxiliar a mulher e o pai do bebê a vivenciarem a transição existencial imposta pela maternidade/paternidade e favorecer o estabelecimento de relações mais dialógicas na família.

No Núcleo, observou-se que tais pressupostos permeiam as concepções das profissionais, as posturas por elas assumidas, assim como a própria estruturação do serviço especialmente no que se refere à ênfase aos trabalhos de fortalecimento da mulher e dos vínculos familiares. Os depoimentos das usuárias, por sua vez, corroboraram a importância desses trabalhos, na medida em que estes foram ao encontro de demandas vividas durante o ciclo grávido-puerperal e associaram-se a experiências de ampliação e efetivação de potências - incluindo-se aí vivências de empoderamento. Ademais, algumas profissionais relataram a contribuição desses trabalhos de fortalecimento à promoção de uma cultura de paz; o que se fez consonante com as considerações acerca de apego seguro (BOWLBY, 1990). Esse é um 
ponto merecedor de atenção em estudos futuros, principalmente por sugerir a possibilidade de a humanização do cuidado associar-se à promoção de mudanças mais amplas na sociedade, auxiliando a gerar nova e melhor qualidade nas relações estabelecidas entre os indivíduos não em termos determinísticos, como salientado algumas vezes ao longo deste trabalho, já que não parece razoável desconsiderar o impacto de experiências posteriores, mas como a oferta de uma primeira base favorável ao desenvolvimento da família e do bebê. De todo modo, mostrou-se relevante compreender o cuidado humanizado ao pré-natal e ao puerpério também como aquele que se compromete com o fortalecimento - e, portanto, com o empoderamento - da mulher e dos vínculos familiares. Apesar de essa compreensão ser, de alguma maneira, mencionada em manuais do PHPN (BRASIL, 2006b), ela mereceria maior ênfase.

Não há como desconsiderar, nesse cenário, a importância, destacada no Núcleo, do estabelecimento de vínculos entre mulheres e profissionais de saúde; não quaisquer vínculos, mas aqueles em que o cuidador ocupa o lugar de figura de apego seguro. Tal processo evidenciou-se também fundamental à humanização, especialmente por associar-se à promoção de autonomia e à potencialização da experiência de empoderamento. Além disso, os dados coletados sugerem que o vivido nessa relação contribui para a mulher, o pai do bebê e os demais membros familiares contatarem, descobrirem e/ou construírem recursos em si mesmos que lhes permitam assumir esse lugar de figura de apego seguro perante o bebê, assim como estabelecerem relações mais dialógicas entre si - o que mereceria melhor investigação.

Feitas essas considerações, é interessante retomar as perguntas levantadas nos capítulos iniciais do presente estudo a partir das contradições apreendidas no PHPN: seria possível garantir uma maternidade segura apenas com o cumprimento de um conjunto de procedimentos básicos? Seria possível concretizar uma humanização do cuidado privilegiando-se tais procedimentos - ao definir indicadores de processo que tratam apenas deles? Aventou-se na ocasião que dificilmente os resultados desejados seriam alcançados a partir de tais caminhos; o que foi reafirmado a partir do que se pôde observar, apreender e refletir ao longo deste estudo.

A despeito de o PHPN enfatizar a importância do acolhimento e de um conceito de saúde e de homem integral, o estabelecimento de indicadores de processo voltados apenas à análise de resultados de procedimentos abre espaço para uma série de equívocos, 
especialmente por não se validar, de modo consistente: os demais processos de cuidado; a complexidade do vivido pelas mulheres e seus familiares, a qual marca o que se poderia chamar de experiência da maternidade de maneira segura; e as demandas por eles vivenciadas em meio à produção da atenção, que, uma vez não validadas, remetem ao silenciamento da voz de tais atores. Uma das questões mais sérias desse panorama é que o PHPN mantém-se, então, atrelado ao paradigma tecnocrático, o qual se contrapõe à possibilidade de efetivação das mudanças necessárias à humanização do cuidado.

Pensando-se em tais temas, houve a preocupação ao longo deste trabalho de refletir, paralelamente à investigação de como a humanização é mobilizada pelos processos de acolhimento, produção de vínculo e integralidade, acerca de eventuais fatores que se fizessem presentes nos serviços de atenção pré e pós-natal do Núcleo Monte Azul e que favorecessem/permitissem tais processos. Dois elementos destacaram-se a esse respeito.

O primeiro enquadra-se no que Deslandes (2004) nomeou de humanização da produção do cuidado. Observou-se que, embora a garantia de condições de trabalho remuneração, carga horária, recursos e, principalmente, funcionalidade da equipe - e o oferecimento de espaços de reflexão, supervisão e contínua formação demonstrem-se importantes, ainda mais fundamentais são o reconhecimento, a valorização e a legitimação institucional da condição de pessoa do profissional. É claro que isso passa pelas condições de trabalho e pela afirmação de autonomia - que no Núcleo revelou-se principalmente na garantia de plasticidade de atuação e de liberdade de proposição de ideias e projetos. A preocupação, no entanto, de promover o desenvolvimento integral dos colaboradores e o acolhimento e a elaboração de suas vivências subjetivas destacou-se como fator essencial à concretização da humanização - indicando a relevância, aliás, de melhor investigar o tema da Escola-Oficina Social que há na Associação, em estudos futuros. Diante do paradigma tecnocrático ainda hegemônico a permear contextos de formação profissional, de produção de conhecimento e de atenção em saúde, é frequentemente necessário convidar o trabalhador a também se reconectar com sua própria condição humana.

A despeito de essa questão ser discutida na literatura, sendo salientadas a importância do trabalho com a subjetividade do profissional (HOGA, 2004; CASATE; CORREAA, 2005; BACKES; LUNARDI FILHO; LUNARDI, 2005; OLIVEIRA; COLLET; VIERA, 2006) e a legitimação de espaços de cuidado ao cuidador (BACKES; LUNARDI FILHO; LUNARDI, 2005; CASATE; CORRÊA, 2005; OLIVEIRA; COLLET; VIERA, 2006; ROLIM; 
CARDOSO, 2006), as reflexões aqui desencadeadas a partir dos indícios colhidos no Núcleo buscaram ressaltar que o trabalho com a dimensão subjetiva em tais espaços deve também se pautar na dialogicidade e de fato mobilizar o contato e a elaboração de uma série de questões. O vivido na prática cotidiana certamente precisa ser abordado, também em razão do envolvimento e da presença que a humanização exige do profissional. Entretanto, são ainda focos fundamentais: a história pessoal; o modo de inserção no mundo de relações, tema que envolve a disponibilidade de estar-com aquele de quem se cuida e eventuais dificuldades que aí se interponham; e a motivação concernente ao trabalho desenvolvido, que não pode, é claro, ser vista de modo apartado do contexto em que a atuação se dá. Esse é um terreno, portanto, em que o psicólogo pode contribuir de modo especial.

Daí se depreendeu que a restituição da condição de humanidade e de integralidade implicada na humanização deve não apenas visar o profissional como, possivelmente, dar-se em primeiro lugar com ele, porquanto será ele que oferecerá as bases sobre as quais a relação produtora de humanização com o usuário será construída. Ademais, entende-se que, embora com os cuidadores esse seja um processo imprescindível, como a humanização é também produzida pelos demais trabalhadores, estes devem ser aí igualmente incluídos, ainda que sob outros focos de ação - tal como parece se dar na Associação.

Pois bem, se tal restituição, ou reafirmação, de humanidade entre os colaboradores se mostrou tão fluidamente orquestrada no Núcleo é, principalmente, porque o tema do desenvolvimento integral de tais atores é tido como um dos valores da Associação, o que contribui de modo significativo para a validação de tal condição de humanidade do profissional e de sua importância à produção do cuidado; e para o desenvolvimento de ações de cuidado e de incentivo a esses atores.

Afigura-se aí, então, o segundo fator aqui apreendido, que se mostrou favorecedor para a efetivação das mudanças necessárias à humanização do cuidado. No Núcleo, projetos, formas de conceber e estruturar o trabalho, de lidar com as dificuldades encontradas, tudo vai sendo tecido em torno da Antroposofia e dos valores e ideais da Associação. Em decorrência, sucede-se uma significativa consonância entre os discursos das profissionais, e entre tais discursos e a prática desenvolvida, assim como posturas e condutas mais consistentes e articuladas umas com as outras porque fundamentadas em concepções de uma dada filosofia e/ou relacionadas com os valores e ideais da Associação. 
humanista e holístico - tal como a Antroposofia, que concebe o homem e o mundo sob a perspectiva da integralidade e da inter-relação - revela-se, portanto, o elemento mais potencialmente transformador quando se pensa em instaurar um contexto humanizado e humanizador; especialmente quando ele se faz acompanhar de um intenso trabalho, como o que parece se dar na Associação, de promoção de sintonia dos profissionais - incluindo-se colaboradores e coordenadores - com tal referencial, assim como com os ideais e valores a ele associados, que constituem os pilares de uma dada instituição.

Como se discutiu ao longo deste trabalho, a hegemonia do paradigma tecnocrático parece se destacar como um dos maiores desafios à humanização. Foi por se entender que as posturas, práticas, produção de conhecimento e elaboração de políticas públicas estão sempre pautadas em uma dada forma de conceber o homem e o mundo - ainda que nem sempre os atores percebam e se remetam a tal fundamentação - que se defendeu a urgência na adoção de outro referencial - humanista e holístico - que venha a se contrapor ao tecnocrático e ofereça uma visão de mundo, de homem, de processos de saúde e doença, assim como de gravidez, parto e puerpério, consonantes com o contexto de atenção humanizada que se quer instaurar.

Pensando-se no contexto do SUS, nota-se, por meio de seus documentos, manuais e cartilhas, uma tentativa de construir um novo referencial, oferecendo, para tanto, algumas concepções norteadoras de compreensão da realidade. Parece, porém, não se tratar ainda de um referencial suficientemente forte e consistente, capaz de articular posturas e estruturação de práticas e de projetos interventivos e políticos, já que o mesmo SUS, que define como um de seus princípios a integralidade, também estabelece indicadores de processo que não apenas se contrapõem a ela como remetem à tecnocracia que ainda o permeia. $\mathrm{O}$ desafio se torna ainda maior quando se toma o SUS como projeto inserido em uma sociedade pautada por uma lógica de fragmentação, cuja história vem sendo marcada por dicotomias que impõem a separação entre homem e mundo, entre corpo e psique, entre razão e sentimento, entre técnica e política; e como projeto público em inter-relação com o Estado, cujas propostas de governo mudam com seus governantes, definindo-se e redefinindo-se constantemente as diretrizes de projetos políticos.

Diante disso, talvez qualquer possibilidade de mudança soe utópica. O microuniverso da Associação Comunitária Monte Azul, porém, encoraja a crença de que algo é possível e, portanto, que vale a pena a luta. Uma luta cujos progressos e retrocessos já vividos, e que ainda o serão, são certamente entrecortados pelas questões desse contexto mais amplo. Mas 
que talvez se torne mais fortalecida e efetiva se se pautar em bases mais consistentes; o que deve envolver, fundamentalmente, a compreensão de que a melhor sedimentação de um referencial filosófico no SUS, e na política de humanização - alvo do presente estudo -, não pode se dar de forma apartada dos atores envolvidos com essa luta. Em última análise, não se faz possível empreender uma humanização se cada um desses atores não se reconhecer nessa condição de humanidade que se quer reinstaurar nos processos de produção de saúde e no próprio viver. A superação das contradições aqui discutidas não pode se efetivar apenas no universo dos discursos; ela precisa também se dar, de modo profundo, na existencialidade de cada um dos sujeitos que de tais discursos se fizer portador e multiplicador. 


\section{REFERÊNCIAS ${ }^{29}$}

ABMA - Associação Brasileira de Medicina Antroposófica. Euritmia Curativa. Disponível em: <http://www.medicinaantroposofica.com.br/euritmia-curativa $>$. Acesso em: 18 abr. 2009a.

Quirofonética. Disponível em: <http://www.medicinaantroposofica.com.br/ quirofonetica>. Acesso em: 18 abr. 2009b.

- Terapia Artística. Disponível em: <http://www.medicinaantroposofica.com.br/ terapia-artistica>. Acesso em 18 abr. 2009c.

AINSWORTH, M. D. S. et al. Relationships between infant behavior in the strange situation and maternal behavior at home. In: of the strange situation. New Jersey: LEA, 1978. cap. 8, p. 137-153.

ALVES, A. J. O planejamento de pesquisas qualitativas em educação. Cadernos de Pesquisa, São Paulo, n. 77, p. 53-61, mai., 1991.

ALMEIDA, C. A. L. de; TANAKA, O. Y. Perspectiva das mulheres na avaliação do Programa de Humanização do Pré-Natal e Nascimento. Revista de Saúde Pública, São Paulo, v. 43, n.1, p. 98-104, fev., 2009. Disponível em: <http://www.scielosp.org>. Acesso em: 27 mar. 2009.

BACKES, D. S.; LUNARDI FILHO, W. D.; LUNARDI, V. L. A construção de um processo interdisciplinar de humanização à luz de Freire. Texto \& contexto - Enfermagem, Florianópolis, v. 14, n. 3, p.1-15, set. 2005. Disponível em: <http://www.scielo.br $>$. Acesso em: 27 mar. 2009.

BALDI, V. M. Enfermagem e Antroposofia: uma possibilidade de diálogo. 2003. 153 f. Tese (Doutorado em Enfermagem) - Escola de Enfermagem de Ribeirão Preto, Universidade de São Paulo, Ribeirão Preto, 2003.

BEE, H. A criança em desenvolvimento. Porto Alegre: Artes Médicas, 1994.

29 De acordo com a Associação Brasileira de Normas Técnicas. NBR 6023. 
BERNARDO, W. M.; NOBRE, M. R. C.; JATENE, F. B. A prática clínica baseada em evidências: parte II - buscando as evidências em fontes de informação. Revista da Associação Médica Brasileira, São Paulo, v. 50, n. 1, p. 104-108, 2004. Disponível em: $<$ http://www.scielo.br/>. Acesso em: 20 jun. 2007.

BOEMER, M. R. O fenômeno morte: o pensar, o conviver e o educar. 1989. 111 f. Tese (Livre Docência) - Escola de Enfermagem de Ribeirão Preto, Universidade de São Paulo, Ribeirão Preto, 1989.

BOSI, M. L. M.; UCHIMURA, K. Y. Avaliação da qualidade ou avaliação qualitativa do cuidado em saúde? Revista de Saúde Pública, São Paulo, v. 41, n. 1, p. 150-153, 2007. Disponível em: <http://scielosp.org>. Acesso em: 27 mar. 2009.

BOWLBY, J. Apego e Perda - Volume I: Apego. 2. ed. São Paulo: Martins Fontes, 1990.

BRASIL. Ministério da Saúde. Área de Saúde da Mulher. Assistência Pré-Natal: Normas e manuais técnicos. 3. ed. Brasília: Ministério da Saúde, 1998.

Ministério da Saúde. Portaria no. 569, de 1o. de Junho de 2000. Institui o Programa de Humanização no Pré-Natal e Nascimento, no âmbito do Sistema Único de Saúde. Diário Oficial da União, Brasília, DF, 8 jun. 2000a.

Ministério da Saúde. Portaria no. 570, de 1o. de Junho de 2000. Institui o Componente I do Programa de Humanização no Pré-Natal e Nascimento - Incentivo à Assistência Pré-Natal no âmbito do Sistema Único de Saúde. Diário Oficial da União, Brasília, DF, 8 jun. 2000b.

Ministério da Saúde. Portaria no. 571, de 1o. de Junho de 2000. Institui o Componente II do Programa de Humanização no Pré-Natal e Nascimento - Organização, Regulação e Investimentos na Assistência Obstétrica e Neonatal, no âmbito do Sistema Único de Saúde. Diário Oficial da União, Brasília, DF, 8 jun. 2000c.

- Ministério da Saúde. Portaria no. 572, de 1o. de Junho de 2000. Institui o Componente III do Programa de Humanização no Pré-Natal e Nascimento - Nova Sistemática de Pagamento à Assistência ao Parto. Diário Oficial da União, Brasília, DF, 8 jun. 2000d. 
princípios e conquistas. Brasília: Ministério Saúde, 2000e.

Ministério da Saúde. Secretaria de Políticas de Saúde. Área Técnica de Saúde da Mulher. Parto, Aborto e Puerpério: Assistência humanizada à mulher. Brasília: Ministério da Saúde, 2001.

Ministério da Saúde. Secretaria Executiva. Programa Humanização no Parto: Humanização no Pré-Natal e Nascimento. Brasília: Ministério da Saúde, 2002.

Ministério da Saúde. Secretaria de Atenção à Saúde. Departamento de Ações Programáticas Estratégicas. Política Nacional de Atenção Integral à Saúde da Mulher: Princípios e Diretrizes. Brasília: Ministério da Saúde, 2004a.

Ministério da Saúde. Secretaria Executiva. Núcleo Técnico da Política Nacional de Humanização. Política Nacional de Humanização - Humaniza SUS. Brasília: Ministério da Saúde, 2004b.

- Ministério da Saúde. Secretaria de Atenção à Saúde. Departamento de Atenção Básica. Política Nacional de Práticas Integrativas e Complementares no SUS - PNPICSUS. Brasília: Ministério da Saúde, 2006a.

Ministério da Saúde. Secretaria de Atenção à Saúde. Departamento de Ações Programáticas Estratégicas. Área Técnica de Saúde da Mulher. Pré-Natal e Puerpério: Atenção Qualificada e Humanizada. 3. ed. revisada. Brasília: Ministério da Saúde, 2006b.

Ministério da Saúde. Pacto Nacional pela Redução da Mortalidade Materna e Neonatal: Balanço de 3 anos. 19. ed. Brasília: Ministério da Saúde, 2007a.

- Ministério da Saúde. Secretaria-Executiva. Subsecretaria de Assuntos Administrativos. Programa MultiplicaSUS: curso básico sobre o SUS: (re)descobrindo o SUS que temos para construirmos o SUS que queremos. 2. ed. Brasília: Ministério da Saúde, 2007b.

Ministério da Saúde. Secretaria de Atenção à Saúde. Núcleo Técnico da Política Nacional de Humanização. Acolhimento nas práticas de produção de saúde. 2. ed. Brasília: Ministério da Saúde, 2008. 
. Ministério da Saúde. Conselho Nacional das Secretarias Municipais de Saúde. O SUS de A a Z: garantindo saúde nos municípios. 3. ed. Brasília: Ministério da Saúde, 2009.

BRAZELTON, T. B. O desenvolvimento do apego: uma família em formação. Porto Alegre: Artes Médicas, 1988.

CAMELO, S. H.H. et al. Acolhimento à clientela: estudo em unidades básicas de saúde no município de Ribeirão Preto. Revista latino-americana de enfermagem, Ribeirão Preto, v. 8, n. 4, p. 30-37, ago., 2000. Disponível em: <http://www.eerp.usp.br/rlae>. Acesso em: 10 mar. 2009.

CARDELLA, B. H. P. O Amor na Relação Terapêutica. São Paulo: Summus, 1994.

CARMO, P. S. do. Merleau-Ponty: uma introdução. São Paulo: EDUC, 2002.

CARVALHO, M. L. M. de. Participação dos pais no nascimento em maternidade pública: dificuldades institucionais e motivações dos casais. Caderno de Saúde Pública, Rio de Janeiro, v. 19 supl. 2, p. 389-398, 2003. Disponível em: <http://www.scielosp.org>. Acesso em: 14 mar. 2006.

CASATE J. C.; CORRÊA A. K. Humanização do atendimento em saúde: conhecimento veiculado na literatura brasileira de enfermagem. Revista Latino-americana de Enfermagem, Ribeirão Preto, v. 13, n. 1, p. 105-11, jan./fev., 2005. Disponível em: $<$ http://www.eerp.usp.br/rlae >. Acesso em: 10 mar. 2009.

CAVALCANTE, M. A. A. A experiência do homem como acompanhante no cuidado prénatal. 2007. 153 f. Tese (Doutorado em Enfermagem) - Escola de Enfermagem, Universidade de São Paulo, São Paulo, 2007.

CIORNAI, S. Percursos em Arteterapia. São Paulo: Summus, 2004.

CONNECTIVITY - From thinking to action. Ute Craemer. Disponível em: $<$ http://www.connectivity2006.org/index.php?id=738\&L=7>. Acesso em: 20 mai. 2009.

COSTA, A. M.; GUILHEM, D.; WALTER, M. I. M. T. Atendimento a gestantes no Sistema Único de Saúde. Revista de Saúde Pública, São Paulo, v. 39, n. 5, p. 768-774, out., 2005. 
Disponível em: <http://www.scielosp.org>. Acesso em: 23 fev. 2006.

COUTINHO, T. et al. Adequação do processo de assistência pré-natal entre as usuárias do Sistema Único de Saúde em Juiz de Fora-MG. Revista Brasileira de Ginecologia e Obstetrícia, Rio de Janeiro, v. 25, n. 10, p. 717-724, nov./dez., 2003. Disponível em: $<$ http://www.scielo.br>. Acesso em: 23 fev. 2006.

CRAEMER, U.; IGNACIO, R. K. Transformar é possível: A Associação Comunitária Monte Azul entre desafios e conquistas. São Paulo: Peirópolis, 2008.

CRITELLI, D. M. Analítica do Sentido. São Paulo: EDUC/ Brasiliense, 1996.

CYRULNIK, B. Os Patinhos Feios. São Paulo: Martins Fontes, 2004.

DAVIS-FLOYD, R. The technocratic, humanistic, and holistic paradigms of childbirth. International Journal of Gynecology \& Obstetrics. v. 75, p. 5-23, 2001. Disponível em: $<\mathrm{http}: / / \mathrm{www}$.journals.elsevierhealth.com/periodicals/ijg $>$. Acesso em: 07 ago. 2008.

DELFINO, M. R. R. et al. O processo de cuidar participante com um grupo de gestantes: repercussões na saúde integral individual-coletiva. Ciência \& saúde coletiva, Rio de Janeiro, v. 9 , n. 4, p. 1057-1066, out./dez. 2004.

DENNIS, CL.; ROSS, L. Relationships Among Infant Sleep Patterns, Maternal Fatigue, and Development of Depressive Symptomatology. BIRTH. v. 32, n. 3, p. 187-193, set., 2005.

DESLANDES, S. F. Análise do discurso oficial sobre a humanização da assistência hospitalar. Ciência \& Saúde Coletiva, Rio de Janeiro, v. 9, n. 1, p. 7-14, jan./mar., 2004.

DIAS, M. A. B. Humanização da assistência ao parto: conceitos, lógicas e práticas no cotidiano de uma maternidade pública. 2006. 283 f. Tese (Doutorado) - Instituto Fernandes Figueira, FIOCRUZ, Rio de Janeiro, 2006.

DINIZ, C. S. G. Entre a técnica e os direitos humanos: Possibilidades e limites da humanização da assistência ao parto. 2001. 242 f. Tese (Doutorado em Medicina) - Faculdade de Medicina, Universidade de São Paulo, São Paulo, 2001. 
. Humanização da assistência ao parto no Brasil: os muitos sentidos de um movimento. Ciência \& saúde coletiva. Rio de Janeiro, v. 10, n. 3, p. 627-637, jul./set. 2005.

DUARTE, G. Extensão da assistência pré-natal ao parceiro como estratégia de aumento da adesão ao pré-natal e redução da transmissão vertical de infecções. Revista Brasileira de Ginecologia e Obstetrícia, Rio de Janeiro, v. 29, n. 4, abr., 2007.

DURÃES-PEREIRA, M. B. B. B.; NOVO, N. F.; ARMOND, J. E. A escuta e o diálogo na assistência ao pré-natal, na periferia da zona Sul, no município de São Paulo. Ciência \& Saúde Coletiva, Rio de Janeiro, v. 12, n. 2, p. 465-476, 2007.

ENKIN, M. et al. Guia para atenção efetiva na gravidez e no parto. 3. ed. Rio de Janeiro: Guanabara Koogan, 2005.

ESPERANÇA, A. C.; CAVAlCANTE, R. B.; MARCOLINO, C. Estudo da demanda espontânea em uma unidade de saúde da família de uma cidade de médio porte do interior de Minas Gerais, Brasil. REME - Revista Mineira de Enfermagem, Belo Horizonte, v. 10, n. 1, p. 30-36, jan./mar., 2006.

FELIX, L. G.; SILVEIRA, M. F. A. Como os usuários percebem a prática do acolhimento no programa saúde da família? Disponível em: $<$ http://scholar.google.com>. Acesso em: 27 mar. 2009.

FEW (Federação das Escolas Waldorf). Fontes, históricos e princípios da Pedagogia Waldorf. Disponível em: <http://www.sab.org.br/fewb/pw1.htm>. Acesso em: 5 jun. 2007.

FIGUEIREDO, P. P. de; ROSSONI, E. O acesso à assistência pré-natal na atenção básica à saúde sob a ótica das gestantes. Revista Gaúcha de Enfermagem, Porto Alegre, v. 29, n. 2, p. 238-245, 2008. Disponível em: <http://www.ufrgs.br/revistagauchadeenfermagem>. Acesso em: 10 mar. 2009.

FIGUEIREDO, R. M. D. Saúde sexual e reprodutiva de mulheres de baixa renda: Favela Monte Azul - um estudo de caso. São Paulo, 1999. 94 f. Dissertação (Mestrado em Antropologia) - Faculdade de Filosofia Letras e Ciências Humanas, Universidade de São Paulo, São Paulo, 1999.

FORGHIERI, Y. C. Fenomenologia e psicologia. São Paulo: Cortez Editora, 1984. 
Psicologia fenomenológica: fundamentos, método e pesquisa. São Paulo: Pioneira Thomson Learning, 2002.

FRANCO, T. B.; BUENO, W. S.; MERHY, E. E. O acolhimento e os processos de trabalho em saúde: o caso de Betim, Minas Gerais, Brasil. Cadernos de Saúde Pública, Rio de Janeiro, v. 15, n. 2, p. 345-353, abr./jun., 1999.

FRANCO, T. B.; MAGALHÃES JR., H. M. Integralidade na assistência à saúde: a organização das linhas do cuidado. In: MERHY, E. E. (Org.). O trabalho em saúde: olhando e experienciando o SUS no cotidiano. São Paulo: Hucitec, 2003. p.125-134.

FRANKL, V. Em busca de sentido: um psicólogo no campo de concentração. São Leopoldo, Editora Sinodal; Petrópolis, Editora Vozes, 1991.

GAY, C. L.; LEE, K. A.; LEE, S. Sleep Patterns and Fatigue in New Mothers and Fathers. Biological Research for Nursing, v. 5, n. 4, p. 311-318, abr., 2004.

GUERRA, M. Terapia Biográfica e Salutogênese. Disponível em: $<$ http://www.terapiabiografica.com.br>. Acesso em: 13 jul. 2009.

GILDE, R. A massagem rítmica. Tradução de Valdemar W. Setzer. Disponível em: $<$ http://www.medicinaantroposofica.com.br/massagem-ritmica $>$. Acesso em: 13 jul. 2009.

GOMES, M. C. P. A.; PINHEIRO, R. Acolhimento e vínculo: práticas de integralidade na gestão do cuidado em saúde em grandes centros urbanos. Interface - Comunicação, Saúde, Educação, Botucatu, v. 9, n. 17, p. 287-301, mar./ago., 2005.

GONÇALVES, S. C. M.; SALDANHA, A. A. W.; MENDONÇA, D. Aspectos relevantes do atendimento psicológico no ciclo grávido-puerperal. Jornal Brasileiro de Ginecologia, Rio de Janeiro, v. 108. n. 7, p. 223-229, jul. 1998.

GONÇALVES, R. et al. Avaliação da efetividade da assistência pré-natal de uma Unidade de Saúde da Família em um município da Grande São Paulo. Revista brasileira de enfermagem, Brasília, v. 61, n. 3, p. 349-353, mai.jun., 2008. Disponível em: $<$ http://www.scielo.br>. Acesso em: 10 mar. 2009. 
GRAnGeIRO, G. R.; DIOGENES, M. A. R.; MOURA, E. R. F. Atenção Pré-Natal no Município de Quixadá-CE segundo indicadores de processo do SISPRENATAL. Revista da Escola de Enfermagem - USP, São Paulo, v. 42, n. 1, p. 105-111, mar. 2008. Disponível em: $<$ http://www.scielo.br>. Acesso em: 06 mai. 2008.

HERNANDEZ, G. G.; KILMELMAN, M. J.; MONTINO, O. R. Salud mental perinatal en la asistencia hospitalaria del parto y puerperio. Revista médica de Chile, Santiago, v. 128, n. 11, 2000. Disponível em: <http://www.scielo.cl>. Acesso em: mai. 2008.

HOGA, L. A. K. A dimensão subjetiva do profissional na humanização da assistência à saúde: assistência à saúde uma reflexão. Revista da Escola de Enfermagem - USP, São Paulo, v. 38, n. 1, p. 13-20, 2004. Disponível em: <http://www.scielo.br>. Acesso em: 10 mar. 2009.

HOTIMSKY, S. N. Parto e Nascimento no Ambulatório e na Casa de Partos da Associação Comunitária Monte Azul: Uma Abordagem Antropológica. 330 f. São Paulo, 2001. Dissertação (Mestrado em Saúde Pública) - Faculdade de Saúde Pública, Universidade de São Paulo, São Paulo, 2001.

HYCNER, R. Relação e cura em Gestalt-Terapia. São Paulo: Summus, 2000.

INOJOSA, R. M. Acolhimento: a qualificação do encontro entre profisssionais de saúde e usuários. Trabalho apresentado no X Congreso Internacional del CLAD sobre la Reforma del Estado y de la Administración Pública, Santiago, Chile, 2005. p. 18-21. Disponível em: $<$ http://bresserpereira.org.br/view.asp?cod=2139>. Acesso em: 10 mar. 2009.

JACOBS, L. O diálogo na teoria e na Gestalt-Terapia. In: HYCNER, R.; JACOBS, L. Relação e cura em Gestalt-Terapia. São Paulo: Summus, 2000. cap.3, p.67-94.

KLAUS, M. H.; KENNELL, J. H. Pais/bebê: a formação do apego. Porto Alegre: Artes Médicas, 1992.

KLOETZEL, K. et al. Controle de qualidade em atenção primária à saúde. I - A satisfação do usuário. Cadernos de Saúde Pública, Rio de Janeiro, v. 14, n. 3, p. 623-628, jul./set., 1998.

LEITE, T. A. A. F.; STRONG, M. I. A influência da visão holística no processo de humanização hospitalar. O mundo da saúde, São Paulo, v. 30, n. 2, p. 203-214, abr./jun., 2006. Disponível em: <http://www.scamilo.edu.br/pdf/mundo_saude/35/influencia 
_visao.pdf $>$. Acesso em: 10 mar. 2009.

LIMA, A. P. C. Paternidade: a construção de uma vivência. São Paulo, 2003. 87 f. Trabalho de Conclusão de Curso (Psicologia) - Faculdade de Psicologia, Pontifícia Universidade Católica, São Paulo, 2003.

O uso de recursos corporais e expressivos no acompanhamento de gestante para fortalecimento do vínculo mãe-feto/bebê: experimentos em Gestalt-Terapia. Trabalho apresentado no II Congresso Brasileiro de Psicologia: Ciência e Profissão. ppt. São Paulo, 2006.

A compreensão da vivência do ciclo grávido-puerperal sob um enfoque gestáltico. Aula ministrada no curso de aperfeiçoamento "Gestalt-Terapia com crianças", promovido pelo Instituto Gestalt de São Paulo. ppt. São Paulo, 2009.

LIMA, A. P. C.; FERNANDES, M. B. Resiliência: um enfoque da Gestalt-Terapia. Revista de Psicologia do Instituto Gestalt de São Paulo, São Paulo, v. 3, p. 49-57, 2006.

LIMA, M. A. D. S. et al. Acesso e acolhimento em unidades de saúde na visão dos usuários. Acta Paulista de Enfermagem, São Paulo, v. 20, n. 1, p. 12-17, mar., 2007. Disponível em: $<$ http://www.scielo.br>. Acesso em: 27 mar. 2009.

MALDONADO, M. T. Psicologia da Gravidez. São Paulo: Saraiva, 1999.

MALDONADO, M.T., DICKSTEIN, J., NAHOUM, J.C. Nós estamos grávidos. São Paulo: Saraiva, 1996.

MARQUES, G. Q.; LIMA, M. A. D. S. As tecnologias leves como orientadoras dos processos de trabalho em serviços de saúde. Revista Gaúcha de Enfermagem, Porto Alegre, v. 25, n. 1, p. 17-25, abr., 2004. Acesso em: 27 mar. 2009.

MARTINS, J.; BICUDO, M. A V. A pesquisa qualitativa em psicologia: fundamentos e recursos básicos. São Paulo: Moraes, 1989.

MATTOS, R. A. Os sentidos da integralidade: algumas reflexões acerca de valores que merecem ser defendidos. In: PINHEIRO, R.; MATTOS, R. A. (Orgs). Os sentidos da 
integralidade na atenção e no cuidado à saúde. Rio de Janeiro: Instituto de Medicina Social, Universidade do Estado do Rio de Janeiro/ABRASCO, 2001. cap.2, p. 39-64.

. A integralidade na prática (ou sobre a prática da integralidade). Cadernos de Saúde Pública, Rio de Janeiro, v. 20, n. 5, out. 2004 . Disponível em: <http://www.scielosp.org>. Acesso em: 27 mar. 2009.

MAYAN, M. Una introducción a los Métodos Cualitativos: un módulo de entrenamiento para estudiantes y profesionales. International Institute for Qualitative Methodology. Alberta, Canada: Qual Institute Press, 2001. Disponível em: <http://www.ualberta.ca/ $\sim$ iiqm/pdfs/introduccion.pdf $>$. Acesso em: 26 abr. 2008.

MERHY, E. E. A perda da dimensão cuidadora na produção da saúde - uma discussão do modelo assistencial e da intervenção no seu modo de trabalhar a assistência. In: CAMPOS, C. R; MALTA, D. C; REIS, A.T. (Orgs). Sistema Único de Saúde em Belo Horizonte: reescrevendo o público. São Paulo: Xamã, 1998. p. 103-120.

Um ensaio sobre o médico e suas valises tecnológicas: contribuições para compreender as reestruturações produtivas do setor Saúde. Interface - Comunicação, Saúde, Educação. Botucatu, v. 4, n. 6, p. 109-126, fev., 2000. Disponível em: $<$ http://www.interface.org.br/revista6/debates1.pdf $>$. Acesso em: 10 mar. 2009.

A micropolítica do trabalho vivo em ato: uma questão institucional e território de tecnologias leves. In: Hucitec, 2002. cap. 2, p. 41-66.

Saúde: a cartografia do trabalho vivo. 3. ed. São Paulo: Editora

MERHY, E. E; FRANCO, T. B. Por uma composição técnica do trabalho centrada nas tecnologias leves e no campo relacional. Saúde em debate, Londrina, v. 27, n. 65, p. 316323, set./dez., 2003.

MERLEAU-PONTY, M. Fenomenologia da percepção. São Paulo: Martins Fontes, 1994.

MINAYO, M. C. S. O desafio do conhecimento: Pesquisa qualitativa em saúde. 7. ed. São Paulo: Huatec-Abrasco, 2000.

Sobre o humanismo e a humanização. In: DESLANDES, S. F. Humanização dos cuidados em saúde: conceitos, dilemas e práticas. Rio de Janeiro: Fiocruz, 2006. 
MONTE AZUL - Associação Comunitária Monte Azul. Disponibiliza informações sobre a Associação. Disponível em: <http://www.montezul.or.br>. Acesso em: 14 mar. 2007.

NAGAHAMA, E. E. I.; SANTIAGO, S. M. O cuidado pré-natal em hospital universitário: uma avaliação de processo. Cadernos de Saúde Pública, Rio de Janeiro, v. 22, n. 1, p. 173 179, jan. 2006. Disponível em: <http://www.scielosp.org.br>. Acesso em: 23 mai. 2008.

NASCIMENTO, E. R. do; PAIVA, M. S.; RODRIGUES, Q. P. Avaliação da cobertura e indicadores do Programa de Humanização do Pré-natal e Nascimento no município de Salvador, Bahia, Brasil. Revista Brasileira de Saúde Materno Infantil, Recife, v. 7, n. 2, p. 191-197, abr./jun., 2007. Disponível em: <http://www.scielo.br>. Acesso em: 23 mai. 2008.

NASCIMENTO, E. R. do; RODRIGUES, Q. P.; ALMEIDA, M. S. Indicadores de qualidade da assistência pré-natal em Salvador, Bahia. Acta Paulista de Enfermagem, São Paulo, v. 20, n. 3, p. 311-315, jul./set., 2007. Disponível em: <http://www.scielo.br>. Acesso em: 23 mai. 2008.

NOBRE, M. R. C.; BERNARDO, W. M.; JATENE, F. B. A prática clínica baseada em evidências. Parte I: questões clínicas bem construídas. Revista da Associação Médica Brasileira, São Paulo, v. 49, n. 4, 2003. Disponível em: <http://www.scielo.br>. Acesso em: 20 jun. 2007.

NOGUEIRA, C. R. et al. Reflexões sobre o desenvolvimento da criança segundo a perspectiva da Gestalt-Terapia. Revista de Gestalt, São Paulo, n. 4. p. 87-94, 1995.

NOGUEIRA-MARTINS, M. C. F.; BÓGUS, C. M. Considerações sobre a metodologia qualitativa como recurso para o estudo das ações de humanização em saúde. Saúde e sociedade, São Paulo, v. 13, n. 3, dez. 2004. Disponível em: <http://www.scielo.br>. Acesso em: 28 jul. 2008.

ODENT, M. A cientificação do amor. Florianópolis: Saint Germain, 2002.

O camponês e a parteira: uma alternativa à industrialização da agricultura e do parto. São Paulo: Ground, 2003.

OMS (Organização Mundial da Saúde). Assistência ao Parto Normal: um guia prático. Série Maternidade Segura. Genebra: OMS, 1996. 
OLIVEIRA, S. C. et al. A participação do homem/pai no acompanhamento da assistência prénatal. Cogitare Enfermagem, Curitiba, v. 14, n. 1, p. 73-78, jan./mar., 2009.

OLIVEIRA, B. R. G. de; COLLET, N.; VIERA, C. S. A humanização na assistência à saúde. Revista Latino-Americana de Enfermagem, Ribeirão Preto, v. 14, n. 2, abr. 2006. Disponível em: <http://www.scielo.br>. Acesso em: 27 mar. 2009.

PARADA, C. M. G. L. Avaliação da assistência pré-natal e puerperal desenvolvidas em região do interior do Estado de São Paulo em 2005. Revista Brasileira de Saúde Materno Infantil, Recife, v. 8, n. 1, p.113-124, jan./mar., 2008. Disponível em: <http://www.scielo.br $>$. Acesso em: 5 out. 2008 .

PARADA, C. M. G. L; TONETE, V. L. P. O cuidado em saúde no ciclo gravídico-puerperal sob a perspectiva de usuárias de serviços públicos. Interface (Botucatu), Botucatu, v. 12, n. 24, mar. 2008 . Disponível em: <http://www.scielo.br>. Acesso em: 5 out. 2008.

PENNA, L. H. G.; CARINHANHA, J. I.; RODRIGUES, R. F. A mulher no pós-parto domiciliar: uma investigação sobre essa vivência. Escola Anna Nery Revista de Enfermagem, Rio de Janeiro, v. 10, n. 3, p. 448-455, dez., 2006. Disponível em: $<$ http://portalbvsenf.eerp.usp.br>. Acesso em: 21 jun. 2008.

PINHEIRO, R; LUZ, M. T. Práticas Eficazes x Modelos Ideais: Ação e Pensamento na Construção da Integralidade. In: PINHEIRO, R.; MATTOS, R. A. (Orgs.). A construção da integralidade: cotidiano, saberes e práticas em saúde. Rio de Janeiro: IMSUERJ/ABRASCO, 2003. Apresentação, p. 7-34.

PINHO, I. C.; SIQUEIRA, J. C. B. A.; PINHO, L. M. O. As percepções do enfermeiro acerca da integralidade da assistência. Revista eletrônica de enfermagem, Goiânia, v. 8, n. 1, p. 4251, 2006. Disponível em: <http://www.fen.ufg.br/revista/revista8_1/original_5.htm>. Acesso em: 10 mar. 2009.

QUEIROZ, M. V. O et al. Indicadores de qualidade da assistência ao nascimento baseados na satisfação de puérperas. Texto e contexto de enfermagem, Florianópolis, v. 16, n. 3, p. 47987, jul./set., 2007. Disponível em: <http://redalyc.uaemex.mx>. Acesso em: 27 mar. 2009.

RAMOS, D. D.; LIMA, M. A. D. S. Acesso e acolhimento aos usuários em uma unidade de saúde de Porto Alegre, Rio Grande do Sul, Brasil. Cadernos de Saúde Pública, Rio de Janeiro, v. 19, n. 1, p. 27-34, jan./fev., 2003. 
REHUNA - Rede pela Humanização do Parto e do Nascimento. Disponibiliza informações sobre a organização. Disponível em: <http://www.rehuna.org.br>. Acesso em: 18 abr. 2006.

RIBEIRO, J. P. Gestalt-Terapia de curta duração. São Paulo: Summus, 1999.

RIBEIRO, J. M. et al. Atenção ao pré-natal na percepção das usuárias do Sistema Único de Saúde: um estudo comparativo. Cadernos de Saúde Pública, Rio de Janeiro, v. 20, n. 2, p. 534-545, mar./abr., 2004.

ROLIM, K. M. C.; CARDOSO, M. V. L. M. L. O discurso e a prática do cuidado ao recémnascido de risco: refletindo sobre a atenção humanizada. Revista Latino-Americana de Enfermagem, Ribeirão Preto, v. 14, n. 1, 2006. Disponível em: $<$ http://www.revistasusp.sibi.usp.br/scielo.php>. Acesso em: 27 mar. 2009.

SCHIMITH, M. D.; LIMA, M. A. D. S. Acolhimento e vínculo em uma equipe do Programa Saúde da Família. Cadernos de Saúde Pública, Rio de Janeiro, v. 20, n. 6, p. 1487-1494, nov./dez., 2004.

SERRUYA, S. J.; LAGO, T. G. do; CECATTI, J. G. Avaliação preliminar do programa de humanização no pré-natal e nascimento no Brasil. Revista Brasileira de Ginecologia e Obstetrícia, Rio de Janeiro, v. 26 n. 7, p. 517-524, ago. 2004(a).

O panorama da atenção pré-natal no Brasil e o Programa de Humanização de PréNatal e Nascimento. Revista Brasileira de Saúde Materno Infantil, Recife, v. 4, n. 3, jul./set. 2004(b).

SILVA JR., A. G.; MASCARENHAS, M. T. M. Avaliação da atenção básica em saúde sob a ótica da integralidade: aspectos conceituais e metodológicos. In: PINHEIRO, R.; MATTOS, R. A. (Orgs.). Cuidado: as fronteiras da integralidade. Rio de Janeiro: ABRASCO / São Paulo: Editora Hucitec; 2005. p. 241-257.

SILVEIRA, F. J. F. da; LAMOUNIER, J. A. Fatores associados à duração do aleitamento materno em três municípios na região do Alto Jequitinhonha, Minas Gerais, Brasil. Cadernos de Saúde Pública, Rio de Janeiro, v. 22, n. 1, jan. 2006. Disponível em: $<$ http://www.scielosp.org $>$. Acesso em: 27 mar. 2009.

SILVEIRA, M. F. A. et al. Acolhimento no Programa Saúde da Família: um caminho para a 
humanização da atenção à saúde. Cogitare enfermagem, Curitiba, v. 9, n. 1, p.71-78, jan./jun. 2004.

SOLLA, J. J. S. P. Acolhimento no sistema municipal de saúde. Revista Brasileira de Saúde Materno-Infantil, Recife, v. 5, n. 4, p. 493-503, out./dez., 2005.

SPINK, M. J. P.; MATTA, G. C. A prática profissional Psi na Saúde Pública: configurações históricas e desafios contemporâneos. In: SPINK, M. J. P. (Org.). A psicologia em diálogo com o SUS: prática profissional e produção acadêmica. São Paulo: Casa do Psicólogo, 2007. cap.1, p. 25-51.

SZYMANSKI, H. Entrevista reflexiva: um olhar psicológico para a entrevista em pesquisa. Psicologia da Educação, São Paulo, n. 10/11, p. 193-215, $1^{\circ}$ e $2^{\circ}$ sem. 2000.

TANAKA, O. Y. et al. Avaliação Nacional do Programa de Humanização no Pré-Natal e Nascimento. Revista de Saúde Pública, São Paulo, v. 42, n. 2, p.383-387, 2008.

TAKEMOTO, M. L. S.; SILVA, E. M. Acolhimento e transformações no processo de trabalho de enfermagem em unidades básicas de saúde de Campinas, São Paulo, Brasil. Cadernos de Saúde Pública, Rio de Janeiro, v. 23, n. 2, p. 331-340, fev., 2007.

TEIXEIRA, R. R. O Acolhimento num serviço de saúde entendido como uma rede de conversações. In: PINHEIRO, R.; MATTOS, R. A. (Orgs.). A construção da integralidade: cotidiano, saberes e práticas. Rio de Janeiro: IMS-UERJ-Abrasco, 2003. p. 89-111.

- Humanização e atenção primária à saúde. Ciência \& Saúde Coletiva, Rio de Janeiro, v. 10, n. 3, p.585-597, 2005.

TORNQUIST, C. S. Armadilhas da Nova Era: Natureza e maternidade no ideário da humanização do parto. Revista de Estudos Feministas, Florianópolis, v. 10, n. 2, p. 483-492, jul./dez. 2002.

. Paradoxos da humanização em uma maternidade no Brasil. Cadernos de Saúde Pública, Rio de Janeiro, v. 19, n. 2, p. 419-427, 2003. Disponível em: $<$ http://www.scielosp.org >. Acesso em: 27 mar. 2009. 
TRAVERSO-YÉPEZ, M.; MORAIS, N. A. de. Reivindicando a subjetividade dos usuários da Rede Básica de Saúde: para uma humanização do atendimento. Cadernos de Saúde Pública, Rio de Janeiro, v. 20, n. 1, p. 80-88, jan./fev., 2004.

TREVISAN, M. R. et al. Perfil da Assistência Pré-Natal entre Usuárias do Sistema Único de Saúde em Caxias do Sul. Revista Brasileira de Ginecologia e Obstetrícia, Rio de Janeiro, v. 24, n. 5, p. 293-299, jun. 2002.

TSUNECHIRO, M. A.; BONADIO, I. C.; OLIVEIRA, V. M. de. Acolhimento: fator diferencial no cuidado pré-natal. In: Simpósio Brasileiro de Comunicação em Enfermagem, 8., 2002, São Paulo. Anais eletrônicos... Escola de Enfermagem de Ribeirão Preto - USP. Disponível em:<http://www.proceedings.scielo.br>. Acesso em: 11 abr. 2006.

TURATO, E. R. Tratado de metodologia da pesquisa clínico-qualitativa: construção teórica-metodológica, discussão comparada e aplicação nas áreas da saúde e humanas. Petrópolis: Vozes, 2003.

VERISSIMO, D. S. A pessoa com tumor cerebral e seus familiares em grupo de sala de espera: investigação da experiência vivida. 2005. 132 f. Dissertação (Mestrado em Ciências na área de Psicologia) - Faculdade de Filosofia, Ciências e Letras de Ribeirão Preto, Universidade de São Paulo, Ribeirão Preto, 2005.

WALKER, L. O.; WILGING, S. Rediscovering the "M" in "MCH": Maternal Health Promotion After Childbirth. Journal of Obstetric, Gynecologic and Neonatal Nursing (JOGNN). v. 29, n. 3., p. 229-236, maio./jun., 2000.

WILHEIM, J. O que é psicologia pré-natal. São Paulo: Casa do Psicólogo, 1997.

YONTEF, G. M. Processo, diálogo e awareness: Ensaios em Gestalt-Terapia. São Paulo: Summus, 1998. 


\title{
ANEXO A - INDICADORES DE PROCESSO PARA MONITORAMENTO DA ATENÇÃO AO PRÉ-NATAL E PUERPÉRIO
}

\author{
Ministério da Saúde (BRASIL, 2006b, p.12)
}

- Percentual de gestantes que se inscreveram no programa e realizaram a primeira consulta até o quarto mês, em relação à população-alvo (número de gestantes existente ou estimado pelo número de nascidos vivos do município);

- Percentual de gestantes inscritas que realizaram, no mínimo, seis consultas de prénatal;

- Percentual de gestantes inscritas que realizaram, no mínimo, seis consultas de prénatal e a consulta de puerpério;

- Percentual de gestantes inscritas que realizaram, no mínimo, seis consultas de prénatal e todos os exames básicos;

- Percentual de gestantes inscritas que realizaram, no mínimo, seis consultas de prénatal, a consulta de puerpério e todos os exames básicos;

- Percentual de gestantes inscritas que receberam imunização antitetânica (no mínimo duas doses durante o pré-natal ou dose de reforço em mulheres já imunizadas, ou nenhuma dose nas mulheres com imunização completa);

- Percentual de gestantes inscritas que realizaram, no mínimo, seis consultas de prénatal, a consulta de puerpério e todos os exames básicos, o teste anti-HIV e a imunização antitetânica. 


\title{
ANEXO B - PARÂMETROS ESTABELECIDOS PARA A ATENÇÃO AO PRÉ-NATAL E AO PUERPÉRIO
}

\author{
Ministério da Sáude (BRASIL, 2006b, p. 10-11)
}

1. Captação precoce das gestantes com realização da primeira consulta de pré-natal até 120 dias da gestação;

2. Realização de, no mínimo, seis consultas de pré-natal, sendo, preferencialmente, uma no primeiro trimestre, duas no segundo trimestre e três no terceiro trimestre da gestação;

3. Desenvolvimento das seguintes atividades ou procedimentos durante a atenção prénatal:

3.1 Escuta da mulher e de seus(suas) acompanhantes, esclarecendo dúvidas e informando sobre o que vai ser feito durante a consulta e as condutas a serem adotadas;

3.2 Atividades educativas a serem realizadas em grupo ou individualmente, com linguagem clara e compreensível, proporcionando respostas às indagações da mulher ou da família e as informações necessárias;

3.3 Anamnese e exame clínico-obstétrico da gestante;

3.4 Exames laboratoriais:

- ABO-Rh, Hemoglobina/Hematócrito, na primeira consulta;

- Glicemia de jejum, um exame na primeira consulta e outro próximo à $30^{\mathrm{a}}$ semana de gestação;

- VDRL, um exame na primeira consulta e outro próximo à $30^{\mathrm{a}}$ semana de gestação;

- Urina tipo 1, um exame na primeira consulta e outro próximo à $30^{\mathrm{a}}$ semana de gestação;

- Testagem anti-HIV, com um exame na primeira consulta;

- Sorologia para hepatite B (HBsAg), com um exame, de preferência, próximo 
à $30^{\mathrm{a}}$ semana de gestação;

- Sorologia para toxoplasmose (IgM), na primeira consulta (se disponível).

3.5 Imunização antitetânica: aplicação de vacina dupla tipo adulto até a dose imunizante (segunda) do esquema recomendado ou dose de reforço em mulheres já imunizadas;

3.6 Avaliação do estado nutricional da gestante e monitoramento por meio do SISVAN;

3.7 Prevenção e tratamento dos distúrbios nutricionais;

3.8 Prevenção ou diagnóstico precoce do câncer de colo uterino e de mama;

3.9 Tratamento das intercorrências da gestação;

3.10 Classificação de risco gestacional a ser realizada na primeira consulta e nas subseqüentes;

3.11 Atendimento às gestantes classificadas como de risco, garantindo vínculo e acesso à unidade de referência para atendimento ambulatorial e/ou hospitalar especializado;

3.12 Registro em prontuário e cartão da gestante, inclusive registro de intercorrências/urgências que requeiram avaliação hospitalar em situações que não necessitem de internação.

4. Atenção à mulher e ao recém-nascido na primeira semana após o parto, com realização das ações da "Primeira Semana de Saúde Integral" e realização da consulta puerperal (entre a $30^{\mathrm{a}}$ e $42^{\mathrm{a}}$ semanas pós-parto). 


\section{ANEXO C - AUTORIZAÇÃO DA ASSOCIAÇÃO COMUNITÁRIA MONTE AZUL À REALIZAÇÃO DA PESQUISA}

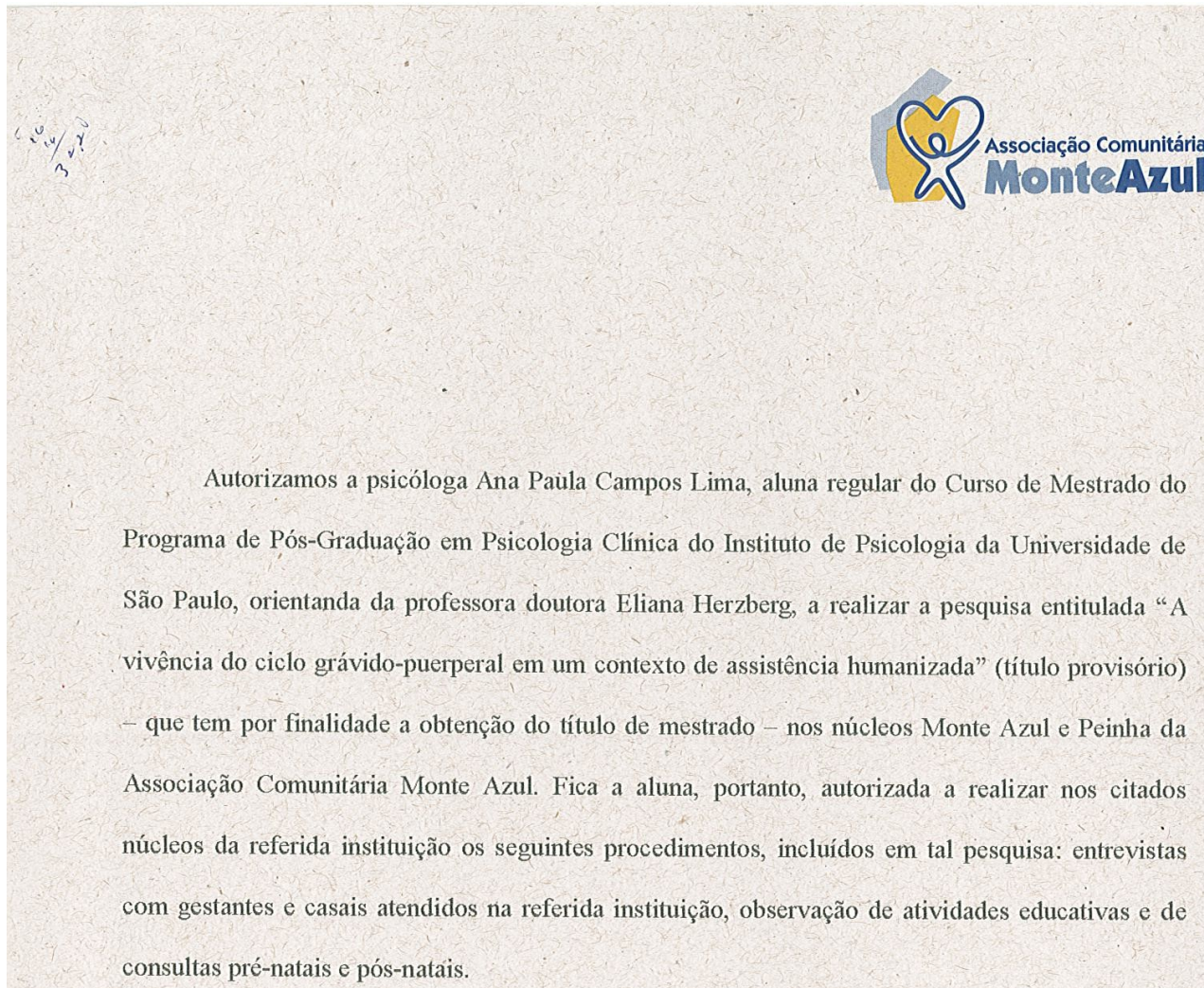

consultas pré-natais e pós-natais.

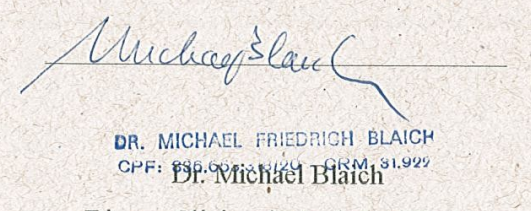

Diretor Clínico do Ambulatório da

Associação Comunitária Monte Azul
São Paulo, 17 de janeiro de 2008

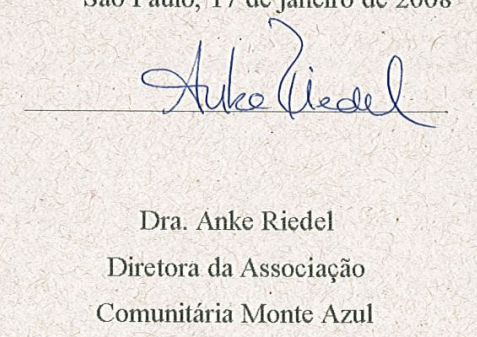

NÚCLEO MONTE AZUL ENDEREÇO DA SEDE:

NÚCLEO PEINHA AV. TOMAS DE SOUSA, 552 NÚCLEO HORIZONTE AZUL. $05836-350$ SÃO PAULO SP TEL (11) $5851-5370$ MONTEAZUL@MONTEAZUL.ORG.BR MONTEAZUL.ORG.BR 


\section{ANEXO D - PARECER DO COMITÊ DE ÉTICA DO IP-USP}

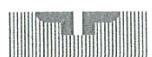

Prot-3007/CEPH-IP13/11/2007.

Senhor Professor,

O Comitê de Ética em Pesquisa com Seres Humanos do IPUSP (CEPHIP) aprovou o projeto intitulado "A vivência do ciclo grávido-puerperal em um contexto de assistência humanizada", a ser desenvolvido pela mestranda Ana Paula Campos Lima, junto ao Programa de Pós-Graduação em Psicologia Clínica do Instituto de Psicologia da Universidade de São Paulo, sob a orientação de V. Sa.

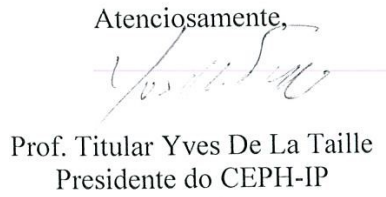

Ilma. Sra.

Profa.Dra; Heliana Herzberg

Departamento de Psicologia Clínica

Instituto de Psicologia da Universidade de São Paulo 


\title{
ANEXO E - TERMO DE CONSENTIMENTO PÓS-INFORMAÇÃO
}

\author{
DADOS DE IDENTIFICAÇÃO DO CASAL PARTICIPANTE DA PESQUISA
}

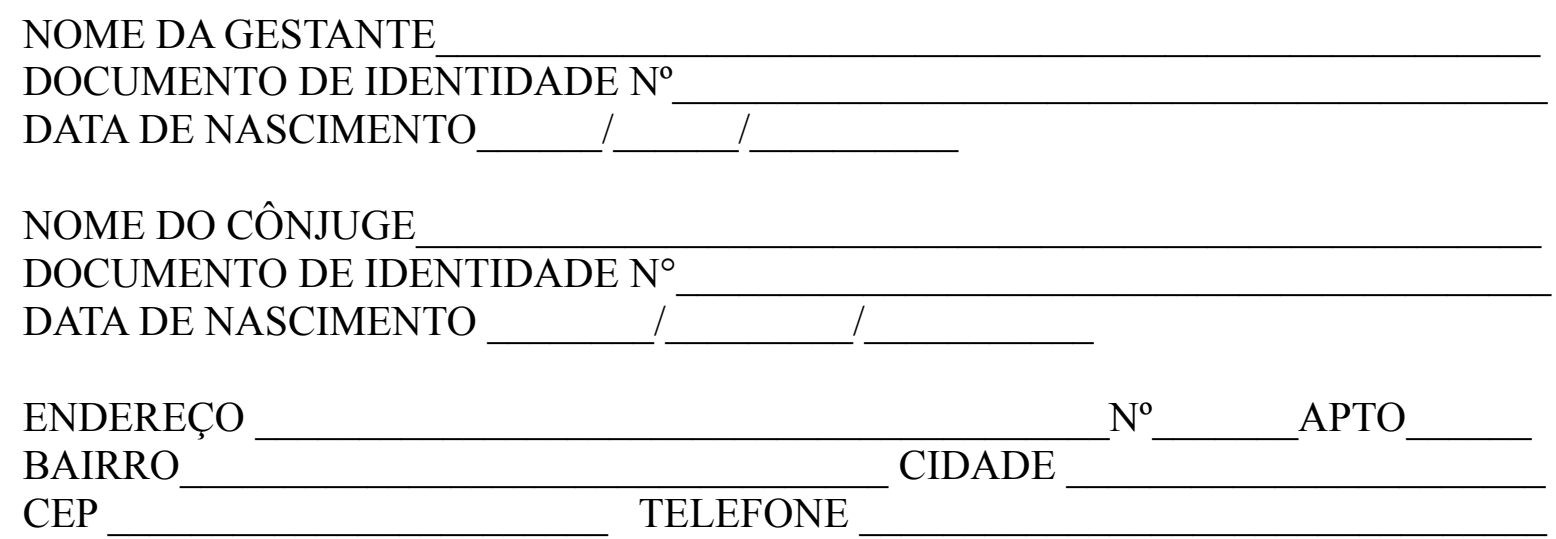

Eu, Ana Paula Campos Lima, psicóloga CRP ${ }^{\circ} \mathrm{XX} / \mathrm{XXXXX}$ tel. XXXX-XXXX, aluna regular do Curso de Mestrado do Programa de Pós-Graduação em Psicologia Clínica do Instituto de Psicologia da Universidade de São Paulo, estou desenvolvendo a pesquisa A VIVÊNCIA DO CICLO GRÁVIDO-PUERPERAL EM UM CONTEXTO DE ASSISTÊNCIA HUMANIZADA, sob orientação da Profa. Dra. Eliana Herzberg, psicóloga CRP $n^{\circ}$. XX/XXXX, tel. XXXX-XXXX.

Essa pesquisa visa compreender como o casal, diante de seu primeiro filho, percebe que ser acompanhado por um serviço humanizado - no caso, a Associação Comunitária Monte Azul - interfere, ou não, na forma como vive a gestação, o parto e o puerpério (cerca de quarenta dias após o parto).

Antes de iniciar a pesquisa, é importante que eu entenda como a assistência ao pré-natal e ao pós-natal, prestada pela Associação, funciona e, mais especialmente, de que maneira seus usuários a percebem. Para tanto, precisarei do depoimento de alguns casais que estejam sendo atendidos no Núcleo Monte Azul, local em que o presente trabalho será realizado, acerca de como eles percebem os serviços prestados e de que maneira os avaliam.

Serão feitas poucas perguntas, que deverão tomar cerca de quinze minutos. Se vocês concordarem, os depoimentos serão gravados em fita cassete. Tais depoimentos serão colhidos nas dependências da instituição.

É muito importante que os Srs. saibam que:

- Podem, a qualquer momento, pedir informações e esclarecer dúvidas sobre a pesquisa;

- Podem, a qualquer momento, resolver interromper a participação na pesquisa; 
- Sua possibilidade de atendimento na instituição prestadora de serviço de assistência à gestação, ao parto e ao puerpério não sofrerá qualquer alteração (ou prejuízo) se por alguma razão os Srs. resolverem não participar mais dessa pesquisa;

- O fato de participar desta pesquisa não implica em continuidade de atendimento regular na instituição prestadora de serviço de assistência à gestação, ao parto e ao puerpério;

- As informações e os dados que o Srs. fornecerem serão utilizados para fins de pesquisa e eventuais publicações, porém serão observados o sigilo e a confidencialidade quanto à identidade dos participantes;

- As fitas nas quais forem gravados os depoimentos serão destruídas após o término desta pesquisa;

- Embora essa pesquisa não envolva riscos à sua integridade física e psicológica, caso sinta necessidade, pode entrar em contato com a pesquisadora pelo telefone acima, mesmo fora dos horários marcados.

Declaro que, depois de ter recebido esclarecimentos da pesquisadora e ter entendido o que me foi explicado, consinto em participar do presente Projeto de Pesquisa.

São Paulo, de de 200

Assinatura da gestante

Assinatura do cônjuge

Assinatura da Pesquisadora

Ana Paula Campos Lima

Departamento de Psicologia Clínica do Instituto de Psicologia da Universidade de São Paulo

Av. Prof. Mello Moraes, 1721, Bloco F. Cidade Universitária. CEP: 05508-030

São Paulo-SP Tels: 3091-4173 e 3091-4910 


\title{
ANEXO F - TERMO DE CONSENTIMENTO PÓS-INFORMAÇÃO
}

\author{
DADOS DE IDENTIFICAÇÃO DA PARTICIPANTE DA PESQUISA
}

NOME DA PARTICIPANTE

DOCUMENTO DE IDENTIDADE N ${ }^{\circ}$

DATA DE NASCIMENTO /

ENDEREÇO
BAIRRO TELEFONE
CEP

$\mathrm{Eu}$, Ana Paula Campos Lima, psicóloga CRP ${ }^{\circ} \mathrm{XX} / \mathrm{XXXXX}$ tel. XXXX-XXXX, aluna regular do Curso de Mestrado do Programa de Pós-Graduação em Psicologia Clínica do Instituto de Psicologia da Universidade de São Paulo, estou desenvolvendo a pesquisa A HUMANIZAÇÃO DO CUIDADO PRÉ E PÓS-NATAL EM UMA ORGANIZAÇÃO NÃO-GOVERNAMENTAL, sob orientação da Profa. Dra. Eliana Herzberg, psicóloga CRP $\mathrm{n}^{\mathrm{o}}$. XX/XXXX, tel. XXXX-XXXX.

Essa pesquisa visa observar, descrever e compreender como se dá a humanização do cuidado pré e pós-natal na Associação Comunitária Monte Azul; entendendo que participam da produção dessa humanização tanto os funcionários e coordenadores da Associação, quanto os usuários de seus serviços.

Como parte da pesquisa, é importante que eu entenda como a assistência ao pré-natal e ao pós-natal, prestada pela Associação, funciona e, mais especialmente, de que maneira seus usuários a percebem. Para tanto, precisarei do depoimento de algumas mulheres que tenham sido atendidas no ambulatório do Núcleo Monte Azul - local em que o presente trabalho será realizado - acerca de como elas percebem os serviços prestados, de que maneira os avaliam e se acreditam que o serviço possui algum efeito sobre a sua gravidez, seu parto e seu puerpério (período que abarca cerca de 40 dias após o parto).

Serão feitas poucas perguntas, que deverão tomar entre vinte e trinta minutos. $\underline{\text { Se você }}$ concordar, os depoimentos serão gravados em fita cassete. Tais depoimentos serão colhidos nas dependências da instituição.

É muito importante que a Sra. saiba que:

- Pode, a qualquer momento, pedir informações e esclarecer dúvidas sobre a pesquisa;

- Pode, a qualquer momento, resolver interromper a participação na pesquisa;

- Sua possibilidade de atendimento na instituição prestadora de serviço de 
assistência à gestação, ao parto e ao puerpério não sofrerá qualquer alteração (ou prejuízo) se por alguma razão a Sra. resolver não participar mais dessa pesquisa;

- O fato de participar desta pesquisa não implica em continuidade de atendimento regular na instituição prestadora de serviço de assistência à gestação, ao parto e ao puerpério;

- As informações e os dados que a Sra. fornecer serão utilizados para fins de pesquisa e eventuais publicações, porém serão observados 0 sigilo e a confidencialidade quanto à identidade dos participantes;

- As fitas nas quais forem gravados os depoimentos serão destruídas após o término desta pesquisa;

- Embora essa pesquisa não envolva riscos à sua integridade física e psicológica, caso sinta necessidade, pode entrar em contato com a pesquisadora pelo telefone acima, mesmo fora dos horários marcados.

Declaro que, depois de ter recebido esclarecimentos da pesquisadora e ter entendido o que me foi explicado, consinto em participar do presente Projeto de Pesquisa.

São Paulo, de de 2008

Assinatura da participante
Assinatura da Pesquisadora

Ana Paula Campos Lima

Departamento de Psicologia Clínica do Instituto de Psicologia da Universidade de São Paulo Av. Prof. Mello Moraes, 1721, Bloco F. Cidade Universitária. CEP: 05508-030 São Paulo-SP Tels: 3091-4173 e 3091-4910 


\title{
ANEXO G - TERMO DE CONSENTIMENTO PÓS-INFORMAÇÃO
}

\author{
DADOS DE IDENTIFICAÇÃO DA PARTICIPANTE DA PESQUISA
}

NOME DA PARTICIPANTE

DOCUMENTO DE IDENTIDADE N ${ }^{\circ}$

DATA DE NASCIMENTO /

ENDEREÇO
BAIRRO TELEFONE
CEP

$\mathrm{Eu}$, Ana Paula Campos Lima, psicóloga CRP ${ }^{\circ} \mathrm{XX} / \mathrm{XXXXX}$ tel. XXXX-XXXX, aluna regular do Curso de Mestrado do Programa de Pós-Graduação em Psicologia Clínica do Instituto de Psicologia da Universidade de São Paulo, estou desenvolvendo a pesquisa A HUMANIZAÇÃO DO CUIDADO PRÉ E PÓS-NATAL EM UMA ORGANIZAÇÃO NÃO-GOVERNAMENTAL, sob orientação da Profa. Dra. Eliana Herzberg, psicóloga CRP $\mathrm{n}^{\mathrm{o}}$. XX/XXXX, tel. XXXX-XXXX.

Essa pesquisa visa observar, descrever e compreender como se dá a humanização do cuidado pré e pós-natal na Associação Comunitária Monte Azul; entendendo que participam da produção dessa humanização tanto os funcionários e coordenadores da Associação, quanto os usuários de seus serviços.

Como parte da pesquisa, é importante que eu entenda como os funcionários e coordenadores da Associação - mais especialmente, aqueles ligados ao serviço de atenção pré e pós-natal prestado no ambulatório do Núcleo Monte Azul, local de realização dessa pesquisa percebem tal serviço e o trabalho que realizam; e como compreendem a humanização do cuidado ao ciclo grávido-puerperal.

Para tanto, precisarei do depoimento de alguns desses colaboradores. Serão feitas poucas perguntas, que deverão tomar entre vinte e trinta minutos. Se você concordar, os depoimentos serão gravados em fita cassete. Tais depoimentos poderão ser colhidos nas dependências da instituição ou em outro local que lhe seja mais conveniente.

É muito importante que a Sra. saiba que:

- Pode, a qualquer momento, pedir informações e esclarecer dúvidas sobre a pesquisa;

- Pode, a qualquer momento, resolver interromper a participação na pesquisa;

- As informações e os dados que a Sra. fornecer serão utilizados para fins de pesquisa e eventuais publicações, porém serão observados 0 sigilo e a 
confidencialidade quanto à identidade dos participantes;

- As fitas nas quais forem gravados os depoimentos serão destruídas após o término desta pesquisa;

- Embora essa pesquisa não envolva riscos à sua integridade física e psicológica, caso sinta necessidade, pode entrar em contato com a pesquisadora pelo telefone acima, mesmo fora dos horários marcados.

Declaro que, depois de ter recebido esclarecimentos da pesquisadora e ter entendido o que me foi explicado, consinto em participar do presente Projeto de Pesquisa.

São Paulo, de de 2008

Assinatura da participante

Assinatura da Pesquisadora

Ana Paula Campos Lima

Departamento de Psicologia Clínica do Instituto de Psicologia da Universidade de São Paulo Av. Prof. Mello Moraes, 1721, Bloco F. Cidade Universitária. CEP: 05508-030 São Paulo-SP Tels: $3091-4173$ e 3091-4910 